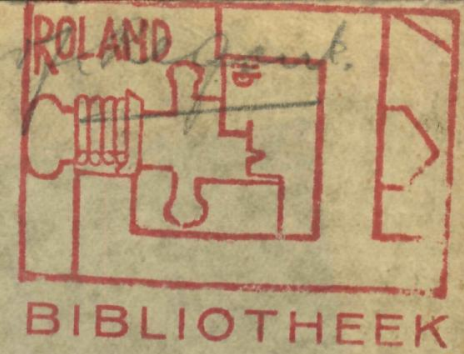

\title{
A SYNTAX
}

OF

THE ENGLISH LANGUAGE

OF

ST. THOMAS MORE

BY

F. TH. VISSER

A. THE VERB 



\author{
A SYNTAX \\ OF \\ THE ENGLISH LANGUAGE \\ OF \\ ST. THOMAS MORE
}

A. THE VERB 
PROMOTOR: PROF. DR. AUR. POMPEN O.F.M. 1941

CH. UYSTPRUYST - RUE DE LA MONNAIE 10 - LOUVAIN 


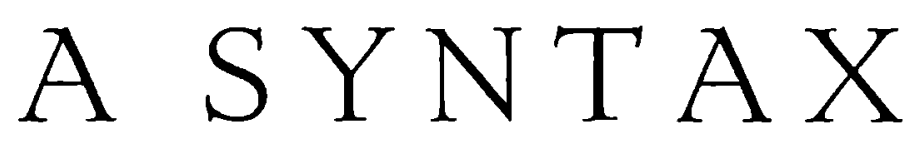
OF

THE ENGLISH LANGUAGE OF

\section{ST. THOMAS MORE}

A. THE VERB

$\diamond$

ACADEMISCH PROEFSCHRIFT TER VERKRIJGING VAN DEN GRAAD VAN DOCTOR IN DE LETTEREN EN WIJSBEGEERTE AAN DE KATHOLIEKE UNIVERSITEIT VAN NIJMEGEN, OP GEZAG VAN DEN RECTOR MAGNIFICUS, VOLGENS BESLUIT VAN DEN SENAAT IN HET OPENBAAR TE VERDEDIGEN IN DE AULA DHR UNIVERSITEIT OP WOENSDAG, 17 SEPTEMBER 1941. DES NAM. TE 3 UUR DOOR

FREDERIKUS THEODORUS VISSER GEBOREN TE ENSCHEDE 
Gedrukt met steun van het Dr. van Gils-fonds. 
Aan mïn $O_{\text {rouw }}$ en Kinderen 



\section{N T R O DUCTIO N}

Syntax has long been the most neglected part of the historical studies of the English language. Of late years, however, a vivid interest in it has been spreading rapidly among students of English in all parts of the world, and at present the conviction that, though various good or specious reasons may be adduced for this neglect in the past, the history of syntactical constructions is at least of equal importance for a scientific study of the language with that of its phonology and its accidence, seems to have become general. In a certain sense it is of more importance. For it contributes directly, at any rate more directly than the other two, to a proper understanding and a reasoned appreciation of the great writers of the past, and perhaps even of the present. Experience has repeatedly proved that passages in a certain author which seem dark, strange or corrupt find their natural explanation when viewed in the light of earlier periods, and grammarians have repeatedly committed themselves to wrong statements and conclusions owing to their ignorance of earlier usage. It is e.g. unavoidable for assertions concerning the style of an author living in the past to be jejune or fallacious before the way in which words and word-groups were generally used at the time has been comprehensively, if not exhaustively, described, an author's personal style being mainly characterized by his own choice from and handling of existing possibilities in linguistic usage. Certain features in the language of a particular writer have often been called idiosyncrasies until they appeared to be common to the diction of the period and consequently not typical of the author's individual usage at all. Thus, for instance, the trick of duplication and triplication of synonyms may be found mentioned as an individual characteristic of more than one 15th and 16th century writer, whereas it was nothing but a recognized figure of rhetoric at that time and long before. For one striking instance of the enlightening character of the study of the history of language-structure the reader may be referred to $\S 547$, where the adduced evidence makes it clear that Shakespeare's conciseness in "Many have and others must sit there" (Rich. 2 V. v. 27) is neither a stylistic freak nor a hapax legomenon.

It stands to reason that for the study of historical syntax to be of use as a basis for comparison of earlier, later or contemporaneous usage it must not restrict itself to a few selected periods or to capita selecta, but ought to extent its activities over all those writings that 
may be considered as trustworthily reflecting the language in its successive stages. With this in mind it may safely be said that the study of the history of the syntax of the English language is still in its initial stage. In spite of the not inconsiderable amount of work already done - especially during the last few decennia - more than one gap needs filling up. Chaucer has had numerous syntactical studies devoted to him; Shakespeare's language has been amply described in W. Franz's well known grammar. But the period between has been left practically unsearched. Only that part of it that lies before \pm 1500 has aroused a certain amount of interest ; but the result mainly consists of monographs and articles dealing with individual points of syntax, and of scattered observations in the introductions to critical editions or in general works on historical syntax (such as Einenkel's Gesch. der Eng. Spr. II ; Hist. Synt. 1916 ; Trnka's On The Syntax of The English Verb from Caxton to Dryden 1930). Two publications, however, of a less unpretending nature, are of outstanding merit: H. J. v. d. Meer's Main Facts Concerning the Syntax of Mandeville's Travels (1929) and A. Dekker's Some Facts Concerning The Syntax of Malory's Morte D'Arthur (1932). In them, at least, two of the fifteenth century authors have been given their due.

As to the other part, the sixteenth century, but for G. Klausmann's Formenlehre und Syntax des Verbums in der Froissart-Ubbersetzung von Lord Berners (1919) and R. E. L. Weyl's Syntactical Studies in Bishop Fisher's English (1937), the territory still lies fallow, so that of the period that leads up to the great Elisabethans next to nothing is known syntactically. The wonder of it is, of course, that St. Thomas More, of all others, should have escaped attention, St. Thomas, who, according to no less a critic than Prof. R. W. Chambers (On The Continuity of Eng. Pr. 1932 p. 1iii) "was the first Englishman to evolve an effective prose, sufficient for all the purposes of his time : eloquent, dramatic, varied." Of no one can it be said with more truth than of Saint Thomas More, that he occupies a key-position in the history both of English literature and of the English tongue. It has been demonstrated by the same critic that his language, especially that occurring in the numerous passages of dramatic dialogue, is the direct ancestor of the prose-style of the great English dramatists, not excluding that of Shakespeare. This is so true that for many purely syntactical constructions in the Elisabethan drama that seem to defy analysis the clue is to be found in the natural and untrammelled language of the man who, in his youth, was connected with the begin- 
nings of the English drama in the household of Cardinal Morton, where, at the Archbishop's Christmas feasts, he "would... suddenly sometimes step in among the players, and never studying for the matter, make a part of his own there presently among them" (W. Roper, Life p. 8), and who, later, undoubtedly helped and advised John Rastell in the building of the first stage for play-acting on English soil.

About St. Thomas More's eminence as a prose-writer men of his time had no doubt. Even Tyndale's objection to his "painted poetry, babbling eloquence" contains nothing depreciatory in this respect, referring as it does to the good-humoured lightness of manner in the treatment of serious matter occasionally indulged in by his opponent. There is abundant proof that for a long time after St. Thomas' death his fame as a stylist was not forgotten. Shakespeare himself underwent his influence and must have been an observant reader of his works. It is well known that for his Richard The Third and Henry The Sixth (at least its third part) he is largely indebted to St. Thomas More and that the number of almost verbatim borrowings is not small. And when Ben Jonson wants illustrative evidence for his Grammar, he takes it by preference from St. Thomas More's English writings, because, as Dr. Johnson, in the Introduction to his famous dictionary, says, "they were considered as models of pure and elegant style."

How deeply the stamp of St. Thomas' genius is impressed on his language can be seen by every reader who is so privileged as to have access to the complete works. One of the first things of which he will become aware is the amazingly great versatility of St. More's art. Indeed almost all the different genres of literary prose will be found represented. If he seeks for lively historical narration, he has only to open The History of Richard III at random ; if for legends, parables, allegories, short tales or animal stories, he will find them in no small number in The Boke of Comforte Agaynste Tribulation. For St. Thomas as a biographer he may tum to his Life of John Picus. St. Thomas the humorist peeps round the corner in numerous places in The Confutacion of Tyndal and is not to seek even in the works written in prison. What his ironical pen can do may be seen in The Apology, The Debellacion of Salem and Byzance, The Dialogue of Heresies, The Supplicacion of Soules, The Answer To The Poisoned Book and The Confutacion of Tyndal, where St. Thomas also shows himself as an accomplished controversionalist. $A$ Treatice To Receive The Blessed Body and $A$ Treatice Vpon The Passion testify to St. Thomas' mastership as a writer of devotional prose, while, at the 
same time, they are rich in instances of sublime lyricism. Dramatic dialogue abounds in Richard III and The Boke of Comfort. More touching examples of the familiar-letter genre than those which St. Thomas wrote to his daughter Margaret shortly before his execution are not on record.

Space forbids going into details here. Only one point, perhaps, requires, and deserves, illustration. It does not appear to be generally known that the Theophrastic art of "character-writing" was practised long before Overbury, Bishop Hall and Francis Bacon by St. Thomas More. But whoever will turn to The Four Last Things or to The Boke of Comfort can find some indubitable specimens. To quote only two examples. Here is part of a description of the Envious Man :

... the sicknes of enuy, which is vndoutedly both a sore torment $\mathcal{E}$ a very consumpcion. For surely enuy is suche a torment, as al the tyrants in Sicil neuer deuised a sorer. And it so drynketh vp the moysture of the body, and consumeth the good bloode, so discoloreth the face, so defaceth the bewty, so dysfigureth the visage leuing it al bony, leane, pale, $\mathcal{E}$ wan, that a parson wel set awork with enuy, nedeth nome other image of deth, than his own face in a glasse. This vyce is not onely deuilish, but also very folysh. For albeit enuy where it may ouer, doth al the hurt it can, yet sith the worse most commonly enuieth the better, $\mathcal{E}$ the febler the stronger, it happeth for the more parte, that as the fire of the burnyng hyl of Ethna burneth only it self, so doth the enuious parson, fret, fume, $\mathcal{E}$ burne in his owne hert, without ability or power to do the tother hurt (Wks. p. 85).

And this is More's picture of the Scrupulous Man :

Thus fareth lo the scrupulous person which frameth himself mani times double the feare that he hath cause, and many times a great feare, wher there is no cause at al, and of that that is in dede no sinne, maketh a venial ; and that that is venial, imagineth to be deadly, $\mathcal{G}$ yet for al that falleth in them, being namelye of theyr nature such, as no man long liueth without. And then he feareth that he bee neuer full confessed, nor neuer full contrite, and then that his sinnes bee neuer ful forgiuen him, and then he confesseth and confesseth again, and combreth him selfe and his confessour bothe. And then euery prayer that he saith, though he say it as the frayle infirmitie of the man wyll suffer, yet is he not satisfyed, 
but if he say it againe, and yet after that agayne. And when he hath sayd one thing thryse, as litle is he satisfied with the last, as wyth the first, and then is hys hart euer more in heauynes, vnquyet, and in feare, ful of dout and dulnesse, withoute comfort or spiritual consolacion (Wks. 1182).

Great as St. Thomas More's versatility appears to be in his handling of various literary genres, his mastership of the most diversified styles and ways of writing, of nearly all the idiomatic and syntactical possibilities of the English language is no less astonishing. For vivacity, directness, variety, resourcefulness and ease it is difficult to find his equal among early sixteenth century writers. His prose is energetic, racy and frequently thoroughly colloquial ; it is impassioned or dispassioned, as the occasion demands. Now it is playful, now honest and straightforward, now concise, now rhetorical, now objective. In many places it smoulders with the slow fire of subdued irony or it flares out with passionate indignation into an eloquent diatribe, and sometimes it even rises to mystic rapture like wreaths of incense. How rich an instrument the English language was at the time we learn when this maestro plays on it.

That this great man, though a Humanist and a friend of Erasmus, should write most of his works in the vernacular, was for him the most natural thing in the world. In his character there was nothing of the cloistered scholar, and when the first literary exercises were over, he never pretented to write for Humanists or scholars. The man "of the greatest virtue this kingdom ever produced," as Dean Swift (Wks. ed. Temple Scott III 301) calls him, the enthusiastic champion of the faith and of liberty of conscience, the "hero of whom the whole of England is proud" (R. W. Chambers, Th. M. p. 351), the saint "with a power of detached and selfless vision vouchsafed in such a degree to no other Englishman of that age" (Campbell, Pref. to The Wks. p. xii), who besought our Lord to "brethe of his holy spirit in to the readers breste, whiche inwardely may teache hym in harte, without whom little auayleth all that the mouthes of the worlde were able to teache in mennes", this man, naturally, chose the medium which would enable him to reach the ears and the hearts of all his countrymen who could read English, in order to teach them, as Wyllyam Rastell says in the Dedication of the 1537 edition of The Workes, "not onelye the eloquence and propertie of the English tonge, but also the trewe doctryne of Christes catholike fayth, the confutacion of detestable 
heresyes, or the godly morall vertues that appertaine to the framinge and fourminge of mennes maners and consciences, to live a vertuous and deuout christen life". And not solely for this reason. For however much he may have loved the classic languages, St. Thomas undoubtedly loved his own language best and considered it in no way their inferior. Richard Mulcaster's words, "I honor the Latin, but I worship the English", might have been spoken by St. Thomas More. He rejected as "but a fantasy" the idea that English could not suffice for every purpose :

For as for that our tong is called barbarous, is but a fantasye. And if they would call it barayn of wordes, there is no doubte but it is plenteous enough to expresse our myndes in anye thing wherof one man hath vsed to speke with another (Wks. 243).

It is a fact that More exercised considerable thought and care when using the vernacular. He frequently gave proof of this by acting the schoolmaster towards a writer who misused English words or phrases, by elucidating the meaning of words and expressions, or by establishing some subtle grammatical distinction :

And then sayth he here: "But it reygneth now betweene spyrytuall men and temporall men." - I am content to let hys "but" alone, and wyll not shote ther at for this ones. Howbeit surely hys "but" being a preposicion aduersative, standeth more properlye to shote at betweene hys twoo "nowes" then it would if it were turned into some coniunction copulative (Wks. 876).

But "the" sygnifieth oftentimes some speciall thing, and dyuideth it from the general (Wks. 447).

the article... declareth that the worde wherto it is set, signifieth not a thyng generally and confuse at large, but some special thing determinate of that kind (Wks. 449).

thys woorde "nouum", seemeth not there to bee putte for an adverbe, but is a nowne adiective (Wks. 1328).

Tyndall hath been so long out of Englande, that he could not tell howe to use these english aduerbes (Wks. 1106).

"oportet"... is translated also into english, not only by this word "must" which yet signifieth not all way an impossibility of the contrary, but oftten times by this worde "it behoueth" which worde signifieth that it is to bee done for our behoofe and com- 
moditye, and not that it can in no wise be auoyded but that it must nedes be (Wks. 838).

I woulde not here note by the way, that Tyndal here translateth "no" for "nay", for it is but a trifle and mistaking of the englishe worde : sauing that ye shoulde see that he, whych in two so plain englishe wordes, and so common as is "naye" and "no", can not tell when he should take the tone, and when the tother, is not, for translating into englishe, a man very mete... And thys thing, lo, though it be no great matter : yet I have thought it good to give Tindall warning of, because I would have him write true one way or other, that though I can not make him by no meane to write true matter, I would have him yet at the lest wise write true englishe (Wks. 448).

After what has been said above it may seem strange that St. Thomas should have had to wait four hundred years for his real importance as a writer to be universally and fully understood. Apart from the fact that the only complete edition of his works, that of 1557 , was never reprinted during all those years, most of the reasons for the delay lie outside the domain of literature. For the most important of these the reader may be referred to the Epilogue of Prof. R. W. Chamber's Th. $M$. (pp. 351-400). It must, moreover, be remembered that for a long time literary historians were only too apt to look upon St. Thomas principally, or even exclusively, as a Humanist. The attention was chiefly concentrated on the Utopia, which he wrote in Latin, and his English writings were left in the shade, so that most readers hardly knew of their existence. As a matter of fact it is only recently that his very important historical work The Life of Richard III has become recognized as authentic, thanks, especially, to the learned studies of O. Hübschmann (Tekstkrit. Untersuchungen 1910) and Prof. R. W. Chambers (in The Works of St. Th. M. ed. Campbell, Vol. I 1935 pp. 55 ff.).

Many modern scholars have collaborated or even rivalled with each other in making up for the four centuries of neglect. Algernon Cecil, Henri Bremond, T. E. Bridgett, M. Grünziger, Mgr. Ph. E. Hallett, W. H. Hutton, Chr. Hollis, Fr. Bede Jarret, Fr. Vincent Mc Nabb, Sir J. R. O'Connel, Prof. Phillimore, G. R. Potter, E. M. G. Routh, D. Sargent and C. E. S. Shebbeare, each in his own field, have been contributive towards the exploding of a multitude of prejudices and towards the revelation of St. Thomas More's greatness. A. S. Taft has supplied 
a modern critical edition of The Apology, Dr. E. V. Hithcock correct texts of Harpfield's and W. Roper's Lives, and Dr. Elis. F. Rogers a Calendar of the Correspondence of St. Th. M. (in the Eng. Hist. Rev. 1922 pp. 546-64). In his Early Tudor Drama Prof. A. W. Reed has shown us how much St. Thomas had to do with the origins of the Tudor drama. Prof. W. E. Campbell has undertaken the task of reediting The English $W$ orks, and as a result of his labours two magnificent volumes, with introductions and notes by A. W. Reed, R. W. Chambers, W. A. G. Doyle Davidson and B. White, together with facsimile reproductions of the 1557 text, modern versions and apparatus, are already at the readers' disposal.

But the two scholars that have done most for revealing the significance of St. Thomas as a writer of English are Prof. R. W. Chambers and Prof. Joseph Delcourt. The former - the latest and greatest authority on More - whose Thomas More (London 1935) is the standard modern Life, has given us, in On The Continuity of English Prose (originally written as an Introduction to E. V. Hitchcock's Harpsfield) the explanation of the greatness of the prose of St. Thomas, thus throwing light where light was most needed: "When Thomas More determined to be an author, not merely in Latin, but in English also, he had not to make an English prose. He found it ready to hand : not in Chaucer's Parson's Tale, not even in Malory, whose book he may perhaps never have opened, but in the living tradition of the English pulpit, and in the large body of devotional vernacular literature dating from the Fourteenth Century and the early Fifteenth."

The second, Prof. Joseph Delcourt, the writer of the admirable study Essai sur la Langue de Sir Thomas More (Paris 1914), has laid every lover of English under a debt by his detailed discussion of the principal aspects of St. Thomas' language and especially by his masterly observations on St. Thomas' style. How high St. Th. More as a writer of English stands in his estimation appears from the following passage, which is to be found at the end of his chapter on Le Style: "le style que nous avons essayé de décrire n'en reste pas moins un composé unique, particulièrement riche en tendances et en promesses d'avenir, et dont aucun des écrivains du commencement du seizième siècle n'offre vraiment l'équivalent. Et quand on se rappelle que, parmi les différents œuvres en prose de ce temps, aucune presque n'est antérieure aux premières manifestations du talent de More, on reconnait qu'il n'est pas trop injuste d'affirmer qu'il fut bien le 
premier maître qu'ait eu la prose anglaise et en un sans le fondateur de la littérature anglaise moderne."

That Prof. Delcourt, for reasons that must be respected, should not have chosen to enlarge his stray observations on Tournures into a more complete syntax is a matter of regret, for no one would have been more capable of such a work than the learned author of the Essai, in spite of his assertion that "en passant de la morphologie de More à sa syntaxe, on a un peu l'impression qu'on fait un saut dans l'inconnu". And if then, in the following pages, I have taken over this task, I am well aware of the audacity therof, for which perhaps the only excuse is : the fact that the work badly needed doing, and the consideration that "if no man should dooe it, but he that might sufficientlye dooe it, no man should dooe it." (Wks. 2).

In what follows, I have tried to give a complete analysis of one feature, but a central feature, of the language of St. Thomas More, namely the verb, its meanings and functions. I have made this investigation without committing myself to any linguistic theory, aiming only at the greatest possible objectivity. I have endeavoured to lay before the reader all the constructional forms to be observed in the English works of St. Thomas More and, remembering that the study of syntax is essentially a study of context and situation, I have done my best to adduce only full-length quotations. Though it has been my primary concern to give a synchronic description, I have considered it a part of my duty to find out, whenever possible, how far More's usage agrees or disagrees with that of earlier and later times. For this purpose I have not only gone through a fair number of Old and especially Middle English texts, but have also made extensive and grateful use of the immense store-house of the Oxford English Dictionary and of the results obtained by other workers in the field of syntax. Apart from a few recapitulations, I have refrained from attempting a synthetic summing up, deterred as I was by the almost complete absence of informative data concerning the usage in contemporaneous authors.

My method of treatment may require a few words of explanation and justification.

Taking form, and not meaning or function as a starting-point, I have divided the word-sequences into groups with one, or with more verbal forms as their centre, and have given them the name of syn- 
tactical units. This term comprises sentences, clauses, infinitive- and participial constructions, "free adjuncts" and the like. A classification of these units according to the number of verbal forms they contain led to the following sub-divisions : syntactical units with one verb (e.g. I go; seeing him) ; syntactical units with two verbs (e.g. I shall go; I had seen; he was writing; I saw him go); units with three verbs (I shall have gone; he was allowed to go; I have seen him go); further : units with four verbs, etc.

It is especially in dealing with the syntactical units containing two or more verbs that I have followed an order for which I cannot appeal to any authoritative precedent. It is hoped that the obvious objectivity of the procedure and the results obtained by it will be deemed a sufficient excuse. All combinations of two or more verbs have been reduced to two classes : they consist either of a simple juxtaposition of verbal forms as in shall be done, or they consist of verbs formally separated, but syntactically united by an intervening (pro)noun with a bilateral function, as in I saw him go. Examples of the first class have been grouped under the title direct nexus of two (three, etc.) verbs, the term indirect nexus of two (three, etc.) verbs being employed for constructions of the second class. Both direct nexus and indirect nexus are again classified according to the form of the last verb, which may be an infinitive (e.g. I shall go; I saw him go), a past participle (e.g. I have gone; I saw it done) or a form in -ing (e.g. I am reading; I saw him coming). Further subdivisions arise from the nature of the first verb.

As to the grammatical terminology adopted, a little elucidation may seem imperative, and sufficient. The time-honoured terms designating the different parts of speech and the parts of the sentence (such as subject, predicate, object and adjunct) have been kept, apart from a few deviations of minor importance. So have the terms "present tense", "preterite", "infinitive" and "part participle", though I am not convinced that they are sufficiently objective and was at first tempted to replace them by more neutral appellations, such as "the unmodified invariable stem" (for infinitive), "the unmodified variable stem" (for present tense), "the modified invariable stem" (for past participle) and "the modified variable stem" (for preterite), or by even more pasigraphic terms, such as Form I, Form II, Form III etc. Practical considerations, however, have led me to relinquish this plan. The term "Form in -ing" is used to denote the form of the verb to come in "He is coming", as well as in "On his coming home...". 
Apart from the terms "Direct Nexus" and "Indirect nexus" (see above), the collocations of two or more verbal forms are left without a name and are merely referred to by mentioning the type of construction. This procedure has been adopted not only because the number of existing appellations is too limited to cover all the various combinations, and many of them (e.g. Future Tense; Progressive Form) are misleading in that they designate only one of the possible functions of a special combination, but also because the application of the traditional labels almost inevitably leads to the discussing of only such combinations as correspond to forms with similar meaning in Latin or other, preferably classical, languages, with the result that many groups of purely English or Germanic origin remain nameless and consequently run the risk of being overlooked.

It is possible that this study might have been improved by a systematic counting of the frequency of the separate syntactical features (as is done e.g. in G. K. Zipf's Psycho-Biology of Language, London 1936). I have attempted to compensate for the absence of statistical data by the use of such qualifying adjectives as unique, rare, exceptional, frequent, etc.

No one is more conscious than myself of the drawbacks of a system which attempts to arrange the phenomena of a language into set divisions, subdivisions and paragraphs, and consequently traces lines of demarcation where in reality, owing to the protean character of many constructions, the boundaries are fluid and vague. Wherever necessary or advisable I have indicated the more or less arbitrary nature of the classification, and the very full Table of Contents and the various Indexes may partly remedy the unavoidable evils consequent on grammatical divisions of any sort.

One redeeming quality of my work will be apparent at least to every reader who can appreciate racy English. For St. Thomas's words, lavishly sprinkled over nearly every page, will stand the most exacting tests. May this great writer and Saint not look down with disfavour upon my attempt to subject his language to a process of vivisectional analysis and to use his lively sentences as illustrations of dry-as-dust expositions of grammatical facts. 


\section{CONTENTS}

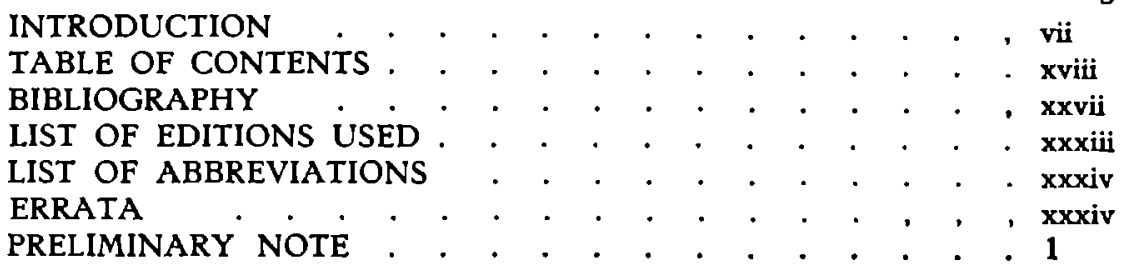

\section{SYNTACTICAL UNITS WITH ONE VERB}

\section{VERB AND SUBJECT . . . . . . . . . . . 3-48}

It as subject $6^{1}$ ) ; conceptional it 7 ; concrete it 8 ; summarizing it 9 ; it in the emphasizing formula 10 ; proleptic it $11-17$; type it happed me 17 ; type me thinketh $18-24$; subject not expressed $25-36$; commands $31-36$; introductory there $37-39$; two subjects $40-41$; concord $42-49$

\section{VERB WITHOUT COMPLEMENT . . . . . . 49- 76}

Subjective verbs $50-64$; subj. verbs not recorded before More's time 51 ; subj. verbs now obsolete 52 ; verbs of motion with in or into 53 ; subj. verbs with predic. adjuncts 55 ; vicarious do replacing a subjective verb 56 ; shall, should, will, may as subj. verbs 57 ; objective verbs used absolutely 58 ; reflex. verbs without reflex. pronouns 59 ; to do replacing an objective verb 60 ; semi-independent will, can, may, etc. 61 ; subj. verbs with passive implication 62 ; type to have a fall 63-64.

\section{VERB WITH COMPLEMENT}

Character of the copula 65 ; to be $66-8$; copulas of aspect (become, wax, fall, grow, etc. ; remain, continue, abide, kepe) 69-78, copulas of modality $79-82$; quasi-copulas 83 ; complement of copula a noun 84, an adjective 85 , a pronoun 86 , an adverb 87 , a prepositional phrase 88 , a syntactical unit 89 ; semi-independent use of the copula 90 .

NO DISTINCT SUBORDINATION (VERB + OBJECT)

The term object 91 ; objective verbs not recorded before More's time 92 ; obj. verbs now obsolete, archaic, etc. 93 ; to dark - to darken 94 ; denominatives 95 ; independent can, will, ought + object 96 ; causatives 97 ; vicarious to do + object $98-100$; semi-independent shall + object 101 ; to be content + object 102 ; type to have a feeling 103.

THE KINDS OF WORDS USED AS OBJECT

Nouns, pronouns, and clauses as object 104 ; concrete it as obj. 106 ; summarizing it as obj. 107-8; "absence" of summarizing it 109 ; conceptional it as obj. 110 ; type to walk it, to lord it 111 ; proleptic it as object with predic. adjunct 112 ; idem without predic. adjunct 113 ; so as obj. 114.

1) These numbers refer to the paragraphs. 
Verbs with one object. Ordinary or direct objects 115 ; objects of result 116 ; cognate objects 117 ; the object of a form in -ing 119-126; absence of anaphoric object after the + form in -ing 127 ; object + predic. adjuncts 128 ; the predic. adjunct is a (pro)noun 129, an adjective 130 , a prepositional group 131 ; the group of the type a fire 134 ; the predic. adjunct preceded by for 133 ; idem preceded by as 134 ; the predic. adjunct is an adverb. 135 ; indirect objects 136 ; reflexive objects 137 142. compound pronoun as reflex. obj. 137 ; personal pronoun as reflex. obj. 138 ; reciprocal objects 143 ; prepositional objects $144-5$; endpositionel and prepositional 375.

Verbs with two objects. Ordinary + prepositional object $147-8$; type take delight in 149 ; two prepositional objects 150 ; ordinary + indirect object 151 ; indirect object proper 152 ; indirect object of benefit 153 ; indirect object of interest 154 ; type they patted them upon the pates 155 ; two direct objects 156.

\section{THE PRESENT TENSE}

Forms 157 ; time-sphere $158-173$; neutral time $159-161$; past timesphere 162 ; in narratives 163 ; present time-sphere 164 ; future timesphere $165-168$; time stretching from past to present 169 , from present to future 170 ; the 'before future' time-sphere 171 ; indirect speech 172 ; aspect I 174-179; aspect II, perfectivity and imperfectivity $180-1$; modality $182-204$.

\section{THE PRETERITE}

Forms 205-6; 'Strong' verbs 207 ; time-sphere 208-16; past timesphere 208 ; neutral time-sphere 209 ; present time-sphere 210 ; future time-sphere 211 ; time stretching from past to present 212 ; the 'pre-past' time-sphere 213 ; indirect speech $214-16$; aspect $217-8$; modality $219-$ 243 ; was and were $228-39$; modest statements 236 ; second pers. sing. in -st in units with a modality of imagination 239 ; historical remarks $240-243$.

\section{THE INPINITIVE}

Character 244 ; the inf. as subj. 245 ; idem after the type me rueth 246 ; idem after proleptic it + verb 247 ; idem after prol. it + adjective 248 ; idem after prol. it + noun 249 ; the inf. after a copula 250 ; the inf. as object 251 ; the group what to think 252 ; the inf. as an adjunct to a noun $253-7$; idem to an adjective 258 ; the inf. construction as an equivalent to a clause of purpose $259-62$; the type to say the truth 262 ; the inf. construction equivalent to a clause of concession 263 ; idem of result 264-67; idem of cause 268 ; idem of condition or supposition 269 ; the inf. preceded by a preposition like without 270 ; the inf. after and, (n)or, than, but $276-81$; the 'split infinitive' 282 ; to in end-position without following inf. 283 ; voice of the inf. $284-90$; easy to sec and easy to be seen 286 ; modality of the inf. 291 ; time-sphere 292 ; summary of the use of the plain and the prepos. inf. 294 ; idem of the types a man to go, for a man to go; for to go 295.

\section{THE PAST PARTICIPLE}

Forms 299 ; functions 300 ; the past p. as a prenominal adjunct $301-8$; idem as a postnominal adjunct $309-14$; the past $p$. after a copula 315 ; the past p. as a predicative adjunct 316 ; idem as an equivalent to an 
adverbial clause 317 , of time 319 , of reason, cause and means 320 , of condition and restriction 321 , of attendant circumstances 322 ; the past $p$. in the rounding- off formula 325-5; the past $p$. in a few other cases 326-9; types not found in More 330; conversion 331-3.

\section{THE FORM IN -ING}

The form in -ing as subject 335 ; the form in -ing after a copula $336-8$; the form in -ing as dir. object $339-40$; idem as an attrib. adjunct $342-51$; type in time coming 347 ; type medecines of their (own) devising 348 ; type frying panne 349-50; type the tormente of beating 351 ; the form in -ing as a predic. adjunct 352 ; type al wakende 353 ; the form in -ing after prepositions $354-5$; type he gave it in lening 356 ; the form in -ing after than and but 357 ; the form in -ing as an equivalent to an adverb clause of attendant circumstances 359 ; of time 360 , of cause, means and instrumentality 361 ; of condition 362 , of rejected comparison 363 , of purpose 365 , of concession 366 ; juxtaposition of form in -ing and infinitive 367.

\section{CHARACTERS OF THE FORM IN -ING}

Adjectival 369 ; nominal $370-1$; verbal 372 ; mixed 373 ; adverbial 374 ; conjunctional and prepositional 375.

THE OBJECT OF THE FORM IN -ING

THE SUBJECT OF THE FORM IN -ING . . . . . . . sisting of of + noun $380 ;$ a pers. pronoun in the oblique case 381 ; a pers. pron. in the neutral case 382 ; a noun in the neutral case 383 .

VOICE OF THE FORM IN -ING .

Active 384 ; passive $384-5$.

TIME-SPHERE OF THE FORM IN -ING .

A-chronic, future, present, past time-sphere 386 ; comparison of after having fallen and after falling, etc. 386 .

\section{II.}

\section{SYNTACTICAL UNITS WITH TWO VERBS}

\section{DIRECT NEXUS OF TWO VERBS}

\section{A. FIRST VERB NOT SUBORDINATED TO THE SECOND . . . . - -}

\section{SECOND VERB AN INFINITIVE}

Types forget + infin. 390 ; desire + infin. 390 ; intend + infin. 391 ; expect + infin. 3929 ; attempt + infin. 393 ; other verbs + infin. 394 ; hear + infin. 395.

SECOND VERB A FORM IN -ING .

Type forbear laughing 396.

1) Here the present volume breaks off; owing to the war the remainder could not yet be printed. 
B. FIRST VERS SLIGHTLY SUBORDINATED TO THE SECOND .

\section{SECOND VERB AN INFINITIVE}

Attendant verbs of aspect (e.g. begin, cease) + inf. 398 ; to use + infin. $399-403$; att. vbs. of modality (e.g. seem) + infin. 404 ; att. vbs. of fortuity (e.g. hap) + infin. 405 ; other attendant vbs. + infin. 406-9.

SECOND VERB A FORM IN -ING .

Type cease whining 410 .

\section{FIRST VERB DISTINCTLY SUBORDINATED TO THE SECOND}

\section{a. AUXILIARY + INFINITIVE .}

To be + infinitive.

Type that is to say 412 ; idem they be to blame 413 ; idem the glory that is to come 414 ; idem this chapter is to treat of... 415 ; idem he was to speak 416 ; idem if I were to dispute 417.

To have + infinitive

Type Now we have to consider 418 ; idem They have yet saint Peter's cope to shew 419 ; idem they had not to eat 420 .

To do + infinitive .

Constructions unknown in Pres. D. Eng. (e.g. 'I order him to do come') 421 ; to do in poetry 422 ; idem in affirmative units $423-25$; idem in interrogative units 426 ; idem in dependent questions 427 ; idem in questions opening with subject 428 ; idem in negative declarative units with not 429 ; idem in negative commands 430 ; idem in negative questions 431 ; the construction No do ye? 432. Types not found in More 433.

Shall $\&$ will + infinitive .

Shall expressing a necessary condition 435 ; shall needs 436 ; shall $=$ what is right or becoming 437 ; shall/will in commands 438 ; shall/will 1 st pers. voluntary future action, 2 nd $\mathbb{Q} 3$ rd pers. the speaker's determination to bring about some action $439 ; s h / w .=$ to be able $440 ;$ sh./w. to express mere futurity $441 ;$ sh $/ w$. to express result to be expected in supposed case 442 ; "prophetic" shall $443 ;$ sh./w. in phrases opening with proleptic it 444 ; shall $=$ what ordinarily occurs $445 ; s h J_{w}$. in questions $446-8$; will $=$ voluntary action, strong determination 449 ; will to express willingness 450 ; will to express inference regarded as possible 451 ; will to express natural disposition 452.

Special uses in dependent units : Shall in attrib. clauses 453 ; shall in clauses after desirative verbs, verbs denoting emotion, verbs or nouns of hoping, after phrases like it is strange $454 ;$ shall in hypothetical, conditional and temporal clauses denoting a future contingency 455 ; shall in clauses of result or purpose 457 ; shall in clauses opening with how(so)ever etc. $458 ; s h / w$. in reported speech 459.

\section{Should $a$ would + infinitive .}

Should $=$ former obligation 460 ; should needs $461 ;$ sh. to denote what was formerly settled 462 ; sh. in statements of duty or propriety 463 ; sh./w. to denote futurity from a point in the past $464 ;$ would expressing power in the past 465 ; woud expressing volition in the past 466 ; would expressing willingness in the past 467 ; would expressing natural disposition $468 ; s h . w$. in the apodosis of a hypothetical proposition $469 ;$ would $=$ should like to $470 ; w / s h$. in the type 'I shoulde wene' 471 . 
Special uses in dependent units : $S h / w$. in reported speech $472 ; s h . / w$. after units expressing expectation, etc. $473-4 ; s h / w$. after desiderative units $475-6 ; s h . / w$. in clauses denoting fear $477 ; s h . / w$. after units denoting surprise, etc. $478 ; s h / w$. after units expressing justice, propriety, etc. 479 ; sh.w. after such phrases as 'it is (un)likely' $480 ; \mathrm{sh} / \mathrm{w}$. in attributive clauses $481 ; s h . / w$. in adverb clauses and object clauses with final meaning 482 ; sh./w. in temporal clauses $483 ; s h / w$. in clauses of result $484 ;$ sh./w. in clauses of rejected comparison $485 ; \mathrm{sh} . \mathrm{w}$. in concessive clauses 486 ; $s h / w$. in hypothetical clauses 487 . Sh. $h$. in questions 488 ; notes on shall, will, should, would 489 ; the type he sh(w)ould escaped 490 ; he had would 491 ; shall can, shall may + infinitive 492 ; will $=$ would 494 ; the type chese what way he shall 495 ; synonyms of will \& would 496.

Can \& may + infinitive

Can/may = to know how $497 ;=$ ability, power $498 ;=$ objective possibility $499 ;=$ permission or sanction $500 ;=$ what is often the case 501 ; $=$ subjective possibility 502 ; may in exclamatory expressions of wish 503 ; may in dependent clauses 504.

\section{Could $\&$ might + infinitive}

Could/might in units with a past time-sphere 505 ; might in the apodosis of a hypothetical statement 506 ; might $=$ may 507 ; could $=$ would be able 508 ; might in dependent clauses 509 ; mote $=$ may 510 ; types 'What may you want ?', 'What might your name be ?' 511 ; to mow; mowing 512 ; the type Yo have mought + infinitive 513 ; mought + infinitive 514 ; the type You may ... to like it 515 ; can will + infinitive 516 ; shall can + infinitive 517 ; synonyms of may, can, might a could 518-519; can be able + infin. 520 ; could $=s h(w)$ ould have been able 521 ; may $=$ might 522 .

\section{Mote + infinitive}

Origin 523; mote $=$ may $523 ;$ mote $=$ must 523 .

\section{Must + infinitive}

The type me (him, us) must + infin. 524 ; must expressing necessity in contexts with a present time-sphere 525 ; must not $=$ ought not to 526 ; must expressing necessity in contexts with a past time-sphere 527 ; must expressing the inferred certainty of a fact 528 ; must expressing desire or want 529 ; must in units with a modality of imagination 530 ; obsolete uses of must 531 ; must (needs) in satirical references to some annoying action 532 ; synonyms of must 533 ; must be bounden 534 .

Owe + infinitive

Owe $=$ to have a duty 535 ; the type him oweth + infin. 535 .

Owed + infinitive

Owed = ought 536 .

Ought + infinitive

Ought expressing duty or obligation 537.

Dare + infinitive

Dare $=$ to have boldness 538 ; I dare say 539 ; dare be bold 540 .

Durst + infinitive

Durst $=$ had the boldness 541 ; durst $=s h(w)$ ould have the boldness $542 ;$ durst $=I$ dare 543 . 
Need(ed) + infinitive

Need expressing a necessity arising from circumstances 544 ; needed expressing a necessity in the past 545 ; notes on need and needed 546.

Contraction of parallel constructions with auxiliaries.

Types $I$ shall and can go; he can go and will; I have and shall touch them; I shall and have touched them; I love you and shall; he was false and ever shall 547.

\section{b. AUXILIARY + PAST PARTICIPLE . . .}

To be + past participle.

To be + past p. of copulas 548 ; idem of verbs of motion 549 ; idem of other subjective verbs 550 ; idem of such subjective verbs as, in other contexts, may be used with an object 551 ; comparison of he is come, etc. and he has come etc. 552-4; to be + past p. of objective verbs 555-60; static passive $555-9$; actional or dynamic passive 560 ; time-sphere of the passive construction 561-2 ; functions in the sentence of to be (infin.) + past participle 563 ; idem of being + past p. 564 ; to be suppressed 565 ; to be not repeated 566.

The grammatical subject of the passive construction

The corresponding active construction contains a direct object 567-72; idem a direct object + a predic. adjunct 573 ; idem two direct objects 574 ; idem a direct and an indirect object 575-6; idem a prepositional object 577 .

The agent in the passive construction .

The agent not expressed 578 ; the agent expressed by a (pro)noun preceded by by, of; with, from, through, etc. $579-81$; the type there is giving of almes 582 .

To have + past participle .

Development of the construction $584-7$; time-sphere of he hath + past p. $588-93$; idem of he had + past p. $594-8$; the fault $I$ found $=$ the fault I had found 599 ; he had + past p. in units with a modality of imagination 600 ; functions of to have (infin.) + past p. 601 ; idem of having + past p. 602 ; the type Have done 603.

\section{c. AUXILIARY + FORM IN -ING .}

He was in (at, a) hunting; the book was in making 604-5; he is sleeping $606 \mathrm{a}$; plans are forming $606 \mathrm{~b}$; the water is somewhat pricking 607 ; to be + form in -ing of verbs like kneeling 608 ; idem of verbs of motion 609 ; idem with other verbs 610 ; type he lyeth groning 611 ; functions of to be + form in -ing $612-4$; types he was star-gazing; be going I; he is being polite 615 .

\section{INDIRECT NEXUS OF TWO VERBS .}

\section{VERB + (PRO)NOUN + INFINITIVE .}

The term indirect nexus 617 ; different characters of the group 618-20; type helping her to dress his dinner 621 ; idem he called on folk to build churches 622 ; the type $I$ saw him come with verbs of a) seeing, etc. 623 ; b) causing 624 ; c) inducing 625 ; d) compelling 626 ; e) commanding 627 ; f) allowing 628 ; g) forbidding 629 ; h) wishing $630 ;$ j) understanding 
Q thinking $631 ; k$ ) saying $\mathcal{Q}$ declaring 632 ; with reflexive pronoun 633 ; type thinking him to persever 634 ; comparison of it he thought it true and he thought it to be true 635 ; type enforce thyself for to stand (with for) 636 ; type the hope of mercy to follow 637 ; time-sphere of the infin. in the direct nexus 638 ; voice of idem 639 ; prepositional or plain infin. 640 ; historical note 642 ; comparison with Pres. D. usage 643 .

VERB + (PRO)NOUN + FORM IN -ING .

Type I hear one talking 644 ; type to let a man from going 645.

\section{VERB + (PRO)NOUN + PAST PARTICIPLE .}

Type I saw it done with verbs a) of seeing etc. 645 ; b) of causing 647 ; c) of allowing 648 ; d) of wishing 649 ; e) of thinking $\&$ believing 650 ; f) of saying and declaring 651 ; summary 652 ; type he left the land dispeopled 653 ; type a hope of his estimation preserved 654 ; relative frequency of the three constructions saw it go; saw it going; saw if done 655 .

III.

\section{SYNTACTICAL UNITS WITH THREE VERBS}

\section{DIRECT NEXUS OF THREE VERBS}

\section{THE THIRD VERB IS AN INFINITIVE .}

Auxil. + attend. verb + infin. (e.g. I will assay to show) 658 ; aux. + aux. + infin. (e.g. God may do send it) 659 ; to be + form in -ing tinf. (e.g. he is willing to go) 660 ; to have + past. p. + inf. (e.g. he has desired to go) 661 ; to be + part p. + inf. (e.g. he is forbidden to teach) $662 \mathrm{~A}$; to be + past p. + inf. (e.g. it was laboured to suppress the faith) $662 \mathrm{~B}$.

\section{THE THIRD VERB IS A PAST PARTICIPLE}

Attend. verb + to be + past p. (e.g. he desireth to be comforted) 664 ; aux. + be + past p. (e.g. it shall be seen) 665 ; type he shall be come 665 ; is + to be + past p. (e.g. is to be done) 666-70 ; was + to have + past p. (e.g. I was to have dined with him 671 ; attend. verb + to have + past p. (e.g. he thought to have got it) 672 ; aux. + have + past $p$. (e.g. he would have cried) 673-4; the types have mought go, have would go 675; had have been, had had had 676; is + being + past p. (e.g. it is being built) 677 ; verb + being + past p. (e.g. I hate being helped 678 ; to have + been + past. p. (e.g. It has been seen) 679 ; type he has been come 682 ; having been seen 683 ; to have + past. p. + past p. (e.g. I have heard spoken thereof) 684 ; to be + past p. + past p. (e.g. miracles are told done) 685 .

\section{THE THIRD VERB IS A FORM IN -ING}

Aux. + infin. + form in -ing (e.g. he sall cease writing) 687 ; aux. + be + form in -ing (e.g. they shall be dying) 688 ; to have + been + form in -ing (e.g. they have been going) 689 ; to have + past p. + form in -ing (e.g. he hath forborne doing it) 690 ; to be + past $p$. + form in -ing (e.g. he was heard asking) 691 ; to be + form in -ing + form in -ing (e.g. he was sitting smoking) 692. 


\section{INDIRECT NEXUS OF THREE VERBS}

\section{THE THIRD VERB IS AN INFINITIVE .}

Types we had heard him speak; we shall hear him speak 694 ; type he bade them go whistle 695 ; type he understood them suffered to go 696 .

\section{THE THIRD VERB IS A FORM IN -ING}

Types we had seen him hanging; we shall see him hanging 697 ; type I saw them lying gaping 697.

\section{THE THIRD VERB IS A PAST PARTICIPLE .}

Type they will find their opinions proved 698 ; type what have you heard her told 699 ; type they forbade the book to be read 700 ; comparison of the types I suffered it done and I suffered it to be done 701-2; type $I$ see the gale being opened 703 ; type they are making their influence felt 704; type he thought Picus to have spent time enough 705 ; type they ween themselves to be fallen 705 .

\section{DOUBLE INDIRECT NEXUS}

Type $I$ beseech him to suffer me live 706.

\section{IV.}

\section{SYNTACTICAL UNITS WITH FOUR VERBS}

\section{INDIRECT NEXUS OF FOUR VERBS}

General observation 707 ; types they shall be suffered to preach; they have been suffered to preach; it may serve to seem to prove his purpose; it is to be feared to follow etc. 708 ; type these books are not suffered to be read $709 \mathrm{~A}$; type he was attempted to be won $709 \mathrm{~B}$; type they might have been spared 710 ; type they had conspired to have slain him 711 ; other combinations 712 .

\section{DIRECT NEXUS OF FOUR VERBS}

The (pro)noun stands in the middle.

Types $I$ shall cause it to be written; ye could find your self moved to take it; he will bid us go prove it; he had made them leave off crying; he will suffer no things long lie hid 714 ; type he had heard the door being locked 715 .

The (pro)noun stands between third and fourth verb

Types $I$ would not have suffered him go; they would have had that man burned; it must have hindered him so intending 716.

The (pro)noun stands between first and second verb

Types we believe ourselves to be bounden to do it; they consider themselves to long to be comforted; he affirmeth it to have been done 717 . 
V.

\section{SYNTACTICAL UNITS WITH FIVE VERBS.}

\section{DIRECT NEXUS}

Constructions in which to have occurs twice (e.g. what would it have profited to have done it) 718 ; idem in which to be occurs twice (e.g. it would never be found to be worshipped) 718 ; other types 718 .

\section{INDIRECT NEXUS}

Constructions in which to have occurs twice (e.g. I had heard him to have ben emprisoned 718 ; other types 718 .

\section{VI.}

\section{SYNTACTICAL UNITS WITH SIX AND MORE VERBS}

\section{INDIRECT NEXUS}

Miscellaneous types (e.g. ye might have happed to have been moved ; it would not have failed to have been given; they might be suffered to begin to fall in disputing; he would have looked to have been better to be belived then they) 719 .

\section{DIRECT NEXUS .}

Type I might have happed to have made you wake too soon 719 .

\section{CHRONOLOGICAL RECAPITULATION}

INDEX OF WORDS

INDEX OF GRAMMATICAL TERMS

LIST OF QUOTATIONS FROM ST. THOMAS MORE'S WORKS LIST OF QUOTATIONS FROM SHAKESPEARE'S WORKS . 


\section{BIBLIOGRAPHY}

1637 Jonson, Ben; English Grammar, ed. A. V. Waite, New York 1909.

1859 Marsh, G. P.; Lectures on the Eng. Language. London.

1863 Chuld, F. J.; Observations on the Language of Chaucer. Boston.

1871 Erdmann, A. ; History \& Modern Use of the Verbal Forms in -ing. Uppsala. White, $R$. G.; Words and their Uses. London.

1873 Hall, F.; Modern English. London.

1879 Stoffel, C. ; Der Accusatuv c. Infin. mit for im Eng., Archiv, xoxiii

1881 Hall, F.; On the Origin of had rather go. Am. J. Ph. ii, 7.

Spekker, St.; Ueber die Congruenz des Subjects und des Praed. Bremen.

1882 Blume, $R$.; Die Sprache der Paston Letters. Bremen.

1885 Flamme, J.; Syntax der Blickling Homilies. Bonn.

Matzner, E.; Englische Grammatik w. Berlin.

1886 Koehler, $K$.; Der synt. Gebrauch des Inf. und Partiz. im Beowulf, Muinster. Schuddekopf, A.; Sprache des mi. eng. Gedichtes Will. of Palerne. Gottıngen.

1887 Etnenkel, E.; Streifzuge durch die mi eng. Syntax. Munster.

Nader, E. ; Tempus und Modus im Beowull. Anglia x.

Stoffel, C.; Had rather and Analogous Phrases. Taalstudie viii.

Wandschneider, W. ; Zur Syntax des Verbs in Langley's P. P., Kiel.

1888 Abbott, E. A.; A Shakespearean Grammar. London.

Graef, A.; Das Perfektum bei Chaucer. Diss. Kiel.

Nader, E.; Tempus und Modus im Beowulf. Anglia xı.

1889 Buchtenkirch, E. ; Der synt. Gebrauch des Infin. in Occleve's De Reg. Princ., Jena.

Callaway, M. ; The Absol. Participle in Anglo-Saxon, Baltımore.

Graef, $A$; Die praesentischen Tempora bei Chaucer. Anglia xur.

Hoser, J.; Die synt. Erscheinungen in Be Domes Daege. Halle.

Kuhn, $P$.' J.; Die Syntax des Verbums in Aelfrics Heiligenleben. Leipzig.

Reussner, $H$. A. ; Die Syntax in dem ags. Gedichte vom H. Andreas. Leipzig.

Rohs, A.; Syntaktusche Untersuchungen zu Bacons Essays. Marburg.

1890 Kellner, $L$. ; Introd. to Caxton's Blanchardyn. E. E. T. S. 58.

Pitschel, E.; Zur Syntax des ne. Gedichtes Will. of Palerne. Marburg.

1891 Enenkel, E.; Der Infin. im Mitteleng. Anglia xiv.

Kittredge, G. L.; Observations on the Lang. of Chaucer's Trollus. London. Sommer; Introduction to Malory's Le Morte Darthur. London.

1892 Blackburn, F. A.; The English Future, Its Origin and Development. Leipzig. Franz, W.; Zur Syntax des alteren Neuenglish. Eng. Studien xvi1.

Ross, C. H. ; The Absol. Participle in Middle G Mod. Eng., P. L. M. A. viii.

Storm, $H$.; Englische Philologie. Leipzig.

1893 Franz, W.; Zur Syntax des alteren Neuenglish., Eng. Studien xvin.

Graef, $A$; ; Das Futurum und die Entwicklung von shall und will. Flensburg.

$S$ path, J. $D_{\text {.; }}$ Die Syntax des Verbums in dem ags. Gedicht Daniel. Leipzig.

1894 Baldwin; The Inflections and Syntax of the Morte Darthur. Boston.

Emerson, $O$. ; The History of the English Language. London.

Jespersen, $O^{\prime}$; Progress in Language. London.

Stoffel. C. : Studies in Englush. Zutphen.

Wulfing, E.; Die Syntax in den Werken Alfred des Groszen I. Bonn.

1895 Caro, G.; Zur Lehre vom alteng Perfectum. Anglia xvur.

Dietze,H.; Das umschreibende do in der neueng. Prosa. Jena.

Gorrel; The Indirect Discourse in Anglo-Saxon. P. M. L. A. x.

Morris, $R$. ; Histor. Outlines of Eng. Accidence. London.

Swaen, A. E. H.; To Dare. Eng. Studien xx.

1896 Sarrazin, $G . ;$ ' $I$ dare' als Praeteritum. Eng. Studien xxii.

Smith, $A$. ; Pres. Indic. -s Endings with Plural Subjects. Baltimore.

1897 Deutschbein, $M$; Shakespeare Grammatrk. Cothen.

Jespersen, $O$,; Dare, use and need as Praeterita. Eng. Studien xxui.

Rohde, $E$.; Transitivity in Mod. English. Lund.

Sples, H. ; Studien zur Geschichte des Eng. Pronomens im. xv. Jhr., Halle. 
1898 Barnwell, C.; The Syntax of Bale's Plays. Harvard.

Caro, G. ; Das eng. Perfektum and Preterstum. Anglia xxi.

1899 Dalheimer, V.; Die Sprache Alex. Barclays. Zurich.

1900 Bradley, H. ; Must as a Past Tense, Eng. Studien xxvı.

Tanger, $G$.; 10 be to in Vergleich mut $I$ shall. Archiv. cv.

Schmedt, $E$.; Studres in the Language of Pecock. Uppsala.

Stoffel, C. ; Must in Mod. English. Eng. Studien xxviıl.

Sweet, $H$. ; The History of Language. London.

Zickner; Syntax and Stil in Pecock Repressor. Greifswald.

1901 Blain, H. ; Syntax of the Verb in the A. S. Chron.; Univ. of Virg. Monogr. Callaway, M.; The Apposite Participle in Anglo-Saxon. Mod. Lang. xv1.

Pers; The Apposite Participle in Anglo-Saxon. P. M. L. A. xv1.

Kluge, $F$.; Geschichte der Eng. Sprache. Berlin.

Wulfing, E. ; Die Syntax in den Werken Alfred des Groszen. II. Bonn.

1902 Baumann, I.; Die Sprache der Urkunden aus Yorkshire im 15 Jht. Heidelberg. Farrar, T. J.; The Gerund in Old English. Baltımore.

Fyn v. Draat, $P$. ; The Loss of the Prefux ge -. I , Eng. Studien xoxi.

Moser, $O$; Untersuchungen ueber die Sprache John Bale's. Gottingen.

Nesbitt, $H$. $A$.; The Loss of the Prefis ge -. Eng. Studien xxxi.

Ottmann, $F . J . ;$ Formen und Syntax des Verbs bet Wycliff. Berlin.

Schmidt, Alex.; Shakespeare Lexicon. Berlin.

1903 Dahlstedt, F.; The Wordorder of the Ancren Riwle. Sundsvall.

Fyn v. Draat, P. ; The Loss of the Prefix ge - II ; Eng. Studien xxxui.

Pollard, $A$. W. ; Introd. to Fiftheenth Cent. Prose and Verse. London.

Shearın, H. G. ; The Expression of Purpose in O. E. Prose. Yale Studies xvii.

Staden, W. $v_{.}$; Entwicklung der Praes. Indic. Endungen in Eng. , Rostock.

Sweet, $H$.; A New English Grammar. Oxford.

Unna, J. ; Die Sprache J Heywoods Berlin.

1904 Boerner, $D$.; Die Sprache Rob. Mannyngs of Brunne. Halle.

Bradley, H.; The Making of English. London.

Einenkel, E.; Einige Fragen aus der Eng. Hist. Syntax. Halle.

Graf, W. v. d.; The Transition from the Impers. to the Pers. Construction. Heidelberg.

1905 Ebisch; Zur Syntax des Verbums im a.e. Gedicht Eule \& N. ; Leipzig.

Onions, C. T.; An Advanced English Grammar. London.

Sussbier, K.; Sprache der Cely Yapers. Berlm.

Willert, $H$. ; Vom Gerundum. Eng. Studien xxxii.

1906 Lange, H.; Das Zeitwort in den beiden Hss. von Layamon's Brut. Berlin. Redepenning, E. ; Synt. Kapitel aus der Ancren Riwle. Rostock.

Robertson, W. A. ; Tempus and Modus in der alteng Chronk. Marburg.

1907 Ginneken, J. v.; Principes de Linguistique Psychologique. Amsterdam. Grainger, J. M. ; Studies in the Syntax of the King James Version; Stud. in Phul. II.

Kaluza, M., Hist. Grammatık der Eng. Sprache Berlın

Kruger, G.; Die partızıpıale Gerundial-fugung. Eng. Studien xxxvir.

Schmidt, $H$.; Syntax der Wycliffe-Purveyschen Uebersetzung. Anglia xxx.

1908 Bodtker, $A$. T., Contributions to Early English Syntax. Christiania.

Borst, E.; Pro-Infintive. Eng. Studien xxxix.

Puttmann, A.; Die Synt. der sog. Progr. Form in Alt und Mr. Eng.;

Anglia xxxi.

Rossmann, B. ; Zum Gebrauch der Modi im Fruhme.; Kiel.

Schmidt, $l . ;$ Clrammatik der Eng Sprache. Berlin

Scholz, E. ; Der absol. Infun. bei Shakespeare. Berlin.

Zettlin, $]$.; The Acc. + Inf. and Some Kindred Constructions. New York.

Vocht; Das Adjectiv bei Christopher Marlowe. Berlin.

1909 Ellinger, J.; Das partız. pras. in gerundialer Verwendung. Eng. Studien xxxv1.

Ellinger, j.; Vermischte Beitrage z Syntax des neueren Eng., Leipzig.

Grunziger, $M$. ; Die neueng. Schriftspr. in d. Werken des Th. Morus. Freiburg.

Hoffmann, F. ; Das Partizipium bei Spenser. Berlin.

Kenyon, J. S.; The Syntax of the Infin. in Chaucer. Oxford. 
Krapp, G. P.; Mod. English. Its Growth and Present Use. New York. Riggert; Der synt. Gebrauch des Infunttivs in der alteng. Poesie. Kiel.

Stoet, F. A.; Middelnederlandsche Spraakkunst, Syntaxis. 's-Gravenhage. Wolff, A.; Zur Syntax des Verbums im a.e. Lay of Havelok. Berlin.

1910 Druve, H.; Der absol. Infin. in den Dramen der Vorganger Shakesp., Kiel. Ellinger, J.; Gerundium, Infin. und that - Satz. Anglia xxuiii.

Emerson, O. F. ; A Brief History of the Eng. Lang. New-York.

Fun $v$. Draat P.; Rhythm. in English Prose. Heidelberg.

Jespersen, $O$.; For + Subject + Infinitive. Vietors Festschr. Marburg.

Owen, E. T.; The Relations Expressed by the Passive Voice. Wisconsin.

Rhyne, O. P.; Conjuction + Parilic. group in English. Stud in Phil Carolina. Zenke, W. ; Synthesis und Anal. des Verb. im Orrmulum. St. z. Eng. Phil. xv.

1911 Akerlund, A.; On the History of the Definite Tenses in English. Lund.

Bradley, C. B. ; Shall \& Will ; an Hist. Study. Trans. Proc. Am. Phil. Soc. xvii. Gerıcke, F. ; Das Partizipium Prasentıs bei Chaucer. Kiel.

Knecht, J.; Die Kongruenz zwischen Subj. und Pradikat im Elis. Engl., Heidelberg.

Smith, Reed; Partıcıple and Infın.; Bull. Unıv. South Carolina xxvii.

Walker, F. C. ; Syntax of the Infin. in Shakespeare Harvard.

Wendt, $G_{r}$; Syntax des heutigen English I. Heidelberg.

Willert, $H$.; Vom Infın. mit to. Eng. Studien xhii.

Zettlin, J. ; For + Subject + Infinitive. J. E. G. Ph. x.

1912 Courmont, Studies on Lydgate's Syntax in the Temple of Glas. Paris.

Curme, G. O.; History of the Eng. Gerund. Eng. Studien xlv.

Eichhorn; Das Partizipium bei Gower. Kiel.

Gaaf, W. v. d.; The Origin of woud rather. Eng. Studien xlv.

Kern, J. H. ; De met het Part. Praet. omschreven werhwoordsvormen. A'dam.

Nesfield, J. C. ; Modern Englush Grammar. London.

1913 Callaway, M. ; The Infinitive in Anglo-Saxon. Washington.

Curme, G. O. ; Development of the Prog. Form in Germanic. P. L. M. A. xxvii.

Kittred and Farley; An Advanced Eng. Grammar. Boston.

Kellner, L.; Hist. Outlines of English Syntax. London.

Lichtsinn, P. ; Der synt. Gebrauch des Infin. in Layamons Brut. Kiel.

1914 Akerlund : A Word on the Passive Definite Tenses. Eng. Studien xIvii.

Bergeder; Die periphrastusche Form des Eng. Verbums in 17. Jht. Halle.

Delcourt, J.; Essas sur la Langue de Sir Th. More. Paris.

Einenkel, E.; Zur Herkunft des eng. Gerundiums. Anglia xxxvii.

Einenkel, E.; Die Entwicklung des eng. Gerundrums. Anglia xxxviu.

Huttmann; Das Partız. Praes. ber Lydgate. Kiel.

Poutsma, H. ; A Grammar of Late Modern Eng. II Sect. I A. Groningen.

Preussler, W. ; Syntax im Poema Morale. Breslau.

Sanders; Die synt. Gebrauch der Infin. im Fruhneueng. Heidelberg.

Wendt, G. ; Syntax des heutigen English Il. Heidelberg.

1915 Emenkel, E.; Die Entwicklung des eng. Gerundiums. Anglia xxxix.

Hasselhoff; Das Verbum substantivum im Fruhne. Munchen.

Marınoff, $V$.; Die periphr. Form des eng. Verbums. Halle.

Royster, J. F. ; The do-Auxulary (1400-1450). Mo. Philol. xu.

Stoelke, $H$.; Die Incongruence zwischen Subj. und Praed.; Ang. Forsch. 49 Heidelberg.

1916 Ennenkel E.; Gesch. der Eng. Sprache; II Hist. Synt. 3rd ed. Strassburg. Dubislav, G. ; Studien zur mitieleng Syntax I, II. Angla xL.

Poutsma, H. ; A Grammar of Late Modern English II. Sect. I B. Groningen.

Royster, ]. F. ; Lydgate's Use of the to do Auxlliary. Stud in Philol. xw.

Steadman, J. M. ; The Origin of the Hist. Present in English. Chicago.

1917 Aronstein, Ph.; Shall \& Will zum Ausdruck der Idealitat. Anglia xli.

Kruger, G. : Schwierigkeiten des Eng. ; II Syntax. Dresden.

1918 Aronstein, Ph. ; Die perıphrastısche Form im engl. ; Anglia xlii.

Gaaf, W. v.d.; Three Remarkable Infinitives. Neophilologus ini.

Moore, $S$.; Robert Mannyng's Use of do as Auxiliary. M. Lang. N. xxxiii.

Zitting, $O$.; Das Hilfsverb do im Mittelenglischen. Halle. 
1919 Klaussmann, G.; Syntax des Verbums in der Froissart Uebersetzung. Greifswald.

Poutsma, H. ; Participles. English Studies i.

1920 Brink, B. ten; Chaucers Sprache und Versbau. Leipzig.

Kruisinga, E.; A Rival of the Object-Infin. Construction. Eng. Studies ii. Paul H.; Prinzipien der Sprachgeschichte. 5te Auflage. Halle.

1921 Bryan, W. F.; The Midland Pres. Pl. Ind. Ending-e(n). M. P. xviii. Dubislav, G.; Studien zur mitteleng. Syntax. III, IV. Anglia xli. Juhl, $H$.; Der synt. Gebrauch des Infin. bei Lydgate. Kiel.

Kruisinga, E.; The Aspects of the Infin. and Participle. Eng. Studies iii 2. Sapir, Edw. ; Language. New York.

Sommer, F. S.; Vergleichende Syntax der Schulsprachen. Leipzig.

1922 Boer, C. de; Essays de syntaxe française moderne. Groningen.

Brunot, F. ; La Pensée et la Langue. Paris.

Funke, $O . ;$ Die Fügung ginnan mit dem Infin. im Mitteleng. Eng. Studien lvi. Kruisinga, E.; The Norminative-Infin. and Participle. Eng. Studies iv. 1. Laan, J.v. d.; An Inquiry into the Use of the Progr. Form. Gorichem.

Royster, J. F.; Old Eng. Causative Verbs. Stud. in Phil. xix.

Wyld, H. C. ; A History of Modern Colloquial English. London.

1923 Curme, G. O.; The Proper Subject of the Passive Verb. M. Lang. N. xxviii. Hittmair, $R$.; Das Zeitwort do in Chaucer's Prosa. Wiener Beiträge. li. Huchon, $R$.; Histoire de la Langue anglaise I. Paris.

Jespersen, $O$.; Growth and Structure of the Eng. Language. Leipzig.

Steadman, ].; The going to Future. Manly Ann. Studies. Chicago.

Wright, $J$. $\dot{\mathcal{E}}$ E. ; An Elementary Middle Eng. Grammar. London.

1924 Behagel, O. ; Deutsche Syntax. Leipzig.

Franz, W.; Shakespeare Grammatik. Srd ed. Heidelberg.

Jespersen, $O$.: The Philosophy of Grammar. London.

Palmer, $H$. ; A Grammar of Spoken English. Cambridge.

Pompen, A.; Over Verbal Nouns. Tijdschr. De Drie Talen, Feestbundel 1924. Roloff: Das Praesens Historicum im Mitteleng. Giesen.

Wyld, H. C. ; A Short History of English. 4th ed. London.

1925 Fries, C. C.; The Periphr. Future with shall and will. P. M. L. A. xl. Grattan and Gurrey; Our Living Language. London.

Kruisinga, E. ; Indirect Object and Dativus Commodi. Eng. Studies vii. Langenhore, Ch. v.; On the Origin of the Gerund in English. Gand.

1928 Biorling, A. ; Studien in the Gramm. of the Early Printed Eng. Bible Versions. Lund.

Fowler, H.W. ; A Dictionary of Modern English Usage. Oxford.

Kihlbohm, A.; A Contrib. to the Study of xv Century English. Uppsala.

Poutsma, $H$.; A Grammar of Late Modern English II, sect. III. Groningen.

1927 Fries, C. C.; The Expression of the Future. Language 2.

Gebhardt; Die Progressive Form bei Shakespeare. Marburg.

Kruisinga, E.; Retained Accusatives in Passive Sentences. Eng. Studies ix. 2.

1928 Fischer, F.; Die Syntax des Reimchroniks des Rob. von Gloucester. Wien.

Gaaf, $W . v$. $d$.; The Gerund Preceded by the Common Case. Eng. Stud. $x, 2,3$.

Gaaf, W. v. d.; The Predicative Passive Infinitive. Eng. Studies $x, 4$.

Gaaf, W. v. d. ; The-Post-adjectival Passive Infinitive. Eng. Studies $x, 5$.

Jespersen, O.; Modern English Grammar II. 3rd ed. Heidelberg.

Jespersen. O.; Modern English Grammar III. Heidelberg.

Karpf, F., Prepositional Accusative and Plain Infinitive. Eng. Studies. x, 1.

Overdiep, G. S.; Moderne Nederlandsche Grammatica. Zwolle.

Poutsma, H.; A Grammar of Late Mod. Engl.. I, 1st half, 2nd ed. Groningen

Wijk, N. v. ; 'Aspect' en 'Aktionsart'. De Nieuwe Taalgids xxii, p. 225.

1929 Frazy, L. G.; Studies in the Syntax of the Old Eng. Passive. Baltimore.

Gaaf, W. v. d. ; Conversion of the Indir. Object. into the Subj. of a Pass.

Constr.; Eng. Studies xi.

Gauger, $H$.; Die Umschreibung von have und be. Ztsch. f. fr. G e. Unt. xxviii. Irvine, $A$; The Participle in Wycliffe. Univ. of Texas St. in Eng. ix.

Koschmieder, E.; Zeitbezug und Sprache. Leipzig. 
Kruisinga, E.; Synt. Groups with the Aux. to have. Eng. Studies xi, 1. Mc. Knight, G.; Modern English in the Making. London.

Meer, H. J. v. d. ; Main Facts Conc. the Syntax of Mandev.'s Travels. A'dam. Poutsma, H. ; A Grammar of Late Mod. Eng. I, 2nd half, 2nd ed. Groningen. Taft, $A$. S. ; Introduction to More's Apology. E. E. T. S. no. 180.

1930 Brusendorff, $A$. ; The Relat. Aspect of the Verb. Miscell. to Jespersen. Copenhagen.

Curme G. O.; The Gerund Preceded by the Common Case. Eng. Studies xii, 3, 5.

Gaaf, W. v.d.; The Passive of a Verb Accompanied by a Preposition. Eng. Studies xii.

Gaaf, W. v. d. ; The Gerund Preceded by the Common Case. Eng. Studies xii. Gaaf, W. v. d. ; Some Notes on the Hist. of the Progr. Form. Neophilogus xv. Helming ; The Absolute Participle in the Apollonius of Tyre. M. Lang. N.xlv. Huchon, $R$.; Histoire de la langue anglaise II. Paris.

Karpf, $F$.; Studien zus Syntax in den Werken Chaucers. Leipzig.

Kruisinga, E. ; Syntactic Groups with Verbal -ing. Eng. Studies xii. 1, 2, 3. Rowe F. J. \& $W e b b, W . T$. ; A Guide to the Study of English. London.

Trnka, B.; On the Syntax of the Eng. Verb. from Caxton to Dryden. Prague. Wiencke, $H$.; Die Sprache Caxtone. Leipzig.

1931 Bock, H.; Studien zum praepos. Infinitiv, und Akk. Anglia Iv, 1.

Curme G. O.; A Grammar of the English Language III Syntax. London.

Chambers $R$. W. Q Daunt $M$.; A Book of London English ; 1384-1425. Oxford.

Deutschbein, M. ; System der neueng. Syntax. Leipzig.

Gaaf, W. v. d., Beon and habban + Infinitive. Eng. Studies xiii.

Gerike, F. ; Das Partiz. Praes. bei Chaucer. Kiel.

Ginneken, J. v.; Grondbeg. v. d. Schrijfwijze der Ned. Taal. Hilversum.

Karpf, F. ; Studien zur Syntax in den Werken Chaucers. Wiener Beitr. lv.

Kruisinga, E.; A Handbook of Pres. D. English II. 1. 5th ed. Groningen.

1932 Dekker, A.; Some Facts Conc. the Synt. of Malory's Morte D., Amsterdam. Ellinger, $J$.; Das Pronomen it als formales Object. Anglia Beibl. July. Goedsche, C. $R$; The Terminative Aspect of the Expanded Form.

J. E. G. Ph. xxoxi.

Jespersen, O.; Modern English Grammar IV. Heidelberg.

Koziol, $H$.; Grundzüge der Synt. der mitteleng. Stabreimdichtungen. Wien.

Kruisinga, E.; A Handbook of Pres. D. Eng. II, 2, 3, 5th ed. Groningen.

Schönfeld, M.; Hist. Grammatica v. h. Nederlandsch. Zutphen.

Zandvoort, $W . ;$ On the Perfect of Experience. Eng. Studies xiv. 1.

1933 Curme, G. O.; A Grammar, etc. See 1931.

Deutschbein, M.; Grammatik der Eng. Sprache. Leipzig.

Jespersen, O.; Essentials of English Grammar. London.

Koziol, $H$. ; Das emphatische Praesens-pro-Future. Eng. Studien lxviii.

Langenfelt, L.; Sel. Stud. in Colloq. Eng. of the Late Middle Ages. Lund.

Murray, J. A. H. ; etc. ; The Oxford English Dictionary. Oxford.

1934 Callaway, M. Jr.; The Consecutive Subjunctive in Old English. Boston. Deter, H. ; Alte Partizipia auf -en, -ed und -ate. Münster.

Ross, A. ; The Origin of the -s Endings in the Pres. Indic.; J. E. G. Ph. xxxiii.

1935 Baugh, $A$. C.; A History of the English Language. London.

Bloomfield, $L$.; Language. New York.

Curme, O. ; A Grammar of the Eng. Lang. II. Boston.

Hittmair, $R$; Zu den Aktionsarten im Mitteleng. Eng. Studien lxx, 1.

Jespersen, $O$. ; Growth and Structure of the Eng. Language. Oxford.

Koziol, $H$. ; Bemerkungen z. Gebrauch einiger Zeitformen. Eng. Studien lox, 1. Mirowitz, A.; Die Aspektfrage im Gotischen. Wilno.

Muir, L.; Influence of the Rolle \& Wyclif Psalters. M. Lang. N. xxx. 3.

Russell, J. W.; The Dangling Participle. Amer. Sp. x.

Volbeda, $R$.; The Definite Forms. Neophilologus $x^{2}, 3.4$.

Zipf, G. K. ; The Psycho-Biology of Language. London.

1936 Bryan, W. . $_{\text {; }}$ The Preterite and the Perfect Tense. J. E. G. Phil. xxxv. 3. $D^{\prime}$ Ardenne, $S$.; Introd. to Liflade of St. Iuliene. Liège. 
Koziol, H. ; Die Entwicklung der Umschreibung mit to do. Germ. R. M. xxiv. Robertson, Stuart; The Development of Modern English. London.

Sugden, $H$. W. ; The Grammar of Spenser's Fairie Q. ; Philadelphia.

1937 Bodelsen, $C$. A.; The Expanded Tenses in Mod. Eng. ; Eng. Studien lxi, 2. Jespersen, $O$.; Analytic Syntax. London.

Klingebiel, J.; Die Passivumschreibungen im Altenglischen. Berlin.

Meyer, K. $H_{\text {.; }}$; on : Mirowicz, Die Aspektfrage. Indog. Forsch. Lv. 2.

1938 Bazell, C. B. B. ; On Form and Function. J. E. G. Phil. xxoxvii. 3.

Buchholz, E.; Das Verbum Substantivum im Mitteleng.; Berlin.

Engblom, V.; On the Origin of the Auxiliary to do. Lund.

Funke, O.; William Bullokars Bref Grammar For English. Anglia lxii.

Gehse, H. ; Die Kontamination in der eng. Syntax, Breslau.

Koziol, $H$.; Zur Synt. der eng. Urkundensprache des 14. und 15. Jht.

Anglia Lxii.

Knorrek, $M$. ; Der Einflusz des Rationalismus auf die eng. Sprache. Breslau. Mossé, F.; Hist. de la Forme périphr. être + part. pres.; Paris.

1939 Deutschbein, M. ; Aspekte und Aktionsarten im Neueng. ; Neuphil. Mts. x, 4. Satchell, Th. ; Expanded Tenses. Eng. Studies xxi, 5. 
THE EDITIONS OF ST. TH. MORE'S WORKS, FROM WHICH THE QUOTATIONS HAVE BEEN TAKEN.

\begin{tabular}{|c|c|c|}
\hline TITLES & EDITIONS & $\underset{\text { AS }}{\text { QUOTED }}$ \\
\hline $\begin{array}{l}\text { A Mery Jest } \\
\text { Nyne Pageauntes } \\
\text { A Ruful Lamentation } \\
\text { Certain Meters... For the Boke of F. } \\
\text { The Lyfe of Jhon Picus } \\
\text { The History of Kyng Richard the Third } \\
\text { A Treatice Vppon The Four Last Things } \\
\text { A Dialogue Concerning Heresies } \\
\text { The Supplication of Soules } \\
\text { The Confutation of Tindales Answere } \\
\text { The Aunswere to Frithes Letter } \\
\text { The Debellacion of Salem G Byzance. } \\
\text { The Answer to The Poysoned Booke } \\
\text { A Treatise to Receyue the Bless. Body } \\
\text { A Treatice Vppon the Passion } \\
\text { A Godly Instruction } \\
\text { A Godly Meditation } \\
\text { A Devout Prayour } \\
\text { Certen Letters } \\
\text { The Apologye Of Sir Thomas More } \\
\text { A Dialogue Of Comforte } \\
\text { Autograph Letters }\end{array}$ & 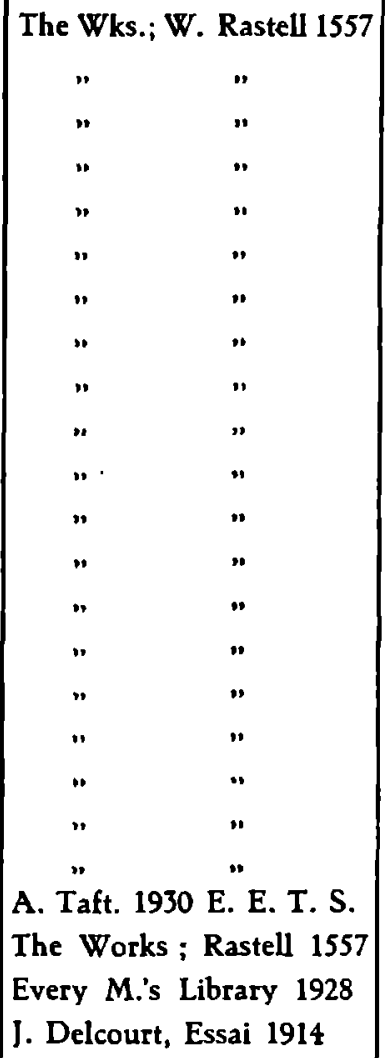 & $\begin{array}{l}\text { Jest } \\
\text { Pageants } \\
\text { Lament. } \\
\text { Boke of F. } \\
\text { Picus } \\
\text { Rich. } \\
\text { Last Th. } \\
\text { Dial. Her. } \\
\text { Supplic. } \\
\text { Conf. Tynd. } \\
\text { Lett. Fryth } \\
\text { Debell. } \\
\text { Answer } \\
\text { Bless. B. } \\
\text { Passion } \\
\text { Instr. } \\
\text { Med. } \\
\text { Prayer } \\
\text { Lett. } \\
\text { Apol. (Wks.) } \\
\text { Apol. } \\
\text { Dial. C. (Wks.) } \\
\text { Dial. C. } \\
\text { Aut. L. }\end{array}$ \\
\hline
\end{tabular}




\section{ABBREVIATIONS}

(Among the writers on syntactical subjects to whom I am indebted for illustrative evidence of earlier and later usage, there are a few on whom I have too often drawn for repeated acknowledgments to be practicable. Their names are given below with the abbreviations by which the quotations are designated. For full titles see the Bibliography).

B. = Buchtenkirch, E. 1889.

Co. = Courmont, A. 1912 .

C. = Curme, G. O. 1931.

D. = Dekker, A. 1932 .

De. = Deutschbein, M. 1931 .

Di. = Dietze, H. 1895.

E. = Einenkel, E. 1916.

En. = Engblom, V. 1938.

F. = Franz, W. 1924 .

G. = Gaaf, W. v. d. 1904 etc.

Ge. = Graaf, A. 1888/9.

Gz. = Grünziger, 1909.

H. = Hüttmann, 1914 .

Hi. = Hittmair, R. 1923.

J. $=$ Jespersen, $O$. 1928/32.
K. = Kenyon, J. S. 1909.

Kl. = Kellner, L. 1890/1913.

Kla. = Klausman, 1919.

Ko. $=$ Koziol, H. 1932/5/6.

Kr. = Kruisinga, E. 1931/2.

L. = Lichtsinn, P. 1913.

M. = Meer, H. J. v. d. 1929.

Mo. $=$ Mossé, F. 1938.

P. = Poutsma, H. 1914 etc.

Pr. = Preussler, W. 1914.

R. = Redepenning, E. 1906.

S. = Sugden, H. W. 1936.

T. = Irnka, B. 1930.

W. = Weyl, R. E. L. 1937.

Z. = Zickner 1900 .

OED $=$ Oxford English Dictionary.

\section{ERRATA}

p. 1 1. 8 from bottom. For beasted read beastes.

p. 2 1. 2 . For Rich. read Last $T h$

p. 2 l. $2 . \quad$ For vagraunt mind read vagaraunte minde.

p. 4 1. 18 from bottom. For 9 read 8.

p. 7 l. 13 . Insert with between stand and your.

p. 28 1. 10 from bottom. For ennnuy read enemye.

p. 28.

p. 29.

p. 41 1. 8 . Dele 11.1 and 2 from bottom.

Dele 11. 1-6.

For Dial. Her. read Dial. C.

p. 42 I. 14 from bottom. For occured read occurred.

p. 42 1. 12 from bottom. For first read last.

p. 45 l. $19 / 20$.

p. 51 i. 7.

p. 53 Footnote.

p. 69 1. 1 .

p. 76 l. 12 .

p. 92 1. 14.

p. 93 Running title.

Dele from Apol. 82 to Apol. 104.

Insert do not between verbs and seem.

For nor read mo.

For ione read ioine.

For occurence read occurrence.

For conuyte read conuyct.

For subjective read objective.

p. 97 1. 15 from bottom. For look; at to read look at; to.

p. 120 1. 19 from bottom. For oft hem read of them.

p. 149.

Dele 11. 9-12.

p. 153 1. 7 from bottom. For so read se.

p. 155 1. 16 .

p. 218 i. 3.

p. 340 l. 4 .

Insert a between lose and good.

For PREPOSITIONAL read INDIRECT.

p. 433 1. 14 from bottom. For conversing read conversion. 


\section{PRELIMINARY NOTE}

1. Owing to the strong analytical tendency of English, leading to the morphological levelling of different parts of speech, a verb can in many cases be distinguished from other kinds of words only by its function in a syntactical unit. As this cannot always be done without arbitrariness, a few doubtful cases will be discussed first.

2. The following kinds of words have not been looked upon as verbs and have consequently been excluded from this study :

a. parasynthetic formations.

Last Th. 96 G 7, gorebelyed glotony. | Rich. $57 \mathrm{D}$ 12, she is now in the more beggerly condicion, onfrended and worne out of acquaintance. | Rich. $62 \mathrm{C} \mathrm{12,} \mathrm{harde} \mathrm{hearted.} \mathrm{|} \mathrm{Dial.} \mathrm{G.} \mathrm{344,} \mathrm{fieble} \mathrm{faythed} \mathrm{folke.} \mathrm{|} \mathrm{Conl.}$ Tynd. 736 G 5, asseheded. | Bless. Body 1272 G 14, sylver buttened. Last Th. $92 \mathrm{E} \mathrm{12,} \mathrm{highe} \mathrm{harted.|} \mathrm{Last} \mathrm{Th.} 73$ A 2, daynty stomaked| Rich. 37 C 8, ill fetured | Dial. C. 152, meane wytted men. | Rich. 37 D 3, hee came into the world with his feele forwarde ... and also not ontothed. | Apol. (Wks.) 1072 G 15, styffenecked.

b. nouns or adjectives $+-e d$.

Rich. 57 A 10, visaged. | Dial. Her. 201 B 1, wilted men. | Last Th. 77 $\mathrm{C} 12$, the wretched affeccions of the body. | Last Th. $93 \mathrm{D} \mathrm{10}$, his hed hanging in his bosom and his body croked. | Rich. $71 \mathrm{E} \mathrm{1,} \mathrm{horned}$ beasted.

c. words like fall, cure ${ }^{1}$ ), preceded by an adnominal word [a, the, his, etc.].

Dial. C. 139, to be preserued from the fal in temptacion. | Dial. C. 134, the care of that persone is in a maner desperate.

$d$. original past participles no longer realized to be such.

Dial. Her. 246 F 1, sicke folke often have such a corrupt tallage. | Rich. 67 E 7, suspect. | Conf. Tynd. 525 F 2, elect.

1) The use of the vicarious to do in the following quotation shows the strongly pronounced verbal character of words of this kind : Conf. Tynd. 430 C 11, So hath he ... taughte them holye ceremonies to be rsed about hys blessed sacramentes ... to the encrease of christen mennes deuocion, as in dede it doeth what goeuer Tyndall bable. 
e. original present participles ending in -ant,-aunt,-ent, etc.

Rich. 76 D 13, a cagraunt minde. | Dial. C. 198, wee may fynde that eyther of them is incydente in to the olher. | Dial. Her. $147 \mathrm{~B} \mathrm{5,} \mathrm{[Christ]}$ wyll hee to the worldes end present and assistent. | Dial. C. 128, whiche wee moore feare then all the remenaunt. | Dial. C. 222, then shal he he thereby so specially participant of Gods passion. I Picus 3 D 5, Now had he ben .vir. yere conuersant in these studies. | Conf. Tynd. $583 \mathrm{G} \mathrm{3}$, Manne can not tourne vnto him without ... concurraunte helpe of goddes especial grace.

f. words like marriage, reimpression, deliverye (" nouns of action $)$ ).

Rich. 59 C. 13, The only widowhed of Elisabelh Gray tlough she wer in al olber things conuenient for you, shold yet suffice as me semeth to refrain you from her mariage ').

g. words ending in -ing that are clearly thing-words (doubtful cases will be discussed).

Dial. Her. 135 \& 10 , [they] wer fain to throw their offring ouer their felowes heddes for prease. | Payeants (tille), Mayster Thomas More in his youth deuysed in hys father's house ... a goodly hangyng of lyue paynted clothe.

3. The following kinds of words have been included as verbs.

a. original past participles ending in -ate, -at.

Jial. Her. $137 \mathrm{~B} \mathrm{9,} \mathrm{the} \mathrm{general} \mathrm{consails} \mathrm{...,} \mathrm{comprobate} \mathrm{and} \mathrm{corrobo-}$ rate by the whole body of christendom. | Lett. to P. Giles, not studied for, but sudden and unpremeditate. I Dial. Hor. $134 \mathrm{H} \mathrm{15}$, she was hnuseled in sight of the people with an host onconsecrate. | Dial. Her. 124 D 1 , [it is] wel knowen that the worship of saints and ymagrs ben alowed, approbate, \& accustomel for good ... vertues. | Dial. Her. 121 D 10, holy places, not by enchauntement dedical to the deuill, but by goddys ordynaunce ... consecrated vnto him self. | Dial. C. 345 , satiale. P'icus 18 F 6, if the world were adnihilate.

$b$. original past participles ending in -it, -ute.

Rich. $52 \mathrm{G} \mathrm{14,} \mathrm{there} \mathrm{were} \mathrm{adhibit} \mathrm{very} \mathrm{lew.} \mathrm{|} \mathrm{Dial.} \mathrm{Her.} 161$ D 13, saturdaye, which was the sabbaoth day institute by God among the

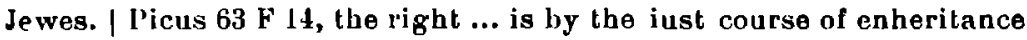
... deuolute and comen vnto the most excellent prince.

c. past participles like contract, infect.

Rich. 40 G 5, kindness sodainely contract. | Last Th. 80 B 1, many a man is infect with the great sicknes.

1) $\mathrm{Her}$ is the object of the (noun) marriage; the meaning is : to refrain you from marrying her. 


\section{I. - SYNTACTICAL UNITS WITH ONE VERB}

4. Under the lerm "syntactical unit " are comprised : sentences, clauses, clause equivalents, free adjuncts, participial and infinitive constructions, elliptic sentences, etc. According to the number of verbal forms occurring in these units, they are called : syntactical units with one verb, syntactical units with two verbs, syntaclical units with three verbs, and so on, and are consequently dealt with in this order.

The paragraphs on syntactical units with one verb not only contain a discussion of the functions and meanings of the infinitive, present tense, preterite, past participle and form in -ing, but also deal with the various ways of combining the verb with its subject and its objects.

\section{VERB AND SUBJECT}

5. As in earlier and in later usage, the subject in More's language is expressed in various ways, viz., by nouns, pronouns, syntactical units, etc. A few instances will suffice :

noun. Rich. $71 \mathrm{E} 2$, What fole q[uotb] the fox thou maist abide wel inough, the lyon ment not by thee.

pronoun. Dial. C. 151, they agree together in profession of Christes name.

for + noun (preceding an infinitive). Picus 5 B 13, it were not possible for a man to vttre ... more conning.

syntactical unit (simple or compound). Last Th. $98 \mathrm{G} 15$, to tell is ... the wordes of holy wrylte, is but a dul profe. | Dial. C. 218, comforting of her could haue no place. | Dial. C. 163, that god gaue him here in this world all thynge double that he lost, litle toucheth mi mater.

\section{IT AS SUBject}

6. To denote the different kinds of $i t$, the following terms will be used :

the conceptional (= the unspecifled, notional) $I T$, as in : it rains ;

the concrete IT (referring to a previously mentioned thing or being); 
the summarizing it (referring to the conlents of a preceding syntactical unit);

IT in the emplasizing formula it is my father who;

the proleptic it (developed in a following syntactical unit, as in : Dial. Her. $251 \mathrm{~A} l$, it is no meruail though his vife be well teeming).

\section{The conceptional it as subject.}

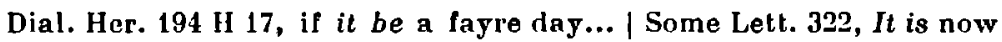
my good doughter late. | Dial. Her. 157 A 2, they knew whan it was time. | Dial. C. 157, it is but earely dayes. | Dial. C. 218, ere it was very long after, she hong her selfe.

Aut. Lett. xxı, 20, beseching the kinges highnes ... how so euer it shold happe to fall betwene hym and Spayne yit to considre his auncient amite. Jest p. 3 F 4 , It hath with me, Bene betler than it is. I Dial. G. 236, Thus fareth it in this temptacion. | Dial. C. 255, here would it fare by the poore man, as it fared by the woman in one of Esopes fables. | Picus $13 \mathrm{C}_{4} 4$, it is written : In what measure that ye mete, it shalbe mette you again. | Picus I F 1, which workes I wolde require you gladly to receiue: ne were $i t$, that they be such, that ... | Rich. 64 D 2, were it for wonder or feare ... : not one word was there answered.| Rich. 37 B 13, whose death Kyng Edwarde (al be it he commanded it)... pitiously bewailed.

The same usage before and after More; ne were it, were it, it fareth are obsolete now.

\section{The conchete it as subject.}

Last Th. $85 \mathrm{~B} 1$, enuy where it may ouer, doth al ye hurte it can. I Dial. Her. 126 (Margin) ${ }^{1}$ ), Glasse and wherol it is made. | Aut. Lelt. 1x, 11 , as towching the veneson ... he was very gladde that hit lyked yor grace so well.

This pronoun it has an anaphoric function and usually refers to non-personal nouns. That it may also refer to persons is proved by the following instances :

Dial. Her. $131 \mathrm{H} \mathrm{7,} \mathrm{she} \mathrm{was} \mathrm{...} \mathrm{delyvered} \mathrm{of} \mathrm{a} \mathrm{fayre} \mathrm{boy} \mathrm{\&} \mathrm{forsoth} \mathrm{it}$ was not than ... passing the length of a fote. | Dial. Her. 166 G 5 , Nowe quod I this man that god byddeth you go to, ... will it make any chaunge ... whether it be man or woman? | Answer 1130 B 9, maister Masker ... make as many straunge faces ... as it were an olde riueled ape.

In the last quotation Pres. D. Eng. would prefer he, since the nominal predicate has a descriptive rather than an identifying function. In the following quotation there, instead of $i t$, would perhaps be used now :

1) The marginal relerences are probably by Rastell. 
Dial. Her. $167 \mathrm{H} \mathrm{10,} \mathrm{if} \mathrm{any} \mathrm{woulde} \mathrm{after} \mathrm{take} \mathrm{the} \mathrm{contrary} \mathrm{waye,} \mathrm{were}$ it one or mo, were it fewe or many ... yet can I nothing doubte which parte to beleue.

He refers to a thing in : Apol. 149, For amendes the law geueth him none against any of theym, nor it wer not well done he sholde. Debell. $979 \mathrm{D} 13$, their othe shall not be what hee is in dede, but what themselfe thinke of hys othe.

9. The summariziva it as subject.

it booted. Rich. $44 \mathrm{~F} \mathrm{4,} \mathrm{at} \mathrm{whiche} \mathrm{dealinge} \mathrm{he} \mathrm{wepte...} \mathrm{but} \mathrm{it} \mathrm{booted} \mathrm{not.}$ it forceth. Dial. Her. $130 \mathrm{~F} \mathrm{4,} \mathrm{Whyther} \mathrm{they} \mathrm{be} \mathrm{miracles,} \mathrm{...} \mathrm{or} \mathrm{mer-}$ uayls ..., it forceth not for this purpose of ours. | Dial. Her. 215, $G$ 14, no man can tell who nor whither: it forceth not for our wyse case.

it liketh me. Hich. 59 F 9, I mary where it liketh me

it pleased them. Hich. $42 \mathrm{~F} 1$, they sente awaie... whom it pleased them it were a token. Dial. C. 220, It he wcre founden of the first fashion, it were a token that the dyuel hath puffed him vp.

it is to your pain. Pageants, Deth 1. 6, Witsafe to sende (though it be to your payne) lo me a fole, some of your wise brayne.

Here, just as in the preceding section, the pronoun it is anaphoric : it refers back to the preceding syntactical unit, the contents of which it repeats or summarizes in condensed form. 'The two syntactical units may also, however, be joined without the summarizing pronoun :

Dial. C 163, that god gaue him liere in this world all thynge double tbat he lost, little toucheth mi mater.

The use or omission of it seems to have been arbitrary, perhaps to the same extent as it is in Pres. D. Eng., where the two constructions occur side by side, though the construction with $i t$ seems to be the more usual one now. Compare : Pilot 1905, 14/5, Whether the change ministers to the comfort of those whom it most influences, is hard to say. | Walpole, Fortitude I, How far cards might have helped him it is difficult to say.

It forceth and it liketh (me) are obsolete now. A few earlier and laler instances follow :

a 1400-50 Alexander 2001 , pen how fale be alt pe flole, it forcez bot lityll. | a $1450 \mathrm{Knt}$. de la Tour 66 , The poor soule cried ... but it hoted not. | 1603 Owen Pembrokesh. 150, Whose soever they be $y t$ forceth not. | 1604 Shak. Oth. II, iii, 49, it dislikes me.

10. IT AS SUBJEGT IN THE EMPHASIZING FORMULA it is (my father) who.

Dial. Her. 206 A 10, It was not the scripture that made them beleue 
l.hat. | Dial. Her. 276 G 2, it is not the clergy that laboreth to haue them punyshed by death. | Dial. Her. 254 F 8 , it was not it [scil. the council] that he appeled vnto. | Rich. $71 \mathrm{E} 3$, it is none horne that is in thine head. | Dial. Her. $236 \mathrm{D} 3$, thys manne it was that lold me so. | Dial. Her. 139 G 9, Onely God is it, that geueth all good.

This construction serves to make a cerlain word in the proposition conspicuous; it breaks up a single iclea (e. g. the scripture made them belene...) into two syntactical units, and places the subject in extra-position in the form of a clause. It has a proleptic character, except in the last two of the above quotations, which show inversion ${ }^{1}$ ).

The construction was in regular use before More's time :

a 1250 Owl \& Night. 1163, Her vore hit is that me the shunelh. I c 1420 Sir Amadas 284, Hyt is in the deyd name that I speyke (OED).

In Pres. D. Eng. it is quite comnon : It is but seldom that he comes our way. I It is not everybody who can afford to buy a car.

11. The pholeptic it as subject.

(t. with verbs of complete predication ${ }^{2}$ ) :

it appereth. Picus $10 \mathrm{E} \mathrm{9,} \mathrm{It} \mathrm{appereth} \mathrm{by} \mathrm{this} \mathrm{epistle,} \mathrm{that...}$

it (be)falleth. Last Th. $95 \mathrm{D} 8$, so falleth it daylye, that the cye is... I

Picus D 7, if it happly so befal : that he may not as he would...

it booteth. Lament. Stanza 9 1. 6, it bocteth not for me to wepe or cry.

| Rich. 59 A 9, it boted not greatly lo say nay.

it ensueth. Rich. $76 \mathrm{E} \mathrm{10,} \mathrm{it} \mathrm{must} \mathrm{thereof,} \mathrm{ensue,} \mathrm{that} \mathrm{we} \mathrm{shal...} \mathrm{do}$ good...

it foloweth. Dial. Her. 149 A 12, it foloweth of necessite that the church doth not misse vnderstand those textes | Dial. Her. 156 D 4, Holy scripture ... is such as $I$ have sayed, and yet nothinge foloweth $i t$, that God hall not caused it to be wryten well. | Dial. Her. 172 D 13, it consequentlye foloweth that the churche all wayes bath and all wayes shall haue the knowledge ... of such lhinges. I Dial. Her. $177 \mathrm{G} \mathrm{16}$, it shoald els folow, that the church bad a wrong beliefe. 1 Picus 19 G 8, It foloweth in the psalme : Funes ceciderunt...

it forceth. Apol. 818 (Wrs.) E 4, it shall not force greatlye whiche one... [they shall read].

it fortuneth. Dial. C. 307 , if it so fortune ... that the Turkes shall eyther be well withstanden... | Dial. Her. 192 B 11, it mai fortune ... that of one hedde there may be sondry partes.

1) They seem to contradict Curme's stalement (1933, p. 9) on this use of it: "When we desire to call especial attention to the subject we often withbold it for a time, causing the feeling of suspense".

2) I. e., subjective verbs and other verbs not requiring a complement. 
it goeth to theyre hearte. Last Th. $86 \mathrm{G} \mathrm{2,} \mathrm{it} \mathrm{goeth} \mathrm{to} \mathrm{theyre} \mathrm{hearte,}$ whan they see any manne lesse esteme them.

it hrppeth. Dial. G 184, so happed it ... that his wyfe and he together dyned.

it longeth. Jest, p. $3 \mathrm{C} 4$, it longeth for our order, To hurt no man.

it nedeth. Dial. Her. $181 \mathrm{~B} 12$, It nedeth not to assigne any place, wher the very churche \& true christen congregacion is. | Dial. Her. 195 E 5, It nede ${ }^{1}$ ) not to tel you that euery man laughed than.

it rennes in mannes myndes. Dial. Her. $200 \mathrm{E} 6$, $t$ renneth in mannes myndes that miracles may be fained.

it semeth. Picus $1 \mathrm{C} 12$, it semeth that their frendship is but fleshly,

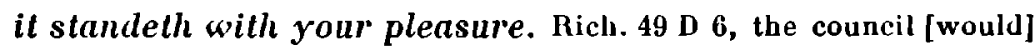
be content..., if it might stand your pleasure to be in such place.

it suffiseth. Rich. $38 \mathrm{H} 6$, For it suffiseth not that al you loue them, y? eche of you bate otber. | Hich. $62 \mathrm{D} \mathrm{17,} \mathrm{it} \mathrm{sufficed} \mathrm{...} \mathrm{to} \mathrm{haue} \mathrm{ben}$ of kinred ... with any of those.

The word it in these constructions has a proleptic function : it announces or anticipates the subject which is developed in the following syntactical unit ${ }^{2}$ ). Most of these developed subjects appear in the form of a 'that' clause; some of them are units containing an infinitive (e. g. it nedeth... to assigne; it sufficed ... to haue been).

All the above quotations contain subjective verbs. With other verbs the construction is not so often met with ${ }^{3}$ ):

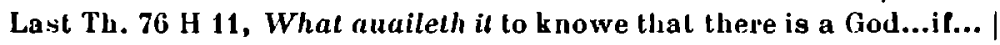
rial. Her. 121 A 6 it smelleth of ydolatry, to visit this place.

In the latter case front position of the full subject seems more usual :

Dial. C. 163, that god gaue him here in this world all thynge ... litle toucheth mi mater.

The following quotation contains a very peculiar use of the construction il shold (with proleptic $i t$ ) :

Apol. 922 (Wk.s) E 5, if euer it shoulde ... by such colde slouth and neglygence on the catholique parte, ... that the heretykes parte should hap to growe so strange, as thei should conspyre to...

5) Contamination of $I$ nede and it nedeth?

2) There is some resemblance between the function of this proleptic It and that of the determinative words, as in : Apol. 6, yf this were vntrew that I say. | Dial. C. 144, As good a medicine must this nedes be that preseruelh our helth. | The difference lies in the absence of stress on $i t$.

3) Compare, however, the constructions with a 'dative' object (it boted him, it yrketh me) $\$ 17$. 
The construction is so very exceptional that it cannot be far wrong to assume that a word (sc. happe) has fallen out, perhaps owing to the fact that another "shold happe" occurs in the next unit. This might then be called a case of syntactical haplology.

There are no innovations in More's language in the usage of the proleptic $i t$ with verbs of complete predication, as may be gathered from the following historical data.

it appeareth. $\mathrm{c} 1374$ Chaucer, Boeth. $\mathrm{v}$, iv, 162, pat it may apere pat pe prescience is signe of this necessite (OED).

it (be)falleth. c1175 Cott. Hom. 231, pa be-fel hit swa pat hym a pance befell. | c 1340 Cursor M. 11929, hyt fille vpon an holiday...thesu and othir childryn insamen went hem by the river to gamyn (OED).

it boteth. $\mathrm{c} 1400$ Roland 499, It botes not to abide (OED).

it foloweth. 1449 Pecock. Repr. III, iv, 304, It foleweth that it stondith weel with the proces (OED).

it forceth. a 1400.50 Alexander 2001, pen how fele be att pe lote, it forceth bot lityll (OED).

it fortuneth. 1460 Past. Lett. $n^{\circ} 461$, II, 115, It so fortuned your seid besecher cowd not performe the said apoyntment (OED).

it goeth to my herte. 1481 Caxton, Reyn. 88, I trowe hit shold not moche goe to my herte so that another dyde it (OED).

it happeth. c 1400 Maundev. xxv, 118, If it happe pat any man ... dye by pe way (OED).

it longeth. a 1400 Prymer 73, God to whom it longeth alone to haue mercy (OED).

it nedeth. 13... K. Alis. 6525, Hit nedeth nothing to wond.|1387, Trevisa, Polychr., Cott. Ms, 35, it nedeth not to telle you (OED).

it semeth. c 1386 Chaucer, Mel. 355, And al be it so that it seme that thou art in seker place, yet... (OEI)).

It suffiseth. 1422 Yonge, tr. Secr. 178, Hit suffichyth that ... we fyndyth $y$-writte, that... (OED).

Of it ensues and it avails ${ }^{1)}$ no instances anterior to More

1) The absence of these verbs, as well as of to appear, fall, suffice, bote, long, follow, in the sections on impersonal and quasi-impersonal verbs in Dekker's Syntax of Malory's Morte Darthur (1932, \$ 311 If) seems due to the fact that he restricts the meaning of quasi-impersonal vel'bs to : "verbs governing a noun or pronoun in the dalive or accusative and often used quasi-impersonally". Occasionally, however, he seems to have lost sight of this definition; see, e. $g . \$ 321$, it fortuned he was sore hurte. $\$ \$ 328$, hit nedeth not to reherce them. 
have been found. The earliest quotations in OED are dated 1581 and 1538 respectively.

In Pres. D. Eng. the usage is restricted to a small number of the above verbs; only it seems and it appears may be called current now. It forces, it needs are obsolete. It boots, it ensues are rare. In archaizing style it haps, it falls, it fortunes, it stands with your pleasure, are occasionally met with. It suffices is often followed by for.

12. The proleptic it as subject.

$b$. with to be + adjective.

it is according. Picus $13 \mathrm{C} 2$, Verelye $t$ is accordyng, that god should despyse thee being a man.

It is amisse. Dial. Her. $105 \mathrm{G} 7$, so were it not much amisse ... to provide for the worste.

it is better. Apol. 12, But yf the precher proue that it were better for a man to kyll hym selfe than dye... | Dial. Her. $211 \mathrm{G} \mathrm{9,} \mathrm{better}$ wer it the faute to be quytte, than the fautles to be punyshed.

it is like. Dial. Her. 135 F 12, it is more like that he will suffer no such thinges longe lye hid.

it ts likely. Dial. Her. $140 \mathrm{G} \mathrm{1}$, it is likely that he set great ... imposicions vpon them.

it is long. Last Th. $72 \mathrm{C} \mathrm{4,} \mathrm{Long} \mathrm{would} \mathrm{it} \mathrm{be} \mathrm{to} \mathrm{take} \mathrm{the} \mathrm{beste} \mathrm{of} \mathrm{theyr}$ woordes. | Picus 5 B 7, longe it was or he could be brought therto.

it is mete. Dial. Her. $243 \mathrm{~F} \mathrm{11,} \mathrm{it} \mathrm{wer} \mathrm{mete} \mathrm{for} \mathrm{men} \mathrm{vnlearned} \mathrm{to} \mathrm{be}$ busy with...

it is requisite. Apol. 190, yf it were requisite I coulde bryng forth wytnesses mo then men wold wene.

it is trewe. Dial Her. 139 G 14, yf it were trewe that ye defende the thynges withall...

There is nothing in this construction, as such, that calls for comment : it was in use before More's time and is still employed in ordinary diction in Pres. D. Eng. For it is according, it is like, it is mete see the following data :

it is according.

EARLIEA

1483 Caxton, Gold. Leg. 399.3, A clerke sayd it was not honest ne according to mysentrete the holy body (OED).
LATER

No la ter quotations in OED. Not in Schmidt, Shak. Lex. In Pres. D. Eng. obsolete. 
it is like.

c 1375 Barbour Bruce xvi, 324, It wes weill lik... That he myght haff conquerit... The land of Irland (OED).

it is mete.

a 1300 Cursor M., 3675, Sco... cled him, sum it was mete, wit his broper robe pat smelled suete (OED).
1733 E. Elskine, Serm., Wk.s. II, 152, The temple where it is like Isaiah got the manifestation(OED). In Pres. D. Eng. only dial.

1846 French, Mirac., Introd. 38, It was only meet that his Son should be clothed (OED).

In Pres. D. Eng. archaic.

\section{The proleptic it as gubject.}

c. with to be + preposition + noun.

it is in vain. Rich. $62 \mathrm{H} 1$, it is in vain to keep in counsel that thing that all men know.

it is in question. Dial. Her. 257 A 12, if it were in question whither the scripture were euydent for him.

it is whthout peril. Dial. C. 146, it ts not without peril a man to think otherwise.

OED has no earlier quotations. It is in question is obsolete now.

\section{The PRoleptic it as subject.}

d. with to be + noun.

it is almoyse. Conf. Tynd. $446 \mathrm{~B} 6$ al their heresies fully be burned $\mathrm{vp}$ and fal as flatte to ashen as it were almoyse all obstinate heretiques dyd. |Rich. 45 (= 44) E 10, il were almoise to hang him.

it is no cause. Dial. Her. $245 \mathrm{~B} \mathrm{2,} \mathrm{it} \mathrm{is} \mathrm{no} \mathrm{cause} \mathrm{to} \mathrm{kepe} \mathrm{the} \mathrm{corps} \mathrm{of}$ scripture out of the handes of anye Christen people.

it is his dishonestie. Picus 7 F 4, it was his dishonestie and rebuke ... that his negligence ... gaue his seruauntes occasion of disceit.

it is a do. Apol. 173, it wolde be somewhat a do to finde many wuche.

it is doubt. Dial. Hor. $167 \mathrm{G} \mathrm{11,} \mathrm{yet} \mathrm{is} \mathrm{it} \mathrm{no} \mathrm{doubte} \mathrm{but} \mathrm{if} \mathrm{I} \mathrm{wil} \mathrm{beleue}$ the Churche I must beleue them.

it is foly. Picus 21 B 9, foly it is to looke for heauen with pleasure and delight.

it is a fransey. Apol. 42, that were a thynge whereol $y^{-t}$ were a very fransey to doute.

It is guyse. Boke of F. p. $7 \mathrm{G} 1$, it is fortunes guyse, to graunt no manne all thyng that he wyll axe.

it is grief. Dial. C. 163, was it no grief then when he muste cast out the mother and the chylde both? 
it ts your hap. Dial. Her. $203 \mathrm{~F} 1$, it has been your happe to be there. it is labour. Dial. Her. 224 A 14, so were it ... litle labour ... to translate the ... booke.

it is good manner. Dial. C. 260 , so is it very good manner lhat a man of your age ... lette his slepe not slippe away.

it is mastry. Dial. Her. $109 \mathrm{E} 7$, it were no mastry to make it seme that...

it is meruail. Dial. Her. 251 A 1 , It is no meruail though his wife be wel teeming. | Dial. Her. $184 \mathrm{~F} \mathrm{5,} \mathrm{it} \mathrm{is} \mathrm{more} \mathrm{than} \mathrm{meruel} \mathrm{that...}$

it is nede. Apol. 184, It was well perceyed that great nede it was euer after to represse ... suche sedycyouse heresies. | Dial. Her. 156 $H 4$, nede was it in the begynning to geue theim knowledge therof. it is pity. Dial. Her. $225 \mathrm{H} \mathrm{9,} \mathrm{th} \mathrm{is} \mathrm{pytye} \mathrm{that} \mathrm{we} \mathrm{sce} \mathrm{suche} \mathrm{lyghte} \mathrm{so}$ sielde.

it is praise. Picus 7 A 3 , he perswaded that... $t t$ was no praise to gather richesse.

it is proofe. Dial. Her. 230 A 10, more proofe is it of a wyse gouernour to rule well fyue wyues than one.

it is reason. Dial. Her. $138 \mathrm{G} 13$, than is it reason that we shew you some such case. | Dial. Her. $132 \mathrm{G} 6$, no reason wer it, to withdrawe his thank. | Dial. Her. $275 \mathrm{E} \mathrm{9,yet} \mathrm{is} \mathrm{it} \mathrm{no} \mathrm{reason} \mathrm{to} \mathrm{loke}$ that Ghrysten princes should su(fer' ').

it is his rebuke. See it is his dishonestie.

it is an old said saw. Dial. Her. $105 \mathrm{~B} 2$, It ts an olde said saw, that one bysynes begetteth another.

it is a common saying. Picus $5 \mathrm{C} 1$, it was a common saying with him, tbat such altercacions were for a logician, and not metely for a philosopher.

it is shame. Picus $14 \mathrm{E} \mathrm{13,} \mathrm{it} \mathrm{were} \mathrm{shame} \mathrm{to} \mathrm{abide} \mathrm{stil} \mathrm{in} \mathrm{the} \mathrm{better...}$ it is surety. Rich. $66 \mathrm{~B} 10$, it was no surety to retreate.

it is a tale. Dial. Her. $269 \mathrm{~F} 2$, it is but a tale to saye that...

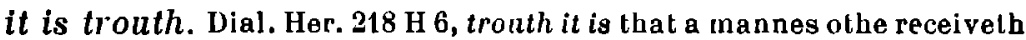
interpretacion.

it is an untowardnes. Dial. Her. $133 \mathrm{H} 16$, it is a great ontowardnes ... to mystrust all them that say they haue sene it.

it is comen usage. Boke of F. p. $5 \mathrm{~A} 4$, Of this poore sect, it is comen usage, onely to take that nature may sustayne.

1) Also without it in the collocation as reason is : Debell. $985 \mathrm{~A} 1$, And so lye there as reason is sometyme some for felonye to, repryed vpon causes from one session to another. Now obsolete. Latest quot. in OED 1671 (Milton). 
it is wisdom. Dial. Her. 109 H 12, $t$ were wisdom, not to call them Lutherans.

It is wonder. Last Th. $98 \mathrm{E} \mathrm{3,} \mathrm{wonder} \mathrm{it} \mathrm{is} \mathrm{that} \mathrm{tho} \mathrm{worlde} \mathrm{is} \mathrm{so} \mathrm{mad.}$ it is a worlde. Dial. Her. $184 \mathrm{E} \mathrm{12,} \mathrm{It} \mathrm{is} \mathrm{a} \mathrm{worlde} \mathrm{to} \mathrm{see} \mathrm{what} \mathrm{boste} \mathrm{the}$ mad man maketh.

This section is a real treasure-trove of the obsolete and the archaic. The frequent absence of the indefinite artice $a$ (it is shame) is especially conspicuous. The following list shows the result of an attempt to ascertain to what extent these idioms were known before and after More's time. Owing to the scarcity of syntactical investigations and the regrettable gaps in OED, a number of lacunae could not be filled up.

EARLIER
it is almoyse. c 1430 Lydg. Bo-
chas Prol. 30, It is almes to cor-
rect and amend the vicious folke
(OED).

it is cause.

it was his dishonestie.

it is a do ${ }^{1}$ ).

it is dout. 1398 Trevisa, Barth.

Do P. R. xvr, 569, No man shal wene that it is dout or fals that god hath sette vertue in precyous stones (OED).

it is foly. c 1400 Lanfranc's Cirurg. 212 , it ts fulie lor to lete him blood (OED).

it is fransey.

it is grief.

it is guise. (1420 Pall. on Husb. II 68, To wede ek cornys drie, is no good gise : OED).

it is hap. c 1420 Pall. on Husb.

III 710, Hit ts bot happe of a plaunte a tre to gete (OED).

\section{LATER}

1623 Sanderson, 35 Serm. Wks. I 87 , If he be hungi'y, it is alms to feed bim, but if he be idle..., it is alms to whip him (OED).

In Pres. D. Eng. obsolete. (Cf. 1548 Udall, Erasm. Par. Matt. $\mathrm{V} 42$, There is no cause why to cut off the members) (OED).

Not in OED; but : Shakesp. Rich'. II, i, 299, deposed ' $t$ is dout be will be.

Not instanced in OED, but is permissible in Pres. D. Eng. : It is folly even to think of such a thing.

a 1529 Skelton, Ph. Spar. 1251, It were no gentle gyse This treatyse to despyse.

In Pres. D. Eng. obsolete. (1813, Scott, Frierm. III, Introd. III, Be it hap, or be it harm : OED.) In Pres. D. Eng. obsolete.

1) Properly an infinitive preceded by Norse $a t=$ Eng. to. It is doubtful whether it still has this verbal character in the quotation from More. 
it is labour. c 1400 Destr. Troy 10770, Hit were labour to long hir lotis to toll (OED).

it is ... manner. No earlier quotations in OED.

it is mastry. 13... Sir Beues (A.) 1738, 'So me helpe God' quep Beues po,'Hit were no meistri, me to slo.'

it is meruail. c 1380 Wyclif, Wks. 265, It is grelt meruaile pat god ... distroyep not all pis cursid peple.

it is nede. c 1175 Lamb. Hom. 9, Hit is muchel neot pet we ponkien ure drihten (OED).

it is pity. 1470-85 Malory, Artbur I, XXII, It were grete pyte to lese Gryflet (OED).

it is praise.

tt is proof.

it is reason '). 1340 Hamp., Pr. Consc. 6891, parfor it es reason and ryght pat pai ay se pat grysely syght (OED).

it is his rebuke.

it is an old said saw. 1470-85 Malory, Arth. X, LxI, 519, Euer
Not in OED; but cf. Shakesp. Compl. 239, what labour is 't to leave the thing we have not. 1530 Palsgr. 415, 1, it is no good manner to abrayde me therof (OED).

In Pres. D. Eng. obsolete (in singular).

1601 B. Jonson, Discov. Ingen. discrim. I, It is a little maistry to know them (OED).

In Pres. D. Eng. ohsolete. 1515 Brinklow, Compl. xi, 26, It is meruel ... that fyre descend not down. | 1647 Clarendon, Hist. Rep. $1, \S 19$, it is no Maroail ... that he could think of no better way(OED). In Pres. D. Eng. obsolete.

1676 Hale Contempl. I 351, The best of men are visited with them and it is but need they should (OED).

In Pres. D. Eng. obsolete. 1593 Shaksp. 3 Henr. vi, IV, i, 22, and 't were pittie to sunder them. This is the latest quot. in OED ; but see the title of John Ford's play (1633) : 'Tis pity she's a whore.

In Pres. D. Eng. obsolete.

Not in OED ; but cf. Shakesp. Troilus II, ij, 145 so to be valiant is no praise at all.

1864, Manning, Let. to Pusey, 28, It is, however, but reason that I should rejoice. (OED)

In Pres. D. Eng. rare.

1861, Flor. Nightingale, Nursing 50 , It is an ever ready saw that an

1) Influence of Old French il est raison, c'est (bien) raison? 
hit is an old sawe guye a chorle rule and thereby he wylle not be sulfysed (OFiD).

it is a common saying.

it is shame. c 1380 Wyclif, Wks.

72 , It is schame to written it (OED).

it is surety.

it is a tale. The only quotation in OED is our quotation from More.

it is tronth.

it is an untowardness (= obstinacy).

it is usage. 13... Sir Beues (A.) 3170 , Ase hit was lawe \& ri3t vsage (OED).

it is wisdom. c 1420 Hoccleve, Min. Poems XxIv, 215, Is it wysdam as pat it seemeth yon, were it on your fyngir continuelly? (OED)

it is wonder. c 1100 Brut I, 1, it was sonder to wete... (OED)

it is a worlde. c 1440 Generydes, 2205, It was a world to here the sperys brekc. (OED) ege is equivalent to a lb. of meat (OED).

1839, Scott, Ivanhoo xL, It were shame to our profession were we to suffer it (OED).

In Pres. D. Eng. poetical.

Not in OED ; but cf. 1843 Haliburton, Attaché II, vir, 128, Fact I assure you, it's gospel-truth.

1831 Scott, Ct. Rob. xvir, It is wisdom to choose a better protector. (OFD)

In Pres. D. Fing. archaic.

c 1520 Skelton, Magnyl. 85, And it is wonder that your wylde Insolence can be content.

All the later quotations in OED have $a$, no etc. before wonder.

1596 shak., Tem. Shr. II, i, 313, 'tis a world to see How lame a wretch can make the cursest shrew.

1881 Leicester, Gloss. It's woo'ld to see that theer little un order the big ones. (OED)

In Pres. D. Eng. obsolete or dial.

15. The proleptic it as aubject.

$e$. with to be + infinitive.

it were to pray. Dial. C. 161, it were to pray that they shoulde neuer haue temptacion. 
Of this type only one instance has been found '). In Old English, Latin gerunds (e. g. dicendum est) were translated by adding an infinitive + to to the verb to be (e. g. Greg. 263,9 , pret is to cypanne). It is probable that the type it were to pray has descencled from this type and that at a certain time ${ }^{2}$ ) the vaguer it was substituted for the more distinct that. It is not plausible to regard as prototype the $O$. E. constructions with a dative pronoun (c. g. c 897 Elfred, C. P. 269, Us is to witenne; c 1000 Elfric, Hom. I, 308, Us is to smeagene), since in these collocations the dative pronoun was regularly replaced by a nominative in Middle Eng. (e. g. c 1122 O. E. Chron. an. 1083, pa muncas nyston hwet heom to donne were $>1380 \mathrm{Wycl}$. Sel. Wks. I, 120, he wist what he (s'as to do).

The voice of the infinitive to pray in it were to pray may be called activo-passival (cf. $\$ 4(3)$, since the construction allows of being interpreted in two ways : either it were a good thing for us to pray or it is to be prayed.

The following quotations prove that the idiom was known before More :

c 1400 Maundev. Tr. 34, 20, wherefore it is not to beleue pat... | c 1412 Occleve, De R. Pr. 121, It is to leeve and deeme, yf an kyng shyne In vertu, that his sone shalle sue And to his faders maners enclyne. | 1456 Sir G. Haye, Law Arms (S. T. S.) 271, For it is to se that the provour has beginnyn his clame... | c 1480 Malory, M. Arth. 141, 9, hit is to suppose... / idem 445, 27, $i l$ is to understand...

Berners (Froissart) has : vi, 154, it is to suppose that the great puissance.... abasshed the Yrisshemen. R. E. L. Weyl (1937, $\$ 235$ a) has found only one inslance in St. John Fisher : 302, 16, Moche rather it is to suppose that... The fact that More and Fisher only rarely avail themselves of this construction warrants the supposition that the idiom was already obsolescent. It seems to have died out in the century after them ${ }^{3}$ ). The latest

1) For similar constructions introduced by other words than it (e. g. that is to witte) cf. $\$ 412$.

') It does not seem to be on record when this substitution took place. H. Boch (1931, p. 206) does not mention it; be discusses the development of pat is to sepencanne, pat ping sint to donne > pey bep to be blamed.

$\left.{ }^{3}\right)$ Not so in Dutch and German : het ware te wenschen; es wäre su wünschen. 
quotation in OED is : 1528 Perkins, Prof. Bk. I $\$ 36,16$, how it is to show. In Shakespeare we find : II Henry VI, III, ij, 2, We have dispatched the duke... O I that it were to do, in which, hovever, it is not proleptic ${ }^{1}$ ); he has numerous constructions with other subjects than it (e. g. Troilus III, ij, 124, What's to do; Lover's C 101, such a stor'm As oft 'twixt May and April is to see). Pres. D. Eng. has to he + past participle (e. g. it is to be expected). These longer groups were frequently used by More too (e. $\mathrm{B}$. Apol. 78, it is to be fered. | Dial. C. 222, it is to be considered.) See the paragraphs on Syntactical Units with Three Verbs (\$ 666).

\section{The proleptic it as subject.}

$f$. with to be + past participle.

$\alpha$. it was ment. Dial. Her, 272 F 10, it was not ment that euer theyr sinnes tourned them to good.

it was mervayled. Some L. xil, p. 331, it was mervayled that I stacke so much in my conscience.

it was ordeyned. Apol. 118, it was ordeyned that the clergy sholde kepe a lenger lent.

it is ... well done. Dial. Her. $105 \mathrm{G} \mathrm{b}$, it is well done to deme the beste. it was writlen. Dial. Her $179 \mathrm{C} 10$, as it was written in the Actes of the Apostles, Erat multitudo credentium...

$\beta$. it was answered. Dial. Her. 264 A 7, then was it answered hym that...

it was asked. Dial. Her. 264 A 2, and then was it asked hym whither... it was informed. Debell. $996 \mathrm{~F} \mathrm{10,} \mathrm{after} \mathrm{it} \mathrm{were} \mathrm{informed} \mathrm{the} \mathrm{iudges,}$ that they reuoked theyr first saying.

it is lefte. Dial. C 139, it is lefte vs by Gods ordinaunce to striue againste it.

it was objected. Dial. Her. $265 \mathrm{G} \mathrm{11,} \mathrm{it} \mathrm{was} \mathrm{objected} \mathrm{vnto} \mathrm{that} \mathrm{man...}$ it was said. Dial. Her. $263 \mathrm{C} 11$, therefore was it sayd to him : Yf ye... it was thought. Rich. $48 \mathrm{G} \mathrm{4}$, the Lorde Cardinal shewed vnto her, that it was thought vnto the protectour... 2) that her kepyng of the kinges biotber in that place was...

1) An early instance with non-proleptic it is found in Chaucer: Can. Yeom., Prol. \& T. 321, The Philosophres stoon ... I warne yow wol, it is to seken euere.

2) Compare it thinketh me in 17. 
All these quotations contain passive constructions. The usage was no innovation :

$1390^{\circ}$ Gower, Gonf. I 15, Bot it is said and evere shal, Betwen two stoles lyth the fal. | 1497 Bp. Alcok. Mons. Perf. G j 6/2, Cryst cam into ye worlde, as it is wryte. | 1470-85 Malory, Arth. VI, VIII, For as it is enformed me thou ... hast done grete despyte and shame vnto knyghtes of the round table.

As the OED only records this usage with a very few verbs, it is difficult to trace the fate of this idiom after More's time ${ }^{1}$ ). The latest quotation of it is informed us is dated 1548 (Hall, Chron. Henr. VIII, 61 , It is informed us that your young and ryotous people will ryse.)

Our quotations show two kinds of constructions : $\propto$ those without an indirect object (it was ordeyned); $\beta$ those with an indirect object (it was answered him). Type $\alpha$ is still found in Pres. D. Eng., but type $\beta$ seems to have died out.

It is interesting to compare what Trnka $(1930$, p. 56$)$ says concerning these constructions : "The passive impersonal construction of the type it was sent for me, it is informed me were turned into the personal $I$ was sent for, $I$ was informed at the beginning of the sixteenth century, while they were preserved if the personal object was not expressed n. - The above quotations show that there is something wrong in Trnka's statement. If the transition into the personal construction did occur in the $16^{\text {th }}$ century, it must at any rate have been after More's time.

17. The proleptic it as subject.

g. in the type it happed me.

it abhorreth his hearte. Dial. C. 346, th shall abhorre hys harte to think on them.

it becometh us $^{2}$ ). Dial. Her. $189 \mathrm{E} 5$, it becommeth os and well behoueth os to inake frendes of such as be hath in fauor. | Answer $1115 \mathrm{H} \mathrm{9}$, it as properlye becommeth the manne to taunte, as it becommeth a camel to daunce.

1) For the usage in St. John Fisher, see Weyl, 1937, \$ 73.

2) Also occurs with an auxiliary : Dial. C. 294 , hys promise, which for his owne honoure il can not become him to break. | Apol. 927 F 10, it may become him. 
it behoveth us. Answer 1124 B 3, But let oportet signifye, be must or it behoueth hym to dye. See also becometh.

it belongeth to God. Dial. C. 253, To God it belongeth to gouern the tonge.

it hoted him. Rich. 54 F 15, It boted him not to aske why. Dial. C. 134, it booteth no man to speake to them.

it delyted him. Apol. 72, yet hath it delyted... hym to laye these fawtes to the clergyes face.

it forthinketh me. Conf. Tynd. 438 (i 13, as we say in english it forthinketh me or I forthinke, and I repent or it repenteth me.

it may fortune you. Dial. Her. $130 \mathrm{C} 8$, It maye ... fortune ... you, to line so long. | Vial. Her. 1.55 A 6 , What if it shold fortune him to finde some texte of scripture that...

it greucth you. Dial. Her. $159 \mathrm{E} \mathrm{3,} \mathrm{What} \mathrm{greueth} \mathrm{it} \mathrm{you...,} \mathrm{which}$ name God by the prophete hath geven to all good men. | Dial. Her. $152 \mathrm{G} \mathrm{10,} \mathrm{it} \mathrm{greueth} \mathrm{nol}$ reason to lonke thereon. | Lament. Stanza 8, God wotte full oft it greued hath my minde, That ye should go where we should seldome mete.

it happed me. Dial. Hel. $262 \mathrm{E} \mathrm{3,} \mathrm{It} \mathrm{happed} \mathrm{me} \mathrm{to} \mathrm{bee} \mathrm{lately} \mathrm{present.} \mathrm{I}$ Dial. Her. 131 F 5, it happed them ... the one to cast the mind to the other. | Rich. 55 C 18, it happed the Lord Chamberlen by the way to slay his horse. | Dial. G. 208 , it happed my mynde to fall sodaynly from that. | Dial. C. 223, Of the matler may you gather if il haue happed hys reuelacions belore to proue false.

it liked her. Dial. C. 217, it liked her wel to thinke theron. I Dial. Her. 165 H 7, it liked him ... to bring you out of such a great perplexitie. | Aut. Lett. (sterentyped beginning), Hit may like yor good Grace to... | Dial. Her. 159 A 8, so hath it lyked our lorde ... to pronide, that...

it makes no matter to you. Dial. Her. 238 A 6, it makes no mater to jou which way they stand.

it pleased him. Dial. C. 331, a feaste, that it pleased hym ... to prepare for them. | Rich, $48(=45) \mathrm{E} 10, \mathrm{gf}$ it please hym to take the payne. | Dial. Her. $152 \mathrm{~A} 7$, it shall please our lorde ... to revele it. | Dial. Her. $165 \mathrm{~A} 14$, my prayour ... that il might please his goodnesi ... not to leue me perplexed.

it repenteth mee, see forthink.

it semeth me. Dial. Her. 169 A 9, It semeth me... that all this goeth well.

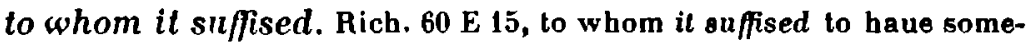
what to say.

it thinketh me. Dial. Her. 163 E 1, me thinketh it wel said that ye hacue said ').

1) For a quotation with it was thought onto the protectour see $\$ 16 \beta$. 
it yrketh me. Answer 1135 B 11, It yrketh me to looke vppon the place agayne. | Apol. (Wks.) $847 \mathrm{E} \mathrm{7,} \mathrm{It} \mathrm{is} \mathrm{lyttle} \mathrm{meruayl} \mathrm{that} \mathrm{it}$ seme long and tedious vnto them ..., whome it irketh to dooe so much as loke it ouer.

The fact that this type of construction (it thinketh me) has two semantic equivalents - me thinketh $(\$ 18)$ and $I$ think - shows clearly how unsettled English usage was in this respect in More's time. There is nothing which affords a certain clue to decide whether More had a predilection for any of the three constructions. The quotation with forthink is rather instructive; it might be inferred from it that me forthinketh, me repenteth were already felt as obsolescent by More. As a matter of fact no quotations with these two verbs in the last-mentioned construction have been discovered. The same, however, cannot be said of the other verbs.

Both the types it thinketh me and $I$ think are developments of one and the same construction, viz. of me pinkep, me licap, me grevez, hym happed, and it can therefore not be maintained ') that the type $I$ think is a transition-form of both it thinketh me and me thinketh. The reasons commonly mentioned for the transition (v. d. Gaaf, 1904, $\$ \$ 32$ ff ; Trnka, 1930, p. 57) are not valid in both cases, since it is evident that the presence of the subject-word it prevented the noun-object (orig. dative) from being mistaken for a nominative, as it happened in e. g. mi lord likes to have. As a matter of fact the type it thinketh me had a rather long life ${ }^{2}$ ); with some verbs it survived into Pres. D. Eng. (e. g. it behoves us, $t t$ grieves me, it becomes me); with others it is now used as an archaism only; there is a quotation in OED dated 1628 of it should fortune each; another dated 1613 of like it your grace; another dated 1690 of it will not boot you. Those

1) As V. d. Gaaf, 1904, seems to do, who among the constructions that underwent the change from the "impersonal "to the "personal " constructions also mentions some that are of the type it thinketh me (Type A. e. B. it happed hym, p. 18 ; it mystreth me, p. 20 ; yet it plese yow, p. 22, etc.). In his subsequent discussion of the general causes of the transition (\$32), however, he never mentions them again.

2) V.d. Gaaf, 1904, p. 143, says that the A-construction of hap(pen) [= it happened me] became obsolete about 1500 . The quotations show that More still used it frequently. 
constructions that stressed the non-subject function of the (pro)noun by developing the preposition to before it, were sure of survival (it seems to me, it belongeth to Godl).

The reason for the ultimate falling into disuse of a great number of these constructions lay in their redundancy by the side of the construclions with a full subject (e. g. I like; he h(tppened), it being a well-known fact that a language does not suffer two words or construclions of absolutely the same meaning to exist simultaneously, but always discards one of them in the long run, if no differentiation sets in.

EARLIEn
it abhorreth me. Nol in OED.

it becometh us. OED has no quotations rvith plain object.

with to. c 1175 Lamb. Hom. 45, Nu bicomep hil ... to unwilchen cristene monne to haligen penne dei (OED).

it behoreth us. 1388 Wyclif 2, Sam. IV 10, il behofte me to yeue mede (OED).

it helongeth to God. $1413 \mathrm{Lgdg}$., Pylgr. Sowle I, xI, Neuer ne left he... his burdon, as tl bylongeth to a good pylgrym (OED).

it boted him. No quotalions in OED $\left.^{1}\right)$.

\section{LATER}

1541 Elyot, Im. of Gov. 7, It abhorreth me to expresse bis beastly lyuyng (OED).

In Pres. D. Eng. obsolete.

1661 Marvell, Corr. xxvin Wks. II 66 , There a re nakednesses which it hecomes us to cover (OED).

1826, Scott, Lockhart vil, 230, I thought it became me to make public how lar I was concerned (OEI)).

1879 T. Hardy, F. F. M. Cr. xxix, It doesn't become you to talk about him.

1611 Bible, Hebr. II 17, In all things it behooued him to be made like vnto his bretbren (OED).

1855 Reed, Lect. Eng. Lit. I 28, What books does it behoove me to know (OED).

without object : 1821 Keats, Isabel xLIx, Here it doth not well belong To speak (OED).

1690 Walker, Idiom Anglo-Latin, 65, It will not boot you to say so (OED).

In Pres. D. Eng archaic.

1) OED has only earlier instances of the types it botes not to abide (without object), and him booteth (without $i t$ ). 
it delyted him. Not in OED. it forethynketh me. 1393 Langl. P. Pl, cxxI, 92, Sore hit me forthynketh of pe dede pat ich haue don (OEI)).

it may fortune him. 1487 Will. Surrey, Archeol. Coll. III 163, At that aulet belore which tt shall fortune me to be buried (OEI)).

it greveth youl. a 1300 Cursor M. 10443, It gleves me wonderly sare, I se pe leudy ma suilk care (OED).

it happed me. 1385 Cbaucer, L. G. W. 634, Cleopatras in the see hit happed him to mele (OED). 1509 Hawes, Past. Pleas. xvı, 30, It may me happe a remedy to finde (OKD).

it liked her. c 1205 Lay. 8746, Hit pe likede wel pat pu us adun laeidest (OED).

it makes no matter to yoll. No quot. in OED with object or with object + to (ct. 1478 W. Paston, P. Letters III $237, \ldots$ how corse so euer it be it makyth no matyr.)

it pleased hym. 1388 Wyclif, Esther Ix, 13, If it plesith the kyng (OED).

1406 Hoccleve, La male regle, 416, If it thee lyke and plese... (OED).

it repenteth me. a 1400 Morle Dart. 1391, 1 salle repent vs fulle sore and we ryde forthire (OED).

\section{Not in OED.}

1588 A. King tr. Canis. Catech. Cont. 12, It forthinkes me sore that I haue sinned.

(Latest quotation in OED). In Pres. D. Eng. archaic. 1628 Digby, Voy. Medit. 3, If it should fortune each to loose other.

(Latest quotation in OED).

In Pres. D. Eng. obsolete. 1852 Mrs. Stowe, Uncle T. C. xxy, 239 , It really grieves me to have you be so naughty (OED).

No quotations later than 1509 in OED.

In Pres. D. Eng. obsolete.

1613 Shakesp. Henry vIII, I, i, 100, Like it your grace. The state takes notice.

(Latest quotation in OED).

In Pres. D. Eng. obsolete.

Not in OED. Shakespeare has only 1) it is no matter for that...; 2) no matter (see Schmidt, Shak. Lex. s. v. matter 6).

In Pres. D. Eng. archaic.

1822 B'ness Bunsen in Hare Life I, vı, 196, Wherefore he follows this plan it has never pleased him to explain (OED).

1560 Daus, tr. Sleidane's Comm. 147, It shall not repent them of yt service.

1878 Swinburne, Tri. Tim. Ixı, Will it not one day in beaven repent you? (OED).

In Pres. D. Eng. archaic. 
it semeth me. c 1489 Caxton, Sonnes of Aym. xxir, 400, Yf it semeth you that I baue doone amys... (OED).

1439 E. E. Wills, $128, \ldots$ it shall seme hem necessarie (OED).

it sufficeth me. c 1400 Rom. Ros. 6005 , Therfore il suffiseth me Her good herte and her beaute (OED).

it thinketh me. c 1386 Cbaucer, Knt. T. 2183, Thanre is it wysdom, as it lhynketh me to maken vertu of necessitee (OEI)).

it yrketh me. The earliest quot. in OED is our quot. from More. Not mentioned by Dekker, Kellner, V. d. Gaaf.
1584 B. H. tr. Herodotus I 6 b., it semed them best to deale so roughly wt them (OED).

Later quotations in OED only with to before the object, as in Pres. D. Eng. e. g. 1908 Bagot A. Cuthbert Ix, 86, It seems to me that looking into holes... (OED).

In OED no quotations later than 1400 . The other quotations illustrate the use will a full subject or the type me sufficeth.

In Pres. D. Eng. obsolete.

The lalest quotalion in OED is daled 1386, but : Shakesp. Hamlet V, ij, 63, does it not, thinks't thee, stand me now upon. In Pres. D. Eng. obsolete.

1552 Latimer, Serm. Lincoln, IV, 88, It irked them that they should pay tribute. (OED)

1850 Hawthorne, Scarlet I., III, 84, It irks me...that the partuer of her iniquity should nol stand on the scalfold by her side(OFD). In Pres. D. Eng. archaic.

\section{The TyPe : Me Thinketh}

18. The number of verbs which in older English could be used in constructions consisling of a verb in the third person singular preceded by a noun or pronoun in the object-case and followed by the "real " subject in the shape of an infinitive construction or that-clause, had become much smaller in the course of the Middle English period. The few survivals of this usage which have been met wilh in More, are given below. The quotations in the second column illustrate More's use of the same verbs in transitional constructions, $i$. e. in such in which the function of the (pro)noun preceding the verb is not recognizable on account of its neutral form. The third column contains quotations in which the verbs occur in " personal " conslructions. 


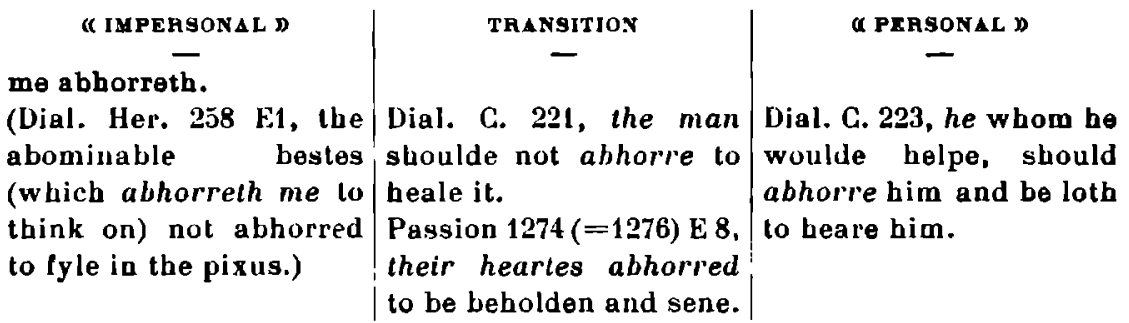

them be seeme.

(Dial. C. 131, vaynge them in such order as shall bee seeme them.)

me lacketh.

(Dial. Her. 270 E 11, I Last Th. 90 G 10, if thou haue labored and strieuen a good strife,... now lacketh me no more for me, but the crowne of iustice.) lacke thou shalte labour to thy power.

Boke of F.p. 4 C.8, whose country larkt defence.

Apol. 924 (Wks.) H 16, least ... hys scollers shoulde ... lacke theire learnyng.

me list ; me lust.

Boke of F. p. 1 B 8, me boke of F. p. 2 C 4, as $\mid$ Picus 10 G 6, such serlyst nut frendly on them soon as Fortune list to uice as she list to put loke.

Dial. C. 280, the Almain tong wherin... me listed to shewe my cunnyng.

Picus 7 G 5, I know wel ye luaue mought oftentimes, \& yet may desceye an ye list.

Dial. G. 313, the libertie to bee where hym lyste. laugb agayne.

Dial. C. 166, as long lasting as hymselfe lust.

Dial. C. 224, God maye... bothe lycence and com. mand... if hymself list.

Picus 30 A 5. For certes who so list, he may puruay to beare his body in earth.
Hich. $61 \mathrm{H1}$, that thyng that... ye haue long time lacked.

Dial. Her. 265 B 5, the manne lacked you there.

me nedeth.

Pageants p. 7 A 5, me Apol. 74, a man nedeth Dial. C. 127, So shall we nedeth not to bost.

neuer to atudy for occasions therof.

Dial. Her. 109 F 12, What nedeth to call him a Lutherane? vnto them.

Boke of F. p. 6 C 7, she rennetb loose, and turneth where she lyst.

Dial. Her. 123 H 7, we byst not ones go moue our fote thilherwarde. Dial. C. 263, conveying l hem whyther hee liste. 
me rueth.

Picus 34 B 9, Griunt me fro Sathanes seruice to astart with whom me rueth so long lo haue be thrall.

\section{me semeth.}

Last Th. $81 \mathrm{~F} \mathrm{10,} \mathrm{it} \mathrm{is} \mathrm{me}$ seemeth lrewe...that... Rich. 59 E 4, him semed that this marriage was not vnprofitable...

Rich. 51 C 11, her semed the Cardinal... redy to depart.

Last Th. 77 G 4, thou wouldest as thee than semed, haue bene content with such a chaunge. Dial. Her. 130 H 4, by which ye would seme, that it were well proned. Passion 1328 G 2, yet semeth me llat the tother exposycion is muche more apte.

me thinketh, me thought. Dial. Her. 169 D 13, me thynke... he bydueth me beleue them.

Last. Th. 89 B 5, god and nature loketh not as me thinketh inuch farther.

Dial. C. 338, Me think we shall be strong ynough. Rich. 49 B 5, me lbinketh it were as great commoditie to them both.

Last. Th. 92 E 8, me thoughte alway that...

Jest p. 2 A 11, Him thought, That way was nought.

Picus 15C11, the company ...degcanted therol to his rebuke, as them thought.
Dial. Her. 124 D 14, Dial. C. 321, the thing whiche thinge sith ye semeth me so plain.

seme to impugne, I shall Hich. $70 \mathrm{G} 8$, he rather ...make you answere semed him to folow bym therunto.
Apol. 129, yf thys be thus ...whyche I trow no man thynketh.

Apol. 98, it appareth by these wordes, that neyther hymselfe thinketh, nor hath herde so muche. Aut. Lett. xiv, 107, If the townys be so easy to be wonne...than thinketh his grace that...

Apol. 66, wolde she thinke you beleue him ? Last Tb. 78 C 6, Thinke ye not now that it will be a pleasure?

Rich. 70 A 13, many..men think it valikely yt...

Dial. Her. 238 C 3, What
Last Th. 79 G 10, when we be sick ... than we think how meri a thing it wer.

Picus 5 C 13, He thought that vtterly it could vnneth be.

Jest p. 3 E 7, No harmo she thought. 
Some Lett. I p. 279, Now thought yourselfe therin? al was it so, that in mine Apol. 152, such sinnes... own mind me thought as ye thinke were good my self ${ }^{1)}$ not concluded, to growe.

yet this argument semed me...so sutle...that I could againe aunswere nothing.

me were liefe ; lever.

Rich. 63 A 8, them were leuer to leese all...lhen to haue suche a villany done them.

Boke of F.p. 6 D 4, Lo, in (Last Th. $78 \mathrm{H} \mathrm{11,} \mathrm{he} \mathrm{had}$ this ponde be fyshe and lener double his own frogges both, Cast in payn, than suffer vs to your nette : but be you scape from pain.)

liefe or lothe, Hold you content as fortune lyst assyne.

hlm was (were) good; best ; well.

Jest p. 2 G 4, of an offcere, | Dial. C. (Wks.) 1124 H 5, a Than gan enquere, What man were almost as good him was best to do. lack both as haue bolh. Apol. 152, excepte...such synnes ... as ye thinke were good to growe.

Dial. C. 140, How many men attayne helth of body that were betler for their soules helth were sick.

Dial. G. 255, Some man thet bath not two ducates... were better forbeare.

Dial. G. 242, Wel were himself that euer was be born.

\section{me jrketh.}

(Dial. C. 169, of beauen and of hell that yrked them to think of.)

Dial. C. 286, They were in manner as good be dead al once.

Dial. Her. 123 H 5, surely we were worsr...if we would be so negligent.

(Apol. 65, Iwysse such wordes were well done to be lefte on both sydes.)

1) This emphasizing of the person concerned by means of a reflexive pronoun in -self after me thought is very interesting. No other examples of this phenomenon have been observed. Cf. the quot. from Dial. Her. in the second column. 
(woo worthe hlm).

Hich. 43 E 2, Ah woo Rich. 63 H 15, Woe is Dial. C. 136, Wo mayworthe him, quod she.

that Realme, that hathe they be, whych in tribua chylde to theyre kynge. lacion lacke that mynde. Dial. C. 154, Wo may you be that laughe now.

19. Of the following verbs no constructions of the me think type have been found : become, behove, be loth, eyl, fare, fayle, force, (mis)fortune, greve, grudge, (mis)hap(pen), (mis)like, (fore)long, ought, please, reck, suffyse and thurst. They only occur in transitional constructions and (or) in constructions with a full subject, as appears from the following list. (For $I$ forthynk and $I$ repent see $\$ 17$.)

TRANSITIONAL

to become.

to behove.

to be loth. Last Th. $92 \mathrm{H} \mathrm{2,} \mathrm{beg-}$ gers that be as loth to spend ought.

to eyle. Dial. C. 207, What eyleth this gyrle.

to fare. Last Th. $72 \mathrm{G} \mathrm{13,} \mathrm{folk} \mathrm{fare}$ commonly as he doth that...

to fayle. Picus 11 D 2, as though that now...the deceitfull worlde, and the cursed deuill failed... to force.

to (mis)fortune.
(CERSONAL)

Pageants, Manhod 1. 5, These thynges become a very man in dede.

Last Th. 90 G 10, thou shalte labour... to geate that thee and thyne behoueth.

Dial. G. 156, he would be loth to haue any sucb grace at al.

Ricb. 54 A 7, What thing should bim aile.

Last Th. 79 E 10, surely so fare we by death.

Last Th. 100 F 3, in this we fare ...like a leude master of a ship. Boke of F. p. 1 B 10, Thus like the fox they fare.

Rich. $67 \mathrm{H} \mathrm{3,} \mathrm{euen} \mathrm{those} \mathrm{fayle} \mathrm{me.}$ Rich. 55 A 12, frendes fayle fleers.

Picus 7 B 5, he litle forced, whether his workes went out vnder his owne name or not.

Dial. C. 263, how lewe scape and liue he litle forceth.

Apol. 7, the reder sholde in euery place where he fortuneth to fall in redynge...

Dial. C. 243, when he missefortuneth to falle. 
to greue.

to grudge.

to (mis)hap(pen). Aut. Lett. xıv, 100, if these townys happen to proue lyke so that without long siege....they will no be (wo)nne.

to (mis)like. Aut. Lett. xı, 55, His grace likelh not that themperor settetb on so slowly.

to (fore)long. Answer 1036 D 11, this maketh many folke long to se.

Dial. C. 135, I speake here of him that longeth to be comforted.

Hich. 68 A 4, the man ... forelonged vpwarde.

ought. Apol. 112, Men ought with reuerence to receyue him.

to please. Jest p. 3 F 16, But I would now, comen with you,... yf you please.

to reck. Picus $12 \mathrm{H} 14$, no man recketh whether god lyke hym or nol.

to suffise. Picus 28 A 8 , The loue that is deuided among many, unneth suffiseth that euery part haue any.

to thyrst. Rich. $45(=14) \mathrm{H} \mathrm{2,} \mathrm{the}$ prolecloure so soore thyrsted for the finishynge of that he hadde begonne, that...
Apol. 45, this is the thyng whych greueth this blessed bretherhed a little more.

Dial. C. 212, mi conscience grudgeth me not of any thinge.

Dial. C. 165, yet wyll he that we shal eat our meat when we can happe to get it.

Aut. Lett. xIv, 196, they might releue his ouerthrow if he so myshapped.

Dial. C. 260, we will assaye how our'e diner shall lyke vs.

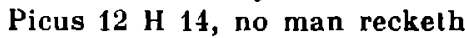
whether god lyke hym or not.

Some Lett. $x$, p. 320, That you feare your owne frayltie, Margret, nothinge misliketh me.

Dial. G. 168, tluan they lie and long for day.

Dial. Her. 169 B 14, more ought I to belene God.

Boke of F. p. 6 C 5, that the aunswere please you not alway, Blame ye not me.

Apol. 43, thys myche...suffiseth for this poynt.

Rich. 40 E 11, whither they sorer thirsted after their own weale, or our woe... it wer hard to gesse.

20. The number of constructions of the type me thinke(th) is not great; only seem, think, list, beseem, need, doubt, rue, were leuer and were best appear to have withstood the general attack on this construction in the Middle English 
period. Indced, the first three resisted so successfully that they do not give the impression of being in a state of decadence at all. These constructions are very much alive and are copiously used by More; moreover they are not exclusively found with the pronoun $m e$, but take other pronouns as well (hym, her, them, ye, thee).

This last fact shows the erroneousness of some of the statements regarding this usage in V. d. Gaal, Transition. In $\$ 12$ he says : "thinketh, thought,... accompanied by other pronouns than me became obsolete about $1500 \ldots$ The only $16^{\text {th }}$ century writer that still occasionally uses such constructions is Gavin Douglas "; in $\$ 79$ : "In the $16^{\text {th }}$ century works the old construction [i. e. me list] only occurs sporadically "; and in $\S 66$ [on rue] : " The A-construction [i. e. me rueth] kept its ground till about the end of the $15^{\text {th }}$ century. "

21. The construction in quot. Rich. $63:$ them were leter, with the verb to be, has a semantic equivalent in the collocation with to have : we had leuer. Of these trvo constructions the latter seems to have been the commoner, to judge from the great number of constructions with had that have been found : ')

Last Th. $98 \mathrm{E} \mathrm{3,} \mathrm{Wonder} \mathrm{it} \mathrm{is} \mathrm{that} \mathrm{the} \mathrm{worlde} \mathrm{is} \mathrm{so} \mathrm{mad,} \mathrm{that} \mathrm{we}$ had leuer take sinne with pain, than vertue with pleasure. I Last Th. 78 H 11, he had leuer double his own payn, than suffer vs to scape trom pain. | Apol. 63, he had as leue his ennuy were let alone. I Apol. 150, then had I as leue the iudge might do that as they. | Dial. C. 328, Some man shall you see that abideth dedly torment, and suche as some other had leuer dye then endure.

Of these constructions the last one deserves special notice ; the construction clearly betrays its origin, and the meaning of some other had leuer dye, etc. is easier to grasp if some one is looked upon as a "dative " object instead of as a subject.

Another case of contamination or blending is contained in the following quotation :

b) For a discussion of the blending of the three constructions (them were lever, they were lever, they had lever) the reader may be referred to Hall 1881, Stoffel 1887, and especially to the exhaustive treatment in V. d. Gaat 19u4, 844 If. 
Dial. C. 140, How many men atlayne helth of body that were better for their soules helth were sick.

Since in the other quotations the collocation were better, were leuer is followed by an infinitive, the form were in were sick seems exceptional. We should expect : men that were belter be sick.

22. There are in the quotations in the first column of $\$ 18$ a few doubtful cases, viz. those with yrketh them and abhorreth me. If the words that (hell that yrked them to think of) and which (bestes which abhorreth me to thinke on) may be looked upon as subjects, the construction properly belongs in the third column. It is, however, more plausible to assume that that is an ohject to think of and which an object to thinke on, so that the clauses are equivalent to [it] yrked them to thinke of that (= hell); [it] abhorreth me to think on them (= bestes). And so their place in the first column is defensible.

23. Most of the causes of the transition of the construction me thinketh to the present-day idiom $I$ think are found instanced in the second column (transitional constructions) :

$a$. In the majority of the cases the object was not a pronoun, but a noun (woe is that realme; the protectour thyrsted). This noun could catachrestically be looked upon as a subject, as its object-character was no longer to be inferred from its form, and as there was virtual concord between subject and verb. Even in the case of plural nouns this concord seemed to exist, since a verb in -eth could also have a plural subject in More's language. (Picus $10 \mathrm{E} 1$, Here foloweth the epistles. | Dial. C. 175, the wordes soundeth. | Dial. Her. $115 \mathrm{G} \mathrm{9}$, as the wordes of the scripture showeth. | Dial. Her. $128 \mathrm{G} \mathrm{8,} \mathrm{they} \mathrm{twaine...doth} \mathrm{and} \mathrm{truely} \mathrm{shewe} \mathrm{me').}$ IVith the verb list there was nearly always concord, as it did not take endings as a rule. The same may be said of the forms ending in -ed and the other preterites (with the exception of the thou-forms).

Quite naturally in all these cases the pronouns he, she, they, etc. interchanged places with the nouns. The change

1) Cf. Staden 1803, pp. 41 ff ; Grünziger 1909, \$234; Knecht 1911 ; Delcourt 1914, p. 153-4; Franz 1924, \$ 156. 
from thinketh, seemeth, into think(e), seem(e) was probably due to analogy with the list-forms ').

$b$. In such fortus as a man were almost as good lack both misunderstanding of the original meaning was increased by the fact that the form were ("subjunctive") agreed with all kinds of subjects.

c. The invariability of words like that (Last Th. $92 \mathrm{H} 2$, beggers that be loth) facilitated the progress ${ }^{2}$ ).

$d$. The forms myself, himself, etc., were in equally frequent use as subjects and as objects, e. g. : Dial. C. 222, a certayne apparicion shewed vnto hym, as hymselfe saill... | Dial. C. 218, and hymself is ... such as I reken for ryght honest. | Dial. C. 228, Besides this, himselfe...seeth and perceiueth the thing. | Dial. C. 139, Oursell can better tell then he. It was therefore impossible to realize the exact function of these words in units like : Dial. C. 224, God may bothe licence and connmaund if bymself list ${ }^{3}$ ).

$e$. As, with the wearing off of inflectional endings, a fixed word order had become essential for the recognition of the functions of the words in a unit, it had become more and more natural to consider the pre-verbal word in declarative sentences as the subject. Hence the eventual ousting of me, him, etc., from this front-position.

$f$. Another cause of the transilion is to be found in the not infrequent juxtaposition of the two constructions :

Apol. 98, it appereth by these wordes that neyther hymselfe thinketh, nor hath herde so much. | Dial. Her. $215 \mathrm{C} 4$, himself liked it, and allowed it, and therfore wrole it out. | Conf. Tynd. 725 F 4, these heretikes receiue such as lyke them and refuse such as they list. | Debell. $934 \mathrm{C} \mathrm{11}$, ...me thought and yet thynke ${ }^{4}$ ). I Rich. $68 \Lambda 4$, the man had a high heart and forelonged vpwarde.

24. So far only one kind of transition has been dealt with, viz. the change from me thinketh to $I$ think, in which the new conslruction consists of subject + verb, but has no " da-

1) Trnka 1930, p. 55

2) V. d. Gaaf $1904, \$ 36$

3) This cause of the transition is not mentioned in V. d. Gaal 1904. Nor in Trnka 1930.

4) If, however, thinke stands for thinketh (as it often does) this intance is not to the point. 
tive " object. It is clear that constructions consisting of subject + verb + object (This discension yrked hym; if the answer please you; our dinner shall like us; these things become a man; conscience grudgeth me; the thyng whych greueth us) cannot be explained in the same way, as the original "dative " objects are still there 1). It cannot therefore be said that here also the original " dative " rvas replaced by a " nominative ". Evidently these constructions are direct descendants from the $i t$-constructions, so that the development is : it yrked him $>$ that yrked him, the eliscension yrked him | it greueth me $\rangle$ this greneth me, the thing greneth me. This kind of transition would then be much easier to account for than the other.

\section{Subject Not EXPRESSEd}

\section{Before being.}

There are a few instances in More of being, instead of they being, $I$ being, it being, etc., as an introductory word to a clause-equivalent :

Dial. Her 214 H 11, But howe coulde that be so against so many proues sworne, and deposyng the matter vpon theyr othes, beyng though they were but men, yet men of wit and honestye.

Dial. C. 280, I lyked my selfe the better, because mee thoughte my woordes beeynge but a straungyer, wente yet with some grace in the Almain tong.

Aut. Lelt. V 25, after that his grace was cummen home bither and had dined being VI of the clokke in the nyght I offred my selfe agayne to his grace.

The first of these quotations is the earliest instance of this usage recorded in OED. From this, it may perhaps be inferred that this idiom was not yet very old in More's time. Later instances are : $c 1590$ Marlowe, Faust, this makes me wonder above the rest, that being in the dead time of winter ... how you should come by these grapes. | 1507 Shakesp. 2 Henry Iv, II, i, 203, You loyter heere too long, being you are to take souldiers up. | 1641 Best. Farm. Bke. 120, They went all for halfe gates, beinge that they coulde not bee discerned.

In Pres. D. Eng. the usage is archaic or dialectical.

1) The adativen sometimes appears in the form of a prepositional group with to : Pageants, Chyldhood l. 4, But would to God lbese hateful bookes all, were In a fyre brent to pouder small. 
it being is used in the following passage : Passion 1349 A 12, he discerneth nol the bodic of our lorde, that is to wit, considereth it not... as he ought to dove, it being the body of our lorde as it is.

\section{After as.}

Dial. C. 221, whyche kynde (scil. of lies) S. Hieron. as by diuers places in his boks apereth, taketh not fully for so much. | Last Th. 99 D 5 , nature ... is sustained with right litle (as wel appered by the olde fathers.) | Dial. Her. $189 \mathrm{G} \mathrm{13,} \mathrm{Saint} \mathrm{Ausline} \mathrm{as} \mathrm{is} \mathrm{written} \mathrm{by} \mathrm{possidonius}$ ... cured anolher with his prayour.

Though there are numerous instances besides the above, in Mor'e, of the "absence" of a subject-word afler as, the "absence" may not be looked upon as a regular feature :

Picus $15 \mathrm{C} \mathrm{Il}$, the company of the court ... diuersly (as it is their vnunerly manoi') descanled (herof to his rebuke. ( Picus 15 D 8, his vncle... comfortellt and encorageth him, as it is in the course therof euident. | Hich. $58 \mathrm{E} 7$, After that king Edward the fourthe had deposed kinge Henry the Sixt, ... determining himself to mary, as il was requisite bothe for himsell and for the realme, he sent...

Sometimes the word as can be looked upon as the subject, as in the following quotation :

A pol. 152, excepte there be any such synnys ... as ye thinke were good to growe.

\section{After so.}

Dial. Her. 156 D 17, as it was wryten by men, so was indited by God. , Dial. Her. 171 E 7, I wil ... proue you the trueth ... of the church by the trueth of them. And so semeth me good reason.

If the word so is considered the subject, these quotations are not relevant. Pres. D. Eng. would seem to require it here: Tennyson, Dora, 26, Bıt in my time a father's word was law, And so it shall be now for me.

\section{After and and but.}

Apol. 92, yf they were inuited in to relygyon on the other fashion, and were sayde vnto them thus :... | Apol. 179, when that after I sealed a commissyon and sent it vpon the assaye, it made theyr hartes fainted and were so well come downe that they layed all the wyght to a fewe lewde followes. | Gonl. Tynd. 655 H 15, but as the churche of Christe is but one so be there of those a vengeable maynye, and be not comprehended vnder any one churche. | Cont. Tynd. 367 \& 12, ... as Moises for necessitio left tho children of Israel vucircumcised, and were yet thought to be in no worse case than they that were circumcised. I Conl. Tynd. $439 \mathrm{D} 8$, Here secinelh a godlye thyng, and is in dede very 
deuelishe. I Apol. 149, For amendes the law geueth him none against any of theym, nor it wer not well done be sholde but may whan he is after by other. xir. acquyte, goe grealle hym home and be mery.

Delcourt ') suggests that this word and has the value of a pronoun, so that we may read : Herc seemeth a godlye thyng which is in dede verye deuelishe. This explanation tallies with the guotalions he mentions himself, but it is impossible to account in the same way for the usage in the first two quolations of the above collection. It would be better to ascribe the absence of the subject to the possibility - greater than in Pres. D. Eng. - of omitling the subject if it could be easily gathered from the context. There is plenty of evidence that this kind of syntaclical economy was the established usage in older English. Compare : Aelfr. Hom., pe gelicolle gode peos ben, and carap to Salome... Chaucer, And efter thal hire thought gan for to clere, and sayde... I In Shakespeare we find : Wint. T., IV, iv, 168, They call him Doricles, and boasts himself To have a worthy feoding.

In Pres. D. Eng. this omission of the subject is not possible.

\section{Before to be.}

Dial. IIer. 161 F 9, By what scripture is euidently knowen that every man and woman hath power to minister the sacrament of baptisme? Dial. Her. $243 \mathrm{E} 12$, al these thinges which is not possible for vnlearned men to attayn vnto. | Picus 5 $B$ 12, where he so behaved him self, that was wondre to beholde, how all the audience reioyced to heare hym. I Apol. 115, this thousand yere was neuer the tyme that all so dyd.

Properly speaking it is not correct to assume absence of the subject here, as it is really expressed in the unit that follorvs. It may be said that in the first three cases Pres. D. usage would require it before the verb, and in the last the word there. The words which and that (quotations 2 and 3 ) may also play a part.

30. In units opening with as for.

Ipol. 71 , as for the fawtes of some partyculare partys, ... is nothing that oughte of reason be rekened for the cause of this diuysyon.|Apol. 77, For as for the speche of folys is not to be compted for a prove. | Last

1) 1914, pp. 196 : “il n'y a en apparence aucune raison pour que la ... conjonction ne prenne pas toute la valeur d'un pronom ". 
Th. 82 (f 15, As for wrallie and enuy be the knowen children of pride. ! Last Th. 9:3 B $5, A s$ for the gloten is redy to here of temperance... when lis bely is wel filled. | Dial. Her. $236 \mathrm{~B} 1$, as for these three matters ... proned very Iryfles. | Jest $2 \mathrm{C} .5$, As for the price could him not miscontent. | Hich. $59 \mathrm{G} \mathrm{4,} 1 \mathrm{~s}$ for possibilitie of more inheritance ..., is often the occasion of more trouble. | Dial. Her. $115 \mathrm{G} \mathrm{4}$, as for the richesse of the temple..., coulde make no matler to the people. I Apol. 51 , as for all the landes \& fres that $I$ have in all kingland ... is not ... wurth yeiely ... the somme of full fyfty pounde. | Debell. 936 B 11, But as for me to peruse hys whole book of denision thorow was no part of my purpose.

Delcourt (1914 pp. 214, 215), Reed (1931 Phil. Notes p. 207), and $\operatorname{OED}(\mathrm{s}$. v. as for, $33 \mathrm{~b}$ ) apparently share the opinion that the subject is missing in these constructions. They evidently compare this usage after as for with the usage in Pres. D. Eng., no doubt assuming that as for had the same meaning in More's time as it has now, vi\%. as regards ; which seems rather doubtful. What the exact meaning was, is difficult to state. But it may have been felt as an emphasizing attribute to the following noun, in some respects resembling the word now in e. 1597 Hooker, Eucl. Pol. V, XIX \$2, Now the principal thing required in a witness is lidelity. | 1881 Jowett, Thucid. 1, 1.50, Yow the Archarnians are famous for their skill in slinging.

Busides, to speak of omission in constructions that never ') oceur in another form seems illogical and as fallacious as the statement that in contact-clauses (e. $g$. this is the boy we spoke of) the word that is missing.

That there is nothing omilted in the conslruclions with as for is still nore clearly brought out by the fact that the noun immediately following as for is hardly ever repealed in the form of a pronoun, whatever function in the sentence it may have. Ci. A pol. 125, But as for his inuche people I sette nol myche by. A. I. 'Taft, who (in his edition of 'The Apology, 1929, 27) interpolates the word $h y m$ after the words I coulde in the following unit : $134 \mathrm{l} .6$, and as for Constanlyne hymselfe [ coulde [hym] in guod faith no thanke, misunderstands this interesting idiom. 'The construclion wilh as for, as instanced here, seems to

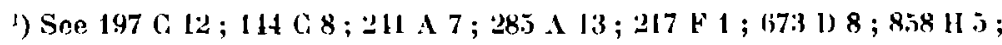
1226 C 8 ; 236 H 5 . 
date from More's time, the earliest quotalion in OED being dated 1525 : Ld. Berners, Froiss. II, cxuvi, 75̄6, As for these townes wyll nener tourne frenche | The latest is : 1586, Cogan, Haven, Ileallh, $20 \mathrm{ij}$, As for herbs and fruits, especially raw, at all times are to be refused.

The usage does not occur in Shakespeare. (Cf. Schmidl, 1902).

\section{In commands.}

In syntactical units expressing a command, the lexicographical form of the verb is used withoul subject word.

Last Th. $75 \mathrm{~A} 1$, Looke vpon his holy apostles / Picus $7 \mathrm{G} 8$, If I be ought in your delle, I stall paie by and by. If ye be in myne, paye me, either now ... or hereafter. | Apol. 186, yf this tynker were detected ... and thervpon sent for ... be sholde ... say bring me forth mine accuser Apol. 186, suppose me now that a tynker ... were now become hymselfe an vssher | Boke of F. p. 5 B 7, Now haue I shewed you bothe : chese whiche ye lyst. | Apol. 68 Lo thus yt begynneth.

It appears from these quotations that this construclion was not only used in commands, but also in exhortations, directions, cautions ${ }^{1}$ ), etc. The noll-expressed subject is the person(s) spoken to. The usage was no innovation; it has survived into Pres. D. Eng. Only the word $l o$, profusely used in More's argumentative prose, is archaic now.

32. The following set of quotations shows that it was not exceptional for the subject to be expressed in commands, exhortations, etc.

a) Last Th. $89 \mathrm{D}$ 3, Seke ye fyrste for the Kingdom of heuen ... | Boke of F. p. $6 \mathrm{G} 5$, If that the answere please you not alway, Blane ye not me | Picus $13 \mathrm{~A}$ 3, Come ye my blessed children, possesse ye the kingdome that hath been prepared for you / Picus 15 G 3, Fare ye well. | Picus $15 \mathrm{~F} \mathrm{12,} \mathrm{If} \mathrm{the} \mathrm{worlde} \mathrm{...} \mathrm{hate} \mathrm{you} \mathrm{:} \mathrm{know} \mathrm{ye,} \mathrm{that} \mathrm{it} \mathrm{hated} \mathrm{me} \mathrm{be-}$ fore you. | A pol. 180, feare ye not for that syr | Picus 12 D 11, Bul crie thou therfore with the prophete :... | Picus 16 C l's, goe thou boldely foorth thy iourney. | Picus 16 D 11, Let dead men alone with dead men, folow thou me. | Picus $12 \mathrm{E}$ 15, Wherfore my child, goe thou neuer about to please them, whom vertue displeseth.

1) To express disapprobation More often uses the exclamation go to. Debell. $1023 \mathrm{G} \mathrm{12,} \mathrm{Well} \mathrm{goe} \mathrm{to} \mathrm{now} \mathrm{:} \mathrm{let} \mathrm{vs} \mathrm{rehearse} \mathrm{hys} \mathrm{owne} \mathrm{wordes}$ againe. Also 47 F 13 ; 673 E 8 ; 1031 I 13; 1107 B 9 . 
b) Picus $13 \mathrm{~A} 1$, our lord shall say : (ro ve cursed people inlo eurrlusting fycr. | Last Th. $81 \mathrm{~F}$ ll, Nowo come fourth ye proude prisoner.

c) Picus $13 \mathrm{E} 8$, myne ignorances, remembre not good lorde.

The subject always follows the verb and is in a) the pronoun ye or thou, in b) the pronoun ye + noun or thon + noun, and in c) noun only.

Pres. D. Eng. has both front- and post-position of the subject, e. g. You take it from me that he lies. I Come you here, my boy ').

33. The character of the collocation verb + pronoun is doubtful in : Apol. 66, I pray you good man ... gete you shortely hense | Pageants, Fame l. 1, Fame I am called, maruayle you nolbing. | Mich. $53 \mathrm{~B} \mathrm{13,} \mathrm{My} \mathrm{lord,} \mathrm{quod} \mathrm{the} \mathrm{lord} \mathrm{Hastings,} \mathrm{neuer} \mathrm{doute} \mathrm{you.}$

Il is possible to look upon you in these units as a reflexive pronoun. Compare : Dial. C. 216, the man waxed wroth ... and bode her get her in. | Dial. C. 338, I fear me when I hear'e that. | I pol. 180, And with suche good hope the good man groeth hym home. (Sce the paragraphs on reflexive objects.)

34. The usage illustrated in the following quotations deserves further discussion :

Last Th. $85 \mathrm{G} 11$, enuy is ... the doughter of pryde in so farrelorth that as this holy doctor sayeth, strangle the mother and thou destroyest the doughter. / Dial. Her. $120 \mathrm{~F} \mathrm{1,} \mathrm{loke} \mathrm{me} \mathrm{thorow} \mathrm{christen-}$ clome, and ... ye shall finde the frute of those. | Apol. 58, loke my dyalogue ... and ye shall clerely se that ... | Picus 27 A 1, Take euery sporte, that menne can thee deuise, And among' them all ... 'Thou shalt no pleasure comparable linde. I Debell. $980 \mathrm{C} 2$, reade the stories who so will, and he shall finde bolhe by Platina and Cronica ... that...

It is evident that the verbs in these quotations have not the same function as those in the quotations of $\$ 32$ : they do not express a command, an exhortation, etc. The passages consist of two syntactical units counected by and and resemble hypothetical statements, the protasis containing the condition,

1) The usage in the Rolle and Wyclifite P'salters and in the Auth. Version is discussed by Muir, 1935. On p. 306 be says : "Another peculiarity of W. [= the Wyclifite Ps.] is the insertion of the subject after imperatives. Therefore when R. [= Holle's Ps.] and $A[=$ Aulb. V.] have

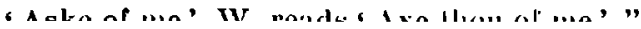


(he apodosis the conclusion or the consequence '). The nonexpressed subject of the protasis can be gathered from the apodosis, in which as a rule it is expressed. This is, however, not necessarily so : Rich. 5l F 15, kepe one safe and both be sure. I I)ial. C. 293, Break one of his commandementes and hreak al. Forsake one poynte of hys faythe and forsake al.

The usage was known before More and has survived into Pres. I. Eng.

35. All the above quotations show that More had only one form for the singular and the plural; he does not make use of the form in -eth, -es, when addressing more than one person, a usage common in older English, e. g. c 897, Ellred, Cur. Pasl. 343, Nime ge and settath. 971 Blickl. Hom. 241, Behealdap pow and zeseop hine. 13 ... Cursor $M 15233$ (Cott.), Takes and eles o pis bred. The usage seems to have dropped into disuse not long before More. It may be inferred from the following evidence that vacillation set in about the middle of the $15^{\text {th }}$ century.

a. with -eth. c 1425 Cursor M. 661 (Trin.), Bep ware \& take\} good pntent. | c 1440 Gesia Rom. I, 4, (Harl. Ms.), seith nowe, goode men. | 1482 Monk of Evesham (Arb.) 27, Settith before vs the bred (OED).

b. Ivithout -eth. c 1440 York Myst. xxxı, 146, Saie! beene venew in bone fay, Ne plesew et a parle remoy.

36. The unchanged form of the verb could also be used to express a command, a wish, an exhortation, etc., in reference to the first person plural (cf. French donnons; Italian diamo).

971 Blickling Hom. 11, Arweorpian we Crist on binne aselene. I a 1250 Owl \& Night. 177 (Cott.) Ac lete we awei pos cheste. | 1593 Shaksp. Rich². I ii 6, Put we our quarrell to the will of heauen (OED).

Of this usage only one instance has been found in More ; it is slightly different, owing to the absence of the pronoun we :

Dial. C. (Wks.) 1263 B 6, When we feele vs to bolde : remember our owne fieblenesse. When we fele vs to laynte : rememher Chrystes strenthe 〈viz. strength >.

1) Jespersen 1924 p. 315 uses the lerm “imaginary imperalive » to denote this construction; Kruisinga $1931 \$ 178$, points out that in Pres. D. Eng. rising intonation at the end of the first sentence makes it clear that a the function of the stern is that of a subordinale clausen. 


\section{INTHODUCTORY TIENE}

37. a) Picus $2 \mathrm{D} 10$, there appeared a fierye garland. | Picus $31 \mathrm{C} \mathrm{8,} \mathrm{oft}$ from his eyes there falleth many a tere. | Picus $1 \mathrm{~F} 8$, The workes are suche, that ... I suppose ... ther commeth none in your hande more plofilable. Last Th. 85 F 8, Whan this condicion was offered, than began there som courtesye betwene the enuyous and the couetyse. Picus 6 E 9, fell there neuer so great misaduenture ... he could neuer ... be moued to wrath.

b) Hich. $66 \mathrm{E} \mathrm{10,} \mathrm{With} \mathrm{this} \mathrm{there} \mathrm{was} \mathrm{a} \mathrm{gret} \mathrm{shout,} \mathrm{crying} \mathrm{King} \mathrm{Ri-}$ chatrle. | Picus 5 A 4, it might appere, there were nothing in any of them, that were vnknowen. | Dial. Her. $195 \mathrm{~A} 13$, vp in a wood is there a chapel. | Dial. C. 142, ther was dew to that synne ... a fur greater punishment. | Hich. $49(=46) \mathrm{B} 8$, from that tyme hytherwaide, was there neuer so vndeuow te a kinge, that durst that sacred place violate.

c) Picus 4 B 9, ther were in them many thingos straunge.

Though in some of these quotations there is still a certain reminiscence of the old local or demonstrative character in the word there [as in : $\mathrm{vp}$ in a wood is there a chapel], in the majorily of cases there seems to have been reduced to a mere anticipatory element serving to occupy the place of the subject which comes later. It differs from the proleptic it in that the verb agrees in number with the following subject.

This usage with there as an introductory subject is exclusively found a) with verbs that do not require a complement (fall, come), and b) with the verb to be, forming whal Jespersen calls "existential sentences". Here, as with the proleptic $i t$, the end-position of the full subject is not always in the first place due to a desire to create a feeling of suspense and thus attract altention more forcibly to the subject, but rather to the fact that front-position of the subject would not make a properly balanced unit ${ }^{1}$ ).

38. Constructions like the following, in which it lakes the place of there have not been met with : c 1300 Havelok 154, nis it no corn... ? | c 1603 Beggar's Dau. Bedn. Gr. I, 1, Itt was a blind beggar, had long lost his sight ... 1798 Coleridge, Anc. Mar., It is an ancient mariner, And he stoppeth one of three.

1) This is also brought out by the fact that there is not used where a proper balance can be created in another way: Picus 8 B 9, he answered, that be had leuer take him to mariage, as that thing in which was lesse seruitude, and not so much ieopardie. 
39. One kind of units opening with there degerves special notice.

Picus 5 1) 4, There was nothing passed him ... of those caplious sulbtillies and canillacions of sophistrie. | Dial. Her. $208 \mathrm{D} 10$, There is n ineane may serve betwene both. I Conf. Tynd. $513 \mathrm{D} \mathrm{13,} \mathrm{Then} \mathrm{was}$ there yet one texte remayned. | Dial. Her. $212 \mathrm{H} 4$, And therefore if his iudges wronged him, there was neller man had right.

Here is a case of grammatical economy, nothing in There. was nothing passed him performing a function in two syntactical units. This is an instance of what Jespersen (1928 pp. 1332 if) calls " contact clauses", Kruisinga (1931 \$2293) " unconnected clauses", and Curme (1933 p. 236) "paratactic clauses".

The usage was known before More's time '), an the following evidence proves :

a 1366 Chaucer, Rom. Rose 1239, Ther is no cloth sllteth bel on damiselle, than doth roket.|1470-85 Malory, Arth. xin, 616, There was no knight knewe from whens he came. | 1470.85 Malory, Arth. 212, 4, there were many knygles bare hyin record nyghe thre score.

In the earlier Middle Fng. lexts, however, instances do not frequently occur. Jespersen (1928 p. 135) points out that one of the rensons may lie in the character of these texts, which is far from being colloquial. More's using the construction so frequently is rather striking, as contact clauses are often said ${ }^{2}$ ) to be avoided by such writers as are strongly influenced by Latin syntax. It is well known that Samuel Johnson called the omission of the relative a colloquial harbarism.

In Pres. D. Eng. such contact clauses are profusely used in unconstrained diclion.

\section{Two Subjecta}

40. It often happens that a subject standing in the first part of a sentence is repeated by means of a personal pronoun farther on in the sentence.

Dial. C. 168, But some men nowe whan thys callyng of god causeth thein to be sadde, they be lothe to leaue theyr synneful lustes. | Rich. $47 \mathrm{~F} \mathrm{3}$, Howe ber it muche of this mischiefe if wyse menne woulde sette

1) In Malory instances are [requent (Dekker 1932 \& 107).

3) Jespersen 1924 p. 136. 
their bandes to, it ') mygbte bee amended. | Last Th. 97 C. 2, The boly scripture rehearseth, that in desert the children of Israel when they had sitlen down \& wel eaten \& dronken, then roose they vp \& playd Ibe ydolaters. Dohell. 930 D 2, this piece it was told me that in the new aunswere it was reasoned at length, \& set forth very lustely.

Instances abound. This usage may not be looked upon as a grammatical solecism; it finds its natural explanalion in the fact that in lively language the subject springs forth in the speaker's mind as the most important thing before it is felt as a subject ${ }^{2}$ ) and is then repealed in the form of a personal pronoun in its regular place immediately preceding or following the verb, especially when a lengtly group of words intervenes. The repetition is, however, not necessary, as appears from those passages in which More avoids this kind of pleonasm, e. g. Apol. 909 (Wks.) D 7, And myselfe whan I was chaunceler, vpon such secret informacion haue put some out of commission.

Though it is dangerous to make statements concerning intonation and stress, it seems almost certain that this usage afforded a device to emphasize the most important word : Dial. Her. 163 H 13, The wordes that God speake to Moyses, where thei not goddes wordes all... ? | Dial. Her. $122 \mathrm{G} \mathrm{14,} \mathrm{those} \mathrm{which} \mathrm{be} \mathrm{the} \mathrm{best}$ lemples of god in their soules, thei most vse to come to the temple of stone. If this is true, Delcourt's statement (1914 p. 222) that in these cases "le pronom personel répète sans raison un sujet" would be wrong.

More does not deviate from older practice :

c 1400 Mandrville, 129, 13, Men of pat contree whan bere frendes ben seke pei hangen hem vpon trees (M). | 1470-75 Malory, 222, 25, Bul at the laste the black knyghle within an houre and a half he felle doune of hors in swoune (D).

The following quotations illustrate the usage in St. John Fisher and in Spenser : Fisher, Eng. Wks. EETS., 305, 20, This same noble prynces y $\mathrm{l}$ she had contynued in this worlde, she sholde dayly haue herde \& sene mater \& cause of sorowe. I Spenser, F. Q. I, 2, 9, But subtil Archimago, when his guests He saw divided ... he praisd his devilish arts (S).

1) Nole the place of the comma.

2) Gompare : Dial. C. 140, Some yonge lonely lady, lo that is yet good inough, God seeth a storm come toward her. | Apol. 15t, And therefore thys palche of thys pacyfyer... euery wyse man may bere wytnesse that there is lytle wyt theryn. - What at first sight seems the subject turns out to be an adjunct. 
In Pres. D. Eng. the construction is still used in popular and colloquial speech, e. g. : William Allen While, A Certain Rich Man, Ch. virI, Now, they ain't many women that would just let a man stand up like that and give her danghiler away under her nose, but my wife, she's been well trained (C.).

Special attention should be given to those conses in More in which the emplasizing character of the repetition is incontestable, as in : Dial. Her. 346, he careth not to haue his flesh shyne he, nor like a sparke of tyre to skippe about in the skye. | Dial. Her.

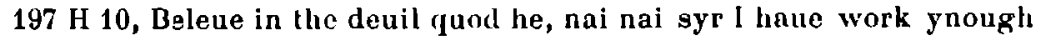
to beleue in god $I$.

This usage is frequently met with in the prose passages in Ben Jonson's plays : Ev. Man Out of His H. IV, v, 16, Xay, we have no art to please our friends, we ! Poetaster III, i, 603, I have stood up and defended you, I. | Poetaster III, i, 624, I'll make a gathering for him, I.

41. After the relative but that More expresses the subject by means of a referring word :

Picus $18 \mathrm{E} 4$, There is no crealure but that it noedeth other creatıres. । Conf. Tynd. 643 D 1, He shall nol lyghtly fynde any of those olde, but that he vsed allegoryes.

This seems to be a neologism dating from More's time. OEI) has no earlier instances (s. v. but 12 b.). In Pres. D. Eng. both that and the referring word are dropped, e. g. : 1866, Kingsley, Herew. XLI, 495, Hardly one of the Frenchmen round, but looked on Hereward as a barbarian Englishman.

Note. - For the subject of the infinilive (Dial. C. 130, the bodye not to feel that it feeleth, all the witte in the worlde cannot bring about) and of the form in -ing (Picus $13 \mathrm{~F} 15$, I haue passed now the boundes of a letter, the mater drawing me forth), sec the chapters on these verbal forms.

\section{Concord in Number hetween Subject and Vera}

42. In accordance with older and with Pres. D. usage, a singular sulject requires a singular form of the verb and a plural subject a plural form of the verb.

Picus $15 \mathrm{H} \mathrm{9,} \mathrm{God} \mathrm{hath} \mathrm{exalted} \mathrm{him.} \mathrm{|} \mathrm{Dial.} \mathrm{C} \mathrm{205,} \mathrm{in} \mathrm{the} \mathrm{night} \mathrm{eueri}$ bushe ... semeth a theefe. | Dial. 201, than are we safe. | Boke of F. p. $6 \mathrm{D} \mathrm{14}$, in this ponde be fyshe and frogges. | Picus 4 A 5, those conclusions were good and standyng.

For exceptions, such as : Apol. 51, all the landes and fees that I bave in all England ... is not at this day ... wurth yerely ... the somme of full filly pounde, see $\$ 48$. 
43. When the subject is plural, the verb not infrequenlly ends in $-(e) n$.

Dial. $\mathrm{C} 204$, in the nighte wrilken all the beastes of the woods. I Conf. Tynd. 668 A 10, And lrere Huskyn, Tindal, Suingles glosen it. | Mich. $36 \mathrm{~F} 10$, al the bandes broken that binden manne and manne together.

Picus 18 li: 7, as philosophers and diuines prouen. | Dial. Her. $121 \mathrm{C} 11$, They that gone on pilgrimage. | Picus 19 D 2 ... euyl men forsaken reason, whiche standeth al in the soule, and folowen sensualitie, that standeth al in the bloode. I Also : Cont. Tynd. $411 \mathrm{G}$ 2, dependen; (ionf. Tynd. 454 B 6, preachen; Conf. Tynd. 540 A 8, diellen; Conf. 'lynd. 599 D 11, consenten; Answer 1103 G 5, murmouren.

This is evidently a survival of Middle English usnge (Midland dialect) : c 1300 Debate Body \& Soul (p. 48 in limerson, Middle ling. Il.), pat alle pine frend ben fro pe fledde. I c 1300 story of Joseph (Emerson, M. F. R. p. 12) pe lene hacen pe fette freten.

In later English such endings are occasionally lound in Spenser, IVyatt, Surrey, Lyly and Shakespeare. It is well known that Ben Jouson called the disappramance of the -en ending " a great blemish to our tongue".

43. There are a few instances of the plural ending-(e)s. Picus $30 \mathrm{D} \mathrm{1,} \mathrm{[god]...} \mathrm{whom} \mathrm{hell,} \mathrm{earth,} \mathrm{and} \mathrm{all} \mathrm{the} \mathrm{heauen} \mathrm{obaise.}$ Apol. 851 II 17(Wks.), they exercises his lawe wrilten] in their beartes. | Passion $1499 \mathrm{G} \mathrm{1,} \mathrm{some} \mathrm{thinkes} \mathrm{it} \mathrm{was} \mathrm{Saynte} \mathrm{James|Passion} 1380 \mathrm{~B}$ ti, whyle such persons ... beginnes lesse and lesse to mislyke it.

This form is probably due to the analogy of the singular form. In older English it occured in the Northern and Fast Midland dialects '), though rarely in prose texts ${ }^{2}$ ).

The first two quotations should be read wilh a cerlain reserve, since they are taken from the second part of " A Treatice vpon the passion ..." (pp. 1350-1405), which was perhaps not written by More in English; it opens with the following introduction : "An exposicion of a parle of the passion of our sauiour Jesus Christe, made in latine by syr Thomas More Knight (while be was prisoner in the tower of London)".

The word obaise in the first quotation allows of a threefold interpretation. It may be the plural of the verb to obay and then its place in this section is justified; it may be the uninflected form of the verb obeis, the latest quotation of which in OED is dated 1500 . Or it may be the third person singu-

1) Wyld 1924 \$29.

2) Dolcourt 1014, p. 154 lootnote 4. 
lar in $-\mathrm{s}^{1}$ ) of the verb obay, it being by no means exceptional for More to use a singular form of the verb after an enumeration. Cf. $\$ 48$.

For a few isolated plurals in $-s$ in Shakespeare, see Franz $1926 \$ 155$; in Spenser, Sugden $1936 \$ 208$.

44. The third person plural of the verl) frequently ends in -eth.

Last Th. 87 A 2, the lawes ... consydereth, pondereth, and punisheth, the trespasses done to euery manne. | Picus $12 \mathrm{~A} \mathrm{11}$, the delites of this world, which in the seking wery vs, in the hauing blindeth vs, in the lesing peineth vs. | Picus $10 \mathrm{E} \mathrm{1,} \mathrm{Here} \mathrm{foloweth} \mathrm{thre} \mathrm{epistles} \mathrm{of} \mathrm{the} \mathrm{saide}$ Picus. | Last Th. 72 D 3, These wordes geueth vs al a sure medicine yf we forslouth not the receinyng. | Picus $20 \mathrm{~B} 6$, my raines ... not only now enclineth me not to sinne, but also chideth me.

One of the striking features of More's English is this frequent use of the ending -eth in the third person plural, by the side of the uninflected form of the verb ${ }^{2}$ ). Though various scholars ') duly mention the occurrence of this form in -eth, and account for its origin, no attempt seems to have been made to find the reason(s) why in one case the short form, in another case the long form is used. The hypothesis seems untenable that so careful a writer as More should have used both forms at random and unsystematically. It is possible that in a language in which short forms were so often used to express or help to express modality, the forms in -eth afforded an efficient means to emphasize reality.

Plurals in $-s$ or $-t h$ were both considered proper in the $16^{\text {th }}$ century. Endings in -th repeatedly occur in Alex Barclay, e. g., Ship of F., Stanza 966 (Engl. Versions, p. 50) ; st. 257 (idem p. 60) ; st. 637 (idem p. 62). Even Spenser ${ }^{4}$ ) and Shakespeare ${ }^{5}$ ) occasionally use them.

1) There are a few indubitable cases of -s third person singular in More : Conf. Tynd. 612 A 14, right seldome it happes that ... I id. $539 \mathrm{E}$ 6 , the holye gost that kepes a mannes harte. | Boke of F. p. 3 B 2, Fortune alone ... vnstable here and there among them flites.

2) Sentences like the following are therefore quite regular: Hich. 49. H 4, I doubte not but shee nowe as sore myndeth it, as we the lette therof. At first sight the constructions seems to be sylleptic.

$\left.{ }^{3}\right)$ Staden 1903 ; Bauch 1935 p. 234 ; Franz $1924 \$ 156$; Wyld $1924 \$ 32 \theta$.

1) Sugden $1936 \$ 238$.

5) Franz $1924 \$ 153$. 
45. After the relative words that, whlch, who, as the verb agrees in number with the real subject expressed in the antecedent : .

Dial. Her. 121 C 11, They that gone on pilgrimage. | Picus 5 fI 10, let vs speake of them that helonge to the acliening of noble acles. | Ricb. 45 $(=44)$ D 2, sach of the Dakes seruantes as rode with the carles ... that were taken ... they shewed vnto the people. | hich. 58 A 3 , such as had wit, \& were in aucl boritic. | Picus 5 H 7, But now let vs passe ouer those power's of his soule, which appertaine, to vnderstanding and knowlage. Hich. 47 B 8, theeues, of whiche thrse plares bce full, and which nener fall tro the crafte.

The following quotations illustrate concord in person after a relative pronoun.

Picus 32 C. 7, O holy God ... whiche heauen and rarth directest all alone. | I)ial. C. 201, IIierusalem, IIierusalen, that killest the prophetes, and stonest vinto death them that are sent vnto the... ')

46. Constructions " ad sensum " ${ }^{2}$ ), in which a subjecl with a singular form and a plural meaning stands wilh a plural verb, are not infrequent.

Christendome. Dial. C. 151, al the corps of Christendome bi so manye hundred yeares hane belieued the contrarye.

church. Dial. C. 157, we see that the whole chureh in the comun seruice sse dyuers collectes. | Dial. Her. 176 F 8 , ye saide ye shoulde nol beleue the churche telling a tale of their owne ...

clergy. A pol. 80, All the clergy do vse to agree together. | A pol. 104, the clergy punyssheth those that speke against the sacrament of matrimony \& yet they punisshe not those that ...

But : Dial. Her. 120 B 13, the clergie is glad to fanour theis waies. comynaltie. Apol. 89, the comynaltie were fallen in grulge.

corps, see christendome.

counsayle. Letters 1425 D 13 , the connsayle ... suere fayne to bring forth a brief, by which they pretonded those defawtes to be supplied.

folk. Picus $15 \mathrm{G} 3$, if folk backbile va, and saie euill of vs : shall we so greunusly take it, that lest thet should begin to do yuel ... 3) i

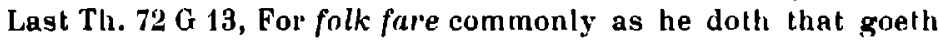
forth fasting.

1) A deviation from this (crule ) is seen in : 1538 Bale, God's Promises III $\mathrm{C} \mathrm{ij}, \mathrm{O}$ most myghtye gouernous of thy people,... that of two maketh one, vnynge the Jews will the gentyles in one churche.

2) Sommer $1921 \$ 3,3$.

3) The forms backbite and sale prove nothing in this respert, since the modality of the unil (after if causes the short forms to be used. 
Germanye. IDial. C. Išl, all Germanye for all they\% dyuel's opynions, ... as they arree logether in profession of Christes name, so agrec they nowe together in...

horse. Dial. C. 212, horse be dele in this country, specially such sofle amblei's.

jewery. Iial. Her. $238 \mathrm{D} 1$, the Jewery which were right honest men.

olde. Conf. Tynd. 613 D 1, He shall nol lyghllye fyncle anye of those olde, but that ho visel allegoryes.

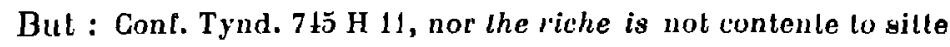
will the poor.

part. Rich. $45(=44)$ E 7 , Muche part of the common people were therewitl vcrye well salislyed $\left.{ }^{1}\right)$.

But : (Dial. Her. 121 E 7, all which holy thinges greal parte whereol was from hande to hande left in the clutch) ${ }^{2}$ ); Dial. C. 120, eche part sufforeth other to shyft for it selfe. I Mich. 70 D I, Ile lad bene fant vpon the part of king Henry while that part "'as in wealtb.

peple. Hich. 63 E 7, Peple fal al distance among themself. | Picus I D 2, all faithfull people are rather spirituall then carnall. | Apol. 82, I neuer yet pcrceyued the people make so great offerynges ... that we sholde ... pytye greatly theyr costc. | Apol. 104, the peple halle an opinion, that...

posteritie. Last TL. $85 \mathrm{C} 13$, their posteritye goe crooked thereof.

realme. Rich. $63 \mathrm{H} 15$, Woe is that Healme, that hathe a chylde to theyre Kynge.

remnant. Dial. C. 191, I baute lahoured more then all the remnaunt haue.

richesse. Picus 7 i 3 , he perswaded, that to a philosopher ... it was no praise to gather richesse, but to refuse them.

But : Dial. C. 254, without the danger of eternal damnacion, euen for hys riches alone, though be demened it neuer so wel.

thing. Picus $28 \mathrm{D} 2$, The third point of a perfit lower is, To make him (reshe to see that al thing ${ }^{3}$ ) bene, Appointed wel, and nothing set a mis.

sect. Hoke of F. p. $5 \mathrm{~A}$, OI his poore sect, it is conen vsage, onely to take that nature may sustayne... They be conlent, and of nothyng complayne.

1) were is perhaps due to attraction $(\$ 49)$.

$\left.{ }^{2}\right)$ In this quotation part refers to things, in the other instances to persons.

3) For the plural for'm thinges see : Picus 12 C 5, al these thinges be ... trewer than truth itself. 
sorte. Hich. 47 \& 12 , And then see on the toller syde what a sorte there be commonlye therein, of them whome wylfull vinthiftynesse hathe bronghte to notght. | Dial. C. 134, Another sorte are there, lhat will secke for no comforte. | Dial. C. 13I, For first one sorte therc are... | Dial. C. 134, One sorte are those...

Compare : Dial. C. 130, Than is there another kinde ol folke...

vitaille. Rich. $53 \mathrm{G} 2$, the kinges coronacion, of which the time appointed then so nere approched, that the pageauntes and suttelties were in making day and night at westminstor, and much rilaile killed therfore... ')

Oving to the fact that the forms in -eth and the short forms in syutaclical units with a modality of doubt, unreality etc., make decision iı a great number of cases impossible if a referring pronoun (e. g. they) offers no help, it is not easy to illustrate this usage more fully. Indeed no attempt at treating this subject in a more exhaustive way has been made, as the question bears upon the characler of the noun rather than upon the syntax of the verb and is therefore to a large extent beyond the scope of the present study. For the same reason a discussion of the separate instances as well as the adducing of historical data have been forgone.

47. If the verb precedes and the subject is plural or consists of two of more nouns connected by and, both the plural and the singular form of the verb may be used.

a. Boke of $\mathrm{F}$. p. $6 \mathrm{D} 4$, in this ponde be fyshe and frogges...

b. Dial. C. 150, Verely, good vucle, this liketh me very wol, but yet is there ye wote wel some of these things now brought in question. | Dial. Her. $115 \mathrm{C} 12$, I would faine witle of him though there were no pore folke amonge them at the timp of the makinge, was there neuer none among them aftor the time of the keping? | Dial. Her. $115 \mathrm{~F} 11$, there was no pore people in his roialme...

Itich. 68 1) 8, forthwith was the prince and his brother bothe shet vp. (Aich. 42 il 2, the king ... was taken, her brother, her sonne and her other frendes arrested, \& sent no man wist whither.) ${ }^{2}$ )

Instances with a singular verb in this position (especially when the predicate is introduced by there) ${ }^{3}$ ) are not rare in

1) If we have a case of syllepsis here, and was instead were ought to be read after vilaille, this quolation is irrelevant (cl. also the word much).

2) Perhaps syllepsis.

3) CP. Fr. il y a ; Germ. es glebt; Sp. hay. 
More. The usage may find its origin in a tendency for the speaker or writer to use a singular form of the verb if at the time it was spoken or written he was not yet fully aware of the exact form of the subject, or as Franz $(1924, \$ 672)$ puls it : "Da er [sc. the writer] häufig ihre Zahl [ = of the subjects] nicht von vornherein überschaut und ihre summiering immerhin einige gedaukenarbeit erfordert, so bezieht er das prädikal auf das erste der subjekte odor auf dasjenige, das ihm am meisten in gedanken beschäftigen mag". Compare Jespersen 1928 p. 169 and Finenkel 1916 p. 65.

Instances from earlier and later writers :

c 1400 Mandeville, 95, 27, And panne after is Hircanye Bactice Hiberye \& many oper kyndomes (II). I a 1533, Berners, Huon, Now, where's the Bastard's braves? | 1600 Shakesp., Is Y. L. I. I, ii, 104, There comes an old man and his three sons. I 1650 Baxter, Saints' R., I, i (166i2) 3, There's lew will deny, that (rod knows (OFI)).

48. When the subject precedes the verb and consists of a catenation of nouns connected by and or with ${ }^{1}$ ), the predicate may be either in the plural or in the singular.

a. plural. Hich. 68 H 4, Very trouthe is it \& well knowen, that ... bothe Dighton and he were examined. I Last. Th. $84 \mathrm{E} 9$, in this prison of the yerth we driue forth a while ..., till that sodeynlye nothyng lesse loking for, yong, old, pore \& rych, mery \& sad ..., bee put to deth in diuer's wise.

b. singular. Bıke of F. p. $1 \mathrm{C} f$, myrth, honour and richesse, much better is than penury and payne. I Boke of F. p. 1 A 4, Ye shall spye that richesse, worship, wellh and dignilie, Joy, rest, and peace, and all thyng tyually ..., is all at my deuyse and ordinaunce. | Dial. C. 151, in the meanc whyle ... contentions, despicions, wyth incharytable behatuioure, is prohibited and forboden.

Both the subjects are plural nouns in :

Apol. 5t, for as all the landes and fees that I hate in England ... is not ... warth yerely ... the somme of full lifty pounde.

The joining of a singular verb to a double or an enumerating subject, though a formal irregularity, is of course not a

1) In the case of neither ... nor the verb is in the plural : Rich. $60 \mathrm{~F} 2$, it was ... concluded, that this doclour Sha should in a sermon ... sygnifie to the people, that neither king Edward limself, nor the Duke of Glarence, were lawfully begotten. [The earliest quot. in OED (s. v. neither $\mathrm{A}, 1, \mathrm{~d})$ of neither ... nor wilh two subjects and plural verb is clated 1750]. 
logical incongruity, but as much a constructio ad sensum as a plural verb with a collective noun-subject. It is clear that the writer menlally summarizes the enumeration (actually done in the secon(l quot. b), and substitules e. g. all this in its stead as the logical subject.

In those cases in which the last of the subjects is a singular noun, the use of a singular verb may also be due to attraction, i. e. the lendency to make the verb agree with the last named of the preceding suljjects. This tendency dales from before More's time and was perhaps due to Latin or French influence ${ }^{1}$. The altraction may be so strong that it causes the verb to agree with a preceding noun even if this noun is nol the subject of the sentence, as in :

Dial. C. 161, For trowe you Cosyn that the temptacions of the dyuel, the world and the fleshe, ... is nol a greal inward trouble and secret griefe to hys hart ${ }^{2}$ ).

That the practice of using a singular verb after a double subject or after an enumeration was known bcfore More's time and held its ground after it, may be seen from the following evidence.

1300 Sir Gawaine 1, Sipen po seze and pe assaul wals sesed at Troye. | c 1400 Maundev. Trav. 115, 2, And the arm and the hond pat he putte in oure lorles syde ... is yit lygingnge in a vessell withouten the tombe (M). | c 1489 Caxton, Blanch. 119, 29, The kyng Alymodes and all his oost was riglit sore affrayed (OED)). | 1523 Berners, Froissart I 339, Therewith the kynge of Engliucle and the prince his sonne was redy at the gate. | idem II 217, [they] came to Burdeux, wher as the Prince and Princesse was. | 1575 Gammer (iurton X., Her joye and life is gone. ? 1586 Marlowe, Tamb. 20l66, Now shane and duty, loue and feare presents A thousand sorrows to my martyred soule. | 1605 Shakesp. Lear III, iv, 141, Our fesh and blood is grown so vile. | 1590 Spenser, F. Q, I, i, 13, Whom God and man does hale.

In l'res. D. Eng. the usagre is all but unknown, except in a few isolated cases, such as : the long and the shorl of the matter is, and of course when lwo subjects joined by and denote

') See Paul 1920 \$96 and Brunot 1922 p. 264 : " Le verbe peut avoir plusieurs sujets. La tradilion était de ne faire l'accord qu'avec le plus rapproché ".

2) It is difficult to account for the form was instead of were in : Dial. Her. 156 G 10 , the preceptes that he gaue by mouth was thre. Twayne commaundynge generacion and etynge. The thirde lorbedynge the tre of knowledge. 
one conception, as in : A needle and thread was soon found. I His son and nainesake and successor was an infant.

49. It is also due to attraction that in the following instances the plural form of the verb is used in spite of the fact that the subject is in the singular.

Dial. Her. $124 \mathrm{I} 1$, it is wel knowen that the worship of saints and ymages ben alowed, approbate, \& accustomed. I Dial. Iler. $146 \mathrm{HI} 1$, the substaunce of those wordes that he inent bene knowen, where some parte of the writing is vnknowen. ' Dial. C. 294 , the great harm that the hauing of theym do to jour soule. | Gonf. Tynd. 701 B 15, Nowe that je see thesc lwoo textes of scripture which he bringeth for hym, do nothyng make for hym in deede, and the latter of the twaine make against him.

The usage was not uncommon in older English. It seems to have died out in the course of the seventeenth century. Instances in Shakespeare are not rare (J. Caes. V, i, 33, The posture of your blows are yet unknown. | John III, i, 295, The peril of our carses light on thee).

In Pres. D. Eng. this kind of agreement would be looked upon as ungrammatical.

Although in the above quotations the subjects consist of a noun + of-adjunct, the usage should be kept apart ') from that in which the noun in the compound subject is a collective (swarm of...; multilude of...), as in : c 1400 Mandeville, Tr. 195, 10, And the most part of hem dyen withouten syknes (M.). | Bulw. L., The brood of serpents are in my hand. | 1703 Maundrell, Journ. to Euphr. (1732) 2, Here are a multitude of Subterraneous Aqueducts (OED).

In this case a plural verb is often idiomatic in Pres D. Eng. too. The following quotation illustrates this usage in More : Rich. $45(=44) \mathrm{E}$, Muche part of the common people were therewith verye well salisfyed.

\section{2. - THE VERB STANDS IVITHOUT COMPLEMENT}

\section{Subjective Verbs}

50. The term subjective verb is used to denote "intransitive" verbs like to demur, to forfare, to stye, which do not require an object to complete their meaning. The "intransitive" verbs that are construed with a prepositional object,

1) Ein enkel 1916, p. 65 neglects to make the distinction. 
such as to devise upon, to force for are dealt with in the paragraphs on objective verbs (\$\$ 91-156).

No attempt at collecting and classifying the subjective verbs in More has been made. The following remarks refer only to those verbs that in some respect or other show peculiarities.

51. A number of subjective verbs seem to have been used before More's time; a few of them follow here - will the date of thcir earliest quotation in OED.

accustom. Conf. Tynd. 894 H'5

(1571)

appalle. Dial. Hor. 226 D 2 (1528)

auaunt. Dial. C. 236 (1549)

ball. Dial. G. 338 (1570)

blunt forth. Last Th. $76 \mathrm{C} 7$ (1535)

buskle. Last Th. 81 F 9 (1535)

card. Dial. C. 322 (1548)

cheve. Dial. C. 263 (1500)

demur '). Dial. Her. 215 H 17 (1639)

doctor. A pol. 165 (1533)

drie up. Conf. Tynd. 805 B 11 (1535)

fall out. Rich. 59 v 7 (1562)

fimble. Last Th. 77 E 11 (1577)

frame $\left.{ }^{2}\right)$. Conf. Tynd. 783 G 3 (1533)

freer. Jest p. 3 A 15 (1525)

fret. Last Th. 85 B 7 (1551)

frj" (fig.). Picus 27 B 1 (1573)

fumble. Passion $1293 \mathrm{C} 1$ (1534)

fume. Last Th. 85 B 7 (1522)

fyle. Dial. Her. 258 E 3 (1560) go above (fig.). Apol. (Wks.) 877

F 4 (1577)

go by. Dial. Her. $194 \mathrm{E} 3$ (?)

grase. Apol. (Wks.) 901 H 2 (1579)

gyrn. Conf. Tynd. 432 F 2 (1552)

hymp. Conf. Tynd. 766 C 9 (1533)

intrude. Conf. Tynd. 829 B 13

(1534)

medle. Dial. Her. 183 H 3 (1555)

mammer. Conf. Tynd. 342 B 6 (1535)

pule. Last Th. 89 B 12 (1535)

quaff. Supplic. 331 E 11 (1523)

reel ${ }^{3}$ ). Supplic. 331 G 3 (?)

relapse. Apol. (Wks.) 889 E 2 (1570)

reserve 4). Dial. Her, 179 E 5 (1529)

$\operatorname{roy}\left({ }^{5}\right)$. Last Th. 97 D 6 (?)

succeed. Passion 1347 F 8 (1537)

launt. Rich. 57 B 9 (1513)

wamble. Last Th. 73 F 8 (c 1518)

sind out. Dial. Her. 164 F 2 (a 1569)

52. The following list contains subjective verbs that are no longer so used or have become obsolele or archaic after More's time.

\footnotetext{
1) $=$ to object.

2) = to conform.

$\left.{ }^{3}\right)=$ to waver in an argument.
}

4) = to remain in existence.

s) said of a drunken man. 
to agryce = to shudder.

Dial. C. 268, their heartes agryce and shrynke in the remembrance of the payne.

Now obsolete. EQ. ') a 1000 Laws of Cnut (Thorpe I, 374), pæt he for belle agrise. I.Q. 1598 Sylvester, Du Bart. II, IV, III, 223, Already in each nook agrising, Fell, wall-break Famine illadvising Howls hideously.

to appal = to lose flavour.

Dial. Her. 2:6 B 2, if the salt once appalle, the woorde muste nedes waxe unsauery.

Now obsolete. No quot. in OFD before More. LQ. 1568 North, Diall. Princes 622,2 , He found the wine wel watered before that it had stood a pawling long.

to arise $=$ to rise in rank or eminence.

Dial. C. (Wks.) $1252 \mathrm{G} \mathrm{4,} \mathrm{Some} \mathrm{by} \mathrm{handy} \mathrm{crafte...,} \mathrm{some} \mathrm{by} \mathrm{other} \mathrm{kynde}$ of liuing, arise \& come forward in the world.

Now obsolete. EQ. 1340 Ayenb. 24, pe ilke pet zuo he3c arise ine prosperile. LQ. 1756 J. Warton, Ess. Pope (1782) I, IV, 229, Ob- stacles, which migbt prevent his arising to that height.

to auaunt $=$ to be off, to go away.

Dial. C. 236, making a crosse vpon their heartes, and byddyng the deuill auaunt.

Now obsolete. HQ. 1519 Coverdale, Erasmus, Par. Jud. 21, That they should not auaunt ... into the dongeon of eternal damnacion. LQ. 1601 Chester, Love's II. xi1, 83, It causeth them from thence for to allaunt.

to ball = to shout al the top of one's voice.

Dial. C. 338 These Turkes come yalping and balling vpon vs.

Stil current in the form to bawl. EQ. 1570 Levins, Manip. 12

Baull, to cry, vociferare.

to become $=$ to come (to a place), to arrive.

Answer 1037 A 4, the dyshe is so deare and so daintie, that euery christen man hath his hart bent therto, \& therfore hys eye set thereon to see where it becometh.

Now obsolete. HQ. c 885 Elfred, Oros. IV, VIII \$ 3, llannibal to pam lande becom. | LQ. 1737 Whiston, Josephus' Antiq. VIII, III $\$ 2$, That they might become into one through another.

to buskle = to prepare oneself.

Last Th. 81 F 3, arte thou goynge oul ... whan ... thou beginnest to set the firste foote forward to goe out, in what place of the house so ener ye stand whan ye buskle forward.

Now obsolete. No quot. before More. LQ. 1602 Warner, Alb. Eng. XII, Ixxvii. 313, Then buskling to his Sword cride Theeues.

1) All quntations Irom OED, unless olherwise stated. EQ. - earliest quotation; $L Q .=$ latest quotation. a $1500=$ ante $1500 ;$ c $1500=$ circa 1500 . 
to cary = to drive, to ride, to move.

Last Th. 88 A 11, Who could ... be so very wroth ..., if we remembred that we be ... already laid in the cart carying toward execucion.

Now obsolete. EQ. 1362 Langl. P. Pl. A. Prol. 28, Coueyte not in cuntre to carien aboule. LQ. 1513 Douglas, Aen. XII, XI, 136, Lat ws follow that way, and thidder cary.

cheuing = ending. Evil chening = bad luck.

Dial. C. 363, thei bee ... so handeled, that as for this worlde they comme to an euill cheuing.

Now obsolete (to cheve). EQ. c 1500 Cocke Lorelles B. 2, The people blesselh hym with evyll cheoynge. LQ. 1596 Ifarington, Ulysses, You haue vsde a Doctour farre worse, and therfore look for ill rhieving.

to come forward $=$ to rise in rank.

Dial. C. (WVks.) $1252 \mathrm{G} 4$, Some by handy crafte ... some by other kynde of living, arise \& come forward in the world.

Now obsolete. Not mentioned in OED, sv. come forward.

to comen $=$ to talk.

Rich. 70 F 12, perceiuing now this duke glad to comen with bim, fed him with faire wordes.

Now obsolete. EQ. 1388 Wyclif, Eccl. XXVI, 9, Sche comyneth with all men. LQ. 1581 Savile, Tacitus' Hist. I, XV, 10, we two ... common plainly togellier.

to consent $=$ to agree (to a doctrine or statement).

Conf. Tynd. 599 F 8, whereto consenten the wordes of our sauiour hymself.

Now obsolete. EQ. 1382 Wyclif, Rom. VII, 16, I consente to the law, for it is good. LQ. 1788 Lond. Mag. 32 This is what all must consent to who have been obliged to ride on horseback ... aller a hearty dinner.

to dase $=$ to be bewildered, to be dazzled.

Dial. Her. 252 A 4 , be could shewe a fayre law incorporate in the decrees of the church, which law ... wold make al theyr eyen dase | Supplic. $331 \mathrm{E} 5$, Whan his bead first began to dase, of that evill drynke.

Now obsolete. EQ. c 1325 E. E. Allit. P., C. 383, per he dased in pat duste, with droppande teres. LQ. 1635 Quarles, Embl. III, I (1718) 125, Whose more than Eagle-eyes Can ... gaze On glitl'riug beams of honour, and not dase.

to draw (to) $=$ to resort (to) ; to join the party (of a person). Rich. $43 \mathrm{D} 5$, somme... drewe to them that holpo to carrye a wronge waye.

Now obsolete. EQ. c 1205 Lay. 10530, Alle heo wullep to me dra3en. LQ. (1568) 1893 Nat. Observer 13 May 643/2, Like draws to like. 
to enterpause $=$ to pause in the midst of something.

Dial. C. (Wks) $1169 \mathrm{E} \mathrm{3,} \mathrm{In} \mathrm{talkynge} \mathrm{so} \mathrm{longe} \mathrm{together} \mathrm{withoute} \mathrm{enter-}$ palsyng betwene. | Ibid. 1199 H 12, Manje woordes ... spoken ... without enterpausing.

Now obsolete. No other quot. in OED.

to fall = to come to pass ; to happen ; to occur.

Dial. C. 330, The case ... falleth not very often, but yet somclime it dooeth. | Debell. $976 \mathrm{~B} \mathrm{5}$, these cases fall so seldome.

Now obsolete, exc. poet. EQ. c 1290 S. Eng. Leg. I 16, 512, Mani miracle par feol a-day.

to flour $=$ (of persons) to be in the height of one's fame.

Dial. Tynd. $688 \mathrm{D} \mathrm{3}$, the vertuous that so floured in the church, that was in saint Austines time.

Now obsolete. EQ. 1340 Ayenb. 28, Ase ine yere pet wel flourep ine guode. LQ. 1531 Elyot, Gov. I, XI, That noble clerke of Almaine, which late floured, called Agricola.

to fode ${ }^{1}$ ) $=$ to delay.

Dial. C. 209, But the Wolfe would not come to confession tyl he saw first Palme sonclaye past : and then foded yet forth farther, until good Friday.

Now obsolete. No quot. in OED. of this subjective use besides this one from More.

to forfare $=$ to perish.

Boke of F. p. 5 D 6, ye may ... as easily ... in drye lande cause fishes to endure, And make the burnyng lyre his heat to spare, And all thys worlde in compace to forfare.

Now obsolele. EQ. O. F. Chron., an. 910, IIi pær mæat ealle sippan forforen. LQ. 1578 Scot, Poems 16th G. II, 178, This warld sall all forfair.

to frame = to suit, to fit, to conform.

Conf. Tynd. $783 \mathrm{C} 3$, How would then those wordes frame.

Now obsolete. No quot. in OED. anterior to More. LQ. 1642 Rogers,

Naaman 436, Bids us try the Unicorne whether he ... draw our cart ... meaning that his wildnesse will not frame to it.

to frampe = to revel (?) ; to indulge greedily (?).

Conf. Tynd. $716 \mathrm{C} 13$, which not content with ... manna ... murmured that they might not frampe in lleshe.

Now obsolete. No other quot. in OED.

to frote $=$ to $\mathrm{rub}$, to chafe.

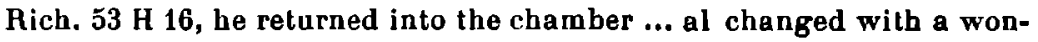

1) to fode also occurs as an objective verb in the sense to lead on by ralsing delasive expectations : Dial. C. 218 , she wold no more suffer anye nor deceyue her, and fode her forth with delaies. Also obsolete. 
derful soure angrye countenance, knitting the browes, frowning and froting and knawing on hys lippes.

Now obsolete. KQ. a 12:5 Ancr. R. 284, pe caliz ... puruh so monie duntes \& frolunges, to Godes bihene ... so swupe ueire afeited. LQ. 1688 H. Holme, Armoury II 239 , I, [To] Froll or Ihub themselves as Hawks will do ... is to rub her eyes on her Wings.

to fyle (subjective verb) = to void excrement.

Dial. Her. $258 \mathrm{E} 1$, the abominable bestes ... not abhorred to fy le in the pixys.

Now obsolete. EQ. 1560 Becon, New Gatech. Wks. (1844) 62, If doves, or any other fowls ... file upon thoir [i. e. the images] heads, they perceive it not. LQ. 1611 G. Wilkins, Mis. Inf. Marr. III in Old Plays (1825) V. 40, Oaths are ... like smoak Prom a chimney that files all the way it goes.

to fyst $=$ to stink.

Dial. C. 1262 II 18, the byting of a lyttle fy-sting curre.

Now obyolete. EQ. c 1000 Elfric. Gloss in Wr. Wülcker 162, 43,

Fesiculatio, fisting. LQ. 1611 Colg'r., Venneur, a lizsler or fy-ster.

to game = to amuse oneself ; to sport.

Answer 1048 A 7, (rod sent men hither to wake and work, and as for sleepe and gaming (if any gaming be good in this vale of miserye in this lime of leares) it must serue but for a refreshing of the wearye ... body.

Now obsolete, exc. dial. EQ. c 1000 Alfric, Gen. XIX, 14, pa wres him sepuht, swilce he gamnizende spræce.

to gyrn = to show the teeth in laughing.

Conf. Tynd. 432 F 2, he laugheth but from the lyppes forwarde, and gyineth as a dogge dooeth, when one porrell hym in the teeth with a slycke.

Now obsolete. EQ. 1552 Latimer, Serm. Lincolnsh. V, 105, They goe with the corses girning and fleering. LQ. a $1711 \mathrm{Ken}$, lidmund, Poet. Wks. (1721) II, 299, Cur's'd Satan guerning slood, the while he spake.

to gern = to snarl (cf. gyine).

Dial. C. (Wks.) 1251 B 11, The bitch had founde the foote agayn : \& on she came gerning.

Now only north. and Sc. EQ. 1375 Barbour, Bruce IV 322, Than lukit be awfully thame to, And said, gyrnand, 'bangis \& drawis!'

to hove = a) to wait ; b) to sil (on a throne).

Last Th. 93 D 4, I let passe olde men that houe and gape to be executours to some that be yonger than themself. I Boke of F. p. 2 I 3, Fortune at them laugheth, and in her trone Amyd her treasure and waueryng rychesse, Prowdly she houeth as lady and empresse.

Now obsolete. The verb was largely superseded by to hover in the $16^{\text {th }}$ century. EQ. c 1220 Bestiary 525 , [He] stirep up and houep 
stille. LQ. 1595 Col. Clout 666, The which in court continually hooved.

to iet $=$ to $\mathrm{walk}$, to stroll.

Passion 1359 H 6, suppose thon woldest ... while he sate stil \& gaue good eare vnto thee, in the vttering of thy sute al the while iet vp \& down before him, \& when thou hadest ielted thy fil squat thee down fair \& wel in a chaire...

Now obsolete. EQ. a 1420 Hoccleve, De Reg. Princ, 428, pogh he letle forth a-mong pe prees, And ouer loke euery pole wight. LQ. a 1777 Robin Hoode \& Q. Kath. XIX in Child, Ballads V, cxlv, Thus he ietted towards louly London.

to let $=$ to live (in sin); to tarry.

Dial. Her. $272 \mathrm{~F} \mathrm{7,} \mathrm{he} \mathrm{bath} \mathrm{letted} \mathrm{and} \mathrm{sitte} \mathrm{styl} \mathrm{a} \mathrm{while} \mathrm{in} \mathrm{sinne.}$

Now obsolele. This seems to be the weak subjective verb to let, illustrated (in approximately this sense) s. v. let $v^{2}+2$ b. in OFD. EQ. c 1385 Chaucer, L. G. W. 2167, Ariadne, And in that yle half a day he lette. | c 1386 Chaucer, Shipman's T. 250, And doun be goolh, no lenger wolde he lette. I.Q. c 1435 Torr. Portugal 2058, He bare it to the cite grett, There the kyng his fader lett, As a lord of jentille blood.

to lieue $=$ to believe.

Conf. Tynd. 799, G 3, because it is a presumpteous hope, loking to be saued with damnable deuelyshe lieuing.

Now obsolete. EQ. a 900 O. E. Martyrol. 8 Nov. 202, pa lyfde se gode ond fulwihte onfeng. LQ. c 1570 Pride \& Lowl. (1841), 67, And choose him how this matter he wyl leeven.

to linne $=$ to stop, to cease.

Picus 26 A 3, This wretched lifo..., Sithe that houre, in which it did beginne, It holdeth on the course, and will not linne, But fast it runneth on...

Now obsolete. EQ. Beowulf 1478, Gif ic æt pearfe pinre scolde aldre linnan. - Still in Sc. (lein, leen, lean).

mammering. To be in a mammering $=$ to be in a state of doubt (persons); to be yet unsettled (things).

Conf. Tynd. 343 B 2, He was in a mamering whether he would retourne agayn ouer the sea. | Dial. C. 198, when I was in Saxony, these matters were in a maner but in a mammering.

Now obsolete. The earliest quot. in OED is the first of the above quotations. LQ. 1639 Horn \& Hob, Gate Lang. Unl. xc \$ 886 The one goes on forward ... without respit, the other staggers (is in a mammering).

to medle = to busy oneself, to act.

Dial. Her. $183 \mathrm{H} \mathrm{1,} \mathrm{no} \mathrm{man} \mathrm{maye} \mathrm{...} \mathrm{take} \mathrm{vpon} \mathrm{him} \mathrm{to} \mathrm{preache} \mathrm{or} \mathrm{medle}$ as priest, til he be chosen by the congregacion.

The earliest quot. of to medle so used is dated 1555 (OED s. v. 
meddle v. 8 b) : Eden. Decades 9, They shuld meddle no further than their commission.

to misfortune $=$ to happen unfortunately.

Apol. 94, Whych thynge to se so mysfortune betwene any two crysten folke, is a thynge myclie to be lamented.

Now obsolete. EQ. 1466 Mann. \& Househ. Exp. (Roxl).) 173, It mestortened me ... to hurte my lege. LQ. 1615 E. Howes in Slow, Ann. Pref. \$ 7, The Qucene after mariage was conceiued wilh childe, but it misfortuned.

to mishap = a) to happen unfortunately, Apol. (Wks.) 872 F 4 A thing ... muche more to bee lamented, when it myshappeth to fall betwene a man $\&$ his wyfe.

Now obsolete. EQ. c 1390 R. Brunne, Chron. Wace (Rolls) 13280, Grace til hym wold non bytide, But euere mys happed on his syde. LQ. 1647 Hexham, Misschieden, to Mishap, or to Fall out ill.

to $\operatorname{mishap}=\mathrm{b}$ ) to have the misfortune to... Apol. (Wks.) $900 \mathrm{G} 11$, Mo men then so many, haue mysse happed to be ... mys punished.

Now obsolete. EQ. c 1330 R. Brunne, Wace (Rolls) 4967, For pou myshappedest y pe first ende, Now schallow spede er pat pou wende. No later quotations in OED.

to plain = to complain.

Dial. Her. 157 B 8, god wold that we were lerned ... to suffer our sensuall parties plaine and mourne.

Now poet. and dial. EQ. 1297 R. Glouc. (Rolls) 3576, Mest in is herte was uor anguysse to playne.

to pursue $=$ to follow or come after in order.

Dial. Her. $145 \mathrm{~F} \mathrm{10,} \mathrm{so} \mathrm{is} \mathrm{yet} \mathrm{again} \mathrm{our} \mathrm{purpose} \mathrm{double} \mathrm{proued,} \mathrm{Fyrst} \mathrm{...,}$ secondly (which pursueth there upon) by that he...

Now obsolete. EQ. 1485 Rolls of Parlt. VI, 332, 2 The Dede and

Fyne, wherof the tenour persueth. LQ. 1688 Ilolme, Armoury. I,

I, 2, Lest ... scandal do arise and effusion of blood do persue.

to reel $=$ to waver (in an argument).

Supplic. $331 \mathrm{G} \mathrm{3,} \mathrm{Yet} \mathrm{said} \mathrm{he} \mathrm{therwith} \mathrm{one} \mathrm{thing} \mathrm{or} \mathrm{twayn,} \mathrm{that} \mathrm{could}$ not stand tberwith : and therby may ye see that he began to reel.

Now olssolete. No earlier or later instances in OED.

to remyt ouer $=$ to resort to ; to have recourse to.

A pol. (Wks.) 817 H 10, I would that the reader shoulde in euerye place where be forluneth to falle in reading, have at his hande without remytting ouer elles where, ... as much as shall seme requisite.

Now obsolete. Not in OED.

to repugne $=$ to be contradictory.

Answer 11:1 B 9, Be thou content to knowe that goddes will, his worde, and his power, boe all one, and repugne not.

Now obsolete. EQ. c 1374 Chaucer, Boelh. v pr. iii 119 (Camb. 
MS.), It semyth quod I to repugnen and to contraryen grelly pat god knowit byforn alle thinges, and pat ther is any freedom of liberte. LQ. $1654 \mathrm{Z}$. Coke, Logick 68, Inseparable which is not easily separated from the subject, though to be separaled nothing repugneth.

to reserve $=$ to remain in existence.

Dial. Her. $179 \mathrm{E} 2$, yf their opinions hadde any where continualsye endured there woulde theyr bokes haue continually reserned.

Now obsolete. No quot. before More in OED. LQ. 1641 L'Tistrange, God's Sabb. 26, Because it tainled against nature and miraculously reserued vpon other days.

to rown $=$ to $\mathrm{whisper}$.

Rich. 64 D 6, al was as styl as the midnight, not so much as rowning among them, by whych they myght seme to comen what was best to doe.

Now archaic (to round). EQ. c 1000 Aelfric, Gram. xxxvr, 217, Susurro, ic runize.

to royl $=$ a) (said of a drunken man) to swing about with the whole body in trying to walk or stand.

Last Th. $97 \mathrm{I} 2$, Is it not a bestly thing to se a man that hath reson, so to rule himselfe that his fete may not beare him? but when he conmeth out he weneth that the skie wold fall on his hed ? \& there royleth \& releth till he fal downe the canel...

Now obsolete. Not in the OKD.

to royl $=$ b) to wander, to roam or rave about.

Conf. Tynd. $747 \mathrm{G} 8$, such apostalas woulde be bound to no cloyster, but haue all the worlde to royle in. | Dial. Her. $194 \mathrm{~F} 2$, Whal say we then ... of the harme that goeth ... by royling aboute in ydlenes.

Now obsolete. EQ. c 1308 Old Age in Rel. Ant. II, 175, Hail be se, freris, ... Evir ze belh roilend the landis al a-boute. LQ. 1619 Bert Treat. Hawkes 57, If thy hawke will not come, or not abide company ..., or will royle or house.

to ronne at ryot $=$ to disregard all limitations.

Dial. Her. 141 E 5, without which we wer like to walke wide in wordes, \& ronne at al ryot so lose, that our matter could neither haue grounde, order, nor ende.

Now obsolete; now to run riot. EQ. 1530 Tindale, Answ. More, (Parker Soc.) 114, They ... either run altogether at riot, or keep the law with cautels and expositions of their own feigning. $L Q$. 1579 Tomson, Calvin's Serm., Tim. 12, 1. So soone as a man beginneth to runne at riot, \& leaueth the streight line.

to rowt - to snore.

Passion 1353 D 8 , while the false dissemblyng Pharisey laye at his ease rowting in his soft bed ...

Now obsolote, exc. dial. EQ. c 725 Corpus Crloss. 1923, Slertens = hrutende. 
to run out (against) = to launch out in proluse speech. Drbell. $942 \mathrm{C} \mathrm{13}$, his reason runneth out against euery kinde of men. Now obsolete. EQ. 1.554 in Strype, Eccl. Mem. (1824) III, Append. $\mathrm{XX}, 56$, Then he ran out against the late government. LQ. 1779 Mirror $N^{\circ} 4$, They ran ont in praise of French cookery.

to staker = to waver, to hesitate mentally in a state of indecision.

Apol. 91, Calanius perceuyng them begn in the mater somwhat to staker and stay, persuaded them easily to concorde wyth those that they hadde byfore.

Now olssolele. LQ. (s. v. stucker) 1402, Pol. Poems (Rolls) II 40, Every state slakerth unstable in him silfe. LQ. 1519 Coverdale, Erasmus Par. Jas. 32, He whiche stackreth not to anenture in hys onely sonne whome he loned so syngularly.

to stint $=$ to ceaso moving; to stop.

Bless. Body $1205 \mathrm{G} 11$, therwith the legion of deuyls maye gelte leaue of Curyste, so to enter into vs, as they gate leaue of hym to enter into the hoghes of Genezareth : and as they ran forth with them, and neuer stinted, til they drowned them in the sea.

Now obsolete. EQ. c 1290 Becket 1118 in S. Fng. Leg. 138, Five and twenti mile he wende... Are he stunte in anie stude. I.Q. 1818 Scolt, Hob. Hoy, XXI, But come on, what stint ye for?

to ston = to be amazed.

Answer 1112 14 , then the disciples ... mugt nedes have woondered, stonned, and staggered ... A Answer $1112 \mathrm{C} 16$, that thing must nedes haue made the apostles wonder, stonned, \& stagger.

Now obsolete in this meaning. The only example in OED. is 1533

Tinclale, Supper of the L. 13 b., Thei ... musle bere nedis baue wondred, stonned and staggerd.

to stye $=$ to ascend.

Bless. Body 1266 B 6 , the thirde daye gloriouslye did arise again to life, and with the soules of holy saintes..., ascended and styed $\mathrm{vp}$ woonderfullye into heauen.

Now obsolete. EQ. c 825 Vesp. Psaller LXVII, 19, stizende in heanisse. LQ. 1652 Benlowes Theoph. VI, XVIII, That She might stye to th' Seat of Beatifick Mirth !

to succeed $=$ to happen.

Passion 1347 F 5, prophesyed by the verbe of the pretertemps or tyme passed, to signifyc that the thyng prophecied sholde as surely succede and be verifyed, as though it wer passed alreadye.

Now obsolete. EQ. 1537 Gromwell, in Merriman, Life \& Lett. (1902) II 63, Nothing is succeded sythens my last writing. LQ. $1653 \mathrm{tr}$. Carmeni's Nissena 78, She desired to be inforn'd of ... what had succeeded since the Prince Doralbo's expedition.

to surmount $=$ to mount, rise (above something).

Dial. C. 348, howe farre those heauenly ioyes shall surmount aboue 
all the coumfort that euer came in the mind of any man liuing here vpon eartb.

Now obsolete. EQ. 1430-40, Lydg. Bochas I, II, 15, 2, so hih a tour ... Which that sholde surmounte aboue the skie. LQ. 1563 Shute, Archit. F. II, If the piller surmount from 25 to 30 the height of the pillor must be deuided into 12 parles.

to sweat $=$ to sulfer waste or loss.

Debell. 1002 G 4, Hys soule is safe ynoughe, lhough hys purse may happe to aweate, if he bounde himself to pronide the timber at his own perill.

Now obsolete. No oller quot. in OED.

to taunt $=$ to make a smart rejoinder.

Rich. 57 B 7, a proper wil bad she, \& could bolh rede wel \& write, mery in company, ... somelime taunting without displesure \& not without disport.

Now obsolete. No quot. in OLD anterior to More. LQ. 1596 Dalrymple tr. Leslie's Hist. Scot. vil (S. T. S.) 8, This man lane in the feild the Bruse mirrilie tantis, and sayis, Welcome father, says ho.

to the $=$ to prosper.

Jest p. 1 B 5, he that ... can no skyll, Is neuer lyke lo the. | Jest p. 4 F 14, III mote he the, 'That caused me, To make my selfe a frel'e.

Now obsolete, and already archaic in More's time (see OFI)). EQ.

Boowult 8, He ... weox under wolcnum, weorp-myndum pah. LQ. 1573 Tusser, Husb. (1878) 19, Giue oner to sudgerne, that thinkest to thee.

to tole $=$ to peep.

Dial. Her. 225 D 4, euery man carieth a clouble wallet on his shoulder, and into the one that hangeth at his brest he putteth other folkes taultes, and therin he totelh and poreth often.

Now obsolete (exc. dial.) EQ. 1225 Ancr. $R$ 52, Is hit nu so ouer vuel uor to toten utward? Auh toten vt wiputen vuel ne mei nouper of ou. LQ. 1603 Sir C. Heydon, Jud. Astrol. Iv, 140, While the Astrologer tooteth vpward, and examinelh in what signe is the Moone.

to variaunce $=$ to disagree.

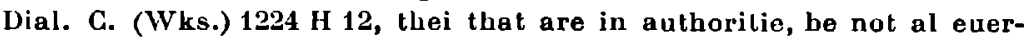
more of one mynde, but sometyme variaunce amonge them.

Nol in Pres. D. Eng. Not recorded in OED.

to vary (in something) = to differ in opinion; to disagree. Ijial. Her. $141 \mathrm{G} \mathrm{9}$, is ther any other thing wherin ye think that we shal sary, but the interpretacion of the scripture?

Now obsolete. EQ. 21428 Rec. St. Mary at Hill (1905) 13, Y the said parsons, wardeyns \& iiij parisshens of the said Chirch ... sarye of their said chosyng of the same preest ... \& can nat 
accorde. LQ. 165̃7 S. Purchas, Pol. Flying-Ins. 55, Give mee leave to vary from so learned an Author.

to voyd = to go arvay.

Hich. 35 H 3, Whose warres who so well consyder, hee shall no lesse commende hys wysedome where hee voyded, than hys mannehoode where he vainquisshed. | Dial. C. 133, we shall be able to commaund a great moynlayn of tribulacion to soyde from the place where he stode in o11 Lert. | Passion 1275 (=1277) H 10, He soyded not at Gods commyıg, but abode to see the sentence of theyr dampnacion.

Now obsolete. FQ. 13... Goer de L. 2192, The folk of the countre gan renne, And were fain to soid and flenne. LQ. 1606 Ilolland, Sueton. 102, He caused all his traine and company to soyd.

to walk = a) to go away.

Dial. Her. 269 A 3, he would in the daye of iudgement speake to them that badde by faith wroughte wonders in his name without good workes, and charitye, whom he would than bydde, walke workers of wickednesse.

Now obsolete. EQ. c 1460 Towneley Myst. ii, 106, Leif brother, let vs be walkand. In Pros. I). Eng. only colloq. (= to go away perforce; to be turned out), also slang (= to die).

to $w a l k=b$ ) to go about in public, live, move (in a place or region).

Rich. $40 \mathrm{~A} \mathrm{12,} \mathrm{Robbers} \mathrm{and} \mathrm{riuers} \mathrm{walking} \mathrm{at} \mathrm{libertie} \mathrm{vncorrecled.}$

Now obsolete. EQ. a 1300 Curs. M. 17800 , In mi cite of aramathi par ar pai [sc. the risen dead] walkand witerli. LQ. 1559 Bp. Scot in Strype, Ann. Hef. (1709) I. App. x, 32, Upon the which Place St. Augustine wrylelh thus, Christe tooke Fleshe of the blessed Virgin his Molher, and in the same be did walke.

to walk at rovers $=$ to have no settled abode.

Dial. Her. $298 \mathrm{C} 12$, The order is rebuked by the priestes begging and lewde liuing, which either is fayne to salke at rovers and liue upon trentalles or worse, or...

Now obsolele. No other quot. in OED. For the obsolete at rovers cf. : Conf. Tynd. 786, 2, Either their dede and declaracion must nedes stande and be firme, or else all runne at rouers and nothing be certain or sure. | Dial. C. (Wks.) 1200 H 5, I mene not, to let euery malefactor passe furth vnpunished, and frely runne out and rob at rouers. (Also 1347 A 2).

to walke followed by $a+$ form in $-i n g=$ to go.

Answer $1076(=1078) \mathrm{H} 5$, Like as if a ryght great man woulde wantonly walke a mumming, and disguise hymself.

Now obsolete. No other quot. in OED.

to walk wide in words = to argue at cross purposes.

Dial. Her. $141 \mathrm{E} \mathrm{3,} \mathrm{wherupon} \mathrm{it} \mathrm{will} \mathrm{be} \mathrm{requisite,} \mathrm{that} \mathrm{we} \mathrm{firste} \mathrm{bee} \mathrm{both}$ agreed : w(ith)out which we wer like to walke wide in wordes ...

Now obsolete. No other quot. in OED. 
to walter $=$ to roll to and fro.

Jest p. 4 C 7, they spye, The captaynes lye, Both waltring on the place. Now obsolete, exccpt. dial. EQ. c 1400 tr. Higden (Rolls) VII, 203 , He feled a ping pat was myzli and picke sualtre and lurne atwixe hyın and his wif. LQ. 1692 Ilay, Disc. II, II. (1693) 87, The Globe cannot waller or reel towards any side.

to wamble (of the stomach or its contents) $=$ to be felt to roll about (iu nausea).

Last Th. $73 \mathrm{~F} \mathrm{7,} \mathrm{it} \mathrm{maketh} \mathrm{the} \mathrm{stomak} \mathrm{wamble} \mathrm{and} \mathrm{fare} \mathrm{as} \mathrm{it} \mathrm{would}$ vomit. | Answ. 1054 A 1, Theyr forefalher's murmured in desert against Moyses for Manna, and sayde that theyr stomake wambled agaynst that light mrale. | Passion 1274 (=1276) D 10, Scant was the fruite passed downe theyr throtes, when it so began to wamble in their stomakes.

Now obsolete, except dial. EQ. c 1518 Skellon, Magnyl. 1617, A, howe my stomake wambleth ! I am all in a swete. LQ. 1831 Landor, Exam. Shaks., Wks. 1853 II 266/1, No wonder, Masler Ephraim, thy entrails are moved and wamble.

to wind ont $=$ to extricate or disenlangle oneself from a state of embarrassment.

Dial. Her. 164 E 9, if it so were, that in that dispicions ye coude not make your andience to discerne the truthe,... what way wold ye winde out?

Now obsolete. EQ. 1412-20 Lydg. Chron. Troy I, 2207, Love in his lawes often schulde erre, And wynden out ol bonestees cheyne. LQ. 1667 Mlitton, P. L. VI, 659, Long strugling underneath, ere they could wind Ont of such prison.

wanyand. In the wanyand $=$ with a vengeance.

Supplic. 306 G 17, He would of lykelyhoode bynde them to cartes and beate theym, and make theym wed in the waniand.

Now obsolete. Waniand is the north. pres. participle for $\mathrm{m}$ of wanien $=$ to wane. In the phrase in the waniand there is probably ellipsis of the noun mone (“ on wanizendum monan 》). The original meaning may lave been at the time of the waning moon = in an unlucky hour (GP. OED). EQ. a 1352 Minot, Poems V, 30, In pe wilde waniand was paire hertes light. LQ. 1570 Levins, Manip. 25,23 , Ye Wenyant, in malam crucern.

to wink $=$ to close one's eyes.

Last Th. 94 F 3, thei willingly wink, \& liste not to loke at him.

Now obsolete. EQ. c 897 Ell fred, Gregory's Past. C. XXXIX,287, Se stæp p forp mid pam fotum \& winkap mid pæm eazum. LQ. 1816 Scott, Bl. Dwarf V, I thought I saw him slill, though I winked as close as ever I could.

to wrable $=$ to wriggle.

Answer $1041 \mathrm{G} \mathrm{4}$, the hotle fyre of hel shalbe so fast tyed in all theyr tayles wrabelyng there together, that neuer shal they get the fyre fro their tayles. 
Now obsolete. EQ. 1513 Douglas, Eneid VIII, X. 84, About hir palpis ... The tua twynnis... Sportand full tyle gan to wrabill and hing. - No quot. in OED. later than More.

to $w r i e=$ to go ; to turn.

Dial. G. (WVks.) $1162 \mathrm{~A} 5$, the griel of thys great pange pyncheth them at the hert, and of wickednes thei wrie awaye and fro this tribulacion thei turne to theyr fleshe for helpe and laboure lo shake of this thought.

Now obsolete. EQ. c 1310, in Wright, Lyric P. XV, 48, pat feyre ...

wriep awey as hue were wroht. - No later quotations in OED.

to wroote $=$ to turn up the soil with the snout.

Bless. Body 1265 C 5, swyne, wrootynge in the dirte, and wallowynge in the myre.

Now obsolete. EQ. c 725 Corpus Gloss. $\$ 689$, subigo, wrotu. LQ. 1641 Best, Farm. Bks. 144, To lye it wheare it tnay bee well wroten amongat wilh swine and beasts.

\section{Veras of Motion Folloived by IN on Into}

53. A rule that when verbs like fall, renne, etc., are used translocally ${ }^{1}$ ) the adjunct of place must be preceded by into instead of in does not exist for More; both prepositions are used indiscriminalely.

to renne. Picus $4 \mathrm{C} 6$, that ho ranne not in perpetuall infaury and sclaundre.

to fall. Rich. 39 F 6, that we ... fall not in that occasion agayne | Dial. C. 340, he falleth in a sodayı brayde.

(Dial. C. $198 ; 142 ; 269$; L. Th. 91 C. 8 ; 97 B 3 ; Picus 11 D 13 ; Rich. $70 \mathrm{~A} 12$; etc.)

to come. Boke of F., 6 D 1, The rollyng dyse ... caine neller in myne hande. | Last Th. 76 G 10 , Thoughe we haue heard of hel, yet came we neuer in it.

to enter. Apol. 885 (Wks) B 6, enter in.

Picus 17 F 2, thei renne forth hedling in to all mischiefe. | Last Th. $85 \mathrm{G} 9$, redy to run into the Iyre.

Apol. 168, by the passion of ire men fall in to manslaughter. Dial. C. 355, hell ..., in to whiche we fall while we flee from this. (Dial. C. 144 ; 206 ; elc.)

Hich. 60 F 14, John Dighton, about midnicht ... cane into the chamber | Apol. 150, it often happeth that a man cometh in to a shoure.

A pol. 885 (Wks) B 4, enter into...

1) The term is Behagel's [1921, II, p. 175]. He distinguishes a intralokale verba ) and “translokale verba ", the latter expressing motion from without to a point within limits of space, time, condition, circumstance, etc. and vice versa. 
In Old English, the translocal meaning was expressed by in with the accusative, and so distinguished from the intralocal meaning, which was expressed by in followed by the dative. When the weakening and loss of case-endings in the course of the Middle English period made another means of differentiation necessary, the preposition in to or into came to be used when the sense implied motion or direction from without to a point within, or transition from one state or condition to another. There was, however, no uniformity, and for a long time the use of in and into remained arbitrary, even in such writers as are oflen said to be strongly influenced by Latin synlax, which so rigorously distinguishes the two cases by means of the localive (and dative) on one hand and the accusative on the other $\left.{ }^{1}\right)$.

Compare the following evidence :

c 825 Vesp. Psalter xuvir, 9, Stizende in heanisse. ' a 1300 E. E. Psaller xxIx, 12, pou torned mi weping ... In blisse.|1470-85 Malory, Morle D'A. $\mathrm{xxI}, \mathrm{v}, 29$, yf I throwe this ryche swerclo in ${ }^{2}$ ) the water. 1503 Thrissil \& Rois, Slanza 7, Quhen this wes said, departit sho, this quene, And enterit in a lusty gairding gent. | 1513 Gawin Iouglas, Prol. xxu Bk. Eneados 3, Dame Cyulhia doon rollyng in the see. 1506 Stephen Hawes, Passelyme of Pl. xxxıI, 12, my cralty wytle is ... Love for to bring in perturbation. $1533 \mathrm{~J}$. Heywood, Iard. \& Frere. 41, Yt that you enter in any hous any where. 1520 Skelton, Magnyl. 1998, Fy, fy, that ever I sholde be bronght in this snare. 1523 Berners, Froiss. I, cxulx, 177, He fyll in seruyce with a man of armes. | 1531 Elyot, Gouern. Bk I, xvin, 22, and with a ioyfull maner to be broughte in the presence of him that is chiefe in the company. I idem xvir, 134, the horses wente in water to the necke. | 1535 Coverdale 2 Esorlras III, 4, And hast brethed in him the breth of life. 1540 Surrey, Transl. Aeneid B II 342, It was the timn, when graunted from the godds The first slepe crepes most swele in wery lolk. | $15 \mathrm{~s} 3$ Udall, Royst. I. III 3, 31, He thinketh ecle woman to be brought in dolage. | 1563 Snckvillc, Mirr. Mag. Induct. st. 5, The beare, that in the Iryshe seas has dipt. $\mid 1590$ Shakesp. Mids. N. II, i, 108, Hoined hoaded frosts Full in the fresh lap of the crimson Rose (OED).

1) Note the translation of : in ... desideria multa inutilia et nociua, que mergunt homines in interitum et perditionem. (I)ial. C. 245) : into manye desyres vnprofitable and harmefull, which drownd men into death and into destruction, and compare: Passion $1352 \mathrm{k} 6$, we ... drown us all to late in fruitlesse sorow \& care.

2) But : idem xxI, v, 32, he came ageyn vnto the king, and sayd he had ben at the water and had throwen the swerde in to the water. 


\section{Subjective Veras ivith Quasi-Onjects ${ }^{1}$ )}

54. Some adjuncts of place strongly resemble objects, so that it is difficult to decide whether the verb is subjective or not.

Picus 16 G 12, go thou boldely footh thy iourney. J Jest p. $3 \mathrm{E} \mathrm{2,} \mathrm{[He]}$ sayd mayden go thy way. | Nich. 55 I 12 , God sende grace sir quod the messenger, and went his way. | Last Th. 93 A 12 . bo went his way houily. | Dial. C. 128, All the waye that hys armye cummeth. | Picus 25 I) 1, The pleasure, whiche thine euill worke doth contayne, Glideth his way, thou maist him nol restraine. | Last Th. $76 \mathrm{D} \mathrm{11}$, the very face shewetl the mind walking a pilgrimage. | Boke of F. p. 4 A 7 , she Reeth her way. | Dial. C. 171, howe manye madde wayes oure mynde wandereth the whyle. | I)ial. C. 197, counsayle dare I gyue to no man, to aduenture that waie with him.

No deviation from older and later practice. To walk a pilgrimage is obsolete now.

Earlier examples :

c 900 tr. Beda's Hist. 1, xxm, Hi3 ... summe dæl pæs wezes zefaren hæfdon. | c 1380 Wyclif, Wks. (1880) 32, No weddid man owip to leue his wile ... \& goo many hundred myles in drede of peues and enemyes (OED).

\section{Suhjective Verbs with Predicative adjuncts}

55. Some subjective verbs have adjuncts which a) denote the state or condition of the subject during the action; b) the state or condilion of the subject in consequence of or after the action.

a) Dial. G. 143, he died a very good man. | Some Lett. IX p. 318, his true subject wil I line and dye.|Dial. C. 301, we than stande in great ieopardye there to lyae wretches for euer. | Dial. C. 157, they let bym lye lame styl in hys fleshlye lustes. I Conf. Tynd. $778 \mathrm{C} 3$, let it lye bare. | Jest p. $2 \mathrm{~F} \mathrm{12,} \mathrm{he} \mathrm{lay} \mathrm{so} \mathrm{sick} \mathrm{alway.} \mathrm{|} \mathrm{Apol.} \mathrm{100,} \mathrm{he} \mathrm{wolde} \mathrm{slycke}$ styffe in his olsstynacy. | Picus $15 \mathrm{E} 19$, the apostles went ioyfull and glad from the counsell house. I Boke of F. p. 4 I) 7, the fyrst can neuer ceuse but wepe, To see how thick the blynded people go. I Dial. Her. $126 \mathrm{~A} 8$, the hole earth bangeth in the ayre, and men walk fote against fote, \& shippes saile bottom against boltom. | Hich. $43 \mathrm{~F} 6$, none coulde passe onserched. | Apol. 176, heretykes may go onarrested. | Last Th. $85 \mathrm{C} \mathrm{13}$, their posteritie goe crooked therof. / Picus 23 A 3, Enforce thysolf not onely for to stande snuainquished against the deuils might. | Dial. G. 203, byim that suffreth dark and onknowen. | Instr. 1405 1313 , If he be nought, eyther he shall amende and die good ... or abyde nought and die nought.

b) Jial. G. 172, he thrise fell prostrate in his agonie.

1) For the type to flow milk and honey see $\$ 93$ s. $\nabla$. flow. 
The adjuncts are either nouns or adjectives. In a great number of these cases the verb is in a more or less advanced stage lowards the copula state (cf. to stand unvanquished, to remain unvanquished, to be unvanquished) ').

The nature of the construction verb + adjunct is not always clear, since words like styffe, thick, were still used by More both as adjectives and adverbs. It is therefore from the context or situation only that we can gather whether the adjunct is adnominal or adverbial. In the following quotation the word soft can only be interpreted as an adverb adjunct, orving to the fact that it stands in juxtaposition with easily : Boke of F. p. 4 A 10, The head that late lay easily and full soft, In stede of pylows lyeth after on the blocke.

Earlier instances : a 1225 Ancr. R. 108, Heo ouh for to deien martir in hire meseise. | a $1215 \mathrm{St}$. Marher 18, Hit were pi gein pet tu gest unblescet. | c 1511, 1st Eng. Bk. Amer. (Arb.) Introd. 27, This people goeth all naked (OED).

Later instances : 1611 Bible, $\Lambda$ cts XXVI, $5, \Lambda$ fter the most strailest eect of our religion, I liued a Pharisee. | 1859 G. Meredith, Juggling Jerry $X, I$... have lived no gipsy. | 1856 Aytoun, Bothwell I, V, And yet - he bandies texts wilh Knox, And walks a pious man! (OED).

Pres. D. Eng. of ten has as or like before the noun : They live like goats and die like asses.

\section{Vigarious To Do replacing a Subjective Verb}

56. Dial. Her. 126 D 10, Than said he ferther that yt was more meruayle that the fyre shall make yron to ronne as siluer or led dothe. | Last Th. $81 \mathrm{~A} 8$, as sore laboreth to the dissolucion of the whole body as other sicknes do. | Jest p. 3 B 11, The frere sayd, God spede layre mayd, Here lodgeth such a man, It is told me: Well syr quod she, And yf he do what than. | Boke of F. 2 I) 2, on whiche the mased people gase and stare,... as dogges doe for the bone. | Dial. C. 183, between you and me it fared as it did once betwene a Nunne and her brother. | Dial. C. 125 ; $154 ; 162 ; 168 ; 169 ; 176 ; 182 ; 228$, etc. ; Jest 4 B 16; Rich. 55 F 14 ; 37 G 10, elc.; Last Th. 72 G 13 ; 85 H 5; P'icus 26 A 3 ; 18 A 3 , etc.

Although to do is a substitute for a subjeclive verb, its own character seems to be objective, the object being the contents of the preceding unit (in the majority of cases summarized by means of the word as : as dogges doe). It is also possible to

1) See Jespersen 1928 p. 358 (" quasi-predicatives"); Curme, 1933 p. 2627, 30 ("predicate apposilives"); Poutsma 1926 LIx, 22, 23. 
look upon to do as a semi-independent auxiliary ") : make yron to ronne as silver dothe [ronne].

The usage dates from the earliest periods : c 1000 Aelfric, Man. Astron. (Wright) 2, [seo sunne] scinp under par'e eorpan on niltlicre tide swa swa heo on dre 3 dep bufan urum heafdum.

In Pres. D. Eng. it is very common, e. g. He speaks as well as you do.

Constructions with subslitutive to do as illustrated in the following quotation from More, are no longer possible : Dial. C. 162, though he were byryed where his father was, yet whether ho went to the rest that his father $d y d$, ... I cannot tel.

\section{Shall, Shorld, Witl, May as Subjective Verbs ')}

57. A pol. 884 (Wks.) F 6, loe syra these folke that are in religion shall oute, come you into relygion in theyre stedes. | Dial. C. 180, if god wil we shal hence, than dothe he much more for vs. | Lament. p. $1 \mathrm{D} 3,0$ Je... That so lyue here as ye should neuer hence. | Dial. C. 252, [he] geue him a greate bagge by his syde, filled euen full of gold, but geuing him this knot therwith that within a litle while, out be shold in his old ragges again. | Dial. C. 187, I know my lingering not likely lo last longe, but out wil my snufte sodainly some daye. / Hich. $54 \mathrm{~F} \mathrm{13}$, for by saynt Poule (quod he) I wil not to dinner til I se thy hed of. | Dial. C. 192, when he saw it woulde not bee, but downe into the floude headlonge nedes he shoulde : in a sodeyn flight he cried out : | Last Th. 85 B 1, enuy where it may ouer, doth al the huit it can. I Apol. 925 A 7, so that home must the tinker againe.

This is a remnant of the old use in which these verbs had a fuller meaning and could consequently be combined with adverbs denoting direction; it seems therefore wrong to call this usage elliptical or quasi-elliptical, as OED. does. In Pres. D. Eng. the old idiom is occasionally found in literary language and in proverbs; in spoken English it is now archaic. The latest quot. in OED with may over = prevall, is dated c 1430 .

\section{EARLIER}

LATER

\section{shall.}

Beow. 1179, ponne pu forp scyle. idern 2817 , ic him wefter sceal. 1287 R. Glouc. 7113, pe ssephurdes

1597. Shakesp. 2 Henry Iv, V, i, 1, By cocke and pye,... you shall not away to-night.

り) Ge. the semi-independent use of will, can, may, etc. $\$ 61$. 
\& pe ssep al so ssollep to pe pine of helle.

should.

c 893 Aelfr. Oros. III, V, hie ... wiston bwider hie sceoldon.

1377 Langl. P. PI. XV, One ... tolde me whyder I shulde.

will.

Beow. 318, Ic to see wille.

13 ... Curs. MI. 20356, Furst my lord was brought to dede... And now my ladi coil me fro.

may.

c 1430 Pol. Rel. \& L. Poems, 197-03, For \& thou ouer me mygtist, as y ouer pee may.

must.

c 1386 Chaucer, Man of L. T. 281, Allas ! vn to the Barbre nacion I moste anoon.
1828 Scott, F. M. Perth XXIX, Thou shalt with me to lona.

1598 Shakesp. Merry W. III, v, 14, If the bottome were as deepe as helle, I shold down.

1905 Humph. Ward. 83, a precipitate exit lest the inward laugh should out.

1590 Sluakesp. Merry W. III, iii, 145 , Ile in, Ile in.

1885-94, Bridges, Eros XVIII, I wlll to thee o'er the stream afloat.

Pres. D. Eng. proverb : Murder will out.

In Pres. D. Eng. obsolete.

1611 Shaks. Cymb. III, V, 2, My emperor hath wrote, I must from hence. - Now archaic.

\section{Objective Verbs used Absolutely}

58. The objective verbs occurring in the following quotations are used absolutely, $i$. e. their complements are not expressed, but are understood or can be inferred from the situation or the context.

Passion 1319 C 1, Jesus began to do and to teach. | Apol. (Wks.) 873 A 1, tyll you meeke your selfe and amende them, thys anger of your husband will neuer be well appeased. | Picus $5 \mathrm{C} \mathrm{4}$, He saide... that such disputacions greatly profited, as were exercised with a peasible minde. | Dial. C. 345, To him that ouercometh, I shal geue him to eate of the tree of life. | Picus 31 B 4, But eate he, drinke he, sitte, lye downe or walke, He burneth euer as it were with a fire. J Jest p. $2 \mathrm{E} 9$, There spent he fast, Till all was past. | Last Th. $89 \mathrm{C} 14$, they neither sow nor repe, nor gather to no barns. | Jest p. $1 \mathrm{C} \mathrm{13,} \mathrm{The} \mathrm{wayes} \mathrm{to} \mathrm{buy} \mathrm{and} \mathrm{sell.} \mathrm{|} \mathrm{Apol.} \mathrm{96,}$ fayn | Dial. G. 214, forbede | Dial. G. 209, begin | Rich. 40 F 10 wyt | Jest p. 4 B 14, turne | Picus 31 B 10, sing | Last Th. 88 D 9, leaue of | Last Th. 99 B 2, minish | Rich. 40 G 7, build | Rich. $48(=45)$ B 10, keep |

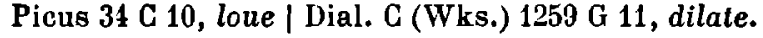

It is not easy to draw the line between subjective verbs on the one hand and objective verbs used absolutely on the other, 
the distinction being of a syntactical rather than a semasiological kind. Through the suppression of the complement a verb is apt to change its status, since the centring of the attention on the verbal idea causes the verb to be felt as subjective; its meaning is then less concrete or special (cf. The ways to buy and sell).

More's usage is in agreement with earlier and later practice.

Earlier instances : 1382 Wyclif, Rev. III, 21, I shal jine to him that shal ouercome. 1393 Gower, Conf. III 89, The wise man accompteth After the formal proprete of algorismes a be ce (OFI)).

\section{Reflexive Verbs Wiruout Reflexive Pronouns}

59. In More's English we do not find many clear instances of reflexive verbs used absolutely. The restriction clear is necessary, for it is not difficult to interpret a number of what are usually called real subjective verbs in such a way that they denote a reflex action (arise $=$ se lever ; sit down $=$ s'asseoir) '). Clear instances occur in the following Pres. D. sentences : 1854 Poultry, Cbr. I 49, Here the birds can wash | 1844 Dickens, Mart. Ch. XXVI, Even archbishops shave, or must be shaved, on a Sundey. It is this latter idiom that is seldom met with in More; as a rule he uses the reflexive pronouns, though the possibility of omitting them existed already before his time, at least with some verbs (to wash, earlicst quot. in OED. dated 1175 ; to rejoice 1468 ; to bow 1000 ; etc.).

The following quotations can be given from Nore :

Conf. Tynd. $348 \mathrm{C} 5$, he would with good will haue ones abiured, \& ones periured againe. | Aut. Lett. IV, 63, enemyes agaynst whom somme of those contrees baue been vsed bolh to defend \& make invasions at theyre awne cost and charge. | Dial. G. 197, counsayle dare I gyue no man, to aduenture that waie with them. | Conl. Tynd. $399 \mathrm{C} \mathrm{10,}$ if he might once mete ye deuyl in the dark, he would ... crosse \& blesse apace. | Conf. Tynd. $784 \mathrm{~F} \mathrm{2,} \mathrm{yet} \mathrm{coulde} \mathrm{he} \mathrm{not} \mathrm{holde} \mathrm{but} \mathrm{somewhat}$ show himselfe in that worke. I Conf Tynd. 829 B 13, the false herelyques intruded... into theyr places. | Bless. Body 1264 I) 10, they prepare to receiue him with honest and clene soules. | Aut. Lett. XII, 56 ... for he think(eth) that if themperor entre in it wold geve good corage to the Duke to declare. | Dial G. 211, Now belore I medle wyth your second

1) This manner of interpreting by means of older stages of the language or of foreign, even dead languages (Latin medium) may easily lead to wrong conclusions. There are perhaps languages in which $g \circ$, hang, stand are reflexive. 
[scil. obieccion] your third wyl I ione to this. | Picus $1 \mathrm{C} \mathrm{13,} \mathrm{their} \mathrm{frend-}$ ship ... stretcheth in manner to the body only. | Dial. C. 155, He saith not here lo, let him laughe and make mery.

If it is true what Einenkel (1916 p. 133) says concerning the collocation in the last of the above quotations (make mery), namely that it came from " to make it merry ", the quotation is irrevelant.

The reciprocal object is absent in : Debell. $933 \mathrm{~F} 5$, Than stande they both styll there as thei fyrst meete, and that is the strete by lykelyhode (for there folke most comonly meete, that meete at aduenture as they doe).

\section{To Do, replacing an Ohjective Verb, vaed abolutely}

60. Hoke of E p. D 2, And he her curseth as other fooles do. | Dial. C. 168 , the deuyll...suffreth hym not than to take it for a fable. And yet if he dooe, then fyndeth it the wretche no Pable. I Dial. C. 341 , he did but delaye his trouble for a little while ... he repented furthwith verye sore, that he so had doone. | Dial. C. 212, He must do as doth a ship, | Dial. C. 305 , Sometime he taketh them to him out of the pryson ... as he has done by many a good holye manne. | Rich. $49(=46)$ G 9 , which [saintuarye] good menne might ... without sinne sommewhat lesse regarde then they do.

Here to do replaces an objective verb; its own character is therefore also objective [" he her curseth as other fooles do her]. Another interpretation is that not the pronoun, but the verb + pronoun ought to be supplied after do [" he her curseth as other fooles do curse her] In this case to do may be looked upon as a semi-independent auxiliary instead of a pro-verb or a substitutive verb and then the words so and as [he so had done] may nol be regarded as objects.

The idiom was known before More's time : c 1175 Lamb. Hom. III, Summe lauerdes ... god gremiap, swa saul pe king dude. It is common in Pres. D. Eng., e. g. We pay double the price we formerly did. In the following quotation present usage would seem to require to do after hath canse: Dial. C. 208, Thus fareth to the scrupulous person which frameth himself mani times double the feare that he hath cause.

The Semi-Independent Use of Will, $G_{A N}$, May, etc.

61. Jest p. 3 D 3 , go hym to, And say an austen fryre, Would wilh hym speke... Quod she I wyll, Stonde yo here styll. Till I come downe agayne, I Jest p. $3 \mathrm{C} \mathrm{4}$, It longeth for our order, To hurt no man, But as 
we can '), Euery wight to forder. | Dial. C. 166, helpe our selues as wel as we canne ${ }^{1}$ ), he can make his plage as sore as hymselfe lust. | Picus 16 F 12, then shall thei coueit to ensue them in liuing, whan thei maie not. | Dial. Her. 130 A 2, god might breke vp,the hole world if he wold. Boke of F. p. 6 A 1, Serve her ... as reuerently ..., as any seruant may. Last Th. 76 F 11, we know them eilher by faith or experience. And yet not so very thorowly as we might peraduenture, \& berafter ... shal. | Dial. C. 235, He feareth also where he nedeth not.

Though in the sentences will, can, elc. stand alone, they do so only from a syntactical standpoint; semantically they form a direct nexus with the verb in the preceding unit. Frontposilion of the clause containing the semi-independent verb occasionally occurs : Rich. $51 \mathrm{G} 10$, if ye cannot els where, then may you leue him here.

EARLIER

will. 1175, Lamb. Hom. 15, Al hit mei us rede and to lare gif we wulleth (OED).

shall. a 1225 Leg. Katl. 2390, Leste 30 eft wepen echeliche in helle, ... as ze schullen alle, ... (OED).

can. a 1300 Curs. M. 23945, I wald spek if I cupe (OED). may. a 1000 Guthlac 1082, Aras pe eorla wynn heard hygesnottor, swa he brapost meahte (OED). need? Earliest quot. in OED. is dated 1577-87.

\section{LATER}

1870 Morris, Earthl. P. 241, 2, And so mid varied lalk the day went by, As such days will, not quite unhappily (OED).

1710 Swift, Jrnl. Lo St. 22 Oct., This would vex me, but it shall not (OED).

Pres. D. Eng. He will come if he can.

1857 M. Arnold, Rugby Chap. 34, we ... have endured Sunshine and rain as we might (OED).

1710 Steele, Tatler No $137 \S 1$, Some use Ten Times more Words than they need (OED).

\section{Subjegtive Verbs with a Pagsive Implication ${ }^{2}$ )}

62. Of sporadic occurrence are units containing subjective verbs with a distinctly passive implication, like the following

1) In some cases can in this position is not semi-independent, but entirely independent; its meaning is then to know : Dial. Her. 274 E 1, they deuyse by all the wayes thei can to geat so many to fall into their sorte, that ... (See \$96).

2) For the passive character of the infinitive and the form in -ing see the seclions on these verbal forms. 
in Pres. D. Eng. : The first consignment sold out in a week. | The boat upset. | The eggs hatched out easily. | Such houses sell easily.

In More we find : Dial. Her. 252 A 4, which law ... wold make al theyr eyen dase. | Debell. 943 A 1, For now shal you good readers se, what litle insight the man hath in anye thing that readeth. | Answer 1121 A 9, for which as for litle trifles his hart freteth sore. | Rich. 35 D 2, Katheryne whiche longe tyme tossed in either fortune sommetime in wealth, ofte in aduersilye, at the laste ... is by the benignitye of her Nephewe ... in verye prosperous estate. | Dial. G. 182, a litle casting back 1) ... were in this great age of yours, no litle danger and peril. | Dial. Her. 164 E 10, what way wold ye winde out? Supplic. 321 A 6, The tone is a light flame sone ended, the tolber smowdreth ${ }^{2}$ ) much lenger. | Answer 1059 D 15, therol a promise had passed \& a vow was made.

That this idiom occurs so rarely is connected with the fact that in More's language the reflexive verb is seldom to be found without the reflexive pronoun. Later on, when the pronoun came to be more generally dropped, the door was opened for imitations and analogies on a large scale. For it may be assumed that in the majority of cases the passive meaning developed through the reflexive form as an intermediary (She tossed the coin $>$ she tossed herself $>$ she tossed $=$ she was tossed). Though the bulk of the verbs now so used, underwent this change only after More's time (as may be gathered from the appended list, compiled from the quotations in OED. and giving the earliest dates of their passival or activo-passival ${ }^{3}$ ) use), a not inconsiderable earnest of this phenomenon is met with in writers before More. Delcourt's statement 4) therefore that the use of to read with the meaning of se lire must be reckoned among the Modern English features of More's language appears to be erroneous.

c 1000 open. Aelfr. Hom. u, 25s, Burgene openodon mid deadum banum.

c 1175 break. Lamb. Hom. 83, pet gles ne brekep.

c 1200 herbergen. Trin. Coll. Hom. 87, Gif he mai per inne herbergen.

1) Cf. Milton, Samson : mine, cast back with age, Came lagging after.

2) The transitive meaning is older, see OED.

3) Jespersen, 1928 p. 347.

1) 1914 p. 228 : “ les traits proprement modernes ... les principaux d'entre eux :... l'emploi de to read avec le sens de se lire". 
c 1275 wear. Serving Christ 68, per werep vre wlite in wurmene won. 1297 drench. Curs. M. 18113, A deu, al for to make pam hale on pam sal spred.

a 1300 wipe. Curs. M, 8952, If pat ani vertu be of halines wit-in pat tree, wit sinful mens fett... Onganging it sal wipe a-wai.

c 1386 derive. Chaucer, Kn. T. 2148, wel may men knowe but it be a fool That euery part dirryueth from his hool.

1390 trouble. Gower, Conf. viII, 3009, But hou so that it trowble in their, The sonne is evere briht and feir.

1398 fold. Trevisa, Barth. De P. It. Xvir, Xxvir, 620, The cassia is best that brekyth not soone but bendeth and foldeth.

1398 consume; waste. Trevisa, id. $\mathbf{x I x}$, xxi, 876, Those persones whyche done consume and waste.

a 1417 strike. York Memor. Bk I, 224, Fra evynsang ryng ... on to the morne that prime stryke at the mynster.

c 1450 compare. Merlin xx, 317, Thei ben so fewe that they may not compare with them.

1486 fret. Bk St. Alban's, B. II B, And that same penne shalle frete asonder and fall away.

1509 toss. Hawes, Past. PI. II, 14, So forthe I went tossynge on my braine.

1526 tear ; rent. Pilg. Perl. 260 b., His handes and fete dyd rent and teare for the weight.

1530 soil. Palsgr. 724, 2, I love to weare satten of Bruges but it wyll soyle anone.

1538 pour. Elyot, Dict., Ruo = to falle, to poure out.

1552 taste. Huloet; Tastynge or castynge an yll taste or sauoure, virosus.

1562 mask. G. Cavendish, Wolsey, 108, noble gentlemen who daunced and masked.

1581 tell. Hudson, Du Bartas' Judith 696, better tels to lose like Jewes, thon winne like infidels.

1585 preserve. T. Washington, tr. Nich. Voy. III, I, 69 b, The snow preserveth all the whole sommer in hys accustomed nature and coldnesse without melting.

1589 male. Warner, Alb. Eng. vi, The gayest Females mate With louts as soon as Lordes.

1592 cure. Shak. Romoo I, 2, 49, One desperate grief cures with another's grief.

1594 plant. Willobie, Avisa rLv, 5, No reason rules, where sorrowes plant.

1601 offer. Holland, Pliny I, 57, There offereth to our eie first the towne Nicaea. 
1604 ruin. E. Grimstone, Hist. Siege Ost. 202, They suffered it to burne and rutne.

1605 bake. Shak., Macb. Iv, 1, 13, Fillet of a Fenny Snake, In the Cauldron boyle and bake.

1605 shape. Bacon, Adv. L. I, V $\$ 4$, Young men, when they knit and shape perfectly, doe seldome grow to a further statue.

1606 sell. Shak. Tr. \& Cr. I, II, 306, Let vs ... show our fowlest ware, And thinke perchance they'll sell.

1607 drink. Heywood, Woman Kilde, Epil., The wine ... drunk too flat.

1607 fll. Shak. Timon IV, 11,244 , The one is filling still neuer compleat.

1612 mould. Dekker, If It Be N. G., B 4, Blest raigne! The Golden worlde is molding new againe.

1612. fashion. Hrerewood, Lang. \& Rel. vi, 50, It was spoken corruptly, according as the peoples tongues would fashion to it.

1613 plle. W. Browne, Brit. Past. I, iv, The hart-like leaves oft each with other pile. As do the hard scales of the Crocodile.

1618 obtain. Hales, Gold. Rem. II, 66, Their opinions have now obtained for a bundred years.

1627 steer

1634 peel

1638 separate

1641 slay

1659 people

1665 plash

(1668) ') read

1672 rhyme

1682 flx

1687 marshal

1688 strip

1692 spoil

a 1721 flatten

1722 form

1726 saw

1727 hatch

1737 pit
1737 mellow

1747 glaze

1751 cut

1762 plough

1765 wash

1787 catch

1792 utter

1796 transplant

1799 upset

1800 pillow

1807 graduate

1810 powder

1812 pay

1812 translate

1815 modulate

1827 write

1828 uprear
1837 smooth

1840 rip

1841 bury

1843 develop

1847 poise

1852 print

1860 temper

1870 perfect

(1877) ') stain

1883 smoke

1884 let

1886 trace

1894 rear

1896 patch

1904 smash

1913 transmit

1) In OED, but see our quot. from More in the beginning of this $\$$.

$\left.{ }^{2}\right)$ In OED, but in Shak. Love's L. L. II, I, 48 : If virtue's gloss will stain with any soil. 


\section{TyPE : To Have a $F_{A L L}=$ To $F_{A L L}$}

63. Collocations consisting of a verb (have, make, take) and noun are trequently used as approximate equivalents of subjective verbs.

to have a fall = to fall. Dial. C. 267, he made a proude promise and sone had a foule fall.

to have a purpose $=$ to purpose. Dial. C. 143, lette vs ... haue a good purpose wyth vs of sure slanding by his holy faithe.

to have sporte $=$ to be full of joy ; to enjoy oneself. Dial. C. 216, Ther were slanding other tolk by, which had a good sporte to hear her chide.

to have meruayle = to marvel. Apol. 94, Mych meruayle haue I to se some folke so boldely speke.

to have spede $=$ (to speed); to prosper. Apol. 182, I nothyng dout ... but that ... the heretykes sholde haue such spede, as they haue before this tyme had.

to catch a fall = to fall. Dial. C. 145, he might haue caught a foule fal.

to make a oysage = to look. Dial. Her. $271 \mathrm{H} \mathrm{3}$, they make a oysage as though they came streight from heauen.

to make praiers = to pray. Dial. C. 139, we may neuer wel make praiers so presysely. | Dial. Her. 165 A 12, so wold I ... knele me downe and make my speciall prayour to God. | Dial. Her. 165 E 12, thoughe ye had made your special prayour to spede well.

to make boste = to boast. Boke of F. 4 B 9, Great boste slie maketh yl one be by her power Welthy and wretched bolh within an bowre.

to make delayes = to delay. Apol. 147, beyng called in for wytness they haue fyrst made many delayes.

to make a lie $=$ to lie. Apol. 175, they ... made a lie agayne.

to make a shrift = to go to confession. Rich. $54 \mathrm{~F} \mathrm{16,} \mathrm{he} \mathrm{toke} \mathrm{a}$ priest at aduenture, \& made a short shrift.

to make an end = to end. Dial. C. 139, they turne ... to God, and call for mercy, and make a right good end.

to take thought = to think; to grieve. Last Th. $89 \mathrm{C} 8$, Why takest thou thought now in thy self...?

to take $a$ fall = to fall. Dial. G. 339, [they] maye soone take a foule fall.

to take penance $=$ to repent etc. Dial. C. 197, to take no thougtt, but make mery, nor take no penance at all.

to take a good stomacke to oneself $=$ to be bold. Dial. C. 206, good thynges, whyche (if lie tooke a good stomake to hym in the trust of Gods helpe) he were wel able to do. 
to break one's fast $=$ to breakfast. Dial. C. 238 , both brake I $m y$ fast euen as you came in, and also...

The use of the analylic form (to hove $a$ fall) instead of the simple verb can be accounted for in several ways. It may in the first place be a question of style and rhythm, since the use of the analytic phrase affords an opportunity to arrange the adjuncts in a more elegant and somelimes more eflicient way (e. g. adjectives instead of adverbs; cf. "he soon fell foully - he had a foul fall; "I would pray specially to God - I wold make my special prayour to God). A second cause for the development of the periphrastic collocation may be sought in the tendency - then already very strong (see the use of the attendant verbs) - to use analytic constructions '). The main cause, however, lies in the fact that the periphrasis enables the writer to express more distinctly the particular aspect of the syntactical unit. If we compare he had a fall and he fell, it is evident that the terminative aspect is considerably more distinct in the analytic construction than in the other. In the former the various semantic and syntactic functions may be separately expressed : the noun (fall) is the bearer of the mere verbal notion, the verb (have) takes the task of expressing the finer shades of aspect, modality, time-sphere, etc. There are moreover other differences between the two forms. In he had a fall the singleness, or one-ness ${ }^{2}$ ) of the act comes to the fore, which may not be the case in he fell, and - owing to the fact that the verb in the analytic form is not entirely a linkword, but has retained something of its full meaning the subject in he had a foul fall is not in the first place represented as the doer, the agent, but rather as the person who experiences the pleasant or unpleasant consequences of the action. Similar arguments may be used regarding the other verbs (to have spede = to prosper; to make a lie = to lie).

1) Deutschbein (1931 a $\$ 21$ ) sees the cause of the development of these analytic forms in " eine ausgesprochene Neigung zum gegenständlichen Denken" and speaks of the " nominaler Character der eng. Sprache".

$\left.{ }^{2}\right)$ Deutschbein (1931 a $\left.\$ 28\right)$ makes a difference between " abstractgenerelle" and "actuelle Sätze" and (p. 66 note 1) speaks of "dauerencie Handlung" and "einmalige Handlung", 
64. Both Curme ') and Poutsma (1926 LIV, 13) call the anal$y$ tic form colloquial, the flrst adding that the method of using a full verb is felt as too formal, too scientific. This may be true for Pres. D. Eng. [though the above observations render it doubtful], but it is beyond gainsay that in More's quotations there is no question of colloquiality; there is decidedly none in those taken from such works as The A pologye, where More writes in a constant mood of holy earnestness. The regrettable absence of syntactical studies dealing with this phenomenon in older English, makes it impossible to give an historical view of its development. The following batch of quotations from OED "), showing the earliest occurence of this usage, prove that, with a number of verbs at least, the idiom was known before More's time.

to catch a fall. $1537 \mathrm{~W}$. T. Expos. St. John. 79, They be taken tardy and ketch a fall. (Rhythm!)

to have purpose. a 138t Chancer H. Fame 377, Who-so to knowe hit hath purpose Rede Virgile in Eneydos.

to have marvel. 1303 R. Brunne, HandI. S, 3927, pe lorde and pe gestes alle had meruyele pat byt was so.

to have speed. 1535 Goodly Prymer S. j. b., That temyng women may haue ioyfull spede in their labour.

to have sport. c 1515 Cocke Lorell's is. 3, To soarche theyr bodyes fayre and clere, Therof they had good sporte.

to make bost. 1377 Langl. P. PI. XIV, 247, And whether be ligter to breke? lasse boste it maketh, A beggeres bagge pan an yrenbounde coffre.

to make an end. a 1300 Curs. M. 27783, For drede pat he may noght mak end.

to make prayers. c 1420 Chron. Vilod 3911, when po quene haddo made hurre preyzerus pus.

1) 1933 p. 22 : « In colloquial language there is here as elsewhere a tendency to more concrete forms of expression. A noun seems nearer to popular feeling than the more abstract verb. "It may be asked what there is more of concreteness in a fall than in to fall. The terms limitless (to fall) and limited (a fall) would be more to the point.

2) The OED. is far from exhaustive in this respect, since some of the collocations, as such, have no separate paragraph; to have a fall is not given; s. v. have (= experience) we find as earliest quotation : 1590 have a sport; further : 1697 have a stroke; 1760 have a dip ; otc. 
to make a lie. a 1533, Ld. Berners, Huon. XXXVII, 116, Huon thus being in displeasure with hymselfe for the lye that he made.

to make delay. 1583, Hollybrand, Gampo d. F, 47, To do so great an enterprise, I make no delay.

to take penance. 1470-85 Malory, M. Artb. XXI, VII, Grele Penaunce she toke as cuer dyd synful lady in thys londe.

to take thought. 1523 Ld Berners, Froiss. I, CCXXXII, 324, His wyle ... toke moche thought for his departyng.

to take one's way. a 1300 Curs. M. 11382, pis kinges thre par wai pai tok A tuelmoth ar the natiuite.

te take (a good) stomach unto oneself. 1514 Bale, Exam. Oldcastle 26 b, He toke stomake onto hiin agayne ').

\section{3. - THE VERB STANDS IVITH A COMPLEMENT}

\section{DISTINCT SUBORDINATION} (COPULAS)

\section{Chafacter Of The Consthuction}

65. The degree of subordination of the verbs to their complements in units such as he was wood for payne, we be slace, those are ours, is in some cases so considerable that they may be called mere link-rwords or copulas. It does not, however, follow that they can be done without, for, instead of being dispensable, they are of the greatest importance as the only words in these syutactical units that enable the latter to carry out a number of syntactical functions and express semantical notions. Thus the copula helps to express :

a. a question : Was the king sure? ('f. The King was sure.

b. a command : Last Th. $81 \mathrm{D} \mathrm{3,} \mathrm{Be} \mathrm{mery} \mathrm{manne.}$

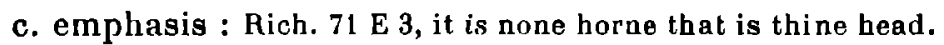

d. time-sphere : Lament. St. 81.6 , That we lest feare, full oft it is most nye. | Jest p. $4 \mathrm{E} 13$, he was wood for payne.

e. modality of non-reality, doubt or uncertainty : Picus 21 C 3 , then wer it no right, That any seruant ... shoulde stande in belter condition than his lorde. | Last Th. $88 \mathrm{C} 10$, Doubt ye whether this wrath be pride?

f. aspect : Rich. 65 E 14, then waxed he bolde.| Dial. C. 260, he falleth desperate of all belp.

1) For periphrastic collocations of this type, approximately equivalent to objective verbs, see $\$ 103$. 
g. various kinds of adverbial relations : Picus 13 C 2, And verely it is accordyng, that god should despyse theo being a man, whan thou being a inan despysest a man. / Rich. 59 D 16, mariage being a spiritual thing, ... to be made for the respecte of God.

\section{The Copela to be}

66. The commonest copula is to be. Just as in Pres. D. Eng. it either classifies or identifles. In the flrst case it states of what sort the subject is, i. e. that the subject has a place among the things distinguished by a specified quality or name in the complement (as in : Dial. Her. $166 \mathrm{G} \mathrm{8}$, whether it be

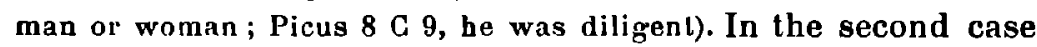
it states what the subject is, $i$. e. that the subject is identical with the complement (as in : Picus 17 B 1, thou art god my sauiour.)

The verb to go in the following unit may be looked upon as a synonym of to be.

Dial. G. 269, How be it manye a manne maye weene himself farre therefro, that yet may fortune by some one chaunce or olher : to fall in the case that eyther for the trouth of fayth, or for the trouthe of iustice, (which goe almoste alyke) he may fall in the case.

It follows from whal has been said in $\$ 65$ about the functions of the copula, that whenever the particular character of the unit as regards time-sphere, modality, aspect, etc. can be inferred from the situation or context, the link verb is superfluous. There are, indeed, various examples in More's English which point to the truth of this conjecture ${ }^{1}$ ) :

Rich. 61 A 6, he declared then, that king Eduard was neuer lawlully maried, vnto the quene, but was before god, husband vnto dame Elizabeth Lucye, \& so his children bastardes. | Dial. C. 347 , those heauenly ioyes ... of whiche our carnal heartes halh so fleble ... a feling, and our dull wordly wittes so little able to conceue. | Picus 3 A 5, [he] would bold it in sure remembrance : which in olber folkes wont ${ }^{2}$ ) commonly to happen contrary. | Hich. 55 F 11, [they] should that day be behedded at Pomfret : which he wol wyst, but nolhing ware that the axe hang ouer his own hed. | Last Th. 93 A 18 , if theyr hertes had bene sore set vppon righte small lhinges, it wolde haue bene a great let. And no maruaile ${ }^{3}$ ) thoughe couetous be hard to hele. | Rich. 55 G 2, And to

\footnotetext{
1) For tho "absence" of the copula to be in units of the type : He flndeth it no fable. | He thinketh his game sweet, etc., see $\$ 129$.

2) Or perhaps the verb to wont; but the earliest illustration in OED of this verb in the sense to be wont is daled a 1517.

3) In Pres. D. Eng. still in : worse luck; what matter; all the more reason, smatl wonder etc.
} 
how the world is turned, now stand mine enemies in the daunger... and $I$ neuer in my life so mery, nor neuor in so great suerty. | A pol. 13, more then four partes ... could neuer rede cnglyshe yet, and many now to olde to begynne to go to scole.

Similar constructions were not rare in earlier English.

67. No examples have been found of the following type ("omission" of being) : Barrie, Litt. M. 257, It would be a wild, presumptious thing and him a great minister (J.).

68. The other link-verbs are not merely subservient in expressing certain syntactical notions, but perform functions of their own on the strength of their original character; they may therefore be divided in to the following groups :

a. copulas of aspect (become, wax, fall, remain, etc.).

b. copulas of modality (seme, appere, loke, etc.).

\section{Copulas of Aspect}

69. to become '). Dial. C. 253, he promised not, neither to geue awaye all, nor to become a begger. | Dial. C, 172, Christ ... became obedient vnto the death. | Jest p. $1 \mathrm{C} 2$, An olde butler, Becum a cutler, I wene shall proue a fole. I Dial. C. 227 ; 336 ; 253 ; 310 ; Apol. 153, etc.

Dial. C. 336, they wyll hy theyr owne willes lette theyr syckenesse ... growe ... tyll it be come incurable.

In the last example be and come are printed separately so that come may perhaps be regarded as a past participle and be as an attendant verb. In that case come would be another link-verb.

Sometimes to be has the same aspect as become: Apol. 51, by twyse weddynge [I] am come in the case that I can neuer be preste.| Jest p. 1 H 1, many a man ... hath with good cast, Be ryche at last, That hath begonne with lesse.

Older usage : c 1175 Lamb. Hom. 47, pa bicom his licome swipe feble. I c 1400 Mandev., Tr. 90, 25, After began he for to wexe wyse and ricbe and he was a gret Astronomer.

70. to wax. Dial. G. 130, I waxed therwith my self sodeinly sumwhat a flyghte. / Rich. $65 \mathrm{E} 12$, When the duke had this leaue \& pardon

1) Become may also be usèd as a subjective verb : Dial. Her. 274 B 2, And where were become al good ordre among men, if euery misordred wretche myght alledge that his mischieuous dede was his desteny. Passion 1353 B 15, But nowe where are these folke become, that stande very muche in theyr owne conceyte... 
to speake, then waxed he bolde. | Dial. C. 244, there are two times of darknesses : the tone ere the morning wax lyght, the tother when the euening waxeth darke. I Jest p. $3 \mathrm{H} \mathrm{9,} \mathrm{This} \mathrm{merchaunt} \mathrm{there,} \mathrm{For} \mathrm{wrath}$ and lece, He waxing welnygh wood, Sayd borson thefe..., Who has taught the thy good? | Rich. 49 G 9, waxeth the lesse able. | Last TL. 87

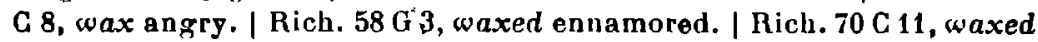
familiar. | Picus 17 D 1, waxest colde. | Picus 17 F 8, waxe prowde.

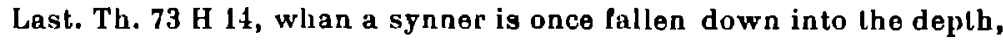
he waxeth a desperate wretche.

It is difficult to see whether More discriminated semasiologically between become and wax, both having adjectives as well as nouns for complements and both denoting a gradual as well as a sudden change (to wax wood). To wax, however, is much more frequently used than to become ').

Older usage : c 1200, Ormin 2479, sho wass waxen summ del great.

The verb wax has now been superseded by grow in its general colloquial use (and by get, still more colloquial), except with reference to the moon. In Pres. D. literary Eng. it is somewhat archaic; it is still current in dialects.

71. to fall. Dial. G. 236, yf they fall sicke in our service, ... yet maye we not in any wyse turne them than out of dores. | Dial. C. 355, I wene that when socuer he falleth sicke nexte, he wyll wyshe that he hadde ba kylled for Chrystes sake before.| Dial. C. 200, be falleth desperate of all help. | Dial. C. 240, some fall so fearde therol that...

The complements are adjectives, no nouns. (Earliest example with noun in OED. is dated 1591). In the ferv instances that have been found the adjectives all denote an unfavourable condilion (sicke, desperate, etc.).

Older usage : a 1400.50 Alex, 856, Philip falne [was] sare sicke (OED). Pres. D. Eug. : 1889 A. Sergeant, Luck of House I, IX, 129, Her tongue would fall silent (OED).

72. to grow. Gonf. Tynd. $60 \pm \mathrm{F} 2$, till the horse be with meate and rest beller growen in heart. | Dial. C. 135, Godde shall ... suffer our tribulacions to growe so great, that...

This verb is not oflen met with in More. In earlier English it was common : a 1300 Cursor $M .6941$, par pai [sc. wandes] gru, ne less ne mare, Bot euer als pai forwit ware. | c 1440 Prompt. Parv. 215, 1, Growe ballyd, calvesco. Growe blake, nigresco (OED). In Pres. D. Eng. it is used to express a gradual becoming, often with the

1) Exceptionally is lound to encrease : Passion 1322 B 1, the desyre... encreased greater. 
connotation of increase in magnitude or quantity : 1874 Green, Short Hist. IV \$ 5, 198, The Jews grew wealthy enough to acquire estates (OED).

73. worthen. More does not use the verb worthen (OE. weorpan, wurpan). It seems to have died out in the meaning of become not long before 1500. The ouly quotation after 1500 in OED is : 1513 Douglas, Aeneis IV, Prol. 245, O lust... Thyself consumyng worthis insaciable. Here it was perhaps already felt as an archaism. More has : Rich. $43 \mathrm{E} \mathrm{2,} \mathrm{Ah} \mathrm{woo} \mathrm{worthe} \mathrm{bim,} \mathrm{but}$ here worthe is not a copula.

74. Other copulas of inchoative aspect.

Units with other copulas of inchoative aspect (e. g. turn, come, go, run, get) have not been found. Earliest quotations in OED : come 1310 (1862); turn 1450 ; run 1513; go 1583 ; get 1596. T'o turn (in)to (with noun) is, however, frequently used : Passion $1274(=1276)$ D 9, the walowe sweete pleasure of that fruite, soone turned to displeasure and payne. | Dial. C. 238, the pryde turneth into rebuke and shame. | Dial. C. 239, he was turned from a bright glorious angel, into a darke deformed deuil.

75. to remain. Dial. Her. 183 F 8 , than shall ... the hole body of christes holy church remaine pure... | Rich. $67 \mathrm{D} 5$, the murther of his innocent nephewes, the young king and his tender brother. Whose deathe ... hathe natheless so far comen in question, that some remain yet in doubt, whither they were in his dayes destroyed or no. | Passion 1335 A 6 , the ... bodye ... remaynynge deade on the crosse.

The use of to remain as a copula cannot have been old, the earliest quotation in OED being : 1509 Hawes, Past. Pl. xxvir, 132, I made mine othe ... Unto them all for lo remayne full true In stedfast love. In Pres. D. Eng. it is very common.

76. to continue. Instr. $1421 \mathrm{C} 10$, if he shall continue nought and be dampncd, than... | Answer $1066 \mathrm{~B} 4$, [they] that list not willingly to continue fooles.

The earliest instance in OED of this use of to continue dates from the beginning of the $16^{\text {th }}$ century : 1503-4 Act 19, Hen. VII, c. 39, Preamb., Sythen whiche tyme your seid Subgiect halhe contynued your feythfull and true liegeman.

77. to abide. Dial. C. 177, the wealthye manne for all his almose abydeth ryche styll. | Dial. C. 254, no place ... in which ther coulde anye man abide riche without the daunger of eternal damnacion. I Instr. 
1405 B 13, If he be nought, eyther he shall amende ... or abyde nought and die nought.

Older usage : 1366 Maundev. xxvir, 289, The Coles willen duellen and abyden alle quyk. Pres. D. Eng. : 1881 Globe 21 Sept., One of the few Southerners in public life who abided faithful to the Constitution when the battle of secession began.

78. to kepe. Gonf. Tynd. 377 D 14, if they ... entende to kepe stil. | Answer $1046 \mathrm{G} \mathrm{14}$, and yet kepeth it whole. I Answer $1016 \mathrm{H} \mathrm{2}$, and yet kepe ... stil himselfe.

The earliest quotation in OED of to keep in this function is dated 1590 (Shakespeare). In Pres. D. Eng. it is current.

\section{Copulas OF Modality}

79. to seme. Dial. Her. 133 B 2, I se not gretly why I shoulde mistrust any one that 8, meth bonest. | Dial. Her. 131 A 7, One or lwo or three ... semeth me to few. | Picus 6 B 2, it semed rather a gift then a sale. | Dial. C. 205 , in the night euery bushe to hym that waxelh once alerd, semelh a theele. | Dial. C. 219 ; 311 ; 321 ; Last i'h. 75 H 4 ; 88 F 6 ; 86 F 14 ; 98 H 6 ; Rich. 48 E 6 ; 49 A 11 ; 57 A 10 ; Apol. 6 ; etc.

80. to appere. Apol. 126, in some part at the lest hys wordes appere false. | Dial. Her. $127 \mathrm{~F} 8$, thinges that hy reason and nature seme and appere impossible. | Dial. C. 274, the thyng shal not appeare so terrible vnto them. I Dial. C. 274, these causes of terroure ... shall well appeare in conclusion, thinges nothing so muche to be dred and ned fro, as to folke at the fyrst syght thei do sodainly seme. | Debell. $976 \mathrm{H} \mathrm{13}$, a man ..., that appereth plainly vpon all their othes... the very chief herelike of al.

From these quotalions it is evident that appear was used in the meaning of prove to be ${ }^{1}$ ); this meaning is also expressed by fuln into : Dial. G. 205, But when the daye was sprongen ... And wben they caine thither, they founde that the great leareful army of the Turkes, so soberly coming on, tourned (God be thanked) into a fayre long hedge standing euen stone styl.

The earliest quotalion in OED with to appear = "to seem, as distinguished from to be" is dated 1559 .

81. to loke. Boke of F. p. 2 B 5, Sometyme she loketh as louely faire and bright, As goodly Venus mother of Cupyde.

This usage was known before More and is still current.

1) Compare seem and appear in : Passion $1326 \mathrm{E} \mathrm{11,} \mathrm{And} \mathrm{so} \mathrm{scemeth}$ it moste playne to appeare vppon the wordes of saynte Luke. 
Earliest quot. in OED : c 1400 Destr. Troy 8742, Ymages ... Lokend full lyuely as any light angels. No instances have been found in More of the combination to look + adverb, as in : 1611 Shakesp., Wint. T. mi, iii, 3, The skies looke grimly. Yet the absence of -ly after fair and bright in the quotation from the Boke of $F$. does not prove that these words were adjectives. (Cf. Dial. C. 215, many ... that haue bene sore combred. | Dial. C. 221. Therefore must you fayre and casely touch hym.)

82. to prone. Last Th. $88 \mathrm{G} \mathrm{9,} \mathrm{than} \mathrm{proue} \mathrm{thei} \mathrm{more} \mathrm{foles,} \mathrm{than} \mathrm{they}$ that liue from hande to mouthe. | Dial. C. 219, least his reuelacions ... wold prone illusions of the diuel. And so proned it after in dede. | Dial. C. 293, it it haue happed hys reuelacions before to proue false.

Current in earlier and later English. EQ. 13... E. E. Allit. P., B 704, Wel nyze pure paradys most preue no better.

\section{Quasi-Copulas ${ }^{1}$ )}

83. Dial. C. 197, sythe these olher folke sylle so mery without tribulacion. | Dial. C. 288, though that they [scil. the gifles of fortune] be indifferent of their nature : yet cannot the vse of them lightly stand indifferent but determinately must either be good or bad. / Dial. Her. 215 B 10, I coulde mystrust their tale well ynough ... as they stode onsworne. | Dial. C. 196, he standeth bounden to no common rule. | Dial. C. 319 , the gryselye cruell hangman death which ... hath euer hooned a loofe. | Rich. $66 \mathrm{G} 6$, he that playeth the sowdayne is percase a sowter. / Jest p. 4 G 12, Play not the frere. | Dial. Her. 138 F 12, Ye tolde me that ye sette nought by Logycke, but now ye playe the Logicien out right. | Last Th. 84 B 5, If thou sholdest p(er)ceue that one wer ernestly proud of the wering of a gay golden gown, while the lorel playth the lord in a stage playe, woldest thou not laugh at his foly, considering that thou art very sure, that whan the play is done, he shal go walke a knaue in his old cote?

A clear line of demarcation cannot be drawn between this usage and that of a subjective verb + a predicative adnominal adjunct, as illustrated in $\$ 55$ (e. g. go unarrested; die nought). The distinction depends upon the degree of subordination of the verb.

Earlier usage : a 1035 Laws Cnut II, Lxxı1, 360, sitte ælc wuduwe werleas. I c 1420 Lydg. Assembly of Gods, 1887, Thy witte stant a crooke. | c 1200 Bestiary 525, [He] stireb up and hothep stille. | c 1374 Chaucer, Troyl. II, 1191, But ye han pleyed tyraunt neigh to longe.

1) Gl. Jespersen $1932 \S 17,1$ (“quasi-predicatives "); Curme 1933 p. 27; Sweet $1903 \S 263 \mathrm{ff} ; 2339$. 


\section{The Complement of the Copulas}

\section{Nouns.}

Rich. $63 \mathrm{~B} 2$, yet bee ye the people whom he had as singular cause wel and kyndly to entreale. | Picus 17 B 4. all the tyme of oure life is but a moment. | Dial. C. 253, to become a begger. | Dial. Her. 134 G 1, what colour is my gowne ${ }^{1}$ ).

The noun is sometimes preceded by as or like : Picus 12 B 4, The wicked inans heart is like a slormy sea. | Dial. G. 205, our hody is but as the garment of the soule.

When the subject is plural the complement of the copula has a plural form [for exceptions (e. g. we be slave) see belowi :

Dial. C. 219, least his reuelacions ... wold prone illusions of the deuil. |

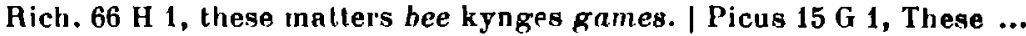
be thinges which do appertaine to a noble prince.

'The collocations to be a let, to be the let, as illustrated in the folluwing quofations, are obsolete now.

Dial. C. 330, except the fear'e of shame ... shoulde be the lelte. | Dial. c. 179, to fingshe our talkynge for this time, lest I should be to Inng a let vnto your olher business.

A striking feature is the absence of the indefinite article before abstract nouns, especially when the grammatical subject is it :

Rich. 53 D 3, surely great pity was it. | Dial. Tyud. 132 G 6, reason were it to withdraw his thank. | Rich. $45(=44) \mathrm{E} 10$, it were almoise to hange them.

\begin{tabular}{ll|ll} 
commoditie & Rich. 49 B 7 & reason & Rich. 63 G 10 \\
death & Picus 29 A 13 & shame & Picus 14 E 13 \\
euil & Last Th. 75 H 4 & litlle sinne & Dial. C. 216 \\
foly & Rich. 70 G 13 & surely & Rich. 66 B 9 \\
litle labour & Dial. Her. 224 A 14. & thanke & Apol. 117 \\
madnes & Last Th. 98 F 13 & troulh & Dial. Her. 218 H 6 \\
maystrye & Rich. 49 H 8 & osage & Boke of F. p.5 A 4 \\
nede & Last Th. 95 B 6 & wisdoin & Dial. Her. 109 H 2 \\
pride & Last Th.88 C 11 & wo & Dial. C. 163 \\
proofe & Dial. Hor. 230 A 10 & wondre & Picus B B 12
\end{tabular}

Occasionally, however, the indefinite article is used : A pol. 42, that were a thynge wherof $y t$ were a very fransey to doute. Picus 2 E 1, which apparence was peraduenture a token that ... | Picus

1) Constructions of the type he was my age have not been observed. (See Jespersen 1928 p. 398). 
$11 \mathrm{C}$ 10, how great $a$ wonder were this. | Picus 1 B 7, It is, and of longe lime hath bene a custome. | Dial. C. 321, if this thing ... seme but a sophisticall fantasy.

The difference between the two usages may be accounted for by assuming that in the former group (it is folly) the character of the copula is not purely identifying, but rather connotative, so that the words foly, madnes, shame are semantically equivalent to adjeclives (=it is foolish, etc). The same distinclion seems to hold good when the complement refers to a person :

a) with indefuite article ${ }^{1}$ ).

Dial. C. 216, the man was a carpenter. | Picus 3 B 10, in that. ij. yere, yet being a childe, he compiled a breuiary. | Picus 24 A 8, it is more pleasure farre, Ouer the deuil to be a conquerore. | Dial. C. 205, in the night euery bushe ... semeth a theefe. | Picus 13 G 3 , god should despyse thee being a man, whan thon being a man despysest a man. | Mich. 59 F 15, as though I wer a ward that wer bound to niary by thappointment of a gardain. | Lich, $58 \mathrm{~F} \mathrm{7,} \mathrm{dame} \mathrm{klizabeth} \mathrm{Gray} \mathrm{which} \mathrm{was} \mathrm{after} \mathrm{his}$ quene, at that line $a$ widow.

b) without article ${ }^{2}$ ).

Dial. C. 310, he shuld lake it for so sore a thing ... to become thorowe chaunce of warre bonde vinto a man, while he is alredy through synne, become willinglye thral and bond vnto the ditiel. I Apol. 51, by twyse weddynge [I] am come in the case that I can neuer be preste. | Rich. 56 E 2, One that was scole master of Poules ... said ... | Dial. C. 353, better is it to be thrall vnto man a while for the pleasure of God. | Lament. st. 7 I. 6, Erst wer you father, \& now must ye supply, The molliers part also. | Rich. 58 D 3, the prolectour's owne mother, which was mother to

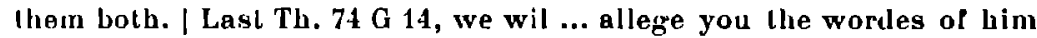
that is doctor of them al, our sauior Jesu Christ. | Dial. Her. 166 a 5 , Nowe quod I this man that God byddeth you go to, ... will it make any chaunge ... whether it be man or woman? | Dial. C. 310 , the manne that we be slave vinto.

In the first group (a) the complement expresses the class

1) When the complement-noun is preceded by an adjective the indeflnite article is used in both cases: Hich. 56 H 10, He was an honest man.| Picus 3 D 1, he was ... a parfet philosophre, and a parfet diuine. | Last

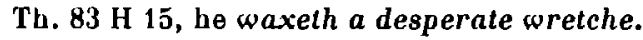

8) Not included are those cases in which the complement denotes a slale, a quality, elc, that is unique : Picus $17 \mathrm{~B} 1$, thou art God my sauiour. | Rich. $35 \mathrm{C} \mathrm{5}$, Elisabeth, whose fortune and grace was after to bee Queene. | Rich. 38 A 10, then wyll ... the Duke of Gloucester bee Kynge. 
to which the subject belongs (she is a widow); in group b) the complement qualifies the subjecl and is adjectival in function. Besides the absence of an arlicle the use of the singular form of the noun-complement when the subject is plural (we be slave; last quotation) is indicative of this qualifying character of the copula.

\section{Adjegtives.}

Rich. $60 \mathrm{~A} \mathrm{3}$, the kinge was sure t' dame Elisabeth Lucy and her husband before God. | Picus $8 \mathrm{C} \mathrm{7}$, we speake not of those obscruances, which the churche commaundeth to be obserued : for in those be was diligent. | Picus 2 G 12, He was of feture and shappe semely, and bewteous of stature goodly and high, of flesh, tendre end sof( ').

This usage does not call for any remarks. In the group it was long or the verb to be approximates in meaning to to last, and its character as a copula is consequently doubtful : Picus 5 B 3, when Hercules Estensis ... desired him to dispute at Ferrare ... longe it was or he could be brought therto.

To be + ware is still written in two words in More's language : Picus $12 \mathrm{C} \mathrm{9}$, There shal come to the ... innumerable impedimentes... : which might feare thee from the purpose of good ... liuing. and (but if thou be ware) shall throw thee down hedling. | Rich. $51 \mathrm{H} 5$, he you wel ware that you fer not ... to little. | Dial. C. 245, they fall and be caughte and drowned in ere they be ware.| Rich. $55 \mathrm{~F} 11$, they should that day be behedded at Poumfret : which he wol wyst, but nothing ware that the axe hang over his own hed.

Comparatives, superlatives and their equivalents are freely used as complements to the copulas :

Rich. 57 C 3, But the meriest was this Shoris wife. Rich. 57 E 6, Her doinges were not much lesse. | Jest p. 4 F 13, Quod he now lost, Is all this cost, We be neuer the nere.| Rich. $62 \mathrm{G} \mathrm{4}$, whoso was beste, bare alway lest rulo. | Rich. $48(=45)$ E 6, none seemeth mee more metelye. | Last Th. $84 \mathrm{~F} 12$, ywis ye be no better. | Last Th. 75 A 15, the mare theyr payn was, the more was their ioy.

It is not worst + infinitive occurs in : Rich. $48(=45) \mathrm{D} \mathrm{12,}$ u were not woorste to sende vnto the Quene ... somme honourable ... manne. (Not in OED, which, however, records Grafton's version : it were not the worst.)

To be the better (= to be profted or advantaged) occurs in :

1) For constructions like the following : Dial. C. 180, Although the thing be luefull to require. | Last Th. $93 \mathrm{~B} 3$, And no maruaille thoughe couetous be hard to hele, see the paragraphs on the infinitive-form (\$ 258). 
Dial. C. 216, What the diuel should she be the better then? The earliest quotation in OED of this idiom (now archaic or dialectical) is dated 1619 (J. Dyke, Counterp. (1620) 37, what are we the better to know our disease?)

\section{Pronouns and phonominal wohds.}

Dial. C. 205, Belgrad which wold God wer ours as wel as it was then. Picus 7 H 14, The wordes that he said vnto him, were these. | Dial. C. 216, whose shall it be? | Dial. C. 202, thou that such one art, wyl the truth of bis promise defend. | Dial. C. 256, He that prouideth not for those that are his, is woorse than an infidele. Those are ours that are belonging to our charge. | Dial. C. 347, thys whole world if it wer hls. | Dial. G. 156, thys semeth 80 in dede. / Last Th. $86 \mathrm{E} \mathrm{3,} \mathrm{theyr} \mathrm{manner} \mathrm{and}$ behauiour be suche, that ... | Last Th. $81 \mathrm{H} \mathrm{9,} \mathrm{Nowe} \mathrm{if} \mathrm{this} \mathrm{be} \mathrm{thus} \mathrm{...} \mathrm{|}$ Rich. 71 F 3, Then longed the duke yet moch more to wit what it was.

The use of the determinative or proleclic pronouns he and it as complements of a link verb deserves notice :

Picus $19 \mathrm{G} \mathrm{3}$, thou art he that shalt drawe me to thee by thy grace, thou art he that shalt geue thy self in possession vato me. | Picus $19 \mathrm{~F}$ 13, Thon good lord art he, that shall ') restore mine enherytance vnto me. | Hich. 47 A 10, I am not he that woulde bee aboute to breake them.| Dial. C. 197, I am not he that wyl enuye theyr good happ. | Dial. Her. $254 \mathrm{~F} \mathrm{8}$, it was not il ${ }^{2}$ ), that he appeled vato.

Earlier instance : a 1300 Curs. M. 3693, It thou be he i luue sa wole (OEI).

\section{Adverbs.}

Dial. C. 207. al cannot alway be well. | Lament. St. 11, 1. 4, well are ye that earthly folly flee. | Dial. C. 301, a fyre that is almost oute. | Debell. $930 \mathrm{G} \mathrm{3}$, Now after that the booke was oute and came into mine handes. | Dial. Her. 130 G 8, It may ... fortune you, to live so long that ye shall fynde no man that was by at your crysteninge. I Rich. 55 D 13, Vpon the very tower wharfe so nere the place where his hed was of so sone after. | Rich. $55 \mathrm{C} \mathrm{10,} \mathrm{The} \mathrm{same} \mathrm{morning} \mathrm{ere} \mathrm{he} \mathrm{were} \mathrm{op.} \mathrm{|} \mathrm{Dial.} \mathrm{C.}$ 238, whyle that we be opward and aloft. i Rich. $55 \mathrm{C} \mathrm{4}$, no such mischounce is toward. | Rich. 71 C 1, The fox ... asked him whither he made al that hast. And he answered, in faith I neither wote nor reck, so I wer once hence.

The same usage before and after More. Earlier instances : a 1375 Joseph Arim. 234, In pe morwe he was oppe. | c 1325 Poem Times

1) This shall appears to be a misprint for shalt; see the preceding quotation.

i) Cl. Dial. C. 359 , The manne is so much the lesse perfyte than I woulde wishe, if it were as easy to be $1 l$ as to wishe it. 
Edw. II (Camden) 120, There hii clateren cumpelin when pe candel is oute. | 1387 Trevisa Higden (Rolls) V, 101, Also for werre and batailles pat were toward (OED). I c 1425 Wyntoun Cron. VIII, XL, 93, Opir Lordis pat war by (OE.D).

To be toward (= imminent) and to be upward are obsolete now.

\section{Prepositional phrases.}

Picus $5 \mathrm{~F} \mathrm{5}$, he was not of the condicion of some folke ... which... Ricl. $61 \mathrm{D} \mathrm{7,} \mathrm{he} \mathrm{sodainly} \mathrm{lefte} \mathrm{the} \mathrm{maller,} \mathrm{with} \mathrm{which} \mathrm{be} \mathrm{was} \mathrm{in} \mathrm{hand.}$ Rich. $62 \mathrm{E} \mathrm{3,} \mathrm{thus} \mathrm{wer} \mathrm{...} \mathrm{your} \mathrm{goods} \mathrm{in} \mathrm{suretye.} \mathrm{|} \mathrm{Rich.} \mathrm{59)} \mathrm{D} \mathrm{13,} \mathrm{[he]}$ was at a pointe in his own mynde. | Rich. $57 \mathrm{C} 16$, she stode many men In gret stede. / Rich. 58 E 8, [he] was in pcasyble possession of tho realme. | Ricb. 56 F 17, Albeil she were oul of al array. | Dial. C. 318, whiche of these two prisoners stoode in worse case. | Dial. C. 196, a vessel that is of his own making.

to be about (theyr) festes, Last Th. 97 C 11

to be aboue the reache of, Answer 1117 G 7 to be at communicacion, Apol. 91 to be at (my) deuice,

Boke of F. p. 1 A 4 to be at ease, Dial. C. 346 to be at the harde wall, Dial. Her. 187 D 14 to be at variaunce, Rich. $38 \mathrm{~F} 1$ to be in ancthorltie, Rich. 58 A 4 to be in distres, Rich. 49 A 3 to be in falloure \& credence,

to be in flesh, Picus $1 \mathrm{D} 5$ Hich. $48(=45)$ E 3

to be in grudge, Apol. 124 to be in helthe, Rich. $49 \mathrm{E} 13$ to be in question, Dial. Her. 257 A 12 to be in service, Hich. 58 F 13 to be In the trueth,

Dial. Her. 171 I) 12

to be in ure, Rich. $42 \mathrm{G} 2$

to be in vaine, Boke of F. p. $1 \mathrm{C} 3$ to be in wealth, Rich. $70 \mathrm{D} 4$

to be of secret confederacy Hich. 55 C 15

to be of kynne, Rich. $49 \mathrm{H} 11$ to be of (such) strength,

Last Th. 72 C 12

to be of sadde age, Hich. $64 \mathrm{~A} 3$

to be of good chere, Jest p. 3 F 8 to be of perfeccion, Picus 18 E 6 to be ont of fauour, Hich. $57 \mathrm{C} 11$ to be out of peril, Rich. 62 F 15 to be out of taste,

Conf. Tynd. 359 H 15 to be without fanlt, Hich. $71 \mathrm{~B} 9$ to be without pain, Last Th. $98 \mathrm{E} 5$ to fall at distaunce, Hich. $62 \mathrm{E} 8$ to fall on a leke, Last Th. 100 F 8 to fall on a rore, Hich. $41 \mathrm{C} 8$ to stand in onsuretie, Rich. 69 A 12 to stand in daunger, Rich. $55 \mathrm{G} 3$ to stand in dread, Hich. 55 F 15 to stand in doubte, Rich. $61 \mathrm{H} 13$ to stand in fere, Hich. $55 \mathrm{~F} 11$ to stand in peril, Hich. 70 B 1 to stand in a plight, Last Th. 83 D 4 to waxe of a new kinde, Apol. 51

In some of these instances the prepositional phrase has preserved a good deal of its original character and might consequently be still looked upon as an adverbial adjunct, in which case the verb is more than a mere link-word. The same 
usage is met with before and after More. A few of the combinations recorded above have fallen into disuse, e. $g$. to be in ure ; in the truth; of confederacy; of perfeccion; in hand with; at a point; out of array; at communicacion; to fall on a leke; on a rore; at distaunce.

Complements of the type a sleepe, a sunder are often printed in two words, which shows that the original preprositional character of $a$ vas still felt :

Rich. 51 F 12, Eche of these children is others defence while they be a sunder. | Dial. C. 225, I douted whither I were a sleepe or a wake. | (Rich. 69 B 2, He ... yet walketh on a llue.| Dial. C. 319, death hath euer houed a loofe).

It is perhaps by analogy that words in which $a$ was not originally a preposilion came to be printed in two words as well :

Dial. C. 225, I douted whither I were a sleepe or a wake. | Dial. C. 346, if he thinke... that he shal neuer be an hungred nor a thyrst. | Dial. C. 130, I waxed therwith myself sodeinly sum what a flyghte [=aflicted]. | Dial. Her. $123 \mathrm{E} \mathrm{12,} \mathrm{Well} \mathrm{quod} \mathrm{I,} \mathrm{than} \mathrm{is} \mathrm{this} \mathrm{matter} \mathrm{out} \mathrm{of} \mathrm{doute} \mathrm{longe}$ a go.

But :

Jest p. 2 G 7, And he answerde Be not aferde. | Dial. C. 244, Thou shalt not be afeard. | Dial. C. 238, whyle yet we be vpward and aloft.

There are a few instances of the type to be of a height, in which $a$ stands for the same :

Dial. Her. 239 F 10, And I promise you those heresies were of a

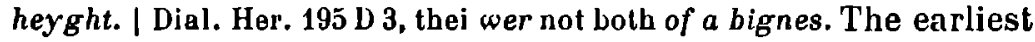
quotation in OED illustrating this idiom (with of before the article; s. v. $a$ 3) is 1601 Shakesp. All's Well I, iii, 244, He and his Phisitions Are of a minde.

One instead of $a$ occurs in : Passion 1319 F 9, the sprynge of the yeare, when the dayes and the nightes be al one lenglh.

89. Syntactical units ${ }^{1}$ ).

Last Th. $90 \mathrm{H} \mathrm{13,} \mathrm{his} \mathrm{pleasure} \mathrm{is} \mathrm{that} \mathrm{thou} \mathrm{and} \mathrm{thine} \mathrm{shal} \mathrm{liue} \mathrm{no}$ lenger. I Dial. Her. 110 F 3, his will and pleasure is, that we should not so much as defende our self. | Last Th. $87 \mathrm{D} \mathrm{11,} \mathrm{the} \mathrm{cause} \mathrm{is,} \mathrm{for} \mathrm{that}$ we parceiue not of what rote the braunches of our sinnes spryng. | Last Th. 74 G 15, And the cause is why, because we can not perceiue the tone, but if we forbeare the tother. / Dial. C. 336, it is almoste in euery country becomen a common prouerbe, that shame is as it is taken.

1) For past-participle forms used as complements of to be the is blessed; unknown) see the paragraphs on direct nexus of two verbs (\$8 548-566). 
In Pres. D. Eng. such syntactical units are never introduced by for (the cause is, for that we perceiue). Otherwise More does not deviate from present practice.

\section{The Semi-Independent Use of the Copulas.}

90. The copulas in More's English often occur in a semiindependent position, that is to say, their complements, which may be inferred from the preceding sentences, are not expressed ${ }^{1}$ ).

Dial. C. 330, As where there is any man of that good mynd that saynt Paule was. | Dial. C. 177, yf payne and wealthe bee eche to the contraryo, as I wene jou wyll agree they bee. I Apol. 26, that his reason is in dede as I say it is, hymselfe that preached yt perceyeth. | Dial. C. 203, [it] maketh them often wene that it were much wursse, then in dede it is.

The same usage in earlier and later English; to seem, however, can no longer be used as it is employed in the following quotation :

Dial. Her. $132 \mathrm{E} 7$, The author shewith that a myracle is not to be mistrustid though it be done in a small matter and semyth vpon a sleyght occasyon. | Passion 1340 E 5, the scripture ... calleth it by the name that it did beare before, \& that it semeth still.

The following passage is remarkable for the coordination of the semi-independent hath and is, each referring to a different verb in the preceding syntactical unit :

Dial. C. 282, Antony : Suche folke make menne ... starke mad, and much cause haue their lordes to be right angrye with them. Vincent : God halh in dede and is I wene. (= God has much callse to be angry and is angry).

\section{NO DISTINCT SUBORDINATION.} (VERB + OBJECT)

91. Synlactical units like : the deuil founde the meane | he toke ill rest | he aspireth to honour, differ from those discussed in the preceding sections [on copulas] in that the verb cannot bo called subordinate to the complement. Where the subject may be called the primary associale of the verb, these comple-

1) For the semi-independent use of shall, will, etc., see 81 . 
ments or objects can be defined as the secondary associates of the verb ${ }^{1}$ ).

It is outside the scope of this study to enumerate the verbs that stand with such a complement in More's English. The following two lists ( $\$ \$ 92$ and 93 ) contain only such as in some respect or other present peculiarities.

\section{Objective Verbs not reconded before Mone's Time}

92. The number of objective ${ }^{2}$ ) verbs of which no instances of earlier usage have been found is not small. A few are recorded below, with the dates of their earliest quotation in OED.

\begin{tabular}{|c|c|c|c|}
\hline bh & $=$ admitted & Rich. 52 G 14 & 1543 \\
\hline erate & $=$ adultered & Conf. Tynd. 636 H 3 & 1531 \\
\hline & $=$ manage to sell & Dial. Her. 189 B 4 & 1617 \\
\hline ee for & $=$ accept as & Dial. Her. 113 A 12 & - \\
\hline & $=$ aggravate & Apol. 67 & 152 \\
\hline allect & $=$ entice & Passion 1274(=1376) C6 & $15^{2}$ \\
\hline ude to & $=$ refer obliquely to & Wks.) A 6 & 153 \\
\hline & $=\mathrm{endo}$ & 5 A 11 & \\
\hline & $=\mathrm{id}$ & 1308 B 3 & \\
\hline lyet & $=$ set at rest & C. 214 & 54 \\
\hline ire & $=$ breathe & Conf. Tynd. 507 B 3 & 15 \\
\hline ay & L temptalions & Conf. Tynd. 562 & 3 \\
\hline & $=\mathrm{id}$ & Apol. 923 (Wks.) & 154: \\
\hline & $=$ pronounce not guilty & Dial. Her. 211 G 8 & 1528 \\
\hline & $=\mathrm{bel}$ & Dial. C & 152 \\
\hline ert & $=\mathrm{es}$ & 1. 607 & 153: \\
\hline iste & with fat & & 1508 \\
\hline elie (a person) & $=\mathbf{m i}$ & Tynd. 748 H 7 & 1601 \\
\hline elike & $=\mathrm{li}$ & C. 332 & 155 \\
\hline ewray & $=\mathbf{e x}$ & Dial. Her. 256 A 6 & 154 \\
\hline ce & arence to & Th. 86 B 17 & 153 \\
\hline t & $=\mathrm{ca}$ & ion 1273 C 5 & 153 \\
\hline luster out & a violent way & f. Tynd. 374 C 9 & 1595 \\
\hline rake & e on the rack & C. 321 & 153 \\
\hline reak (with a p.) & $=\mathrm{r}$ & .217 & 152 \\
\hline & $=\mathbf{e x t}$ & Fich. 70 G 10 & 154 \\
\hline & $=$ cover with mire & Lett. Fryth 833 E 1 & 153 \\
\hline & $=$ idem & Debell. 999 A 14 & 159 \\
\hline 116 & $=\mathrm{re}$ & Tynd, 317 D 10 & \\
\hline
\end{tabular}

1) For the impossibility of giving a less vague definition see Jespersen 1924, pp. $257 \mathrm{If}$; idem 1928 p. 230.

2) Compare $\$ 51$ (subjective verbs) 


\begin{tabular}{|c|c|}
\hline captyue & = captivate \\
\hline cast & $=$ find or declare guilly \\
\hline cast & $=$ revolve in one's mind \\
\hline chaunge (for) & $=$ exchange (for) \\
\hline circumvent & $=$ encompass \\
\hline compact up & $=$ compose \\
\hline condescend & $=$ give one's consent \\
\hline & $\begin{array}{l}\text { = compare } \\
\text { = compre deller in }\end{array}$ \\
\hline conioin & $=$ unite in one substance \\
\hline conserue & $=$ preserve (properties) \\
\hline conuay & $=$ perform (tricks) \\
\hline conuey & $=$ take away \\
\hline conuyet & $=$ confute \\
\hline conuynce & $=$ confute \\
\hline corroborate & $=$ confirm \\
\hline $\operatorname{cow} \operatorname{che}$ & $=$ pul together (words) \\
\hline coucbe vp & $=$ express in a veiled way \\
\hline dance off & $=\mathrm{idem}$ \\
\hline decay & $=$ cause to fall \\
\hline depose & $=$ testify, assert \\
\hline deprehend & $=$ arrest \\
\hline descent of & $=$ comment on \\
\hline descrjbe & $=$ set forth in words \\
\hline deuise & $=$ forge \\
\hline discharge & $=$ part with \\
\hline disgest & $=$ digest \\
\hline dispense & $=$ dissolve (vow) \\
\hline dispute & $=$ maintain \\
\hline disteverence & $=$ treat with irreverence \\
\hline dissemble & $=$ disguise \\
\hline dissipate & $=$ dispel \\
\hline dissolve & $=$ refute, confute \\
\hline dissuade & $=\mathrm{idem}$ \\
\hline dough-baken & $=$ imperfectly baked \\
\hline eat vp & $=$ revoke \\
\hline embrue & $=$ stain in blood \\
\hline engroce & $=$ get together \\
\hline enlength & $=$ lengthen \\
\hline ensourge & $=$ rebel against \\
\hline entangle & $=\mathrm{idem}$ \\
\hline entitle & $=$ ascribe \\
\hline entreat of & $=$ treat of \\
\hline esteem & $=$ hold in estimation \\
\hline estrait & $=$ enclose \\
\hline exact & $=$ extort \\
\hline exaggerate & $=$ pile up \\
\hline
\end{tabular}

Apol. 38

1528

1536

1530

$\begin{array}{ll}\text { Apol. } 884 \text { (Wks.) E } 3 & 1609 \\ \text { Lett. Fryth } 834 \text { F } 10 & 1553\end{array}$

Answer 1087 F $3 \quad 1530$

Rich. 48 E 9

Dial. C. 341

Dial. Her. 245 F $9 \quad 1533$

Passion 1306 (= 1338) E 41552

Passion 1332 D $5 \quad 1577$

Apol. $23 \quad 1530$

Answer 1036 H $8 \quad 1530$

Conf. Tynd. 428 C $2 \quad 1646$

Dial. C. $316 \quad 1530$

Dial. Her. 187 A $4 \quad 1530$

Supplic. 290 B $7 \quad 1529$

Dial. C. 1248 (Wks.) C 61633

Dial. C. 1200 (Wks.) H 91529

Dial. Her.211 F 1 and F 71529

Conf. Tynd. 758 B $4 \quad 1523$

Picus 15 D $1 \quad 1510$

Dial. C. 346

Rich. 56 B 14

Dial. Her. 228 C 4

Rich. 57 I $2 \quad 1548$

Cont. Tynd. 619 G $3 \quad 1532$

Conf. Tynd. 655 G $1 \quad 1610$

Dial. Her. 227 B $13 \quad 1529$

Dial. Her. 283 A $15 \quad 1508$

Conf. Tynd. 401 E 11

Dial. Her. 203 D $3 \quad 1529$

Rich. $42 \mathrm{H} 6$

Dial. Her. 208 F $7 \quad 1529$

Conf. Tynd. 396 D 13 (1535)

Dial. Her. 259 D $10 \quad 1529$

Apol. (Wks.) 881 D $7 \quad 1598$

Answer 1037 B $11 \quad 1530$

Conf. Tynd. 724 B $2 \quad 1523$

Conf. Tynd. 568 D $11 \quad 1540$

Conf. Tynd. 784 A $2 \quad 1550$

Rich. 97 C. $4 \quad 1513$

Conf. Tynd. 810 F $3 \quad 1532$

Dial. Her. 277 E $14 \quad 1529$

Supplic. 308 G $2 \quad 1529$

Apol. 871 (Wks.) C 1 


\begin{tabular}{|c|c|c|c|}
\hline explain & $=$ idem & Rich. 63 E 13 & 1513 \\
\hline extenuate & $=$ make light of & Dial. C. 1218 (Wks) C 9 & 1529 \\
\hline face (a lie) & $=\operatorname{lie}$ & Answer $1131 \mathrm{E} 2$ & 1540 \\
\hline face out of & $=$ exclude Irom & Answer 1132 F 14 & 1601 \\
\hline falsify & $=$ violate & Conf. Tynd. 585 D 3 & (1502) \\
\hline farther & $=$ Purtber & Rich. 58 D 7 & 1570 \\
\hline father upon & $=$ ascribe to & A pol. 855 (Wks.) E 8 & 1542 \\
\hline lasbion & $=$ alter (an argument) & Answer $1115 \mathrm{H} 1$ & 1599 \\
\hline fight together & $=$ contradict each other & Conf. Tynd. 460 HI 1 & 1624 \\
\hline finish up & $=$ finish & Debell. 1026 C 14 & - \\
\hline flesh in & $=$ barden in & Rich. 68 E 9 & 1530 \\
\hline force & $=$ care for & Picus 7 B 3 & $500-20$ \\
\hline forefigure & $=$ prefigure & Answer 1043 G 7 & 1534 \\
\hline loreprophecy & $=$ predict & Answer 1043 G 8 & 1581 \\
\hline frame (fear) & $=$ conceive & Iial. G. 208 & 1597 \\
\hline frame & $=$ adapt & Conf. Tynd. 701 C 6 & 1550 \\
\hline gainecall & $=$ recall & Rich. 39 F 3 & 1611 \\
\hline garnish & $=$ dress, clothe & Picus 29 A 1 & 1529 \\
\hline gather & $=$ infer & Apol. 866 (Wks.) H 6 & 1535 \\
\hline get oneself (away) & = betake oneself & Rich. 43 A 2 & 1513 \\
\hline get up again & $=$ recover $(\operatorname{los} s)$ & Passion 1303 D 17 & 1607 \\
\hline go for & $=$ be valued as & Answer 1085 G 5 & 1556 \\
\hline go in band with & $=$ proceed with & Passion 1323 G 11 & 1534 \\
\hline have by heart & $=\mathrm{know}$ & Conf. Tynd. $783 \mathrm{H} 1$ & 1591 \\
\hline hawk afler & $=$ bunt after & Picus 15 A 11 & 1510 \\
\hline hawse & = raise & Rich. 62 B 6 & 1500 \\
\hline help (I cannot - ) & $=$ idem & Dial. C. 1171 (Wks.) H 16 & 61591 \\
\hline iaber & $=$ jabber & Conf. Tynd. $665 \mathrm{C} 10$ & 1532 \\
\hline immolate & $=\mathrm{jmmolate}(\mathrm{d})$ & Passion 1296 A 5 & 1534 \\
\hline impugn & $=$ oppose & Hich. 39 A 7 & 1577 \\
\hline inculk & $=$ inculcate & Debell. 938 F 3 & 1528 \\
\hline induce & $=$ send for & Dial. G. 1196 (Wks.) H 13 & 1534 \\
\hline infer & $=$ idem & Dial. Her. 147 C 6 & 1526 \\
\hline insimulate & $=$ accuse & Couf. Tynd. 340 A 15 & 1532 \\
\hline insinuate & $=$ express & Passion 1331 H 8 & 1533 \\
\hline instruct (someth.) & $=$ teach (something) & Gonf. Tynd. 583 C 6 & 1623 \\
\hline ingle (away) & $=$ juggle (away) & Conf. Tynd. 436 D 7 & 1590 \\
\hline knyt & $=$ conjoin or unile & Passion 1349 D 6 & 1578 \\
\hline lament & $=\mathrm{idem}$ & Conf. Tynd. 429 A 10 & 1530 \\
\hline lash out & $=$ lavish & Rich. 62 A 9 & 1513 \\
\hline lash out & $=$ pour out & Dial. Her. 287 B 8 & 1529 \\
\hline lay in one's light & $=$ bring as an objection & DiaI. Her. 252 A 6 & 1528 \\
\hline lay open & $=$ reveal & Answer 1087 G 5 & 1588 \\
\hline leave off & $=$ give up (a thing) & Dial. C. (Wks.) $1200 \mathrm{E} 9$ & 91534 \\
\hline linger & $=$ keep waiting & Lelt. 1429 B 3 & 1534 \\
\hline list & $=$ desire & Conf. Tynd. 821 G 6 & 1545 \\
\hline look $(+c$ & $=$ expect & Aich. 62 B 10 & 1513 \\
\hline make & $=$ translate & Dial. Her. 238 E 13 & 1528 \\
\hline
\end{tabular}




\begin{tabular}{|c|c|c|c|}
\hline $\begin{array}{l}\text { nake the best of } \\
\text { nake for }\end{array}$ & $=$ idem & Conl. Tynd. 525 F 12 & $\begin{array}{l}1626 \\
1522\end{array}$ \\
\hline leanes to & $\begin{array}{l}==\text { pretend } \\
=\text { negociate with }\end{array}$ & ial. C. 218 & $\begin{array}{l}522 \\
535\end{array}$ \\
\hline & $=$ complete & onf. Tynd. 583 C 8 & 568 \\
\hline & $=$ regard with hatred & Rich. 37 B 3 & 513 \\
\hline & $=$ equa & onf. Tynd. 705 F 6 & 92 \\
\hline ith & $=$ oppo & al. $\mathrm{H}$ & \\
\hline & $=$ earn & & \\
\hline & $=$ entan & one. Tynd. 491 A 4 & 532 \\
\hline he oneself & $=\mathrm{id}$ & nd. 568 D 12 & 159 \\
\hline & $=\mathrm{in}$ & $(=46) \mathrm{H} 5$ & \\
\hline & wrongly & E 6 & 532 \\
\hline & $=\mathrm{m}$ & r. $130 \mathrm{~F}$ & 1600 \\
\hline & $=\mathbf{s u}$ & $\mathbf{P}$ & 51 \\
\hline & $=\mathrm{ill}-\mathrm{co}$ & 1. Her. 274 B 4 & 152 \\
\hline & $=$ sla & 2 & 153 \\
\hline & $=\mathbf{m}$ & & 1535 \\
\hline & $=\mathrm{m}$ & & 1538 \\
\hline & r wrongly & bis C 4 & 1533 \\
\hline & $=\mathrm{id}$ & 13 & 153 \\
\hline & $=g$ & & \\
\hline & $=\mathrm{c}$ & & 1628 \\
\hline & $=\mathrm{d}$ & & 168 \\
\hline & $=\mathrm{t}$ & & 1518 \\
\hline & the eyes & 19 (Wks. & 153 \\
\hline & $=0 \mathrm{l}$ & & 151 \\
\hline & in existence & $.283 \mathrm{C} 15$ & 152 \\
\hline & $=\mathbf{a}$ & 260 E 2 & 1529 \\
\hline & $=\mathrm{d}$ & & 151 \\
\hline & $=\mathrm{d}$ & e. $\mathrm{T}$ & 164 \\
\hline & & 13 & $15 ?$ \\
\hline & $=0$ & B 5 & 153 \\
\hline & $=\mathrm{ru}$ & nf. Tynd. 8 & 163 \\
\hline & $=\mathrm{e}$ & 42 & 153 \\
\hline & $=\mathrm{t}$ & 16 & 153 \\
\hline & $=\mathrm{w}$ & $797 \mathrm{G}$ & 1532 \\
\hline & $=\mathbf{r}$ & $\mathbf{P}$ & 154 \\
\hline & $=$ idem & nd. 785 G 3 & 1567 \\
\hline & $=p$ & $639 \mathrm{~F} 10$ & 1532 \\
\hline (4) & h (from) & $139 \mathrm{D} 9$ & 155 \\
\hline & $=\mathrm{d}$ & & 52 \\
\hline & detail & Picu & 1 \\
\hline & h ... critical & Hy Ans & 153 \\
\hline & $t$ in order & ks.) $\mathbf{B}$ & 153 \\
\hline & $=$ establish frmly & I. Her. 159 B 10 & 152 \\
\hline & & & \\
\hline & $=$ mock & Gonf. Tyad. 398 G 11 & \\
\hline
\end{tabular}




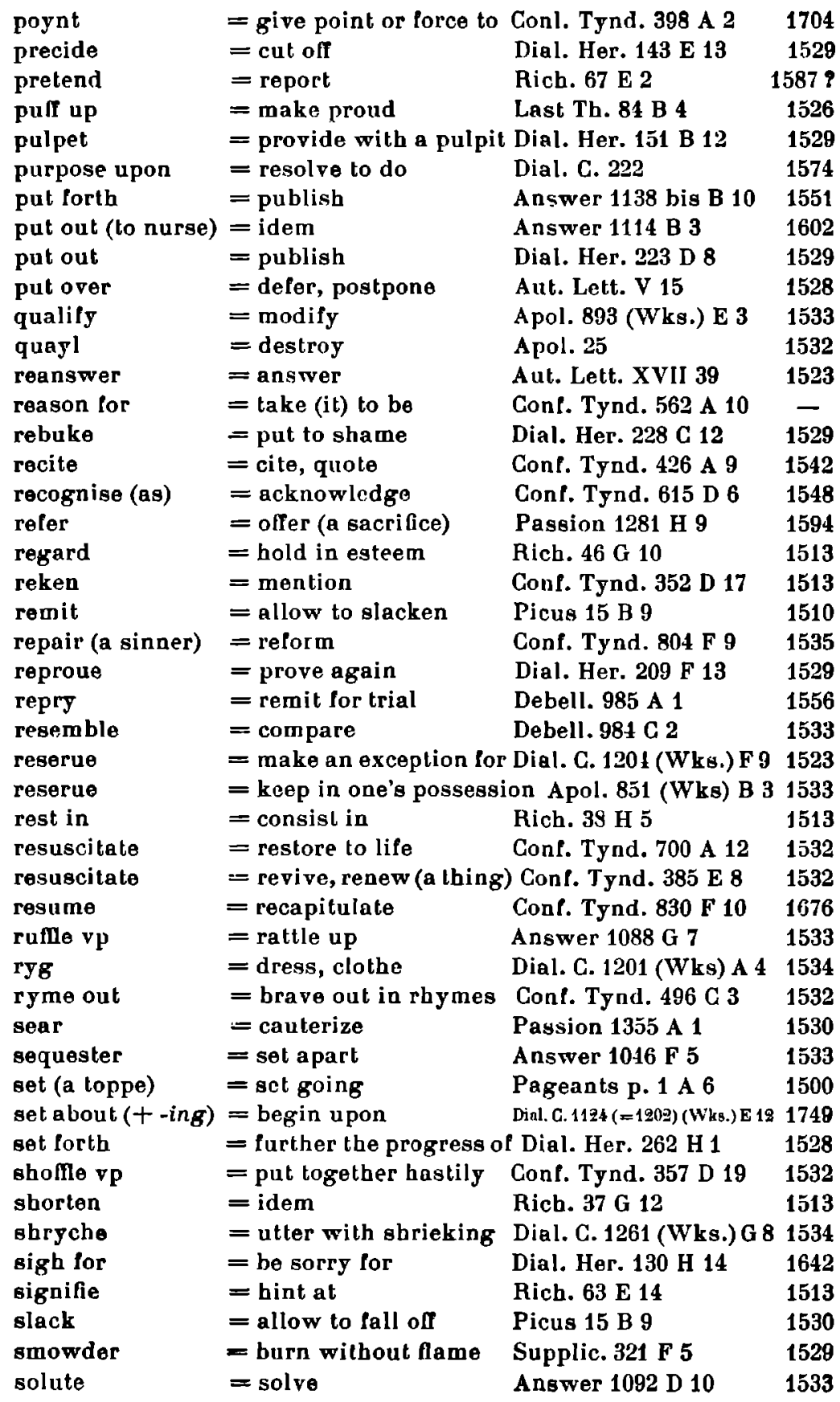




\begin{tabular}{|c|c|c|c|}
\hline sort out & $=$ take out & Dial. C. 1177 (Wks.) G & 1534 \\
\hline souse vp & $=$ surfeit & Jest p. 1 C 10 & 1534 \\
\hline spise & $=$ season $(\mathrm{fg})$ & Dial. Her. 257 F 12 & 1529 \\
\hline stagger (flg.) & $=$ begin to doubt & Answer 1112 G 9 & 1533 \\
\hline stick by & $=$ cling to & Apol. (Wks.) 901 C 2 & 1533 \\
\hline study for & $=$ search for & Dial. Her. 220 G 2 & 1551 \\
\hline substitute & $=$ appoint as deputy & Cont. Tynd. 821 D 4 & 1532 \\
\hline subuert & $=$ ruin country & Supplic. 302 F 7 & 1529 \\
\hline swaddle & $=$ bandage & Last Th. 80 G 4 & 1522 \\
\hline ticle & = stir up ; provoke & Conl. Tynd. 551 A 1 & 1532 \\
\hline unredde & $=$ lorget the contents & Debell. $1025 \mathrm{C} 9$ & 1533 \\
\hline wait vpon & $=$ attend as servant & Last Th. 84 A 10 & 1509 \\
\hline walk with & $=$ be associated with & Dial. Her. 268 E 14 & 1650 \\
\hline way to & $=$ amounl to & Dial. Her. 362 C 1 & 1529 \\
\hline way with & $=$ balance with & Rich. 47 D 6 & 1513 \\
\hline winning & $=$ alluring, enticing & Passion 1336 I 7 & 1586 \\
\hline wive & $=$ furnish with a wile & Rich. 59 F 3 & 1513 \\
\hline work out & $=$ expiate $(\sin )$ & Dial. C. 341 & 1660 \\
\hline wraste out & $=$ tear, wrench out (fig.) & Rich. $48(=45)$ D 9 & 1513 \\
\hline wrought & $=$ worked up, agilated. & Dial. C. 342 & 1585 \\
\hline
\end{tabular}

93. The following list contains illustrations of the use of objective verbs that have become either obsolete, archaic or dialectical since More's time, or are no longer employed in the same way. The dates of their earliest quotation in OED are added, and in the case of now obsolete verbs the dates of latest quotation as well. The evidence shows that some of them lived longer than might be inferred from the data in OED [e. g. dispraise, fein for, forelong, forebeat, mistake oneself, ordain (= destine to a fate), oversee (= consider), race (= slash), right (= correct a person), rule oneself, sowne (in)to.]

(EQ. = Earliest, LQ. = Latest quotation in OED).

to abide $=$ to suffer, to endure.

Dial. C. 223, that kind [of persecution] only, which though the sufferer be lol to fal in, yet will he rather abide it and suffer, then... | Dial. C. 193, they could abide and enduro ... many thinges moe.

Now obsolet? in this sense, except negative. EQ. 1205 Layamon 15565 , He peos dundes abad.

to $a$ blect $=$ to cast down.

Lett. $1456 \mathrm{H} \mathrm{3,} \mathrm{[you]} \mathrm{honour} \mathrm{me,} \mathrm{nowe} \mathrm{ouerthrowne,} \mathrm{abiected,} \mathrm{aflicted,}$ and condemned to prison.

Now obsolete. EQ. c 1475 Henryson, Moral Fables 42, Argumentes 
they rellolue, some abjecting, and some can hald. LQ. 1650 Venner, Via Hecta III, The Spawn of them is to be abjected.

to acerleyn = to make (a person) certain (of a fact).

Dial. Her. 161 A 8, now is the church so well acertened of goddes pleasure. | Aut. L. Iv 57, his giace thought his ... subgietles wold not let to aduaunce forward ... being by hym acerteyned that theyre money shold be paied them.

Now obsolete. EQ. c 1400 Floure \& Leaf 568, For now I am acertained ... Of every thing. LQ. 1789 G. Morris, in Sparks, Life II 3, I wish to be ascertained of the intentions.

to accouple $=$ to join.

Rich. 63 E 12, For lack of which lawfull accoupling, ... the right and title, ... is ... deuolute ... unto the ... prince.

Now obsolete. EQ. 1486 Plumpt. Corr. 50, Ye be acopled as brether and sisters. LQ. 1635 D. Person. Var. II. Fire being accoupled to a matter contrary to its own nature.

to accurse (out of) $=$ a) to drive away with curses.

Conf. Tynd. $828 \mathrm{I}$ 19, like as he that is accursed lawfulli out of a particular church, is accursed out of the whole catholike church.

Not in Pres. D. Eng. Not recorded in OED.

to accurse $=$ b) to pronounce a curse upon.

Conf. Tynd. 710 B 3, Of Noe hys owne sonnes one ye wot wel was so bad, that hys owne father accursed him.

Now obsolete or archaic. EQ. c 1175 Lamb. Hom. 31, pene preost he mot isechen pe hine acursede, pet he hine iblecie onye in pet he bine acursede.

adhibit $=$ admitted.

Rich. 52 G 13, To which counsel, albeit there were adhibit very few ... yet began there here \& there about, some maner of muttering.

Now obsolete. OFD has no other instances.

to aduise $=$ a) to look ; at to observe.

Rich. 57 B 3, whoso wel aduise her visage, might gesse \& denise which p(ar)tes how filled, wold make it a faire face. | Last Th. 82 F 15, thou shalt behold him, \& aduise him such as he is.

Now obsolete. EQ. 1297 R. Glouc. 558, He advisede pe ost suipe wel. LQ. 1603 Holland, Plutarch's Mor. 96, They advised you wel and their eie was never off...

to aduise $=$ b) to make (one) observe (a thing).

Dial. C. 196, therefore woulde I ... aduise one in that case, the consayle whych mayster Gerson gyueth euerye man.

Now obsolete. EQ. c 1460 Townel. Myst. 61, My wand he bad, in thi present, I shuld lay downe, and the avyse How it shuld turne to oone serpent. LQ. 1557 Surrey, Aeneid rv, 461, The troubled ghost doth fruy me, and advise The wronged hed by me of my deare sonne, whom I defraud of the Hisperian crown. 
to $a$ forth = to manage to sell (at such a price).

Dial. Her. $189 \mathrm{~B} 4$, [he] may a forth his plaisters better chepe.

Now obsolete. No quot. in OED anterior to More. LQ. 1793 Smeaton, Edystone L. \$116, The stone could be afforded at somewhat less price than Portland.

to aggreue $=$ a) to find fault with; to blame.

A pol. 67, This pacyfyer aggreueth ... the clergy of englande, for use of the lawes not made by them selfe...

This meaning of to aggrieve is not recorded in OED.

to aggreue $=\mathrm{b}$ ) to aggravate; to exaggerate; to emphasize. Rich. 39 B 11, Sometime a thing right wel intended, our misconstruccion turneth vnto worse or a smal displeasure done vs, eyther our owne affeccion or euil tongues agreueth. | Rich. $62 \mathrm{D} \mathrm{9,} \mathrm{[they]} \mathrm{haue}$ knowen as well their goodes as their parsons greatly endaungered, either by fained quarels, or sinal matters agreuid with heinouse names. | Last Th. 87 A 8, the punyshement is aggreued or mynyshed, made lesse or more, after the difference in degre of woorshippe and reputacion betwene the parties.

Now obsolele. EQ. 1524 State Pap. Henry vm, IV 154, Agrieving somewhat the daunger whiche might ensue. LQ. 1590 Southwell, Marie Magd. Funeral Teares, 195, Want of faith was agrieced with want of all goodnesse.

to agre for = to accept as.

Dial. Her. 113 A 12, I wolde for my parte wel agre them for heresies. I Dial. Her. $113 \Lambda 7$, which thinges ... euery good christen man will agre lor heresies.

Now obsolete. Not in OED (with for).

to allect $=$ to entice.

Dial. Her. 275 D 5, they had vsed al the waies thei could to allect the people by preaching. | Passion $1274(=1276) \mathrm{C} 6$, The other lesse euile, that he alewred and alected her with.

Now obsolete. No quot. in OED anterior to More. LQ. 1552 Huloet,

Allect or styre with some pleasante meane. Allicio, Duco.

to alow = to laud ; to praise.

Cont. Tynd. 672 F 3, Saint Mary Magdaleyn was more alowed of Christ for bestowing that costly oyntmente vpon hys hande ... then if she had solde it. | Aut. Lett. VI, 36, Hit may ferther lykc yor good grace to understand that the kinges grace mych alloweth yor prudent answere. I Dial. Her. 204 D 12, And after that he hadde thus sayde : the remenaunt that were present allowed it muche.

Now obsolete or dial. EQ. c 1315 Shoreham 149, He wolde be God ylyche, To be alowed. LQ. 1783 Crabbe, Village I Wks. II, 81, Proud To find the triumphs of his youth allow'd.

to amoue = to drive away ; to expel. Apol. 30, the thynge that ye have ... these meny days myche desyred, that ye mighte ons be reuenged vppon thys vnhappy senate and amoue 
them from the rome ... thys thyngo haue I ... drought vnto your handes.

This meaning of to amove is not recorded in OED.

to aneyle $=$ to anoint.

Apol. 48, they haue vsed confession, and done penaunce for synnys, and prayed for all chrysten soules, and ben aneyled in their delh bedde.

Now archaic. EQ. 1303, R. Brunne, Hand. S. 11269, many seye,

Anele hem nat but pei shulde deye.

appaied = satisfied ; contenled.

Dial. Her. $133 \mathrm{G} \mathrm{11,} \mathrm{yet} \mathrm{had} \mathrm{I} \mathrm{leuer} \mathrm{haue} \mathrm{gods} \mathrm{blessing} \mathrm{to} \mathrm{beleue} \mathrm{that} \mathrm{I}$ se not, than go so far therfore. - I am well appaied q(uod) I thereof.

Now archaic. EQ. $1297 \mathrm{R}$. Glouc. 117, mid al he was wel a payed.

to appayre = to make worse ; to injure ; to impair.

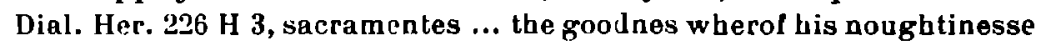
can not appayre... That sacred sacrifice ... can take none empayryng by the fyllhe of his synne.

Now obsolcte. EQ. 1297 R. Glouc. 279, Destrude and apeyrede

Cristendom. LQ. 1643 Prynne, Power Parl. II, 71, The ancient lawes ... be greatly appaired.

to appere $=$ to show.

Dial. Her. 252 H 7, ye ... wyll not beleue the glose, which appereth plainlye that he ment only to forbed vs to do such worship to ymages as is only due to god.

Not in OED.

to apply = to devote one's energy to.

Jest p. 1 A 5 , Wyse men alway ... Affyrme, that best is for a man : diligently For to apply, The busines that he can.

Now obsolete and replaced by ply. EQ. 11495 Plumpt. Corr. 123,

That the poor man for dread dare not apply his business. LQ. 1667

Milton P. L., IV, 264, The birds their quire apply.

to appoint (a thing) to a person = to assign.

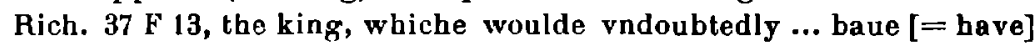
appointed that boocherly office, to some other then his owne borne brother.

Now obsolete. EQ. 1494 Fabyan I, IV, II, He beset or apoynted to hym the Countre of Walys. LQ. 1764 Priestley, Ess. Educ. in Lect.

Hist. 28, Let him appoint rewards to those who shall handle the subject in the most judicious manner.

to $a p p o i n t=$ to determine ; to resolve.

Dial. G. (Wks.) 1214 F 3, And appointe in his heart ... that ... he would rather dye than forsake the faith. | Rich. 59 A 6 , And after he was thus appointed, and had betwene them twain ensured her ${ }^{1}$ ).

Now obsolete (archaic ?). EQ. c 1440 Generyd, 2120, of euery ward to make a capteyn Ffirst he appoynted in especiall. LQ. $1722 \mathrm{De}$ Foe, Hist. Plague 11, To appoint to go away.

1) Also reflexive : Rich. 49 D 10, yf you appoint your selfe to tary here. Now obsolele. 
to appose $=$ to question ; to interrogate.

Dial. Her. $197 \mathrm{H} 5$, the frere apposed hym in confession whilher he medleth any thing with witcherafte ...

Now obsolele. EQ. c 1315 Shoreham 145, jef the faly throf to be aposed, say God nys naust in ther wordle a-closed. LQ. $1615 \mathrm{~T}$. Adams, Two Sonnes, 65, Question against question : the Jewes appose Jesus, Jesus apposeth the Jewes.

to appropre = to assign as property.

Conf. Tynd, 419 F 2, no such custome halb appropred it.

Now obsolete. HQ. a 1384 Chaucer, Gentilesse 18, His vertuous noblesse That is appropred unto no degree. LQ. 1614 Selden, Tilles 67, Astrologers approper cerlain stares to kings only.

to aquyet $=$ to set at rest.

Dial. C. 214, lette hym nol dout to aquyet hys mynde, and tolow that he ther is bidden.

Now obsolete. FQ. 1548 Ld. Somer'set, Epist. to Scots 244, Is it not better to compose \& acquiete al this calamitie and trouble by mariage? LQ. 1613 Sir A. Sherley, Trav. lo Persia 86, No fauour, grace, nor benefits from your Maiesly, can acquiet his mind.

to arace $=$ to tear away.

Conf. Tynd. 355 G 5, so that the remembraunce of theire pestilent errours were araced out of englishn mennes heartes.

Now obsolete. EQ. c 1315 Shorehain 95, That be hyt wolde arace.

LQ. 1530 Palsg. 435, 2, I arrace, I pull a lhyng by violence from one. Je arrache.

to arrect $=$ to impute.

Dial. Her. 271 F 3, but God because be hath from the begynnyng cbosen them to euerlastyng blisse, therfore he arrecteth no blame of theyr dedes vnto them.

Now obsolete. EQ. c 1340 Hampole, Prose Tr. 31, Alett all thi gude dedis sothefastelye to Hyme. LQ. 1549 Chaloner, Erasmus, Morim Enc. F il b, It is arrected for a great praise and charitable kyndnesse unto theim.

to aspire = to breathe (breath or spiritual influence) to or into.

Conl. Tynd. 507 B 3, Though god ... aspired them his grace therin.

Now obsolele. No quot. in OED anterior to More. LQ. 1633, P. Fletcher, Purple Island I, LIX, Thereto may he his grace and gentle beat aspire.

to $a s s a i=$ a) to put to the test.

Rich. 53 E 12, But Calesby whither he assajed hin or assaied him not, reported vnto them, that he founde him so fast ... that ...

Now obsolete (exc. with metals). EQ. 1330 R. Brunne, Chron. 219, He said be wild asay per hors alle in a mile. LQ. 1791 Cowper, Odyse. VIII, 27, With which they should assay his force. 
to assai $=\mathrm{b}$ ) to try with temptations ; to tempt. Conl. Tynd. 563 F 1, [The diuel] ... letted not to assai Job againe and againe.

Now obsolete. No earlier quot. in OED. LQ. 1614 Raleigh, Hist. World, II, 547, Then did he assay them with goodly words, accompanied with gifts.

to assign $=$ to prescribe (a course of action).

Answer 1048 F 3, They assygned bim ... what maner a miracle thei wold haue him do.

Now obsolete. EQ. c 1485 Digby, Mist. II, 214, Make thi curse As

I shall assyng the by myn aduysse. LQ. 1607 Topsell, Four .

Beasts 102, Simeon Setbi ... assigneth them rather to be eaten in winter time.

to assoyle = a) to forgive; to absolve from sin.

Apol. 51, my lather, whose soule our lorde assoyle. | Dial. C. 205, God assoile bys soule.

Now archaic. EQ. 1297 H. Glouc. 464, No man, bote pe pope one, hem asoyly ne mygte.

to assoyle $=\mathrm{b}$ ) to clear up ; to solve.

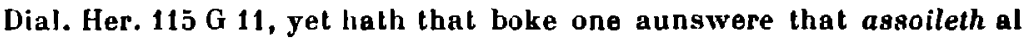
the hole malter.

Now obsolete. EQ. c 1374 Chaucer, Boelh. V, II, 154, pat pei mowen assoilen and vnknytten pe knot of pis question. LQ. 1696

Whiston, Th. Earth, 65, Fever diffculties in the ... Books themselves, than in the ... very Comments which ought to assoil 'em.

to assoyle = c) to pronounce not guilty.

Dial. Her. $211 \mathrm{G} \mathrm{7,} \mathrm{Than} \mathrm{may} \mathrm{the} \mathrm{iudges} \mathrm{acquite} \mathrm{and} \mathrm{assoyle} \mathrm{the} \mathrm{de-}$ fendaunt.

Now archaic. No quot. in OED anterior to More. In Sc. Law still the proper lerm for: To acquit by sentence of court (OED).

to astony $=$ to astound; to amaze.

Dial. Her. 201 D 14, I was therwith astonied.

Now archaic. EQ. 1340 Ayenb. 126, Hou it ssolde ous ssende and astonie.

to attain to $=$ to befall ; to happen to.

Dial. C. 1217 (Wks.) F 12, we shall nede no rehersal of any harne that ... maye attaine therelo.

Now obsolete. No other quot. in OED.

to auert $=$ to turn away in mind or inclination ; to estrange. Conf. Tynd. 607 H 12, Saynte Peter was once from God auerted, and sinnelully turned away.

Now obsolete or archaic. No quot. in OED anterior to More.

to alloide $=$ to expel.

Dial. Her. 285 F 15, [he] calleth such heretikes, wolues cloked in shepes skinnes, \& would that his shepheardes ... should in such wyse auoide them as very shepeheardes would auoyde very wolues. 
Now obsolele. EQ. 1460 Capgrave, Ghron. 178, that this Petir shuld be a voyded. LQ. 1643 Prynne, Power Parl. II, 19, They would avayd all aliens and stangers out of it.

to balk out $=$ to vent; to utter.

Rich. $70 \mathrm{~F} \mathrm{14}$, parceiuing ... the dukes pride now \& then balke oute a lytle breide of enuy toward the glory of the king .... he craftelye sougbt the waies to pricke him forwarde.

Not in OED. EQ. of to belch in this meaning (s. v. belch 2): a 1000 Ags. Ps. (Spelm.) xix 2, Dæ3 pan dæ3 bealcep word. Of to belch out (s. v. belch 3) 1561 Norton, Calvin's Inst. III 193, What spirit do they belche out?

to baste = to moisten by the application of melted fat. Apol. 50, wyth onely raylinge is all theyr roste mete basted, and all ther pot seasoned.

More seems to have been one of the first to use this verb. EQ. of the lit. meaning 1509 Barclay, Shyp of F. I, 100, The fat pigge is baast. EQ. of the fig. use, as in the above quot. 1575 Turbery, Venerie 61, That I the wine should taste ... and so my throte I baste.

to bear over = to overthrow.

Dial. Her. 141 B 10, as ye spake of shotyng in the beginning, this gere howe nere it goeth to the prick, we shal see after. But this I promise you, it would fain beare ouer the but and al.

Now : to bear down. There is one other quot. in OED with oser : 1633 Bp. Hall, Hard Texts, 516, He shall ... heare over and kill those that stood against him.

to beke $=$ to expose (to the warmth of a fire); to bask.

Boke of F. p. 4 C 6, And eke agaynst the sonne, Bekyth hym poore Diogenes in his tonne

Now only Scotlish or north. dial. (to beek). EQ. (c 1230 Wohunge in Cott. Hom. 269, Al pat pinende pik ne walde ham puche bote a softe bekinde bath); 1375 Barbour, Bruce $x 1 \mathrm{x}, 552$, Ane ynglish man, that lay bekand Hym by a fire. LQ. a1774 Fergusson, C. Oyst, Poems 8, How often at that ingle cheek Did I my frosty fingers beek.

Prof. A. W. Reed (in Philol. Notes to Wks. p. 197) says " bekyth $=$ stoops, bends or cronches). He refers to the verb beck $=$ to make a sign of recognilion, respect; to nod; to make a slight bow (OED). This verb beck is also used by More (Boke of F. p. 2 B 7, She becketh and she smileth on euery wighl), but in all the quotations in OED this varb is written either with ck or wilh $k k$. S. v. beek we find moreover the following quotation: 1553 Brende, Q. Curtius II, 11, Diogenes was beking of himself in ye sunne. Compare : 1730 Ramsay, Gent. Sheph. Wks. II, 95, She and ber cat sit beeking in her yard. 
to befile = to make foul or dirty; to defile.

Conf. Tynd. 685 B 2, Then shall ge see ... thys fayr'o egle byrde foule befile hys nest.

Now obsolete. EQ. c 1000 Sax. Leechd. III, 208, Handa him befylde jesihp weorca unrihta zetacnap. No quot. in OED later than More.

to belike $=$ to like; to be pleased with.

Dial. C. 332, such christen folke ... belike ... to be serued as the snayle was, and yet muche woorse too. For they be like to have their house ... bounde fast vpon their backes for euer.

Now obsolete. No quot. in OED before More. EQ. 1557, North, Gueuara's Diall Pr. (1582) 403 a, Those that are beloued and belyked of prynces.

to bere in hand = to make believe ; to lead (one) to believe. Apol. 63, yf that $y t$ so were, that one founde two men standyng to gether, \& wolde steppe in betwene them, and bere them in hand they were about to figbt... | Dial. Her. $109 \mathrm{C} \mathrm{12,} \mathrm{to} \mathrm{dowte} \mathrm{whither} \mathrm{Luther}$ himselfe... wrote in dede so euyl as he is borne in hande. | Rich. 41 H 2, thus bare they folke in hande.

Now obsolete. EQ. c 1300 Beket 909, We wolleth the bere on hond: that thu ert his traitour. LQ. a 1716 South VI, 25, If Popery and Fanaticism are so irreconcilable, as our True Prolestants would bear us in hand that they are.

to beshrew = to curse ; to blame greatly.

Debell. $948 \mathrm{H} \mathrm{6,} \mathrm{I} \mathrm{durste} \mathrm{well} \mathrm{in} \mathrm{the} \mathrm{same} \mathrm{worde} \mathrm{(some} \mathrm{say)} \mathrm{beshrewe}$ bym, and beshrowe hym againe. | Dial. C. 217, yl thou smyte it not of, I beshrew thine horesons hart. I Jest p. $1 \mathrm{~F} 3$, They do therefore Beshrew theinselfe at last.

Now obsolete. EQ. 1377 Langl. P. Pl. B Iv, 168, A shireues clerke byshrewed al pe roule. LQ. 1682 N. O., Boileau's Lutrin II, 106,

Trembling she lay, and in ber heart beshrewed him.

to bestow $=$ to place.

Dial. G. (Wks.) $228 \mathrm{~B} 12$, As rowmes and liuinges fal voyde to bestow them in. | Aich. 54 F 10, Then were they al quickly bestowed in diuerse chambres.

Now archaic. EQ. c 1374 Chaucer, Troilus I 967, Thy god of love

bath the bystowid In place digne unto thy worthines.

to betake = to give; to hand over; to grant.

Rich. 51 E 5, she with her owne handes betoke him to them of trust. |

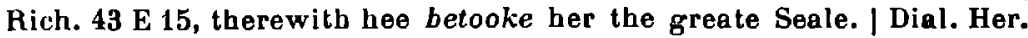
$285 \mathrm{D} 10$, I haue quod he, betaken Hymyneus and Alexander to the deuill to teache them to leave their blasphemye. | Passion 1338 H 1, The onely sacrifice betaken by Chryst vato his christen church.

Now obsolete. EQ. c 1205 Lay. 6251, Heo scullep eow, pat lond bi-taken. LQ. 1649 Selden, Laws. Eng. I, LIX, 110, The Empress perceiving the power of the Clergy betakes Ler case to them. 
to betoken $=$ to be a type or emblem of ; to symbolize.

Passion 1331 G 18, Thys excollente high sacrament ... betokeneth also manyfold merueilous mysteries.

Now obsolete. EQ. c 1175 Lamb. Hom. 89, pet lomb bitacnede cristes prowunge. LQ. 1867 Milton, P. L. XI, 867, In the Cloud a

How ... Betok'ning peace from God and Cov'nant new.

to bewray oneself $=$ to expose oneself.

Dial. Her. $255 \mathrm{H} \mathrm{3}$, sodenly the fonde felowe becorayed hym selfe vnware.

Now obsolete. OED has no instances of this reflexive use of to bewray.

to bewray (a deception) $=$ to expose.

Dial. Her. 256 A 3, Than may ye se ... hys marueilouse profonde prudence, that had not the wit to beware that hymselfe bewrayed not hys owne so folishe a deuice.

Now obsolete. EQ. 1548 Udall, etc., El'asm. Par., Pref. II, In bewraiyng tho iugleyng sleightes. LQ. a 1601 Nowell in Strypo, Ann. Ref. I, I, xxxix, 451, Finding therein cerlain notable untruths ... he did bewray them to the audilors.

to bide by $=$ to stick to ; to maintain.

Dial. Her. 141 B 10, as ye spake of shotyng in the beginning, this gere howe nere it goeth to the prick, we shal see after. But this I promise you, it would fain beare ouer the but and al. For if it might bold \& be bidden by, \& wer as well able to bee proued trew, as I trust to proue it false, the butte we shote at wer quite gone, for any suretie that we could reken of our faith \& christendome.

Now obsolete. EQ.1494 Fabyan VI, cciv, 214, For this [batlle] was so strongly bydden by, that men coude not iudge whiche parte had the better. LQ. 1844 Tennyson, P'cess V, 316, Worlby reasons why she should Bide by this issue.

to bigrace $\Rightarrow$ to do reverence to ; to address as 'your grace'. Lest Th. 86 B 16, whyle they knele \& crouche to hym, \& at euerye word barehed bigrace him.

Now obsolete (?). No quotations antedating the above from More. LQ. 1802 Wolcott (P. Pindar) Gr. Cry \& Lit. Wool, Wks. 1812 V 180 , She's begraced and beduchess'd already.

to blame = to address with rebuke; to chide.

Dial. Her. 116 B 12, The good Kinge Dauyd ... blamed his folishe wile. Now obsolete. EQ, 1297 R. Glouc. 163, Bi fore hym he lette brynge vs men, \& bi gan hem faste blame. LQ. 1559 Mirr. Mag., Jack Cade V, No reproche can be to much to blame her.

to blench $=$ to disconcert.

Dial. C. 205 B 3, For now if ye so shold haue answered him as I haue shewed you, thoughe ye shoulde haue somwhat blenched bim therwith, yet be...

Now obsolele. EQ. (1400 9), 1485 Caxton, Trevisa's Hidgen, IV, 
xxxII (1527) 181, The enemyes were blente thrugh goddes myghte. LQ. a 1640 Jackson, Wks. (1814) VIII, 122, Being blenched in his right course by the shadow.

to blesse (away, out) = to drive (out, away) by making the sign of the cross.

Answer 1060 B 6, And those vowesses lo that happen to haue any such mind, let them at the pyrst thought make a crosse on their brest and blesse it away. | Passion 1273 C 5, When the dyuell fyrste casteth any proude vayne thoughte in to our mynd ... let vs forthwith make a crosse on our breast, and blesse it oute.

Not in Pres. D. Eng. No earlier quot. in OED ; one later, with to bless ... into.

to bluster ont $=$ to utter with stormy violence and noise.

Conf. Tynd. 374, E 5, He bloweth and blustereth out at last his abhominable blasphemy.

Now obsolete. The above is the earliest quot. in OED. LQ. 1604

T. Wright, Passions Iv, I, 110, Foolish mouths ... bluster foorth follies.

to bolt $=$ to fetter ; to shackle.

Dial. C. 323. He bolteth their arms with a paulsy, that they cannot lift their hands to their heads.

Now obsolete. EQ. 1377, Langl. P. PI. B. VI, 138, If he be ... bolted with grnes ... LQ. 1606 Shaks. Ant. \& Gl. v. ii, 6, That thing ... which shackles accedents, and bolts vp change.

to bost (a person) = to laud ; to extol.

Rich. $70 \mathrm{G} \mathrm{9,} \mathrm{the} \mathrm{duke} \mathrm{began} \mathrm{to} \mathrm{praise} \mathrm{\&} \mathrm{bost} \mathrm{the} \mathrm{king.}$

Now replaced by to boast which rarely occurs with a personal object. EQ. 1543 Grafton, Gontn. Harding 524, When the duke beganne fyrste to prayse and boaste the Kyng. The later quot. all have non-personal objets.

to brake $=$ to torture on the rack.

Dial. C. 321, in this prison ... folk be... as sore handled ... and wrenched and ... braked in such paynfull wise, that ...

Now obsolete. OED has only the foll. quot. 1530, Palsgr. 463, The false murdrer was braked thrise or euer he would confess the trouthe.

to break = to cut short; to stop.

Answer $1058 \mathrm{H} \mathrm{4,} \mathrm{A} \mathrm{better} \mathrm{then} \mathrm{we} \mathrm{both} \mathrm{shall} \mathrm{breake} \mathrm{the} \mathrm{strife} \mathrm{betwene}$ vs. | Dial. Her. $167 \mathrm{G} \mathrm{7,} \mathrm{For} \mathrm{the} \mathrm{wordes} \mathrm{of} \mathrm{God} \mathrm{muste} \mathrm{breke} \mathrm{the} \mathrm{strife.}$

Now obsolete. EQ. 1330 R. Brunne, Chron. III (Mätz.), Our tale tale wille we no breke, bot telle forth the certeyn. LQ. 1709. Strype, Ann. Ref. I, xLvII, 510, To use means to break the match.

to break (with a person) = to reveal what is in one's mind. Dial. C. 217, wyth hym she secretely brake, and offered hym ten ducates for bys labour.

Now obsolete. The one earlier quot. illustrates the verb to break 
to (a person) : 1463 Paston Lett. 473 II 134, He kept not his owyn councel but brak to euery man of it. | The earliest quot. with to break with is the above Prom More. LQ. 1614 Raleigh, Hist. World V, VI, \& 8, To this effect Scipio brake with the Consul.

An instance of the still current verb to break news, a matter, a secret occurs in the following passage :

Rich. $53 \mathrm{E} 12$, But Catesby ... reported ... that he founde him so fast, and hard him speke so terrible woordes, that he durst no further breke.

to bring furth = to adduce; to put forth.

Conf. Tynd. 475 F 5, The places of Scrypture whiche Heluidius broughte furth for the contrarye.

Now obsolete. EQ. a 1300 Cursor M. 12L38, To bring forth sli talking. LQ. 1611 Dible, Isa. XLI, 21, Bring foorth your strong reasons.

to bring in (a person) = to prevail upon (?).

Dial. C. 193, with suche preachyng wer the people so brought in, lhat some fel to break their fastes on the fastyng days.

Now obsolele. Not recorded in OED.

to bring $u p:=$ to bring into vogue; to introduce; (to invent). Picus 8 G 9, but we speake of those ceremonies, which folke bryng op setting the very seruice of God aside. | I)ial. Her. $283 \mathrm{C} 13$, which thing had vndoubtedly neuer been obteined among the people, ... if god had not broughte it op hymselfe.

Now obsolete. EQ. 1483 Caxton, G. de la T., D vu b., To hasty intakynge ony newe thynges brought up. LQ. 1741 Richardson, Pamela, The torture is not used in England and I hope you won't bring it up.

to bymire = to cover with mire.

Answer 833 D 20, If only they that are alredy bymiled, wero... myred on inore and more.

Still current (to bemire). No earlier quot. in OE.D.

to byshop = to confirm ; to administer the rite of conflrmation to.

Dial. Her. $130 \mathrm{G} \mathrm{9,} \mathrm{No} \mathrm{man} \mathrm{that} \mathrm{was} \mathrm{by} \mathrm{at} \mathrm{your} \mathrm{crysteninge,} \mathrm{nor} \mathrm{when}$ ye were byshopped neyther.

Now arch. or obsolete. EQ. c 1000 Thorpe's Laws II, 348, se bisceop

bip zesett ... to blsceopzenne cild. | LQ. 1786 J. Roberts, Lile 29

How many of them have been bishop'd?

to call upon (a letler) $=$ to ask for.

Aut. Lett. Iv 72, the leltre ... which the kinges grace caused me whan his grace had redde hit to deliver it forthwith to my said lordis seruant tarying \& incessauntly callyng uppon hit. So that I could not wryte hit owle agayne.

Now obsolete. Not in OED. 
to cant $=$ to apportion ; to divide.

Dial. C. 322, our very prison this earth is. And yet therof we cant us out dyuers partes dyuerslye to our self. | Debell. $943 \mathrm{H} \mathrm{11}$, To diuide and cant it among good poore husband men.

Now obsolete. EQ. c 1440 Promp. Parv. 60, Cantyn or deparlyn $=$ partior. OED has no later quotations.

to captyve = to captivate; to subdue.

Apol. 38, God vseth the tone token of the word to the wasshynge \& clensynge of the soule thorow the meane of obedyence of the will, in captyuynge of hys reason. | Apol. 39 , he will walke and wurke wyth God by captyuynge of hys own underslanding.

Now obsolete. No earlier quot. of the fig. meaning in OED. LQ. 1781 Churchill, Rosciad, If music ... Captives the ear.

to cast $=$ a) to find or declare guilty.

Debell. $976 \mathrm{G} 4$, some ... confessed hys felonyes at the galowes, when thei were on the lader. And some ... became approuers when they were caste, and called for a coroner.

Now obsolete. No quot. in OED anterior to Nore. LQ. 1849 Grote, Greece II Ixvii, vil 463, There was no man ... who might not be cast or condemned, or fail in his own suit, even with right on his side.

to cast $=$ b) to revolve in one's mind.

Rich. 49 (= 46) G 2, For if she caste suche fonde doubtes, that shee feare his hurte : then wyll shee feare that hee shall bee fette thence. | Dial. C. 240, a good man casting in his mind the peril of...

Now obsolete or dial. EQ. 1530 Palsgr. 477, 2, I have caste many thynges in my mynde... | 1577 Hanmer, Anc. Eccl. Hist. (1619), 168, The Judge, casting doubts with bimselfe ... | c 1590 Marlowe, Feust,, , 26, Cast no more doubts. LQ. a 1719 Addison (J.), I have lately been casting in my thoughts the several happinesses of life.

to cease = to stop (with object).

Dial. C. 166, he shortly ceased the tempest.

Now obsolete when referring to state or condition of things. EQ. 1393 Gower Conf. II, 9, Thus was cessed the debate of love. LQ. 1691 E. Taylor tr. Behmen's Threef. L. xviI, 313 A dead man's sence is ceased.

to cham = to chew (also flg.).

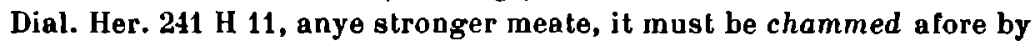
the nurse. | Dial. Her. 242 A 9, Not for the reading \& receiuing : but for the busy chamming therof.

Now obsolete. EQ. 1398 Trevisa, Barth De P. R. xvII, v, 606, It is full harde and maye not be chewed and whyles men chamme theron, the butter sauour wythyn is not felte. LQ. 1675 Hobbes, Odyss. xi1, 263, When she my men cham'd in her ugly chaps (1825, 1881, dial.). 
to charity $=$ to love with the Christian love of our fellowmen.

Conf. Tynd. 434 F 9, But elles if Tindall fall not to the chariting but to the louing of his neighbors wife.

Not in OED.

to circumuent $=$ to surround by hostile stratagem.

Lett. Frylh. 834 F 9, it greuelh me very sore, to see thys yonge man so circumuented and begiled by certayn olde limmes of the deuil (917 A 5).

Still in Pres. D. Eng. EQ. 1553 Eden, Treat. Newe Ind. 13, The gouernour ... so by crafte circumuented him that he toke him priesoner.

to cloute up = to patch (flg.).

Last. Th. $80 \mathrm{E} \mathrm{4}$, once or twise a day, we be fayne to take medicines inwarde to cloute them (scil. our bodies) op with al, \& kepe them as longe as we can.

Now arch. or dial. EQ. (of the fig. use) 1413 Lydg., Pilgr. Sowle II xLIII (1859) 49, They peruertyn holy Scriplure by false vnderstandynge ... kouerynge ... and cloutynge ... the lawe of Chrystes gospel.

to comen $=$ to discuss (a thing, etc.).

Rich. $64 \mathrm{D}$ 8, they myght seme to comen what was best to do.

Now obsolete. EQ. c 1460 Fortescue, Abs. \& Lim. Mon. xvir, 150, pat his entente therin be comened with his counsell. LQ. 1607, J. King, Serm. 20, To comen it (this scriplure) is priuate with his owne spirits.

to comber $=$ to distress; to trouble.

Some Lett. 333, I comber you good Margaret much, but I would be sory, if it should be any lenger than to morrow.

Now obsolele. EQ. a 1300 Cursor Mundi 8018 (Cott.), Es nathing pat mai him cumber. LQ. 1852 Dickens, Bleak H. xxvil, I disgrace nobody and cumber nobody.

to clock (chickens) = to call (chickens) together.

Dial. C. 201, how often like a louing hen, he clocketh home vnto him,.. those chikins of hys.

Now obsolete. EQ. c 1420, Pallad. on Husb. 1, 660, Nowe she [the hen] goth before, And clocketh them. LQ. (fig.) a 1716 South, Serm. IV, 54, Engaging men... to hold forth ... wheresoever, and howsoever, they could clock the senseless and unthinking rabble about them. More also uses to clok for (not illustrated in OED) : Dial. C. 201 , the more be clokketh for them, the farther they go from hym.

to conclude $=$ to overcome in argument ; to confute.

Dial. C. 316, these thinges wherewith you rather conuynce and conclude me, then induce a credence and perswade me ... Dial. C. 297, therefore oure Sauioure in few woordes concluded and confuled all these folyes of theim, that ... forsake hym and bis faythe. 
Now obsolete. EQ. a 1300 Cursor M. 14713, Wit wordes suilk war pai wit scil concluded and ouercummin. LQ. 1704 Hearne, Duct. Hist. I 28:3, Though the Scythians had better Arguments to offer ... they would nol be concluded by them.

to condescend = to give one's consent.

Rich. 46 F 7, the temporall menne whole, and good part of the spirituall alsn, thinking none hurt erthly ment towarde the younge babe, condescended ... that ... be should be fetched.

Now obsolete. No quotalions with that-clause anterior to More. EQ. 1557 North, tr. Gueuara's Diall Pr. 97 a/1, It shold not be iust ... that Roine shuld condescende, that any woman ... receyue shame. LQ. 1717 Col. Hec. Penn. III 36, The Gouernour at last Condescended, that the said Commissions be Issued.

to conduce $=$ to lead ; to guide ; to conduct.

Dial. C. 213, he must get a ... cunning Pilote that so can conduce bym

from the rocks on that side.

Now olssolete. EQ. c 1475 Partenay, Prol. 206, Here I hym require To thys nede me aide; and hys moder swet Mi mater conduce to the ende. LQ. 1658 T. Meriton, Love \& War IV. I, I am conduc'd by willingnesse to dye.

to confound $=$ to confule.

Passion 1346 H 1, we see bolb Saynt Hyreneus confounde the Valentinians, and Saynte Hillarius confounde the Arrians, ... by certayn argumentes grounded vpon the veritie of...

Now obsolete. EQ. 1382 Wyclif, Acts Ix 22, Forsothe Saul ... confoundide the Jewis. LQ. 1726 Cavallier, Mem. I 10, She would dispute ... with the Missionaries... and would often confound them.

to conioin = to unite in one substance.

Passion 1306 (= 1338) E 4, not an instrument dead and separate, but by hys instrument linely quicke conioined vned, and for euer vnseparable.

Now obsolete. No quot. in OED anterior to More. EQ. 1552 Lyndesay, Monarche rv, 5593, All Reasonabyll Creature Sal suddantlye slart vp attonis, Coniunil with Saull, Flesche, Blude, \& Bonis. LQ. 1671 J. Webster, Metallogr. Iv 75, Both being conjoyned, dolh draw forth a certain unctuous spirit.

to confer = to compare.

Dial. Her. 245 F 8 , by dyers diuiding the labour among them, and after conferring theyr several parties logether eche with other.

Now obsolete, exc. in the ablor. $c f$. EQ. a 1533 Frith, Disput. Purg. Pref. 85, Let us ever confer them unto the pure word of God. LQ. 1753 Hanway, Trav. II, I, vil, 35, To confer occasionally, in order to see that his accounts agree.

to contrary $=$ to contradict.

Dial. Her. 262 H 13, one part of hys tale euer contraried another.

Now obsolele. EQ. c 1386 Ghaucer, Wile's T. 188, Ne was ther wyl, ne mayde ... that contraried that he sayde. LQ. $1808 \mathrm{~W}$. B. Hewetson, Blind B. I, 1, I see nothing to contrary it. 
to conuay $=$ to perform (tricks); to manage with secrecy or craft.

Apol. 23, a iugler that conuayeth his gulles so craftely that al the table spyeth them.

Now obsolete. EQ. 1530 Palsgr. 498, I, He convayeth his maters as wisely as any man that I knowe. LQ. a 1661 Fuller, Worthies III, 404, He had a secret contrivance wherin he conveyed his exceeding above his monastical pittance.

to con $u y c t=$ to prove (a doctrine) to be wrong; to confute. Conf. Tynd. $428 \mathrm{G} 2$, And thug is in thys poynle Tyndales playne foly, well and playncly conuycled.

Now obsolele. EQ. 1616 Sir T. Browne, Pseud. Ep. III, viI, 122,

Which conceit being already convicted, not only by Scaliger,

Riolanus and others, but daily confutable almost every where out of England. LQ. 1681 W. Robertson, Phraseol. Sen. 387, To convict, or prove the contrary, refutare.

to conuynce $=$ to overcome in argument ; to confute.

Dial. C. 316 , these thinges wherewith you ... rather conuynce and conclude me, then induce a credence and perswade me...

Now obsolete. EQ. 1530 Palsgr. 498, 2, There have been doctours to dispute with hym ... but they all can not convince him. LQ. 1708 Chamberlayne, St. Gt. Brit. I, II, V1I, 69, their oflee is to confirm the wavering, convince the obstinate.

to counterplede $=\mathbf{a}$ ) to make a counterplea; b) to contradict.

a) Passion 1280 B 7 , His mercy no cause had to counterpleade his iustice, in abridgyng the elernitye of the proude spirites paine.

b) Dial. C. 337, I might resonably counterplede thys that you baue sayde.

Now obsolete. EQ. c 1385 Chaucer, L. G. W., Prol. 476, Lat be thyn arguinge For loue ne wele not countyrpletyd be In ryght ne wrong. LQ. 1589 Warner, Alb. Eng. Pros. Add. 338, Aeneas ... thaukfully acknowledged her great hountie, counter-pleading to haue pretended a departure without leaue taken.

to $d a(s) ~ u p=$ to rouse; to awaken.

Jest p. 4 A 12, wilh good rappes, And heuy clappes, He daside hym vp agayne.

Now obsolete. EQ. 1470-85 Malory, Morte D'A., XI, X, The Quene ... felle to the erthe in a dede swounn, and thenne syr Bors took ber vp, and dawed her. LQ. 161'2 Drayton, Poly-olb. vi 90, Thinking her to daw Whom they supposed faln in some inchanted swound.

to decay = to cause to fall off or deteriorate.

Dial. C. (Wks) $1200 \mathrm{H} \mathrm{9,} \mathrm{For} \mathrm{foare} \mathrm{of} \mathrm{decaying} \mathrm{the} \mathrm{common} \mathrm{wele,} \mathrm{men}$ are driuen to put malefactors to pain.

Now obsolete. No quolations anlerior to More in OED. LQ. 1691

Locke, Lower Interest, Wks. 1727 II 38, A Ifigh Interesl decaye Trade. 
to declare $=$ to make known; to state in detail.

Apol. 4, they saye that my wurkes were wurthy muche more credence, yf I had wrylten more indyfferentely and had declared and made open to the people the fawtes of the clergy.

Now obsolete. EQ. c 1340 Hampole, Prose Tr. 23, I shalle telle and declare to the a little of this more opynly. LQ. 1703 Maxon, Mech. Exerc. 237, I will declare their Method.

to defy = to despise ; to disdain.

Boke of F. p. 1 B 10, Thus lyke the fox they fare that once forsoke, The pleasaunt grapes, and gan for to defy them.

Now obsolete. EQ. c $1320 \mathrm{H}$. Brunne, Med, 743, Y haue be skurged, scorned dyffyed, Wounded, angred, and crucylyed. LQ. 1727-38 Gay, Fables I, xxvi, 17, He next the mastifl's honour try'd, Whose honest jaws the bribe defy'd.

to delate $=$ to bring; to introduce.

Passion 1347 G 10, the countreyes into whiche chrystendome bath been and shal be delated and spred before...

Now obsolete. No instances of exactly this meaning in OED.

Nearest s. v. delate v. $1=$ to carry down or away, convey to a particular point.

to delude $=$ to frustrate ; to cheat or disappoint (hopes or purposes).

Rich. $60 \mathrm{G} \mathrm{5}$, he tooke it ... highly that his embasiate was deluded. Rich. $59 \mathrm{~B} 6$, if al his viage were in suche wise frustrate, and his appointmenles deluded.

Now obsolete. EQ. (1493 Petronilla 99, Of his purpose Flaceus was deladed) $149+$ Fabian, Chron. vII, ccxxxIv, 270, The Cristen prynces seinge that they were thus deluded. LQ. 1630 Dekker, $2^{\text {nd }} \mathrm{Pt}$. Honest Wh. Wks. 1873 II, 138, Yet sure i'th end he'll delude all my hopes.

to demean $=$ a) to conduct; to manage (things).

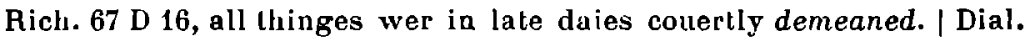
C. (Wks.) 1207 F 3, Euen for hys riches alone, though he demened it neuer so wel.

Now obsolete. EQ. c 1315 Shoreham 167, Thaz hy(t) be thorz senne demeyned. LQ. 1644 Nilton, Areop. (Arb.) 68, As our obdurat Clergy have with violence demean'd the malter.

to demean $=$ b) to manage (a person) ; to deal with.

Rich. $45(=44) \mathrm{C} \mathrm{13}$, them selfe woulde alone, demeane and gouerne the king at their pleasure. | Rich. $48 \mathrm{H} \mathrm{9}$, ther should he be demeaned accordyng to his estate.

Now obsolete. EQ. 1393 Gower, Conf. I, 196, And thought he wolde upon the night Demene her at his owne wille. LQ. 1685 ArgyIl, Declar. in Crookshank, Hist. Ch. Scotl. II, 316, Demeaning and executing them ... as the most desperate traitors. 
denounce (an excommunication) $=$ pronounce.

Dial. Her. $185 \mathrm{G} 14$, Which he neuer was after the deede done, till the excommunycacion denounced.

Now obsolete. No instances with excommunication in OED.

to depart = to sever ; to separate.

Picus 2 F 3, Straunge tokens bath gone before, or followeth the natiuitee of excellent, wyse and verteous menne, departing (an it wer, and by Goddes commaundement) seuering the cradles of such speciall chyldren fro the company of other of the common sorte.

Now obsolete. EQ. 1340 pseud. Hampole, Pr. Consc. 3710, pai or ...

Departed halely fra pe hody of Criste. LQ. 1590 Spencer, F. Q. II,

$x, 14$, Which Seuerne now from Logris doth depart.

to depraue = to disparage ; to defame.

Dial. C. 233, mysse iudging, and deprauing other men, with the delite of theyr owne praise.

Now obsolete. EQ. 1362 Isangl. P. Pl. A ni, 173, I com not to chyde,

Ne to depraue pi persone with a proud herte. LQ, 1667 Milton, $P$.

L. VI, 174, Unjustly thou deprav'st it with the name Of Servitude.

to depure $=$ to free from impurity.

Dial. C. $259,[\mathrm{be}]$... is not yet alwaye so cleere depured from all worldelye affecions, as hymself would very fayne be were.

Now obsolete. EQ. a 1100-50, Alexander 2768, Send ... Sum pured pelloure depurid in oure wedis. | LQ. 1699 Evelyn, Acelaria (1729)

156, Ingredienty ... [which] depure the Blood.

to descant of $=$ to comment upon.

Picus 15 G 12, the company of the court ... descanted therol to his rebuke.

Now obsolete with the preposition of. No earlicr quot. in OED.

to detect $=$ to divulge.

Answer 1035 F 9, horesye woulde he no man suffer to talke at hys table, but woulde bolbe rebuke it and detecte it to, all thoughe the thing touched hys owne borne brolher.

Now obsolete. EQ. c 1465 Hist. Doc. Roch. (E. E. T. S.) 7, But if it shall hap so to know any such [heresies], I shall detecte them to myn ordinarie, LQ. 1725 De Foe, Voy. round W. (1840) 314, One of the lieutenantid discovered and detected this villanous contrivance.

to detest (to the rleuil) = to wish (to the devil).

Cont. Tynd. $40+$ E 1 , he hath abhotred \& detested it to the deuil of hel, that euor any persone ... should afterward runne out of their religion.

Now obsolelo. Not in OED.

to devyse = to contrive or make up deceitfully or falsely ; to forge ; to invent.

Rich. 54 B 14, much mater was ther... deuised, to the slaunder of the lord Chamberlain.

Now archaic. No quotations anterior to More. 
to devyse upon $=$ to consider ; look at attentively.

Dial. Her. $153 \mathrm{~F} 5$, in deuysynge opon the sentenco, in consyderynge what ye rede, in ponderyng the purpose of diuers commentes.

Now obsolele. Not in OED with rpon.

to dilate $=$ to describe ; to enlarge upon.

Dial. C. 348, If we would dilate, and wer hable to declare these speciall gylles ... there would it appeare...

Now obsolete. EQ. 1393 Gower, Conf. II, 190, It nedeth nought that 1 dilate The pris which preised is algate. LQ. 1801 Gouv. Morris in Sparks Life \& Writ. III, 150, I dare give only hints; it would be presumptuous to dilate them.

to disallow $=$ to reject.

Dial. Her. 271 G 8, he said that god reiected, disalowed, and sette at nought al the works of infidels wrought wilhout faith.

Now obsolete. EQ. 1377 Langl., P. PI. B. xIv 139, For pei [the rich] han her hyre here ... an heuene as it were... And whan he deyeth, ben disalowed. LQ. 1660 Stanley, Hist. Philos. Ix (1701) 435/1, [tr. Archytas], The fates of young and old together croud, No head is disallow'd By merciless Proserpina.

to discern = to separate as distinct.

Answer 1050 F 3, Our sauiour would not discerne \& diuide fayth from the woorke, but sayth that the faith it elfe was the woorke of God. I Dial. Her. 148 A 2, And faith is the first substanciall difference discerning christen men from hethen.

Now obsolete. EQ. c 1430 Lydg. Min. Poems 87, Pictogoras... Fonde first out .y., a figure to discerne Theyre lyff here short, and lyff that is eteine. LQ. 1645 Ussher, Body Div. 39, That so he might be discerned from all things created. For nothing is like unto God.

to discharge = to do away with; to part with.

Dial. Her. 228 G 4, thei neuer haue grant of a liuing ... but thei secretely discharge it ere they haue it...

Now obsolete. EQ. 1523 Fitzherb., Surv., 12 b, Mater in writyng may nat be discharged by bare wordes. LQ. $1778 \mathrm{Bp}$. Lowth, Transl. Isaiah, Prelim. Diss. (ed. 12) 44, We can hardly expect ... more ... than to be able ... to discharge and eliminate the errors that have been gathering ... for about a thousand years past.

to discuss = to drive away.

Conf. Tynd. $401 \mathrm{E} 11$, They wil clerely dissipate and discusse the myst. Now obsolete. EQ. c 1374 Chaucer, Boeth. I metr. III 9, When pat nyght was discussed and chased away, derknesses forleften me. LQ. 1651 I. F(reake), Agrippa's Occ. Philos. 17, The Northern Wind, flerce and roaring, and discussing clouds.

to dispayre $=$ to cease to hope for.

Dial. C. 125, seeing the man so sore set on hys pleasure, that they dis- 
payre any amendement of him. | Rich. $38 \mathrm{E} 2$, hee receitued his naturall strengthe soo sore enfebled, that hee dyspayred all recouerye.

Now obsolete or archaic; replaced by to dispair of. EQ. c 1485

Digby Myst. (1882) v. 467, Thei that despeyer mercy haue grett conpunccion.

to dispense ( $a$ bond) $=$ to dissolve the obligation of (a vow, oath, or the like) by ecclesiastical authority.

Conf. Tynd. $619 \mathrm{G} \mathrm{3}$, The churche hathe synce ... dispensed and vndone the bonde.

Now obsolete. No quotations anterior to More in OED. LQ. 1640

Brathwalt, Two Lanc. Lov. 235, Those vowes ... could not so easily be dispenced.

to dispercle $=$ to scatter.

Dial. Her. 182 G 8, not a company ..., but a dispercled noumber of only good men.

Now obsolete. EQ. c 1449 Pecock, Repr. III, vij, 318, Alle weren disperclid abrode. LQ. a 1634 R. Cleı ke, Serm. (1637) 471 (L.), Their spawn [is] disparkled over all lands.

to dispose = to bestow ; to deal out ; to distribute.

Lnst Th. 92 G 10, if thou dydst recken the tresure not thine, but the tresure of god deliuered the to dispose and bestow thy tresure shold be in erth and thy hert in heven.

Now obsolete. EQ. c 1430 Lydg. Min Poems 20, The wiche gyfte they goodly han disposed. LQ. 1818 Cruise, Digest Iv, 243, The enjoyment during life, and the power of disposing to whalever person and in whatever manner she pleased.

to disprayse $=$ to despise.

Dial. C. 334, if ... ther wer on the tone side of the way a rable of ragged beggers and madde men, that wold lespyse you and disprayse you ...

Now olssolete. EQ. c 1386 Chaucer, Melib., 5 Whan Prudence had herd hire husbond avaunte him of his richesse ... dispreising the power of his adversaries. LQ. c 1500 Melusiue xx, 113, Dyspreyse not your enmyes though they be litel.

to disrenerence $=$ treat with irreverence.

Dial. Her. 227 B 10, we should ... rather forbeare the profy te ... than to see his maieslye disrenerenced.

Now obsolete. No quot. in OED anterior to More. LQ. a 1670 Hacket, Abp. Williams I (1692) 127, How is His glory dis-reverenced over all this land?

to dissemble $=$ to disguise.

Dial. Her. 283 A 15, Though he dissemble himselfe to bee a Lutherane ... whyle he was here: yet as sone as he gate him hence, he gate him to Luther strayght.

Now obsolete. EQ. 1508 Dunbar, Tua Marrit W. 254, I wes dissymblit suttely in a sanctis liknes. LQ. 1697 Dryden, Aeneid xIr, 340, Dissembling her immortal form, she took Camertus meen. 
to dissolue $=$ to refule; to confute.

Dial. Her. $203 \mathrm{D} 2$, Whiche obieccion the author answereth and dissolweth.

Now obsolele. No quot. in OED anterior to More. LQ. $1842 \mathrm{Abp}$. Thomson, Laws Th. $\$ 127$ (1860) 271, We may dissolve the argumenl hy shawing its unfitness for proof.

to do (theft) $=$ to commit ; to perpetrate.

Dial. Her. 272 I) 8, no man may lawfully ... do theft or aduoutry.

Now obsolete or arcl. EQ. a 1000 Father's Instr. 70 (Cod. Ex. If. 81 a), peah hi wom don.

to do a purpose $=$ to carry out an intention.

Dial. C. 217, But such as are wel willing to do any purpose that is so shameful, wyl neuer tel their mind to no body for veri shame.

Not recorded in OED.

to $\operatorname{drink}(o f)=$ to have a specified flavour when drunk.

Conf. Tynd. 357 B 12, because it is not so walowe swete but drinketh more of the verder.

Now obsolete. EQ. 1607 Heywood, Wom. Kill. Epil., The wine ... drunk too flat. LQ. $1758 \mathrm{~L}$. Temple, Skelches (ed. 2) 70, The Burgundy drinks as flat as port.

to dyscoumfort $=$ to discourage.

Dial. C. 125 , For al be it that the priestes ... be wonte to calle uppon sicke menne to renembre dealh : yet we worldely frendes for feare of dyscoumfortyng them, haue euer hadde a guyse ... to lifte uppe their heartes, and put them in good hope of life.

Now obsolete. EQ. 1338 R. Brunne, Ghron., To discomfort no ping pe, so faire happe neuer pou fond. LQ. 1706 Phillips, Discomfort $=$ to amict, cast down, or put out of Heart.

to dyspute = to maintain ; to uphold.

Gonf. Tynd. $655 \mathrm{G} \mathrm{1,} \mathrm{He} \mathrm{...} \mathrm{affyrmeth} \mathrm{nowe} \mathrm{that} \mathrm{there} \mathrm{is} \mathrm{in} \mathrm{the} \mathrm{blessed}$ sacramente nothynge elles but bread, ... and dysputeth in his blasphemie that it shoulde be but starche. Also $396 \mathrm{C} 3$.

Now obsolete. In OED no quotations before 1610 : Hp. Carleton, Jurisd. Pref., I haue disputed the kings right with a good conscience, from the rules of Gods word. LQ. Swilt, Gad. \& Van. 344, And these, she offer'd to dispute, Alone distinguish'd man from brute.

to dyssymule = to ignore.

Apol. 28, he hathe sette forth Tyndals reason \& dyssymuled myne answer.

Now obsolete. EQ. a $1450 \mathrm{Knt}$. de la T. 100, The duk, that sawe her sy mplenes, beganne to lawghe and dissymuled her requeste. LQ. 1636 B. Jonson, Disc. Morbi, $1 x, 190$, So in the church, some errors may be dissimuled with lesse inconvenience then they can be discover'd. 
to embrue = to stain ; to dye (one's hand) in blood. Dial. Her. 259 D 10, From howre to howre embruinge theyr handes in bloode.

Still possible in Pres. D. Eng. No quolations anlerior to More (s. v. Imbrue, 2).

to empech $=$ to impede; to hinder.

Aut. Lett. vi, 34, he dowtelh not but yor grace hath and will provide therfore that no lacke of vitaile hyndre or empech theire purpose.

Now obsolete. EQ. c 1380, Wyclif, Sel. Wks III 317, He schall dwelle pere alle his lif, and no man empeche hym. LQ. 1690 Leybourn, Curs. Math. 586, A Ditch, of sufficient ... breadth, and depth, to impeach the assault of an Enemy.

to encountre with $=$ to confront.

Aut. Lett. Iv, 12, his gracis armye ... sholde be compelled to encountre with thentier army of his enemyes.

Now obsolete. EQ. 1555 Eden, Decades W. Ind. II, I (Arb.) 107, Encounteryng with them, he was repulsed with shame and damage. LQ. 1728 R. Morris, Ess. Anc. Archit. 18, The single Enemies I have to encounter with.

to endent $=$ to make a formal or express agreement ; to covenant.

Last Th. $82 \mathrm{D} \mathrm{12,} \mathrm{our} \mathrm{lord} \mathrm{hath} \mathrm{not} \mathrm{endented} \mathrm{with} \mathrm{vs} \mathrm{of} \mathrm{the} \mathrm{time.}$

Now obsolete. EQ. 1489 Paston Lett. 908 III 351 My Lorde of Northethombyrland ... hath endentyd with the Kynge for the kepyng owt of the Schottys ... LQ. 1759 Goldsm. Pres. St. Pol. L. xI, Wks. (1854) II, 50, I fire with indignation when I see persons wholly destitute of education and genius indent to the press, and thus turn book-makers.

to endite of $=$ to accuse of.

Last Th. $100 \mathrm{H} \mathrm{14,} \mathrm{he} \mathrm{is} \mathrm{endited} \mathrm{of} \mathrm{his} \mathrm{own} \mathrm{deth.}$

Now : to indict for.

to enforce $=$ to add force to ; to intensify.

Apol. 5, I reherse theyr reason to the beste that they can make yt theym selfe and $I$ rather enforce $y$ tand strength it of my own. | Passion 1331 B 7.

Now obsolete. EQ. c 1375 Barbour, Bruce V, 355, Douglas ... enforsit on thame the cry. LQ. 1775 Adair, Amer. Ind. 61, To inforce their musical speech.

to engroce = to concentrate property in one's own possession.

Apol. 85, some such haue I knowen that have engroced in to theyr handes myche other mennys goodes.

Now obsolete. No quot. in OED anterior to Shakespeare.

to enhaunce $=$ to exalt in rank, wealth, etc.

Boke of F. p. 2 A 2, he that out of pouertee and mischaunce, List for to liue, and wyll bym selfe enhaunce, In wealth \& richesse... 
Now obsolete. EQ. c 1374 Chaucer, Boeth. IV, II, Oonly bounte and prowesse may enhawnse euery man ouer oper men. LQ. a 1649 Drumm. of Hawth. Wks. 40 To inhaunce with fauours this thy reign.

to ensemble = to bring together, to assemble.

Apol. (Wks.) 920 G 7, Openly by day they ensembled themselfe together to the noumber of an hundred.

Now obsolete. EQ. a 1300 Leg. St. Gregory 982, pe cardinals al togider come, Ensembled pai were alle po. I No quot. later than the above from More.

to enserche $=$ to investigate ; to find out.

Boke of F. p. 1 A 3, Mine high estate power and auctoritie. If ye ne know, enserche.

Now obsolete. EQ. c 1400 Prymer in Eng. II, 130, That thou enquere my wickidnesse and enserche my synne. LQ. $1581 \mathrm{~W}$. Stafford, Ex. Compl. I, 30, Would ensearch the default, and then certilie the good man of the bouse thereol.

to ensourge $=$ to rise in opposition against.

Conf. Tynd. $724 \mathrm{~B} \mathrm{3,} \mathrm{All} \mathrm{the} \mathrm{beretikes} \mathrm{that} \mathrm{rebelle} \mathrm{agaynste} \mathrm{it,} \mathrm{nor} \mathrm{all}$ the tyrauntes vppon earth that ensourge \& oppugne it [the church].

Now obsolete. The above is the only quot. in OED with the objective insurge; the other quotations illustrate insurge against.

to ensue (a person) = to follow (a person).

Pisus $16 \mathrm{~F} 11$, then shall thei coueit to ensue them in liuing, whan thei naie not, whom whan they might haue ensued, thei pursued.

Now obsolete. EQ. 1430 Lydg., Chron. Troy II $x$, I am so dull certayne that I ne can Guido ensewe. LQ. (to ensue an example) : 1599 Davies, Immort. Soul (1876) I 99, while these receiv'd opinions I ensue.

to ensure = to engage by a promise of marriage.

Rich. 59 A 5, after he was thus appointed, \& hadde betwene them twain ensured her: then asked he counsel of his other frendes.

Now obsolete. EQ. c 1450 Lonelich, Grail, LI, 1019, So that ensured thanne bothe they were, And for the Mariages they ordeyned there. LQ. 1606 G. Woodcocke, tr. Hist. Ivstine, 796, No other maide should be contracted and ensured to any husband,...

to enterprise $=$ to atiack.

Picus 26 B 3, Death stealeth on full slily and vnware. He lieth at hande, and shall vs enterprise, we wote not howe soone.

Now obsolete. EQ. c 1450 Merlin, xx, 315, Whan the Kynge Arthur saugh hem so enterprised... LQ. 1513 Bradshaw, St. Werburge II, 135, Danes and Norwaies enterprised this lande.

to entitle $=$ to ascribe.

Conf. Tynd. 784 A 2, the imperfait worke ... which was fyrst ... intiteled vnto sainl Crisostome. 
Now obsolete. In OED no quot. before 1550 : Grammer, Defence 506, In an olher booke, entitled to sainct Augustine is written thus ... LQ. 1724 Swilt, Let. 28, The other [tracl] is entitled to a Weaver.

to entreat $=$ to treat; to deal with.

Picus $7 \mathrm{H} \mathrm{1}$, Ilis louers and frendes with great benignitie and curtesie he entreated. | Picus 13 F 10, Ther lieth ... in them [the volumes of Holy Scripture] a cerlein heauenly strength, ... whiche transformeth and chaungeth the readers mynde into the loue of God, if thei be clene and lowly entreated.

Now obsolele or archaic. FQ. c 1430 Hymmes Virg. 22, So belyn, so woundyd, Entretyd so fuly. LQ. 1875 Jowett, Plalo, I, 135, They evil intreated one another.

to entreat of = to treat of or upon (a subject).

Rich. $37 \mathrm{C} \mathrm{3,} \mathrm{Ricbarde} \mathrm{the} \mathrm{third} \mathrm{sonne,} \mathrm{of} \mathrm{whom} \mathrm{we} \mathrm{nowe} \mathrm{entreate.}$

Now obsolele. No earlier quot. in OED. LQ. $1681 \mathrm{~W}$. Roberlson, Phraseol. Gen. (1693) 510, Allicus in one book did entreat of the Hecords of things done in 700 years.

to envenom $=$ to venom.

Passion 1274 D 1, Being ... so sore enuenomed with so mani poison spottes.

Now obsolele. EQ. c $1300 \mathrm{~K}$. Alis. 5611, Addres ... and dragouns Wolden this folk myche and lyte, Envenymen und abite. LQ. 1725 Bradley, Fam. Dict. s. v. Vives, Do not touch them with your Fingers, for it will invenom them.

to esteem $=$ to estimate the value.

Dial. C. 343, it woulde I donbt not be hable ynongh to make vs set at naught, all the great Turkes tbrettes, and esteme him not at a strawe.

Now obsolete. EQ. 1475 Caxion, Jason $65 \mathrm{~b}$, Ye are in valewe moche more thenne I can extence. LQ. 1776 Sir J. Heynolds, Disc. vii (1876) 422, It is the duty of the connoisseur to know and esteem ... every part of painting.

to estrait $=$ to enclose.

Dial. Iler. $277 \mathrm{E} \mathrm{13}$, at this daie the Turke hath estraited vs very nere, and brought it in within a right narow compace.

Now obsolete. OFD has no other instances.

to exaggerate $=$ to heap or pile up.

Apol. (Wks.) 871 B 15, if hee woulde ... take no suche bywayes, he woulde not ... accumulate and exaggerate the gryefes.

Now obsolete. No quot. in OED anterior to More. LQ. 1677 Hale, Prim. Orig. Man. II vil 191, Trees of Oak and Firr ... covered by ... the Silt and Moorish Karth exaggerated upon them.

to exhibit $=$ a) to offer.

Conf. Tynd. 805 II 3, We ... exhibite our bodies a liuely host.

Now obsolele. EQ. 1490 Caxton, Eneydos V (1890) 21, His Pelaushyppe chosen by hym tor to make and exhibete the sayd sacrefyce. 
LQ. 1657 Howell, Lond. 37, That he said Commissioners should have power to exhibit an oath.

to exhibit $=$ b) to procure; to put on.

Picus $17 \mathrm{C} \mathrm{15}$, Kindle thee when thou waxest colde, conflrme thee when thou wauerest, and exhibite the whinges of the loue of God, whyle thou laborest to heauenwarde.

Now obsolete. EQ. 1548 Hall, Ghion. 195 b, Frendes will not... remember a great gratuitie and benefite in time of necessitie, to them shewed and exhibited. LQ. 1654 Triana in Fuller, Cause \& Gure (1867) 162, He kept Feliciano... as a gentle almsman, exhlbiting diet and some slender accomodations unto him.

to face (upon) = to tell (to).

Answer $1131 \mathrm{E} 2$, He faceth himselle the lye upon me.

Now obsolete. EQ. 1530 Palsgr. 542, 2, Yet he wolde face me with a Iye. LQ. c 1540 Heywood, Four P. P. I, 382, But his boldness hath faced a lie.

to face out of $=$ to exclude shamelessly from.

Answer $1132 \mathrm{~F} \mathrm{13}$, Your false beresy wherwith you would face our Sauiour out of the blessed sacrament.

Now obsolete. EQ. 1601 Shakesp., Tw. N. Iv, II, 101, They ... doe all they can to face me out of my wits. | ibid. v, I, 91. His lalse cunning ... Taught him to face me out of his acquaintance. No later quotations

to fall in hand (with) = to come to words (with).

Dial. C. 285, she fell in hand with hym ... and all to rated him.

Now obsolete. EQ. 1448 Past. Lett. $n^{\circ} 60$, I, 74, When they met to gyder they fell in handes togyder, and [Sir Robert] smot hym ... wilh hys sord. LQ. 1605 Camden, Hem. 275, His wife fell in hand with him, and asked bim...

to fantasie $=$ to fancy.

Rich. 55 A 4, dremes, which either his own fere fantasieth or do rise in the nightes rest by reson of his daye thoughtes.

Now archaic. EQ. c 1430 Lydg. Bochas, Prol. 3, Men of craft may ... Fantasien in their inward sight Devises newe.

to farse = to cram ; to pack.

Dial. C. 220, one that had Lis breast farsed ful of tediousness.

Now obsolete. EQ. c 1386 Cha ucer, C. T. Prol. 233, His typet was ay farsud ful of knyles. LQ. 1634 T. Johnson, Parey's chirurg. xI, JII (1678) 278 , The wound must ... be inlarged ... that so there may be frec passage ... for such things as are farced therein.

to farther $=$ to further.

Hich. $58 \mathrm{D} \mathrm{4}$, in that point could be none other colour, but to pretend that his own mother was one aduouteresse which not withstanding to farther his purpose he letted not.

Now rare. EQ. 1570 North, Doni's Mor. Phil. III, 197, That I might ... farther and aduance my poore familie. 
to fasten (a stroke) $\mathbf{x}$ to deliver effectively.

Dial. C. 354, ... stryketh the deuyll so ... blynde, that he can not see where to fasten a stroke on vs.

Now obsolele. EQ. c 1500 Lancelot 850, Strokis festnit in the shelde. LQ. Dryden, Virgil, Ded. E j, Cou'd he fasten a blow ... when not suffer'd to approach.

to fear $^{=}$to frighten.

Apol. 176, they ... haue made that noyse to fere the ordynaryes therwith. | Picus 12 C 9, impedimentes ... which might feare the from the purpose of good. | Dial C. 353, If he feare vs with exyle and flying...

Now obsolete, exc. archaic or vulgar. EQ. c $1380 \mathrm{Wycliff,} \mathrm{Wks.}$ 109, Hou anticrist and his clerkis feren trewe prestis for prechynge of cristis gospel.

To fear $=$ to be afraid of also occurs in More : Dial. C. 128, Which wee more feare then all the remenaunte. | Picus $13 \mathrm{H} 5$, Farewell and feare God.

to feble = to make feeble.

Conf. Tynd. $644 \mathrm{G} \mathrm{3}$, Lest it should feble hys fleshe...

Now obsolete exc. arch. EQ. a 1340 Hampole, Psalter xvii 40, pai ere noght feblid my steppis.

to fede furth $=$ to lead on by raising delusive expectalions, Conf. Tynd. $524 \mathrm{H} \mathrm{15,} \mathrm{he} \mathrm{longeth} \mathrm{to} \mathrm{leade} \mathrm{vs} \mathrm{in} \mathrm{darkenes,} \mathrm{and} \mathrm{fede} \mathrm{vo}$ furth with his high solemne folies.

Now obsolete. EQ. (cf. fode forth below) $1475 \mathrm{Bk}$. Noblesse (1860)

53, The said maister... fedde hem forthe withe sportis and plaies.

No quot. later than More.

to feefe $=$ to present (a person) with (anylhing).

Apol. 52, some... oft hern wolde in rewarde of ... my labour agaynste these herelyques haue geuen me myche more then euer I dyd, or could deserue. But I dare take God and theym also to recorde, that all they coulde neuer feeffe me wyth ono penny therol.

Now obsolete (or dial.). EQ. 1377 Langl. P. Pl. B. II, 146, And feffe false witnes wilh floreines ynowe. LQ. c 1450 Merlin 374, The kynge hym feffed with his right glove. (1855 hobinson, Whitby Glossary, fefted = "legally secured with a maintenance", He fefted his wife on so much a year).

to fet $=$ to fetch.

Rich. 51 I) 7, nothing lesse loking for then to haue him fet out of sentuary.

Now obsolete. EQ. a 1000 Prov. (Kemble) 61 (Bosw.), Aelc ydel fet unhælo. LQ. 1602 Warner, Alb. Eng. 1x, Lr (1612) 230, ... a Trappe ... into it Wise, Godly, Rich, by Blanchers bace are fet.

to feyne (a thing) for = to pass off for.

Dial. C. (Wks.) $1250 \mathrm{E} 9$, Jupiter (whom the Poetes feyne for the great God). 
Now obsolete. The only quot. in OFD is : 1393 Gower, Conf. I, 17, Lo, bow they feignen chalk for chese.

to florish - to embellish a narration with flowers of speech. Supplic. $291 \mathrm{k}$, many thinges wherwith he florisheth hys matter, to make them seme gay.

Now obsolete. EQ. 13... Minor P. fr. Vernon Ms. LII, 496, peiz pis tale beo Rorlsshed with faire flour. LQ. 1691 G. D'Emilianne, Frauds Hom. Monks, 177, The Catechizer flourish'd his Discourse with Circumstances so extravagant...

to flow (mylk and honey) = to abound in.

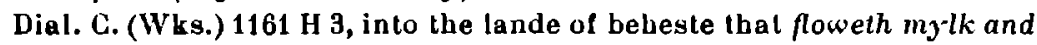
honey.

Not in Pres. D. Eng. OED has the following two quotations (bolh earlier) 1382 Wycliff, Exod. III, 8, A loond that flowith mylk and hony. I c 1400 Mandev. xxx, 137, I sall giffe to zou land flowande mylke and hony.

OED states that Wycliff and Mandeville followed a "barbarism" of the Vulgate. It is, however, more plausible to assume that we have here a survival of Old English usage : hit hagalade stanum; he ongann wepan hluttrum tearum; blode swælan $\left.{ }^{1}\right)$. Alfric has : Exod. II, 8, On pet land pe flewp meolece and hunie. Later the preposition with was inserted. There are a few analogous instances in More of the absence of a preposition before an adjunct, where its use would be required in Pres. D. Eng. : Dial. C. (Wks.) $1229 \mathrm{~F} \mathrm{20}$, Then came he to him, and humblye put him in remembraunce of his graunt passed hys owne mouthe. | Dial. Her. 150 G 1, preacbe I wene thei would, though god would his owne mouthe commaund them the contrary. I Conl. Tynd. $698 \mathrm{~F} \mathrm{10}$, he would hys owne mouth giue his church a law without booke. I Dial. C. 224, The thynge whyche he weneth God by bys angel byddeth, god hall hys own mouthe forbydden. | Dial. C. 218, she hong herselfe her own handes. | Dial. C. 214, when they dare theyr own handes put them self to death. | Debell. $943 \mathrm{H} \mathrm{11,} \mathrm{To}$ diuide and cant it umong good poore husband men, that should til the ground theyr handes. | Rich. $54 \mathrm{E} \mathrm{11,} \mathrm{he} \mathrm{clapped} \mathrm{his} \mathrm{fist}$ vpon the borde a great rappe. | Passion $1318 \mathrm{C} 13$; $1315 \mathrm{H} 7$; 1320 G $10 ; 1320$ H 6 .

But : Dial. C. 294, in remembrance of his graunt passed his owne mouthe and signed with his owne hande.

Compare Jespersen 1938 p. 336 and Kellner $1892 \S 194 ; \S 432$.

to fode forth $=$ to lead on by raising delusive expectations. Dial. C. 218, she wold no more suffer anye nor deceyue her, and fode her forth with delaies.

Now obsolete. EQ. a 1479 Sir J. Paston in Paston Lelt. n 840, III,

1) Cl. the same usage in other Germanic languages, e. g. OHG suertu hauwan (Hildbr. 53). 
255, I hopyd to have borowyd some off Tounesend and he hath floodyd me fforthe evyrsynys. LQ. 1616 Hieron. WVks. II, 42, Hee leeds and foades vs off with vaine words.

to forbear = to deny oneself ; to dispense with.

Dial. Her. 140 H 6, But ... sith ye willed me to forbere nothyng I haue ... rather sette to somewhat. | Dial. Her. $227 \mathrm{C} 10$, ye would rather kepe your present at boine, \& forbeare the thanke. Also : Last Th. $74 \mathrm{C} 11$; Dial. Her. 259 F 11 ; Answer $1036 \mathrm{G} 1$.

Now obsolete. EQ. c 900 tr. Beda's Hist. 1, xvi, 70, Forpon seo aftere cneoris ... alle gemete is to forbeorenne \& to forletenne. LQ. Milton, P. L. Ix, 747, Fruits ... Whose taste, too long forborn, ... Gave elocution to the mute.

to force $=$ to attach importance to ; to care for.

Picus 7 B 5, he litle forced, whether his workes went out vnder his owne name or not.

Now obsolete. EQ. 1500-20 Dunbar, Poems Lvi1, 22, Thay fors bot litill how it fure. LQ. 1611 Speed, Hist. Gt. Br. Ix, xx, 985, They forced not what part they tooke.

to fordo $=$ to abolish.

Dial. Her. 198 G 6, ye would not I truste that lent were fordone. | Dial. Her. $284 \mathrm{~F} \mathrm{4}$, theyr sect hath already fordone the faith.

Now obsolete. EQ. O. E. Chron. an. 986, Se cyning fordyde pæet b'rice æt Hrofe ceastre. 1.Q. 1833 Whittier, Ex. New. Fng. Leg. 3, How has New England's romance fled ... Its riles foredone, its guardians dead.

to forebeat $=$ to beat severely.

Dial. C. (Wks.) $1260 \mathrm{~F} \mathrm{4}$, his forebeaten and sore beaten vaynes and sinewes.

Now obsolete. EQ. (forbeat) 1393 Langl. P. PI. C, xxIII, 198, So elde and hue bit hadde a-feynted and forbete. $L Q$. (c 1470) is anterior to More.

to forefigure $=$ to prefigure.

Answer $1043 \mathrm{G} 7$, the figures of the old testament fore figuring the same.

Now obsolete. No otber quotations in OFI).

to foregrow $=$ to cover with a growth.

Last Th. 74 D 2, [the ground] is foregrowen with nettles breers.

Now obsolete. EQ. c 1200 Trin. Coll. Hom. 129, Forpi is pis western forgrouwen mid brimbles. LQ. 1575 Laneham, Let. 14, Hombre Saluagio ... forgrone all in moss and Iuy.

to foreprophecy = to prophesy beforehand.

Answer $1043 \mathrm{G} \mathrm{8}$, bisides the prophecies of the old prophetes fore prophecieng the same.

Now obsolete. No quot. in OED before 1581. LQ. 1676 W. How, Contn. Blair's Autobiol. xu (1848) 486, Foreprophesying that they would be employed agitinst themselves. 
to forestudy = to apprehend ; to look forward to.

Ricb. 55 G 10, Thus ended this honorable man, a good knigbt and a gentle ... : oth to begile, as he that of good bart \& corage forestudied no perilles.

Not recorded in OED.

to forethink = to consider or think out beforehand; to plan.

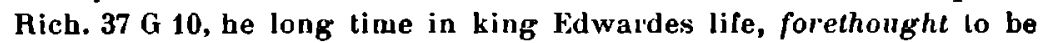
king.

Now obsolete. EQ. c 897 K. ALlfred, Gregory's Past. xv $\$ 5,95$, Se lareow sceal ... forepencean ... pær he nane pinga pæt ryght to suipe... ne bodize. LQ. 1715 Rowe, Lady J. Gr. MI, My brain forethought And fashion'd every action of my life.

to forewery = to weary ; to tire out.

Dial. C. 246, yet are there many of them foreweryed.

Now obsolete or arch. EQ. c 1250 Gen. \& Exod. 3894, Forp pepen he comen to salmona, for-weried grucheden he poa.

to forslouth $=$ to neglect.

Last Th. $72 \mathrm{D} \mathrm{3}$, these wordes geueth vs al a sure medicine yf wo forslouth not the receiuyng. | Picus $9 \mathrm{G} \mathrm{8,} \mathrm{he} \mathrm{would} \mathrm{be} \mathrm{punished,} \mathrm{if} \mathrm{he}$ forslonthed that purpose whiche our Lorde had put in his mind.

Now obsolete. EQ. 1297 H. Glouc. (1724) 197, Wanne hii ... for soke ys, \& for slewped [v. r. uorslewede] \& to non defence ne come.

L. Q. a 1557 Mrs. Basset tr. More's Tr. Pass. Wks. 1362, 2, Hee forslouthed to praje and call for gods help.

to forth $=$ to carry out.

Dial. Her. $162 \mathrm{E} \mathrm{13,} \mathrm{And} \mathrm{as} \mathrm{the} \mathrm{apostles} \mathrm{at} \mathrm{time} \mathrm{taught} \mathrm{the} \mathrm{people,} \mathrm{so}$ did euer some of them that herde them teche forth, and loue their doctrine and tradicions to other that came after.

Now obsolete. EQ. OE. Gbron. an. 675 [Laud.] Hwile man swa hauep behaten to faren to Rome, and he ne muse hit forpian. LQ. c 1460 Townel. Myst. (Surlees) 45, Alle that I say I shalle forthe.

to fostre $u p=$ to bring up (a child) with parental care. Supplic. 337 G 3, Oure fathers also, whiche while we liued fostred vo vp so tenderly.

Now obsolete. FQ. c 1205 Lay. 25900 , Ich wes hire uoster-moder, and feire heo uostredde. LQ. 1697 Dryden, Aeneid vI, 941, The son of Mulciber, Found in the Fire, and foster'd in the Plains.

to frap = to strike (or : to bind tightly?).

Jest. p. 4 E 14, The fryre frappe, Gate many a swappe, Tyll he was full nygh slayne.

Now obsolete in the meaning to strike. There is a nautical term to frap $=$ to bind still extant. EQ. a 13... Coor de L. 2513, With myn ax I schal hem frape. LQ. 1727 Bradley, Tam. Dict. s. v. Biead, You may know that the Oven is hot enough, when frapping a Pole against the bearth ... small Sparks arise. 
to frush $=$ to bruise; to smash.

Picus 9 B 8, refreshing all his membres that were bruised and frushed with that feuer. I Passion 1275 B 12, Enmyty wil I put betwene thee and the woman ... she shal frushe thyne head in peeces.

Now obsolete. EQ. 13... K. Alis. 1814, To frushe the gadelyng, and to bete, And none of heom on lyve lete. LQ. 1609 Heywood, Brit.

Troy, xI, Lxv, With fury each invades His opposite their mutual armour frushing.

to fulfyll = to make complete.

Passion 1274 A 10, a newe kynde of creature, wherewyth he woulde wake vp \& fulfyll ... the nomber of al those euyl angels.

Now obsolete, exc. archaic. EQ. a 1175 Cott. Hom. 219, Al swa fele

pe me mible pat tiope hape fylfellen.

to gainecall = to bring back again, to recall.

Rich. 39 F 2, but sithen thynges passed cannol be gaine called, muche oughte wee the more beware, by what occasion we haue laken soo greate hurte afore.

Now obsolete. There is only one quot. in OED, dated 1611 : Speed,

Hist. Gr. Brit. 1x, xv11, 894, Silh things past cannot be gainecalled. (Speed seems to have used More's words).

to gar = to cause, to make.

Dial. C. (Wks.) 1149 G 7, God ... sendeth him tribulacion betime, whyle he is yet good to gar him ken hys maker.

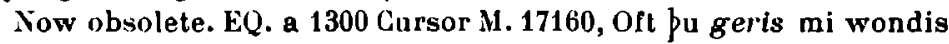

blede. LQ. 1894 Crockett, Lilac Sunb. 68, A dinnle in the elbuck that garred ye loup like a troot.

to garnish $=$ to dress.

Picus 29 A 1, Garnish thy selfe vp in as goodly wise, As comely be. Dial. C. 1220 (Wks.) D 4, ... garnyshed in sylke.

Now obsolete. No quot. in OED anterior to More. LQ. 1566 Painter,

Pal. Pleas. I 55, Ephestion ... repaired vnto him with garments to garnishe him like a king.

to giue $=$ to misgive.

Apol. (Wks.) $863 \mathrm{~B}$, theyr owne conscience giueth them that they shall finde their opinions plainely proued false.

Now obsolete. EQ. $\left.1297^{1}\right)$; LQ. 1748 (1820).

to $g$ lose = to discourse upon, to expound.

Dial. Her. 283 A 11, he glosed ... his wordes with a better sense. Conf. Tynd. 660 A 10.

Now obsolete. EQ. 1362 ; LQ. (arch.) 1820.

1) Economy of space being imposed by war restriclions, the citing in full of the instances in OED has been forgone from here onward except when especially necessary. 
to go by (a thing) = to be associated with; to be concomitant of.

Dial. Her. $194 \mathrm{E} \mathrm{3,} \mathrm{the} \mathrm{harme} \mathrm{that} \mathrm{goeth} \mathrm{by} \mathrm{goinge} \mathrm{of} \mathrm{pylgrimages...}$

Now to go with. Not in OED. Cp. walk with.

to go in hand (with) = to proceed (with).

Passion 1323 G 11, our Sauiour ... went in hande wyth the instituting...

Now obsolete. No quotation in OED anlerior to More. LQ. 1639.

to grisp = to grasp; to grope.

Conf. Tynd. 553 B 6, He grisped and ... felt about ... in the darke.

Now obsolete. EQ. c 1420.

to be grounded in $=$ to be established in.

lnstr. 1421 D 15, folk, as are so grounded in charitye, and so laste cleaue to God, that...

Now obsolete. EQ. 1423. LQ. (with in, exc. grounded in years) 1535.

to hary = to drag.

Rich. 69 B 4, But Sir James Tirel dyed at Tower hill, beheaded for treason. King Richarde himselfe as je shal berafter here, slain in the fielde, hacked and hewed of his enemies handes, haryed on horsebacke dead, his here in despite torn and togged lyke a cur dogge.

Now obsolete. EQ. 13...; LQ. 1624.

to haunse $=$ to elevate.

Dial. C. 331, they will agree to be ... haunsed $v p p e$ in Leauen, and be with god by and by.

Now obsolete. EQ. 1303 ; LQ. 1583.

Haue all to the deuill.

Dial. C. 1174 (Wks.) F 2, They tell of one that was wonte all waye to saye that al the while he liued he would dooe what he luste: for three woordes when hce died shoulde make all saue ynough : but than so happed it, that long ere hee were olde, his horse once stoumbled vppon a broken bridge, and as hee laboured to recouer hym, when he saw it woulde not bee, but downe into the noude headlonge nedes he shoulde: in a sodein flight be cried out in the falling, have all to the deull.

Compare OED s. v. have, v. B $14 \mathrm{~b}$ : " The imperative is used absol. in the sense 'Here !', 'lake this !' Now dial. Have to, towards, used in drinking to any one $=$ here's to arch. » There is only one quot. with have to : 1596 Shaks., Tam. Shr. v, ii, 37, Petr., Spoke like an Officer : ha to the(e) lad. [Stage-direct.] Drinkes to Hortentio.

Haue at you! is used by More in Cont. Tynd. $768 \mathrm{C} 10$.

to hawk after = to hunt after.

Picus 15 A 11, all the aduauntage that ye hawke after...

Now obsolete. No earlier quot. LQ. 1720.

to hawse = to raise ; to exalt.

Rich. 62 B 5, Euery thing was hasesed abous the mesure : amercementes turned into fines, fines into raunsomes.

Now obsolete. EQ. c 1500. LQ. 1600. 
to head $=$ to decapitate ; to behead (a person).

Some Lett. 330, the reasonablenes or the unreasonableness in byndyng a man to precyse aunswere, standeth not in the respect or difference belwene headdyng and burning; but because of the difference in charge of conscience, the difference standeth betwene heading and hel.

Now obsolete. EQ. a 1300 ; LQ. 1608-33.

to hear an incling $=$ to hear a rumour.

Apol. 881 (Wks.) E 4, the tother had heard an incling whiche yet he belieued not.

This phrase is now obsolete, except dial. EQ. a 1400-50.

To have an inkling (=a slight intimation) occurs in Dial. Her. $191 \mathrm{~A} 3$ and Hich. $38 \mathrm{~B} 1$.

to hold onder (one's hand) $=$ to hold (one's hand) under (a thing, etc.) to prevent it from falling.

Dial. C. 200, iustus si ceciderit non callidetur, quia dominus supponit manum suam. The iuste man though he fal, shal not be broosed, for our Lord holdeth onder his hand.

Not in Pres. D. Eng. Not rucorded in OED. EQ. of suppone in this meaning is dated 1611 ; of suppose 1608.

to illude = to trick ; to impose upon.

Boke of F. p. 2 B 3, Cast up thyne eye, and loke how slipper chaunce, Illudeth ber men with chaunge and varyaunce.

Now rare. EQ. 1447.

to impugn $=$ to oppose.

Rich. 39 A 5, eche laboureth to breake that the other maketh, and for hatred of ech of others parson, impugneth eche others counsayle.

Now obsolete. EQ. 1577 ; LQ. 1660.

Note : to impugn = to attack, to assault occurs much earlier (1382).

to in = to reclaim.

Dial. Her. 278 A 12, the landes Inned by diuers owners in the Isle of tenate.

Now obsolete, exc. dial. EQ. 11...; I.Q. 1640.

to inculk $=$ to inculcate.

Debell. 938 F 3, But then laboreth he ... to make the brethern angrye wyth me, and reherseth and inculketh into theyr eares, that I exhorte both the spiritualty and the temporalty to... | Dial. Her. 221 F 15, 280 B 6.

Now obsolete. No quot. in OED anterior to More. LQ. 1576.

to indite $=$ to dictate ; to inspire.

Dial. Her. 156 D 15, the very straunge familiar fassyon therof, may ... well declare, that as it [scil. holy scripture] was wryten by men, so was indiled by god.

Now obsolete. EQ. c 1374 ; LQ. 1815.

to induce $=a$ ) to send for ; to bring in.

Dial. C. (Wks.) $1196 \mathrm{H} \mathrm{12,} \mathrm{S.} \mathrm{James} \mathrm{exhorteth} \mathrm{men} \mathrm{that} \mathrm{they} \mathrm{shall} \mathrm{in}$ their bodely sickenes induce the priestes.

Now obsolete. No earlier quot. in OED. LQ. a 1652. 
to induce $=$ b) to institute.

Answer $1044 \mathrm{~F} 2$, Vpon the occasion of this myracle ... of these fiue loues ..., he tooke his beginning to induce therupon the feast that be would in this world leue perpetually with his church.

Now obsolete. (EQ. 1401 ; LQ. 1836).

to induce $=\mathrm{c}$ ) to initiate.

Passion 1330 A 2, inducyng them into the communyon of the Sacramentes.

Now obsolete. FQ. 1490 ; LQ. 1561.

to infame = to brand with infamy.

Dial. (Wks.) $1206 \mathrm{E} \mathrm{3}$, all whiche whole company wer aroong the people sore infamed of rauin, extorcion, and bryberye.

Now archaic. EQ. 1413.

to infownd = to pour ; to infuse.

Rich. $60 \mathrm{G} \mathrm{3,} \mathrm{he} \mathrm{had} \mathrm{shewed} \mathrm{the} \mathrm{great} \mathrm{grace} \mathrm{that} \mathrm{god} \mathrm{giueth} \mathrm{\&} \mathrm{secretly}$ infowndeth in right generacion after the lawes of matrimony. Conf. Tynd. 383 E 5.

Now obsolete. EQ. c 1420 ; LQ. 1589.

to instruct (a thing) $=$ to teach (a thing).

Conf. Tynd. 583 C 6 , the poyntes of the faylh are not... in such wise shewed, nor the witte in them so thorowlye and so clearly instructed, but that the thing ... may ... be perfited and made $v p$.

Now obsolete. EQ. 1623 ; LQ. 1670.

to insimulate $=$ to charge ; to accuse.

Conf. Tynd. 340 A 15, These ... heretikes haue of longe whyle neither letted, nor ccased, falsly to insimulate \& accuse the churche of god.

Now obsolete. No quot. anterior to More. LQ. 1663.

to insumate $=$ to inspire; to infuse.

Dial. Her. 160 B 1 , he tempereth his reuelacions, \& in such wise dothe insumate \& inspire them in to the brestes of bis christen people, that...

Not in OED. Probably a misprint for insinuate.

to interlace $=$ to introduce as by interweaving.

Cont. Tynd. 739, 2, His goodly doctrine interlaced here and there by the waye. | Answer $1039 \mathrm{H} 7$, diuers false heresies interlaced therin.

Now obsolete. No quot. in OFD anterior to More. LQ. a 1677.

to intryke $=$ to entangle.

Debell. $1001 \mathrm{H} \mathrm{8,} \mathrm{Those} \mathrm{shrewes} \mathrm{haue} \mathrm{holpe} \mathrm{hym} \mathrm{to} \mathrm{...} \mathrm{intryke} \mathrm{the}$ matter. Dial. Her. 141 E 14.

Now obsolete. EQ. 1393 ; LQ. 1549.

to irrite, see to yrryte.

to iudge (to the death) $=$ to condemn (to death).

Rich. 37 B 12, attainted was hee by parliament, and iudged to the death.

Now obsolete. EQ. c 1310 ; LQ. 1675. 
to keep a person (a) promise.

Dial. G. (Wks.) $1230 \mathrm{~F} \mathrm{1,} \mathrm{The} \mathrm{Turke} \mathrm{kepe} \mathrm{you} \mathrm{promise} \mathrm{in} \mathrm{letting} \mathrm{you}$ kepe your substaunce.

Not in Pres. D. Eng. OED does not record this idiom.

to keep scholes = to engage in academic disputation.

Debell. $949 \mathrm{E} \mathrm{12,} \mathrm{We} \mathrm{wyl} \mathrm{in} \mathrm{this} \mathrm{malter} \mathrm{keepe} \mathrm{no} \mathrm{longe} \mathrm{scholes.} \mathrm{|} \mathrm{Dial.}$ Her. $225 \mathrm{~A} 1$, in thys pointe wyll I kepe no scholes with you.

Now obsolete. EQ. (with holde instead of keep) c 1460 ; LQ. 1567.

to knowlege = to recognize.

Dial. Her. 149 A 8, ye also knowlege this matter to be such... / Conf. Tynd. 615 D 6, al these nacions... recognised and knowledged the Pope, not as the byshop of Rome...

Now obsolete. EQ. c 1230 ; LQ. 1643.

No quot. in OED with knowledge as.

to labour to a person = to exert one's influence to obtain something desired.

Apol. (Wks.) $800 \mathrm{E} \mathrm{4}$, If I desired a manne to geue me a thynge, and laboured muche to hym therefore...

Now obsolete. EQ. ? 1475; LQ. 1577-87.

to labour = to work at laboriously ; to apply oneself to.

Picus 2 H 9, Vnder the ... gouernance of his mother he was set to masters, and to lerning : where with so ardent minde ho-labored the studies of humanilee, that ...

Now almost exclusively in : to labour a point, a question and similar expressions. EQ. c 1449.

to lack nothing of (a person) = to be as bad as.

Dial. Her. $257 \mathrm{E}$ 11, [Tindall] hatbe sinse by .Il. olher bookes openly shewed himselfe to lacke nothing of Luther, but that he hath not yet maried a nunne.

Now obsolete. Not mentioned in OED.

to lash onl = a) to lavish ; to squander.

Aich. 62 A 7, there was dayly pilled fro good men \& honest, gret substaunce of goodes to be lashed oute among vnthriftes.

Now obsolete. No earlier quotations in OED. LQ. 1657.

to lash out $=\mathrm{b}$ ) to pour out or forth impetuously (words). Dial. Her. 287 B 8, Colis ... lasheth out scripture in bedelem as fast as they bothe in Almayn.

Now obsolete. No earlier quotations in OED. LQ. 1653.

to lay in (a person's) light = to bring as an objection against. Dial. Her. $252 \mathrm{~A} 4$, he could shewe a fayre law incorporate in the decrees of the church, which law if it wer laied in their light..., would make all theyr eyen dase.

No oller quotations in OED [s, v. light (noun)].

to lay the wite (un) to = to blame.

Dial. Her. $273 \mathrm{E} \mathrm{3,} \mathrm{so} \mathrm{vntrowe} \mathrm{that} \mathrm{he} \mathrm{shouldo} \mathrm{lay} \mathrm{onto} \mathrm{se} \mathrm{the} \mathrm{wite} \mathrm{and}$ 
blame of his own faultes. | Dial. Her. 274 D 8, Our mother Eue layd the wit of her sinne to the serpent.

Now obsolete, exc. Sc. and north dial, EQ. (with wite only) a 1225 ;

LQ. 1886. Ct. to put in the wight.

to learn = to teach; to impart knowledge.

Dial. Her. 157 is 8, Wherein god wold that we were lerned ... to anffer our sensuall parties plaine and mourne...

Now vulgar. EQ. a 1300.

to let = to quit ; to abandon.

Dial. C. (Wks.) 1252 A 1, [il...] ther wer on the tone side of the way a rable of ragged beggers ... that wold despyse ... you ... would gou let your way ... Ior the shameful iestyng?

Now obsolele. EQ. a 1200 ; LQ. 1559.

to let(te) $=$ to hinder ; to prevent.

Last Th. $87 \mathrm{G} 12$, While lue rote remayneth, while we cut of the braunches, we lette wel the browyng and kepe it somwhat inder. Rich. 58 D 7. Picus 10 F 7.

Now archaic. EQ. c 888.

to linger = to keep (a person) waiting.

Lett. $1429 \mathrm{C} \mathrm{6}$, They were not lingered nor made to daunce any long attendance ... as sutours were sometimes wont to be.

Now obsolete. The above quot. from Nore is the earliest in OED.

LQ. 1606.

to list (a thing) $=$ to desire or wish for.

Gonf. Tynd. 821 G 6, freedome to do what they lyst, for they cen list no thing but as the spirit leadeth them.

Now obsolcte. EQ. 1545 ; LQ. 1587.

to look = to expect.

Rich. 62 B 9, I thinke no man loketh that we should remembre you of

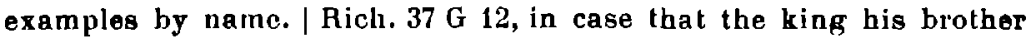
(whose lite hee looked that euil dyete shoulde shorten) shoulde happen to decease.

Now obsolete with clause. No quot. in OED anterior to More. LQ. 1657.

to make = to translate; to render.

Dial. Her. $233 \mathrm{E} 12$, the clergie hath not forboden the byble to bee made and readde in englishe.

Now obsolete. No earlier quot. in OED. LQ. 1612.

to make for $=$ to pretend; to assert.

Last Th. $72 \mathrm{H} \mathrm{6,} \mathrm{This} \mathrm{medicyne} \mathrm{thoughe} \mathrm{thou} \mathrm{make} \mathrm{a} \mathrm{sowre} \mathrm{face} \mathrm{at} \mathrm{it,}$ is not so bytter as thou makeste for. | Dial. Her. 222 A 1, Whyther Luthers matters bee so madde as they bee made for, that shall we see hereafter.

Now obsolete. Neither earlier nor later quolations in OED. 
to makes meanes to $=$ to negociate with.

Dial. C. (Wks.) 1188 B 13, And yet hadde she larther deuised, that another sum of money should after be sent to Rome, and there shuld bo meanes made to the Pope.

Now obsolete. No quot. before 1535 in OED. LQ. 1656.

to make (a person) of one's consayle $=$ to take (one) into confidence; to make privy to.

I)ial. (. (Wks.) 1187 II 14, yet are there some ..., that ... fynde some yet whom their hart serueth them to make of theyr counsuyle therin. ! Dial. C. (Wks.) 1188 A 12, And on a tyme sliee made of her counsayle a poore neighbour of her's. | Dial. C. (IVks.) $1188 \mathrm{~F}, 2$, here she lelled not ... to make one of her consayle yet.

Not recorded in OED (nearest s. v. counsel, sb. 6).

to malign = to regard with hatred.

Mich. 37 13 1, the Quecne and the Lordes of her bloode whiche highlye maligned the kynges kinred (as women commonly not of nalice but of nature hate them whom theire housebandes loue).

Now obsolete. No earlier quot. in OED. LQ. 1667.

to $m a r k=$ to notice.

Last Th. 87 I) 6, I3y which though we marke it not, yet in dede we recken our selfe worthy more reucrence than we do god himself only.

Now poetical. EQ. 1377.

to match with = to join in companionship.

Dial. C. (Wks.) 1209 B 3, when god hath by suche chaunce sent hym to me, and there once malched me with hym, I recken my self surely charged with him.

Now obsolete. FQ. c 1470 ; LQ. 1615.

to meek oneself $=$ to humble oneself.

Apol. (Wks.) 879 A 1, tyll you meeke your selfe and amende ..., thys anger of your husband will neuer be well appeased.

Now obsolele. FQ. 1200 ; LQ. 1563-83.

to meet with $=$ to oppose; to take precaulions against. Dial. Her. 284 II 13, all this ... woulde a fewe mischieuous persons ... bring into thys realme, if the prince and prelates ... did not in the beginnyng mete with their malice.

Now obsolele. No earlier quolations in OED. LQ. 1712.

to meruayle (a thing) = to wonder at.

Picus 12 F 16, There holdell me sometyme... a swone ... when $I$ begin in my self, I not never whelher I shall say, to remember, or to sorowe, to meruayle or to bewayle the appetites of men.

Now obsolete. FQ. 1382 ; LQ. 1819.

to meryt = to earn.

Dial. (WVks.) 1175 H 6, hys onelye Passion meryteth incomparable more for vs, than all our owne dedes dooe.

Still current. EQ. 1543. 
to $\operatorname{mind}=$ to have in view ; to contemplate; to intend.

Rich. 49 (46) G 13, if she double leste hee miglite bee felched from her, is it not likelye ynoughe that she shall sende him somme wbere out of the realme? Verely I looke for none other. And I doubte not but shee nowe as sore myndeth it, as wee the lelte thereof.

Now obsolete. IQ. 1513 ; I.Q. 1691.

to minish $=$ to decry the importance of.

Last Th. $87 \mathrm{E} 10$, could we ... be more moued with the minishyng of our own worship than gods,... if we dyd not in dede sette more by our self than him?

Now archaic. EQ. 1402.

to miscast $=$ to mislay.

Dial. Her. 130 H 14, some sely woman seking saint Sythe when she segliyth for miscasting of her kayes.

Now obsolete, exc. dial. OED has only one quot., dated 1600.

to mischief $=$ to inflict injury upon.

Debell. 971 B 11, he wil of lykelihode hale \& mischief any man by whome he taketh any harme.

Now archaic. EQ. 1483.

misordered = of disorderly behaviour; ill-conducted.

Dial. Ifer. 274 B 3, Where were become al good ordre anong men, if euery misordred wretche myght alledgre that his mischieuous dede was his desteny?

The verb to misorder is now obsolete. No earlier quotations in OED. LQ. 1605.

to misreport $=$ to speak ill of, to slander.

Dial. C. (Wks.) 1209 H 10, leste he should geue other folke occasion to ... misreporte him for an hypocryte.

Now obsolete. No earlier quotations in OED. LQ. 1625.

to misse of $=$ to fail to obtain.

Dial. Her. 282 F. 15, [the devil] often times makes them misse of the vayn prayse, whereof onely they be so prowde.

Now obsolete or archaic. EQ. a 1250 ; LQ. 1868.

to $\operatorname{mis}($ se)content $=$ to displease.

Jest P. $2 \mathrm{C} \mathrm{3,He} \mathrm{rought} \mathrm{not} \mathrm{what} \mathrm{he} \mathrm{spent,...} \mathrm{As} \mathrm{for} \mathrm{the} \mathrm{price,} \mathrm{Could}$ him not miscontent.

Now obsolete. EQ. 1498-9; LQ. 1611.

to misse rehearse $=$ to misquote.

Apol. (Wks.) 846 F 5, loth woulde I be to mysse rehearse anye mannes reason against whom I write. | Debell. 931 A 5 , The man ... hath misse rehearsed them to make the reader wene, that I hadde written wronge.

Now obsolete. OED has neither earlier nor later quotations.

Misrehearsal, however, is quoted more frequently (earliest 1472

lalest 1631). 
to misse say = to speak evil of.

Debell. 936 G 15, I say in those places that the pacifyer misse saieth the people.

Now archaic. EQ. a 1225.

to moder $=$ to regulate; to setlle.

Apol. 87, yf this pacylyer wolde moder \& measure his suffycyencye by the wordes of saynte Poule...

Now obsolete. EQ. (1414) 1495 ; LQ. 1534.

to mortisie = to alienate in mortmain.

Debell. 913 G 9, it wolde be ... profilable to the realme, that the lordes had the landes whose auncestors had mortisied them.

Now obsolele. EQ. c 1380 ; LQ. 1546.

to mow $=$ to deride.

Conf. Tynd. 398 C. 11, witl mocking \& mowing and potting the sacramentes.

Now obsolete. EQ. 1450. The oller quotalions illustrate the sub-

jective to mow, and to mow with.

mysruled = disorderly; lawless.

Conf. Tynd. $777 \mathrm{G} 5$, Agaynst murderers \& theues and against al other mysiruled persones.

To misrale (oneself) is now obsolete, exc. arch. EQ. a 1400 ; LQ. 1563.

to mysse gess = to guess wrongly.

Debell. $976 \mathrm{~F} \mathrm{3}$, he inysse gesseth amongre and weneth it were one, whore in dede it was another.

Now obsolele. No earlier quotations in OEDl). LQ. 1665.

to mysse take oneself $=$ to $\sin$; to do vrong.

Apol. (Wks.) 889 I) 4, those that haue mysse taken themself. I Apol. 104, [they] did not mysse take them selfe at all.

Now olssolete. EQ. c 1330 ; LQ. a 1425.

to mysse wrest $=$ to pervert (the meaning of).

Cont. Tynd. 501 H 10, The heretikes wrested \& misse construed the scripture (as we see that these heretikes much more mysse wrest it nowe).

Now obsolete. EQ. a 1400 ; LQ. 1583.

to muse ont (one's brains) = to rack (one's br.) to excess.

Conf. Tynd. $376 \mathrm{G} 13$, the verye cuuses ... he coulde not haue founden though he would haue mused out his brayn.

Not in OED.

to name oneself $=$ to pretend to be.

Aut. Lett. vı. 55, a simple person an almaigne naming hym selfe seruant vnto the Kinges grace.

Now obsolete. This reflexive use of to name is not recorded in OED.

to necessitate $=$ to compel.

Conf. Tynd. 588 B 8, the will of man wer... ineuitably necessitat by the eternal reprobacion.

Now chiefly Amer. or Sc. No quot. in OED anterior to More.

LQ. 1628 . 
to nosel = to impose upon; to deceive.

Apol. (Wka.) 849 G 2, to the entent that by those woordes changed, the people shold be noseled.

Now obsolete. OFI has no quot. before the latter part of the 17th century (c 1680). L.Q. 1705.

to nowsel = to train, to educate.

Conl. Tynd. 587 B 3, Some be so sore nowseled in the false heresies, that finally thei die therin.

Now obsolete. EQ. a 1519 ; LQ. 1669.

to noy $=$ to harm.

Passion 1348 H 17, And not oner that it nothing auaileth, but ouer that it sore noyeth and hurteth.

Now obsolete. EQ. a 1300 ; LQ, 1602.

to obiect $=$ to place before the eyes.

Dial. C. (IVks.) 1249 B 7, The bodily senses, moned by such thinges ... as are ... oltred $\&$ obiected vnto them.

Now obsolete or archaic. No quot. in OED anterior to More.

to obtein $=$ to preserve in existence.

Dial. Her. 283 C 14, Which thing had vndoubledly nener been obteined among the people ... if god had not broughte it vp hymselfe.

Now obsolete. No quot. anterior to More. LQ. 1565.

to occupy = to put to use ; to use.

Last Th. 91 I 3 , Whereof riseth thys hygh follye, but of the blynde couetous afrecion that he had to that he lost. If he had had it styll, yet he wold peraduenture not haue occupied it.

Now obsolete. EQ. c 1425; I.Q. 1774.

to offer oneself $=$ to present oneself.

Aut. Lelt. v 25, after that his grace was cummen home hither and had dyned ... I offred myselfe agayne to his grace in his awne chambre.

Not in OED.

to open = to expound; to explain.

Answer 1044 A 4, the morr strauge the things wer, the more he opened theim wyth wordes.

Now obsolete or archaic. $\mathrm{EQ}$. c 1200.

to ordain $=$ to destine (to a lot or fate).

Conf. Tynd. $582 \mathrm{H} \mathrm{14}$, he wyll not utterly take awaye the merite fro manne, for as muche as he hath ordayned him to ioy by the meane of some merite.

Now obsolete. EQ. a 1300 ; LQ. 1508.

to order = to treat ; to deal with ; to manage.

Hich. $49 \mathrm{C} \mathrm{12}$, Yet is there none that ... knoweth better how to order him, then I that so long have kept him.

Now obsolele. No earlier quot. in OED. LQ. 1799.

to ouercast $=$ to overthrow ; to upset.

Jest p. 1 H 11, lest sum blast, might ouer cast, His ship, ... He made a good puruay.

Now obsolete. EQ. a 1225. Still found in dialects. 
to onerloke $=$ to look down upon (with contempt).

Last Th. 81 A 5, but he that ouerloketh euery man ... he shal w(ith)in a lew yeres, ... whan deth arrestelh him, haue his deinty body lurned into stinking carien.

Now obsolete. EQ. 1399 ; LQ. 1794.

to ouersearch $=$ to examine thoroughly.

Conf. Tynd. $423 \mathrm{~F} 8$, when I had ouersearched all my booke, and ransaked vp the verie bottom of my brest.

Now obsolete. OED has only one otber inslance (1590).

to ouersee oneself = to fail to perceive; to make a mistake. Dial. Her. 145 H 7, [they] cannot well come thereon, but misse and ouersee themselfe in the assaye. | Dial. Her. $255 \mathrm{C} 2$.

Now obsolete. EQ. 1377 ; LQ. a 1677.

to ouersey $=$ to consider.

Picus 7 F 8 , Neuerthelesse, that mynde of his ... coulde neuer let down it selfe to the consideracion \& ouerseying of these base ... erluly trifles.

Now obsolete. The only instance in OED is daled c 1477.

to ouercype = to wipe away.

Conf. Tynd. 797 G 9, Those synnes onely whiche are with the pencel of daily prayer ouerwyped.

Now obsolete. No olher quot. in OED.

to pass = to reck ; to care.

Passion 1359 H 6, suppose thou woldest vnreuerently, as one that carelessly passed nol what he did, tel thy tale vnlo him... | Passion 1359 D 10, we litle passe how smal deuocion of hart we com to pray withal.

Now obsolete. EQ. 1549 ; LQ. 1633.

to pass (money) $=$ to spend (money).

Dial. C. (Wks.) 1184 C 4, [he] neuer vsed ... to passe vpon himselfe the valure of six pence at a meale.

Not in OED.

to perswade $=$ to demonstrate.

Picus 7 A 3, This waies he perswaded, that to a philosopher ... it was no praise to gather richesse, but to refuse them.

Now obsolete or archaic. EQ. 1528 ; LQ. 1685.

to peruse $=$ a) to consider in detail.

Picus 1 E 3, of whose conning ... we nede here nothing to speake : for as much as hereafter we peruse the course of his whole life.

Now archaic. EQ. 1533.

to pertse $=$ b) to go through (a book) critically; to criticize. Answer $1039 \mathrm{H} \mathrm{2,} \mathrm{I} \mathrm{wyll} \mathrm{good} \mathrm{reader} \mathrm{peruse} \mathrm{the} \mathrm{remanant} \mathrm{of} \mathrm{his} \mathrm{booke}$ after this first part answered. | Ibid. $1078 \mathrm{~B} 3$.

Now archaic. No earlier quot. in OED. LQ. 1551.

to peruse $=$ c) to name.

Dial. C. (Wks.) $1154 \mathrm{C} \mathrm{11}$, It were a long worke to peruse euery comforte that a man maye well take of tribulacion.

Now obsolete. No quot. in OED anterior to More. LQ. c 1550. 
to pil $=$ a) to rob.

Hich. $37 \mathrm{E} \mathrm{11,} \mathrm{for} \mathrm{whiche} \mathrm{hee} \mathrm{was} \mathrm{fain} \mathrm{to} \mathrm{pil} \mathrm{and} \mathrm{spoyle} \mathrm{in} \mathrm{other} \mathrm{places.}$

Now obsolete. EQ. c 1330 ; LQ. 1678.

to pil $=$ b) to pluck.

Dial. Her. 238 B 6, a tale that fleeth thorowe manye mouthes, catcheth manyo newe fethers: which, whan they be pulled away ggayn, leaue him as pilled as a coote.

Now obsolete. OED has no quotations in which to pill is said of feathers.

to plant $=$ to write down.

Aut. Lelt. $v$ 60, Which consideration his grace wold haue planted in to thinstructions with his awne hand saving that he saied yor grace could \& so he requyreth you to do bettre furnish hit \& set hit forth.

Now obsolete. Not in OED.

to plete = to argue ; to dispute upon.

Dial. Her. $158 \mathrm{~B} \mathrm{9,} \mathrm{They} \mathrm{...} \mathrm{that} \mathrm{longed} \mathrm{to} \mathrm{lerne} \mathrm{the} \mathrm{lawe.} \mathrm{Not} \mathrm{to} \mathrm{plete}$ it and for glory to dispule it, but teche it agayne mekely. Also : Dial. Her. 181 A 11 (pleate).

Now obsolele. EQ. 1362 ; LQ. 1577.

to ponder $=$ to ascerlain the weight of (fig.).

Picus 32 I) 4, If thou shouldest onr sinne ponder and waye : who able were to beare thy punishment?

Now obsolete. EQ. o. 1470 ; LQ. 1645.

to porr = to prod ; to poke.

Conf. Tynd. $432 \mathrm{~F} \mathrm{2,} \mathrm{He} \mathrm{...} \mathrm{gyrneth} \mathrm{as} \mathrm{a} \mathrm{dogge} \mathrm{dooell} \mathrm{when} \mathrm{one} \mathrm{porreth}$ hym in the teeth with a stycke.

Now only dial. EQ. a 1400-50.

to $p o t=$ to mock.

Conf. Tynd. $398 \subset 11$, with mocking \& moving and potting the sacramentes.

Now obsolete. EQ. 1549 ; LQ. 1596.

to praise = to set a price or value upon; to value.

Dial. C. (IVks.) 1185 B 6, My conscience can not serue me ... to praise her call aboue twoo pence.

Now obsolete or dial. EQ. 13...; LQ. 1713.

to precide = to cut off.

Dial. Her. 143 E 13, The hole congregacion of christen people professing his name \& his taylh, \& abiding in the hody of the same, not being precided \& cut of.

Now obsolete. OliD has no quot. anterior to the above. LQ. 1657.

to pretend $=$ a) to state as true ; b) to report.

Rich. $67 \mathrm{D} \mathrm{16}$, all thynges wer in late daies so couertly demeaned, one thing pretended and an other ment, that there was nothing so plaine and openly proued, but ... men had it euer inwardely ouspect. | Rich. 
69 I) 6, Thoccasion wheruppon the King and Duke fell out, is of diuerse lolk dinerse wyse pretended.

(C., Rich. $69 \mathrm{G} \mathrm{6}$, and surely the occasion of theyr variaunce is of diuers men diuersly reported).

Now obsolete. EQ. (same meaning ?) 1587.

to prenent $=$ to forestall.

Hich. $36 \mathrm{H} \mathrm{7,} \mathrm{the} \mathrm{Duke} \mathrm{not} \mathrm{endurynge} \mathrm{so} \mathrm{longe} \mathrm{to} \mathrm{tarye,} \mathrm{but} \mathrm{entendynge}$ to preuente his time,...

Now obsolete. EQ. 1432-50; LQ. 1813.

to procure = to prevail upon; to induce.

Dial. C. 194, thei wayled and dydde paynefull penaunce for their synne to procure god to pilie them. | Hich. $53 \mathrm{~F} 7$.

Now obsolete or archaic. EQ. 1340-70.

to propone = to propound ; to set forth.

Dial. C. 280, Whan that probleme was once proponed, till it was full aunswered, no manne eate one morsel of meate more. I Answer 1044 B 3, Our Sauiour used in the proponing thetof unto them diuers waies.

Now obsolete, exc. Sc. EQ. c 1375 ; LQ. 1683.

to proroge $=$ to prolong ; to lengthen.

Picus $9 \mathrm{~F} f$, if he might haue had the space of his life proroged :...

Now obsolete. EQ. 1425 ; LQ. 1878.

to prone $=$ a) to show ... to be in the right.

A pol. 4, I promysed they saye in my preface of my confutacion, that I wold prove the chyrche, and that they say I haue not done.

This meaning of prose is not recorded in OED.

to proue $=\mathrm{b}$ ) to put to the test.

Last. Th. 74 C 12, we list not once prone, what maner of swetenes good and vertuous folke fele. | Dial. C. 227, neuer find we that God proued any mannes obedient mynde, by the commaundemente of bis owne slaughter of himselfe. | Dial. C 221, nolite omni spiritui credere, sed probate spiritus si ex deo sint : geve not credence to euery spirit, but proue the spirits whyther they be of God.

Now archaic. EQ. 1297. It is the prevailing use in the Bible of 1611 and relained in the Rev. V. 1881-85.

to proue = c) to experience ; to learn.

Dial. C. (Wks.) 1157 A 6 , thys we tynd at our iye, and euery day we proue it by playne experience.

Now archaic. EQ. c 1175.

to prowle (uppon) $=$ to look at or study.

Picus 29 A 3, I meane not herehy, that thou shouldest arise, And in the glasse oppon thy body prowle.

Now obsolele. This exact meaning is not given in OED (perhaps, s. v. prowl $n^{0} 3$ ). The still current meuning of to prowl about $=$ to wander about in search of plunder or prey occurs in the following cquot. : Dial. C. 212, It happed hym than as he walked prolling for his geare about : he came... 
to pulpet $=$ to provide with a pulpit.

Dial. Her. 151 B 12, yet would thei long to be pulpeted.

No earlier quot. in OED. The verb is still used.

to purpense = to premeditate.

Dial. Her. 238 F 4, In such a wilfull purpensed haynous cruell dede.

Now obsolete. KQ. 1436 ; LQ. 1548.

to purpose $=$ to propose.

Rich. 65 E 5, [the proteclor] gaue hym leaue to purpose what hym lyked. I Picus 3 D 10, and there... Ix.C. questions he purposed.

Now obsolete. EQ. 1382 ; LQ. 1633.

to purpose upon $=$ to resolve to do.

Dial. C. 222, For whych he is so ioyful, that he fyrmely purposeth opon it.

Now obsolete. FQ. 1574. This is also the latest quot.

to puruay $=$ to bring about.

Picus 30 A 5, For certes who so list, he inay paruay, Though all the wordle woulde him therefro bereuen, To beare his body in earth, his minde in beuen.

Now obsolete. EQ. (1330); LQ. 1604.

to put case $=$ to propound a lypothetical instance.

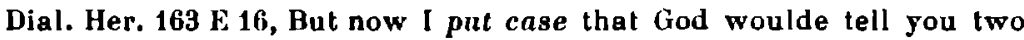
thinges. I Lial. Her. 191 A 2.

$\mathrm{EQ}$. a 1420. Now to put the case.

to put in the wight = to blame.

Rich. $41 \mathrm{C} 12$, all the worlde woulde pnt her and her kinred in the wyght, and say that thei had ... broken the amitie and peace.

Now obsolete, exc. Sc. and nortb. dial. Cr. to lay the wite to.

to put out (children) = to place away from home under the care of some one.

Answer $1114 \mathrm{~B} \mathrm{3}$, The lathers \& the mothers oftentymes put out their children to other folke to nurse.

Still current. FQ. (with put out) 1602. Of to put to nurse (without out) the earliest quot. in OFD is 1593 Shaks. 2 Henr. VI, Iv, ii, 150,

The elder of them being put to nurse, Was ... stolne away.

to put oser = to defer ; to postpone.

Ant. Lett. v 14, he was content to signe the lettres to theymperor... putting over all the remanaunt t(ill this) day in the mornyng.

Now obsolete. EQ. 1528 ; LQ. 1828.

to pyne = to aflict with pain; to torment.

Dial. C. (Wks.) $1260 \mathrm{G} 2$, in suche turment ... [he] suffred to be pyned and payned the space of more then three long bowres.

Now obsolete. FQ. c 893 ; LQ. 1876.

to $q u a y l=$ to destroy.

A pol. 25, Al this chyldesh reason ... whyche he bringeth out of Tyndales chapyter, and fathereth yt uppon saynt James, is ... clene quayled in the trauayle and utterly borne dede. Also 53 E 8 ; 61 C 10 ; 805 (Wrs.) E 8.

Now obsolete. No earlier quot. in OED. LQ. 1654. 
to quethe; quod = to speak ; said.

Dial. Her. 131 E 14, There was in the paryshe ... a man and a woman whiche are yet quicke and quething (= alive).

Jest p. 2 G 12, I feare quod he, It wyll not be, | Hich. 38 A 7, By my trouthe manne quod Pottier then wyll my mayster the Duke ... beo kynge.

Now obsolete, archaic or dial. EQ. c 1200.

to race (said of boars) = to slash with the tusks.

Aich. 54 H 3, a dreme, in which him thoughte that a bore with his tuskes so raced them both bi the heddes, that the blood ranne aboute both their shoulders.

Now obsolete. OED bas only one quot., dated 1470-85.

to ray = to bespatter with dirt ; to dirly.

Conf. Tynd. 614 D 5, I ... shall shew you shortly how angrely he ryseth $\mathrm{vp}$, and royally rayed in dyrte.

Now obsolete. EQ. 1526 ; LQ. 1663.

to reanswer $=$ to answer; to return.

Ant. Lelt. xvir, 39, ... graciouse favor ... which I can never otherwise reanswere than wilh my pore prayor.

Now obsolete. No quot. anterior to More. LQ. 1589.

to re(a)re (terroure) = lo bring about.

Dial. C. (Wks.) 1218 F $5, \ldots$ the causes of terroure and dread ..., whiche .... this mydday deuyll maye ... reare against us to make his incursion with... | Aut. Lett. $x x, 23$, lue ... puttell all his possible power to procure theire destruction and to rere broilerie warre and reuolution.

Now obsolete. EQ. a 900 ; LQ. 1590.

to reason (a thing) for = to maintain that it is...

Conf. Tynd. 562 A 11, Tindall ... maketh mocks and mowes at that blessed sacrament, ... \& reasoneth it rather for starche full like a starke heretike.

Not in OED.

to rebuke $=$ lo put to shame ; to bring into contempt.

Dial. Her. $228 \mathrm{C} \mathrm{12}$, The order is rebuked by the priestes begging and lewde liuing.

Now obsolete. The above quot. is the only one in OED.

to receiue $=$ to perceive ; to understand.

Rich. $38 \mathrm{E} 2$, heo receiued his naturell strenglhe soo sore enfebled, that hee dyspayred all recouerye.

Now obsolete. EQ. 1603 ; LQ. 1667.

to recomfort $=$ to inspire with fresh courage.

Apol. 24, Agaynste all thys feare this one thynge recomforted me, that...

Now obsolete. HQ. 1375 ; LQ. 1667.

to refer $x$ to offer (as a sacrifice).

Passion 1281 H 9, sacrifices duelye referred to God.

Now obsolete. OED has only one quot., dated 1594. 
to refuse $=$ to avoid ; to keep clear of or free from.

Dial. C. (Wks.) $1207 \mathrm{E} \mathrm{12,} \mathrm{Geue} \mathrm{the} \mathrm{Emperor} \mathrm{those} \mathrm{thinges} \mathrm{that} \mathrm{are} \mathrm{his,}$ refusing al extorsion and bribery beside.

Now obsolele. KQ. 1357 ; LQ. 1691.

to regender $=$ to create afresh.

Apol. 39, the man that ys regendred.

Now obsolete. EQ. c 1400 ; LQ. 1597.

to reherse $=$ a) to cite ; to quote.

Apol. 5, he reherseth myne in euery place faintly and falsely to and leueth out the pyth and the strength.

Now obsolete. EQ. a 1400-50; LQ. 1562.

to reherce $=\mathrm{b}$ ) to say ; to speak ; to utter.

Picus 9 E 6, a sermon, which he reherced in the chiel church of all Florence.

Now obsolete. EQ. $1362 ; \mathrm{LQ} .1567$.

to reioyce $=$ to enjoy ; to feel joy on account of (an event). Passion 1279 C 3, His visitacion thei reioysed not, but were afeard to come nere him.

Now obsolete. EQ. 1303 ; LQ. 1577.

to reken $=$ to mention ; to allege.

Conf. Tynd. $352 \mathrm{D} \mathrm{16}$, Belieue me not if any man can reken a place where euer he lounde it otherwyse.

Now obsolete. EQ. 1513 ; LQ. 1596.

to relent $=$ to dissolve (a thing).

Dial. C. 196, eyther should dreade make us tremble and breake our stony hart, or loue should for sorrow relent it into tears.

Now obsolele. EQ. c 1420 ; LQ. 1661.

to remember $=$ to remind.

Rich. 62 B 9, I thinke no man loketh that we should remembre you of examples by name.

Now archaic or dial. EQ. c 1386.

to renay $=$ to renounce; to abjure.

Dial. C. (Wks.) 1212 B 9, Hee ... geueth ... parte to suche as willinglye will reney their faith. | Dial. Her. 179 A 11 , it was a plaine renaying of Christes faith to doo anye obseruaunce therto.

Now obsolete. EQ. a 1300 ; LQ. 1602.

to repair (a sinner) $=$ to reclaim ; to reform.

Conf. Tynd. 804 F 9, the catholyke faythe, whiche... repaireth penytentes.

Now obsolete. EQ. 1535 ; LQ. 1738.

to reproue (an action) = to express disapproval of.

Dial. C. 210, he prudently reproued that point in hym, and preached him a processe of bys own temperance.

Now rare. EQ. a 1340-70. 
to repry (a prisoner) $=$ to remit for trial.

Debell. 985 A 1, And so lye there... somelyme some for felonye to, repryed vpon causes from one session to another.

Now obsolete. OFI) has the following instance : $15556 \mathrm{~J}$. Hey wood, Spider \& F. xxiv, The faughter ... apealth to be repride, from London to Louane, there to be tride.

to resemble = to compare together.

Debell. 984 B 9, How goeth nowe... thys aunswele of this good man ... touchyng the point that I resemble theim for?

Now obsolete. No quot. in OFD anterior to More. LQ. 1673.

to reserue $=$ a) to make an exception of, or in favour of. Dial. C. (WVks.) 1204 F 9, There be very fow ... reserued also, but that they set theyr heat verye sore theron.

Now obsolete. EQ. 1523 ; LQ. a 1806.

to reserue $=\mathrm{b}$ ) to keep in one's possession.

Apol. (Wks.) 851 B 3, the copye that was deliuered me (which copy I reserue and kepe for my declaracion).

Now obsolete. No earlier quot. in OED. I.Q. 1604.

to resort $=$ to return (to a place).

Last Th. $87 \mathrm{G} \mathrm{3,} \mathrm{The} \mathrm{matter} \mathrm{fayling} \mathrm{that} \mathrm{fed} \mathrm{it} \mathrm{[scil.} \mathrm{the} \mathrm{sore],} \mathrm{which}$ continuallye resorting fro the fountain to the place, men may wel daily purge and clense the sore, but they shal hardely hele it.

Now obsolete. EQ. c 1430 ; LQ. a 152 ?.

to rest $=$ to arrest (a person).

Jest p. $2 \mathrm{G} \mathrm{8,} \mathrm{Take} \mathrm{an} \mathrm{accion} \mathrm{therfore,} \mathrm{I} \mathrm{you} \mathrm{beheste,} \mathrm{I} \mathrm{shall} \mathrm{bym} \mathrm{reste,}$ And than care for no more.

Now obsolete, exc. dial. FQ. c 1470 ; LQ. 1622.

to rest in = comsist in.

Rich. $38 \mathrm{HI}$ 3, Ye se their youthe, of whiche I recken the onely suretie to reste in youre concord.

Now obsolete. No quot. in (OED anterior to More. LQ. 1602.

to retein $=$ to hold back.

Answer 1037 B 1, George Jay hadde made a booke ..., which was as yot ... reteined \& kept from the print.

Now obsolete. EQ. c 1386; LQ. 1737.

to renince $=$ to refute, to disprove.

Pial. Her. 254 G 6, [The king] ... effectually reuinced, and confuted the ... pestilent boke of Luther.

Now obsolete. No earlier quot. in OED. LQ. 1686.

to right $=$ to correct or amend (a person).

Dial. Her. 279 H 11, thei hee so far waxen crooked, that seldome canne they bee ryguted again.

Now obsolete. EQ. 871 ; LQ. c 1440. 
rought of = cared for ; thought (much) of.

Dial. Iler. $111 \mathrm{C} 3$, I vnderslode him to haue geuen diligence to the latin tonge. As for other faculties he rought not of.

Now recked of.

to rufle $=$ to put in disarray ; to tangle.

Diat. Her. 274 F 12, the world once rufled and fallen in a wildeness, how long would it be ... ere the waye were founden to set the worlde in order and peace againe?

Now obsulele. KQ. c 1440 ; LQ. 1638.

to $r u / l l e ~ s p=$ to heap up; to rattle up in a careless manner. Answer $1088 \mathrm{G} 7$, He rufleth op all the malter shortelye in a fewe worde.

Now obsolete. No quot. anterior to More. LQ. 1658

to rule oneself $=$ to conduct oneself ; to behave ; to act.

Last Th. $97 \mathrm{D} 2$, Is it not a bestly thing to se a man that hath reson, so to rule himselfe that his fele may not beare him ?

Now obsolete. EQ. 13... ; LQ. 1500-20. No quot. later than More.

to ryd (work) = to dispatch ; to get through.

Answer $1018 \mathrm{D} 13$, therfore wold they faine wit what worke that were that they myghte shortly rid it out of hand.

Now dial. No quot. anterior to More in OEl).

to $r y g=$ to clothe.

Dial. C. (Wks.) 1201 A $\&$, the beggar rygged in his ragges.

Now carlier quolation in OED. Now colloq. or slang.

to $r y m e$ out $=$ to brave (a matter) out in riming terms.

Conf. Tynd. $496 \mathrm{C} 3$, Tindall rymeth it out, \& saith that he hoth denieth and also defietl, that the apostles taught any coremony wherof the reason could not be knowen.

Now obsolete. The above is the only quot. in OFU.

to satisfy (a man) of (a thing) = to reslore.

Rich. 48 [3 3, if one go to saintuary with another mannes goodes, why should not the kyng leauinge his bodye at libertie, satisfy the part [scil. party] of his goodes euen within the saintuary ?

Now obsolete, exc. in legal use. $\mathrm{EQ}$. 1433. Cf. Lhe fig. use of to satisfy $=$ to pay a debl to in : Picus $8 \mathrm{~F} 1$, compelled him within thre daies to satisfy nature, and repaic her the life which he receined of her.

to satisfy for $=$ to atone for.

Supplic. 326 G 15, Obiectyng that no men mai satisfy for another. I Conf. Tynd. $381 \mathrm{G} 8$, as though men dyd reken their penaunce for a thing sumicient to salisfie for their sinne.

Now obsolete exc. Theol. (said of Christ). EQ. c 1450.

to sauour = to care for.

Picus $31 \mathrm{~A} 11$, The louer is of colour dead and pale ..., He sauoureth neither meate, wine, nor ale, He mindelh not, what menne about him talke.

Now obsolete or archaic. EQ. c 1340 ; LQ. (arch.) 1868. 
to scatter = to dissipate, to squander.

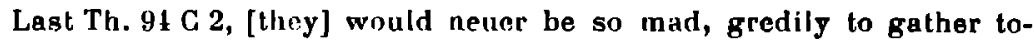
gether that other men shal merely sone after scatter abrode.

Now obsolete or archaic. HQ. 1154.

to scrape (out) = erase (writing) with a knife.

Conf. Tynd. 421 B 1, A ... learned priest ... through out al the ghospels scraped out 'diabolus', and wrote ' Iesus Cristus'.

Now obsolete. EQ. 1303 ; LQ. 1688.

to season = to seize.

Dial. C. (Wks.) 1262 G 8, he [sc. the devil] neuer runnetl uppon a manne to season hym with hys clawes, till he see him downe on the grounde.

Now obsolete [the verb seisin]. EU. c 1425 ; LQ. 1535.

to sequester = to set apart (Eccl.).

Answer $1016 \mathrm{~F} \mathrm{5}$, Hym hath god the father specyally sequestred and seuered and set asyde out of the nomber of all creatures.

Now obsolete. No quot. anterior to More. LQ. 1697.

to serue = to prompt; to encourage.

Dial. C. (Wks.) 1185 D 9, My conscience can nol serue we ... to praise her calfe aboue twoo pence.

Now obsolete. FQ. c 1380 ; LQ. 1596.

to set abroche $=$ a) to broach ; b) to set going.

a) Debell. $939 \mathrm{E} \mathrm{1}$, They [the new brotherhood] be a barel of poyson, that the dyuel hath late set abroche.

b) Dial. Her. 284 H 5, Ascribing all our dodes to destinie ... they ... set al wretchednes abroche.

Now archaic. EQ. 1390 \& c 1475.

to set by $(a$ man $)=$ to esteem.

Dial. Her. $184 \mathrm{~A} 13$, such as were in the church little set by.

Now obsolele, exc. arch. or dial. EQ. a 1300.

to set forth $=$ to further the progress of.

Dial. Her. 262 H 1, To confesse ... what he had done for the settinge forth of that secte.

Now obsolete. No quot. in OED anterior to More. LQ. 1551.

to set to $=$ to add.

Last Th. 73 A 12, Howe muche more ... should his lyfe be painful ..., yf to the remembrance ... of death, a manne should adde and set $t o$, the depe ymaginacion of the dredeful dome of god... | Dial.Her. $140 \mathrm{H} 8$, I haue ... sette to somewhat.

Now obsolete. EQ. c 1200 ; LQ. 1551.

to set out $=$ to show forth.

Apol. 5, excepte I toke some payne to set out theyr argumentes plainly many that rede them sholde lytle wyt what they meane.

Now obsolete. EQ. a 1450 ; LQ. 1681. 
to sewe $=$ to make one's petition.

Dial. C. (IVks.) 1140 D 16, God of duetie byndeth me to sewe to you nowe..., that ilmay lyke you...

Now obsolete with that-clause. EQ. c 1420 ; LQ (with that) a 1529.

to shend = to put to shame or confusion.

Dial. IIer. $263 \mathrm{~B} 2$, as though the churche hall... hyd the true fayth from the people \& that them selfe were now shent for preching the gospel truely.

Now archaic or dial. RQ. c 825 .

to shoflle up $=$ to put together hastily.

Cont. Tynd. 357 D 17, Yet haue I not so slightly sene vnto mine own, nor shoffled it vp so hastili...

Now obsolete. No quot. in OED anlerior to More. LQ. 1659.

to shog = to shake; to rouse from sleep.

Dial. C. (Wks.) $1189 \mathrm{G} 6$, that wold rudely and boysluously shogge hyın \& wakehim.

Now obsolete. EQ. c 1440 ; LQ. 1651.

to short $=$ to shorten.

Dial. Her. $286 \mathrm{H} 8$, if I hadde seen so muche before, it had been likely to haue shorted much part of our long communicacion.

Now obsolete. EQ. a 1300 ; LQ. 1570.

to shoue = to thrust; to precipitate.

Dial. C. (Wks.) 1226 I 2 , He that gathereth treasures shall be shoued into the grynnes of death.

Now obsolete, exc. archaic. EQ. a 900 ; LQ. a 1568.

to shew ( + that-clause) $=$ to tell ; to communicate.

Dial. Her. 223 E 7 , frere IIierom ... came to hym ... shewing him that he wold cast of his abite.

Now obsolete. EQ. a 1300 ; LQ. 1632.

shriluen. To be shriven = to have gone to confession.

Dial. G. (Wks.) 1184 G 12, Be merye manne ... for thys day I thanke God was I wol shriuen.

Now archaic. EQ, 1000.

to shryche = to utter with shrieking.

Dial. G. (Wks.) 126t it 8, that hideous howling that those helhoundes shold shryche.

Now obsolete. No other quotations in OED.

to shryue oneself $=$ to go to confession.

Rich. 54 F 11, except the Iorde Chamberlen, whoin the protectour bade spede \& shryue hym a pace.

Now archaic. EQ. a 1225.

to shyfte (with) = to deal (with).

Rich. 51 B 9, and shyfte whoso would with thys busynes...

Now obsolete. EQ. c 1400 ; LQ. 1529. 
to signifle $=$ to hint at.

Rich. 63 E 13, thinges, which the said worshipful doctor rather signified then fully explaned.

Now obsolete. No other instances in OED.

to skewse $=$ to excuse.

Conf. Tynd. 577 F 3, To skewse bym and keepe hym from beatynge.

Now obsolete exc. in illiterate use. EQ. 1491.

to smore $=$ to smother.

Fich. $68 \mathrm{~F} 6$, smored and stifled, theyr breath failing, thei gaue vp to god their innocent soules.

Now obsolete, exc. Sc. and North. dial. EQ. c 725; LQ. 1585.

to sollicite $=$ to attend to.

Aut. Lett. $v$ 19, he saw of yor graces awn baud that I shold diligently sullicile lhexpedition of those other thinges.

Now ubsoleto. EQ. 1499 ; LQ. 1789.

to solule $=$ to solve.

Answer 1092 D 10, He myght ... haue soluted theyr question.

Now obsolete. No quot. in OED anlerior to More. LQ. 1654.

to sorowe (a thing) = to lament.

Picus 12 F 16, There holdeth me sometyme... a swone,... when I begin in my self, I not never whether I shall say, to remember, or to sorowe, to meruayle or to bewayle the appetites of men.

Now obsolete. EQ. a 1340 ; LQ. 1632.

to sort out $=$ to take out.

Dial. G. (Wks.) 1177 G 5, The tother kynde is thys whych I rehersed second, and sortlyng out the tother twayne, haue hepl it for the last.

To earlier quot. in OED. Still current.

to souse up = to sicken?

Dial. C. (Vks.) $1163 \mathrm{~A} 14$, Let hym go to no leache craft, nor any maner phisick, ... fur sirops shold sosuce him op. I Jest p. 1 C 5, an olde trotte ... with her phisicke will kcepe one sicke, till she haue soused him vp.

Now obsolete. OED has no other instances.

to sowne (in)to = to imply ; to suggest.

Picus 30 G 2, A very louer ... may in no manere Endure that therefro mighten vary, Or any thyng sowne in to the contrary. I Dial. Her. 203 A 3, And consequently proued that no text of scripture seming to sown to the contraryo, can be so taken or vnderstanden.

Now obsolete. EQ. c 1371; LQ. c 1456.

to soyle $=$ a) to refute.

Apol. 7, The most folyshe heretyke in a town may write mo fals heresyes in one lefe, than the wysest man ... can well and couengently oovle \& confute in fourty. | Conf. Tynd, $660 \mathrm{~B} 3$.

Now obsolele. $\mathrm{EQ}$. c 1380 ; LQ. 1567. 
to soyle $=$ b) to absolve.

Dial. C. (Wks.) 1181 G 8, The Wolfe now comming Irom shrift cleane soyled from hys synnes.

Now obsolete. HQ. a 1300 ; LQ. 1530.

to spet $=1$. to expectorate.

Conf. Tynd. 736 C 6, All hys deuelyshe lies which he spetteth \& speweth oute vpon honest men.

List Th. 99 B 14, glotony ... disfigureth the face, discoloreth the skin ... it makes the skin tawny, lhe body fat, ... the nose dropping, the mouth spctling.

Now obsolele, exc. dial. EQ. c 1421 ; LQ. 1697.

to spyll (paper) = to waste by misusing.

Debell. $959 \mathrm{H} \mathrm{8}$, this good man is content to leese tyme \& spyll paper.

Now obsolele. EQ. a 1010 ; LQ. 1786.

to stere ... $r p=$ a) to wake... up.

Answer 1092 F 4, He that eateth my fleshe and drynketh my bloude, ... I shall stere hy op in the last day.

Now obsolete. EQ. 1526 ; LQ. 1683.

to stere...op = b) to ' raise up'.

Cont. Tynd. 284 A 5, We saye also that god hath dayly stered op \& dayly doth sterre up new prophetes in sundry partes of hys catholyke chyrche.

Now obsolete. EQ. 1526 ; LQ. 1564.

to stint (to preach) = leave off (preaching).

Dial. C. 341, he was impriesoned ... : and being from thence deliuered, atinted not to prech on stil.

Now only arch. and dial. EQ. c 1200.

to stock $=$ to set in the stocks.

Dial. C. (Wks.) $1245 \mathrm{E} 15$, he neither nedeth to coller vs nor to stocke vs for any feare of scaping away.

Now obsolete. EQ. c 1325; LQ. 1694.

to strait $=$ a) to shut up in or force into a narrow space.

Passion 1347 G 7, the tyme shall come whan it shal so sore decaye agayne, and the churche by persecucion so strayghted into so narow a corner...

Now obsolete. EQ. c 1420.

to $s$ rait $=$ b) to limit in amount or degree.

Answer $1121 \mathrm{~F} 1$, Frith was but a foole so to straite and to limite the power of almightye god.

Now obsolele. No quot. in OED anterior to More. LQ. 1647.

to strayn = a) to bind fast; to confine in bonds.

Conf. Tynd. 394 B 5, And with these woordes of hys own, will I strayne him last and sure.

Now obsolete. EQ. 1340. No quot. in OEI) later than More. 
to strayn $=$ b) to bridle ; to control.

Dial. Her. 168 F 7, so hath God euer kepte man in humilite, straynyng hiln with the knowledgre of confession of his ygnoraunce. | Answer $1054 \mathrm{E} 2$.

Now obsolete. EQ. a 1340 ; LQ. 1595.

to strayn = c) to forie ; to constrain.

Dial. Her. 200 A 2 , The profe... semeth me not very stronge nor able \& sumieient to strayne a man to consent therto.

Now obsolete. EQ. c 137t; LQ. 1603.

to stretche to $=$ to be serviceable to ; to tend to.

Passion 1330 B 1, that we maye in suche wyse treate therof, that it may ... stretche to the fruit of their soules.

Now obsolele. HQ. 1400 ; LQ. 1621.

to striene a strife

Dial. Her. $270 \mathrm{~F} 10$, I haue labored and strieuen a good strife, I haue p(er)fourmed my course, now lacketh me no more for me, but the crowne ol iustice.

Now rare. EQ. c 1375.

to stroi $=$ to destroy.

Dial. Her. 223 F 12, the newe testament of Tindal was burned because it stroied the masse.

Now obsolete or archaic. EQ. c $1200 ; \mathrm{LQ} .1642$.

to study for = to search.

Dial. Her. 220 F 13, the boke, wherin there were ... falsly translated aboue a thousand textes ... He that shoulde ... studye for that, should studye where to fynde water in the see.

Now obsolete. No earlier quot. in OFD (s. v. study, v. 2 f); LQ. 1748.

to substytute $=$ to appoint (a person) to an office as a deputy or delegate.

Conf. Tynd. 821 I) 1, Yel can they not say nay, but that ... he appointed saint Peter with olher, and that they were all knowen heades. And they dyd also substytute other whyche were knowen beades also.

Now obsolete. No carlier quot. in OED. LQ. 1712.

to sup $u p=$ to absorb.

Dial. Her. 267 C 12, For all other synnes ... be quite absorpt and supped op ... in that fayth. | Conf. Tynd. $713 \mathrm{C} 4$, As for al other sinnes whatsoeuer thei be, faith saith he ... suppeth them al $\varphi_{p}$ in a moment.

Now obsolete. EQ. c 897 ; LQ. 1652.

to suple = to soften ; to mollify (the heart or mind).

Conf. Tynd. 437 A 5, Menne are so supled and made humble in hert, that they will willingly goe shew themselfe their own sinnes to the priest.

Now obsolete or arch. EQ. 1390.

to surceace of $=$ to leave off.

Picus 14 A 4, Wherfore he counseiled Picus to surceace of study.

Now obsolete with of ; otherwise archaic. F.Q. 1428. 
to surmount = to surpass ; to excel ; to be superior to.

Picus $30 \mathrm{D} 5$, A very louer beleueth ... that in that person menne maye nothing finde, But honorable, worthye, and excellent, And oke surmountyng farre in his entent. 1 ll other that he hath kuowen by sight or name,...

Now obsolete. EQ. c 1369 ; LQ. 1667.

to surmyse = to charge upon ; to allege against.

Dial. Her. 110 A 8, Luther saied not so euyll as is surmised vpon him Passion 1354 i 3.

Now obsolete. EQ. c 1100 ; LQ. 1623.

to swage = to mitigate.

Answer $1047 \mathrm{E} 7$, they that gladly would endure a gryele perpetuallye, to haue the pleasure of the continual swagyng.

Now obsolete, exc. arch. or dial. EQ. a 1300.

to swap = to strike ; to hit.

Dial. C. (Wks.) $1256 \mathrm{G} \mathrm{4}$, They that lye in a plewrosy, thinke that euery time they congh, they fele a sharpe sweorde swap them to the heart.

Now obsolete. EQ. a 1400; LQ. 1577-82.

to take one's time $=$ to seize the opportunity.

Dial. C. (Wks.) 1187 D 7 , At that word the diucl toke his time, and whetted her tong agaynst her teeth.

Not recorded in OED.

to take = to deliver ; to hand over.

Dial. Her. 160 G 6, Sainct Paule commaundeth the people of Thessalonica in his epistle, to kepe the tradicions that he toke them either by his wrytinge or by his bare worde. | Dial. C. (Wks.) 1223 B 5. | Answer 1063 C 5.

Now obsolete. EQ. c 1275 ; LQ. a 1553.

to take in = to include (the opposite of : to leave out). Apol. (Wks.) 846 E 5, he leaueth out somewhat that Tyndalle taketh in, that is to wytte, the makynge of mockes and mowys against the masse.

The earliest quot. in OED of to take in = " to admit in to a number or list; to include, to comprise, embrace ; spec. to include in the consideration, take into account "(s. v. lake 82 k.), is dated 1647 .

to tell one tale $=$ to be at one.

Dial. Her. $167 \mathrm{~F} \mathrm{7,} \mathrm{he} \mathrm{...} \mathrm{besecheth} \mathrm{christen} \mathrm{people} \mathrm{to} \mathrm{agre} \mathrm{together} \mathrm{all}$ in one mynde, and in the faythe to tell one tale.

Not recorded in OED.

to teme $=$ to produce offspring.

Cont. Tynd. 614 G 3, Lest it should teble hys fleshe ... and hyndre hys harlot of teming.

Now obsolete. EQ. c 1000 ; LQ. 1636.

to thwyte = to whittle ; to cut down; to pare.

I)ial. Her. $236 \mathrm{H} \mathrm{3}$, thys processe came to a wise purpose, here was a gret post wel thwyted to a pudding pricke.

Now obsolete exc. dial. EQ. a 800 ; LQ. 1674. 
to ticle = to stir up; to provoke.

Conf. Tynd. 551 B 3, The pronity \& mocions in the fleshe ... whereby we be ticled towarde great acluall deadly sinnes.

Now obsolete. No quot. in OFI anterior to Mlore. LQ. a 1592.

to tink = to express or give out by making a ringing sound. Debell. 955 B 20, that the tinkar would haue tinked out of his pannes bottome, a reason that woulde at the leaste wise ring a little better then this.

Now obsolele. No quot. in OFI) anlerior to Mnre. LQ. 1621.

to trow $=$ to suppose.

Rich. $49 \mathrm{G} \mathrm{3}$, it is I trow no great maruaile. / Rich. 50 C 9, troweth he that I parceiue not wherunto his ... processe draweth ?

Now archaic. EQ. a 13 ..

to $\operatorname{try}$ ont $=$ to find ont.

Sipplic. 299 \& 6, time alway trieth out the trouth.

Now obsolete. LQ. c 1325 ; LQ. a 1761.

to turn (a purpose) = to alter ; to pervert.

Dial. G. 241, pride maye peraduenture turne his good purpose.

Now rare or obsolete. l:Q. c 1230.

to undertake $=$ to understand.

Picus 10 B 9, She spake of the seconde death and eucrlasting : $\&$ he ondertoke her of the first death \& temporal.

Now obsolete. EQ. a 13.. No quot. in OED later than More.

to une $=$ to unite.

Passion 1348 E 8 , he is not by the spirite of god unyd with holy saintes as a liuely membre of Christes misticall body. Passion $1306(=1338)$ E 4.

Now obsolete. HQ. c $1400 ; \mathrm{LQ} .1538$. The past participle form unit

is still in tuse in Scolch dialects.

to $u$ ine = to unite.

Picus 13 D 2, [that prayer] which onieth it with hym.

Now obsolete. FQ. a 1433 ; LQ. 1596.

to $u t t e r=$ to reveal.

Pasaion 1305 li 8, Jobn, whome Christe so tenderly loued, that ... to hym secretely he sltred the false dissimuled traylour. | Dial. Her. $213 \mathrm{~F} 3$.

Dial. Her. 249 F 5.

Now obsolete. LQ. 1444 ; LQ. 1677.

to vayl = to be of use; to avail.

Lament. Stanza 3 1. 4, But 0 good God what wayleth all this gere?

Now obsolete. EQ. c 1340 ; LQ. 1608.

to vilayn = to debase; to (legrade; to violate.

Conf. Tynd. 344 A 14, When they haue once vilayned the sacrament of matrimonye, then woulde they make vs vyolate the sacrament of the a uter too.

Now obsolete. EQ. 1412-20. No later quot. than the above from

More. 
to wag hemp = to be hanged.

Cont. Tynd. 715 A 5, Tindall ... feareth not (like one that would at length wagge hempe in the winde) to mocke at all such miracles.

Now obsolete. No other quot. in OLI).

to walk with $=$ to be associated with.

Dial. Her. 268 F. 14, good workes muste walke with fayth and sorow at heart.

Now obsolete. EQ. 1650 ; LQ. a 1709. Cf. to go with.

to ward = lo keep in close custody.

Apol. 99, For then the clergy myght declare their demeanure to ward that man.

Now obsolele. LQ. 1390 ; LQ. a 1670.

to way to $=$ to amount to.

Dial. Her. 262 13 15, it gaue hym occasion to doute lest Luther ment not al thing 80 eluyl as his wordes seme to way to.

Now obsolete. No earlier quot. in OVD. LQ. 1588.

to wene $=$ to think; lo suppose.

Apol. 14, I requyred my frend to fynde the meanes yf he myghte, that I myghte se the boke wenynge that some newe worke of Tindalls hadde bene of late come ouer.

Now obsolcte. The word seems to have dropped into disuse in the 17th century. It has survived as an archaism, esp. in the parenthetic formula $I$ ween (cf. OII) s. v. ween, v.). FQ. (with that) 971 . to wive (a mal) $)=$ to furnish with a vife.

Rich. $59 \mathrm{~F} \mathrm{3,} \mathrm{smal} \mathrm{pleasure} \mathrm{taketh} \mathrm{a} \mathrm{man} \mathrm{...} \mathrm{y} \mathrm{h} \mathrm{he} \mathrm{bee} \mathrm{wiued} \mathrm{against}$ his appelite.

Now obsolete or archaic. No quot. in OFil anterior to More.

to work out $=$ to expiate (a guilt, a siin).

Dial. C. 311, there shall no man whiche denielh our sauioure once,... excape ... He shall peraduenture ... afterward woorke it ont, in the fruitfull woorkes of penance, praier, and almes dede doone in true faith and due charitie, und attayne in suche wyse forgenenesse well ynough.

Not in Pres. I. Eng. The earliest quot. in OEll with to work out

in exactly this sense is dated as late as 1660.

to wraste $(o u t)=$ to tear, wrench out.

Nich. $48(=45)$ D 7, Suche euyl oppinyon once fastenod in mennes heartes, harde it is to wraste outc.

Now to wrest. Nu earlier quot. in OLD.

to write ouer (to a person) $=$ to commit a task (to a person). Picus $6 \mathrm{C} 2$, , he plentuously gaue out his money : and not content only to geue that he had himselfe ready : he wrote ouer, to one Hierome Benineui ... that he should with his own money euer helpe poore folke ... \& alwaie send him woorde, what he had laide out, that he wight pay it him again.

Now obsolete. Not in OHD s. v. to write over (17). 
wrought $=$ worked up ; agitated.

Dial. C. 341 , the sea was sore wrought, and the waues rose verye hygh.

Now obsolete. EQ. 1585 ; LQ. 1702.

to wry $=$ to avert (the head, face) ; to turn aside.

Rich. 70 B 14, [The duke] ... wried hys hed an olher way.

Now obsolete. EQ. c 1400 ; LQ. 1655.

to $\omega y t=$ to know.

Apol. 5, excepte I toke some payne to set out theyr argumentes plainly many that rede them sholde lytle wyt what they meane. | Jesl p. 1, C 5 | Picus 12 F 17. ( Rich. 58 H 9 ').

Now obsolete ar archaic. EQ. Beowulf.

to yeld = to reward ; to renumerate ; to recompense.

Picus 16 G 3, regarde only the iudgement of God, which shal jeld euery man after his owne warkes. | Dial. Her. 238 A 9, naye my lordes quod he, I wil not drinke God yelde you.

Now obsolete or rare arch. EQ. Beowulf ; I.Q. 1608.

to yrryte = to irritate; to provoke.

Last Th. 76 ( 6 , rather ... than ... to yrryte lhem to anger.

Now obsolete. EQ. c 1450 ; LQ. 1661.

VERBS OF THE TYPE : TO DARK, TO LESS.

94. It was about or a little after More's time that verbs like bolden, dusken, ripen, straiten [formed from adjectives or nouns on the analogy of a few verbs in -en which came down from O. E. (e. g. fasten < O. E. frestnian; waken $<$ O. E. wacnan), or were adapled from O.N. (e. g. weaken : Norw. veikna; whiten < 0 . N. hvítna)] came extensively to be used instead of or in combination with the older verbs without -en, as appears from the following dates of earliest quotation in OED :

bolden 1526 endarken 1550 moisten 1580 slacken 1580

cheapen 1574 estraiten 1598 ripen 1561 stiffen(?)1500

dawn 2) 1499 fatten 1552 roughen 1582 strailen 1552

deafen 1597 gladden $^{3}$ ) 1558 scanten 1585 sweeten 1552

dusken 1550 heighten 1523 sharpen 1530 toughen 1582

embolden 1571 lengthen 1500-23 shorten 1513 whetten 1582

') The Old Fng. adverb sewisse is repeatedly used by More and printed in two words : Apol. (Wks.) 873 A 1, I wisse tyll you meeke your selfe ... thys anger of youl husband will neuer be ... appeased.

2) Though to daw is earlier, the form in $-n$ is not due to analogy as with the other verbs; it may have been deduced from the verbal noun dawning.

3) In the sonse : to make glad. Gladden = to be glad is older. 
More, however, kept almost ') exclusively to the use of the shorter verbs :

to blynd. Dial. Her. $282 \mathrm{G} 11$, the thyng that moste blyndeth vs...

to bold. Apol. 3, I was bolded and encoraged...

to daw. Jest p. 4 A 12, with good rappes, And heuy clappes, He dawde hyin vp agayne.

to estrait. Dial. Her. $277 \mathrm{~F} 13$, the 'l'urke hath estraited vs verye nere.

to glıd. Passion $1333 \mathrm{~B} 9$, wyne gladdeth the hart.

to haste. Kich. 61 D) 2, the doctor fearing that he [scil. the king] should com ere his sermon could come to those wordes hasted his matter therto.

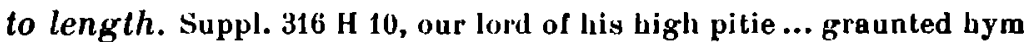
the lengthyng of his lyfe.

Ct. Answer 1037 B 11, he hath somewhat enlengthed it of late.

to ryght. Dial. Her. $279 \mathrm{H} 11$, seldome canne they lee ryghted again.

to rype. Apol. 2l, except hymself be well ryped in the matter.

to sharp. Dial. C. (Wks.) $1187 \mathrm{D}$ 10, her tong ... was wel sharped. | Last Th. 77 E 11.

to slack. Picus 15 13 7, because ye shall not think, that my trauaile and diligence ... is any thing remitled or slacked.

to short. Dial. Her. $286 \mathrm{H} 8$, If I hadde seen so muche before, it had been likely to haue shorted much part of our long communicacion.

to stable. Dial. C. (Wks.) $1140 \mathrm{C} 11$, so shall wee nede ... a gret heape thercol, to stable and strength the walles of our heartes.

to strai(gh)t. Answer $1121 \mathrm{~F} 5$, Frith was but a foole so to straite and to limile the power of almighty god. | Passion $1347 \mathrm{G} 7$.

to swete. Conf. Tynd. 50.1 A 1, to swete hys owne aunswere...

to whet. Dial. C. (Wks.) 1187 D 7, At that word the diuel toke his time, and whetted her tong agaynst her teeth.

Not only did More refrain from introducing new forms in -en "), he even preferred the short forms where the longer verbs were available, as with dark, less, light, loose, meeke, strength and weak, the longer forms of which had been in use since the $11^{\text {th }}$ cenlury (darken 1300, lessen 1300, lighten 1375, loosen 1382, meeken 1300, strenghten 1300, weaken 13...). to dark. Last $\mathrm{Tl} .74 \mathrm{~B} 4$, the swetenes thereof ... darketh ... the felyng of hodily payne. | Dial. Her. 157 G 9.

1) Itich. 37 \& 12, whose life hee looked that euil dyete shoulde shorten.

2) Instead of to false, in use at the time (1553 T. Becon, Heliq. Rome 240 a, All thoe that false the Popes Bull), More uses to falsify (Conf. Tynd. 585 ( 8 ). 
to less. Rich. 36 A 8, Thys fante ... lessy.d and wel lefte. I Dial. C. (Wks.) 1168 F 15.

to light. Dial. C. (Wks.) 1171 A 5, A merye tale wyth a frende,... lyghteth his mynd. | Dial. C. (Wks.) 1168 F 12, Wee ... shall ... fynd our heartes lighted.

to lose. Apol. 29, Now is tliys knot so sure that it can neuer be losed.| Supplic. 320 E 8.

to meeke. Apol. (Wks.) 873 A 1 , tyll you meeke jour selfe and amende. to strength. Dial. C. (Wks.) $1140 \mathrm{C} 11$, so shall wee nede ... a gret heape thereof, to stable and strength the walles of our heartes. I A pol. (Wks.) 860 D 13. | Dial. C. (W ks.) 1142 H 17. | Passion 1333 B 8, Breade strenketh a mannes harte.

to weak. Rich. $49 \mathrm{C} 7$, with which disease nature being forelaborid, foreweried and weaked.

To bold, daw, estrait, glad, less, length, light '), meek, right, sharp ${ }^{2}$ ), short, straight, strength and weak are obsolete now. To dark is archaic and to ripe somewhat rare in Pres. D. Eng. To blind and to stable have never developed corresponding verbs in -en.

As direct descendants of 0 . N. kvikna, 0. E. frestnian and o. E. wcecnan, the verbs quicken, fasten and waken are used with the ending -en in More :

to quicken. Passion 1349 B 15, he is not by the spirite of Christ, animated and quickened.

to fasten. Hich. $48(=45) \mathrm{D} 7$, Suche euyll oppinyon once fastened in mennes heartes, barde il is to wraste oute...

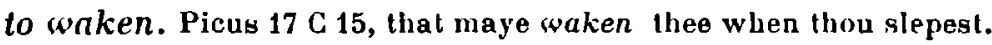

To wake (= to become awake) however, also occurs : Dial. C. 225 , when you wake and ryse.

To make hard instead of to harden is used in : Dial. C. (Wks.) $1145 \mathrm{~F} \mathrm{1}$, hys tribulacion made hyın cal to God, and his helpe made hard bys harle agayne.

\section{Denominatives}

95. The use of nouns as verbs reached its highest point about 1600 (See Abbot $1888 \$ 290$; Delcourt $1914 \$ 197$; Jespersen $1926 \S 166$; Truka 1930 p. 13). The following collec-

1) In the sense : to become or to make light(er).

?) To sharp is still used in the sense of to swindle. 
tion of quotations shows that a number of denominative verbs were alrendy in use in More's time.

to bolt. Dial. C. (Wks.) $1246 \mathrm{D} \mathrm{4,} \mathrm{he} \mathrm{bolteth} \mathrm{them} \mathrm{by} \mathrm{the} \mathrm{armes} \mathrm{with} \mathrm{a}$ paulsy.

to brake. Dial. C. (Wks.) 1245 B 7, in this prison ... folk be ... braked. to brydle Dial. C. (Wks.) 1249 D 18, in suche wise to brydle it ... that...

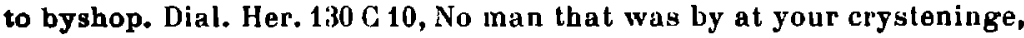
nor when ye were byshopped neyther.

to card. ') Dial. C. (Wks.) 1245 II 1 , in this prison ... they dyce : in this they eard : in this they pipe and reuell.

to cloke. Dial. Her. $262 \mathrm{G} 10$, perceying the maters ... so ferforth comen to light that thei coud in no wise be cloked.

to clout. Last Th. $80 \mathrm{E} 5$, we be fayne to take medicines inwarde to cloute them (sc. our bodies) vp with al.

to coller. Dial. C. (Wks.) $1246 \mathrm{D}$ 3, he collereth them hy the neck with a quinsye.

to doctor ${ }^{\text {}}$ ). Apol. (Wks.) $915 \mathrm{E} 6$, If this pacilyers doctoring wer a good profe.

to dyce. See quot. sub to card.

to father. Apol. (Wks.) $855 \mathrm{E} 8$, All thys chyldishe reason ... whiche he bryngeth oute of Tyndalles Chapiter, and fathereth it vpon Saynte James.

to fense. Dial. C. 204, the soule ... is ... fensed in round about.

to fotter. Dial. C. 324, Goddes prisoner that has his one foote fettered.

to flesh. Hich. $68 \mathrm{E} 9$, a felowe fleshed in murther.

to flower. Cont. Tynd. $688 \mathrm{D} 3$, the vertuous that so foured in the church. to friar ${ }^{2}$ ). Jest p. 3 A 13, his harle for pryde, Lepte in his syde, To see how well he freered.

to ground. Apol. 121, a ... false syrmyse, grounded ... uppon a cherytable imagynacion.

to heap. Dial. C. 251, heapyng uppe of richesse.

to hedge. Last Th. $98 \mathrm{G} 6$, The way ... hedged with thornes.

to lap ${ }^{3}$ ). Dial. C. (Wks.) $1184 \mathrm{E} 12$, pygges, wel lapped in newe strawe. to latyn. Conf. Tynd. 382 C 12, excepte happely some wel latyned Jewes conuerted.

to launce. Dial. C. (Wks.) 1253 D 13, to be lannced and have the flesh cut. to lock. Apol. 134, he sholde so the stockes mended and locked fasle... to maister. Dial. C. 304, your reason shal ... resist it, and ... maister it. to manacle. Dial. C. (Wks.) 1246 D 6, he manacleth their handes.

to mesh. Conf. Tynd. $491 \mathrm{C} 8$, Luther was hymselfe so meshed in thys matter.

to mischief. Debell. 971 D 11, He wil of lykelibode hate \& mischief any man by whome he takelh any harme.

1) The earliest quot. in OED of to card is dated 1548.

2) No quotations anterior to More in OED.

${ }^{3}$ ) Probably trom lap (noun) = fold or piece of cloth (OED). 
to myre. Answer $833 \mathrm{D} 20$, If only they that are alredy bymired, were ... myred on more and more.

to pinne. Lett. 1437 I) 12, I netuer intend to pinne my soule at another mannes backe.

to pipe. See quot. sub to card.

to plaster '). Last Th. $80 \mathrm{C} \mathrm{3,} \mathrm{he} \mathrm{muste} \mathrm{bee} \mathrm{fayne...} \mathrm{to} \mathrm{...} \mathrm{pluster} \mathrm{his} \mathrm{legge.}$ to root. Dial. C. 328, affeccions, that ... are rooted in the mind.

to shadow. Dial. C. 200, Wyth his shoulders shall he shadow the.

to sowse. Dial. C. (Whs.) 1163 A 15, sirops shold sowse him up.

to spise. Dial. Her. $150 \mathrm{~B} 5$, spising their preclyyng wilh rebuking of priesthode.

to sport ${ }^{2}$ ). Dial. C. (Wks.) 1184 H 7, I trow she sported.

to spot. Dial. Her. $269 \mathrm{G} \mathrm{4}$, thynges all spotted with sinne.

to stocke. Dial. C. (Wks.) $1245 \mathrm{~F} 15$, he neither nedeth to coller us nor to stocke us.

to stone. Dial. C. (Wks.) $1259 \mathrm{H} \mathrm{12,} \mathrm{once} \mathrm{was} \mathrm{I} \mathrm{stoned.}$

to syluer. Dial. Her. $220 \mathrm{~F} \mathrm{1,} \mathrm{a} \mathrm{coper} \mathrm{grote} \mathrm{...} \mathrm{sylvered} \mathrm{ouer.}$

to thirst. Rich. $40 \mathrm{E} 11$, whither they sorer thirsted.

to vilayn. Conf. Tynd. 344 A 14 , they have ... silayned the sacrament.

to water. Dial. C. 329, water them with the ... aduertisement of godlye consayle.

to witnes. Dial. Her. 166 F 11, thei coulde neuer witnes against the trouthe.

to wive. Hich. $59 \mathrm{~F} \mathrm{3,} \mathrm{smal} \mathrm{pleasure} \mathrm{taketh} \mathrm{a} \mathrm{man} \mathrm{...} \mathrm{yl} \mathrm{he} \mathrm{bee} \mathrm{wived}$ against his appetite.

\section{INDEPENDENT CA.V, WILL \& OUGHT + OBJEGT.}

Can. Hich. 51 A 5, I can no more. | Apol. 46, I can neyther so myche poetry nor so myche rethoryque neyther. | Dial. C. 210 , other crafte can you none. | Jial. Her. 240 H 14 , ley mennes ..., that can no more but theyr molher tong.

Last Th. 73 B 8, how precisely we presume to shoote our folish bolte, in those matlers most, in whiche we least can skill. | Jest p. 1 A 5, best is for a man :... in no wyse, To enterpryse An other faculte, For he that wyll, And can no skyll, is neuer lyke to the.

Dial. C. 258 , else would Christe haue canned ber much more thanke. Last Th. 88 H 6, strangers that shall neuer can them thanke.

Could. Aich. $56 \mathrm{H} \mathrm{10}$, an honest man and one that could his good, not presuming to touch a kinges concubine. $\mid$ lich. $58 \mathrm{D} \mathrm{4}$, in that point conld be none other colour.

Will. Picus 28 B 7, Parte will he none, but either all or nought. | Boke of F. p. 5 A 11, ye wull, That one is Iree, that olher euer thrall. | Last Th. 90 H 15, he wyll that some other dye by sickenes.| Hich. 47 B 6, I wyll well there bee somme places of refuge for bothe.

1) Or perbaps from O. F. plastrer (OED).

2) Or an aphetic form of the verb to disport. 
Would. Rich. $35 \mathrm{G} \mathrm{10,} \mathrm{He} \mathrm{was} \mathrm{...,} \mathrm{in} \mathrm{the} \mathrm{fielde,} \mathrm{...} \mathrm{no} \mathrm{farther} \mathrm{then}$

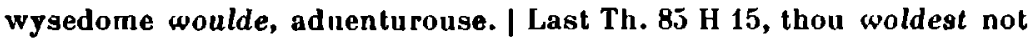
for shame, that men should think thee so mad. | Dial. C. (Wks.) 1173 C 3, I would I could ... mende my faulte. | Dial. C. (Wks.) 1261 D 9, Wold god that... | Debell. $936 \mathrm{G} 3$, if he feared that it would be founden false : then honesty would that he should haue left hys own wordes out. Supplic. $291 \mathrm{H} \mathrm{1}$, he that would rather the man wer belieued than answered.

Ought $=$ had to render; had to pay. Rich. $40 \mathrm{D} 2$, of which eueri one ought him as faithful seruice as they. | Jest p. $2 \mathrm{G} 2$, A marchant man, That he ought money to.

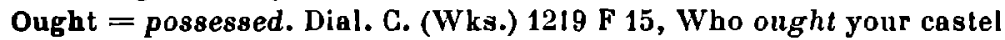
... thre thousande yere agoe?

These verbs have retained the meanings they had before they came to be generally used as attendant verbs and thereby to lose good deal of their independence. In Pres. D. Eng. they can no longer be so used. The form canned, and the infinitive can in the collocation can thank shows that here can was imagined to be a different verb from can in the other constructions. This phenomenon dales from Middle English where the weak inflection is often met with (OED 8. v. $\operatorname{can} \mathrm{v}^{\prime} \mathrm{B}$ 10).

\section{EARLIER}

LATER

can $=$ to know; to be acquainted with.

c 1000 Ags. Gosp., Matt. xxv, 12, 1610 Shakesp. Phoen. \& Turtle 14, Ne can ic eow (OEI)).

c 1380 Chaucer, C. T. A. 3126, I can a noble tale for the nones.

can skill = to be skilled in.

c 1518 Pace in Ellis, Orig. Lett. III, 1, 186, They couth goodde skele in byldyngs (OED). And the priest in surplice white That defunclive music can ${ }^{\mathrm{l}}$ ).

can thank $=$ to acknowledge one's gratitude.

c 1175 Lamb. HoIn. 31, Ne can crist him nenne ponc (OED).

1710 Philips, Paslor. Iv 23, No skill of Music can I (OED).

will + noun $=$ to want ; to desire.

c 825 Vesp. Ps. Lxvir, 31, Tostenc piode pa zefebt willap (OEU).

1584 R. Scot, Discov. Witcher. xIr, x1v, 201, The smitbs will canne them small thankes (OED).

1734 tr. Rollin's Ano. Hist, v 31, He that can do whatever he will is in great danger of willing what he ought not (OED).

1) For other instances in Shakespeare see Schmidt 1902. 
will + clause $=$ to wish; to desire.

971 Blickl. Hom. 61, Deme ze nu swa swa ze willon pæt tow sy eft 3edemed (OFI)).

ought $=$ had to pay.

a 1300 Curs. M. 21422, Pour he was ... And till a juu he mikel aght (OED).

ought $=$ possessed.

a 1000 Beowulf 31 , Leof land-fruma long'e ahte.
156 io Revels Q. Hlis. 112, We woll and commande that Imediately vppon the sight hereof ye delyuer ... vnto Sir Thomas (OLII)).

1535 Stewart, Gron. Scot, I 226, Quhair is the kyndnes thow ancht to Claudius ? (OEI))

a 1670 Spalding, Troub. Chas. I 205, The poor men that aucht thame follouit in (OFI)).

\section{Causatives.}

87. The objective verbs in the following quotations have a causal character, i. e., the post-verbal (pro)noun can be analysed as the subject of the action expressed by the related subjective verbs of exactly the same form.

Dial. C. (Wks.) 1161 C 4, He shortly ceased the tempest. I Lament. st. 10 1. 2, Our lorde encrease your honour and estate. | lial. C. (Wks.) 1262 I) 7, If he feare us with exyle... | I)ial. C. (Whs.) 1148 HI 13, [dyd not he] ... wyn hym eternal saluacion. | Dial. C. (Wks.) 1200 F 3, for foare of decaying the common wele... | Answer $1044^{\mathrm{B}}$ ?, shall serue, to the plantynge, rootynge, and waterynge of the faythe.

Clear examples of this usage are not so numerous as in Pres. D. Eng., where constructions like : He walked me off ; we slid the piano into its place have become recognized idiom. In many cases More uses a collocation consisting of one of the verbs to make, to cause, to let, to have, to get, to gar + a (pro)noun + infinitive, instead of a causative verb. (Cf. the chapters on indirect nexus of two verbs). Occasionally the causative idca is expressed by the verb to give + an abstract noun of action, as in :

Dial. C. (Wks.) 1178 D 14, as God vnto them that ... giue his adversari the ful, hath prepared a crown.

Causative verbs with vowel-mutalion (umlaut) occur in the following instances :

Dial. C. (Wks.) $1162 \mathrm{~F} 13$, he ... besought her to rayse vp) a dead man. | idem $1218 \mathrm{~F} \mathrm{9,} \mathrm{[terroure]} \mathrm{...} \mathrm{whiche} \mathrm{this} \mathrm{...} \mathrm{douyll} \mathrm{maye} \mathrm{...} \mathrm{reare} \mathrm{against}$ vs. I Buke of F.p. 4 A 7 , she lleeth her woy and leyeth them in the dust. | A pol. 93, laye yt in iny necke. | Dial. C. 181, Set a part your pryde. 


\section{Vicarious to no + Orject}

98. Last. Tlı. 87 D 7, we recken our selfe worllye more reuerence than we do go.l himielf. | Dial. C. 296, he sulfereth them manie times to liue in prosperitic longe after ... Long afler ? naye ... that does he no manne. | Dial. (.. 30.5, God sometime delitercth thrim thence as he dyd saint Peter. | Dial. Her. 119 G 7 , all they ... can ... do no more for vs ..., nor bere vs halfe the ... longynge to helpe vs, that doth our sauyour.

Though the same construction occurred in French (e. g. Meriméc Col. 232, llon Juan regrella don Garcia plus qu'il n'aurait fait son frère) the English idiom is not due to French influence, as it is found from the carliest limes. It is current in Pres. D. Eng.

\section{EARLIER}

Beowulf 44, wen ic pret he wille... Geatena leode elan unforhte, swa he olt dyde magenhrep manna.
LATEN

1766 Goldsm., Vicar W. I, I chose my wile, as she did her weddinggown (OED).

99. When the object of to do is the word so, this or $i t$, the vicarious character of to do is less prominent, owing to the fact that those pronominal words may be considered as having taken over the task of replacing the verb occurring in the preceding syntaclical unit :

Last Th. 93 C 8, a thefe ... cut a purse ... And when he was asked why he $d y d$ so,... the wretche said ... | Dial. Her. 113 A 12, I wolde for my parte well agre them for heresies, but yet haue I hard som or this that wold not do so. | Iial. Her. $108 \mathrm{~B} 3$, I shall neuer willingly deceyue your trust. And lest I might hap to do it of ouer sight vnware...

Same usage before and after More :

a 1000 Caedmon's Gen. 2586, Waldend usser gemunde warfast pa Abraham arlice, swa he of dyde (OEI)).

c 1400 Mandev. ur, 10, pai sell benificez of haly kirk, and so duse men in oper places (OEI).
1793 Bediloes, Sea Scurvy 52, They may acquire this principle ... but we have no direct experience of theil doing so (OEI)).

100. According to Jespersen 1928 p. 249 substitutive to do is not often found with an indirect object. His earliest quolation is dated 1599 :

Dekker, Old Fort. 1512, Will you commaund me any seruice, as you have done Orleans.

The usage, however, is very old, e. $\mathrm{g}$. :

1175 Lamb. Hom. 65, Vre gultes ... bon vs lorgeuen al swa we doth alle men pet liuen. 
The following quotations illustrate the use in More's English ; the first two contain to do + indirect object; the last two to do + prepositional object (to mock at, to deal with):

Dial. Her. 117 E 2, Nor these two words Chrislus crucifixus, do not so lyuely represent vs the remembrance of his bitler passion, as dothe a blessed ymagre of the crucilix, neither to lay man nor onto a lerned ').

Med. 1417 B 11, the bretherne of Joseph, could neuer have done him so much good with their loue and fauor, as they did him with their malice and halied.

Jial. Her. 118 H 7, Why doo these heretiques more mock at the maner of Christes chyrche, than they doo at the maner of these Jewes sinagoge.

Dial. C. 157, in such wise deale they wyth him as the mother doth sometyme wyth her chyld.

Occasionally the verb itself is repeated, as in :

Dial. Her. 147 D 9, so should the scripture sland them in as good stede, as a paire of spectacles shold stand a blinde freer.

Semi-independent sifall + Object

101. Dial. C. (Wks.) 1143 H 6, I pray you good vncle, procede you farther in the processe of your matler... That shall I, cosin, with good wille.

Dial. C. (Wks.) $1176 \mathrm{~F} \mathrm{9,} \mathrm{many} \mathrm{a} \mathrm{man} \mathrm{should} \mathrm{stand} \mathrm{...} \mathrm{in} \mathrm{a} \mathrm{very} \mathrm{peri-}$ lous case ... Many so should in dede ... and in dede many so dooe.

The objects are that and so, which replace the contents of the preceding units.

\section{EARLIER}

13... Seuen Sag. 2735, « Risbtfulliche thou him awreke. $\pi$ Th'Eınperour saide, "So ich schall» (OFD). 1470-85 Malory, Arth. x, Lvin, 510, That shall I not, said sir Dynadan (OED).

\section{LATER}

1818 Scolt, Br. Lamm. xxI, a His Mastership will do well to look to himself. " - " That he should, 》 re-echoed Craigengell (OED). $1888 \mathrm{~J}$. Winter, Bootle's Childr. Iv, "I should like to see ber now she's grown up. - a So you shall, (OED).

\section{To be content (SURE) + OBJect}

102. Dial. Her. $113 \mathrm{C} \mathrm{5}$, this am I very sure and perceyue it well,... that from the apostles time hetherto, this maner hath been vsed taught \& alowed.

1) Complements introduced by to, unto (excluding the prepositional objects) are looked upon as indirect objects. Cr. Kruisinga ((adjuncts)); Jespersen ("c to-phrases "). 
Dial. C. (IVks.) $1170 \mathrm{~F} 5$, whan he sittelh with me, I let hym have al the wordes. - Al the wordes quod she? marye that an I content.

OED does not record this idiom; it has only quotations of to be sure + clause. In Shakespeare ive find :

1 Henry vi, V, v, 83, but this I am assur'd, I feel such sharp dissension in iny breast.

Jespersen $1928 \S 12.8^{5}$ gives the following examples :

Iilton, S. A. 424, this I am sure. | ibid 1408, Yet this be sule. | Mrs. H. Ward, Eleanor 253 , What did she expect? Not any of the things which the vulgar bystander expected - that he was certain.

He adds that " in such cases the iviter probably had at first another continuation in mind than the one he finally chose, or began his sentence without having framed it completely in his mind. " It is also possible that the construction vas formed on the analogy of : this $I$ doulht.

\section{ThE TYPE : TO IIAVE A FEELING = TO FEEL.}

103. In the sections on subjective verbs $(\$ 63)$ the abundance of collocations consisting of verb + noun that are equivalent to single subjective verbs (to have a fall = to fall) has already been menlioned as a particularly striking feature of More's language.

Here follows a selection of quotations containing collocations consisting of verb + noun equivalent to single objeclive verbs :

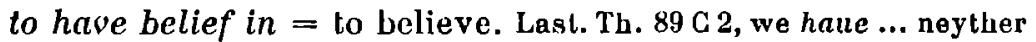
more belief in his holy wordes ... than hath a Jew or a Turke.

to hrve cause of $=$ to expect. Hich. $39 \mathrm{C} 1$, ye neuer had so great cause of hatred, as you haue of loue.

to haue conference of $=$ to discuss. Dial. Her. $111 \mathrm{H} \mathrm{2,} \mathrm{Against}$ which time I woulde so order mine affaires, that we would hane conference together, of all his erande at length.

to haue a feeling of $=$ to feel. Dial. C. 347, those spirituall ... inyes ... of whiche our carnal heartes hath so fieble and so faynte $a$ feling. to haue a glimeryng of = lo see vaguely or imperfectly. Dial. C. 346 , they shall of those heauenly ioyes ... haue ... a gltmeryng, though far from a perfit sight.

to haue hope $=$ to hope. Dial. C. 247 , the good hope that he shold have in goddes helpe.

to have knowledge of = to know. Picus 4 H 15, of the olde fatbers of the church ... great knowlage be had. 
to hrve losse $=$ to lose. Dial. C. 232, Neither losse had they any.

to have list (lust) $=$ to like; to want. Dial. C. 346, he shal neuer hane list to slepe. I A pol. J0, they will neuer haue the luste to loke vpon their bokes.

to have medlyng $=$ to meddle. Apol. 54, there was no man that any medlyng had with theym, into whose handes they were more lothe to come.

to halle misse of $=$ to lack; to miss. Dial. C. 127 , make me now feele and perceiue what a mysse of much coumforte we shall haue when you be gone. | Hich. $56 \mathrm{G} 1$, a comly rud in her chekes (of whiche she had before had most misse).

to haue the possession of $=$ to possess. Picus $19 \mathrm{E} 16$, thoughe I forsake al thyng to thentent that I may haue the possession of god.

to hane a purpose of $=$ to purpose. Dial. C. 143 , lette va ... haue a good purpose wyth vs of sure standinge by his holye faithe.

to have remorse of $=$ to repent. Last Th. $83 \mathrm{~B} 1$, the lechor knowelh he doth nought, \& hath remorse therof.

to hane respecte unto $=$ to heed; to consider. Dial. C. 290 , many men wyll saye so to, that haue pryncipall respecte unto theyr worldlye commoditie.

to halle opinion $=$ to thiuk. Dial. C. 214, some men haue opinlon, that such as once fal in that fantasy, can neuer ful caste it of.

to halle saltoll in $=$ to religh. Dial. C. 345, we can almost haue no maner sauour or taste in any pleasure spirituall.

to hane a sight of $=$ to see. Dial. C. 205, they had yet them selfe somewhat an vnperlyle sight of them.

to haue taste in, see : to have sallour in.

to have a wil = to want; to desire. Dial. C. 134, that persone... that hath a wil to be cured...

to make chaunge in $=$ to change. Rich. $64 \mathrm{~F} 13$, all thy nothing no channge made in the people.

to make a defence for $=$ to defend. Picus $3 \mathrm{H} \mathrm{16,} \mathrm{But} \mathrm{he} \mathrm{not} \mathrm{bear-}$ ing the losse of his lame, made a defence for those ... questions.

ta make a gay game = to ridicule. Conf. Tynd. $605 \mathrm{~B} 10$, where as he ... mocketh \& maketh a gay game, that Saynt Peters laith should be preserued in our Ladye.

to make a glaunce = to glance. Dial. Her. $138 \mathrm{~B} \mathrm{2,} \mathrm{I} \mathrm{touched} \mathrm{it} \mathrm{in}$ the beginning and made in a manner a glaunce therat.

to make meanes to $=$ to negotiate with. Dial. C. (Wks.) $1188 \mathrm{C} 1$. another sum of money should ... be sent to Rome, and there shuld be meanes made to the l'ope...

to make mockes (mowes) of (agains $l$ ) $=$ to ridicule. Apol. (Wks.) $916 \mathrm{G} 8$, they make mockes and mowes of the masse. | Apol. (Wks.) 
846 E5, he leaueth out somewhat that Tyndalle taketh in, that is to witle, the makinge of mockes and mowes against the masse ').

to make a proof $=$ to try ; to test. Last. Th. $76 \mathrm{H} \mathrm{18,} \mathrm{yf} \mathrm{thou} \mathrm{putle}$ it in a saie and make a proofe, thou shalto well fynde...

to make rehearsall of $=$ to repeat. Hich. $64 \mathrm{E} \mathrm{2,} \mathrm{the} \mathrm{recorder...}$ made reherersall ${ }^{2}$ ) to the comens of that the duke had twise rehersed them bimselfe.

to make reporte of $=$ to report. Dial. Her. $107 \mathrm{H} 4$, he hath of all our communicacyon made you faythfully, plain and ful reporte.

to make semblaunce $=$ to pretend. Dial. Her. $287 \Lambda 15$, And yet make thcy semblaunce as though they belieued.

to make a tale of $=$ to discuss. Apol. 153, I wyll make here no longe tale agayne therof.

to make $a$ vow $=$ to promise solemnly. Dial. C. 281, I made a solempne cowe vnto my sclfe,... that...

to make wresting with $=$ lo wrestle with. Passion 1347 D 3, what wrestlyng soewer the inlideles shall make with it.

to call names $=$ to vilify; to abuse. Dial. C. 334 , with all the shameful names that they could call you.

to cast a fantasy to = to take a fancy or liking to. Dial. G. 331, he cast such a fantasy therto that he wolde not go lrom it. (Cf. set one's fantasy vppon).

to do hurt to = to hurt. Picus 7 A 13, He saide, that fame oflentines dtd hurt to men while thei liue, \& neuer good whan thei be dead.

to fall in to the breche of $=$ to break. Dial. Her. $269 \mathrm{D} 11$, folk ..., whiche yet fall in to the breche of gods commaundement by the subtyll suggestion of the deugll.

to geue diligence to $=$ to sludy diligently. Dial. Her. $111 \mathrm{C} \mathrm{3,} \mathrm{I}$ vnderstode him to baue geuen diligence to lhe latin tonge.

to geue $a$ fal $=$ to throw down; to humble; to ruin. Dial. C. (Wks.) 1145 D 11, Christe gaue hym a great fal. | Apol. (Wks.) 846 $H \mathrm{l}$, thon is it ethe ... to gene the selye soule $a$ falle.

to geue the hearynge = to listen to. Dial. C. 140, whyle he preacheth of the paynes of hell, styll they stande and yet geue hym the hearynge. | Dial. Her. $168 \mathrm{G} 4$, to gyue diligent hyrynge ... to the church of Christ.

to put in the wyght $=$ (older : to wyght; to wite) $=$ to blame. Hich. $41 \mathrm{C} \mathrm{9,} \mathrm{of} \mathrm{al} \mathrm{the} \mathrm{hurte} \mathrm{that} \mathrm{therol} \mathrm{should} \mathrm{ensue} \mathrm{...} \mathrm{all} \mathrm{the}$ worlde woulde put her... in the wyght.

1) to mock and to mow in : Conf. Tynd. $398 \mathrm{C} \mathrm{11,} \mathrm{with} \mathrm{mocking} \mathrm{\&}$ mowing and potting the sacramentes.

2) Probably a misprint for re-rehersal.

MATERIALE XIX 
to pritle in a saie $=$ to try ; to test. Isast. Th. $76 \mathrm{H} 18$, yf thou pulle it in a saie and make a proofe, thon shalle well lynde...

to set funtasy oppon $=$ to take a fancy or liking to. I)ial. (.. 322, such folke as so setle theyr fantasy cppon some small symple pleasure.

to take heede into = to heed. I)ial. G. 214, He toke so great hecde onto euery suspicious token.

to take labor for $=$ to strive after. Dial. C. 246, the little pienish plesure ..., that they tooke al that labor and payn for.

to take liking in = to like; to enjoy. Last. Th. $74 \mathrm{E} \mathrm{5}$, inward liking lhat the godly spiril taketh in the diligent labor of good and verluous busines.

to take payn for = to strive after. - See : take labor.

For all attempt at explaining the reasons why More in some cases prefers the analysed form to the simple verb see $\$ 63$. Some of the above collocations have dropped into clisuse in later English, e. g. to have loss of, - list, - lust, - meddling with, - miss of, - opinion, - savour in; to make a glance at, - means to, - mocks of, - mows of, - semblance, - a tale of (= to discuss), - wrestling with; to give diligence to; to cast a fantasy to; to fall in the breach of ; to put in assay, - in the wight; to set fantasy upon; to take labour for, - pain for. The nouns in to have taste in and to make change in are now mostly preceded by the indeflnite article.

OED has no instances of to have belief in,-conference of '), to make a glance, - a tale of $\left(=\right.$ to discuss) $\left.{ }^{2}\right)$, - wrestling with; to give diligence to $\left.{ }^{3}\right)$; to fall in the breach of; to give a person a fall; to set fantasy upon $\left.{ }^{*}\right)$. The earliest inslances in OED of the following groups are later than More : to have a feeling of (1601), - loss (1562), - a meddling (1548), - respect to (1530); to call names (1594); to cast a fantasy (fancy) (1601).

1) The earliest quot. in OFD containing the noun conference is dated 1538.

2) To make no tale of (which is recorded in OED) has a different meaning ( $=$ to hold of no account).

3) But to put diligence and to do one's diligence are recorded.

4) To have a (no) fantasy to, however, is recorded. 


\section{THE KINDS OF WORDS OR WORD-GROUPS THAT ARE USED AS OBJECT}

104. As there is in this respect no difference between More's usage and the usage in Pres. D. Eng., a simple enumeration may suffice.

The olject may be

1. a noun or a pronoun :

Picus 9 G 7, I thretened him two yere together, that he would be punighed, if he foreslouthed that purpose. | Picus 14 E 3, Trewly ... in this point I gainesaye you not. Hich. 54 E 8 , I tel thee thei haue so done.

2. a special form of the verb (see sections on the syntactical units containing two verbs).

3. a clause :

Picus 31 В 3, He mindeth not, what menne about him talke. | Lasl Tb. $78 \mathrm{G} \mathrm{4}$, For wel he knoweth that than he either winneth a man for ener, or for euer leseth him. | Last Th. $87 \mathrm{H} \mathrm{9,} \mathrm{wee}$ shall not gretly dote vppon that we set lyttle by.

\section{IT AS OBJECT}

105. The character of the word it used as an object corresponds fairly well with the character of the same word used as a subject. See $\$ \$ 6-16$.

\section{Conchete it as object.}

Referring to a noun :

Dial. C. (Wks.) 1171 A 16 , a good vertue seruyng to refreshe the mynde, and make it quycke and luslye to labour and study agayn. | Last Th. $72 \mathrm{H} \mathrm{3}$, Surely there canne bee nolhyng so bitter, but wysedome would brooke $i t$ for so gret a profite.

leferring to an adjective :

Dial. C. (Wks.) $1210 \mathrm{C} \mathrm{3,} \mathrm{The} \mathrm{manne} \mathrm{is} \mathrm{so} \mathrm{much} \mathrm{the} \mathrm{lesse} \mathrm{perfyte} \mathrm{than}$ I woulde he were, and happely than hym selfe woulde wishe, if it were as easy to be it as to wishe $i t$.

\section{Summarizing it as OBject.}

Rich. $49(=46) \mathrm{H} 1$, it is not likelye... that she shall sende him somme where out of the realme? ... And I doubte not but shee nowe as sore myndeth it as wee the lette thereof. | Dial. C. (Wks.) $1173 \mathrm{C} \mathrm{14}$, after fell there on me one fit out of course, so straunge and so meruylons, that I would in good faith hane thought it impossible. 
108. Sumiariziva it as object in glauses opening With THE OBJECT WHICH.

Picus 3 B 3, he departed to Bonnnie to studye in the lawes of the church : which when ho luad two yere tasted..., his mynde fill from it. | Dial. C. (Wks.) $1177 \mathrm{G} 5$, The totber kynde is thys whych I reliersed second, and sorltyng out the tother twayne, hate kepte it for lhe last. | Apol. (Wks.) 892 . 15 , as for worldlye countenaunce is among the clergy within these lewe ycares not a lyttle abated. Whych thynge who so lyst wyth an euen eye to looke vpon it, and indilTerentlye consider it, shall nol payle to perceyue...

From a logical standpoint the word it in this kind of units is tautological, the object having already been expressed by means of the word which. 'This construction is nuknown in Pres. 1). Eng., but seems to have been a regular idiom in More's language. Compare the similar kind of redundant repetition in the following passage : Dial. C. (Wks.) $1182 \mathrm{~A} \mathrm{4}$, he that faithfully dwellelh in the hope of Gods help, the pauice of his truth shal ... fense hym round about.

109. Ahsence ') of summarizing It.

Dial. Iler. 237 G 2, Came the thyrd tale to as wise a poynt? Ye shall heare quod I. | Dial. C. (Wks.) 1248 D 14, The tyme of hys impriesonmente I graunte well, was not longe. | Rich. $49 \mathrm{G} \mathrm{3}$, it is I trow no great maruaile. | Boke of F. p. 1 A 3, Mine high estate and auctoritie, If ye ne know, enserche. | Itich. $40 \mathrm{~F} \mathrm{7,} \mathrm{as} \mathrm{great} \mathrm{[sc.} \mathrm{peril]} \mathrm{is}$ growyng, yl wee sulfer this yonge kyng in oure enemyes hande, whiche without bis wyttyng, might abuse the name of his commaundement. Apol. (Wks.) $845 \mathrm{H} 20$, readers which would I wist wel pardon ... such ... ouergight. | Dial. C. (Wks) 1222 G 9, was that ... Oracion ..., any thyng prayse worthye? For you can tell I see. | Dial. C. (Wks.) $1159 \mathrm{C} 4$, whether he went to the rest that his father dyd, ... I cannot tel ${ }^{2}$ ).

The following quotation perhaps belongs here : Hich. 49 (=46) B 8, from that tyme liytherwarde, was there neuer so vndeuowte a Kinge, that durst that sacred place violate, or so holye a Bishoppe that durste $t$ presume to consecrate.

A double interpretation of this last construction seems possible; it may be read : that durste it presume to consecrate $[i t]$, in which the first it is proleptic; or : that durste presume to consecrate it. This would be a case of front-

1) There is of course nothing missing; the term only means that Pres. D. Eng. requires the word it in a greal number of similar cases.

2) Compare the paragraph on the absence of a referring word after a form in -ing preceded by the (they waxed wery of the sekynge) \$ 127. 
position of the object. The verb that most often occurs withoul summarizing it is to tell. The following yuotations, however, show that to tell $+i t$ was also used by More.

Apol. (Wks) $873 \mathrm{G} 1$, who so for such good wyll telleth a man his fautes, vselh to tel hit hym secrelly. | Dial. (.. (Wks.) 1181 F 10, he was somwhat prycked foorth belore them, and came so fast l,acke to tel it them, that they thonght it rallier tyme to make hast.

To tell + so also occurs :

Rich. $50 \mathrm{D} 13$, But the childe cannot require the priuilege, who tolde him so ?

The three cases (1. no backward reference, 2. so and 3. $i l$ ) correspond to the different degrees of definiteness of the real objects, jusl as in Pres. D. Eng.

According to Einenkel (1916 p. 131) the constructions withoul backward reference were scarce in Old Eng., but frequent in Old French (only, however, when the verb was construed with a "dative" object as in : volés que je vos die?). In Middle Eng. the usage was adopted on a large scale, especially when the idea that constiluted the real object was loo vague for its being recapitulated by means of the words it or so. In IVilliam of Palerme (1350) whe read: He is my lege man lelly pon knowes. Chaucer has : I graunte; I mene wel; $I$ say in this entente. In Pres. D. Eng. it is not difficult to find examples; to know, to tell, to see are among the verbs that are oftenest used without any referring word; some verbs even alvays dispense with it (e. g. to try, to care, to forget).

110. Conceptional it as object.

1)ial. C. (Wks.) $1198 \mathrm{H} \mathrm{6}$, [And thus will I finishe this piece]. For me lhinketh I haue made it a long night. | Dial. Her. $111 \mathrm{E} 15$, he [scil. God] hath promised, that if we seke we shall finde, and if we knocke we shall baue it opened to vs. | Jest p. 2 E 15 , With visage stout, He bare it out, Fuen vnto the harde hedge.

This it tends to become quite meaningless, with the result that in some cases, the verb becomes subjective in meaning, e. g. to bare it out. In Old English there occurred similar constructions: hit macian '), hit healden, hit monen [cf. old French, le faire (tenir, asseurer, refuser) bien (mienx, ainsi, etc.] '). Instances from Middle Eng. writers : c 1374 Chaucer,

1) Cr. Aclfric Hom. II 354, 24, swa he hit macode on his life; and Dutch : hij maakt' $t$ goed.

i) See Einenkel 1916 p. 133. 
Troil. IIf, 1650, I baddo it nevere half so hote as now. 1387 Trevisa, Higden (Rolls) VII, 27, pe kyng ... made it as pey were nouzt wroop.| c 1412 Hoccleve, De Reg. Princ., 3516, 'Julius', quod be, ' make it noght so tow ?'

Shakespeare has :

Two Gent. I, ii, 102, She makes it strange, but she would be best pleas'd To be so angred with another Letter.

111. No instances of the type : to go it; to walk it; to coach it; to rough it have been found in More. Neither is the slightly different type : to queen it, to lord it represented. This kind of construction, however, was known before his time :

Blickl. Hom. 231, Min Drihten Hælende Crist, hu mag ic hit on prim dagum gefaren?

As a proof that to foot it was known in More's time the following quolation may serve :

1513 Douglas, Aencis $\mathrm{x} I 1, \mathrm{Ix}, 110$, Thai fut it so that lang war to devys Thair hasly lair.

From the following list, giving the dales of the earliest use of a number of similar collocations with $i t$, may be gathered that the idiom was not yet a regular leature in the language of the first part of the $16^{\text {th }}$ century.

\begin{tabular}{l|l|l}
1579 to lord it & 1611 to queen it & 1787 to run it \\
1579 to trip it & 1628 to leg it & 1821 to go it \\
1579 to face it out & 1642 to run for it & 1857 to funk it \\
1580 to carry it & 1645 to king it & 1873 to have it out \\
1581 to lalin it & 1656 to master it & 1880 to blue it \\
1592 to have it & 1703 hang it ! & 1902 to tube it \\
1597 to brave it out & 1768 to rough it & 1904 to tram it
\end{tabular}

For the usage in Shakesp. see Franz $\$ 295$.

\section{Proleptic it as object.}

a. With predicative adjunct.

Last Th. $78 \mathrm{C} \mathrm{2}$, Have ye not ere this in a sore sicknes felt it very grienous to haue folk babble to you ... whan it was a pain to speake ? Hich. $53 \mathrm{E} \mathrm{10,}$ whither he could thinke it possible to winne the lord Hasting in to their parle... | Rich. $66 \mathrm{~B} \mathrm{10,} \mathrm{tbey} \mathrm{lhought} \mathrm{it} \mathrm{for} \mathrm{the} \mathrm{weale}$ vninersal to take that wai.

Dial. Her. $110 \mathrm{H} \mathrm{12,} \mathrm{he} \mathrm{thought} \mathrm{it} \mathrm{heresye,} \mathrm{to} \mathrm{thinke} \mathrm{the} \mathrm{oppinions} \mathrm{of}$ any man to bee good and catholyque, which been heresyes in dede. Dial. Fler. $105 \mathrm{C} \mathrm{12}$, I thought it ... ynough to tell the messenger my 
niynde by mouth. | Rich. $59 \mathrm{~B} 5$, whiche wer not likely to lake $i t$ well, if al his viage were in suche wise frustrale, and his appointmentes deluded.

Dial. C. (Wks.) $1178 \mathrm{C} \mathrm{11}$, Esteme it and take it ... for a thing of al ioy, when you fall into diuer's and sundrye maner of templacions.

In the majority of cases the real object has the form of a syntactical unit conlaining an infinitive (e. g. to have, to winne). The last two quotations have units opening with conjunctions (if, shen).

The idiom was known before Nore's time :

c 1400 Mandeville 161, 15, And pei han gret conscience and holden It for a grel synne to casten a kny" in the fuyre.

In Pres. D. Eng. the usage is quite common.

Occasionally More construes his sentences wilhout this proleptic it :

Diat. C. (Wks.) 1196 G 3, let no man thynke strange, that I would aduise a man to take consayl of a phisicion. $A_{\text {p }}$ ol. (W $\mathrm{ks}$.) $868 \mathrm{G} \mathrm{6,} \mathrm{I}$ hate euer accompted my deuty to forbeare all sucho maner ol vnmannerly behauioure.

In Pres. D. Eng. this usage is restricted to a few cases in which verb + predicative adjunct form a very close group (to think fit; to think proper; to make plain). In these cases the predicative adjunct is an adjective, and not a noun as in the quotation from Apol. (accompted my deuty).

In the collocalion fynde in one's harte no proleptic it is used :

Dial. C. (Wks.) 1228 A 4, wee shall fynd fewe ... that shal fynde in they hartes so sodainelye to forsake theyr goodes. I Supplic. 290 \& 9 , who coulde euer haue thought that any christen man could ... haue founden in his hert, to seke \& study the meanes, wherby... | Dial. C.

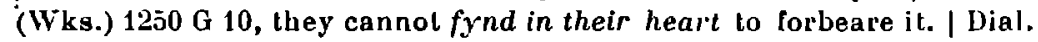
c. (Wks.) $1250 \mathrm{H} \mathrm{4,} \mathrm{[they]} \mathrm{cannot} \mathrm{...} \mathrm{fynde} \mathrm{in} \mathrm{their} \mathrm{heart...} \mathrm{to} \mathrm{goe} \mathrm{to}$ the gret feast.

In Pres. D. Eng. we see that it is would be substiluted for we see it in :

Passion 1327 E 2, wee see it the common manner of holye sclylture, too call hys blessed bodye and bloude, by the former names.

113. b. Without predicative adjunct.

Dial. Her. 126 A 8, if experience had proued it that the hole earth bangeth in the ayre. | Dial. Her. $110 \mathrm{D} 10$, the people take $i t$, that styll those that persecute be the miscreauntes. | Apol. (IVks.) 849 K 8 , bhe hearde him boast it, howe iolily it was preached. | Dial. C. (Wks.) 1222 
B 7, though I could be content to be out runne of an horse, yet would I no more abyde it to be out runne of an esse.

Dial. Her. $114 \mathrm{~F} \mathrm{4}$, I doubte it not but that in the daies of those holy saintes, ornamentes in churches of christ were not only pure and clene, but also very costly. | Dial. C. (Wks.) $1186 \mathrm{G} \mathrm{1,} \mathrm{I} \mathrm{sayd} \mathrm{...} \mathrm{that} \mathrm{of} \mathrm{pusil-}$ lanimitie cometh this templacion ... But yet I ment it not, that of onely faint hart and feare, it cometh and groweth alwaye. | Hich. $59 \mathrm{H} 6$, I neuer wisle it yet that it was forbidden a prince. I Dial. Her. 113 G 5, For this am I very sure and perceyue it well ..., that from the apostles lime hetherto, lhis maner hath ben used taught \& alowed. $\mid$ Rich. 60 G 5 , he tooke $\|$ so highly that his embasiate was deluded, that... I Hich. $49(=46)$ D 3, I dare take it vppon my sonle, she well knoweth slie needeth no such thyng to feare.

In the quotations of the first paragraph the real object follows immediately after the proleptic it; in lhose of the second there is an inlervening word (adverlos: not, yet, well, highly; prep. adjunct : oppon my soule). It is impossible to say anything about the enclier history of this usage, the earliest quolalions in OED being daled 1596 and 1599 :

Shakesp. Merch. V. 1, i, 63, I take il your owne business calls on you ; | Much Ado 1v, i. 206, P'ublish it that she is dead.

According to V.d. Meer (1929 $\$ 232 \mathrm{~d})$ the conslruction is used by Maundeville, when the main-clause contains an adverb; he adduces but one instance : 124, 3, And wyteth it wel pat alter the Auctoures and Astronomye. DC. furlonges of erthe answeren to a degree of the firmament.

In Pres. D. Eng. This idiom is common with some verbs, e. G. May I take it that you will sign the document? In the majority of cases, hovever, there is, both in More's language and in Pres. D. Eng., no proleptic it when there is no intervening word between the verb and the object-clause. A few instances may suffice :

Dial. C. (Wks.) $1255 \mathrm{H} 2$, he repented ... that he so had doone. | Dial. c. (Wks.) 1210 A 1 , [he] dothe truely protest and tistifye... that he dothe it not lor any desyre thereof.

'lhe following constructions seem exceptional :

Dial. C. (Wks.) 1244 H 15, I see very clerely proved that it can be done none otherwise. | Lell. 1458 A 2, I lotle when doughterly loue ... hath no laysure to loke to worldiye curtesy.

One example of an object-clause depending on verb + preposition has been found in More; it contains no proleptic pronoun :

Hich. 59 F 10, I an sure that my cosein of warwik neither loueth we 
so litle, to grudge at that $I$ loue, nor is so vnresonable to loke that I abold in choise of a wife, rather be ruled by hys eye, then by mine own.

\section{So as OBject}

\section{4. a. With to do}

Rich. 54 F 8, I tel thee thei haue so done.| Apol. 6, leuynge out noughte but raylynge... and where 1 so do, I geue the reader warnynge. | Last. Th. 81 B 10, as for that that thy hunger doth thee pleasure whan it is fed, so dothe somtime tbe ytch of a sore leg, whan thou clawest about the brinkes. | Picus 14 E 7, it is not all one to saie we doo well, if we doo so...

\section{b. With other verbs}

Dial. C. (Wks.) 1235 D 8, hymselfe shall (if you so desire hym) not faile to woorke with you therein. | Apol. 57, god lorbede that any crysten man shold meane so. | Dial. Her. 128 F 2, Wote you ... lliat reason and nature tell you so ? Rich. $50 \mathrm{D}$ 13, But the childe cannot require the priuelege, who tolde hym 80 ? | Last Th. $73 \mathrm{G} 8$, I am content ye so think. | Apol. 44, it were not good that yonge men sholde wene so. | Supplic. 289 F 7, we so myght of reason \& 80 shonld of charilie.

The use of so differs from the use of $i t$ in this respect that so refers only to the contents of a preceding syntactical unit '); besides so is less definite than it. In some of the above quotations it is possible to look upon this resumptive so as an adverb of manner; in those cases the verb stands without object (not e. $\mathrm{g}$. in : if you so desire him). More seems to have been tree to place so before or after the verb; no difference in meaning appears to be connected with the wordorder; rhythm and emphasis must have been the decisive factors. In Pres. D. Eng. the front position of so is literary or archaic.

The usage in More of anaphoric so corlesponds to that in earlier and later writers, as appears from the following data.

\section{EARLIER}

c. 825 Vesp. Paalter cxuvi 20, No dyde swe ylcre cneorisse (OED). 1362 Langl. P. Pl. A II 90, pe Tixt tellep not so (OED).

\section{LATER}

1611 Bible, Isaiab xx 2, And he did 8o, walking naked (OED).

1892 Law 'Times, Rep. Lxvı 252, 1, If this had not been true, the pilot would have taken very good care to tell us 80 (OED).

1) Constructions in which the word so refers to a preceding adjective (as in Pres. D. Eng. it was worn away and probably had been 80 for years) have not been discovered in More. 


\section{THE VARIOUS KINDS OF OBJECTS}

\section{A. VERBS WITH ONE OBJECT}

\section{Ordinary or Direct Objects}

115. The relations between verb and object are too multifarious and often too subtle for an accurate classification to be practicable. The terminology adopted here is in accordance with that used by Jespersen (1928 $\mathrm{c} \$ 12.1$. 3), who calls all objects olher than those of result ordinary objects, and observes that this class conlains the most heterogeneous objects, and that neither the names given to these objects in German grammars (richtingsobject or affiziertes object), nor the definitions usually given are comprehensive enough.

Ordinary or direct objecls occur in :

Picus $2 \mathrm{H} \mathrm{9,} \mathrm{he} \mathrm{labored} \mathrm{the} \mathrm{studies} \mathrm{of} \mathrm{humanilee.} \mathrm{|} \mathrm{Dial.} \mathrm{C.} \mathrm{(Wks.)}$ 1222 A 7, he coulde speake no latin at all. | Apol. (Wks.) $864 \mathrm{~A} 14$, the diuel of hell, which so entangleth their tounges, and so distempereth their braines. | Apol. (Wks.) 867 D 1, all they coulde neuer feefle me wyth one penye thereof.

In older English there were verbs that were regularly or usually construed with a noun or pronoun in the dative case - help 1), follow, etc. In the course of the Middle Ages the formal distinclions between dative and accusative were obliterated, so that by More's time every trace of the original funclion of the noun-object had vanished. It may be assumed that this levelling in form went hand in hand with a levelling in function and that in the beginning of the $16^{\text {th }}$ century the average speaker or writer was no longer aware of any difference in character between the object after such verbs as help, follow, etc. and that afler such verbs as see and beat.

For this reason the following quotations may be givell a place in this section :

Picus $7 \mathrm{C} 8$, if I be ought in your dette, I shall paie you by and by. I Picus $30 \mathrm{C} \mathrm{11,} \mathrm{god} \mathrm{whom} \mathrm{bell,} \mathrm{earth,} \mathrm{and} \mathrm{all} \mathrm{the} \mathrm{heauen} \mathrm{obaise.} \mathrm{|} \mathrm{Itich.}$ $67 \mathrm{H} \mathrm{3}$, those that I haue broughte vp myselfe... euen those fayle me. I Rich. 55 A 12, frendes fayle fleers. | Apol. (Wks.) 863 F 2, he Lode me, that y I I woulde see a verye ryghte image of a fiende, I should..., Picus 1 F 5, thei [scil. these works] maie delite \& please any person.

l) e. g. a 1000 IIyıus vii 44 (Gr.), pu monejum helpot. 
The joining, in the last quotation, of one and the same noun [person] as an object to the two verbs delite and please may be looked upon as a proof that no difference in function was realised.

The character of the object of such verbs as pay is different if another object is added (see $\$ 152$, direct object + indirect object).

\section{Objects of Regult}

116. The name object of result ${ }^{1}$ ) is given to such objects as express the result, either attained or aimed at, of the action denoted by the verb (e. g. to weve a webbe). The difference between ordinary objects and objecls of result is clearly brought out by a comparison of the constructions dig the ground and dig a grave.

In More we find the following instances :

Apol. (Wks.) 849 D 4, to weaue a webbe. | Picus 17 A 14, Let them be ashamed that woorke wickednesse in vayne. Jest p. $3 \mathrm{E} \mathrm{7,} \mathrm{No} \mathrm{harme}$ she thought. I Aich. 54 A 9, what were lhey worthy to haue, that compasse and ymagine the distruccion of me? | Rich. $55 \mathrm{~A} \mathrm{4,} \mathrm{dremes,}$ which ... his owne fere fantasieth or do rise in the nightes rest. Dial. Her. $167 \mathrm{~F} \mathrm{10,} \mathrm{he} \mathrm{...} \mathrm{besechelh} \mathrm{christen} \mathrm{people} \mathrm{to} \mathrm{agre} \mathrm{together}$ all in one mynde, and in the faythe to tell one tale. Conf. Tynd. 576 C 3, Thys is a fayre tale of a tubbe tolde vs of hys electes. I Lest Th. $77 \mathrm{H} \mathrm{6}$, neuer was ther body that yet could tel the tale. I Dial. Her. $105 \mathrm{~B} \mathrm{3,} \mathrm{it} \mathrm{is} \mathrm{an} \mathrm{olde} \mathrm{said} \mathrm{saw.} \mathrm{|} \mathrm{Dial.} \mathrm{C.} \mathrm{318,} \mathrm{Is} \mathrm{this} \mathrm{...} \mathrm{a} \mathrm{fond}$ ymagined fantasy, or is it very trueth in dede? I Rich. $54 \mathrm{E} \mathrm{10, \text {ho }}$ clapped ... vppon the borde a great rappe. I Supplic. $326 \mathrm{G} \mathrm{13}$, thei strike the stroke.

\section{Cognate ObJecta}

117. Some of the objects occurring in the quotations of the preceding section express a meaning that is inherent in the meaning of the verb (ymagine a fantasy). The relation may be so close that verb and object are denoted by words that are etymologically akin (weve a webbe, say a saw, tell a tale).

The objects in these and similar cases may be called cognate

1) Also called accusative of gaol (Curme 1933 p. 98) and effective ob ject (orgebnisobject or effziertes object). Cf. Jespersen 1924 p. 159. 
objects '). This name, however, is now commonly restricted to those objects of kindred sense or derivation that serve as a complement to subjective verbs, i. e. such verbs as usually do not take an object (e. g. to die, to strive). There are a few clear instances in More :

Dial. C. (Wks.) $1256 \mathrm{E} 6$, a man ... that dyeth a vyolent deth. | Dial. C. (Wks.) 1263 D 7, What follye is it then ... to flee from that death, whiche thou ... shatte shortelye afler wish thou haddest dyed. | Dial. Her. $270 \mathrm{E}$ 11, I baue labored and strienen a good strife. | Conf. Tynd. 369 G 6, the fastes that Moyses fasted fyrste for the lave.

The following instances are less clear, since the character of pray, worke and preach is cloublful.

Dial. C. (Wks.) 1164 B 15, theyr owne prayers prayed at some oller tyıne. | Dial. C. (Wks.) 1146 F 10, toward this purpose are expressely praied many leuout orasons. | Answer 1040 a 6 , wherby liey sholde worke the workes of God. | Dial. Her. $180 \mathrm{~F}$ 1, whoso ... dollte woorke good workes. | Apol. (Wks.) 8.50 a 9, a sermon once or lwycs openly preached.

The cognate objects proper often acquire the character of adverbial adjuncts, to die a violent death and to strive a good strife being equivalent to to die in a violent way and to strive well. For this function Old English availed itself of the instrumental case [deape sweltan, L. morte mori]. The wearing off of case endings caused the introduclion of prepositions to express the original relation, so that in Middle English to die came to be construed with $b y$, of, with and on :

1382 Wyclifr, Gen. II 17, with deth thou shalt die / idem 1388, Thou shalt die by deeth. | c 1386 Chaucer, Melib. 606, Bettre it is lo dye of bitter deeth. | c 1450 Merlin 52, I knowe not what deth this fole shall on dye.

Occasionally $a$ was used : 1200 Trin. Cull. Hom. 181, pu shalt a depe swelte.

It is probable that this $a$ was a weakened form of the preposition on and came to be treated as the indefinite article, so that it could either be dropped or replaced by such words as what and that :

13... Sir Beues 341, I ne reche, wath deth he dize, sippe he be cold.

The earliest quotalion in OED of to dream with a cognate

1) GC. Deutschbein 1931 a $\$ 19,8$ (" figura etymolorica "); Jespersen 1924 p. 160 \& p. 137 ff. (" inner objects"); Curme 1933 p. 98 ; Kruisinga $1932 \$ 1936$; Kollner $1913 \$ 200$. For the usage in Pecock's Hepressor aee Zickner 1900 P. 9 . 
object is dated 1300 ; of to live (a) life 1000; of to sleep a sleep 825; of to fight a fight (bateil) 1300 ; of to strive a strife 1375 and of to langh a laugh 1470. More's to ymagine a fantasy and to fast a fast are not recorded in OED; they may have been created in his time on the analogy of existing usage, just as other writers subsequently did with other verbs, e. g. to run a race (earliest quot. 1557); to smile a smile (earliest quot. 1837).

For the quasi-objects resembling these cognate objects (e. g. Picus C 12, go thy iourney; Dial. Her. 134 A 6, than had I walked a wise iorney) see $\$ 54$.

\section{The Object of a Form in -iNg}

The following types can be distinguished :

a) 1. their putting to death $(\$ 119)$;

2. nothing mistrusting $(\$ 120)$;

3. in the deed doing ( $\$ 121)$;

4. in stede of our grief taking away ( $\$ 122)$;

b) 1. comforting of her (\$123);

2. the doing of good (\$124);

c) 1. declaring the truth $(\$ 125)$;

2. the doing many good dedes (\$126).

In $a$ the object has front-position; in $b$ it has post-position and is prececled by the parlicle of ; in $c$ it has post-position and is directly joined to the verb.

119. Type a 1 : Their putting to death.

Itich. 5 \& 1 15, hys harte somewhal gruiged, lhat he was not afore, made of counsell in this maler as he was of the taking of her kynred, and of their putting to deatl. | Dial. C. (Wks.) $1164 \mathrm{~A} 13$, somme that lie a divnge saye full deuoutelye the Seuen Psalmes... wylh the P'riesle at theyr anneylinge. | Dial. IIer. 130 ( 9 , no man that was by at your crysteninge. | Dial. C. (Wks.) 1144 G 5 , he that referreth the maner of hys conmforting to God. | Lelt. 1446 II 7, The cause of my close keping... | Apol. (IVks.) $1072 \mathrm{H} \mathrm{4,} \mathrm{they} \mathrm{shoulde} \mathrm{haue} \mathrm{lesse} \mathrm{cure} \mathrm{and} \mathrm{care} \mathrm{of} \mathrm{their}$ belies, the desyre of whose ... filling with perisbable meate,... | Answer $10 \$ 3 \mathrm{H} \mathrm{l} 2$, he gaue hys Apostles and dysciples warning of hys betraieng, of hys taking, of his death, of his resurreccion. I Rich, $49 \mathrm{C} \mathrm{1,} \mathrm{I} \mathrm{dare}$ put no parson ... in trust with his keping. / Rich. 40 F 9, [lhey] might abuse the name of his commaundement, to ani of our ondoing. I Rich. $40 \mathrm{~B} 5$, to the gouernance and ordering of this yong prince at his 
sending thyther... | Passion 1274 D 13, lest ouer sodain enhaunsing ') so high, myght make such pride apryng in theyr hartes, as might be the cause of theyr dryuyng downe agayne, the great goodnes of God measured their state [scil. of the angels].

Here the object has the form of a possessive pronoun; orving to this fact and the presence of a preposition in front of the construction, the nominal character of the form in -ing is fairly pronounced, though less so than when the possessive pronoun is the subject. The frequent occurrence of the construclion in More proves that it was a regular idiom in the language of his time. St. John Fisher, too, makes a frequent use of it : 48, 20, all though this blessed vyrgyn brought forth our sauyour lhesu, yet be made her and was cause of her bryngynge in to the worlde (W.).

The following instance from Malory illustrates earlier usage:

Morle D'A., 821, 32, I wylle be a thousand fold more gladder to brynge her agayne than euer I was of her taking awaye.

The idiom is not rare in Shakespeare and Spenser : Merry Wives, III, iii, 189, Shall we ... excuse his throwing into the water...? Fairy Queen I, 3, 23, And still amidst her rayling, she did pray. In Pres. D. Eng. it is occasionally met with : Bennet, Clayhanger yI i $\$ 2$, He felt that if the lown had been aware of his jilting, he could not have borne the humiliation (K.).

More frequently, however, a passive group with being is used : We took our silver round to a Safe Deposit in order to prevent its being stolen.

The construction alternates in More with that in which the object-pronoun has post-position and is preceded by of :

Picus 6 B 3, all that ... he receyued ... he bestowed in the bying of a litle lande, to the finding of him and his Lowsholde.

In this case the pronoun obviously has post-position owing to its juxta-position with and his howsholde.

\section{Type a 2. Nothing mistrusting.}

Last Th. $87 \mathrm{C} 16$, so riseth of muche settyng by our self that affeccion of anger, by which... | Hich. $48 \mathrm{H} \mathrm{11,} \mathrm{she} \mathrm{in} \mathrm{this} \mathrm{doing} \mathrm{should} \mathrm{...} \mathrm{dooe}$ great good to the realme./ Rich. $52 \mathrm{H} \mathrm{10,} \mathrm{some} \mathrm{one} \mathrm{man} \mathrm{happely}$ somewhal perceiuing, filled mani men with suspicion. / Rich. 41 D 14, they nothynge Earthely mystrustynge, brought the Kynge vppe in greate haste.

1) On the analogy of the other constructions we should expect here: "leat their ouer sodain enhaunsing...". 
Here the object is a pronominal word incapable of showing its case. When 110 preposition precedes the character of the form in -ing is verbal; when prepositions are used (in or of as in the first two (quotations) its character is mixed (nominal + verbal). The idiom is known in Pres. D. Eng., though the reversed order (in doing this, instead of in this doing) is more usual.

121. Type a 3. In the deed doing.

Dial. G. (Wky.) 1183 B 13, hys conscience in the deede doing ... galle him. I Conf. Tynd. 396 C 3, Tbys manner of penaunce doyng, dydde gaynt John baptist teache and dyspute. | Dial. Her. $282 \mathrm{G} 3$, ere euer any lawe was made for such bokes burning. | Dial. C. (Wks.) 1183 G 6, when it camo to the penance geuing, the Foxe found that the most weighty synne in al hys shryft was glotony. | Dial. C. (Wks.) $1156 \mathrm{E} \mathrm{3,}$ Surely thus ... fare ther many lreres..., in comforte geuing to greato men.| Passion 1274 D 2, not so much for credence gyuing to tho serpentes wordes, as to content his wife... | Dial. Her. $150 \mathrm{~A} 11$, [they] plainly make against them, without receiuing or eare geuing to any reason or authoritie of any man quick or dede.

The object is a noun in the common or neutral case. It is possible that deede doing, penaunce doing, bokes burning, penrnce geving had already become so closely united as to acquire the character of a compound; to what degree it is difficult to say without a certain knowledge of the distribution of intonation and stress over these groups in More's time (cf. Pres. D. Eng. house-hunting; orgron-grinding). The question whether the article the in the deed doing belonged to deed only or to the whole group can consequently not be answered eilher.

Constructions of his type do not very frequently occur in More. In St. John Fisher we find : in hospytalites kepynge; almesse doing; so longe respyte ... gynynge; sharpe clothes werynge; harde clothes wering; true pennaunce doing (IV. $\$ 261$ ). The idiom was known in earlier English :

1338 Rub. of Brunne, Chron. 4283, ye ue wil passe us forby Wythoute truage askyng. I c 1340 Ricb. Hampole, Pros. Treat. [ents] 10, 15, With mouthe es it tane in vayne with all athes brekynge. I c 1388 Chaucer, C. T. B 277l, ye shal geten richesses by your wit ... and thal withouten wrong or harm-doinge to any other persone.

In Pres. D. Eng. constructions of this kind have fallen into disuse, if, at least, combinations like house-hunting ctc., may not be looked upon as regular descendants. 
122. 'Type a 4. (In stede) of our grief taking away.

Dial. C. (Wks.) $1146 \mathrm{H} \mathrm{7,}$, in stede of our grief takyng away, pray that God may sende vs...

This construction differs from that discussed in the preceding section in that a possessive pronoun intervenes between the preposition and the noun-object. The possibility of grieftaking forming a close intonation- and stress-group is negligible, because our evidently belongs to grief only (the taking away of our grief and not our taking away the grief). The construction can therefore not be compared with Pres. D. Eng. sentences like How are you getting on with your househunting, in which your belongs to the whole group '). The idiom seems to date from Old Englisb. As a possible prototype V.d. Gaaf 1928 p. 38 mentions :

Elfric, Homily II, Hwylcum nebbe and mid hwylcre gederftinesse derr he genealæcean to godes wiofude pæt he pæs haligan gerenes onfo, se pe is purh his bropur hatunge swa scyldig swa se manslaga.

He refutes Einenkel's argument $(1916 \S 3 \beta)$, who doubts the Germanic origin and assumes (as usual) French influence [e. g. par la paiz fesant, Joinv. I deffendi vous sor les membres perdant, Huon.].

Here follow a few instances from Middle English :

c 1200 Lofsong of ure Lefdi, O. E. H. I p. 207, Iche bede pe ... bi his side openunge, bi his blodi Hune, pet... I a 1300 Cursor Mundi C., insertion alter 17288, 89 ff., Mary mandlayn \& mari Jacobe ... And marie salome Hade boght pam oynementy for oure lord annoyntynge (G.).

The construction is of rare occurrence in More; this is somervhat surprising as it is frequently met with in Middle and Early Modern English (V. d. Gaaf 1928).

It is doubtful whether the following quotation contains an instance of the construction under discussion :

Debell. 99: D 7, for pleasure of hys new fashion preaching (= perhaps new fashion of preaching?).

In the following quotation the possessive pronoun refers to the noun only; the construction, however, is different because it is not introdused by a preposition :

Aut. Lett. $\mathrm{x}, 3$, his grace for yor substantiall counsaile ... his moost

1) This seems also to be the case in More's : Passion $1273(=1275) \mathrm{G} 5$, thys wicked serpent, wyth his questioning and her eare giuing therto, w rought ... some subtil suggestion in her hurt, 
affectuouse thankes geving to yor grace[,] hartely requyreth ... that ... my lord of suffolke... may be advertised of his graces resolute pleasure \& yors.

If instead of a noun a pronominal word like such intervenes batween the possessive pronoun and the form in -ing, the pronoun refers to the form in -ing :

Passion 1340 F 13, [if] you sey that the body of our sauiour is not really vnder the fourme of bread in the sacrament, than say we that in your such expowning, you playn expowne it false.

123. Type b 1. Comforting of her.

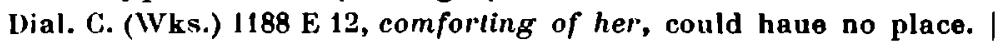
Last Th. 76 B 6, betler were it then holdynge of thy tong, properly to speake. | Dial. Her. 130 H 13, she seghylh for miscasting of her kayes. | Apol. 42, myssespende theyr tyme in redyng of myne answer. | Debell. $990 \mathrm{~A} \mathrm{12}$, rather then trouble the countrey with callyng op of the luries. Hich. $66 \mathrm{G} 6$, one of his tormentors might hap to break his head and worthy for marring of the play. | Dial. Her. $214 \mathrm{~F} 4$, finallye were they fayne for sauing of his life, to devise a fourme of abiuracion. | Some Lett. 278, And therefore are ye bounden to... take the sure way in obeiyng of your prince and swere it. I Hich. $38 \mathrm{C} \mathrm{11}$, vnder the pretext of reuengynge of olde displeasure. | Last Th. $88 \mathrm{C} 7$, men fal at varyance lor kissyng of the pax. | Picus 8 G 12, (very God and very man) whiche at the last for washing of our spottie synne ... willingly ... shede out his most preciouse bloude. | Supplic. $289 \mathrm{G} \mathrm{12,} \mathrm{the} \mathrm{meanes} \mathrm{of} \mathrm{relieuing}$ \& releasyng of our present paynes. I Answer 1036 B 12, after ones or twise warning of them.

This construclion is of much greater frequency than the rival construction with front-position of the object, illustrated in $\$ \S 119-122$. It occurred in Middle Lnglish, e. g. : c 1350 William of Pal. 919, for dreying of bis duel. | 1422 Past. L. $n^{\circ} 7$, in stopping of the noyse. In Old English the construction contained a genitive : Flfr. Hoin. 1 8, purh his weorces fremminge. I Id., ibid. I 240 , to heora metes tilunge. The usage with of was still current in Shakespeare's time (see Franz 1924 p. 560), but has become archaic or dialectical or vulgar in Pres. D. Eng.

\section{Type b 2. The doing of good.}

Picus 5 G 5, disputacions... exercised with a peasible minde to tenserching of the truth. | Picus $14 \mathrm{C} \mathrm{3}$, in the entreting of some proftable actes. I Dial. C. 147, the bare patient taking of hys death should baue serued for the satisfaccion of hys synne. | Rich. $56 \mathrm{C} \mathrm{14}$, lest the delaying of his execucion, might haue encoraged other mischiuous persons. | Rich. $67 \mathrm{G} \mathrm{5}$, the killing of his kinsmen. | Rich. $62 \mathrm{E} \mathrm{17,} \mathrm{the}$ 
getting of the garland. | Picus 7 A 11, in the renaying of this shadow of glorie. | Last Th. $87 \mathrm{E} 11$, with the minishyng of our own worship. Last Th. 74 F 4, the abandoning and refusyng of carnall pleasure. Last Th. $74 \mathrm{E} 13$, the sekynge of pleasure. | Last Th. $75 \mathrm{~F} 5$, thatlaining of which mynde. | Last Th. 102 G 2, the dooing of good. | Dial. C. 248, the hauing of the worldly goodes. | Dial. C. 251, for the not doing of the thing.

Last Th. 77 D 1, without any receiuing of the sentence. | Dial. C. 177, a minyshyng of fleshly wealthe. | Last Th. $81 \mathrm{H} \mathrm{15,} \mathrm{whiche} \mathrm{measuryng}$ of time and minishing of life.

In this section the form in -ing is preceded by an adnominal word (the, $a$, any, whiche) and clearly has the characler of a noun, so that the group of + noun formally resembles an attributive adjunct. From an historical point of view the usage calls for no discussion; it is extremely frequent in Mole's langunge; it was in use before him :

1382 Wycliff, Gen. xiv 17, The kyng of Sodom yede out into the ayengoyng of him.

It is common idiom in Pres. D. Eng.

125. Type c 1. For declaring the truth.

Dial. Her. $109 \mathrm{C} 7$, good men to beo mishandelyd for declaring the trouth. | Last. Th. 81 H 15 , lhcy shold in folowyng theyr yrous affeccion, reuenge themsell... | Last Th. 79 A 4, Than geueth he some false glade of escapyng that sickenes. | Hich. $63 \mathrm{~F} \mathrm{2,} \mathrm{in} \mathrm{auoidinge} \mathrm{dyspleasure} \mathrm{of}$ my noble lord.

of the two types for kissing of the pax (\$123) and for declaring the truth the latler is not nearly so frequently used as the former. It is not easy to account for this fact, the construction without of not being an innovation in More's time, since it had been used (as well as the other) from the fourteenth century ouvard (V. d. Gaaf 1928). It may be that the form in -ing was still on the first part of its way towards assuming a verbal character in addition to its nominal character, and thus only developing the regular duality in function which it has in later English. (The preposition points to its nominal, the direct junction with the object to its verbal character). To bear out this conjecture the following facts may serve :

a. the construction does not occur very frequently in Malory (Dekker 1932 \$ 267);

b. the construction is comparatively rare in More; 
c. Berners, More's comtemporary, does not seem to use it ${ }^{1}$ ).

In Pres. D. Eng. it is the normal construction when no article precedes; it varies with the idiom of type $b 2$, but seems often to be more verbal in character (see $A$. Pompen 1924 pp. 167-173).

126. Type c 2. The doing many good deeds.

Aut. Lott, xm 9, dexterite in thacheving \& bringing to passe his vertuouse \& honolable appetites. | Dial. C. (WVs.) $1166 \mathrm{H} \mathrm{3,} \mathrm{labouring}$ about the doyng many good dedes. | Dial. C. (Wks.) $1146 \mathrm{C} \mathrm{15}$, the dread of the losing these things. | Last. Th. $83 \mathrm{D} \mathrm{14}$, one of his good ... knocking is, the putting 's in remembrance of deth. | Debell. 931 A 4, the man hath ... misse rehearsed them to make the reader wene, that in the reprouing them I hasl written wronge. | Debell. $935 \mathrm{H} 15$, the ... cause that hee layeth, ... that is to wytte the mysse handelyng the people... | Dial. C. 243, goynge oule of the worlde enen strayghte vnto the geuing op his reckoning vnto God.

This type (with article and without of) is of almost as rare occurrence as that discussed in the preceding section, a fact which would seem to corroborate the conjecture proposed there; here the dual character of the form in -ing is still more prominent on account of the deffnite article. Whether this idiom was known before More's time it is difficult to ascertain. From the few studies that treat of this idiom in the works written before 1500 the conclusion can be diaivn that it was an innovation of $16^{\text {th }}$ century English. Trnka (1930 p. 90) has only one instance, but this is dated 1597-1600. V. d. Meer (1929 $\$ 101 \mathrm{~h}$ ) states that in Mandeville an object can follow the "gerund" withoul of, the definite article being used or not. The only instance he gives (of the connynge to knowen bawne) does not, however, seem to illustrate the idiom under discussion $\left.{ }^{2}\right)$. Dekker (1932 $\$ 274$ note) explicitly states that the "gerund" preceded by the definite article and followed by a direct object does not occur in Malory. Onions $(1905,181)$ has the following remark : "In

1) At least, Klausmann 1919, who amply illustrates the olher types, does not poention it.

2) If connynge has the same character as it has in More, it is a noun. OED liats it as such from 1340 onward. Moreover in our quotations from Hore the object is not an infinitive. 
Early Modern English (about 1500-1800 A. D.) three ') alternatives existed : procuring money; the procuring of money ; and the procuring money; this last being very characteristic of the period". The earliest instances which he adduces are, however, from Shakespeare. Il is particularly noleworthy that in Th. More's contemporaries, St. John Fisher and Berners, the construction under discussion does not secm to occur; Weyl (1937 $\$ 260)$ gives instances of the use by St. John Fisher of the types a, b, and c 1, but does not mention c 2 ; Klausmanı (1919 p. 12:3) states: "Die bei Shakespeare und auch in neueren Zeit vorkommenle Koustruktion des mit dem Artikel stehenden Verbalsubstantifs mit folgendem Akkusativobjekt habe ich bei Berners nicht gofunden".

Of the sulbsequent history of the lype the doing good deeds it can be said that it frequenlly occurred in Shakespeare (Franz 192 \& $\$ 667 \mathrm{c}$ ), that is was absent in Spenser (Sugden $1936 \$ 3.54)$ and that in Pres. D. Eng. il is still used alongside the construclion with of; it seems, however, to be more frequent in literary than in spoken English and somelimes the two constructions are not interchangeable.

Instances from Shakespeare :

If $8 \mathrm{II}$, iv, 173, who had been hither sent on the debating $A$ marriage 'twixt the Duke of Orleans and Our daughter Mary. | All's Well iv, iii, 3, On the reading it he clianged almost into another man.

Later instances :

1766 Gollsmitl, Vicar, Ch. II, My attention was fixed on anolher subject, the completing a trart which I intended shortly to publish. I 1870 Disraeli, Lothair I, Cl. vI, 31, This crossing the Alps is a trial (P.).

The construction without of also occurs a) with direct and indirect object, b) with object and predicative adjunct.

a. Dial. C. 135, whother it be by the taking away or the minishmenle of the tribulacion it selfe, or by the geuing him pacience and spirituall consolacion...

b. Passion $1338 \mathrm{C} 1$, lest the naming it breadde, might make some men wene it were but bread in dede...

127. Absence of an Anapyohic Ohjegt After the + form IN - ING.

A pol. 91, they waxed wery of the sekynge. | Rich. 56 D 11, the time betwene his death \& the proclaming could scant haue suffised. | Lellers

1) He overlooks the types a and b 1 (money procuring and procuring of money). 
14.2. I 2, the boke to me semod such as my selfe would not hatio giuen mine owne aduise to the making... | Picus 12 A 12, the delites of this world, which in the seking wery us, in the hauing blindelh us, in the lesting peinelh us. | Last. Th. 72 D 3, these wordes geneth vs al a sure medicine (y/ we forslouth not the receiuyng). | Hich. 53 A 9 , some for their busines made sute to thein that had the doing. | Dial. C. 277, the labi)ur in the getlyng, the leare in the keping, and the payne in the partynge fro ${ }^{1}$ ), doe more than counterpoyse a great part of all the pleasure. I Hich. 68 ( 9 , he allowed not as I haue beard, the burying in so vile a corner. I Passion 1348 C 6 , the blessed sacrament ... Now it is contenient that we somewhal speake, in what maner wyse we ought to vse oursolf in the receininge. | Dial. C. 276 , the lesse surchie that you see you haue of the hepyng, the more cause you haue to be aferde of the losing. | 1)ial. (.. 160, some of them ... be not worth the meating. | Answer $1131 \mathrm{C} 1, \ldots$ as children make castelles of tile shardes, \& then make them their passefime in the throwing downe agayne. | Dial. C. $13 \overline{7}$, if these wayes be laken for the getting I nothing dutl but the gouducs of God shal griue il. Answer 1036 li 8 , yet are thre manye buughte, Nor the pcryll refray neth not muche people from the bjeng.

The abundance of inslances of this usage in More is a proof that it was living idiom in his time. It occurred in Middle English :

13... K. Alis. 4031 (Bodl. MS.), It is ywrite pat euery ping Hym self sluewep in pe tastyng. | a 1366 Chaucer, Kon. H. 5593, For in the getyng he hath such woo, And in the kepyng drede also.

In later English the construction is oflen used wilh telling, toing, asking, taking and occasionally with other verbs :

$1546 \mathrm{~J}$. Heywood, Prov. 67, A good tale yll tolde, in the telling is matde. I a 1533 Ld. Berner's, Huon c. 327, In the doynge is all the mater. | 1819 Tharkeray, Pend. I Ch. xxrv, 253, I might have had this prize for the asking. | 18.78 Thackeray, Virg. Ch. II 27, The gteat rivers swarmed with fish for the laking.

In many cases Pres. D. Eng. prefers a noun lo a form in -ing : the lesing = the loss; the proclaiming = the proclamation; the having = the possession; the seking = the search. In this connection the following quotalion from More cleserves nolice :

Debell. 1018 A 7, or at the leasl wyse name them that baue hact the winning, and them also that baue boin the losse.

The + form in -ing is occasionally construed with so as object :

Anyw. 1016 H 2, that would I neither dooe my self, nor in the so dooyng commend anye man that dooetb.

1) This end-position of fro is very remarkable. 
By the side of the possessive pronouns are used in the construction without object :

Debell. 931 B 11, Some suche places ... as I had happed to finde, I haue remitted the reader vnto in myne apologie, where for his ready findyng I baue numbred bim the lealo.

Mich. 40 F 9, oure enemyes ..., whiche without his wyttyng, might abuse llie name of bis commaundement.

Without his wyttyng had a parallel in O. F. a son escient.

128. Ohjegt + Predicative Adjunct.

Type : He taketh them discrete persons.

IIe beheld the heavens open.

The free use More makes of this construclion is a distinclive mark of his language as compared with Pres. D. Eng. In some cases there is a striking parallelism between this construction (e. g. he graunteth it convenient) and the indirect nexus of two verbs (e. g. he graunteth it to be convenient $\$ 617$ If). Indecd the verbs occurring in the former conslruction and those taking the latter can be categorized in almost the same ivay. Thus there are serbs of perceiving and mental processes (a) ; of causing (b) ; of declaring (c) ; of considerlng (d); of experiencing (e) :

a. Picus 9 B 14, he behelde the heauens open. Apol. (Wks.) 873 D 18, Le sawe some parte of his tale true. | Passion $1327 \mathrm{~K} 2$, we see it the common manner of holye scrypture too call hys blessed bodye and bloude by the former names.

b. Rich. 70 E 14, King Henry ... made him archbishop of Canturburye.

c. Passion 1347 B 8, they confessed the inspiracyon ... requisite.

d. Apol. (Wks.) $882 \mathrm{G} 7$, he taketh them discrete persons. | Boke of F. p. 6 is 10, The gyftes of fortune count them borowed ware.

e. Picus 3 B 2, his mother which longed very to hane him priest. I Last. Th. 79 G 6 , yf thou knewest thy self sick.

The two elements of which the verbal complement consists (she wist herself too simple; he findeth it no fable) form an appositional group, semantically equivalent to a unit with the copula to be (he findeth it is no fable). Consequently the verl (wist, fndeth) bears upon the group as a whole, so that this group and not the first element by itself is the object. There are, however, also cases in which this analysis is not possible, viz. in constructions of the following two types :

a. lest he thee onpurueid catche.

Picus 22 D 10, lest he thee inpurueid, and onready catche. I Dial. C. 
(Wks.) 1248 D 3, our sauiour was bimself take prisoner for our sake, and prisoner was he carled, and prisoner was he keple, and prigoner was he broughl furth belore Annas, and prisoner from Annas caryed vnto Cayphas.

b. he strake him stark blind.

Dial. C. (IVks.) 1115 D 13, he strake hym starke blynde. I idem $1188 \mathrm{I} 6$, he badke grounden it sharpe. | idem $1140 \mathrm{G} 8$, [they] seuer the couples ... a sunder. I idem $1256 \mathrm{G} 1$, knyves culte a two their hert strynges.

Here the object-relation of the (pro)noun is more distinct; the predicative adjunct refers to the state or condition the object is in either during or after the action expressed by the verb.

129. The following lists of quotalions show what words or word-gromps were used as predicative adjuncts in More's English.

a. The predicative adjunct is a (pro)nom.

to call. Last Th. $80 \mathrm{G} 4$, If thou thinke this, than wold I wit of thee what thou callest a sickeness. | Last Th. $87 \mathrm{G} 10$, that kinde of good anger that wee call a good seale. | Picus $15 \mathrm{D} 3$, some called it hypocriste.

to confess. Passion 1347 B 8, they confessed the conspiracyon ... retuisite. | Dial. C. 137, he confessed himself a synner und ciod for good and ryghtuous.

to count. Boke of F. p. 6 B 10, The gyftes of fortune count them borowed ware.

to find. Dial. C. (Wks.) $1162 \mathrm{C} 10$, if he dooe then fyndeth it the wretcbo no fable.

to know. Answ. $1136 \mathrm{D}$ 10, among them whom they know none heretirues.

to have. Dial. Her. 242 E 3, God halh ... so ... ordeyned his churche, that he will haue some readers, \& some hearers, some teachers, and some learners. | Picus 3 B 2, his molhor which longed very to haue him priest.

to hold. Dial. Her. 218 H 1, this pointe I hold it in my minde litle question...

to make. I'icus $9 \mathrm{G} \mathrm{3,} \mathrm{The} \mathrm{executour} \mathrm{of} \mathrm{his} \mathrm{moueable} \mathrm{goodes,} \mathrm{he} \mathrm{made}$ one Antony bis brother. | Rich. $70 \mathrm{E} 12$, King Henry ... made him archbishop of Canturburye. I Picus 9 C 5, the heyre of his landes he made the poor people of the hospitall of Florence.

The first and the last of these quotations with to make show an (in Pres. D. Eng.) unusual front-position of the predicative adjunct. 
to perceyve. Dirl. C. (Wks.) 1251 B 4 , if a foole percejue hymselfe a foole.

to recken. Last Th. $92 \mathrm{G} 10$, if thou dydst recken the lresure not

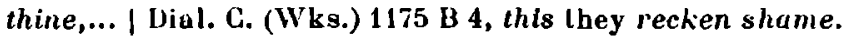

to repute. I'icus $14 \mathrm{G} 9$, philosophers ... which ... repute them selfe kinges of kinges.

to see. Passion $1327 \mathrm{E} 2$, we see it the common manner..., too call hys blessed bodye and bloude, by the former names.

to take. Apol. 88, be taketh them dyscrete persons.

to think. Last TL. $82 \mathrm{~A} 13$, if thou think this reason but a sophisticall sotiltie.

to yeld. Last Tb. $79 \mathrm{D} 2$, some fearful figure \& terrible likencs : by the beholdyng wherof thei conceiue somlime dispaire of saluacion, \& yeld themselfes ') captiues quick.

to ymagine. Dial. C. (Wks.) $1247 \mathrm{E} 14$, oure feare may ymagine them much greater grief then they be.

This usage existed before More's time. Earliest quotations ill OED : call c 1250 ; count a 1300 ; hold 1225 ; know 1300 ; make c 1000 ; reckon c 1450 ; repute 1460 ; take 1100 ; think c 1340 ; yeld 1377. OED has no quotations with find, know, perceive, have and see in this construction. The earliest instances with confess and imagine are :

1608 Shaksp. Per. v, iii 2, I here confess myself the king of Tyre. I 1634 Sir J. Herbert, Trav. 2, We bore up to speake with them, imagining them Enemies and men of war.

In Pres. D. Eng. this idiom is not nearly so frequently met with as in More's time. To know', to hold, to take, to imagine, to see can no longer be so used. A few verbs that still allow of this construction are to call, to confess, to count, to make, to think, to repute and to yield. To find is sometimes construed with an adjective before the predicative adjunct : I found him a willing listener.

130. b. The predicative adjunct is an adjeclive. lo hehold. Picus 9 B 14, he behelde the heauens open.

to call. Picus 14 B 1, Mercennary we call all those thinges.

to catch. Picus 22 D 10, lest he thee onpurueid and onveady catche. Last Th. $78 \mathrm{H} \mathrm{4,} \mathrm{yl} \mathrm{he} \mathrm{catche} \mathrm{a} \mathrm{manne} \mathrm{faste.}$

to change. Answ. $1062 \mathrm{D} 9$, how the bitter walters were changed sivete by the trec.

1) The text has "thèselfas". There is the possibility that this stands for themself as. 
to cleanse. Dial. G. (Wks.) $1250 \mathrm{C} 2$, his death ... should cleanse him cleane.

to drink. Last Th. 82 H 2, [they] drink themself sow drunk ').

to fayn. Apol.97, some one man may myche belter fayne hym self for polyig full catholyke. | Hich. $69 \mathrm{H} \mathrm{12}$, he fained himself sick.

to feel. Dial. C. 354, When we feele is to bolde : remember our owne fieblenesse; when we feele us to falnte, remember Chrystes strentbe. | Dial. C. 355, I feele myselfe somewhat werye.

to find. Last Th. $79 \mathrm{H} 8$, very true we fynde the wordes of the pistle. Dial. C. 212, he fyndeth ... al those comfortes so feable.

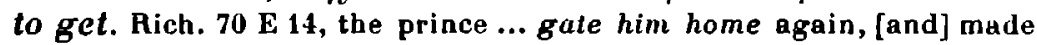
him archbishop.

to graunt. Apol. (Wks.) $919 \mathrm{D} 15$, he graunteth it conventent.

to grind. Dial. C. (Wk9.) 1188 y 6, he hadde grounden it sharpe.

to have. Conl. Tynd. $810 \mathrm{~F} \mathrm{2,} \mathrm{I} \mathrm{haue} \mathrm{the} \mathrm{soluctons} \mathrm{of} \mathrm{all} \mathrm{their} \mathrm{obiec-}$ cions ready. | Apol. 44, no more can I byleue neylher, that the dampned spyryles hane al the naturall gyftes as whole and as perfayte as they Lad before theyr fall. | Rich. $54 \mathrm{H} \mathrm{10,} \mathrm{[he]} \mathrm{deter-}$ mined no lenger to tary, but had his horse redy. I Picus $6 \mathrm{C} \mathrm{2}$, not content only to geue that he had him selfe ready. | Picus 30 A 9, There is no page or seruaunt mosle or lest, That duth vpon his loue attende and waite, ... But that ... the louer hath it precious, lief, and dere. | Dial. Her. 243 A 4, if the commen peple might be bold ... to dispute it, than should ye have, the more blind the more bold : the more ignoraunt the more busie : the lesse wilte the more inquisilife : the more foole the more talkatife.

to hold. Picus $11 \mathrm{G} \mathrm{4,} \mathrm{holding} \mathrm{my} \mathrm{self} \mathrm{content,} \mathrm{|} \mathrm{Last} \mathrm{Th.} 73 \mathrm{G} 16, \mathrm{I}$ hold him madder than they both.

to indge. Picus 14 A 3, he indged a thing saine.

to keep. Dial. C. 248, I cannol well perceiue ... bow anye man maye be riche and keepe hym ryche. | Picus 8 D 10, I warne the[e] kepe it secret.

to know. Last Th. 79 G 6, yl thou knewest thy self sick. | Dial. C. 213, such of his felowes as he knoweth mete.

to leue. Last Th. 85 A 13, [Envy] so dysfigurelh the visage leuing it al bony, leane, pale \& wan.

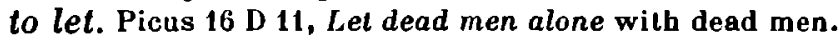

to make. Jest p. 3 E 8, it made some folke wrothe. | Dial. Her. 115 A 14, I dare make me bolde to warrant that... | Rich. 50 A 3, This maketh me much the more farder to deliuer him. | Picus 14 B 3 , he maketh philosophie mercennary.

to perceive. Dial. C. (Wks.) 1251 B 2, he perceyueth hymself drunke. to prove. Dial. Her. $209 \mathrm{~F} \mathrm{13,} \mathrm{An} \mathrm{infidell} \mathrm{whom} \mathrm{thei} \mathrm{haue} \mathrm{proued} \mathrm{and}$ reproued fals in his faith to God.

1) Earliest quotation in OED with to drink oneself (drunk) is daled 1598. 
to receine. Rich. $38 \mathrm{E} 2$, hee recelued his naturall strengthe soo sore enflebled, that hee dyspay red all recouerye.

to recken. Aich. $55 \mathrm{G} 8$, he rekened him self surest. | Hich. $49(=46)$ E. 14, she rechoneth her selfe no wiser.

to see. Last Th, $100 \mathrm{~F} \mathrm{5,} \mathrm{a} \mathrm{leude} \mathrm{master} \mathrm{of} \mathrm{a} \mathrm{ship,} \mathrm{that} \mathrm{golh} \mathrm{not} \mathrm{about}$ to see the ship tight. I Apol. 66, he saw some parte of hys tale trewe. | Apol. (Wks.) 916 B 1, euery manne may see these three thynges true. | Dial. C. 139, if God se the contrary better for vs. | Answer 1047 H 2, whyche oyce God sase so noyous vito mannekinde, that...

to show. Dial. G. 226, a thing of such sort, as sheweth it self nought and false. | Dial. C. (Wks.) 1250 I 7, be will shew him self ashamed of that man. | Last Th. $85 \mathrm{~F} \mathrm{2,} \mathrm{[be]} \mathrm{shewed} \mathrm{hymselfe} \mathrm{wyllynge.} \mathrm{|}$ Apol. (Wks.) 846 C 5, they say ... I shewe my selfe stuspect in the matter \& parciall towarde the cleargye.

to strike. Dial. C. (Wks.) 1145 D 13, Christ... strake hym slatke blynde. to think. Pageants, Manbod 1. 6, Yet thinkelh this boy his peuishe game swetler. | Last Th. 73 G 5, ye think pertuduenture this ensample as mad as the mad man. i Apol. (Wks.) $818 \mathrm{C} \mathrm{4}$, the .VII. psalmes thinke they long ynough without the letany.

For to thinke strange see $\$ 112$.

to try. Apol. (Wks.) 847 G 11, if any one woord ... left oute of chaunce put that profe in doubte, yet haue the brethren... bookes ynough, by which they may trye this true.

to wash. Dial. C. (Wks.) $1175 \mathrm{D} 7$, he washed os there al eleane.

to weene. Last Th. $74 \mathrm{~A} \mathrm{4,} \mathrm{[he]} \mathrm{is} \mathrm{sick} \mathrm{and} \mathrm{felell} \mathrm{il} \mathrm{not,} \mathrm{but} \mathrm{weneth}$ hymself whole. | Dial. C. (Wk.s.) 1187 A 2, of whom you woulde wene the stomake most strong, and their hart and corage most hardye.

wist. Hich. 58 H 8, in conclusion she shewed him plaine, that ... she wist herself to simple to be his wife. | Hich. 54 B 1, of which euery man wyst hymselfe clere.

The type to wash ... clean, to strike ... blind occurs before and after More and is common in Pres. D. Eng.

The type to see... true, to reckon ... worthy, to judge... vain was known in Middle English; the earliest quolations in OED are : to feign ... (sick) 1297 ; to feel ... (bolde) 1225 ; io find ... (true) 1300 ; to hold (content) 1300 ; to judge... (vain) c 1400; to keep. . (secret) 1340; to know... (trne) 1435 ; to reckon ... (natural) 1400 ; to see ... (true) 1435 ; to show... (false) 1200 ; to think... (sweet) c 1205; to try... (true) c 1500.

The construction, as such, has lived on into Pres. D. Eng. (to keep ... secret, to find ... correct, to hold ... precious), but with the majority of the verbs a different construction (either 
with to be or with as and for) has become more usual. To graunt, to know, to perceive are rarely used without to be, etc.; the construction with to try and to see has become obsolete. The verb to think now occurs with or more often without to be. More's free use of to have in this construction is very striking.

Of the type to think strange (instead of to think it strange) there is a quotation in OED dated c 1205 ; this short form is now almost exclusively found in think fit and think proper.

Instead of More's I make me bolde Pres. D. Eng. has I make bold.

131. c. The predicative adjunct is a prepositional group. to bring. Hich. $48(=45) \mathrm{A} 15$, to none other entente, but to brynge all the Lordes in obloquie... | Rich. $58 \mathrm{~F} \mathrm{2,} \mathrm{he} \mathrm{spedely} \mathrm{...} \mathrm{brought}$

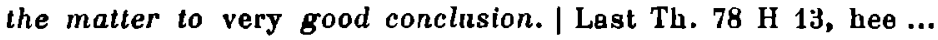
dooeth hys vttermoste deuoyre to brynge is to damnacion.

to eat. Last Th. $100 \mathrm{H} \mathrm{6,} \mathrm{how} \mathrm{many} \mathrm{eate} \mathrm{and} \mathrm{drink} \mathrm{themself} \mathrm{to} \mathrm{death.}$ to find. Last Th. $76 \mathrm{D} \mathrm{4,} \mathrm{yt} \mathrm{thou} \mathrm{find} \mathrm{oughte} \mathrm{to} \mathrm{the} \mathrm{purpose,} \mathrm{speake}$ therto... | Rich. 38 G 15, if they shoulde finde you at saryaunce. to have. Picus $7 \mathrm{H} \mathrm{15,} \mathrm{If} \mathrm{we} \mathrm{had} \mathrm{euermore} \mathrm{before} \mathrm{our} \mathrm{eien} \mathrm{the} \mathrm{painfall}$ death of Christ... | Rich. 71 A 16, to haue him in his custody. | Picus $19 \mathrm{G} \mathrm{1,} \mathrm{I} \mathrm{am} \mathrm{vnhable} \mathrm{to} \mathrm{ascende} \mathrm{by} \mathrm{myno} \mathrm{own} \mathrm{strength} \mathrm{so}$ high, to haue the in possession. | Rich. $63 \mathrm{H} \mathrm{15}$, Woe is that Realme, that hathe a chylde to theyre Kynge. | Last Th. 96 F 11, we se gret cause to haue it in hatred \& abominacion. | Last Th. $72 \mathrm{G} \mathrm{12,} \mathrm{if} \mathrm{enery} \mathrm{man} \mathrm{hane} \mathrm{so} \mathrm{sure} \mathrm{a} \mathrm{medicine,} \mathrm{so} \mathrm{ready} \mathrm{at} \mathrm{hand.|}$ Dial. C. 180, God is nere saith the Prophete to them that haue their hearte in trouble.

to know. Rich. 36 B 10, The Lordes whome he knewe at Varyannce.

to kepe. Last Th. 72 G 1, to kepe os ... fro sin. | Last Th. 72 G 3, to kepe him from sicknes.

to laugh. Dial. C. 276, the grounde on whiche a Prince buyldeth his palice, would lowde langh his lord to scorne, whan he saw bim proude of his possession.

to put. Apol. 6, yf any one worde ... left out ... putte that profe in donte. | Last Th. $83 \mathrm{D} 12$, one of his good \& gracious knocking is, the putting os in remembrance of deth.

to turn. Dial. C. 132, to turne oure short sickenes ... into the endles euerlasting death.

to take. Apol. (Wks.) 869 F 15, they take ... all those woordes of hys well in woorth.

to see. Last Th. $95 \mathrm{D} 11$, Men commonly say, it wer better fil his bely than his eye, \& many men mind it not al til they se the meat on the bord. 
to set. Dial. Her. 231 H 4, some of them woulde baue no wiues though (bat law were sette at large ').

to suffer. Rich. $40 \mathrm{~F} 8$, as great [peril] is growing, yt wee suffer this ronge kyng in oure enemyes hande.

wist. Rich. 59 D 8, The king when his molber had said, made her unswer part in ernest part in play merely, as he that wiste himself out of her rule.

In Pres. D. Eng. a number of similar preposilional groups have distinctly the characler of predicalive adjuncts (know)... at variance, drink ... to death, bring .. to a conclusion). In a few cases, however, (e. g. to bring ... to damnation) the groups might as well be interpreted as adverbial adjuncts. The question depends upon the degree in which the (intra-) local force of $t o, a t$, in, from and the final force of to is realised by the speaker or hearer. In older English the character of the preposilional group would seem to have been more prominently adverbial. In the expressioll, e. g., to crown to king (as in $1297 \mathrm{R}$. Gloucester 383, IVyllam ... let $\mathrm{hym}$ crouny to kynge) the preposition to referred to the new state as the result of a development or the purpose of the action, so that to $k$ ynge was nothing but an adjunct of purpose or result. It may be stated that in older English - including More's language - the contact belween this kind of prepositional group and the verb was looser than it is in Pres. 1). Eng., which explains the greater frequency of the construction in earlier stages of the language, present-day writers having only a restricled number of stereolyped formulae at their disposal.

132. Among the prepositional groups the type (sel) a fire deserves further notice.

a fler. Picus 4 D 8, The comelynes of his body ... set mauy women a fier on thim.

a flote. Dial. C. (Wks.) $1140 \mathrm{~F} 10$, I maye ... gouerne and slaye the shyppe of oure kynredde, and keepe il a flote.

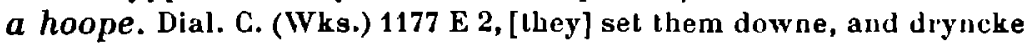
well ..., sette cocke $a$ hoope, and fyll in all the cuppes at ones.

a low. Dial. C. (Wks.) $1176 \mathrm{C} 11$, a heart broken, ... and ... for hys sinnes laide a lowe vnder foote.

1) to set at large is not l'ecorded in OED. 
a mis. Picus $28 \mathrm{D} 3$, al thing bene, Appointed wel, and nothing set a mis.

$a$ right. Last Th. $84 \mathrm{G} 11$, if ye toke the matter a right,... ye wold recken this yere as worshiplul. | Last Th. $86 \mathrm{C} \mathrm{13}$, if we consydered euerye thyng a ryght... we should neuer see cause to enuy anye manne.

a sleepe. Dial. C. (Wks.) $1189 \mathrm{G} \mathrm{2,} \mathrm{the} \mathrm{man} \mathrm{wer} \mathrm{rocked} \mathrm{\&} \mathrm{songen} \mathrm{a}$ sleepe.

a sunder. Dial. C. (Wks.) $1140 \mathrm{G} \mathrm{8,} \mathrm{[they]} \mathrm{there} \mathrm{seuer} \mathrm{the} \mathrm{couples} \mathrm{and}$ the kynred a sunder.

a two. Dial. C. (Wks.) $1256 \mathrm{G} 1$, they feele sharp knyues cutte a two their hort strynges.

a waye. Jest p. D 7, To fall in sule, Tyll he dispute, His money cleane away. | Passion 1323 C 2, washe it a waye.

a woorke. Dial. C. (Wks.) $1124(=1202)$ F 1, such busy folke whom this denill ... setteth a woorke. | Dial. C. (Wks.) 1202 E 7, [he] ... setteth them a woorke with manye maner bumbling busines.

$a$ worth. Dial. Her. 271 F 8, God accepleth and taketh then well $a$ worth be thei neuer'so badde.

This $a$ is a worn-down proclitic form of the O. E. preposition an, on. The spelling in two words (a right) may be looked upon as a proof that by More's time the word $a$ was still felt as a preposition. The usage dates from Old English. $A$ flote scems to have been on flote up to More's time (see OED s. v. afloat). In Pres. D. Eng. afloat, alow, amiss, aright, asuncler, awork (in to set awork) are still used as predicative adjuncts. (To take) a corth has become obsolete. For afire we lind more often on fire now ; $a$ two has been replaced by in two as the regular prose form. To set cocke a hoope (of olsscure origin) has dropped into disuse. The group a fled in the following quotation, though formally resembling the type a fire, has an entirely different origin, it being a form of the verb to aflee = to flee ar'ay (OED s. v. afled).

Jest p. 4 F 10, He shoke his eares, And from grete feares, He thought hym vell a fled.

Besides a fire, $a$ two and $a$ worth More also uses on fre, in twayne and in worth :

Dial. C. (Wks.) $1260 \mathrm{H} \mathrm{3,} \mathrm{to} \mathrm{inflame} \mathrm{our} \mathrm{kaye} \mathrm{cold} \mathrm{hertes,} \mathrm{\&} \mathrm{set} \mathrm{them}$ on fyre. | Dial. Her. 138 B 5 , I balle sene some ... cleae the pricke in twayne. I Dial. Her. 275 B 5, God ... taketh thew wel in worth and imputeth no blame vnlo them.

It should be noted that in More the word after $a$ is not a verb. Combinations like a-wash, a-bask, a-swim, a-tremble, 
are later formations on the analogy of the type $a$ sleep by taking the noun as a verb.

The O. E. lype on pissre wisan is represented in More by a this fashion :

Answer $1117 \mathrm{E} \mathrm{4,} \mathrm{there} \mathrm{is} \mathrm{nothing} \mathrm{left} \mathrm{out,} \mathrm{hut} \mathrm{euery} \mathrm{such} \mathrm{thynge}$ there wrytten in with expresse wordes, or els may he neuer make himself so sure, and face it out $a$ this fashion with expresse woordes, that sauing the very plaine expresse wordes of scripture, we be no man of vs bounden to belieus nothing els.

This idiom became obsolete after Shakespeare :

All's Well Ir, iii, 26.5, Why dooest thou garter vp thy armes a this fashion?

133. $d$. The predicative adjunct is preceded by for.

1. (pro) Nouns.

to accompt for. Picus $16 \mathrm{G} \mathrm{3}$, [they] accompt it for nothing.

to account for. Dial. C. (Wks.) $1252 \mathrm{G} \mathrm{12,} \mathrm{That} \mathrm{seruant} \mathrm{euery} \mathrm{man}$ accounteth for a prosude inthrift.

to accustom for. Dial. Her. 124 D 1, [it is] wel knowen that the worship of saints and ymages ben alowed, approbate, \& accustomed for good ... vertues.

to affirm for. A pol. (Wks.) 859 , which the whole catholyke churche affirmeth for scripture.

to agree for. Dial. Hor. 113 A 12, I wolde ... well agre them for heresies.

to allow for. Dial. C. (Wks.) $1164 \mathrm{H} 11$, you cannot se, for what cause I shold geue any preeminence in comfort vnto tribulacion, but rather allow prosperity for the thyng more comfortable. | Apol. 86, these that thus saye thys pacyfyer alloweth for folke wyso \& dyscrete. - See also to accustom for.

to approbate for, see to accustom for.

to assigne for. Dial. C. (Wks.) 1144 A 1, I wil ... assigne for the fyrst comfort, the desire and longing to be by god comforted.

to avow for. Conf. Tynd. $400 \mathrm{C} \mathrm{14}$, [they] asowe theyr filthie lecherye, for honeste wedlocke.

to byleue for. Dial. Her. $161 \mathrm{C} 14$, no thing is to be byleued for a sure trouth, but if...

to condemn for. Dial. C. (Wks.) 1175 B 1, therelore they condemne it for supersticions foly.

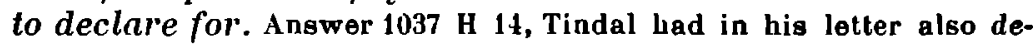
clared him for a fole.

to denie for. Dial. C. (Wks.) $1153 \mathrm{D} 10$, the olde interpretours of scripture ..., of whom they denie not manye for holye saints.

to esleme for. Rich. $36 \mathrm{E} 1$, common people, whiche oftentymes more esteme and take for greater kindenesse, a lyttle courtesye, then a greale benefyte. 
to fear for. Dial. C. (Wks.) $1181 \mathrm{H} \mathrm{14}$, the beast that we heare rore in the darke night of tribulacion, and feare it for a lion.

to feyne for. Dial. C. (Wks.) 1250 E 9, Jupiter (whom tho Poetes feyne for the great God)...

to find for. Conf. Tynd. $402 \mathrm{~F} \mathrm{15,} \mathrm{But} \mathrm{if} \mathrm{Tyndall} \mathrm{fynd} \mathrm{this} \mathrm{for} \mathrm{a} \mathrm{faulte,}$ he must go farre aboue his vill C. yere,

to know for. Dial. C. (Wks.) $1206 \mathrm{E} 1$, they knewe bim for the chiefe of the Publicanes.

to professe for. Apol. (Wks.) 887 H 8, no manne woulde professe hy inselfe for hys accuser.

to put for. Apol. (Wks.) 8.16 \& 9, they are layn to put for faultes in my wryting, suche thinges as ... shall appeare their owne faultes.

to misreporte for. Dial. C. (Wks.) $1209 \mathrm{H} \mathrm{12,} \mathrm{misreporte} \mathrm{hym} \mathrm{for} \mathrm{a}$ hypocrite.

to reken for. Dial. C. (Wks.) $1252 \mathrm{E} 4$, To suffer the lhing for Christes faylh that we worldly wretched fonles wene wer vilany \& shame: the blessed apostles rekened for great glory.

to repute for. I)ial. C. (Wks.) $1195 \mathrm{~F} 8$, One wist I my selfe, that had been long reputed for a righte honest man.

to take for. Last Th. 83 A 2, take themsell for quick saintes. | Picus 18 C 1 , That thing a manne taketh for his god. | Last Th. 84 H 2 , we toke ... true figure for a fantasye.

to warraunt for. Dial. C. (Wks.) $1144 \mathrm{G} 13$, we cannot so well warrannt that mynde for a cause of so great coumforle.

2. ADJEGTIVEs.

to accompt for. Apol. (Wks.) $882 \mathrm{D} 8$, thys pacifier accompteth them for discrete.

to a/firm for. Apol. (Wks.) $871 \mathrm{E} 4$, suche fautes as he speakelh of, he saithe them not as of hymselfe, nor affyrmeth theim not for trewe.

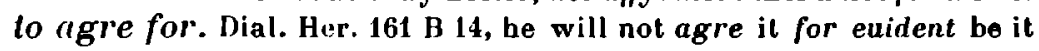
neuer so plain.

to alow for. Dial. C. (Wks.) $1252 \mathrm{C} 6$, it is alowed and approued for very precious.

to approve for, see to alow for.

to allaunce for. Apol. (Wks.) $883 \mathrm{H} \mathrm{16}$, there was none that one man named and allaunced for good, but fiue for that one reiected him.

to bost for. Dial. C. (Wks.) $1238 \mathrm{~F} \mathrm{13}$, the bondage that almost euery man is in that bosteth himselfe for free. | Answer 1038 B 3, one whom the biethren bost for so wyse.

to choose for. Dial. Her. $209 \mathrm{C} \mathrm{12,} \mathrm{his} \mathrm{iudges} \mathrm{which} \mathrm{are} \mathrm{elect} \mathrm{and}$ chosen for indifferent.

to confess for. Dial. C. (Wks.) $1145 \mathrm{E} 7$, he ... confessed hymselfe a sinner, and God for good and ryghtuous.

to elect for, see to choose for.

to graunt for. Dial. C. (Wks.) $1140 \mathrm{C} 5$, I cannot but graunte it for trewe. 
to ludge for. Dial. Her. 203 H 3, plain prole shold we haue, ere we should iudge any man for so euill.

to know for. Apol. 95, they knowe them for good and thynke them good. | Dial. C. 214, whom he knoweth for wel learned and vertuous.

to knowledge for. Last Th. $86 \mathrm{H} \mathrm{4,} \mathrm{one} \mathrm{that} \mathrm{he} \mathrm{...} \mathrm{knowledgeth} \mathrm{for} \mathrm{a}$ great dele his better.

to name for, see to auaunce for.

to perceilue for. Dial. C. (Wks.) $119+\mathrm{D} 12$, he cannol nıke vs perceiue it for such.

to recken for. Last Th. $86 \mathrm{G} 10$, Take me one that reckeneth hymselfe for woorschypfull.

to shake off for. Apol. (Wks.) 857 A 10, [he woulde] shake of the question for nought.

to take for. Last Th. $83 \mathrm{D} 5$, Wher now by theyr pride taking themselfe for good where they be nought, they bee far from al occasion of amendinent.

to tell for. Dial. Her. 125 D 1, it wer bard for them to beleue that energe man lieth which telleth the[e] a tale for trew that reason \& nature semyth to shew them to be false \& impossible.

This very frequent use of for before a predicative adjunct is an oulstanding feature of More's language and gives it a strikingly obsolete character. Only with a small number of verbs has the usage survived into Pres. D. Eng. It was known in older English :

c 1000 .Elfric, Deut. xxxı, 20, And tellap min wed for naht (OED).

13... E. E. Allit. P., C. 519, cum \& cnawe me for kyng (OED).

1340 Ayenb. 214, Al pane time pet pou ne pengst naht a god, pou hise sselt rekeni uor nagt (OED).

1340-70 Alex. \& Dind. 697, Iuno ... 3e iuggen for uoble.

1393 Gower, Conf. I 17, Lo, how they feignen chalk for chese (OED).

c 1400 Mandev. Trav. 114, 12, men holden hire for fals and cursed (M.).

c 1400 Mandev. Trav. 136, 14, In pat conlree wommen pat ben vnmaryed pei han tokenes on hire hedes lych coronales to ben knowen for onmaryed (M.).

c 1400 Mandev. Trav. 210, 10, his seyd conseil, Be the whiche my boke was preened for trewe (M.).

c 1400 Mandev. Trav. 151, 1, Many philosophers pet ben preued for wise men... (M.).

1450 Cov. Myst. 169, I know the(e) for my lorde (OED).

1450 Cov. Myst. 138, knowlyche thiself ffor a cockewold (OED).

1477 Earl Rivers, Dictes 38, As a leche is not reputed nor taken for goode nor connyng that ... can not hele him selfe (OED).

1480 Caxton, Descr. Ireland, 6-1, It is accounted for a myracle (OED).

Instances in older English with the other verbs occurring in More with the for-construction have not been found. The 
idiom seems to have escaped the attention of the editors and the compilers of OED with a great number of verbs; unrecorded are : accustom for, affirm for, "gree for, advance for, approbate for, approve for, boast for, condemn for '), confess for, declare for, esteem for, fear for ' $)$, find for, graunt for, name for, perceive for, profess for, put for, shake off for and warrant for ; the earliest inslances of the usage with the following verbs are later than More : allow for (1593); assign for (a 1665); avow for (1530); condemn for $(1632)$; deny for $\left.(1588)^{3}\right)$; elect for $(1777)$; esteem for (1671).

134. e. The predicative adjunct is preceded by as.

to admit as. Answer 1022 B 12, I admit the case as possible.

to consider as. Dial. C. (Wks.) $1220 \mathrm{C}$ 5, consider them as thinges selte by and beloued.

to kepe as. Dial. C. (Wks.) $1220 \mathrm{E} 5$, some that kepe theyr riches as a thing pleasaunt.

to make as. Dial. C. (Wks.) $1226 \mathrm{E} 14$, lawes that are made as a bucler. to shew as. Rich. $64 \mathrm{E} 10$, the recorder so tempered his tale, that he shewed euery thing as the dukes wordes and no part his owne.

to take as. Hich. 47 B 5, eyther parte taketh other as Traytours. | Rich. $68 \mathrm{C} 13$, the proteclor left that name and toke himself as King.

Though as is perbaps as old as for and to as an introducing parlicle to a predicative adjunct, it became common much later. If we compare the frequency of the constructions with as and of those with for in More, the conclusion suggests itself that the as-construction was still in a nascent stale. It has, however, gone on replacing to and for, with the result that it has become the modern favourite, especially used to stress the identity between the object and the predicative adjunct when this is a noun. The dates of earliest quotation in OED of this usage with consider and take are 1797 and 1531

1) With as instead for : 1601 Shaksp., Tw. N. III, iv, 141, I could condemne it as an improbable fiction.

2) Without any preposition before the predicative adjunct : 1593 Shaksp. 3 Henry VI, v, vi, 12, The Theefe doth feare each bush an officer.

3) Shaksp., L. L. L. Iv, iij, 119, Thou for whom Ioue would sweare ... And denie himanlfe for Iolle. 
respectively. Admit as, kcep as, make as, show as are not recorded in OED.

Only one quotation has been found in More in which the predicative adjunct is preceded by as for :

Last Th. 10.2 F 5, we take it as for a laughynge maller and a sporle.

In Chaucer we read : c 1386 Clerkes T. 251, Thy doghther wol I take ... as for my wife.

In Pres. D. Eng. this idiom is unknown.

135. $t$. The predicative adjunct is an adver $b$.

Post-position of the adverb.

out. Rich. $50 \mathrm{~A} 13$, they recken no pryuilege broken, though thei felche him oul. | Picus 14 H 13, These great fortunes lift $\mathrm{vp}$ a man hie, and sellelh him out to the shew. | Gonf. Tynd. 496 A 3, Tindall rymeth it out. | Apol. (Wks.) 817 C 9, if the reader leaue my wourdes out.

off. Hich. 54 F 14, I wil not to dinner til I se thy hed of. | Dial. c. 214, [they] ... can never ful caste it of.

away. Answer 1600 B 6 , let them ... make a crosse and blesse it away. | Jest p. 1 D 8, Tyll he dispute, His money cleane away. up. Lett. 1435 F 10, [she] bringelh her own up very vertuously and well., Last. Th. 80 E 5, medicines ... to cloute them op with al. | Conf. Tynd. $713 \mathrm{C} \mathrm{3}$, as for al other sinnes..., faith saith he ... suppell them al op.

forth. Dial. C. (Wks.) 122! G 6, be brought il euen blonlly forth.

down. bial. C. (IVks.) 1262 G 8, he [the devil] neuer runnell vppon a manne...till he see hym downe. back.
Post-posilion of the (pro)noun

A pol. (Wks.) 860 B 9, [he] forneth oul his... sentence. $\mid$ Apol. (Wks.) $866 \mathrm{E} 7$, they furnishe oute theyr processe wyth lyenge. | Apol. (Wks.) 847 A 2, I tooke some payn to set out theyr argumentes. | Dial. C. (Wks.) 1222 C 5 , the cumbraunce that he had to study out a better.

Dial. C. (Wks.) 1248 C 4, the daugbler of Herodias delyted them with lier daunsyng, till with her daunsynge she daunsed of Saynt Johns head.

Dial. C. (Wks.) $1205 \mathrm{H} \mathrm{14}$, But as I sayd, to geue away all ... that fynde I no commaundement of.

Picus 14 H 13, These greal. forl unes lift op a man hie. | Last Th. $94 \mathrm{G} 7$, while theyr executours ... ransake op their sackes. I Supplic. $335 \mathrm{~F} 11$, with herawdes at our hearses, \&offring op our helmets, setling op oure skouchin \& cote armours on the wall.

Picus 13 G 14, spurre forth thine hors.

Conf. Tynd. 347 I) 10, Byrle... aluised Constantine ... to call backe hys confession. 
in. Dial. C. (Wks.) 1221 G 4, some ... proper waye to bryng it in with all.
Passion 1342 H 9, These men that betwene the father and the sonne bring vs in not an onitie of nature but of wil...

In some of the cases instanced above the predicative adjunct character of the adverb is clear (e. g. till he see hym downe); in others, however, it is doubtful (e. g. hring up; furnish out); here the collocation verb + adverb is almost a compound verb. The freedom to place the adverb either before or after the object ') seems to have existed in earlier English :

a 1300 Curs. M. 297, If pou ta pe light awai. | a 1300 Curs. M. 14318, He bad ... of pe tumb take of pe lidd.

In Modern English it is a common feature. Yet there is a difference between the usage in More and in the language of to-day, since More also places the pronouns in post-position, a process unknown now :

Hich. $38 \mathrm{G} \mathrm{4}$, the kynge liftinge oppe himselfe ... sayd vnto them... | Lett. 1435 F 8 , sith I haue maried her molher \& brought op her of a child as I have brought op you.

The order of words in the last quotation is apparently brought about by the necessity to bring out the contrast between her and you.

In Ben Jonson we read :

Ev. Man Out of his H., 1v, v, 28, I warrant you, though he turns off thcm, he keeps his tailor, in place of a page, to follow him still.

\section{INDIRECT OBJECT}

136. If there is only one object in a syntactical unit the term indirect object is in the majority of cases out of place, as it is not practicable to make a differentiation based on facts existing in the language either of More or of to-day, in which separate forms corresponding to what in other languages are termed dative or accusative cases are unknown. The objects in he helps me $\left.{ }^{2}\right)$, he touches me, it favours him, we proft ourselves (Picus 7 E 4) will therefore not be looked upon as different in kind from those in he sees me, he believes $t$, etc.

1) Also when the adjunct has the form of a two, a sunder : Dial. C. (Wks.) $1140 \mathrm{G} \mathrm{8,} \mathrm{[they]} \mathrm{seuer} \mathrm{the} \mathrm{couples} \mathrm{...} \mathrm{a} \mathrm{sunder.} \mathrm{|} \mathrm{Dial.} \mathrm{G.} \mathrm{(Wks.)}$ $1256 \mathrm{G} \mathrm{1}$, sharp knyues culte a two their hert strynges.

2) The meaning of the verb offers no help : in some languages to help slands with the dalive, in others with the accusative. 
There are, however, a few cases (e. f. me thinketh) in which the objecty so cleirly represent persons as involved or concerned in an aclivity directed towards them that they are realised as a kind of recipients. It scems defensible to call these complements to the verbal idea indirecl objects.

Last Th. $83 \mathrm{G} 3$, me thinketh that the remembrance of delh, may right easily mend it. | Rich. $43 \mathrm{E} \mathrm{2,} \mathrm{Ah} \mathrm{woo} \mathrm{worthe} \mathrm{him.} \mathrm{|} \mathrm{Rich.} 59 \mathrm{~F} \mathrm{10,} \mathrm{I}$ mary where il liketh me. | Dial. C. 321, the thing semelh me so plain. Apol. 49, they speke me fayre. | Dial. C. 295 , I wyll be at mine owne libertye to do what me lyste myselfe.

Somelimes the receptive character of the indirect object is emphasized by means of prepositions :

Picus 22 (i 11, To him be al al honour and lowly reucrence. | I)ial. C. (Wks.) $1167 \mathrm{D} 5$, al that good meryte groweth to the weallhye manne not by his wealtho. | Lelt. 1422 H 2 , the boke to me semed such as inyselfe would not haue giucn mine owne aduise to the making.

The following quotations contain a special kind of indirect object :

Dial. Her. 120 F 1, Moreover loke me thorow christendome and I suppose ye shall finde the frute of those offerynges a right small parle of the lyuynge of the clergye. | Conf. Tynd. 381 E 7, will ye see that it is so? Go me to Martin Luther.

The word me denotes the person who has an emotional or sympathetic interest in the statement or action. These " emotional" objects occur more frequently when there is a direct object as well (see $\$ \$ 153 \& 154$ ).

\section{Reflexive Objects}

137. The reflexive object is a compound pronoun.

The forms of this compound pronoun are myself(e), yourself(e), thyself(e), our(e)self(e), themself(e). They are frequently written in two words. The forms meself, usself, theeself etc. are nol used by More; they had dropped into disuse before his time (Morris $1895 \$ 166$ ) ').

to accustom. A pol. 50 , he accustomed hymself to...

to appoint. Rich. $49 \mathrm{D}$ 10, yf you appoint yourselfe to lary here.

to bewray. Dial. Her. 255 H 4, sodenly the fonde felowe heswayed hym selfe vnware.

to bless. Dial. C. (Wks.) $1200 \mathrm{HI}$ 1, [let him] blesse himself and call vnto God and pray.

1) Theirselves is used as an emplatic pronoun in : Dial. Her. 121 A I, good bishops haue used them theyrselues. 
to burn. Last Th. 85 B 5, ay the flre of the burnyng byl of Etbna burneth only it self:

to custom. Dial. C. (Wks.) $1144 \mathrm{k} 1$, if we custome our selfe to put our thust ... in ... worldlye thinges.

to deceine. Dial. C. (WVks.) $1216 \mathrm{H} 8$, wa deceine onre selfe.

to deprine. Picus $19 \mathrm{~F} 11$, it were foly for a man vilerly to depriue himself from al pleasures.

to discerne. Iial. G. (Wks.) 123 C 1, [shal ... teach them] betler to discerne thenself.

to drine. Last Th. $100 \mathrm{G} 1,[\mathrm{wr}]$ drine our self in sicknes.

to dros'n. Apol. (Wks.) 905118 , [he] dros'ned hymselfe in a well. I Dial. C. (Wks.) 1193 B 2, [they| ranne into a water and drowned themselfe.

to embusie. Dial. Her. 242 F. 10, Plato ... forloiddeth suche as be not admitled therunto, ... to melle much and embusie themself in reasoning ... vpon the temporal lawes of lhe citie.

to endenour. Apol. (Wks.) 870 I) 5, eyther parte endenonr theymselfe ... to represse ... those enyll ... folke. | itlem $860 \mathrm{E} 6$.

to enforce. Picus 5 A 9, of all these new doclours, be specially commendeth sainct Thomas, as him that enforceth himself in a sure pillar of trueth.

to enlatunce. Boke of F. p. 2 A 2, he that out of pouerlee and migchaunce, List for to liue, and wyll hym selfe enhaunce, In wealth \& richesse...

to ensemble. Apol. (Wks.) 920 G 12, openly by day they ensembled themselfe together to the noumber of an hundred.

to entangle. Cont. Tynd. 568 I) 11, he mist eyther lye toumblynge styll therein ..., and the more he stryueth therewilh the more alwaye meshe and entangle hym selfe.

to exalt. Apol. (Wks.) $875 \mathrm{D} 12$, [they] haue ... exalled themselfe in their own sight.

to flalter. Dial. C. (Wks.) 1228 B 1, flatred they themselfe with neuer so gay a glose of good ... purpose, yet...

to fense. Picus $8 \mathrm{D} \mathrm{14}$, fensyng my selfe with the crucifixe...

to forswear. Dial. C. 194, llue hundred hasardes that ... sweare and forsweare themself.

to garnish np. Picus 29 A 1 , Garnish thy selfe 'p in as goodly wise...

to giue. Picus 3 (: 3 , After this, ... he gane him self whole lo speculacion.

to hang. Dial. C. 218, she hong herselfe.

to hide. Picus 2 F 13, a swarme of bees ..., hiding them selfe among the clowdes.

to humble. Picus 25 A 1, Christ ... Irumbled himselfe for vs.

to ieopard. Dial. C. (Wks.) 1204 D 8, For the thynge that folke sol'e long for, they will uake many shiftes to geatte, and ieopard themselfe therfore. 
to imagine. Last. Th. 75 A 4, Imagine your self in the same case.

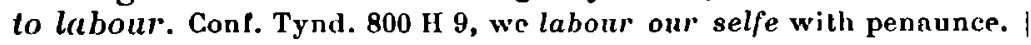
Conf. Tynd. $439 \mathrm{~F} \mathrm{9,} \mathrm{and} \mathrm{god} \mathrm{will} \mathrm{help} \mathrm{while} \mathrm{be} \mathrm{laboureth} \mathrm{himself}$ to land.

to lift up. Rich. $38 \mathrm{G} \mathrm{4,} \mathrm{the} \mathrm{kynge} \mathrm{liftinge} \mathrm{oppe} \mathrm{himselfe...}$

to lyke. Dial. C. (Wks.) $1221 \mathrm{H} \mathrm{14,} \mathrm{I} \mathrm{lyked} \mathrm{my} \mathrm{selfe} \mathrm{hlhe} \mathrm{betler,} \mathrm{because}$ mee lhoughte my woordes beeynge but a straungyer, wente yet with some grace in the Almain tong. | Dial. C. (Wks.) 1221 F 9, he had in a great audience made an oracion in a certayne maner, wherein he liked him selfe so well, that at his diner he sat him thought on thornes, till he myghte here how thei ... woulde commende it.

to lye. Apol. (IVks.) $843 \mathrm{C} 15$, yet in this heresie he sore abhorrelh hys heresie, or els he lyeth himselfe.

to medle. Apol. (Wks.) $869 \mathrm{C} \mathrm{3,} \mathrm{he} \mathrm{shoulde} \mathrm{not} \mathrm{medle} \mathrm{hymselfe} \mathrm{in} \mathrm{the}$ matter.

to meeke. Apol. (Wks.) 873 A 1 , tyll you meeke your selfe..., thys anger of your husband will neuer be well appeased.

to mesh, see to entangle.

to misordre. Dial. Her. $210 \mathrm{C} 7$, there mai percase fauour, ... or some other affeccion inclyne him to misordre him self in the mater.

to misseuse. Dial. G. (Wks.) $1200 \mathrm{D} \mathrm{4}$, douling ouermuch lest they shold misseuse themself, [thry] leve the thinges vndoone.

to myssetake. Apol. (Wks.) $889 \mathrm{D} 2$, those that haue mysse taken them self. | Apol. 104, [they] did not mysse take them selfe at all.

to name. Aut. Lett. vi, 55, a simple person an almaigne naming hymselfe seruant vn to the kinges grace ').

to open. Dial. Her. 269 G 13, Loe now bi this ye haue somwhat opened your self vnware, and declared your oppinion in this matter to bee farre other than ye said before.

to order. Conf. Tynd. $643 \mathrm{~F} 13$, the Jeewes were bounden by the letter of the lawe, to order themselfe in that wyse toward their oxen.

to ollersee. Dial. Her. 145 H 7, [they] cannot well come thereon, but misse and ouersee themselfe in the assaye.

to ouershote. Apol. (Wks.) $916 \mathrm{~F} 12$, they might ... onershote themself.

to payne. Picus $31 \mathrm{D} \mathrm{9,} \mathrm{A} \mathrm{very} \mathrm{louer} \mathrm{will} \mathrm{his} \mathrm{loue} \mathrm{obaye,} \mathrm{His} \mathrm{ioye} \mathrm{it}$ is ... To payne himselfe in all that euer he maye.

to profit. Picus 7 E 1, In louing him [scil. God] also we more profit our self, we laboure lesse $\&$ serue him inore.

to prone. Bless. B. 1265 F 8, Let a man proule him self ${ }^{2}$ ) and so eate that breade, and drinke of that cuppe. Bul than in what wyse shall we prone our selfe.

1) The same idea is expressed by to bear oneself for : Aut. Lett. vi, 94, He bare hymselfe in almaign for the kinges seruant \& bosted that he had a yerely pention of his grace of fiftie markes.

2) = probet se ipsum homo. 
to retrete. Conf. Tynd. 447 A 8 , They flee by night and retrete themself in the darke.

to repent. Apol. (Wks.) $881 \mathrm{C} 8$, [he] repented hymselfe and came into the church agayne.

to rest. Dial. C. (Wks.) 1203 I) 20 , they wold not rest themself.

to rid ont. Apol. (Wks.) $856 \mathrm{~F} 5$, he woulde ... hawe shaken of the mater, and ridde himselfe onte honestlye.

to rule. Last Th. 97 I) 2 , Is it not a bestly thing to se a man that hath reson, so to rule himselfe.

to submit. A pol. (Wks.) 861 A 5, submylling hymselfe to that ablucion. to transfigure. Apol. (Wks.) 887 G 2 , heretikes like the aungels of Suthan transefiguring them self into the likenes of anngelles of light.

to use. Apol. (Wks.) 871 F 11, no man canne ose hymselfe ... more mylclelye. A Apol. (Wks.) 823 (i 2, the spiritual indges missehandle those mallers, \& se themselfe therin cruelly. | Dial. C. (Wks.) 1200 D 4, douting onermuch lest they shold misseuse themself, [they] lewe the thinges vndoone wherin they might use themself well.

138. The reflexive object is a personal pronoun.

to advise. Prayer 1419 I) 8 , we haue somwhat aduised ss theron. Picus 25 I) 6 , When thou laborest thy pleasure for to bye, Uppon the price looke thou thee well aduise.

to arme. Dial. C. (Wks.) $1181 \mathrm{E} 11$, our whole host was warned to arme them in hast.

to beke. Boke of F. p. 4 C 6, against the sonne Bekyth hym poore Diogenes in Jis tonne.

to bethinke. Dial. C. (Wks.) 1172 A 14, we neuer found of worldly recreacion so muche comforte in a yere, as we should fynde in the bethynkyng os of heauen in lesse than half an houre. I Dial. c. (Wks.) 1141 F 9, I bethought me.

to botch 'p. Last. Th. $100 \mathrm{G} \mathrm{1,} \mathrm{[we]} \mathrm{driue} \mathrm{our} \mathrm{self} \mathrm{in} \mathrm{sicknes,} \mathrm{\&} \mathrm{botch}$ os op with phisick.

to conflrme. Picus 17 C 16, Kindle thee when thou waxest colde, confirme thee when thou wauerest.

to coumforte. Dial. C. (Wks.) 1263 A 8 , let vs ... coumforte ss with hope.

to fence. Dial. C. (Wks.) 1263 A 8, let vs fence us with fayth.

to get. Apol. (Wks.) $873 \mathrm{E} \mathrm{11,} \mathrm{I} \mathrm{pray} \mathrm{you} \mathrm{...} \mathrm{gete} \mathrm{you} \mathrm{shortely} \mathrm{hense.}$ Apol. (Wks.) 888 B 3, should he lette hym walke abrode vppon hys promyse to appere agayne, whyche Frith were lykely to breake and geate hym ouer sea. | Dial. Her. 283 A 17, as sone ag he gate him hence, he gate him to Luther straight. | Rich.61 F 12, the preacher gate him bome \& neuer afler durst looke out for shame. | Jest p. 2 E 3, To saint Katherine Straight as a line, He 
gate him at a tyde. | Last Th. $75 \mathrm{G} 12$, if ther be but these two steppes to heauen, he that getteth hym on the tone is halfe vp. I Dial. C. (Wks.) 1251 B 2, when be perceyuelh hymself drunke and geatteth hym faire to bedde.

to go. Apol. (Wky.) 921 a 10 , with such good bope, the good manne goeth him bome.

to grieue. Dial. C. (Wks.) 1253 ( 10 , a man may hane hys legge stricken of ... and grieue him not.

to hye. Jest p. $4 \mathrm{G} 4$, The mayd and wyfe... Hyed them vpward.

to kepe. Dial. C. (Wks.) $1250 \mathrm{E} \mathrm{14}$, the snayle kept her at home, and woulde not come thereat.

to kindle. Picus 17 C 15, Kindle thee when thou waxest colde.

to knele. Ijial. Her. 165 A 12, and so would I haue done I thinke knele me down and make my special prayour.

to lay down. Aich. 39 I 3 , the king ... laide him down.

to maruatl. Conf. Tynd. 254 A 12, 1 marnail me ${ }^{1}$ ) much how he fell inlo such a heap of heresies.

to remember. Last Th. 93 C 8 , I remember me of a thele once cast at Nowgate. | Dial. C. (Wks.) 1183 D 13, I remember me that among other of her fond tales, she told vs once, that...

to sit (set). Apol. (Wks.) $884 \mathrm{H} 5$, [he] sate hym downe \& sighed. I Rich. 53 il 16, and sone after ... he relurned ... and ... sat him down, in his place. | Hich. $41 \mathrm{E} 16$, incontinente after that they were ... departed ..., the Dukes secrellye ... sette them downe in counsayle.

to shriue. Hich. 54 F 11, except the lorde Gbamberlen, whom the protectour bade sirede \& shryue hym a pace.

to squat. Passion $1359 \mathrm{H} \mathrm{11}$, when thou hadest ietted thy fil [thou woldest] squat the[e] down fail \& wel in a chaire.

to styrre. Dial. C. (WVks.) 1254 A 5 , so shold be be kild lying, where ho could not styrre him.

139. This selection may suflice to show that the complementing of the verbal idea by means of a reflexive object was an extremely common idion in More's English. The form of this reflexive complement was not yet stabilized, bolh the simple and the compound pronoun being used in this function. The latter, which about a century earlier (e.g. Malory's Morte D'Arthur) was still in the minority ${ }^{2}$ ), seems to have won so

1) That this $m e$ is not an indirect object of interest (\$ 154), but distinctly a reflexive complement, may be gatbered from the following quotation : Debell. 929 D 4, whan I since considered bow lyttle nede it was, I meruailed mine own self and repented.

2) Dekker $1932 \$ 62$; Koziol 1932 p. 70 : “ Dic einfache Form ist im M. E. noch haüfiger als die verslärkte". 
much ground in the meantime that in More's language it had succeeded in obtaining a secure footing by the side of the simple personal pronoun. Whether it had already begun to oust the shorter form, it is not possible to ascertain, though its greater frequency points lbat way ').

In many cases More's use of either the simple or the compound pronoun was apparently determined by the requirements of rhythm or euphony :

\section{Personal Pronoun}

bethink. Apol. (Wks.) 883 H 12, At that they paused a little and began to bethinke them.

behave. Dial. Her. 107 E 13, [he] studyeth more howe he may behaue him, than what he shall say.

comfort. Dial. C. (Wks.) 1263 A 8 , let vs ... coumforte os with hope. draw. Dial. C. (Wks.) 1195 D 4, the feare of falling into Charibdis ... shall neuer let any wise maister therol, to draw him fro Scilla toward Charibdis fyrst... excuse. Apol. (Wks.) 865 is 2, the good brethrene excuse theim and saye...

feel. Dial. C. (Wks.) 1263 B 6, when we feele os to bolde ... remember our owne fieblenesse.

fence. Dial. G. (Wks.) 1263 A 8, let vo fence os with faytb.

hide. Passion $1274(=1276)$ G 10 , I was naked, and therfore I hyd me.

prepare. Dial. G. (Wks.) 1262 C 4, Let va...prepare os in our mind therto.

quit. Dial. C. (Wks.) 1242 D 4, I had went I had quit me well.

\section{Compound Pronoun}

A pol. (Wks.) $883 \mathrm{G} 2$, [he] bethought himselfe what meane he myght inuent.

Picus 5 B 12, where he so behaued him self, that was wondre to beholde, how all the audience reioyced.

Dial. C. (Wks.) 1139 H 3, comforting himself ther'with...

Jest p. 2 D 14, [he] would not go, Companied so, But drewe himself a side.

Rich. 53 G 9, the protectour came in ... excusyng hymself that he had ben from them so long.

Dial. G. (Wks.) 1263 G 5, now begynne I to feele my selfe somewhat werye.

Picus 8 D 14, fensyng my selfe with the crucifixe.

Passion $1274(=1276)$ G 3, for shame thei fel in a feare, and fled and hydde them selfe.

Dial. G. (Wks.) 1262 C 1, let vs prepare our self with prayer.

Dial. C. (Wks.) 1221 H 12, mee thoughte ... for my parte, I quytte my selfe metelye wel.

1) The longer forms also outnumber the simple pronouns in Berners (Klausmann 1919 \& 60) and in Caxton (Kellner 1890 \$ 10). 
turn. Dial. C. (Wks.) 1236 G 8, then saitb bolye scripture : Bonis omnia cooperantur in bonum, vnto good folke al things turne them to good.
Dial. C. (Wks.) 1144 C B, He that... tourneth hymselfe vnto worldly vanities...

140. There is, however, a group of verbs which, in More, are almost exclusively construed with a personal pronoun, e. B. to get, to go, to hie, to sit, to stir, all verlos of motion or position '), which in Old English had a dalive pronoun as a kind of redundant object (Sweet 1903 \& 1106) : hi eoclon heom; hi fleop him; heo scet hire. The usage still lingers in Pres. D. Eng. in poetical or archaic language :

1854 Patmore, Angel I, II, IX, 225, The foolish hie them post hasto through. $1888 \mathrm{~J}$. S. Winter, Boolle's Childr. xul, Come and sit you down by the fire. | 1892 Cosmopolilan xill 727, So I may go me to mass, mamma, Along with my coal man lover (OED).

141. How far reflexivity has fallen off since More's lime may be gathered from the lists of quotations in $\$ \$ 137-139$. Quite a number of constructions illustrated there are obsolete or archaic now : to appoint oneself, to beek oneself, to bewray oneself, to bless oneself $\left.{ }^{2}\right)$, to botch oneself, to conflrm oneself, to custom oneself, to discern oneself, to embisy oneself, to endeavour oneself, to ensemble oneself, to garnish oneself, to grieve oneself, to humble oneself, to ieopard oneself, to labour oneself, to marvel oneself, to meek oneself, to misorder oneself, to mistake oneself, to misuse oneself, to name oneself, to open oneself, to oversee oneself, to order oneself, to pain oneself, to prove oneself, to quit oneself, to retreat oneself, to rule oneself, to shrive oneself and to use oneself.

The construction I liked myself may have developed out of the impersonal it liked me :

c 1205 Layamon 8746, Hit pe likede wel pat pu us adun laidest. | a 1300 Cursor M. 28336, I ha me llked ai vm-quile In vnnait wordes.

The latest quotation in OED is :

1549 Chaloner, Erasm, on Folly, F ij b, Yet dooe these my old gurles not a little lyke their selves herein.

') ct. French s'en aller, s'agenouiller, s'asseoir, etc.

?) = to make the sign of the cross. 
The following verbs are now often or mostly used wilhout reflexive complement : to hide, to meddle, to mesh, to proftt, to repent, to submit and to prepare. The verb to behave is now used without reflexive object, except when it means to conduct oneself with propriety (chieflly when said of children).

142. When the reflexive object is accompanied by a predicative adjunct we also find both the simple and the compound pronouns :

feel + pers. pron. Dial. C. (Wks.) 1263 B 6, when we feel os to bolde. + comp. pron. Dial. C. (Wks.) $1263 \mathrm{G} 5$, [I] feele my selfe somewhat werye.

hold + pers. pron. Boke of F. p. 6 D 6, Holde you content. + comp. pron. Dial. C. (Wks.) 1241 H 2, [if he] hold hymself content.

keep + pers. pron. Apol. (Wks.) 881 D 12, [they were] fayne to finde a place to hide their heades, or to kepe them from prison finde some other shift. | Dial. C. (Wks.) $1250 \mathrm{E} 14$, the snayle kept her at home.

+ comp. pron. Dial. C. (Wks.) 1190 C 14, he kepe hymself close in hys warme denne. | Picus $4 \mathrm{C} 3$, he had muche worke to kepe him self opright.

In Pres. D. Eng. the pers. pron. is no longer used in this function; to feel + predicalive adjunct is mostly construed with neither of the two pronouns.

\section{Reciphocal Objects}

143. The reciprocal objects appear under the forms eche (to) other, either other and together.

Eche (to) other. Last Th. 81 A 3, the conflict of the diuers qualifyed elementes in our body, continually laboring ech to vanquish other. | Rich. 38 H 6, For it sufflseth not that al you loue them, If eche of you hate other. I Picus 1 G 3, they desire eche to other that yere a good continuance.

Either other. Last Th. 96 F 10, if we loue ether other... | Rich. 47 B 3 , If the Growne happen ... to comme in question, whyle eyther parte taketh other as Traytours...

Together. Gonf. Tynd. $460 \mathrm{H}$ 1, Tyndales wordes fight together. | Hich. 39 D 5, Oure Lorde forbydde, that you loue together the worse, for the selfe cause that you ought to loue the better. | Conf. Tynd. 612 A 6 , let vs ... see how his diffnicion of the churche and hys heresies, will iumper and agree together among themselfe. I Dial. Her. 143 A 2, I geue you a new commandement that you 
lone togither as I haue loued you. | Dial. Her. $161 \mathrm{H}$, thei neuer shall wedde together.

Together as a reciprocal object is obsolele now. The two words eyther other were originally in difierent grammatical relations, one of them (mostly either) being the subject, and the second the object. This is still often the case in More. Later on either other like each other became a compound and could have the preposition to before llie group. The collocation has survived in the form either ... the other :

1874 Morley, Compromise 103, The rights of either to disturb the other.

The two parts of each other can no longer be separated ; they form a compound now, so that eche to other has become to each other.

Some examples of the usage in earlier English follow :

Together. c 1330 H. Brunne, Chron. Wace. 480;3, [Men] pat sypen han loued to gedre wel. | 1483 Vulgaria abs. Terentio 7 b, Scolers shulde loue to gyder lyke as lbei were bredyr (OEI)).

Either other. c 1200 Trin. Coll. Hom. 213, pesse wise biswikep her alper oper.

Each other. a 1000 Battle of Maldon 234, Us is eallum pearf pat Ure azhwyle operne bylde. | 1485 Malory, Arth. u, vi, we wil belpe eche other (OED).

There is a unique example of other as a reciprocal object standing without a correlative each or either :

Rich. $39 \mathrm{H} \mathrm{7,} \mathrm{the} \mathrm{lordes} \mathrm{recomforting} \mathrm{him} \mathrm{with} \mathrm{as} \mathrm{good} \mathrm{wordes} \mathrm{as}$ they could, ... there in his presence ... forgaue other, and ioyned their bands togelher.

In later use this idiom is only found in Scotch :

1809 Camplell, Gertrude I, vi. We know not other-oceans are between.

No examples have been found in More of the use of themselves as a reciprocal object, as in

Spenser, F. Q. vi, i, 4, Thry knew them selves (S.).

\section{Phepositional Objects}

144. The use of prepositional groups as objects to the verbal idea was as common in More as it is in Pres. D. Fng. The following selection illustrates obsolete usage only.

abhor from. Picus 4 D 13, From the desire of whom be not abhorring, ... was somwbat fallen in to wantonnesse. | Conf. Tynd. 807 G 9, Saint Austin abhorreth from Prere Barns heresie. 
ake of. Dial. C. $2 ミ 4, y$, his finger done but ake of an hoate blaine...

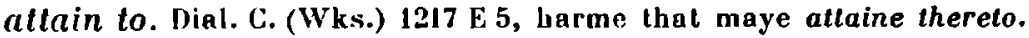
appoint upon. Dial. Her. $282 \mathrm{D} 11$, [the] purpose that they appoynt opon.

be in hand (rith. Delyell. 932 (11, lys new booke that we bee nowe in hand wyth. | Dial. C. (Wks.) 1256 H 7, the maller that we be in hande with. | Ipol. 5l, the matcr wherwith we be now in hande. beck upon '). Last Th. 84 A 8 , them whom he vouchsafelh to take by the hand or beck opon.

beleue on ${ }^{2}$ ). Dial. Her. 110 [) 16, Christ ... wold neuer hatue any man compelled ... lo beleute opon his faith.

blabber on '). Last Th. 75 H 4, it wer'e lesse euil ... to blabber on trifles somewhat sottishly.

call unto ${ }^{3}$ ). Supplic. 288 I) 5, The sely soules ... call onto vs for help. come to. Apol. (Wks.) 902 I) 13, I can come to gondes by suche goodlye wayes.

comen with. Hich. 55 C 18 , it happed the lord lihamberlen hy the way to stay his horse, and comen a while with a priest.

complain upon. Dial. Her. 181 A 4, he which would not amende... should be complayned spon.

confeder with. Debell. $930 \mathrm{~F} 13$, other priestes will confedel with him.

devise upon 4). Dial. C. (Wks.) 1221 G 2, deuysing ... sppon some ... proper waye to bryng it in with all...

dispute of ${ }^{5}$ ). Answer $1121 \mathrm{E} 9$, so bolde ... to dispute of goddes... power.

divine upon. Hich. 37 II 6, whoso diuineth oppon coniectures, maye as wel shote to farre as to short. | Hich. $43 \mathrm{~F} 7$, Then was there greate commocion ... the people diuerselye diuinynge sppon this dealinge.

dote in ${ }^{6}$ ). Passion $1271 \mathrm{C} 12$, [he] began to dole in the regarding and beholding of his own beawty.

dreame on '). Apol. (Wks.) 877 A 1 , this deuision was neuer dreamed on.

ennamored upon. Rich. 57 \ 2, he was sore ennamored opon ber.

ensue upon. Instr. 14117 B 5 , opon the suche delaye of the death may happly ensue the eucrlasting tormentes in hel.

1) Not in OED.

2) Still in thcological language (OED s. v. Jelieve 1).

3) Now to call up(on). Also occurring in More: Picus 13 B 14, he shall not heare the[e] when thou callest on hym.

4) Earliesl quotation in OED is dated 1592.

s) Now to dispute about or on.

-) Now to dote upon; also in More : Rich. 54 D 10, Shores wife on whoe he somwhal doted.

7) Earliest quot. in OED is dated 1592. 
enter into '). Dial. C. (Wks.) 1204 B 15, a ryche manne to enter into the kingdome of God.

entreate of. Rich. $37 \mathrm{C} 4$, Richarde ..., of whom we nowe entreate.

fayle for ${ }^{2}$ ). Last Th. $89 \mathrm{C} 8$, Why takest thou thought now in thy self, and fearest to fayle for foode?

fall in hand with. Dial. C. (Wks.) $1224 \mathrm{C} \mathrm{3}$, whan it was offred hym, she fel in hand with hym ... and all to ${ }^{3}$ ) rated him.

follow of. Last Th. 97 B 11, Of our gloton festes, folowelh not only slouth \& lechery, but... | Last Th. $75 \mathrm{E} 2$, it should therof folow, that...

force of. Conf. Tynd. 345 D 3, he saide that he had alwaye ... taught the gospell of god after bys owne minde... not forcing of the deterininacion of the church.

force for. Apol. (Wks.) 874 B 7, he greatly forced not for the furtheraunce of the catholike fayth.

frete at. Supplic. 302 B 9 , he is angry \& freteth at the opirituall iurisdiccion.

grudge at. Boke of F. p. 7 A 1, Grudge not there at.

hang by. Cont. Tynd. $564 \mathrm{D} 14$, that they repent al their olher sinnes as soone as they be rebuked, hangeth all by the mone shyne.

hap upon. Dial. C. (Wks.) 1158 I) 10, if hymselfe happe opon a feruent longing. | Dial. C. (Wks.) 1147 B 13, How many get out of prison that hap on such harme abrod, as the pryson shuld haue kept thew tro.

harken after. Last Th. 84 G 14, For thei, albeit their hert ... harkeneth, after the sessions, yet haue they some hope ... to breke prison the while.

hast after. Picus 19 B 10, Now after these wordes,... it loloweth. After thei hasted, that is to say : after their ydoles, after their passyons and beaslly desyres.

hawk after. Picus $15 \mathrm{~A} 11$, the aduauntage that ye hawke after.

holde with. Dial. C. (Wks.) 1177 B 14, for myne owne parte I can not well holde with them.

intend unto. Picus $19 \mathrm{~F} 6$, To thend that he may altogether hole haue his mind into heauenward, \& the more purely intend onto the contemplacion of beauenly thynges.

ioyne with. Aut. Jett. xiv, 191, [the army] ... can neither ioyne with the duke to make hym the strenger, nor...

1) But : Picus $12 \mathrm{H} \mathrm{7,} \mathrm{it} \mathrm{is} \mathrm{very} \mathrm{harde} \mathrm{for} \mathrm{a} \mathrm{ryche} \mathrm{man} \mathrm{to} \mathrm{enter} \mathrm{the}$ kingdome of heauen.

2) Not in OED.

3) This all to = soundly, wholly, utterly is of frequent occurrence in More : Apol. 872 C 13, all to buffet; Conf. Tynd. $767 \mathrm{C} \mathrm{18}$, al to chide; Gonf. Tynd. 516 E 15 all to frush; Gonf. Tynd. 592 A 5 , hath al to rayed his gay cote; Cone. Tynd. $803 \mathrm{~F} 6$, he lyeth in the myre all to tumbled in dy't. In Sliakesp. : Per. III. ii, 17. Cf. Schmidt (1902) s. v. All-to. 
knaw on. Rich. $53 \mathrm{H} \mathrm{17,} \mathrm{he} \mathrm{returned} \mathrm{...} \mathrm{frowning} \mathrm{and} \mathrm{lroting} \mathrm{and}$ knawing on hys lippes.

labour about. Dial. C. (Wks.) 1142 D 3, this thing laboured the Philosopher's very much about. | Dial. C. (Wks.) 1166 H 3, In labouryng about the doynge many good dedes, his labor minysheth his quiete and his reste.

laugh upon ${ }^{1}$ ). Rich. 55 I) 4, he laughed opon him, as though he would say, ye shal shal haue sone.

lay against ${ }^{2}$ ). Dial. Her. 114 H 8, that good holy man layeth sore againsl these carued ... ymages.

learn at. Dial. C. (Wks.) $1155 \mathrm{D} 1$, let him learne at me to doe as I have done.

look unto ${ }^{3}$ ). Dial. C. (Wks.) 1186 A 3, when hee [scil. a pbysician] was byinselle once sore sycke, I heard his felowes that then looked onto hym,... wyshe ... that for the tyme of hys owne syckenes ... he had knowen no phisike at al.

look "ipon 4). Last Th. 75 A 1, IVyll ye sce the sample? Looke oppon his holy apostles... | Last Th. $89 \mathrm{C} \mathrm{13}$, loke spon the byrdes in the ayre, they neither sow nor repe.

make against. Supplic. 316 E 10, when it [scil. scripture] maketh against them, they then ... doe but mocke.

mean by. Hich. 7I E 2, What fole quoth the fox thou maist abide wel inough, the lyon ment not by thee.

medle of. Dial. Her. $114 \mathrm{~F}$ 11, of his entente ... I will not much medle. miss of. Dial. Her. $382 \mathrm{~F} \mathrm{15,} \mathrm{[the} \mathrm{devil]} \mathrm{oftentimes} \mathrm{maketh} \mathrm{them} \mathrm{misse}$ of the vain prayse, wherof only they be so proude.

mourn at ${ }^{5}$ ). Last Th. $85 \mathrm{G} \mathrm{14,} \mathrm{euer} \mathrm{since} \mathrm{enuy} \mathrm{goth} \mathrm{forth} \mathrm{mournyng}$ at ellerye mannes wellare.

need of. Dial. C. (IVks.) 1169 B 7, other frendes ... for whome I think more than for your self, you neded of some counsayle.

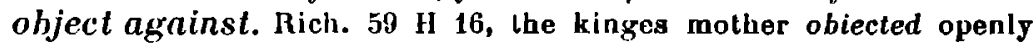
against his mariage.

prease upon. Conf. Tynd. 563 $\mathrm{G} 12$, [he would] assaye hym often, and prease spon hyin styl, not withoute hope of the mans chaunge to his secte.

prye upon ${ }^{2}$ ). Apol. (Wks.) 877 D 7, whoso prye spon every mannes dede so narowlye, as to spye that faute.

procede upon. Dial. C. (IVks.) 1200 H 15, wretches ... spon whom ... iustice may procede.

1) To langh al also occurs in More : Last Th. 73 G 1, Think not that euery thing is plesant, that men for madnes laughe at.

2) Not in OFD.

3) $=$ to attend.

1) = to look at.

5) Now with for or ocer. 
prtrsue upon '). Dial. C. (IVks.) 1193 A 16, certayn holy vertuous virgines ..., being by Gods enemies infideles pursued oppon to be defloured by lorce.

purpose upon. Dial. C. (Wks.) $1190 \mathrm{~F} 12$, he fyrmely purposeth opon it. rail upon ${ }^{2}$ ). Apol. (Wks.) 868 H 2, what neede there were that I should rayle uppon the clergye.

ray in. Con 1 . Tynd. 614 D 8, I ... shall shew you shortly how angrely ho ryselh vp, and royally rayed in dirte.

remit in. Last Th. 77 A 4 , yl oure frailtye coulde endure neuer to remitte or slake in the depe deuising of them...

repugn at. Passion $1336 \mathrm{~F} 1$, Now is thys custome so vnyuersall, that neyther laye nor prest ... eyther otherwyse used..., or anye thyng repugned therat.

rise upon ${ }^{3}$ ). IDial. C. (Wks.) 1193 D 13, his intent ryseth vppon a true reuclacion, and not vpon a lalse illusion.

roun with. Hich. 66 A 13, Vpon this answer geuen, the Duke... rouned ... with other noble men about him.

seek upon. Dial. C. (Wks.) 1248 B 8, In prison was Joseph while his brothern were at large, and yel after were his brethern fayne to seke sppon him for breadde.

seek (lln)to. Dial. (.. (Wks.) 1162 F 12, he sought onlo a wiche. | Dial. H[ar. 13L B 5, First ye speke of seking to sayntys for sleyght causis, as for the losse or misse of kiltes kayes.

serlue of (lo). Picus 5 D 7, ther was nothing that he more hated..., considering that thei serued of nought but to the shaming of such otber lolke as wer in very science much better lerned.

shyft with. Rich. 5l B 8, he would forthwith depart there with all, and shyfte whoso would with thys busynes afterwarde.

shoot at ${ }^{4}$ ). Apol. (Wks.) $876 \mathrm{H} \mathrm{20,} \mathrm{I} \mathrm{am} \mathrm{content} \mathrm{to} \mathrm{let} \mathrm{his} \mathrm{'but'} \mathrm{alone,}$ and wyll not shote therat for this ones.

slake in, see remit in.

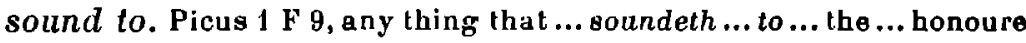
and laude of Grod. / Rich. 58 D 1, To lay bastardy in kynge Edward, sowned openly to the rebuke of tho proteclours owne molher.

stand for ${ }^{5}$ ). Dial. C. (Wks.) 12:5 $\mathrm{C} \mathrm{4}$, the parable of the philosopher can lacke no lestimony, which lykened the seruaunts of great princes vnto the comptours, with which men do cast acompt. For lyke as that countour that standeth sometyme for a farthing, is

\footnotetext{
1) The latest quotation in OED is from Caxton.

2) Now rail at or against.

3) Not in OED.

4) = to assail with censure. Now obsolete. Earliest quotation in OED is dated 1586.

5) This meaning of to stand for is not registered in OED.
} 
sodainly set $v_{p}$ and standeth for a thousand pound, and after as sone sel downe efte sone beneth to stand for a larthing again, so fareth it ... somtyme with those that sceke the waye to rise.

stand in "). Apol. (Wks.) 876 I) 5 , hys lamentable beginning, which standelh ... in lamenting tho change from the old vertues... into the newe vices. I Picus $13 \mathrm{C} \mathrm{9,} \mathrm{I} \mathrm{stire} \mathrm{thee} \mathrm{not} \mathrm{to} \mathrm{the} \mathrm{prayer} \mathrm{that}$ standeth in many wordes.

stand with. Rich. 40 F 6 , [he was] in manye thynges ruled by the beide, more then stode either with his honour, or our profile.

stick with. Dial. Her. 224 C 7, I wyll not greatly sticke with you in that poynte.

stoupe $a t^{2}$ ). Dial. C. (Wks.) $1145 \mathrm{E} 2$, The proude kyng Pharao did abicle and endure two or thre of the fyrist plages, \& would not ones stonpe at them.

study in. Picus 3 B 3, he departed to Bononie to studye in the lawes of the church.

sweat in (about). A pol. (Wks.) $904 \mathrm{G} \mathrm{12,} \mathrm{his} \mathrm{afore} \mathrm{remembred} \mathrm{heresye}$ that he so sweatheth in. | idem $905 \mathrm{~A} 12$, I hearde of late, that he sweateth aboul that matter a fresh.

think (up)on. Apol. (Wks.) 883 F 13, one thing is ther that if ye thought theron, ye woulde I dare say doe fyrste. | Dial. G. (Wks.) $1141 \mathrm{H} \mathrm{13}$, such lhynges, as I before haue readde, hearde, or thought sppon.

trauail on. Debell. $930 \mathrm{~F}$ 3, I longed of their long labour to se some good spede, \& some of those faire babes borne that thei traualled on.

understand of. Rich. $60 \mathrm{C} \mathrm{4}$, when the Erle of Warwick onderstode of this mariage, he tooke it so highly ... that ... he ... assembled a gret puisaunce against the King.

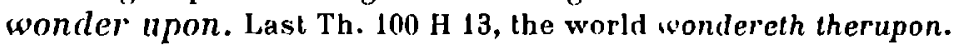

Verbs of this kind form with their prepositions a sort of compound, the meaning of which can often be expressed by an objective ver], without preposition (to seek unto $=$ to visit; to rise upon $=$ to follow; etc.). That in More's English the complement after these prepositions was not realised as different in character from an ordinary object is evident from the fact that corresponding passive constructions regularly occur with these compound verbs (e. g. Apol. (IVks.) 877 A 1, this deuision was neuer dreamed on) ${ }^{3}$ ). By lhe side of the verbs listed above, which have a different construction from that

\footnotetext{
1) = to consist in.

2) = to yield to. Not in OED.

3) See the sections on to be + past participle ( $\$ 5555 \mathrm{fr}$.).
} 
in Pres. D. Eng., there occur in More a great number that take the same preposition as in the language of to-day : Picus 5 D 2, to argue with; Picus 2 B 8, to aspire to; Rich. 69 A 17, to hegin with; Picus 5 II 10, to belong to ; Last Th. 76 B 8, to break into; Picus $12 \mathrm{E} 15$, to consent to; Supplic. $299 \mathrm{D} 14$, to call upon; Apol. 8, can away with; Apol. 43, to cleue to; Last Th. 85 A 2, to come for; Dial. C. 296, to delite in; Instr.

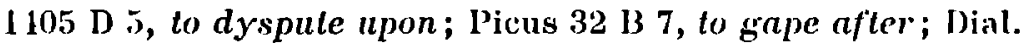
C. 163, to hang upon; Last Th. $93 \mathrm{~B} 6$, to here of ; Dial. C. 196, to hold with; Apol. 97, to inueye against; Rich. $64 \Lambda 10$, to ioyne in; Rich. 56 It 2, to long for; Rich. $49 \mathrm{~B} \mathrm{12,} \mathrm{to} \mathrm{loke}$ to; Last Th. 94 F 15, to labor for; Dial. C. 126, to leanc upon; Picus 15 A 13, to look for; Rich. 61 B 15, to meet with; Dial. Her. $118 \mathrm{H} \mathrm{8,} \mathrm{to} \mathrm{mock} \mathrm{at;} \mathrm{Rich.} 66 \mathrm{~F} \mathrm{14,} \mathrm{to} \mathrm{pay} \mathrm{for} \mathrm{;} \mathrm{Rich.}$ $56 \mathrm{G} \mathrm{8}$, to reioyce in; Rich. $36 \mathrm{D} 4$, to send for ; Dial. Iler. $130 \mathrm{H} \mathrm{14,} \mathrm{to} \mathrm{sigh} \mathrm{for;} \mathrm{Dial.} \mathrm{Her.} 121$ A 7, to smell of; Answer 1035 II 14, to speak against; Rich. 62 D 1, to speak of; Dial. C. 27t, to sticke at; Dial. C. 148, to striue with; Rich. 68 F 11, to strugle with; Rich. 53 B 11, to talk of; Rich. $45(=44)$

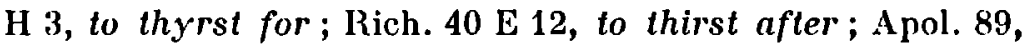
to treat of; Boke of F. p. 6 B 5, to trust in; Jest p. 2 D 9, to wayle on; Dial. Her. 108 B 11, to write of; etc.

As the construclions which conform to present-day usage far outnumber those that do not, More's English does not make a distinctly obsolete impression in this respect.

145. Though the preposilious form a kind of semasiological unit with the verb, they may be separated from it by intervening words :

Dial. G. (Wks.) 1295 C 9, Lhat standeth sometyme for a farthing. Picus $58 \mathrm{D} 2$, sowned openly to the rebuke of... | Conf. Tynd. $777 \mathrm{C} \mathrm{2}$, What grounde ... hath be to ... rayle so rially oppon all the lawes.

146. End-position of the preposition is far from rare. It occurs :

a. In independent units :

Dial. Her. 121 H 6, them we speke not of. | Dial. C. (Wks.) 1142 D 3, this thing laboured the Philosophers very much about. | Conf. Tynd. $398 \mathrm{E} 11$, Blessing of bishops Tindall iesteth opon in moe places then one. 
Especially in passive constructions :

Apol. (TVks.) $877 \mathrm{~A} 1$, this deuision was neuer dreamed on.|Picus $4 \mathrm{~F} 11$, which lessons were so muche the more set by.

b. In infinitive constructions equivalent to a clause :

Dial. C. (Wks.) $1236 \mathrm{E} 2$, And therefore ... to begynne with, let vs be of good comforte. | Dial. Her. 271 B 6, we haue none ... other chapman to sel our ware and our worke snto.

c. In clauses

1. opening with that:

Last Th. $73 \mathrm{G} 1$, Think not that euery thing is plesant, that men for madnes laughe at. | Answer $1035 \mathrm{H} \mathrm{14}$, such communicacion it is that thapostle speaketh against. | Dial. C. (Wks.) $1161 \mathrm{H} \mathrm{1,} \mathrm{synne} \mathrm{that} \mathrm{he}$ was bred and broughle vp so long in. | Debell. $930 \mathrm{~F} \mathrm{3}$, those ... babes ... that thei trauailed on. | Kich. 55 B 10, I am as sure of the man that he woteth of, as I am of my own hand.

2. opening with whom:

Picus 5 C 14, with the desire of worship ... there is ... annexed the appetite of his confusion and rebuke, whom thei argue with.

But : Rich. 56 H 1, she not very feruently loued, for whom she neuer longed.

3. opening with which :

Answer 1043 H 9, he gaue him the name of stone which stone be said after he would build bys church opon.

4. opening with as :

Aut. Lett. xvi, 12, all such thinges as he commaunded me to put yor grace in remembraunce of. | Dial. Her. $107 \mathrm{G} \mathrm{8}$, all suche thinges as he brake of. | Dial. C. (Wks.) 1195 A 1 , good vertuous folke such as himself, ... hath afore longed to stand in estimacion with. | Picus 6 D 4, poore nedie people, euch as him selfe happely coulde not come by the knowlage of.

5 . in asyndetic attributive clauses :

Dial. Her. 108 B 10, that man ye wrote of...

d. For the sake of parallelism, i. e. when the verb + preposition is used in juxta-position with one or more objective verbs without preposition :

Dial. C. (Wks.) $1168 \mathrm{D} 12$, Whoso these thinges thinketh on, and remembreth well, shall ... neither murmure nor grudge.

The preposition withall always has end-position :

A pol. (Wks.) 872 B 4, priestes that so bee dealte wythall. | Dial. Her. $139 \mathrm{G} \mathrm{14,} \mathrm{yf} \mathrm{it} \mathrm{were} \mathrm{lrewe} \mathrm{that} \mathrm{ye} \mathrm{defende} \mathrm{the} \mathrm{thynges} \mathrm{withall.} \mathrm{|} \mathrm{Cont.}$ Tynd. 571 D 11, Fayth is euer assaulted and fought withall. | Last Th. 88 B 12, hym that we be wrothe withal. | Conf. Tynd. $545 \mathrm{H} \mathrm{14}$, what thynge hath Tyndal to defende his exposicion soithal ? ${ }^{1}$ )

1) In Shakesp., A. Y. L. III, ii, 328, Hos. Ile tel you who Time ambles withal, who Time trots withal,... and who be stands atil withal. Orl. I prethee, who doth he trot withal ? 
The end-position of of, forming a semantic unit with to be, as illustrated in the following quotations, deserves special notice :

Dial. Her. 262 H 1, to confesse \& declare ... what oppinions he and oller of his felowes had holden and were of. I Passion 1381 A 16, the hetter nature that euery thing is of, the worse waxeth it at lenglh if it ones beginne to fall out of course.

The practice of putting the preposition al the end already exisled before More's time :

Anglo-Saxon Cliron. 1016, Se here bim fleah beforan. 1300 Ciurs. Mr. 3712, Sithon his son he called him till. I a 1:300 St. Gregoly 1068.70, An lonly man ... pat dyne wer per to done and chrislendome to loke to. I c 1400 Mandeville, Tr. 130, 20, a lityll clout pat pei coueren with here knees. | 1377 Langl. P. Pl. xvir, 202, Who so synnetl in seynt spirit, it semeth that he greucth God, that he grypelh with and wolde his grace quenche. | c 1375 Sc. Leg. Saints xvil, 356, Than lukit he avfully tham to. I a 1485 Hall, Chron. Henry VI, $152 \mathrm{~b}$, After the death of this prelate, ... the alfaires in Fraunce were neither well loked to, nor...

After More's time back-position of the preposition became more and more usual :

1611 Auth. Vers., Job 3, 25, that which I was alraid of, is come vnto me. | 1726 Adv. Gapt. H. Boyle 28, Gardening was what I always took delight in.

In Pres. D. Eng. the usage has to a great extent exceeded its original boundaries - especially in colloquial style :

1907 Huskin, Praeterita 11 75, the cabin, which the waves from the paddle wheels rushed past the windows of. | 1923 A. Huxley, Antic Hay p. 10 l (ed. Albatros), These bright May days are beauliful days for being in love on.

Sometimes More uses the preposition twice, once in frontposition and once in back-position :

Dial. C. (Wks.) 1141 B 2, Therelore good vncle, agaynste thcse borrible leares of these lerryble tribulacions, of whiche some ye wot wel, our house alredy hath, and the remnant stand in drede of, geue vs whyle god lendeth you vs, ... plenty of your ... counsayle ${ }^{1}$ ).

This tautological use of the preposilion occurs in all stages of the English language :

1481 Caxton, Regn. 73, none to whom he has gyuen his saufgarde to. I 1470 Malory, Morte d'A. 696 , the bougbe on whiche the appel henge on. 1805 Stevenson, The Art of Wr. 141, a young Irishman, with whom I was once intimate, and had spent long nights walking and talking with (J.).

1) Similarly with a propositional adjunct in : Conl. Tynd. $513 \mathrm{C} \mathrm{9}$, in which soeuer of these I wo states a man linally dieth in,... 
More uses to gnas on one's lips (Rich. 54 A 2, frowning and froling and knassing on hys lippes) and not to gnaw one's lips. The bulk of the constructions of the type she sat her horse (instend of on her horse), representing a kind of retrogression to the primitive stage of the language, in which no prepositions were used, seem to have sprung up after More's time. A few of these constructions follow with the dates of their earliest quotalion in OED :

she sat her horse 1542 to slip the collar 1579

to jump the rails 1600

il has slipped my memory 1652

to rnsh the boats 1865

\section{B. VERBS WITH TWO OBJECTS}

\section{Ohdinafy Onject + Phepositional. Object}

147. There is a considerable number of verbs in More which are construed with an ordinary and a prepositional object. A ferv of them follow :

abhor something for. Dial. C. (Wks.) 1245 D 16, such harde fasuion as we most abhorre imprisonment for.

appoynt something with. Dial. C. (Whs.) 1188 C 7, he appoynted wyth her the morning when he should come.

associate someone to. Picus 16 D 7, [God] hath associate the(e) to the children of light.

berene someone from (of). Rich. $62 \mathrm{G} 12$, [the king] byreft her from ber husband. | Instr. 1407 C 11, Thys night thon foole, sball they berine the(e) of thy life.

cumber someone with. Conf. Tynd. $478 \mathrm{~F} \mathrm{1,} \mathrm{lest} \mathrm{he} \mathrm{shoulde} \mathrm{haue}$ cumbred hymselfe somewhat with the aunswere.

dedicate something to. Picus 7 D 12, to whom he dedicateth that boke.

deserne something of. Prayer 1418 B 5, heure me gond lord thy lone \& fanour, which thyng iny lone to theewarde ... coulde not but of thy ... goodnes deserue.

desire something of. Dial. C. (Wks.) 1144 H 9, [he whiche] desyreth of chod to be comforted.

encline someone to. Pisus 8 B 13. Libertye ... to which both his owne naturall affoccion, and the studie of philosophie enclined him.

endite someone of, Last Th. 100 If 14, he is endited of his own deth. enseign someone to. Supplic. $313 \mathrm{G} 1$, the ioyfull blisse, to which god hath ... with his holy sacramentes enseygned you.

exhort someone to. Dial. C. (Wks.) 1168 D 8, the thynge whych our Sauiour exhorteth all menne to. 
face someone out of. Answer $1132 \mathrm{~F} \mathrm{13}$, Your talse heresy wherwilh you would face our Sauiour out of the blessed sacrament.

feeffe someone with. Apol. (Wks.) 867 I) 1, they coulde neuer feeffe me wyth one penye.

fasten a stroke on. Dial. C. (Wks.) $1263 \mathrm{~B} \mathrm{4,} \mathrm{he} \mathrm{can} \mathrm{not} \mathrm{see} \mathrm{where}$ to fasten a stroke on vs.

gather something of. Apol. (Wks.) $866 \mathrm{H} \mathrm{6,} \mathrm{as} \mathrm{touching} \mathrm{parcialjlye}$ ... I maruaile whereof hey gather it.

ground someone in. Inslr. 1421 D 15 , folk as are ... grounded in charitye.

grildge oneself of. Dial. C. (Wks.) $1149 \mathrm{D} \mathrm{7,} \mathrm{Mi} \mathrm{conscience} \mathrm{grudgeth}$ me not of anye thinge.

hyndre someone of. Conf. Tynd. 644 G 3, Lest it should ... hyndre hys harlot of teming.

instruct someone of. Dial. Her. 123 A 2, [They] were by hym instructed of enerye trewth.

know a thing from. Dial. C. (Wks.) $1190 \mathrm{E} 5$, markes by whyche the true reuelacyons maye bee knowen frome false illusions.

let someone from. Dial. C. (Wks.) $1182 \mathrm{C} 8$, Thys faute... letteth a man ... from the doynge of manye good thynges.

manasse something unto. Dial. Her. $265 \mathrm{H} \mathrm{4}$, be ... manasseth onto them the paines of hel.

minister matter to. Rich. 63 A 15, among you is most plenty of all such thinges as minister matter to such iniuries.

mean something by". Rich. 55 F 9, That ment he by the lordes of the quenes kindred. | Rich, 53 C 6, This ment he by Cateshy.

recommend someone to. Dial. Her. 107 A 2, As hartily as I possible can, I recommend me to you.

refrain someone from. Rich. 59 D 1,... shold ... sumce ... to refrain you from her mariage.

remit someone unto. Debell. 931 B 11, some suche places ... as I had happed to finde, I haue remitted the reader unto.

reproch someone of. Apol. (Wks.) $876 \mathrm{~B} 2$, Le first reprocheth bothe the partes of great singularitie.

retard someone in. Aut. Lett. xIv 59, his highnes in thabandoning of the siege \& sending his army lorward in to fraunce is nol so much retarded \& letted in his opinion for the hoope of the good that he thinketh could be now done at the siege.

retei(g)n someone with. Aut. Lett. vi 86 , the Kinges grace would ... be content to reteign the duke of Mechelhorough with a yerly pention. | Aut. Lelt. vi 76, he desireth the Kinges higlines to take in to his service \& to reteyne with some convenient yerely pention ducem mechelburgensem.

sell something unto. Picus 6 A 16, the third of therldome... onto John Francis ... he solde.

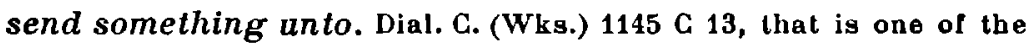
causes for whych God sendeth it snto man. 
set one's hert on. Last Th. 92 F 7, If riches com to you, set not your herl theron.

sewe someone for. Dial. C. (Wks.) $1151 \mathrm{E} 7$, if a man sewe nie wrongfulli for my own lande.

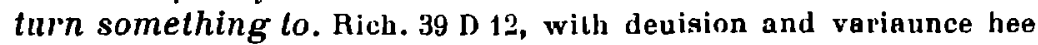
turneth all to mischiefe.

incomber someone of. Dial. Her. $194 \mathrm{H} 6$, they reken that for a pecke of otes she wil not faile to uncomber them of their housbondes.

venem someone with. Supplic. $314 \mathrm{H} 12$, such as are not ... venemed wilh bis mortal heresyes.

wrye something asway from. Conf. Tynd. $615 \mathrm{H} \mathrm{2,...} \mathrm{the} \mathrm{tylle} \mathrm{of}$ hys chapter so sinistrelye written and wryed awaye from the poynte.

Not all these constructions have survived into Pres. D. Fing. ; the following are obsolete or archaic now ') :

to appoint the day with ${ }^{2}$ ), to associate ... to (now (with); to cumber ... with; to endite someone of (now indict for or charge with); to enseign someone to; feelle someone with; to face someone out of; to fasten a stroke on; grudge ... of (now without of : I don't grudge these people their pleasure); to hinder someone of (now from or in); to let a man from; to manasse something unto; to minister matter to; to mean something by; to refrain someone from (now rare); retard someone in ") ; reteign someone with; to uncumber someone of; to senom someone with and to wrye something away from.

Apart from these and other cases the construction itself is a regular feature of the English language before and afler More :

a 1340 IIampole, Psalter, Prol. 3, Now manassand hell till wyckyd. | c 1386 Chaucer, Par's. T. 735, Ihesu crist ... relessed os fro the peynes of belle. / c 1449 Pecock, Itepr. I iv 22, Thoug he wolde relierce tho points ... of the lawe for to remembre the ingis and the peple ther upon.

1711 Addison, Spect. $n^{\circ} 160$, Thus Solomon resembles the Nose of his Beloved to the Tower of Libanon.

Here, too, More often places the preposition at the end :

Debell. 984 B 3, How goeth nowe... thys aunswere of this good man ... touching the point that I resemble them for. I Conf. Tynd. $503 \mathrm{H} 15$,

1) In the senses illustrated.

2) Earliest quot. in OED of to appoint (transilive) = to fur by arrangement the time or place of a meeting is daled 1588 (Shaksp. Tit. A. Iv iv, 1202. Appoint the meeting, Even at his father's house).

3) Not in UED. 
I would fayne wit of Tindal in what place of my booke he fyndelh that I make that conclusion, with whych it pleaseth hym to belye me to swele hys owne aunswere wyth. | Conf. Tynd. 551 B 5, such horrible dedes, as the denill \& the fleshe did moue and styre hyn to. Conf. Tynd. 724 A 2, his ensaumple of grammer and the latine longue, is nothyng like the matter of faith that he resenbleth it onto.

It is exceptional for the prepositional object, alrealy expressed by means of a relative pronoun at the beginning of a clause, to be repeated in the form of a referring pronom at the end of the same clause after the preposition :

Dial. C. (Wks.) 1155 1) 13, they ... whom he ... nener doth vouche safe to fyle his handes vpon theym.

See $\$ 108$, where a sinilar kind of redundant repelition has been illuslrated with the pronoun $i t$.

148. No inslances have been found in More of the Middle English usage of placing the direct object in back-position after the preposition, as in :

c 1394 P. Pl. Crede, 116, Clop to coveren wip our bones. / c 1400 Mandeville, Tr. 130, 20, a lityll clout pat pei coneren wilh here knees.

149. In the type take delight in the noun (delight) has lost so much of its independence as a functional element that it forms a compound with the verb (see $\$ 103$ ). Construclions of this kind are of frequent occurlence in More :

take coumfort in. Some Lett. ix p. 318, I ... take ... gret conmfort in that I perceiue that you live tugether so charitably.

take delyte in. Last Th. 95 D 2, [she] toke ... guch dely-te ... in the beholdy $\mathrm{g}$ of the apple, that she longed to fele the tast.

take harme of. Dial. C. (Wks.) 1182 B 7, that thing, of which be shoulde take none harme.

take heede to. Dial. C. (Wks.) 1183 D 1, a good old woman that tooke heede to her chyldren.

take hold of. Dial. C. (Wks.) $1253 \mathrm{I} 8$, thys dooeth reason alone in manye cases, where it hathe muche lesse help to take holde of.

lake pleasure in. Rich. $57 \mathrm{C} 4$, Shoris wife, in whom the king ... toke speciall pleasure.

lake regarde to. Rich. $49(=46)$ \& 8 , [if she] ... as muche regarde tooke to his wealthe, as to her owne will, she woulde bee as lothe to suffer him from the kinge, as anye of vs bee.

hase acquaintance with. Rich. 66 G 10, to sbewe ... what acquaintance he hath with him.

have cause of. llich. $39 \mathrm{C} 1$, ye neuer had so greal cause of hatred, as ye baue of lone. 
have the gonernaunce of. Boke of F. p. 1 D 9, Fche man hath of him self the gonernaunce.

have mercye on. Picus $17 \mathrm{H} \mathrm{3,} \mathrm{haue} \mathrm{mercye} \mathrm{on} \mathrm{mee} \mathrm{Lorde.}$

have misse of. Rich. $56 \mathrm{G} 1$, a comly rud in her chekes of whiche she before had most misse.

have righte onto. Rich. $63 \mathrm{D} \mathrm{9,} \mathrm{the} \mathrm{righte} \mathrm{and} \mathrm{title} \mathrm{that} \mathrm{the} \mathrm{most}$ excellent Prince Richard ... hath onto the crown.

have title onto, see preceding quotation.

make answer to. Dial. Her. 106 E 6, the very formal words of them whose writings they made answer to.

make courtesye to. Dial. C. (Wks.) 1224 F 5, menne muste make courtesy to them, and salute them with reuerence.

make a soure face at. Last Th. $72 \mathrm{H} 6$, this medicyne thoughe thou make a sowre face at it, is not so bylter as thou makeste for.

make much of. Picus 2 G 4, which pronosticacion one Paulinus making much of, expowned it to signifie to vo the swele hony combes of his plesant writing.

make sute unto. Hich. $58 \mathrm{G} \mathrm{1,} \mathrm{this} \mathrm{pore} \mathrm{Lady} \mathrm{made} \mathrm{bumble} \mathrm{sute} \mathrm{snto}$ the king.

set a glose opon. Dial. C. (Wks.) 1223 F 16, he sawe that thei set a glose opon it for hys praise of their own makgng.

Some of these constructions have dropped into disuse : to take harm of; to take heed to; to take regard to; to have acquaintance with; to have cause of; to have the governance of; to have misse of; to make courtesy to; to make suit to; to set a glose upon. The construclion as such occurs in earlier and later English :

1295 A. Glouc. 1338, Haue merci of him ich pe bidde. I a $1430 \mathrm{Lydg}$, Min. Poems 34, Now no man to me makethe one sute. | 1605 Shakesp. Lear Iv vi 287, I have ingenious feeling of my huge Sorrowes.

\section{Two Prepositional Objects}

150. Occasionally a verb is accompanied by two prepositional objects :

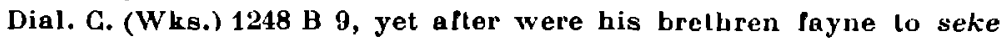
oppon him for breadde. I Apol. (Wks.) $860 \mathrm{E} \mathrm{4}$, if I desired a manne to geue me a thynge, and laboured muche to hym therefore... | Dial. Her. 107 B 3, I am bold ... to send you my special secret frend this bearer, to breake with you ... of the same matters. | Dial. C. (Wks.) $1190 \mathrm{E} \mathrm{12,}$ the special matter, wherin he can neuer wol flit from you.

Those verbs are no longer so used. A few examples from other writers follow :

1463 Paston Lett. 473 il 134, He kept not his owyn councell but brak to every man of it. I a 1556 Cranmer, Wks. I 25, Cyril agreed to Nestorius 
in the substance of the thing that was eaten. | 1612 Irayton, Poly-olb. Song xii 200, With bim lo breake of some intended act.

\section{Ordinafy Object + Prepogitional Ohject}

151. Just as in Pres. D. Eng. there are numerous cases in More in which a verb is construed with two objecls, one of which may be called the primary and the other the secondary object. Thus in syntactical units like they bare him grudge and $I$ moved you these questions the words grudge and these questions are the primary objects, because they are directly associated with the meaning of the verb, wheras him and you are complements to the combination verb + primary object (to bear grudge, to move questions), vieved as a semantic whole. The secondary objects can be divided into three groups :

a. They denote the direcl recipients ${ }^{1}$ ), as in : to graunt her her bone; give us therof some ensample. They are here called indirect objects proper.

b. They denote the indirect recipients, i. e. the persons not involved in the action, but indirectly benefiled by it and experiencing the consequences either to their advantage or disadvantage, as in : I have numbred him the leafe; I shall note you two kinds of folk. They are here called indirect ohjects of beneflt.

c. They denote the persons emotionally interested in the action, i. e. the persons not involved in it, but affected by it as mere lookers-on, and deriving from it a certain amount of pleasure, pain, etc., as in : recken me now yourself a young man; then look me now how few saintuary men there be. They are here called indirect objects of interest ${ }^{2}$ ).

152. Indinect Object Proper.

Dial. Her. 128 C 14, Giue os therof ... some ensample. | Dial. C. (Wks.) $1145 \mathrm{G} 6$, though the tribulacion it selfe, be a meane often tymes to g'el man thys first comfort... yet... | Hich. $60 \mathrm{C} \mathrm{2}$, god loued her betler, then to graunt her her bone. | Prayer 1418 B 5, beare me good lord thy loue

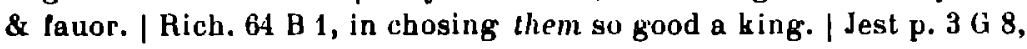

1) Also in the sensp of negative reception, e. $g$. to berieve, to deprive.

2) Also called effective or emotional indirect object (Jespersen); ethicul datloe (Curme) and obltque of interest (Kruisinga). 
thys tydyng That ye me bring. | Picus 9 D 8, he sent him two of his phisicions. | Last Th. $98 \mathrm{G} 15$, to tell 98 ... the wordes of holy wrytte. | Rich. $63 \mathrm{C} 6$, It shall not... nede that 1 rebearse you agayn that ye haue alreadye harde. I Debell. $933 \mathrm{D} \mathrm{19}$, he had not the wytte to perceiue when Bizance speaketh himself and when he redeth him the pacifiers wordes written.

This idiom appears to have been as common as it is now.

The construction to learn a person something occurs in the following illuminating passage, in which More gives his opinion on the use of to learn in the sense of to teach. It appears from it that the construction Richard learneth Robert was considered vulgar and that Bichard learneth (=teacheth) at Oxford was not "true Englishe". It should be noted that the whiche shall learne you my wayes are not More's words, but that they are quoted from Barns, whom More attacks.

Conf. Tynd. 742 B 7, But I wyll not striue muche wylh Prere Barns for a woorde. The man is so sore beside about his rethorike, that it is no meruaile though he can nol entende to speake reason nor true englishe neither, as appereth where he translatelh learning for teaching, in hys fyrste declarasion of this worde, ecclesia, rehearsing the wordes of saynt Paule to the Corinthies thus, I have lent vnto you Timothe, the whiche shall learne you my wayes that be in Chryste Jesu, as I do lerne euery where in al congregacions. As though saynt Paule hadde learned in euerye congregacion where he came, and euery man taught him and not he theim. And though that some vnlearned vise thys worde learne for thys worde teache, with his accusatyue case set oute, as Richarde learneth Robert, yet sayth no man but Barns, Richarde learneth at Oxford, for Richard techeth at $O x$ ford.

To do was more freely used in this construction than it is in Pres. D. Eng. :

Dial. C. (Wks.) 1169 A 3, I trowe I haue thys daye done you muche trybulacion with my importune obieccions. | Dial. C. (Wks.) 1169 B 10, I shal with this good counsayle that I haue hearde of you, doe them some coumfort.

Earlier : a 1300 Cursor M. 13666 (Gott.), He thoght him do solace.

A characteristic feature of More's English is the frequency of constructions of the type to berease a person wealth, which in Pres. D. Eng. would be replaced by constructions consisting of verb + direct object + prepositional object (to bereave a person of a thing) or prepositional adjunct (to provide a pulpit for the fox) :

Picus 25 A 3, peraduenture death within one howre, Shall os bereue, wealthe, riches and honowre. | Conf. Tynd. 765 G 10 , how wil ye... make me know which of them al assigneth me the gery true scripture. 
Conf. Tynd. 74t B 9, lot vs examine and consider now the church that be dyffyneth os. I Answer $1045 \mathrm{C} 4$, Oure sauiour... dinised them a good and perfrlte medecyne. | Lett. $1453 \mathrm{C} 12$, if ther were one that had enformed his highnes manye euill thinges of me that were vnlrue,... I wold be very sory $\left.{ }^{1}\right)$. | Answer 1046 D 4, the priest ministreth os this meale. | Dial. C. (Wk4.) 1140 D 2, truste well in God and he sball pronyde you teachers. I Conf. Tynd. 444 F 4, then may the geese prouide the fox a pulptl. | Dial. C. (Wks.) 1149 F 4, medicine that

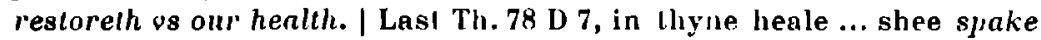
thee not one swete worde. I Apol. 54, neyther was I ... so angry with any man of inyne that I spake them any ely-ll word. | Dial. C. (Wks.) 1223 $\mathrm{D} 12$. Whan he toke him the trealise,... he anked hym howe lie lyked it. | Dial. Her. 214 G 4, wbyle the clergy dothe wilhdrawe il os, ... thei take away our lode.

The normal order in indefendent units is : indirect object direct object (beare me thy love), except when there are two promonns (Dial. C. 199, he shal giue th thee), in which case the direct object is only rarely expressed by another pronoun than it :

Dial. C. (Wky.) 1141 B 2, Therefore good vncle ... gewe vs wbyle god lendeth you us, such plenty of your coumfortable counsayle, as I may write and kepe with vs.

In poetry there is more freedom (Picus 25 A 4, dealh shall os berene wealthe). Apparently for the sake of emphasis the direct object is placed before the verb in : Rich. 61 F 8, w'e such loue beare you, that...

In attribute clauses the direct object comes first : the great fauoure the king bare him.

When the receptive character of the indirect object is emphasized by means of the preposition to, the inclirect object is given back-position, unless the direct object is a clause :

Bless. Hody 1268 D 13, let vs with Martha provide, that al our outward business may be perleyning to him, in making chere to him.

Exceptionally the indirect object is expressed twice :

Dial. C. (Wks.) 1245 G 2 , therof we cant os oul, ... dyuers partes dyuerslye to our self...

All the phenomena dealt with above occurred in earlier English :

c 1200 Trin. Coll. Hom. 33. Hie him birewuden alle hise riche weden (OE!). I 1400 Mandeville, Tr. 57, 28, And perfore all the perueyance pat be hadde ordeyned to make the temple with he toke it Salonon his sone (M.).

1) This construction occurs in the passive in : 1523, Berners, Froise. I, cCLV 378, it was infourmed the prince, howe he wolde turne frenche. 
To bereave a person something is still frequently used by Shakespeare (though only in the passive):

Ven. 391, 't is your faull $I$ am bereft him so. I Ven. 439, say that the sense of feeling were bereft me. $3 \mathrm{ll} \mathrm{VI}, \mathrm{II}, \mathrm{i}, 85$, all your interest in those territories is utterly bereft you.

\section{Indirect ObJect of Benefit.}

Lett. Fryth. 834 F 3, he will kepe her his fayth and not hreke her hys promise. | Dial. Her. 113 D 8, Thou shalt carue thee none ymage. |

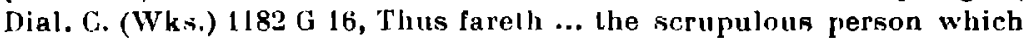
frameth himsclf mani limes double the feare lhat he hath cause. | Dial. C. (IVks.) 12:27 C 3, they frame theym selfe a conscience. | Dial. C. (Wks.) 1230 E 17, thoughe lhe Turke kepe you promise. | Rich. 37 F 9, with large gifles hee get him vnstedfasle frendeshippe... | Dial. C. (Wks.) $1230 \mathrm{~F}$ t, God whose faylue you forsake ... may so lake them fro you, that the great Turke ... is not able to kecpe you theym. | Dial. C. (IVks.) I144 A 11, And here shall I note you two kyndes of folke that are in tribulacion. | Debell. $931 \mathrm{~B} 11$, for his ready finding, I haue numbred him the leafe. I Instr. $1407 \mathrm{H} \mathrm{13,} \mathrm{What} \mathrm{foly} \mathrm{is} \mathrm{it} \mathrm{for} \mathrm{the[e]} \mathrm{than,}$ to auoid this temporal death, as thereby to fall in perill to purchase thy selfe eternal dealh. | Dial. C. (Wks.) 1160 l) 40, [5ou bave] remoued me these arrowes. I Rich. $56 \mathrm{G} 2$, her great shame wan her much praise. I Supplic. $299 \mathrm{G} 8$, he shewelh bymself to haue... so littel witt as to aske the king a question and appoint hym his answer. | Conf. Tynd., $5+2 \mathrm{G} 6$, I shall touch you the place in the pistle of sainct John, wherby Tindal would proue... | Answer $1137 \mathrm{D} 3$, I shal in my second part in taking $v_{p}$ his second course, when we come to fruit, pare him I warrant you those thre peres so nere, that he geattell not a good morselle amonge them. | Dial. C. (WKs.) $1190 \mathrm{~F} 10$, than baue you an entre made yon. I Supplic. 292 F 11, he cannot jet bring you furth a bederoll of theil names. I Apol. (Wks.) $924 \mathrm{C} 2$, bring mee forth myne accuser. | Debell. $936 \mathrm{G} 7$, and he seeke thys seuen yere, he shall in all wine apologye finde you no suche wordes oute. I Supplic. 328 A 14, we baue stopped them that gap.

The line of demarcation between indirect objects proper and indirect objects of benefit is difficult to draw and in some cases the classification cannot be but arbitrary (see quotations with to get, to win, to appoint). It may, however, be said that the omission of the indirect object proper would leave the predicate more incomplete than the omission of the indirect object of benefit (Compare these wordes geueth 's a sure medecine and these words give a sure medecine; I haue numbred him the leafe and I have numbered the leaf). Often the object of benelit is semantically equivalent to an adjunct 
with for. The corresponding passive construction is not a construction wilh to verb to be, but a construction with the verb to have. ("I reciled them the names of the prelates > Apol. (Wks.) $884 \mathrm{C} \mathrm{4,} \mathrm{they} \mathrm{had} \mathrm{the} \mathrm{names} \mathrm{of} \mathrm{this} \mathrm{prelate} \mathrm{and}$ that prelate recited and rehersed unto them by rowe). See $\S 616$.

In Pres. D. Eng. the indirect object of benefit is not nearly so frequently used as in More. According to Deutschbein 1931 p. 283 (who calls the object under discussion dativus commodi, a subdivision of the dations subjections or loser Dativ), the sparing use of this kind of "dative" is indicative of the objective character of moderu English ${ }^{1}$ ). If this is true, More's language must have been of a very subjective nature. (See also $\$ 154$ on indirect objects of interest).

The following quotations prove that the indirect object of benefit was known in earlier English :

c 1000 Ags. Gosp., John IV, 8, His lcorning-cnihtas ferdon pa to pære ceastre woldon him mete biczan. I c 1385 Chaucer, L. G. W. 46, In my bed there dawith me no day That I ne am vp (OED).

\section{Indinect Object of Interest.}

Rich. 47 C 9, Then looke me nowe how few saintuarye menne there bee. | Last Th. 82 B 17, Recken me now your self a yong man in your beste luste .xx. yere of age if ye will. | Dial. C. (Vks.) 1230 A 3, Suppose me that you might be velye sure, that the Turke would breake no promyse wyth you. I Apol. (Wks.) 924 A 10, Suppose me now, that a tynker ... were now become hymselfe an vssher. | Dial. Her. 120 F 1, loke me thorow christendome, and ... ye shall finde the trute of those offerynges... | Last Th. 86 G 10, Take me ono that reckeneth hymselfe for woorshypfull, and looke whether hee shall not bee muche more wrolhe... | Last Th. 80 D 10, I pray thee consider me, that all oure bodies be euer in suche case, so tender of themselfe, that ... we were not hable to lyue one winter weke.

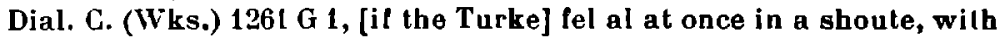
trumpets, tabrets, \& tumbrels al blowen vp at once, \& al their gunnes let go therwith to make os a fearefull noyse... | Answer $1083 \mathrm{D} 11$, Maister Masker maketh os a prity short crede nowe. | Conf. Tynd. 343 F 10, In their Kalender belore their deuout prayers, they baue selte 98 a new saynt...

1) "Bei dem objektiven Sprachcharacter des Neueng. läszt sich orwarten, dasz der Dativus subjectivus im Ne. relativ schwach entwjckelt ist, was tatsächlich der Fall ist". 
The indirect object of interest is always a pronoun. The quotations in the lirst paragraph express a command, an exhortation, a wish, etc., and are only a selection out of the great number of instances occurring in Mlore's works. Constructions like loke me and reckon me have left hardly any trace in Pres. D. Eng.

Not so with the usage illustrated in the second paragraph. It is still used in passiges of a narralive character, though not without giving an archaic flavour to the style. A modern substilute in spoken English is a phrase with for, e. g., There is a fine fellow for you (C.); $1809 \mathrm{~J}$. Moser, Don Quix. II V, He shall carry all the limbs he has got to heaven for me (OED).

EARLiEH
c 1250, Story of Gen. and Fix. 2495, Ilc prince me take hise wond, And do we us hero in godes hond (KI.).

13... Gaw. \& Gr. Kut. 1905, pay fel on hym alle, \& woried me pis wyly wyth a wiol hoyse (OED).

1440 Gesta Hom. 277, Theise two pou most norishh me with thy melke (Kl.).

\section{LATER}

I590 Shakesp. Mids. I, ii, 84, I will roare you as gently as any Sucking Dove.

1820 Lamb, Flia. Ser. I Oxf. in Vac., With great exactitude of purpose he enters me his name in the book (OED).

1874 G. Eliot, Coll. Breakf. P. 388, Anti-social force that sweeps you down the world in one cascade of molecules (OED).

The now obsolete phrases of the type "then says me I", "what did me I but..." seem to have been current in vulgar and colloquial speech about More's time; OED has a quotation dated c 1500 : Robyn Hode II st. 100, Here be the best coresed horse That euer yet saw I me. The colloquiality must have been of a very popular orcler, for though More's English call be fairly collocfuial in places, such phrases do not occur in it.

Closely related to the indirect objects of interest are the pronouns in such conslructions as : Rich. $61 \mathrm{E} \mathrm{9,} \mathrm{the} \mathrm{preacher}$ gate him home; Apol. 93, he satte him down. Because of their markedly reflexive character they have been placed and discussed in the section dealing with reflexive objects $(\$ 140)$. It is possible that something of the original "dative" character was still felt in More's time; it is, however, more plausible 
to assume influence of French reflexive verbs (s'agenoniller, s'asseoir, s'en aller).

It is difficult to classify the pronoun in : I fear me, a collocation which More frequently ${ }^{1}$ ) uses.

Dial. Her. 226 D 3, I feare me, ... that those many be very few in comparison of the multilude. $\mid A$ pol. (Wks.) 881 F 10 , they would aunswere I fere me, that thei be not yet wery of this world. | Dial. C. (Wks.) 1254 B I, I feare me when I heare once that vrchin bitch bark, I shall fall to my feete and forgeatte all together. | Conf. Tynd. 399 D 6, they haue infected and kylled, I feare me, moe selye symple soules, then... | Conf. Tynd. 339 H 14, For I feare me surely that ... God shall not fayle.

Shakespeare, too, seems to have favoured the construction I fear me (Schmidt 1902 gives 20 exx.). Apart from archaic diction, Pres. D. Eng. has done away with the pronoun after to fear. In Apol. (Wks.) 921 G 3, feare ye not for that, we probably have a case in which the person to whom the exhortation is addressed has been expressed by a pronoun, as in blame ye not me; fare ye well; folow thou me (\$\$ 31-37).

$I$ wonder me occurs in :

Answer 1124 C 11, I wonder me, that his scole matter here failed him.

155. TyPE he patted them upon the pates.

Conf. Tynd. $785 \mathrm{G} \mathrm{3}$, Now whan this offeer had comen wyth his sticke and patted them cpon the pates ${ }^{2}$ ). | Dial. C. (Wks.) 1162 A 5, the grief of thys great pange pyncheth them at the hert. | Rich. 61 F 4, it so strake him to the heart, that within fowe daies after he withered \& consumrd away. | Conf. Tynd. 432 i 2 , He... gyrneth as a dogge dooelb, when one porreth hym in the teeth with a slycke.

More uses this construction not infrequently. It distinguishes itself from the rival construction wilh a possessive pronoun (as in Dial. C. (Wks.) 1246 D 6, he manacleth their handes) by the fact that the person concerned is separately expressed, and consequently becomes psychologically more prominent than the thing affected. The personal pronoun may be analysed as the direct object of the rest of the predicate. (Thus them is the direct object of to pat on the pale). In earlier English, however, it was often in the "dative" case ${ }^{3}$ ).

\footnotetext{
1) Only occasionally is the ptonoun absent, e.g. Conf. Tynd. $467 \mathrm{~F} \mathrm{1,}$ tyll ... Antichrist come him self, which ... I feare be very nere his time. Also : Rich. $\{0$ H 7, Jest p. 2 G 12 and Dial. C. (Wks.) 1255 E 10.

2) Earliest instance in OED of to pat on the pate is dated 1591.

3) Deutschbein $1931 \$ 125$ c (dativus der Beteiligung).
} 
This direct object may also be expressed by a reflexive pronoun and by a noun :

Last Th. 99 A 1, if thou shouldest ... claw thyself ... depe into the flesh.

Aut. Lett. x1, 21, his grace saith that yor grace hit the nayle on the hed. | Dial. Har. 221 F 6, With that worde ... ye hyt the naile on the head.

The construction has survived unaltered into Pres. D. Eng. Here, too, a defnite article and not a possessive pronoun is used in the prepositional complement (on the pates, at the hert).

\section{Two Difect Opjects}

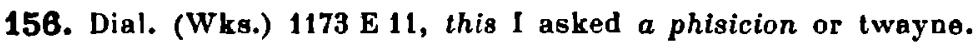
Supplic. 299 G 8, he sheweth hymself to haue ... so littel wit as to aske the king a question. | Prayer 1418 B 8, pardon me good lord that I am so bold. | Diel. C (Wkg.) 1255 D 10, the goodnes of god forgeueth many folke the faut.

In some of these examples the absence of receptive notion makes it clear that the frst of the two objecls is not an indirect object; in others (e. g. forgive) the analysis is doubtful. The two objects may be two (pro)nouns or one of them may take the form of a syntactical unit. The usage occurs in earlier and in later slages of the English language.

\section{THE PRESENT TENSE}

157.

FORMB

\begin{tabular}{|c|c|c|c|}
\hline $\begin{array}{l}\text { I } \\
\text { thou } \\
\text { you, ye } \\
\text { he } \\
\text { we } \\
\text { youl, ye }\end{array}$ & $\begin{array}{l}\text { wene, } \\
\text { wenest, } \\
\text { wene, } \\
\text { weneth, } \\
\text { wene, } \\
\text { wene, } \\
\text { wene(th }\end{array}$ & $\begin{array}{l}\text { entreat(e) } \\
\text { entreatest } \\
\text { entreat(e) } \\
\text { entreateth } \\
\text { entreat(e) } \\
\text { entreat(e) } \\
\text { entreat(eth) }\end{array}$ & $\begin{array}{l}- \\
\text { wene, entreat(e) } \\
- \\
\text { wene, entreat(e) } \\
- \\
- \\
\text { wene, entreat(e) }\end{array}$ \\
\hline
\end{tabular}

To represent a provincial or rustic kind of speech, More uses the torms cha, chaue (= I have); cholde (= I wolde); chote (= I wote), in which $c h$ is an aphetic survival of the older $i c$. The passage in which they occur is spoken by " an olde sage father in Kente".

Dial. Her. 278 B 5, There starle vp one good old father and said, ye masters say euery man what he wil, cha marked this matter wel as som other, ... For 1 knewe it good, and haue marked so chaue, whan it 
began to $\mathrm{w}$ ixe worse | ... yonder same tenterden steple... that by the masse cholde twere a faire fish pole | ... ycbe cannot tell you well why, but chote svell it hath.

Both you and ye can refer to one person and to more persons.

You, singular : Apol. 65, till you meke your self ..., this anger of your liusbande wyll neuer be well appeased. | Rich. $51 \mathrm{H} 8$, let me kiss yon ones yet ere you goe. | Dial. C. 138; Rich. 51 G 6.

Ye, singular : Picus 11 1312, ye (scil. his nephew) exhort me hy your letlers to the ciuile and active life. | Picus 14 D 42, But here ye will saie to me thus: I am content ye studie. I Boke of F. 6 D 1.

You, pliral: Rich. $38 \mathrm{H}$ 6, For it suffiseth not that you loue them, yf eche of you hate other. I Picus 9 E 13, I suppose verely, that ther be none of you, but ye knew John Picus.

Ye, plural: Picus 11 D 13, Be glad ... my brethern, whan ye fall in diuerse temptacions.

$M y$ self and your self are construed with the verb in the third person :

Dial. Her. $113 \mathrm{C} 7$, the places where $m y$ selfe hath ben. | Dial. Her. 187 B 14, as your self agreeth.

This was common usage in the $16^{\text {th }}$ century. In Shakespeare Ive find :

Tit. Andr. Iv, iv, 74, My selfe hath often heard them say, ... That Lucius banishment was wrongfully.

\section{TIME-SPHERE}

158. Since the present tense does not denote or express time, and consequently the time-sphere camnot be determined from this form by itself, it is the context or situation only that shows what the time-sphere of the action ${ }^{1}$ ) is.

The following cases can be distinguished :

a. The syntactical unit is neutral as to time.

b. The action took place in the past.

c. The action occurs at the present moment.

d. The action will occur in the future.

e. The time of the action stretches from a point in the past to the present moment.

1) For the sake of conciseness, throughout this study, the term "action" will be used to express " action", " occurrence" or " state", unless a more explicit statement seems necessary. 
f. The time of the action stretches from the present moment to a point in the future.

g. The action occurs in the " before-future". (Jespersen 1932 p. 2).

a. NEUTAAL TIME.

159. Syntactical units the time-sphere of which is neutral express a truth that has obtained, obtains at the present moment and is expected to obtain in the future; there is no limitation to any particular time. More's English has numerous instances ').

General truths. Boke of F. p 1 D 9, Eche man hath of himself the gouernaunce. | Last Th. 87 B 6, In Spayn, it is sorer taken, and sorer punished, yf one geue another a drye blowe with his fyst, than yl he draw bloode vppon him wilh a swoord. | Last Th. $74 \mathrm{C}$ 7, Iseland loueth no butter till it bee long barrelled. | Picus 14 B 1, Mercennary we call all those thinges, whiche we doo for hire or rewarde.

Natural phenomena, etc. Last Th. $85 \mathrm{C} 2$, like as the ... spider bringeth forth her cobweb... | Dial. C. (Wks.) $1180 \mathrm{G} \mathrm{5}$, in the nighte walken all the beastes of the woods.

Habits and customs; regularly repeated actions.

Picus 23 D 3, Consider fraile glasse may no distres endure, and great aduentures (scil. adventurers) oft curse the dice. | Last. Th. $79 \mathrm{~A} \mathrm{9,}$ if we be so farre gone, that we see we cannot recouer, than he (scil. the devil) easteth in our myndes, presumpcion and securitie of saluacion, as a thing well wonne by our owne workes. | Apol. (Wks.) $847 \mathrm{C} \mathrm{1}$, leauing out noughte but raylyng ... and where I so dooe, I geue the reader warnynge.

Inborn inclinations and natural dispositions. Rich. $37 \mathrm{~B} 4$, women commonly not of malice but of nature hate them whome theire housebandes loue.

Proverbs and proverbial sayings. Boke of F. p 6 B 8, none falleth farre, but he that climbeth hye. Last Th. $92 \mathrm{G} \mathrm{9,} \mathrm{wher} \mathrm{thy}$

1) The following quotation illustrates the point in a very interesting way : Dial. Her 146 E 16 Christe also said, I am with you tyll the ende of the world, not I shal be, but I am, which is the word appropried to his godhed. And therfore the word am, is the name by which our lord wold ... be named vnto Pharao, as a name which from all creatures (syth they be all subiecte to time) clerelye discerneth his godhead, which is euer being \& present without difference of time past or to come. 
tresure is ther ts thyne heart. I Supplic. 299 B 6, time alway trieth out the trouth. | Picus 14 B 3, he maketh philosophie mercennary.., which studicth it not for pleasure of it self. | Picus 28 A 8 , The loue that is cleuided among many, Unnelh snffiselh that eucry part baue any. | Picus 16 D 12, Dead be thei, that line not to god. | Picus $25 \mathrm{C} 10$, Any good worke if thou with labour do, The labour goth, the goodnes doth remayne. | Aich. 55 A 12, frendes fayle fleers. | Answer $1035 \mathrm{E} 11$, euyl communicacion marreth and corrupteth good manners. | Picus 18 $C 8$, the negard ... saith to his money. Deus meus es tu. I Dial. Her. 238 B 6, a tale that fleeth thorowe manye mouthes, catcheth manye newe fethers.

Syntactical units of this kind also occur surrounded by units the time-sphere of which belongs to the past :

Picus 6 D 15, he many daies (and namely those daies, which represent vnto vs luc passion and deth that Christ sulfred for our sake) bet and scourged his own llesh. | Picus $6 \mathrm{~F} 1$, they coulde not miscary ... he verili trusled, sith God is all good ... | Picus 19 F 1 , he wold not talke nor speake of the voluptuous delites, which are euyl pooples gods. | Aich. $61 \mathrm{E} \mathrm{2,} \mathrm{Whyle} \mathrm{these} \mathrm{wordes} \mathrm{were} \mathrm{in}$ speaking, the proteclot accompanied with the duke of Buckingbam, went thorow the pcople into the place where the doclors comonly stand.

160. The use of the present tense in units of neutral time was known before More and is common in Pres. D. Eng. In units denoling inborn inclinalions, habits etc. the attendant verb will is often used in More's English, just as it is to-day :

Dial. C. (Wks.) $1174 \mathrm{E} 11$, he that in hope to bee called towarde nigte, will slepe oute the morninge, and drinke out the daie, is full likelye to passe at nyghte vnspoken to.

A rival verb is use to :

Dial. C. (Wks.) 1212 A 3, he oseth not to force anye manne to forsake his faith.

For further discussion see the sections on syntactical units containing two verbs ( $\$ \$ 399,445 \& 452)$.

\section{EARLIER}

c 1400 Mandev. Travels 3, 6, a semblee of peple withouten a cheuenteyn or a chief is as a llok of sheep withouten a schepperde. (M.)

\section{LATER}

1611 Aulh. Vers. Ps. 116, 11 All men are lycrs. (J.)

Pres. D. Eng. Somo birds build their nests in trees, others on the ground.

161. In the following quotation from More - containing a 
general truth - the preterite (was, bare) is used instead of the present tense (is, bear):

Hich. 62 G 3 thys woto you wel al, that whose was beste, bare alway irst rule.

For more examples see the sections on the preterite.

b. The action took place in the Past.

162. Introducing quotations from works written in former times.

Dial. C. (Wks.) $1236 \mathrm{G} \mathrm{8}$, then saith holy scriplure : Bonis omnia cooperanlur in bonum. | Last Th. 72 F. 10, Remember (saith the byll) thy last thinges and thou shalle neuer sin.

Introducing quotations from persons who lived in the past or referring to their words.

Dial. C. (Wks.) 1253 H 6, I remember the fable that Esope telleth. | Picus 6 D 11, we know many men, which (as saint Hierome saith) put forth their hando to poore folke. | Answer $1035 \mathrm{H} \mathrm{14}$, such communicacion it is therfore that thapostle speaketh ogainst. | Bless. Body 1265 D 6, of this greate outragious perill, the blessed apostle sayncte Paul geueth va gracyous warnynge. | Last Th. $100 \mathrm{~F} 12$, Thus fare we saith Plutarch. | Last Th. 85 E 9, Esop..., as I thinke ye haue heard, fayneth that one of the paynym goddes came down into earth. | Picus 15 E 10, Our lorde Jesu Christ ... affirineth, that our reward shal be plentuous in heauen.

Compare, however, the form sayd in a similar context :

Dial. C. (Wks.) $1167 \mathrm{G} 1$, as the philosophers sayd in that thyng very well of olde : vertue standelh in thinges of hardnes and diffcultie.

Referring to books written by contemporaries.

Apol. (Wks.) 846 E 5, he leaueth out somewhat that Tindalle taketh in, that is to witte the making of mockes and mowes against the masse. | Apol. (Wks.) $855 \mathrm{E} \mathrm{8,} \mathrm{Al} \mathrm{thys} \mathrm{chyldishe} \mathrm{reason} \mathrm{...} \mathrm{whiche} \mathrm{he}$ bryngeth oule of Tyndalles Chapiter, and fathereth it vpon Saynte James. I Conf. Tynd. 668 A 10, As frere Huskyn, Tindal, and Suinglius glosen it. | Picus 7 D 8, The same thing also in bis boke, which he entilled ') de Ente \& Uno, lighsomely he treatelh.

The following sentence contains a coordination of wished and saith ${ }^{2}$ ) :

bial. Her. 119 A 8 , Luther ... which wished in a ser'mon of his, that he had in his hande all the peces of the holy crosse, \& saith that if he so had, he would throw them there as neuer sonne sholde shyne on them.

b) Note this form instead of entitles.

') See 8206. 
Referring to statements previously made by the writer himself.

Apol. (Wks.) 868 A 7, letle theym tell where I commende pompe and pryde, where I prayse auaryce, where lechery, or suche other thing.

This form alternates with a construction with to have :

Last Th. $88 \mathrm{~A} 2$, sith that by the destruccion of pryde, followeth as I hane said the destruccion of wrath. | Last Th. $85 \mathrm{G} 11$, enuy is as I haue said and as saint Austine say th the doughter of pryde.

This construction seems to be used here because neither place or time is mentioned to designale the past time-sphere; $I$ say would consequently convey a different idea.

In the emphasizing formula it is :

Picus 22 G 5, he it is, by whose mighty powre, The worlde was vainquished and his prince cast out.

It was, however, is also possible :

Dial. C. (Wks.) 1232 D 18, it was oure Sauioure hym selfe, whyche in the sixte chapiter of Sainte Mathewe saythe...

With the verb to SAY when another person's statement is repeated immediately after it is made.

Hich. 59 F 5, I dout not but there be as yo saye other, that be in euery point comparable wilh her.

Referring to the contents of a letter newly received.

Picus 14 B 12, Ye exhort me by your letters to the ciuile and acliue life, saying, that in vaine ... haue I studied in philosophie. | Picus 14 G 5. Ye writ vinto me, lhat it is tymo for me to put my selfe in houshould with some of the great princes of Italic. | Dial. C. (Wks.) $1211 \mathrm{D} 13$, he that wrote the letter, saith that it is secretly sayd in Constantynople, that...

In the case of words or statements written or spoken in times long gone by (as Saint Paul, Esop saith), More seems to use the present tense only if the statements are of present interest or still carry weight in points under discussion.

In none of the cases listed above did More make innovations, nor is there any difference from Pres. D. Eng. Regarding the emphasizing it is (he it is, by whose powre The world was vanquished) Jespersen (1932 p. 24) says : "It is in the present tense is used referring to a future event (It is here that I shall die). This usage is thus different from what takes place when the verb in the relative clause is in the preterile, for then it was is the general rule (It was here that he died;...)". More's use of to be would then be obsolete. 


\section{EARLIEA}

Beowulf, Ic pæl gehyre, pæet pis is hold weorod frean Scyldinga.

c 1175 Lamb. Hom. 39, penne selst J)imitte... (OED).

- 1225 Juliana II, Beo hit sop pat tu seiist (OED).

c 1175 Lamb. Hom. 45, Eft urelauerd seolf seit (OED).

1340 Ayenbite 134, Ase salp zainte paul (OED).

\section{LATER}

1667. Milton, P. L. v, 815, Unjust thou saist Flatly unjust, to bind with laws the frce (OED).

1750. Gray, Long Story 73, So Humour says... (OED).

1819. Scott. Ivanhoe xIxIv, For what saith holy writ (OED).

\section{The Phegent These in Narhativeg ')}

163. To picture past events as if they were happening at the present moment the present tense is sometimes used by More, with the result that the narralive becomes very lively.

Jest 4 A 15, The frere toke harte, And vp he starte, And well he layde about, And so there goth, Betwene them bolb, Many a lusty cloute. They rent and tere "), Eche ol hers here, And claue logyder fast. Tyll with luggyng, And with tuggyng. They fell downe bothe at last. | Jest p. 3 D 14, He inistruslyng, No maner thyng, Sayd mayden go thy way, And fetche him hyder, That we togyder, May talk. Adowne she gothe, Up she hym brought, No harme she thought, But it made some folke wrothe. | Jest p. 3 A 12, His harte for pryde, Lepte in his syde, To seo how well he Preered, Than forth a pace, Unto the place, He goeth in goddes name. | Jest p. 4 B 10, Than on the grounde, Togyder rounde, With many a sadde stroke, They roll and rumple, They turne and tumble ... | Boke of Fort. p. 4 A 10, The head that late lay easily and full soft, In stede of pylows lyeth after on the blocke.

It should be noled that all the above passages are taken from More's poetry; in his prose works there is no example of the use of the present tense in direct narration; even in the work in which it might be most expected, i.e. in The History of King Richard, with its frequently very lively style, il does nol occur.

For a lew cases in which the present tense and the preterite alternate without any discernable reason see $\$ 208$.

1) Also called the " historic" or "dramatic" present. (Jespersen 1932 p. 19 ; 1924 (9) p. 258; Curme 1933 p. 355 ; Sweet $1903 \$ 2228$; Steadman 1917; Holoff 1924; Einenkel 1916 p. 26; Kellner $1013 \$ 368$; Trnka 1930 p. 17.) Cf. the " historic infinitive ", illustrated in $\$ \$ 272-3$.

2) Since rent and clave are preterite forms, tere is probably used only for rbyme. 
The use of the present tense in direct narration of past events seemy to have been unknown in Old English. (There are two doubtful cases, both in Be Domes Dage; see J. Höser 1889, and E. Nader 1887, pp. 542 If.) In Middle English, however, the usage gradually gained ground (Mätzner 1885 p. 71); at first it appeared only sporadically (in Horn and Havelok only a few cases occur), but in the middle of the $14^{\text {th }}$ century it spread rapidly (Roloff 1924). Chaucer used it frequently : according to Graef 1889 p. 566 it orcurs about 1150 times in the Canlerbury Tales. In Wyclif it is of trequent occurrence (H.Smilh 1907 p. 455). In Koziol's syntax of Middle English alliterative poetry (1932 p. 97) we find the following statement : "Sehr haüfig wird die Präsensform in der Erzählung verwendet..., so haüfig, dass man sie neben dem Präleritum als die gewöhnliche Zeit der Erzählung bezeichnen kann." Curiously enough Mandeville does not seem to use the form under discussion (V. d. Meer 1929 p. 2 note).

\section{EARLIER}

1250 Slory of Gen, and Ex. 1172, Quilum er Pharao hire toc Nu takep Abimelech hire oc (KI.).

c 1275 Lay. 10500, pe king pe gretep Basan and seggep mid sore pat... (OED).

1362 Langl., P. Pl., now bigynneth Glotour for to go to schrifte and kaires hym to kirke-ward (OED). 13... Purily, E. E. T. S. 1401, when alle segges wer per set, pen seruyse begrnnes (Ko.).

\section{LATEF}

1575 Gamm. G. N. 100, My gammer sat her downe... And by and by... or she had take two stitches... by chance asyde she leares, And Gib, our cat in the milkepan she spied.

1933 Lawrence, Lady Ch. L. (Odyssey Press. p. 237), Anyhow just when I was twenty-one, back comes Bertha, with airs and graces.

\section{THE agtion occurs at THF PREgENT MOMENT.}

164. Rich. $71 \mathrm{E} \mathrm{3,} \mathrm{it} \mathrm{is} \mathrm{none} \mathrm{borne} \mathrm{that} \mathrm{ts} \mathrm{in} \mathrm{thine} \mathrm{bead.} \mathrm{No} \mathrm{mary}$ q(uod) he that wote I wel ynough. I Answer 1422 B 12, I admit the case as possible. | Picus $16 \mathrm{E} \mathrm{10,} \mathrm{they} \mathrm{wot} \mathrm{neuer} \mathrm{thrm} \mathrm{selfe,} \mathrm{what} \mathrm{lbei} \mathrm{do.} \mathrm{|}$ Last Th. 89 B 9, me semeth verely, that ... | Dial. C. (Wks.) 1211 A 11, I praye you good vncle kepe your cuslomable maner. | Dial. C. (Wks.) 1211 A 9, this one part of our matter, whiche onely now remaineth. Dial. G. (Wks.) 1211 D 8, the grrate Turke prepareth a marueylous mightie armye. | Dial.C. (Wks.) 1139H11, you take my departynge from you so heauelye ... | Dial. C. (Wks.) 1140 H 3, no small parle of our own folke that dwelle euen bere aboute ve, are fallynge to bym. Dial. C. 
(Wks.) 1141 C 16, nowe striue there twayne lor vs. | Dial. C. (Wks.) $1141 \mathrm{G} \mathrm{10,}$, regarde him not a ryshe. | Rich. $62 \mathrm{D} 1$, What speke we of losse. | Hich. $55 \mathrm{D} 2$, whereto talke you so long with that priest ?

This usago is very common in More's English, just as it was before his time (Trnka 1930 p. 16). The " preseyt moment" in units of this kind is of course not a point, but a period including part of the past as well as of the future. Pres. D. Eng. knows the same usage; but as soon as the imperfective aspect of the action becomes prominent, construclions with to be + form in -ing (he is striving) are used with some kinds of verbs, as was already occasionally done by More too (see section of aspect).

\begin{tabular}{c|c} 
EARLiEh & LATER \\
c 1000 Ags. Gosp. John. YI 26, Nu & 1819 Shelley, Cenci v, I, 61, Even \\
he spycp openliche (OED.) & whilst we speak The ministers \\
c 1386 Chaucer, Kn. T. 425, Thou & of justice wait below (OED). \\
walkest now in Thebes at thi & 1924 Mary Webb, Precious Bane, \\
large (Gf.). & Ch.6 p. 101, I live on the moun- \\
$\begin{array}{c}\text { c1400 Mander. Tr. 42-17, Theise } \\
\text { folk pat I epeke of (M). }\end{array}$ & tain over yonder.
\end{tabular}

\section{d. THE ACTION WILL OCCUA IN THE FUTURE.}

165. 1. IN INDEPENDENT UNITS.

1. In threats.

Jest p. 3 H 3, Thou shalt obay, Come on thy way, I haue the(e) in my clouche, Thou goest not hence, For all the pense, The mayre hath in his pouche.

In Chaucer we read :

C. T. C 752, Thou partest nat so lightly, by Seint John !

The usage also occurs in Pres. D. Eng. :

1918 H. Walpole, Fortitude 1, ch. 10 p. 124, “ Let me go, falber ", Peter said, very white, and putting down the bag. - " Be damned to you," said his father. " You don't get through this door " (Kr.).

2. In the warning exclamation : you fall I

Dial. C. (Wks.) 1197 G 11, some man shall vpon such a bridge, if folke call vpon him, you fall you fall, fall with fantasy that he takelh therof ... | idem H 4, The deuill fyndelh the man of his owne fond fantasy alerd, \& then cryeth he in the eare of his hert, thou fallest, thou fallest, \& maketh the fonde man afeard, that he shoulde at eueryo foole fall in dede.

Nothing similar has been observed in other English writers. Very common in Dutch, e. g. Pas op, je valt. 
3. If the coming event is looked upon as a certainty.

Boke of F. p. $1 \mathrm{C} \mathrm{3}$, but let them write, theyr labour ts in vayne. I Picus 21 B 6, the rewarde when we die Is nought but lire and paine perpetually. | Boke of F. p. $3 \mathrm{C} 9$, But in a whyle when sbe louelb hym no more, She glydeth from hym, and her giftes to. And he her curseth as other fooles do. | Last Th. 84 D 7, Surely can we al tel that die we shal. And clerely know we that of this delh we get no maner pardon.

This usage shows some resemblance with what Koziol (1933 pp. 81 fr.) terms "das emphatische Præsens-Pro-Future".

In his interesting article he adduces examples from the $14^{\text {th }}$ century onward. In Shakespeare we find :

Hamlet III, iii, 5, Now might I do it pat, now he is praying, And now Ile doo't, and so he goes to Heaven, And so am I reueng'd.

More himself comments on this idiom in the following passage, where is gone is used instead of will be gone or will go. (Note his use of the term pretertemps.)

Passion 1347 E 11, In omnem terram exiuit sonus eorum, et in fnes orbis terre verba eorum, Into all the worlde is gone out the sowne of them, and into the endes of the roundel of the earth the wordes of them (which wordes wer writlen by the prophele Dauid many yeres ere the apostles wer bornc, and yet prophesyed by the verbe of the pretertemps or tyme passed, to signifye that the lhyng prophecied sholde as surely succede and be verifyed, as (hough it were passed alreadye).

4. To express an intention.

This case is illustrated by More in the following instructive quotation; from it we learn that this usage was common in spoken Englislı.

Dial. Her. $161 \mathrm{G} \mathrm{3,} \mathrm{For} \mathrm{when} \mathrm{the} \mathrm{aungel} \mathrm{had} \mathrm{said} \mathrm{vnto} \mathrm{her,} \mathrm{Lo} \mathrm{thou}$ shalte conceiue in thy wombe and brynge forth a childe, \& thou shalte call his name Jesus, slee answered him, how may this bo? for as for man I know none, which though it be spoken but for the time than present, yet must it nedes signifie that she neuer woulde knowe none, after the maner of spekynge. By which a nonne myght say, as for man there medeleth none with me, signifienge that neuer thrre shall. And in common speche is that figure much in use. By which a woman saith of one, whom she is determined neuer to mary, we maye well talke together, but we wedde not together, meanyng that thei neuer shall wedde togetber.

(Similarly : Answer 1059 D 20-F 7.)

5. If the fulfilment of the action is dependent on the fulfiment of another action expressed in a sub-clause.

Dial. C. (Wks.) $1179 \mathrm{~F}$ I, than are we sale, it we wil tary ther. | Dial. Her. $179 \mathrm{~F} 1$, For what yl they wyll shewe you Boheme and now in Saxony wher Luther is, and peraduenture in a good part of Germanye? 
Marje quod I, yt thei saye so, than lepe they lyke a flounder out of a frying panne into the fyre ${ }^{1}$ ).

Trnka (1930 p. 19) says that " the future event is occasionally expressed by the present in the apodosis of the conditional sentence, if futurity is formally denoted in the protasis ". From the following quotations it is evident that it is not necessary that futurity should be formally denoted in the protasis; the context may offer sufficient indication as to the time-sphere :

luast Th. $72 \mathrm{D} \mathrm{3}$, these wordes geueth va al a sure medicine, yf we forslouth not the receiuyng. / Rich. $71 \mathrm{E} \mathrm{3,it} \mathrm{is} \mathrm{none} \mathrm{horne} \mathrm{that} \mathrm{is} \mathrm{in}$ thine head. No mary q(uod) he that wote I well ynough. But what \& be cal it an hol'n, wher am I then? | Dial. C. (Wks.) 1162 B 6, Peccator cum in profundum venerit, contemnit. When the sinner commelh euen into the depth, than he conteinneth and setteth nought by nothing.

\section{2. IN DEPENDENT UNITS.}

1. After IT IS LIKELY, IT IS NECESSARY, etc.

Last Th. 76 A 11, if the fantasies leue vs not sleping, it is not likely that euer they leaue vs waking. | Last Th. $102 \mathrm{~F} \mathrm{11,} \mathrm{it} \mathrm{is} \mathrm{nccossarye} \mathrm{that}$ we constder wel the weight. | Rich. 63 G 6 , It shall not ... ncde that I rehearse you agayn that ye haue alreadye harde.

2. In object clauses after verls denoting a desire, etc.

Hich. 47 B 3, yf the Crowne happen ... to comme in questyon, whyle eyther parte taketh olher as Traytours. I wyll well there bee somme places of refuge for bothe. | Last $\mathrm{Th} .90 \mathrm{H} \mathrm{14}$, he wyll that some olber dye by sickeness. | Hich. $65 \mathrm{~A} 2$, we require ye that ye to morow go with ve ... '2).

3. In adverbial clauses of purpose or result.

Dial. C. 180, in feare lest he $d y e^{3}$ ) not wel. | Picus $26 \mathrm{C} 1$, well ought we then be forde to done offence, Impenitent lest we departen hence. Picus 22 D 10, Lest he thee vnpurueid, and vnready calche Thou must with the prophete stande and kepe watche. | Picus 11 B 3, Let vs then beware ... that we be not dronken in the cuppes of Circe. | Rich. $39 \mathrm{~F} 4$, muche oughte wee ... beware ... that we eltesoones fall nol in that

1) No earlier example of this proverb is recorded in OED (s. v. fryingpan).

2) In this case shall + infinitive also occurs : Last Th. $90 \mathrm{H} \mathrm{13,} \mathrm{his}$ pleasure is that thou and thine shal liue no lenger. The following quotation contains independent shal : Dial. C. 180, if god wil we shal hence, than dothe be much for vs.

$\left.{ }^{3}\right)$ After lest we also find should (Dial. C. (Wks.) 1168 B 9); shal (idem 1182 F 13); wold (idem 1183 H 11); might (idem 1203 H 13). 
occasion agayne. | Aut. Lelt. v1, 34, yor grace ... will provide ... that no lacke of vitaile hyndre or empech theire purpose. | Rich. 39 B 5, thei that by euill meues betore pleased him best, shal after fall farthest out of fauour, so that euer at length euil driftes dreue to nought, \& good plain wayes prosper.

4. In concessive clauses opening with THOUGH, when futurtty can be inferred from the context.

Picus 20 D 4, Et caro mea requiescet in spe, And my flesh shall rest in hope, that is to say, that though it loy not by and by, as in receyuing his glorious estate mediatly afler the death, yet it restelh in the sepulchre with this hope, that ... / Rich.68 D 3, Alas I woulde my vacle woulde lelle me haue my lyfe yet, though I lese my kingdome.

5. In clauses opening with the determinative $\mathrm{HE}$, WHAT (SOEVEH), WHO (SOEVER), etc., when futurity is evident from the context.

Bless. Body 1265 D 10, Who so euer eat the bread and drinke the cuppe of our lord vnworthy, he shalbe gilly of the body and bloud of our lorde. | Rich. 50 E5, I say lie that agaynst my wyll taketh out him, breakelh the sanctuary. | Rich. $63 \mathrm{H} \mathrm{7,} \mathrm{the} \mathrm{labor} \mathrm{\&} \mathrm{study} \mathrm{...} \mathrm{that} \mathrm{shal}$ come ... to whomso euer so wel occupy the roume, as ... he wil. | Dial. C 295, I wyll be at mine owne libertye to do what me lyste.

6. In conditional clauses, when futurity can be inferred from the context.

Hich. 43 E 6, if thei crowne any other kinge then your sonne,... we shal on the morowe crowne his brother. | Picus 13 B 3, neyther thy glory shal be lesse if thou be happy with fewe. | Aut. Lett. vi1, 77, lettres sent vuto his Grace in conmendation of the kinges orators in case the Duke accepte the ordre.

It is not necessary for the principal unit to contain the auxiliaries shall or will:

Last Th. 76 A 11, if the fantesies leue vs not sleping, it is not likely thal euer thei leaue vs waking. | Last Th. $87 \mathrm{G} 9$, if we percene once the rote and digge vp that, we be very sure the branches bo surelye gone.

The same phenomenon occur's in :

Last Th. 85 G 11 , strangle the mother \& thou destroyest the doughter.| Debell. $936 \mathrm{G} 7$, and he seeke lhys keuen yere, he shall in all mine apologye fynde you no sucbe wordes oute.

7. In temporal clauses, when futurity can be inferred from the context '). a) After WHEN :

Dial. C. 338, when I heare once that vrchin bark I shall fall to my teete... | Dial. C. 222, when you list you may enter into the special matter. | Picus 13 B 14, he shal not heare the when thou callest on hym.

1) Shall, however, also occurs in these clauses : Last Th. 95 A 5, whan death shal once waken vo, our gay golden dreame shal vanish. 
It is not necessary for the principal unit to contain the auxiliaries shall or will :

Dial. C. (Wks.) 1162 B 6 , when the sinner commeth euen into the depth, than he contemnetb and settcth nought by nothing. | Dial. C. (Wks.) 1262 B 12, whon doatl commeth ..., that the deuyll draweth him to dispayre.

b) After TILL, ERE, OR, BEFORE :

Dial. C. (Wks.) 1159 A 6 , before I medle wyth your second, your third wyl I ioine to this. I Instr. $1408 \mathrm{~A} 5$, at the bare blast of the trumpet, before the balaile beginne, be is quyte and cleane ouerthrowen wilhout any stroke at al. | Picus $11 \mathrm{~F}$, Is ther ... any of lhose trifles, in the getting of whiche a man must not suffre many labours, many displeasures .... or be get it? | Aut. Lett. xn, 42, ere the duke suspecte. | A pol. 65 till you meke yourself and amende them, this anger of your busbande wyll neuer be well appeased.

8. To avoid the repetilion of SHALL or WILL.

Last Th. $78 \mathrm{E} \mathrm{1,} \mathrm{And} \mathrm{whyle} \mathrm{thou} \mathrm{lyest} \mathrm{in} \mathrm{that} \mathrm{case,} \mathrm{their} \mathrm{worder} \mathrm{shal}$ be tedious, that thou will wyshe all that they aske for, vpon a red fyre, so thou mightest lye one balfe howre in rest. | Apol. 5, excepte I toke some payne to set oul theyr argumentes plainly, many thal rede them sholde lytle wyl what they mcane.

167. The usage in nearly all these cases is a reminiscence of the Old English custom of expressing futurity without the help of attendant verbs. It is therefore not difficult to find instances dating from before More's time, though of course in the interval the analytic forms had been steadily gaining ground. As a result of his investigation into Orm's language, Dr. Zenke (1910 part III) shows that already in this author the present tense with future meaning was falling into disuse. In the Ormulum there are $3+1$ compound forms denoting futurity as against 70 simple, synthetic forms, and of the synthetic forms 40 are of the verb beon. The form of the present is moreover only used where the future time-sphere is indicated by or to be inferred from the context.

In Pres. D. Eng. the possibility of using a present tense in a syntactical unit referring to future time lias become still more limited than it was in More's time, especially in independent sentences (e. g. Dial. C. (Wks.) $1179 \mathrm{~F} \mathrm{1,} \mathrm{than} \mathrm{are}$ we safe, if we will tary here). In some cases the use of the present tense instead of the analytic construction now 
gives an archaic or poetical flavour to the style, as in : R. Kipling, Recessional, Lord God of Hosts, be with us yet, Lest we forget, Lest we forget.

168. There is one case which requires separate treatment, viz. the one in which a future aclion is considered as a part of a programme already seltled (Paimer 1924 p. 144), so that the dispositions made in the present time-sphere towards the fulfilment of the action expressed by the verb are included. (Truka 1930 p. 18 uses the term " dispositional present.") There is one instance in More :

Picus 1 E 3, of whose connyng and vertue we nede here nothing to speake : fornstmuch as hereafler we peruse the course of $h$ is whole life.

In Pres. D. Eng. this usage has become quite common, not only with verbs of motion, but also with a number of other verbs :

1026 Canfield, Her Son's Wile 13, Malph graduates from the university this coming June, doesu't he?

That the usage with other than verbs of motion is not a recent development, is proved by the above quolation from Nore and loy :

1588 Shakesp. LLL, Iv, ii, 161, I do dyne to day at the father's of a certain pupil of mine. | 1633 Massinger, New Way, II, ii, 30. But to our business, Meg; you have heard who dines here.

Whether this idiom is a continuation of $O$. E. usage or an innovation that set in after the use of shall and will to help to express futurity had already become the rule in the majority of independent sentences, is difficult to ascertain owing to the scarcity of informalive data as to the usage in Middle and Early Modern English. Neither Jespersen (1932 pp. $21 \mathrm{fr}$.) nor Poutsma (1926 pp. $251 \mathrm{ff}$.), who both discuss and illustrate the point comprehensively, have early quotations; Jespersen does not go farlher back than Shakespeare. The usage is not mentioned in Kellner 1913, v. d. Meer 1929 (Mandeville), Dekker 1932 (Malory) or Graef 1889 and 1893 (Chaucer) ').

1) In Trnka, On the Syntax of the Eng. Verb from Caxton to Dryden, p. 18, we find the following statement: " the present tense is Prequently used in Early Modern Eng. in the function of the future almost in the same limits as in Late Modern English. In head-clauses the future 
In the following instances from IVyclif, representing literal translations from the latin Vulgate, there is a slrong resemblance to the usage under discussion :

Matt. 21, 30, and he answeride, and seide, Lord, Y $\mathrm{Y}_{\mathrm{g}}$; and he wento

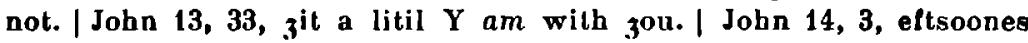
Y come.

169. e. THE TIME OF THE ACTION STRETCHes FROM A POINT IN THE PAST TO THE PRESENT MOMENT.

Last Th, $85 \mathrm{C} 12$, there gaue them so great a fal by theyr owne foly, that vato thys daye all their posteritye goe crooked thereof. | Dial. C. (Wks.) $11+1$ C 11, The greal Sowdon of Sirry thought himselfe more then his matche, and long since you were born, hath he that Empire too. Dial. Her. 216 E 11, there were so many ... proues agaynst the man of whom wo speake all this whyle. | Some Lett. Ix p. 317. And I thanke our Lorde ... sinco I am come hither, I sette by death euery daye lesse than other. / Picus 1 G 8, a ncuewe of the sayde Emperour called Picus, by whom al the auncestors of this John Picus, undoutedly bear'e that name.

Just as in Pres. D. Eng., the present tense is rarcly used in units in which the time of the action stretches from a point in the past up to the present moment; in More's English, too, constructions wilh the attendant verb to have are decidedly in the majority, e. 6 . :

Rich. 55 C 6, yet hath it hen of an olde rite \& custome obserued as a token oftentimes ... foregroing some great misfortune. | Dial. C. (Wks.) $1140 \mathrm{E} 14$, You bee nol ignoraunl ... what heapes of heauynesse, hathe of late fallen amonge vs alreadye. | Dial. C. (Wks.) 1139 D 5 , you ... good vncle, that haue so long liued vertuously.

In Middle English the construction without to have occurred only sporadically (Trnka 1930 p. 16; V. d. Meer 1929 \&; Graef 1889 p. 537 ; Smith 1907 p. 454) In Pres. D. Eng the form with to have prevails.

meaning of the present tense is restricled... 1. To cases in which the fulfilment of the action or state is represented as part of a programme already fixed in the present moment." Since such a sweeping slatement has hardly any value without a reasonable number of passages quoted in support, the reader eagerly turns the page in order to find them, only to be sadly disappoinled : the sole quotation given is absolulely irrelevant. It runs : "Diomed gives a grand feast next week, Poutsma Grammar II, 2, 252 " If we look up Poutsma I1, 2, 252, we find that the quotation is from Last Dajs of Pompeii, wrillen by Buwler Lytlon in 1834. 
EARLIER
1382 Wyclif, Luke 15, 29, Lo, so
many jeeris Y serue thee (T).
1374 Ghaucer, Troilus $v, 1351$, But
in two moncthes yit ye not
retonrne.
$1422-1509$ Paston Lett. yI, I thynke
longe that I heer nott from yow
syns (E).

\section{LATER}

1602 Shak., Hamlel III, i, 91, Good my lord, How does your honor, lor this many a day? (J).

1611 Shak., Cymb. Iv, ii, 66, I saw him not these many years.

1867 'Trollope, Duke's Ch. 2, 264, Well, Lady Mab, and how are you this long time? (J).

There is a curious juxtaposition of have been, had and teach in the following passage :

Dial. Her. 249 G 2, Now if that wore trewe ... how happed it than ... that of so many vertuouse, wise \& cunning fathers as haue ben in Ghristes church in so many hundred yeres, neuer none had the wit... to spye thys great thing, but al teach confession, tyll now that Tyndale came.

So far only the cases in which the action actually lasts from a moment in the past up to the present moment have been dealt with (Jespersen's " inclusive present "). It is also possible that the action came to an end before the present moment is reached, but that the consequences or the result form the connecting link with the present moment (Jespersen's " retrospective present"). The following quotation contains an instance from More's language :

Last $\mathrm{Tb} .86 \mathrm{~F} 14$, Wherof riseth thys waywardnesse?

Here, too, Pres. D. Eng. prefers the construction with to have.

170. . THE TIME OF THE ACTION STRETCHES FROM THE PRESENT INTO THE FUTURE.

Dial. C. 128, Such as are here and remain still. | Lament. st. 4 l. 7, The jere yet lasteth. | Rich. 60 D 10, nothing lasleth alway. | Dial. C. 127, God ... byndeth me to sewe to you nowe ... in thys shorte tyme that we haue you, that it may lyke you ... | Rich. $60 \mathrm{H} 1$, it continueth not in their blood long. | Rich. 69 B 2, Dighton in dede yet walketh on a liue. | Dial. C. (Wks.) 1230 A 10, How longe? As long as I lyue. I Dial. C. (Wks.) 1213 A 2, as long as it standeth in this case.

The particular time-sphere (present $\rightarrow$ future) of these units, though not expressed by a special form of the verb, is in many cases inherent in the meaning of the verb itself (remain, last, continue). In other cases adverbs (to walk on) or conjunctive 
words (as long as) are used. Earlier inslance : 1440 Goventry Mysterie; 104, This nine monthis thou seyst me nowth (KI.).

Later instance : Shakesp., Much Ado, IIr, i, 110, No glory lices behinde the backe of such (OED).

171. g. THE ACTION OCGURS IN THE “ BEFORE FUTURE" ${ }^{1}$ ),

Rich. 47 B 8, as for thecues, of whiche these places bee full, and which neuer fall fro the crafte, after thei once falle therto, it is a pitie the saintuary shoulde serue them.

Syntactical units of this kind contain a present tense form which denotes an action that will be past by the time anolher action takes place ("thieves will never fall from the craft after they (will) have once fallen to it). Chaucer's use of this idiom is illustrated in :

Minor Poems 5, 55, And rightful folk shal go, afler they dye, To heven.

Older instances :

c 1000 Ags. Gosp. Luke II, 22, ๓fter pam pe ic of deape arise. | c 1175 Lamb. Hom. 51, Efter pan pet pe mon bip dead.

Later instance :

1853 Bronte, Villelte 28, Shall I never see him again after I leave England?

\section{INDIREGT SPEEGB}

172. When the verbum dicendi is a present tense (he says, thinks that ...), the present tense contained in the original statement remains unaltered in indirect speech :

A pol. 3, they say ... I shew myselfe suspecte in the mater \& parciall toward the clergy. | Apol. 52, Some of them saye, that I haue more auauntage of these maters then I make for.

The use of was instead of is in the following quotation therefore seems irregular :

Answer $1050 \mathrm{~F} \mathrm{4}, \ldots$ our sauiour would not discerne \& deuide fayth from the woorke, but sayth that the faith it selfe was the woorke of god.

It is, however, possible that sayth stands for sayd, as this interchange of $d$ and $t h$ is not rare in More's printed works. See $\$ 173$ and 206.

1) Jespersen 1932 p. 2 \& p. 25.

MATERIALS IIX 
173. When the verbum dicendi is a prelerite (he said, thought that ...) the present tense in the original statement is shifted into the preterite (see Jespersen 1932 pp. $151 \mathrm{ff}$. on " back-shifting".)

Picus 10 A 12, [He] also saide, that he knew well, it he lied in that place, he wer worthie eternal damnacion. | Rich. $71 \mathrm{C} 1$, The fox ... asked him whilher he made al that hast. | Rich. 57 B 11, The king would say ${ }^{1)}$ that he had .iii. concubines, which in three diuers properlles exceled.

The present tenses in the following quotations seem irregular :

Lett. 1430 B 1, Than sayde my Lorde of Westminster to me, that bow soever the maller semed unto mine owne minde, I had cause to fere that mine owne minde was erroniouse, When I se the gret counsail of the realme determine of my mind the contrary, and that therefore I ought to change my consciens. | Dial. Her. 110 B 10, Finally he said that many good \& wel lerned men thought plainly that the clergie semeth farre out of all good order of charile.

The th of semeth may be a phonemic variant of $d$, as is occasionally the case. See $\$ \$ 172 \& 206$.

Absence of tense shifting is regular in the case of general truths, natural phenomena, etc. $(\$ 159)$ :

Hich. $66 \mathrm{H} 1$, and so they said that these matters bee kynges games. Picus 5 C 14, He thought that ... wilh the desyre of worship ... ther is ... annexed the appetite of his confusion and rebuke, whom thei argue with. Picus $7 \mathrm{C} 11$, Oftentimes in communicacion he would admonishe his familiar frendes, howe greatly these mortal thinges bowe and drawe to an ende. | Lelt. 1452 B 4, there uppon demaunded me, whither that I thought, that the Kynges grace myght not exact of me such thinges as are conteined in the statules.

That this is not a hard and fast rule is brought out by the following quotations :

Dial. Her. 271 C 8, be said that God reiected, disalowed, and sette at nought al the workes of infidels. | Picus $5 \mathrm{C} 8$, he saide, that those dispicions did great hurt, that were holden openly to thostentacion of lernyng. | Picus $5 \mathrm{C} 1$, it was a common saying with him, that suche altercacions were for a logician, \& not metely for a philosopher. | Picus

1) The present tenses after would say in the following quotation are exceptional :

Debell. 952 B 9, the selfe same folke... would then ... say that they spende vpon noughly beggers the good that was wont to keepe good yomen, and that thereby they both enfeable and also dishonour the realme. 
5 G 4, He saide also, that such disputacions greatly profited, as were exercised with a peasible minde. | Picus 7 A 3, this waios he per'swaded, that to a philosopher, \& him that seketh for wisdome, it was no praise to gather richesse.

It is a remarkable fact that usage in this respect has always remained unsettled and that in Pres. D. Eng., as Sweet (1900 p. 70) points out, there is still some hesitation as to the "right" form of the verb in such sentences as " the ancients did not know that Africa is (or was) an island" ").

The following quotations from More deserve notice because of the coordination of two different verbal forms in the reported passage :

Picus 7 A 13, He saide, that fame oftentimes did hurt to men while thei liue, \& neuer good whan thei be dead. | Dial. G. (Wks.) 1183 E 5, The Foxe asked the esse before be began benedicite, wherfore he came to confession so sone, before Lent begin.

An instance of semi-indirect speech occurs in :

Dial. Her. 216 B 14, And than if we woulde say that was neuer so : he would aske vs, howe can we be sure thereol, whyle we can not say nay but it myght be so.

If this were indirect speech, we should expect a different word order and the preterite could ( ${ }^{\star}$ he would aske us how we could be sure); in the case of direct speech a different pronoun ( $y$ ou instead of we) would be required : " he would aske us : "How can you be sure?"

\section{ASPECT 1}

174. This first kind of aspect (Aspect I) corresponds to what Dr. E. Koschmieder, in his authoritative treatise Zeitbezug und Sprache (Leipzig, 1929), calls " Aktionsart", which he distinctly differentiates from " Aspecte". On p. 27 we read ") : " Dazu ist es erförderlich zu erklären, was man

1) Compare Apol. (Wks.) $845 \mathrm{C} \mathrm{1,} \mathrm{the} \mathrm{crowe} \mathrm{that} \mathrm{accoumpted} \mathrm{her} \mathrm{own}$ byrdes the fayrest of all the fowles that flew.

2) Koschmieder's opinion is cited here in view of the fact that in modern grammars a consensus as to the meaning of the terms in question is far to seek; many grammarians have even invented systems of their own (Deutschbein, Curme, Jespersen). For a negalive criticism of Streitberg's conception see Trnka 1930 p. 32 (he calls it " a fallecy evident to all Slavonic philologists") and N. v. Wyk 1928 p. 225. Cf. Sehönfeld 1932 p. 149 \&111 and Opm.; Mirowitz 1935 and Meyer 1937. 
unter Aspecten zu verstehen hat. Das slavische Verbum verfügt über eine Fülle von Bedeutungsnuancen, die andere Sprachen sehr oft nur durch adverbielle Bestimmungen wiedergeben können. So besagt z.B. das polnische Verbum powyciagac " der Reilhe nach herausziehen", dass es sich hier un die lätigkeit des Heratısziehens mehrerer Gegenstände nacheinander handelt, ähnlich wie russisch pozakryvát' bedeutel " der Reihe nach zudecken", wo also das Distributive schon im Verbum selbst enthalten ist. So gibt es Iterativa wie polnish mawiac, “ zu sprechen gewohnt sein", momentane Verba wie russisch krikurit' " aufschreien ", Ingressiva wie tschechisch zazpivati " anstimmen, lossingen", und viele andere. All das sind Gruppen von Verben, die nach gemeinsamen Komponenten ihres lexikalischen Bedeutungsinhalles zusammengestellt sind und die sich je nach der Feinheit der Unterscheidungsmerkmale in einer mehr oder weniger groszen Anzahl aufslellen lassen. Man hat sie "Aktionsarten" gemannt, da die betreffenden Verben die Art der Ausführung der durch die Wurzel bezeichneten Tätigkeit characterisieren. Von diesen Aktionsarten, die nach bestimmten Gesichtspunkten verbale Gruppen nach ihrem lexikalischen Bedeutungsinhalt zusammenstellen, sind die ASPEkTE zu unterscheiden. Jedes slavische Verbum - mit nur ganz vereinzelten Ansnahmen - ist, gleichviel zu welcher Aktionsart es gehört, entweder perfektiv oder imperfektiv; dabei kann dieselbe Aktionsart, oft mit bestimmten Bedeutungsschattierungen, sowohl perfektiv als auch imperfektiv auftreten, so dasz es z.B. perfektive und imperfektive Durativa gibt."

175. The most prominent kinds of aspect 1 recognisable in the verbs used by More are the ingressive aspect, the durative aspect, the terminative aspect and the iterative aspect. In $\$$ 176-179 a number of instances of each are given, with only a few words of comment, since these kinds of aspect in contradistinction to aspect II (perfectivity and imperfectivity) - pertain to lexicology rather than to syntax. 


\section{THE INGRESSIVE ASPEGT ${ }^{1}$ ).}

Last Th. 8। F 11, Nowe come foorlh ye proude p(ri)soner. | Last Th. 86 E 4, wrathe soinetyme ryseth vpon a wrong done vs. | Dial. C. 256, yl they fall sicke in our seruice ... Aut. Lett. xIr, 42, ere the duke suspecte. | Apol. 130, to pacylye the grudge ere gt bygynne. | Dial. C. 245 , ere they be ware. | Rich. 51 H 8, let me kis you ones yet ere you goe.

As the verbs in these and similar cases have no special forms to denote their ingressive character, the latter can only be inferred from the context. The distinction between ingressive and terminative aspect being rather nice, it is sometimes difncult to decide whether the verb refers to the initial or to the final stage of the action.

The inchoative character is often emphasized by means of such attendant verbs as begin, fall, go:

Dial. C. 167, he falleth to thynke vpon hys death. | Last Th. 79 G 10, when we be sick, then begin we to know our self. | Dial. Her. 123 II 7 , we lyst not ones go moue our fote thitherwarde. | Dial. C. 252, [he] calleth vpon him, till he goe seke op all his creditors.

\section{EAPLIEA}

c 1205 Layamon 16078, Ah flih, flih pinne wæi (OED).

13... Thrush and Night. 4, in Relig. Antiq. I, 241, The dewis darkneth in the dale (OED).

\section{LA TER}

1596 Dalrymple tr. Leslic's Hist. Scot. I, 47, A maler that wirkis out of the stanes, and hardnes through the calde nature of the Sey (OED).

1883 Hardwich's Phot. Chem. 248, such papers darken in the sun (OED).

\section{THE DUAATIVE ASPECT.}

The majority of syntaclical units the aspect of which is not distinctly ingressive or terminative may be called durative or conlinuative, as the action is mainly realised by the hearer in the stage belween initiation and end.

Rich. 38 G 7, My Lordes, my dere kinsmenne ..., in what plighte I lye you see and 1 feele. | Dial. Her. 127 B 10, many limes men doubte why ther ye speke in sporte. | Picus 31 B 10, whyle other playe, reuil, sing and daunce. | Last. Th. 83 D 9, our lord, which alway standeth at the dore of mans hert. | Supplic. $292 \mathrm{G} \mathrm{11}$, they haue in dayes passed seen as many sicke begrars as they see now. For as for other sicknes, thei rain not... but after such rate as they haue done in times passed. | Last. Th.

1) Cl. Curme 1933 p. 377 (" Point-action Aspect; Ingressive Aspect "; Deutachbein 1831 \& 35 ("Inchoativum "). 
99 B 6, than the head aketh, \& the stomake knaweth, and the next meale is eaten without appetile. | Dial. Her. 169 A 9, It semelh me ... that all this goeth well.

\section{EARLIER}

c 1220 Bestiary 1, pe leun stant on hille (OED).

a 1272 in O. E. Nisc. 98, Hwat speksta of eny stone? (OED)

\section{LATER}

1562 J. Heywood, Prov. \& Epigr. 184 ; He standth well in his owne conceyte (OED).

1819 Shelley, Cenci v, I, 64, Even whilst we speak The ministers of justice wait below (OED).

\section{THE TEMMINATIVE ASRECT.}

In units with a terminative aspect the attention of the hearer is drawn to the final stage of the action; this may be due to the cliaracter of the verb, in which the resultalive aspect is inherent (e.g. to catch), to abverbs (e. g. to erit up), or to the context; in the last case especially when the result is mentioned in the form of a predicative adjunct $(\mathrm{e}$. $\mathrm{g}$. he died a very good man ').

Last $\mathrm{Th} .78 \mathrm{H} 4, \mathrm{~g}^{\mathrm{f}}$ he calche a manne laste at the tyme of bys dealh, he is sure to keepe hym for euer. | Dial. C. 165, Fasting is better then eatyng, and more thanke hathe of God. | Dial. C. 179, wilhout which no manne can geat to heauen. | Last Th. $100 \mathrm{G} 14$, if there be a man slain of a stroke, there is as reson is, muche speache made thereof, the coroner sltteth, the queste is charged, the verdit geuen, the felony founden... | Last Th. 97 D 6, till be fal downe the canel, \& there lye down tyll he be taken vp. | Last Th. $84 \mathrm{G} 1$, Ye build the tower of Babilon in a corner of the prison ... : \& somelime the gailor beteth it down again wilh shame. | Last Th. $74 \mathrm{H} \mathrm{3,} \mathrm{few} \mathrm{folk} \mathrm{find} \mathrm{it} \mathrm{out.} \mathrm{|} \mathrm{Lasl.}$

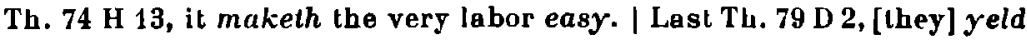
themsel ves captiues. | Dial. C. 143, be died a very good man.

\section{EARLIER}

1225 Ancr. R. 294, Keccep us ... pe 3unge uoxes (OED).

1388 Wyclif Prov. 11, 1, Mi sone, if thou resseyuest my wordis, and hidist myn heestis anentis thee (OED).

\section{LATER}

1583 Hollyband, Campo di Fior 199, Drinke up all, Seeing there is but a little left (OED).

Pres. D. Eng. : he drinks his whole earnings (OED).

1) G. Curme 1933 p. 381 (“" Effective aspect "). 
179. THE ITERATIVE ASPECT ').

The units showing iterative aspect not only refer to actions consisting of a series of separate acts (e. B. to sparkle), but also to habitual and customary actions :

Last Th. $95 \mathrm{D} \mathrm{8}$, surely so falleth it daylye, that the eye is not only the coke ... | Hich. 53 B 3, not comen people only that waue with the winde, but wise men also. | Picus 12 E 10, they daily see the iustice of God. | Boke of F. p. 2 D 2, on whiche the mased people gase and starc, And gape therefore, as dogges doe for the bone. | Last Th. $70 \mathrm{H} \mathrm{13,} \mathrm{hee}$ (scil. the devil) whan wee drawe to deathe, dooeth hys uttermoste deuoyre to biynge vs to damnacion. | Boke of F. p. 2 B 7, she amileth on euery wight.

To emphasize this kind of aspect More frequently uses attendant verbs (to be wont; to use; will) :

Picus 8 H 3, When the priest enquired of him these thinges, \& such olher, as thei be wont to enquere of folke in such case. I Apol. 79, he semeth to meane the honoure that crysten people here in the world use to do to the church. | Dial. C. 159, some wyll in welth fal into foly.

\section{ASPECT II}

\section{Penfectivity and Imperfectivity}

180. Actions may be looked upon by the speaker in two ways : his mental point of view lies either outside the (time of the) action, so that he sees it as a complete whole; or it lies within it, so that he contemplates the action in its progress from past to future. To express these two ways of looking upon an action the Slavonic languages have two different, but formally related verbs each with a regular conjugationsystem and identical in lexicographical meaning ${ }^{2}$ ), called respectively perfective and imperfective verbs. Though such pairs of verbs are unknown in English ${ }^{3}$ ), this language is

1) Gf. Curme 1933 p. 386, 4; Deutschbein 1931 \& 29 (" Iterativum, frequentalivum ").

2) Koschmieder 1929 p. 46 : " Die Aspecte sind knine lexikalischen Gruppen sondern die grammatischen Kalegorien für den Zeitrichtungsbezug ".

3) It is wrong to call drink and ascend imperfective and drink up, mount perfective, as is often done in modern grammars (Kruisinga, Deutschbein, Poutsma, etc.). See Koschmieder 1929 p. 29 on jagen and erjagen and his adverse criticism of Leskien's and Streitberg's theory and compare N. v. Wijk 1928 p. 225. 
not without a means of expressing these different ways of looking upon an action whenever for clearness' sake it is necessary to do so. If the speaker sees the action from a timepoint within the action, so that in his mind's eye it moves in the direction of past to fulure, he uses a verb-group of the type is walking, was walking, will be walking $\left.{ }^{1}\right)$; if he slands outside the action(-time) and realises it as a complete whole, he says walked, will walk, elc. ${ }^{2}$ ).

Already in More's time the use of this distinctive expedient was known; it was, however, employed rather sparingly; by the side of a number of to be + ing-forms, there is a considerably grealer number of present tense forms performing the same function. Here follow a few instances of the latter usage, in which the action occurs at the time of speaking :

Dial. Her. 252 E 6, thys stoulde ye haue seene il ye badde eyther redde as I say, the law next folowing or the glose of that law that ye redde. I idem E 9, mary quod he but in the lawe selfe that we rede, good saint Gregory sailh plaine the contrary. | Dial. Her. 211 G 3, this one mater that we now speke of. | Dial. Her. 169 A 9, It semeth me ... that all this goeth well. | Boke of F. p. 3 B 1, Lo thus ye sce ... Fortune alone ... Unstable here and there among them filtes. | Dial. C. (Wks.) $1248 \mathrm{C} 8$, whyle Herode and Herodias full heauilye silte in hell burning both twayn ... the deuil with the damsel dannce in the fyre afore them.

1) In speaking of an action occurring at the time of speaking it is only natural that the position-in-time of the speaker is in the middle, so that (at least in Pres. D. Eng.) it is unavoidable that in this case the verb appears in the to be + ing-form. To take up such a position is not possible with actions of neutral time or timeless actions (e. $g$. in elernal or gencral truths), with actions without duration (to explode), nor with habitual and regularly repeated actions, unless encompassed in the time-period expressed by always, ever. Ingressive and teruinative verbs allow of the analytic form only when, througb a slight change in meaning, their character has become dutative.

2) In his article on " Expanded Tenses" in Eng. Studies xxI, 5 (1939) Th. Satchell also recognises the notions of completion or incompletion as determinative. He says that phenomena may be regarded from two aspects, which may be conveniently called the static and dynamic aspects, and ndds in a nole that in using the term " aspect" he does not intend to imply that the " expanded" and " unexpanded "tellses in English coincile with the inperfective and perfeclive aspects of the verb in Hussian, but that there is, however, suffcient similarity to make the use of the term significant. 
Last Th. $82 \mathrm{E} 6$, how many as yong as thou haue bene slain in the self same waies (= roads) in which thou ridest, | Dial. C. 129, Nowe striue there twayne for us. | Dial. C. (Wks.) 1164 A 5, whyle our tong pattereth vppon oure prayer a pace, good God, howe manye madde wayes oure mynde wandereth the whyle. | Boke of F. p. 4 C 6, And eke against the sonne Bekyth hym poore Diogenes in his tonne. | Picus 31 B 10, whyle other playe, reull, sing and daunce. | Dial. C. (Wks.) $1191 \mathrm{H} \mathrm{9,} \mathrm{do} \mathrm{I} \mathrm{not}$ now wagge my hande, shake my head, and slampe witb my loote here in the flore? | Dial. Her. 127 B 10, men doubte whyther ye speke in sporte. | Dial. C. (Wks.) 1211 D 8, by whiche letter it appearelh, that the greale Turke prepareth a marueylous mightie armye. | Dial. Her. 137 B 1, (she) firsl could not beleue it, but saide, what ye mock Iwis, I pray you tel trouth.

181. How far, in this respect, the language has developed since More's time appears from the fact that in the majority of the cases illustraled above, Pres. D. Eng. preferg the to be + ing-construction '). Before More's time the single verb was still oftener used in this imperfective function, the to be + ingform occurring very rarely in Middle English, at least in prose (see Aronstein 1918 and $\AA$ kerlund 1911).

\section{EARLIER}

971 Hlickl. Hom. 149, Hwæl is ... pis folc pe her pus blude singeth? (OED)

a 1272 in O. E. Misc. 98 , Hwat spekstu of eny stone? (OED)

c 1400 Pety Job 329 in 26 Pol. Poems 131, Allas, I walke in a lake of dediy synne that dolh me tene (OED).

c 1386 Ghaucer, Kn. T. 425 , thou walkest now in Thebes at the large (GI).

c 1386 Chaucer, C. T. C 828, I shal ryve bim thurgh the sydes tweye whil that thou strogelest.

\section{LATER}

1599 Shaks. Hen.V, iv, i, 319. I haue built I wo Chauntries, Where the sad and solemne Priests sing still for Richards Soule (OED).

1819 Stelley Cenci v, i, 64, Even whilst we speak, The ministers of justice wait below.

1) A curious alternation of present-tense forms and constructions consisting of to be + lorm in -ing is contained in :

1570 Ascham, Scholemaster B 1, leaf 11, back : For when 1 am in presence either of father or mother, whether I speake, kepe silence, sil, stand, or go, eate, drinke, be merie, or sad, be sowyng, plaiyng, dauncing or doing anie thing els, I must do it, as it were, in soch weight, mesure, and number... 


\section{MODALITY}

182. Modality is that particular character given by the speaker to a syntactical unit from which it appears whether or in how far he wants the action or state denoted by the verb occurring in it (or in the case of a group of verbal forms by the principal verb) to be looked upon as real or as imaginary, as cerlain or as doubtful, as feared or as wished for.

To impart this character the speaker has a number of grammatical and non-grammatical expedients at his disposal : lacial expression, gestures, intonation, stress, modal adverbs, conjunctions, special verb-forms (" $\operatorname{moods}$ ") and verb-groups.

Whereas English has an almost endless variety of verbcombinations to express the subtlest shades of modality, the number of special verb-forms that (help to) express modality is restricted to two ') : a LONG FonM (he looketh) and a sHont Form (he looke). Moreover, only the second and third person singular are subject to this differentiation ${ }^{2}$ ), the first person and the second and third persons plural having only one form (with the exception of to be).

The following survey ( $\S 182-204$ ) shows in what cases the long and in what cases the short form of the present tense was used by More; only instances with the second and third person singular have been adduced ${ }^{3}$ ).

183. INDEPENDENT UNITS.

1) When the unit denotes an aclual fact the long form only is used.

Last Th. $82 \mathrm{C} \mathrm{4}$, His galowes \& dealh standeth within .x. mile at the farthest ... | Apol. 23, a iugler that conuayeth bys galles so craftely

1) Apart from the use of the preterite in units the time-sphere of which is not the past, e. g. Last Th. 88 A 8 , who could be angry for the losse ...? (see $\$ \$ 219 \mathrm{ff}$.).

?) Not, however, with all verbs; lyst (3'd person) e. $B$. occurs only in one form : Boke of F.p. 5 B 4, Who lyst to aduise them bothe, perceyue he shall, As great difference betwene them. I Picus $33 \wedge 11$, Worthy onough are thei Be thei neuer so vnworlby : whom that hee List to accept. | Boke of F.p. 2 G 4, As soone as Fortune list to laugh agayne ... | Apologye 45, Who so lyst to rede my bokes...

3) And occasionally the form $I$ be. 
that al the table spyeth them. | Picus $20 \mathrm{C} 9$, he that so doth prospereth in all thing.

To stress the reality of the action More sometimes uses the modal adverb well :

Rich. 47 B 3, yt the crown happen ... to comme in question, whyle eyther parte taketh other as Traytours, I wyll well there bee some places of reluge for bothe. | Dial. Her. 217 B 6, Ye for God quod he that will I well. | Dial. G. (Wks.) 1249 G 4, That I belieue wel cosin.

\begin{tabular}{c|c} 
EARLIER & LATER \\
a 1400 Bk. Curtasye 451, He strykes & 1867 Freeman, Norm. Conq. I App. \\
hom vp with forket wande(OED). & $\begin{array}{l}754, \text { It strikes me that the scribe } \\
\text { confounded these laws (OED). }\end{array}$
\end{tabular}

2) In independent questions the long form is used ’).

Lament. St. 3 1. 4, But o good God what payleth al this gere? | Hich. $51 \mathrm{G} \mathrm{1}$, what wise merchaunt aduentureth all his good in one ship? Picus $26 \mathrm{D} \mathrm{8}$, Why loneat thou so this brotle worldes ioye? Last Th. $86 \mathrm{~F} 14$, Wherol riseth thys waywardnesse?

For the use and the omission of to do in questions of the type illustrated by the last two quotalions, cf. the sections on to do + verb (\$\$ 421 ff.).

\begin{tabular}{l|c} 
EARLIER & LATER \\
$\begin{array}{l}\text { c 1205 Laymon 3005, Waet seist tu ? } \\
\text { (OED) }\end{array}$ & $\begin{array}{c}1601 \text { Shakesp. Tw. N. } 7, \text { i, 9, how } \\
\text { dost thou, my good fellow ? }\end{array}$
\end{tabular}

3) In negative statemenls the long form is used.

Apol. (Wks.) 871 E 4, suche fautes as he speaketh of, he saythe thein not as of hymselfe, nor affyrmeth theim not ${ }^{2}$ ) for trewe. I Picus 14 B 3 , Then he maketh philosophie mercennary ... which sludieth it not for pleasure ol itself.

As appears from these instances the use of not does not necessarily entail a periphrasis wilh to do, as in Pres. D. Eng. For further discussion see the sections on to do + verb (\$\$ $421 \mathrm{ff}$.).

1) Though this was the rule in Middle Engl. as well, there are a lew exceplions, e. g. c 1386 Cbaucer, C. T. H 273, Allas ! lhat I was wroght! why nere I deed?

2) Double negation is regular in More, cl. Apol. 6, gf this were vntrew ... some of them could assigne ... some one suche place for a sample. But that thyng neyther do they, nor neuer can. | Last Th. $90 \mathrm{C} 13$, the byrdes in the ayre, lhey neither sow nor repe, nor gather to no barns. Picus 13 D 4, Nor I care not howe long ... thy prayer be. 


\section{EARLIER}

1390 Gower, Conf. 111, 159, So that here kinges yhe is blent And wot not hou the world is went (OED).

\section{LATEP}

1590 Spenser F. Q. I, 1, 30, With holy lather sits nol wilh ouch thinges to mell.

4) In imperalive, jussive, precative and exhortative units the short form is the rule.

Last Th. 89 D 3, Seke ye fyrste for the kingdom of heuen \& the iustice of hym, \& al these thinges shal be cast vnto you beside. I Instr. 1405 B 6, Beare no malice nor euill will to no man liuing.

\begin{tabular}{c|c} 
EARLIEA & LATER \\
a 1300 Curs. M. 14349, 'Lazar' wit & 1889 Jerome, Three M. I. A. B. III, \\
pis, 'cum forth' he badd (OED). & $\begin{array}{l}24, \text { Now get a bit of paper and } \\
\text { write down ... }\end{array}$
\end{tabular}

5) In optative units the short form is used ${ }^{1}$ ).

Lament. st. 10 1. 2, Our lorde encrease your honour. | Jest p. 1 D 3, I pray god spede hym well. | Hich. $40 \mathrm{~F} \mathrm{6,} \mathrm{thanke} \mathrm{he} \mathrm{to} \mathrm{his} \mathrm{grace} \mathrm{that}$ peril is paste. | Dial. C. (Wks.) 1186 D 18, yes, Cosyn, manye en hundred, and els God forbede. | Rich. 39 D 5, Our Lorde forbydde, that you loue together the worse. | Hich. 43 E 2, Ab woo worthe him quod she, for hee is one of them that laboureth to destroye me and my bloode. I Dial. Her. 238 a 9, Naye my lordes quod he, I wil not drinke God yelde you. | Dial. C. (Wks.) $1145 \mathrm{~B} 12$, thys ... is a good cause of greate coufort in deede : our Lorde in tribulacion send it vs.

\begin{tabular}{|c|c|}
\hline EAHLIER & LATEA \\
\hline $\begin{array}{l}1300 \text { Havelok } 803 \text {, God yelde him } \\
\text { per i ne may, pat haueth mo } \\
\text { fed to bis day (OED). }\end{array}$ & $\begin{array}{l}1814 \text { Wellington in Gurw. Desp. } \\
\text { xil, } 6 \text {, God send that I may be in } \\
\text { time to prevent mischief (OED). }\end{array}$ \\
\hline
\end{tabular}

To bid a person God spede occurs in :

Conf. Tynd. 831 H 13, no man [should] after vouchsafe ... to bidde them ones God spede.

6) In hypothelical units of the type : strangle the mother \& thou destroyest the doughter the short form is used.

Last Th. $85 \mathrm{G} \mathrm{11}$, enuy is ... the doughter of pryde in so farreforth that as this holy doclor sayeth, strangle the mother \& thou destroyest the doughter. | Apol. (Wks.) 870 A 1, as for mine owne part, loke my

1) The long form is quite exceptional : Conf. Tynd. 413 G 2, did not then our lorde ... make him aungwere in this wise : suffiseth vnto thee my grace. 
dyalogue ... and ye shall clerelye see ... | Picus 27 A 1, Take cuery sporte, that menne can thee denise, And among them all ... Thou shalt no pleasure ... finde. | Dial. G. (Wks.) 1228 G 7, Breake one of bis commaundementes, and break al. Forsake one poynte of hys laytbe, and forsake al. | Debell. $980 \mathrm{C} 2$, reade the stories who so wyll, and be shall finde bolhe by Platina and Cronica cronicarum to, that ...

EARLier
c 1300 Seyn Julian, Bicome christen
for my loue, and me pou Last
bezite (E).
c 1385 Chaucer, Leg. of G. W. 735 ,
wre the glede and hotter is the
fre; Forbeede a love, and it is
ten so woode.

\section{LATER}

1913 Punch 13 Nov., Gice them something rally good and they snill at it; but give them something risky and look you couldn't get a seat if you tried (Kr.).

\section{DEPENDENT UNITS ( $\$ \$ 184-204)$.}

In (subject-)clauses opening with who so both the short and the long forms are used.

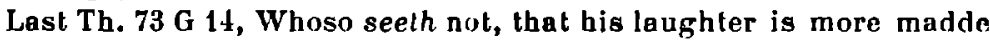
than the laughter of the nuad man ... | Rich. 37 H 6, whoso diulneth vppon conieclures, maye as wel shole to farre as to shorl.

Dial. C. (Wks.) 1204 H 1, who so that dye') for defaulle wbere we myght helpe them ... | Rich.35 H 3, Whose warres who so well consyder, hes shall no lesse commende hys wysedome where bee voyded, than hys mannehoode where he vainquisshed. | Apol. (Wks.) 877 D 8, whoso prye vpon euely mannes dede so narowlye... | Dial. IYer. 180 F 13, who so kepe $^{2}$ ) the faith ... grod will plucke him out ...

W'hen the indefiniteness of whoso is strengthened by the addition of ever, the short form seems to be the regular one.

Last Th. $85 \mathrm{H} \mathrm{5}$, whosoeuer enuye anotber it is for some thyng, whereof him self wold be proude if he had it. | Bless. Body 1265 D 10, Who so euer eat the bread and drinke the cuppe of our lorde. | Dial. C. (Wks.) $1263 \mathrm{C} \mathrm{14}$, who so ener shrynke awaye with forsakynge hys faythe ... he shall bee ... | Dial. C. (Wks.) 1161 B 7, what so euer he saye... | Rich. 63 H 9, whom so eller so wel occupy the roume, as I dare

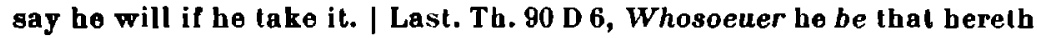
this ...

1) This may be plural, since the relerring pronoun is them. In that case there is of course no question of long or short form. The other quotations, however, prove that who 80 may stand with the referring pronoun he.

2) Delcourt 1914 p. 112 wrongly assumes here " chute de la dentale finale " of the same kind as the omission of the th-ending in the present tense form of verbs ending in $t$, as in (he) list, let, admit. 
The use of either the short or the long form after who so (ever) seems to have been unsettled ') throughout all the stages of the Eng. language; in Pres. D. Eng. there is a predilection for the long form, if, at least, no attendant verbs are used; in spoken English the short form is unknown.

\section{EARLIEA}

LATER

LONG FORM.

1297 R. Glouc. 6253, ofte wo so coueitep al, al leselh (OED).

c 1400 Deslr. T'roy 555!, Who so staris on pis story ... Take hede on pe harmys \& the hard lures ? (OED)

1498 in J. Hulloch, Pynoul's 57, And quhais doys in the contrar ... salbe punist (OED).

SHORT FORM.

c 1205 Layamon 2:307, Who swa come gladliche he sculden wurpe riche (OED).

c 1400 Maundev. xix, 113, Hem somelh pat whosoenere be meke ... he is holy \& profitable (OEI)).
1593 Shakesp. 3 Hen. VI, Iv, vii, 74, And whosoe're gainsayes King Edwardes right ... I challenge him to single fight (OFD).

1883 Whitelaw, Sophocles, Antig. 35, Whoso does this deed, $A$ public death by stoning is his doom (OED).

1607 Shakesp. Timon $v, i, 212$, Who so please to stop Affliction, let biin lake his haste (OED).

1876 Morris Aeneids vul, 122 , 'Come forth', he said, 'whoso ye be' (OED).

185. In subjecl-clauses announced in the principal unit by proleptic it (types: it semeth that; it greueth me that) the use of either the short or the long form seems to depend upon the character of the principal unit.

If the principal unit is a neutral (= non-emotional) slatement the long form is used; if it denotes emotion,

1) There does not seen to have existed any particular reason why in one case the long and in another the short form was used; compare the following two quotations :

Bless. Body 1265 D 10, Who so euer eat the bread and drinke the cuppe of our lord vnworthyly, he ...

1539 Bible, John vi, 54, Whoso eateth my flesshe \& drinketh my bloude, hath eternall lyfe.

The explanation is perhaps to be found in the Latin manducaverit and manducat. 
astonishment, uncertainty, (dis)approval, etc., the short form often occurs. No general rule, hovever, can be given, owing to the paucity of quotations illustrating the point, most sentences that contain a unit with proleptic it being of the type : It is almes to correct the vicious. | it is foly to looke for heauen...

Shont ғонм. Last $\mathrm{Th} .75 \mathrm{G} \mathrm{9}$, it is not ynough that a man do none euyl, but he must also do good. | Rich. $50 \mathrm{G} \mathrm{10,} \mathrm{It} \mathrm{is} \mathrm{not} \mathrm{honorable}$ that the duke bide here. | Dial. C. (Wks.) 1211 A 16, so is it very good maner, that a man of your age ... lette his slepe not slippe awaye. / Rich. $59 \mathrm{~F} \mathrm{9,} \mathrm{No} \mathrm{more} \mathrm{is} \mathrm{it} \mathrm{reason} \mathrm{that} \mathrm{it} \mathrm{mislike} \mathrm{any}$ man, that I mary where it liketh me. I Apol. 6, It is lytle meruayle that $\mathrm{yt}$ seme long and tedyouse vnto them. Hich. 63 G 10, And reason is that it so be. | Last Th. 85 B 9, litle meruail it is though enuy be an vngracious grale [= grafl; grafl]. For it commelh of an vingracious stocke.

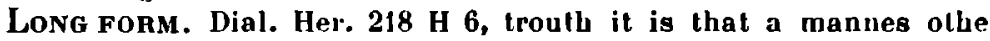
veceiueth interpretacion. | Dial. Her. 211 / G 3, it is a good token that the matter \& substance of them is true. | Last. Th. $98 \mathrm{E} \mathrm{3,}$ Wonder it is that the worlde is so mad.

If though instead of that is used the short form is regular.

Dial. Her. 259 C 2, thei woulde say ... . Ah, fy fy for shame what meruaile is it though god sende a vengrance amonge you.

In the majority of cases More uses attendant verbs :

Dial. Her. $211 \mathrm{H} \mathrm{14}$, more likely is it also that one may forgelte the thing that he herd, than that a nother should remember that thing that he herde not. | Dial. Her. $152 ; 13$, it is ... plain against the rule of reason that an heuy budy should moue alone any other mocion then downward. | Dial. Her. 145 F 4, then can it not be that he shal suffer the deuill to worke wonders.

In Pres. D. Eng. the short form is not used, except in literary and poctical style.

\section{EARLIER}

\section{LATER}

\section{LONG FORM.}

1390 Gower, Conf. I, 100, No wonder thogh he siketh ofte (OED).

c 1380 Wyclif Wks. 265, It is gret meruaile pat god ... distroleth not alle pis cursed peple (OED).

1749 Fielding, Tom J. III, iv, ‘ No Man is wise at all Hours'; it is therefore no Wonder that a Boy is not so (OED).

1855 Orr's Circ. Sci. 226, It is not unlikely that the gas thus formed occupies the place of water(QED).

SHORT FORM.

1390 Gower, Conf. vi, 382, Though god his grace caste aweie No wonder is (OED).

1545 Brinklow, Compl. II, 26, It is meruel ... that fyre descend not down from beauen (OED). 
186. In object-clauses dependent on principal units containing a will, a desire, etc., short forms are the rule, and long forms exceptional.

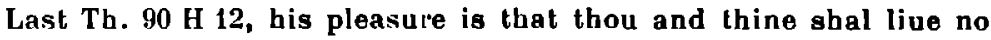
lenger but die and depart by famine, as he wyll that some other dye by sickeness. | Dial. (Wks.) $1193 \mathrm{~F} 5$, tell hym, that he shewe you whereby he knoweth ... that himself is not a slepe. | Hich. 47 B 6, I wyll well there bee soinme plnces of refuge for bothe. | Picus 13 G 5, Now to make an endo with this ono thing. I warne thee ... that thou neuer forget these .ii. thinges. | Rich. $39 \mathrm{E} 9$, what trouble balhe within these fewe yeares growen in this realme, I praye Godde as well forgeate as wee well remember.

Aut. Lett. XII, 55, His grace lyketh not that themperor setteth on so slowly.

By the side of these forms constructions with auxiliaries are not infrequent :

Dial. C. (Wks.) $1160 \mathrm{~F} \mathrm{6}$, Y the send the scourge of scarcity and of greate famyne, he wil we shal beare it paciently; but yet wyl he that we shal eat our meat when we can bappe to get it. Yt he sende vs the plage of pestilence, he wyl we shal paciontly lake it ... | Last. Th. 90 H 12, his plrasure is that thou and thine shal liue ...

In older English the clauses dependent on desiderative verbs were almost exclusively constructed with the short forms, unless combinations wilh attendant verbs took their place. In Pres. D. Eng. the use of the short forms is restricled to poetical and literary language, and to parliamentary formulas such as "I move that action be postponed".

EARLIER

SHOAT FORM.

971 Blickl. Hom. 61, Deme je nu swa swa ze willon pert eow $s y$ eft yedemed (OED).

c 1350 Will. Palerne 281 pat y am pat ilk weish i wol wel pou coile (OFD).

\section{LONG FORM.}

1000 Luke ix, 54, Wylty we eecgap pæt fyr come of heofene? (Kl.) 1400 Bury Wills 48, I wille that she disposyth as she and her frendes thinke beste (KI.).
1591 Shaksp. Two G. Iv, iii, 41, I wish all good befortune you (OED).

Pres. D. Fug. (poetical) : 1822 Shelley, Charles I, ii, 456, Go desire Lady Jane Sho place iny lute (OED).

1691 Shadwell, Scowters IV, iv, I wish the house in not robbed (OED.)

1751 Monitor, $n^{\circ} 35, x, 325$, I wish the old hag has done him no mischiof (OED). 
187. In object-clauses dependent upon principal units which contain the verbs see, look or synonyms and denote an admonishment or exhortation, the short form is used.

Picus 32 A 9, Freelye looke eke thou serue that thereto neuer Truste of rewarde or profite dooe the bynde. | Picus $22 \mathrm{D} 5$, One sinne vainquished loke thou not tary, But lye in awayte for an other. | Picus 26 G 5, See thou behaue thee wisely with thine hoost.

Pres. D. Eng. uses the long form here; a short form is occasionally found in affected diction. Before More's time (e. B. in Vyclif - see Smith $1907 \S 133$ ) and for some time after, the short forms allernated with constructions with attendant verbs.

BHORT FORM.

c 897 Alfred, Greg. Past. LIx, 415, Lociap nu pot pios eowi'u leat ne weorpe oprum monnum to biswice (OED).

a $1300 \mathrm{~K}$. Horn 452, se he holde forward (OED).

c 1380 Wyclif, Wks. 38, Seynt petyr comaundip zil ony speke, loke he speke as goddis wordis (OED).
1523 Fitzherb. Husb. \$ 21, Let hym beware, that he trede not to mocbe vppon the corne (OIED). 1575 Gammer Gurton 11, i, 77, Now, Hodge see thou take heede.

1590 Sliakesp. Mids. N. D. Iv, i, 15, have a care the hony bag breake not.

188. Of object-clauses dependent on a unit containing the verb to provide two instances have been observed; one of them has a short, the other a long form.

Rich. $60 \mathrm{H} \mathrm{1,} \mathrm{god} \mathrm{alway} \mathrm{so} \mathrm{prouideth,} \mathrm{that} \mathrm{it} \mathrm{continneth} \mathrm{not} \mathrm{in} \mathrm{their}$ blood long ... | Aut. Lett. Iv, 34, he dowleth not but your grace hath and will provide that no lacke of vitaile hyndre or empech theire purpose.

To provide is no longer used in this meaning; the latest quotation in OED. is dated 1573. The short forms (apart from constructions with attendant verbs) seem to have predominated:

1538 Starkey, England 11, ii, 181, We muat prouyd ... that by no prerogatyle he sourpe epon the pepul any such authorysyd tyranny. 1573-80 Baret, Alv. P. 801, To prouide that a thing happen not.

189. In object-clauses dependent on units denoting emotion, astonishment, doubt, uncertainly, hope, etc., the short form does not seem to have been obligatory; the greater number of the quotations containing this kind of clause are construed with the long form. 
Dial. Her. 123 H 9, We meruayle muche that God sheweth no mo myracles nowe adaies. | Dial. Her. $98 \mathrm{E} \mathrm{3,} \mathrm{Wonder} \mathrm{it} \mathrm{is} \mathrm{lhat} \mathrm{the} \mathrm{worlde}$ is so mad. | Last Th. 97 A 17, who douteth but that the body dilicately fed, maketh as the rumour saith an vnchast bed. I A pol. (Wks.) $876 \mathrm{E} 2$, I can not perceiue which of the twoo partes calleth which nor who

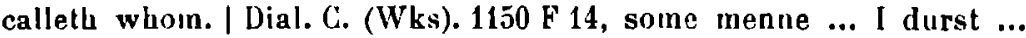
put ... in right good hope, that God sendeth il vnto them. | Apol. (Wks.) $864 \mathrm{~F} 1$, I am sory that their maner is no better.

Dial. C. (Wks.) 1169 G 8, thrrefore am I nowe verye gladde, tbat you be come. | Dial. (C. (WVks.) $1177 \mathrm{E} 10$, such as feare least thal waye be not sure ... | Dial. C. (Wks.) 1230 D 6, he that doubteth whither there be any God or no.

In Old Eng. the short form was often used in object-clauses of the kind illustrated above; in Middle Eng. it alternated with the long form; in Pres. D. Eng. it hardly ever occurs. Here follow a few quotations with long forms :

1611 Shaksp. Wint. T. v, i, 30, what were more holy, Then to reioyce the former Queene is well. | 1596 Dalrymple tr. Leslie's Hist. Scot. I, 36, This cau es men to wonder, that vnder that earth ar fund grel slokis.

190. In object-clauses after care not, force not, reck not, etc., the short form is used.

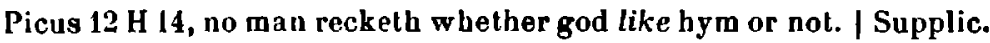
$298 \mathrm{~F} 11$, But to thende that ye may se how littel thys man forceth how lowd he lye : consyder that he sayth that ... I Suppl. 302 B 6, he neyther deuyseth ferther, nor ferther forcelb who have it. | Picus 13 D 4, Nor I care not howe long or how sbort thy prayer be.

The short forms scem to have been the rule in older English. To-day only long forms or constructions with auxiliaries are current in the spoken language.

\section{EARLIEH}

c 950 Lindist. Gosp. Mark Iv, 38, No reces pu pwt we deado sie (OED).

1485 Caxton, Chas. Gt. 196, I relche not though he be put to dethe (OED).

1500-20 Dunbar, Poems Lvil, 22,

Thay fors bot litill how it fare (OED).

\section{LATER}

1606 Shaksp. Tr. \& Cr. v, vi, 26, I wreake not, though thou end my life to-day (OED).

1871 Morley, Voltaire 3, Men had almost ceased to care whelher there be any rnoral order or not (OED).

191. In object-clauses dependent on the verbs to think, to wene, the short forms are used to emphasize the uncertainty or cloublfulness of the statement; in other cases long forms are found. 


\section{LONG FORM.}

Dial. C. (Wks.) 1186 F 8, me thinketh ... that it is rather a thinge that comelh of a great corage. | idem 1173 A 3, I thynke that that is sayde suffyseth. | idem 1191 D 1, the thynge whyche he weneth God by his angel byddeth, god hath by hys own mouthe forbydden. | Last Th.73G1, Think not that euery thing is plesant, that men for madnes laughe at.

\section{SHORT FORM.}

Dial. Her. 153 A 4, His eyen may ... be deceyued \& wene thei se that th'y se not, if reason geue ouer his hold, excepte ye thinke the iugler blow his galles through the gobletes bottom, or cut your gyrdell afore your face ... and make it hole agayne. Cl. $\$ 229$ (cuere).

The two forms were similarly used in older English (Curme 1933 p. 4 (6). In Pres. D. Eng. only long forms or auxiliaries are found. A few quotations with long and short forms follow :

a 1300 Cursor M. 7557, Quat! wyns pou i am a hund? / 1400 Mander. Trav. 143-8, sum men trowen pat half the cros ... be in Cipres. 11523 Berner's, Froissart III, 386, I beleue it be the Frenchmen. | jdem Iv, 422, yf syr John ... thynke that the other knyght haue ad vauntage, let hym set on his helme in lyke manner.

192. In indirect questions long and short forms alternate.

Dial. C. (Wks.) 1191 F 6, you shall haue good cause ... to demaund ..., wherby he knoweth that hys vision is Gods true reuelacion.

Dial. C. (Wks.) $1190 \mathrm{D} 14$, Many other tokens are ther in the work of master Gerson ... to consyler by, whylher the person ... do ... fayne his reuelacions hymself. | idem $1192 \mathrm{G} \mathrm{16}$, In Sampson all menne make not the matter very sure, whither he be saued or not. | Bless. Body 1265 G 9, no manne liuyng knoweth whether he bee worth the fauour or batred of god. | Dial. Her. 118 F 1, these heretyques... demaunde whyther god and his saintes lack lyght or whyther it be night with them that they can not se wythout candle.

If the clause opens with whither (= whether) the short form prevails. The usage in More does not essentially differ from that of older periods. In Pres. D. Eng. only long forms are used, excepl occasionally in literary language.

\section{EARLIER}

a $\mathbf{2 2 5}$ Leg. Kath. 2312, Loke nu hweper pe beo leouere don pat ich pe leare ... oper ... (OED).

a 1300 Curs. M. 4918, Now wel is sene Queper pat yee be fule or clene (OED).

\section{LATER}

1610 Shaksp. Temp. v, i, 123, Whether this be, Or be nat, I'le not sweare.

1676 Ray, Corr. (1848) 122, Tell me whether any such bird be known to you (OED). 
193. In attributive clauses with the modality of fact the long forms are used; if the clause denotes an uncertain attribute or a quality of the antecedent required or sought for, the shor' form ') is used.

Rich. 5.) B 10, I am as sure of the man that be woleth of, as I ain of my own hand. | Rich. 60 G 4, the great grace that god giueth \& secretly infowndeth in right generacion. | Picus 6 G 6, the ... brode way that leadeth to hell.

Dial. C. (Wks.) 119.5 C 6, now this good man neither hath any of goddes enemies to be by his own deth reuenged on, nor any woman that violently pursue him by force.

In older English short forms are not rarely met with :

750 Elene 371, Nu ge rape gangap and findap gen pa pe fyrngewritu purh snyttorcreft selest cunnen. | c 1400 Mandev., Tr. 96, 6, And men seon in pat contre a mountayne to the whiche noman come.

In Pres. D. English only long forms are used; in literary diction the particular function of the short form is sometimes taken over by shall or should, as in :

Woo.lrow Wilson, Jan. 1901, It is bard to construct an argument here which shall nol be heated.

Compare the "subjonctif" in French : "je cherche une maison qui ait dix chambres' (C. de Boer 1922 p. 85).

194. In adverb clanses of time opening with before, ere, or or til, the short form is used.

Before. Dial. G. (Wks.) 1183 E 5, The Foxe asked the asse before be began benedicite, wher fore he cane to confession so sone, before Lent begin. | Instr. $1108 \mathrm{~A} 5$, at the bare blast of the trumpet, before the balaile beginne.

Ere. Hich. 39 A 5 , there must it nodes bee long ere any good conclusion goe forwarde. | Aut. Lett. $x 11$, 42, ere the duke suspecte. | Apol. 130, to pacilye the gru(lge ere yt bygynne. | Dial. C. (Wks.) 1202 D 16, ere the morning waxe lyght.

Or. Picus $11 \mathrm{~F} \mathrm{1,} \mathrm{Is} \mathrm{ther} \mathrm{...} \mathrm{any} \mathrm{of} \mathrm{those} \mathrm{trifles,} \mathrm{in} \mathrm{the} \mathrm{getting} \mathrm{of}$ whiche a man must uot sulfre many labours ... or he get it?

Til. Picus 16 F 2, thei renne forth hedling in to all mischiele, ... til that death set on them vnware. | Apol. (Wks.) 887 B 3, sleepe [they] shall till Gabrielles trumpe awake them and call them vp. | Last. Th. $97 \mathrm{D} 6$, till he fal downe the canel, \& there lye down tyll he be taken vp. | Last Th. $101 \mathrm{C} 3$, now shall they be ... lefte in the mire, til Gabriell blowe them vp.

1) For the similar use of were see 8231. 
The long form turneth in the following quotation is exceptional :

Rich. 39 D12, ambicion ... where he once entreth crepeth foorth so farre, tyll with deuision and variaunce bee turneth all to mischiefe.

In older English, too, the short forms prevailed (Roszmann 1908 ; Smith 1907 p. 457 ; Klausmann 1919 p. 80 ; V. de Meer $1929 \$ 32,4)$. In Pres. D. Eng. only long forms occur, except in poetical language.

\section{EARLIER}

a 1225 Ancr. H. 296, Cwench hit ... er pen hit waxe (OED).

a 1400 Mandev. Tr. 9, 32, it filleth himself euerich jeer til pat it go oiser aboue (M.).

1420-30 Prymer [E. E. T. S.] 64, Alle pe daies in whiche ye trauele now, $y$ abide til my chaungyng come.

\section{LATER}

1601 B. Jonson, Poetaster, Prol., Stay monster, ere thou sink. 1610 Shakesp., Temp. I, ii, 465, I will resist such entertainment, lill Mine enemy ha's more pow'r. 1850 Tennyson, In Mem., xill, 8, Silence, till I be silent too.

195. After the conjunctions while, as long as, when(soever) the long form is regular, even when the reference is to fulure time. There is one instance of a short form after all the while that.

While. Rich. 66 G 9, if one should can so lyttle good ... to calle him by his owne name whyle he standeth in his majestie. | Rich. $01 \mathrm{E} 1$, whose remembrance can neuer dye while he liueth. | Last Th. $78 \mathrm{C} \mathrm{10,}$ while our life walketh awaiward.

As long as. Dial. C. 261, as long as it standeth in this case. | Last Th. 81 D 2, thou shalt neuer dye as long as thou liuest.

When(soever). Dial. G. 168, when the sinner commeth euen into the depth, than he contemneth and setteth nought by nothing. / Last Th. 84 A 12, [he shall] ... whan deth arresteth him, haue his deinty body lurned into stinking carien. | Picus 17 D 4, whan thou comest home. | Dial. C. 355, I wene that when so euer ho falleth sicke nexte, he wyll wyshe ....

All the while that. Dial. Her. $217 \mathrm{H}$ 14, I neuer can conceiue good hope of his amendement all the while that pryde abyde still in his heart.

How consistent More was in the use of a long form after when ') and a short form after ere appears from the following quotalion :

1) Draw after whan in the following quotation can be interpreted as plural : Picus 20 A 12, than is a man perfit, whan his soule, but also his flesh draw forth to godward. 
Dial. C. (Wks.) 1124 (=1202) D 15, there are two times of darknesses : the tone ere the inorning waxe light, the tother when the euening waxeth darke.

Before More's time short forms were used alongside of the long ones :

971 Blickl. Hom. 97, He sceal wianan \& sorgian, hwonne se dæg cume. I c 1440 Generydes 1245, Ser, on to hir loggyng, When euer it please yow, I shall be your gyde. | 1425 Cast. Pers. 2542 in Macro plays 153, It is good, whon-so be wynde blowe, A man to haue sum-what of his owe (OED).

c 1400 Avow. Arth. xxiv, Quen thou art armut in thi gere, Take thi schild and thi spere (OED.

In Mandeville's 'T ravels short forms after when are the rule, long forms exceptional (V. d. Meer 1929 \$ 32, 4 d.).

After More's time short forms were only sporadically used :

1592 Daniel, Delia xLI, 1, Thou canst not die while any zeal abound ...

In Pres. D. Eng. the long form or constructions with auxiliaries are the rule.

196. In adverb clauses of place the long form is regular, even if they refer to future events.

Last Th. $78 \mathrm{H} \mathrm{7,} \mathrm{where} \mathrm{so} \mathrm{euer} \mathrm{the} \mathrm{stone} \mathrm{falleth} \mathrm{there} \mathrm{shall} \mathrm{it} \mathrm{alsyde.}$ Fich. $39 \mathrm{D} \mathrm{12}$, Suche a pestilente serpente is ambicion and desyre of vaineglorye and soucrainlya, whiche amonge stales where he once entreth crepeth foorth so farre, tyll ...

Instances of short forms in earlier English are very rare; they do, however, occur :

1000 Andrew, Hafa blessunge ofer middangeard mine, pær pu fere $(\mathrm{Kl})$.

Later example :

1600 Shaksp., Twellth N. Il, iv, 65, A thousand thousand sighs to save, Lay me, $O$, where Sad true lover never find my grave.

197. In clauses of hypothetical similarity of the type as who say(th), both long and short forms are found.

Last Th. $84 \mathrm{E} \mathrm{4,} \mathrm{holy} \mathrm{David} \mathrm{saith} \mathrm{to} \mathrm{this} \mathrm{gailor} \mathrm{whither} \mathrm{shal} \mathrm{I} \mathrm{go} \mathrm{fro}$ thy spirit, \& whither shal I fle fro thy face : as who saith nowhither. Dial. C. (Wks.) 1213 F 8, accordyng to Christes woordes : ... whan the son of man shal come agayn, that is to wit, to the daye of general iudgemente, wenest thou that he shal fynde faith in the earth? as who say, but a litle. | Passion $1323 \mathrm{C} 2$, as who saye washe it a waye.

According to Einenkel (1916 p. 42) this formula is an imitation of Old French come qui die > Modern French comme qui dirait. It was frequently used in Middle English : 
1303 R. Brunne, Handl. Synne 7046, Alle pat spake of syre Troile Was skraped awey, as who sey oyle. | c 1330 Metric. Hom., Signs of Doom (in Emerson $M^{1}$. E. Reader p. 149 l. 5), 'For hevin and erpe sal passe par, Bot my word passes never mar'. - Als qua sai, ping pat I tell Ne mai na miht fordo ne felle. I a 1340 Hampole, Psalter cxliii, 6, Lorde helde $p i$ beuens and descend ... Aswhasay, we ere in leghtynge ...

As it appears from More's English, the expression lived longer than Einenkel assumes ("findet sich bis in das 15. Jahrh. hinein" "). About the end of the $13^{\text {th }}$ century long forms appear by the side of the short :

1297 R. Glouc. (Rolls.) 24, Severne \& temese; hombre is pat pridde; \& thanne is, as jwo seip, pat pur lond amidde.

In this form il survived into early Modern English :

1550 Bale, K. Jobn $2358, A s$ who sayth, I woulde for pleasure of my persone ... have suche an enterpryse done.

By the side of it the periphractic formula as who should say came to be used :

c 1375 Cursor M. 8611 (Fairf.), Ho turned hir ouer... As qua sulde sat, I knaw na harme.

This also occurs in More :

Passion 1377 Q 2, Lo quolh he the howre is at band and the sonne of man shalbe deliuered into the bandes of sinners. As who should say ...

Of the three variants only as who should say has survived into Pres. D. Eng.; it is, however, somewhat archaic now.

As one would say occurs in :

Passion 1373 E 8, he sayde vnto theim why slepe ye? As one would say, it is no time for you to slepe nowe.

198. In adverb clauses of condition opening with if, and, what and, in case, so, so that, bul if, without or except the short form is used without any exception ${ }^{2}$ ).

If. Last Th. 80 (r 4, If thou thinke this, than wold I wit ... | Dial. C.

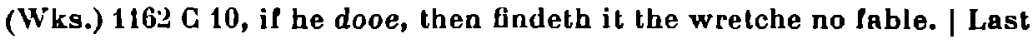
Th. $78 \mathrm{H} \mathrm{4,} \mathrm{yl} \mathrm{he} \mathrm{calche} \mathrm{a} \mathrm{manne.}$

And. Debell. 9:36 G 7, and be seeke thys seuen yere, he shall in all mine apologye finde you no such wordes of mine.

1) OED. has a quotation dated 1611.

2) That is to say, if there is only one clause introduced by one of these conjunctions : Last Th. 89 D 8, either he beleueth not that Christ spake these wordes ... 'sr els yl he beleue that Christ spake them \& yet feareth

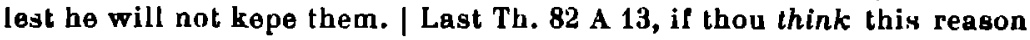
but a sophisticall sotiltie, \& thinkest ... 


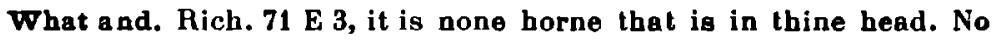
mary $q$ (uod) he, that wote I wol ynough. But what \& be cal it an horn, wher am I then?

In case. Aut. Lelt. $\mathbf{} I 1,77$, lettres sent vnto his Grace ... in commendation of the kinges orators in case the Duke accepte the ordre.

So. Picus $18 \mathrm{C} 12$, so he haue money, he thinketh hymselfe well.

So that. Supplic. 302 B 4 , they may sone perceiue that be nindelh not their almoise, but only the spoile of the clergy. For so that the clergy lese $\left.{ }^{1}\right)$ it, he ncyther deuyseth ferther, nor ferther forceth who haue it.

But if. l'jcus 12 C 9, impedimentes ... : which might feare theo ..., and (but if thou be ware) shall throw thee down hedling. | Dial. C. 208, he is not satisfied, but if he say it againe.

Without. Dial. C. (Wks.) 1153 F 5, good workes to Godward woorketh no man, without God worke with him.

Except. Dial. C. (Wks.) 1171 H 11, he that cannot long endure to hold $\mathrm{vp}$ his head and hure talking of heuen except he be nowe and than betwene ... relreshed with a meri ... tale. | Dial. Her. 141 H 12, Except your iustice abound \& excede the iustice of the Scribes and Phariseis, ye shall neuer come in beauen. | Dial. C. (Wks.) $1179 \mathrm{H} \mathrm{4}$, except any farther thing fal in our wai.

How imperative the necessity of using short forms was in these cases is manifest from the following quolations, in which, in spite of the fact that the sequence of tenses requires the forms ate and bode, the latter are replaced by eate and byde, apparently because forms like ate and bode are unable to express modality $\left.{ }^{2}\right)$ :

Dial. C. (Wks.) 1184 F 15, For he thought that if be eate not that meate, some other beast mighte happe to haue it. | Rich. $49(=46) \mathrm{E} \mathrm{18}$, [she] verely beleueth and knoweth, that they woulde bee as sorrye of his harme as her selfe, and yet would haue hym from her yf she byde there.

The modal influence of if occasionally stretches over two clauses, oue dependent on the other :

Debell. $1001 \mathrm{H} \mathrm{14}$, if there appere manifest tokens that he dooe it not of any corrupt alfeccion.

In view of the fact that More uses the short form only, it is interesting to notice that in Old and in Middle English both

1) This may, however, be plural.

2) For a similar usage in Pres. D. Eng. see Puutsma 1926, xL1x, 3a; he adduces among others the following quotation : " Burroughs, Tarzan of the Apes, Ch. I, 3, She insisted that be accept, and, indeed take her with him". His comment that it is a recent innovation is rendered doubtful by the above evidence from More. Cl. 225. 
forms occurred ${ }^{1}$ ); the long when the conditional clause implied that the speaker held no adverse opinion as to the truth of the statement, the short when the clause implied that the speaker guarded himself from endorsing the truth or realisation of the statement. Alter More's time loo, both forms remained possible (Klausmann 1919 p. 82; Franz 1924 p. 526). In Pres. D. Eng. the short form is characteristic of literary diction.

\section{EARLIER}

LATER

SHOAT FORM.

Beowulf 452, Onsend hizelace $3^{\text {il }}$ mec hild nime (OED).

c 1000 Ag*. Gosp., Matth. Jv, 3, jyf pu godes sunu sy (OED).

1382 Wyclif, Matth. Iv, 3, $3^{\text {if thou }}$ be [1388 art; Tindale und all versions to 1611 be, R. V. art] Goddis sone, say that these stones be maad looues (OED).
1523 Berners, Froiss. Iv, 205, Yea, truely,... so thou do no hurte to any persone in (his house ( $\mathrm{Kl})$. 1534 Tindale Luke, xıII, 9, If it beare not then ... cut it doune (OED).

1611 Bible, John xx, 15, Sir, if thou haue borne him bence [Wyclif, Genev.,Aheims,R.V.hast](OED).

\section{LONG FORM.}

Beowull 447, Ac he me habban wile d(r)eore fahne $z^{\text {if mec deap }}$ nimep (OED).

1382 Wyclif, John I, 25, What therfore baptysist thou, if thou arl not Christ, nethir Elye, nother prophete (OED).
1611 Bible, Gen. Iv, if thou doest [Coverd. do] not well, sinne lieth at the doore (OFD).

1864 Bowen, Logic vi, $\$ 3,165$, If $A$ is true, $O$ is false (OED).

198. In flnal or purpose clauses, opening with so that, that or lest both long and short forms are used.

Dial. C. (Wks.) 1189 G 8, Therefore must you fayre and casely touch hym, and with some pleasant spech awake hym so, that he waxe not waywarde. | Dial. C. (Wks.) 1160 H 15, he wyl that the shipmen shal ... do the best they can for themselfe, that the Sea eate them not vp. I Picus $28 \mathrm{~A} \mathrm{8}$, The lowe that is deuided among many. Unneth suffiseth that euery part haue any.

Dial. G. (Wks.) 1168 G 6, in feare lest he dye not wel. | Picus 17 F 4, If any perfite manne looke vppon his owne estate, there is one peryll

1) Conditional clauses were sometimes construed without conjunction, as in Rob. of Gl., habbe thou power ynow, thou my3t be glad (Einenkel 1916 p. 43). Instances of this idiom have not been found in More. 
therein, that is to wytte, lest he waxe prowde of his vertue. | Picus 22 D 9, wherefore continually vpon thy towre Lest he thee vnpurueid, and vnready catche Thou must with the prophete stande and kepe watche.

There is a unique instance of a form in -en after lest :

Picus 26 G 2, lest we departen hence.

In older Eng., too, the short form was regular; nfter More's time it became less usual; in Pres. D. Eng. it belongs to archaic or poetical language.

Earliea
c 1400 Maundev. Tr. 114, 5, pei brennen bis body ... to pat intent pat he suffre no peyne in erthe to ben eten of wormes (M.).

c 1440 Jacob's Well 121, Turne pi face fro no pore man, pat god turne no $z^{t}$ his face from pe(OED).

a 1240 Lolsong, in Colt. Hom. 209, Ne bi-hold pu ham ... nout leste pu wreoke ham on mo (OED).

c1330 Spec.Gy. Warw. 856, Go, man, while pat pu hast liht, Lest pe of-take pe derke nilt (OED).

\section{LATER}

1523/25 Berners, Froiss. Iv, 53, go thy waye that thou be not founde (KI).

1605 Shaksp. Macl. I, v, 47, Come, thick night, And pall thee in the dunnest smoke of hell that $\mathrm{my}$ ... knife see not the wound it makes.

1606 Shakesp. Troil. 11, iii, 77, lest perchance be think we dare not move the question of our place. 1677 Moxon, Mech. Exerc. 41, Forge your work as true as you can, least it cost you great pains at the Vice (OED).

200. In concessive clauses with front-position of the verb the short form seems to be the rule.

Picus 31 A 11, The louer is of colour dead and palo ... : He mindeth not, what menne about him talke, But eate he, drinke be, sitte, lye downe or walke, He burneth euer as it were with a fire. | Last Th. 78 G 6, For haue be him neuer so fast alore, yet if he breake trom him than, he can after his death neuer geat hym again. | Picus $26 \mathrm{C} 10, B e$ it ioge or paine, endure it shall for euer. | Picus $26 \mathrm{C} 2$, Live he in neuer so prosperous estate, He thinketh him wretched and infortunate. | Dial. C. (Wks.) 124t A 1, walke he neuer so loose, ride he with neuer so strong an aimy ...

The fullowing long form is exceptional :

Instr. $1407 \mathrm{H} \mathrm{13,Thretneth} \mathrm{he} \mathrm{v8} \mathrm{neuer} \mathrm{so} \mathrm{much,} \mathrm{let} \mathrm{vs} \mathrm{not} \mathrm{be} \mathrm{such}$ beastly cowardes, that for his only rude roringe, we fal down flat to the grounde.

In older English the short form was regular. In Pres. D. Eng. this form and the order of words are unusual, except in literary language and in proverbs. 


\section{EARLIER}

a 1250 Owl \& Night. 345, Ne beo pe song neuer so murie ... (OED).

c 1400 Maundev. Tr. xxxir, 151, A man may nozt here anoper, crie he neuer so hie (OED).

\section{LATER}

1611 Bible, Trans. Prel. 4, Sufflcient for a whole host, be it neuer so great (OED).

Proverb : Home is home, be it never so homely.

201. Concessive clauses opening with a conjunction are usually constructed with the short form.

Though. Picus 16 A 9, And so though it lese nothing of the integritie of our perfeccion, yet it leseth of the rewarde. | Picus 20 D 6, though it toy not by and by ... | Picus $18 \mathrm{C} \mathrm{10,} \mathrm{though} \mathrm{honor} \mathrm{faile} \mathrm{...} \mathrm{|} \mathrm{Pageants,}$ Deth 1. 6, Witsafe to sende (though it be to your payne) To me a fole, some of your wise brayne. | Rich. $66 \mathrm{G} 1$, though be paye for nothing elles. | Debell. $978 \mathrm{G} \mathrm{14}$, though it be alledged.

Apparently to obviate the implication of doubt or uncertainty inherent in the short form, More often adds such formulas as " as it is (dolh) in dede" :

Debell. $932 \mathrm{E} \mathrm{13,} \mathrm{though} \mathrm{the} \mathrm{man} \mathrm{do} \mathrm{as} \mathrm{he} \mathrm{doth,} \mathrm{say} \mathrm{contrary} \mathrm{therto}$ himselfe. | Dial. Her, $244 \mathrm{H} \mathrm{4}$, For though it bee as it is in dede, great wisdome for a preacher to vse discrecion ... (Coupare Passion $1270 \mathrm{C} 3$, It it be ... true, as oute of doubte it is euen verye true that $S$. Paule ... sayeth ...).

The long and the short form occur in juxtaposition in :

Last Th. 81 A 6, though it be as sore against the continuance of our nature, \& as sore laboreth to the dissolucion of the whole body as other gicknes do ${ }^{1}$ ).

How. Picus 9 G 6, how be it, this I speake only by coniecture. | Picus 6 B 10, He was content with meane fare at his table : how be it somwhat yet reteyning the olde plentie in deintie viande and siluer vessell.

How soever. Dial. Her. 281 B 11, therfore be we not excusable, if we belieue anye man to the contrarye of the fayth, howe good or howe cunnynge soeuer be seme.

All. Conf. Tynd. $688 \mathrm{G} 11$, all bee il he coulde not saye naye.

The use of all introducing a concessive clause dates from the $13^{\text {th }}$ century (Einenkel 1916 p. 43). It was originally added to the conjunctions if and though to emphasize the supposition or concession, as in (1366 Maundev. II, 13) " zif alle it be so, that Men seyn", but they were later omitted when the idea of concession was expressed by the reversed order of verb and subject, as in (c 1365 Chaucer ABG 46) "Al have I ben a beste".

1) Compare p. 263 , tootnote 2 . We may perhaps formulate the 'rule' that the modal influence of a conjunction does not stretch bejond the conjunction and introducing a second clause. 
In Pres. D. Eng. albeit has become a fossilized phrase; that this state of complete synthesis was not yel reached in More's time is evident from the fact that were could be substituled for be and that by the side of it other pronouns could be used :

Dial. C. (Wks.) $1168 \mathrm{G} \mathrm{12}$, he shalbe welcom, al wer th so that he should come ere the wer wel pourged. | Conf. Tynd. $385 \mathrm{H} \mathrm{11,} \mathrm{All} \mathrm{were} \mathrm{he}$ neuer so olde eare he were baptysed.

In many cases albeit can be looked upon as equivalent to a conjunction synonymous with though. Curiously enough the long forms are more frequenlly used than the short ones in this case :

Last Th. $86 \mathrm{E} \mathrm{3,} \mathrm{albeil} \mathrm{that} \mathrm{wrathe} \mathrm{sometyme} \mathrm{ryseth} \mathrm{vpon} \mathrm{a} \mathrm{wrong}$ done vs. | Last Th. $84 \mathrm{C} 13$, And in worse case be we, then those that be taken \& imprisoned for theft. For thei, albeit their hert heuily harkeneth, after the sessions, yet baue they some hope ...

Dial. Her. 28: H 9, albeit that thys frantike pleanure ... be the only thing that satisfied and contentelh some, yet ...

In older English the short forms were the rule in concessive clauses of the types discussed above. In Pres. D. Eng. they occur in literary language und proverbs only.

\section{EARLIER}

12... Moral Ode 356, Ne mai non vuel ... beon inne gode ricle peb per bep wunienges fele (OED).

a 1440 Sir Degrev. 864, I shal be juste with that duke, Or I gete a rebuke, However that hyt be (OED).

c 1460 Fortescue, Abs. \& Lim. Mon. 30, Albeit that the Frenche kyng's Revenuz be miche greller (OED).

\section{LA'CEP}

1539 Bible, Job xill, 15, Though he slaye me, yet wyll I put my trust in bym (OED).

1848 Thackeray, Van. Fair 1, vii, 71, I'll beat 'em, thougb it cost me a thousand guineas $(P)$.

Proverb : Though the sore be healed, yet a scar may remain.

202. In clauses of concessive alternative the short form is used.

Picus 31 C 8, whither his loue be with him or elsewhere, Oft from his eyes there falletb many a tere. | Dial. Her. $166 \mathrm{G} 5$, Nowe quod I this man that God byddeth you go to ... will it make any change ... whether it be man or woman. | Debell. 995 G 7, which whyther he graunt or no, yet very true it is.

In older English the short forms were more usual than the long; in Pres. D. Eng. the short form is still fairly common. 


\section{FARLIER}

c 1380 Wyclif. Sel. Wks. 1, 3:21, pat pis world is belcrid bi every ping pat lallip perinne, where that it be good or y vel (OED).

\section{LATER}

1678 Buller, Hud. IrI, ii, 174, For Loyalty is still the same, whether it win or lose the Game (OED).

1885 Mason, Fng. Gram. § 507, Whether he succeed or fall, it will not matter to me.

203. In clauses of result both forms are used.

Dial. C. (Wks.) $1160 \mathrm{E} 2$, if euery kynde of tribulacion be so profitable that it be good to haue it as you saye it is, I cannot see. | Dial. C. (Wks.) $1161 \mathrm{G} 2$, And than bogrynneth be to thynke that it were good to make sure and to be mery, so that he be wyse therwith. | Dial. (Wks.) C. 1190 $\mathrm{C} 12$, if the diuel be yet so subtyl, that he kepe bymself close in hys warme denne. | Rich. $49(:=46) \mathrm{G}$ ? , For if she caste suche fonde doubles, that shee feare his hurte : then will she feare ...

Apol. (Wks.) 854 F 2, a iuggeler that conuayeth bys galles so craftely, that al the lable spyeth them. | Dial. C. (Wks.) 1190 F 11, For whych he is so ioyful, that he fyrmely purposeth vpon it.

This is in accordance with the usage in earlier English (Morgan Callaway 1934). In Pres. D. Eng. long forms or constructions with auxiliaries are the rule.

\begin{abstract}
EARLIEA
1340 Ayenb. 53, pe ilke ... willep hyealde hire fole uela 3 redes, zuo pet hi ne conne ne hi ne moze healde mesure (OED).
\end{abstract}

\section{LATER}

1523/25 Brrners, Froissart u1, 259, he shulde so deale, that he here no more tidinges of displeasure towarde therle.

idem Iv, 204, Nat so hardy that thou take any thynge that is myne.

In the second halves of the following syntactical units, which may be looked upon as equivalent to resultative clauses, only short forms are used :

Dial. C. (Wks.) 1328 G 7, Breake one of his commaundementes, and break al. Forsake one poynle of hys faythe, and forsake al.

Still possible now.

\section{General note on the modality of the present tense.}

In the frequent use of the short forms to (help to) express modality More's language shows more agreement with the usage before 1500 than with later practice, especially in Pres. D. Eng.; the abundance of short forms gives an archaic character to More's style. 


\section{THE PRETERITE}

\section{FORMS}

$\begin{array}{llll}205 & \text { I } & \text { saw(e), despysed, } & \text { was, wer(e) } \\ \text { thou } & \text { sawest, despysedst, } & \text { wast, wer(e) ') } \\ \text { he } & \text { saw(e), despysed, } & \text { was, wer(e) } \\ \text { we } & \text { saw(e), despysed, } & \text { wer(e) } \\ \text { you, ye } & \text { saw(e), despysed, } & \text { wer(e) } \\ \text { they } & \text { saw(e), despysed, } & \text { wer(e) }\end{array}$

The majority") of the (originally) "weak" verbs form their preterites by adding -ed (-id) or $d(e)$.

Conf. Tynd. $350 \mathrm{~B} 13$, thero vnto god confessed and asked his mercy. | Hich. $49 \mathrm{~A} \mathrm{4,}$ which he wiste well sho specially tenderid. | Dial. Her. 122 E 6, so lolyd he for worshippers. | Picus 3 A 1 , the verses which be heard once red. I Jest p. 1 A 14, He dacode him vp agayne.

A few instances of other formations follow :

Picus 3 E 13, he fastened and set vp ... Jest p. 4 E 1, Up they hym lift. | Jest p. 4 A 16, vp he starte. | Boke of F. p. \& C 8, Byas, whose countrey lackt defence. I Hich. $42 \mathrm{G} 2$, as sone as they came in his presence, they lighte adowne.

Bailded occurs in Cont. Tynd. $693(=663) \mathrm{H} 6$, the same holye man buylded therupon the selfsame buylding.

A good number of verbs appear in two or more forms :

Conf. Tynd. 349 F 9, red; idem 349 E 12, redde; Conf. Tynd. 349 H 1, sayed; idem 350 B 8, said; Conf. Tynd. 563 E 14, mist; Debell. 983 B 10, myssed ${ }^{3}$ ); Last Th. 102 G 1, went ${ }^{3}$ ) (=thought); A pol. (Wks.) 920 E 12, wend ${ }^{3}$ ); Picus 22 A 3, tempt ${ }^{3}$ ); Picus 24 C 7, tempted ; Dial. Her. 105 F 9 , passid; Debell. 979 D 2, paste ${ }^{3}$ ); Dial. Her. 267 D 3, meaned; Conl. Tynd. 563 E 8, ment.

Was, instead of were, is used with a plural subject in :

Dial. Her. $156 \mathrm{G} \mathrm{11,} \mathrm{the} \mathrm{preceptes} \mathrm{that} \mathrm{he} \mathrm{gaue} \mathrm{by} \mathrm{mouth} \mathrm{was} \mathrm{thre.}$ Dial. Her. 227 F 6, Than was all holye orders in hygh honour. | Dial. Her. 229 D 6, Saint Poule, whose epistles ... coas peraduenture not comen to the handes of other apostles.

The singular form of the verb in the last of these three quotations may be accounted for by taking epistles as the title of a book.

1) E. g. Conl. Tynd. 728 E 13, Diddest not thou tell me ... that thou wer at her graue thy self?

2) Fur a comprehensive survey of the different lorms see Grūnzinger $1909 \$ 5223$ ff.

3) Past participle. 
206. There are a few cases in which the ending -th is printed where -ed might be expected, and conversely -ed where - th would seem to be more consislent ${ }^{1}$ ) :

Dial. Her. 225 F 10, The most benigne father most mildely made answere. And linally he fynished \& endeth bys booke as it were with a Gloria patri. | Dial. Her. $282 \mathrm{H} \mathrm{9,} \mathrm{albeit} \mathrm{that} \mathrm{thys} \mathrm{frantike} \mathrm{pleasure} \mathrm{...}$ be the only thing that salisfied and contenteth some. I Conf. Tynd. 418 D 9, Tindal either euyl perceyueth my wordes, or els euil remembred

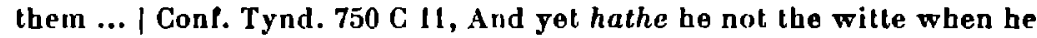
sawe the matter in the lother mannes boke before hin, yet hadde be not I saye the witte well to perceiue it ... | Conf. 'Tynd. 674 E 5, Luther and he wene that ... they lye al in a sleepe slyll ..., \& therefore Tyndall bidded vs praye to them ... | Cont. Tynd. $695 \mathrm{H} 5$, And that Godde helpeth vs forward ... apperclh by clere textes ... As where he sayth, woe be thou Chapbarnaum ... And also where he sayd vnto Hierusalem ... And where he biddeth saynct Thomas ... | Answer $1092 \mathrm{G} \mathrm{9}$, in the firste parte Christ sheweth what be would gyue them to eate,... and in the second part be shewed them why he would gyue the world his fleshe to eate ... | Cont. Tynd. 707 B 14, But then cometh he forth in the ende of bys chapyter, and shewed vs that god euer in the old testament dyd let the greal multitude erre. | Rich. $55 \mathrm{C} \mathrm{1}$, the same morning in which he was behedded, his hors twise or thrise stumbled ... Now this that foloweth was no warning, but an enemiouse scorne. The same morning ... came a knight vnto him ...

If, however 'this that foloweth' means 'the incident described in the following lines', the last quotation is irrelevant.

207. The following list records the form of the preterite and the past participle of those verbs that in Old English belonged to the classes of strong verbs, reduplicaling verbs, preteritopraesentia and ' anomala'.

[When in the references no title is menlioned [e. g. $68 \mathrm{G} \mathrm{5}$ ] the reference is to the 1557 edition of The Works.]

\begin{tabular}{|c|c|c|}
\hline INFINITIVE & PRETERITE & PABT PARTICIPLE \\
\hline $\begin{array}{l}\text { abyde, } 47 \text { E } 12 \text { abide, } 1 \text { D } 5 \\
\text { agryce, } 1215 \text { F } 2 \\
\text { arise, 29 A } 4 \text { aryse, } 20 \text { D } 10 \\
\text { backbite, 15 G } 4\end{array}$ & $\begin{array}{l}\text { abode, Jest } 2 \text { F } 12 \\
\text { abyde, } 281 \text { F } 8\end{array}$ & $\begin{array}{l}\text { abyden, } 207 \text { E } 3 \\
\text { abidden, } 183 \text { F } 10 \\
\text { arisen, } 785 \text { G } 13\end{array}$ \\
\hline
\end{tabular}

(1) Compare the interchange of -th-and - $d$ - in Supplic. 298 B 6, murder; Rich. 47 C 1, murther; Jest p. 4 B 11, logyder; Rich. $51 \mathrm{H} \mathrm{10,} \mathrm{togither;}$ Cont. Tynd. 618 F 14, Bedlem; idem 605 E 4, Bethleem; Boke of F. p. 1 D 6, forther; Jest p. 3 G 7, forder; Picus 2 G 3, fader; passim, father. 


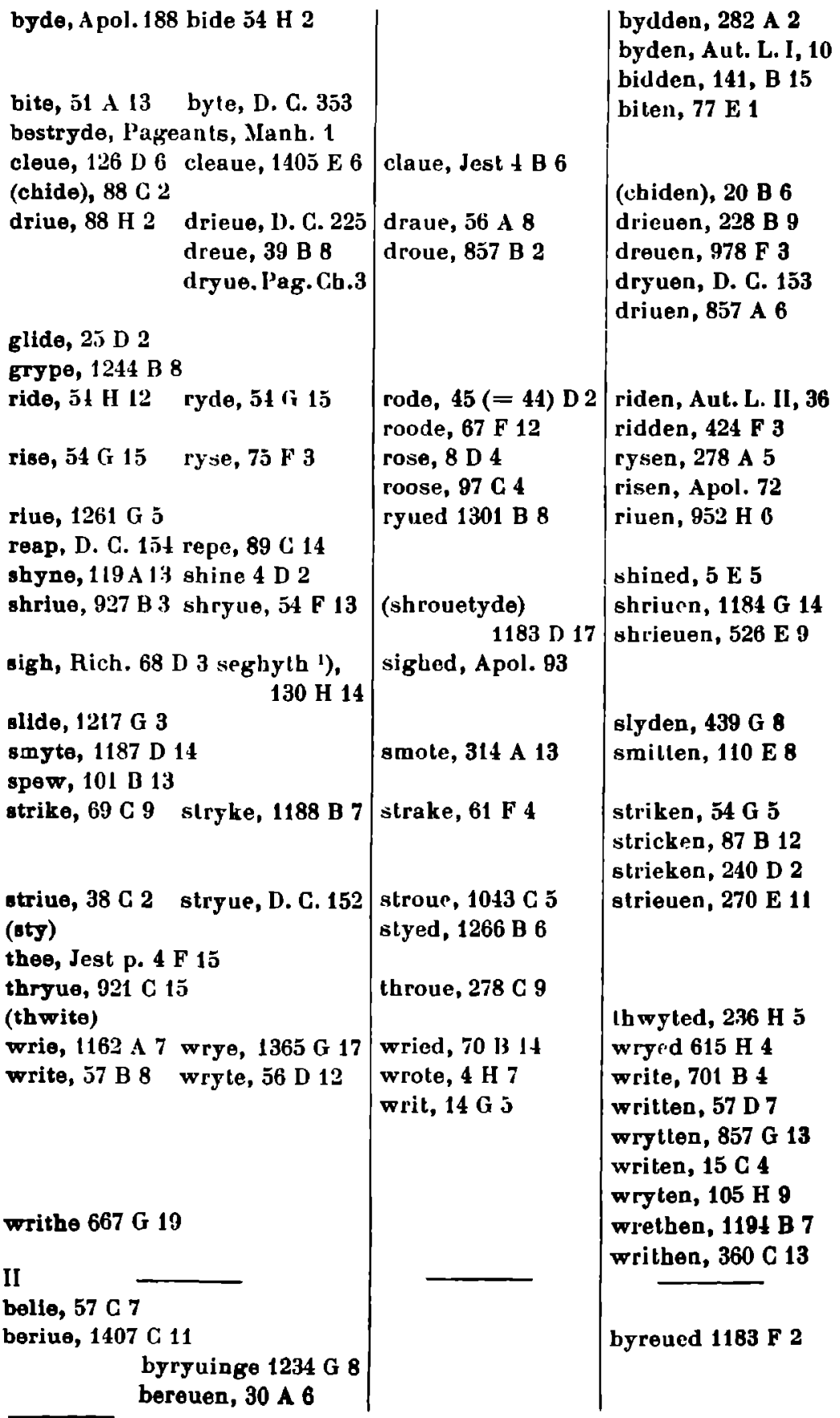

1) Probably a misprint for ayeheth. 


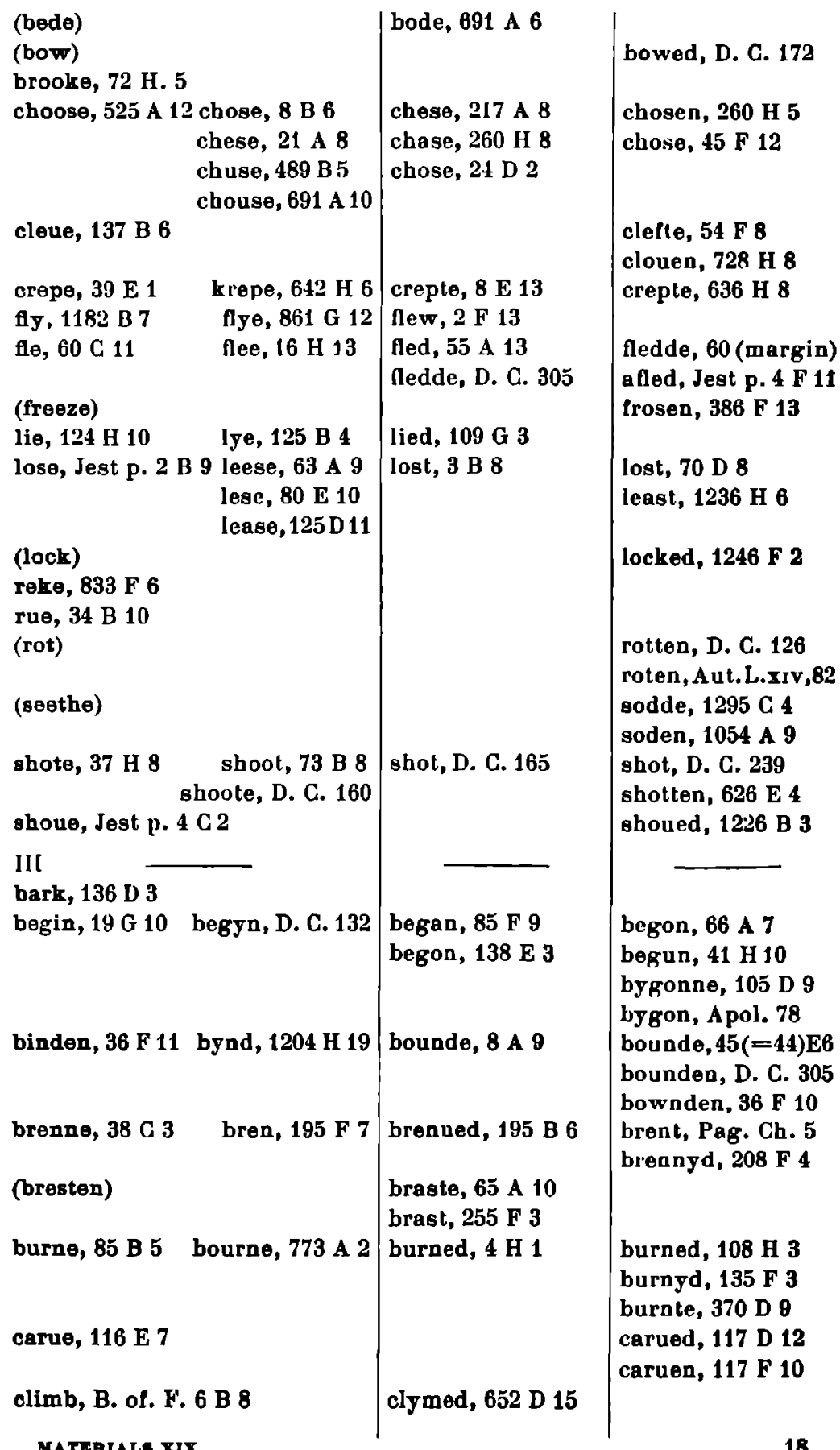




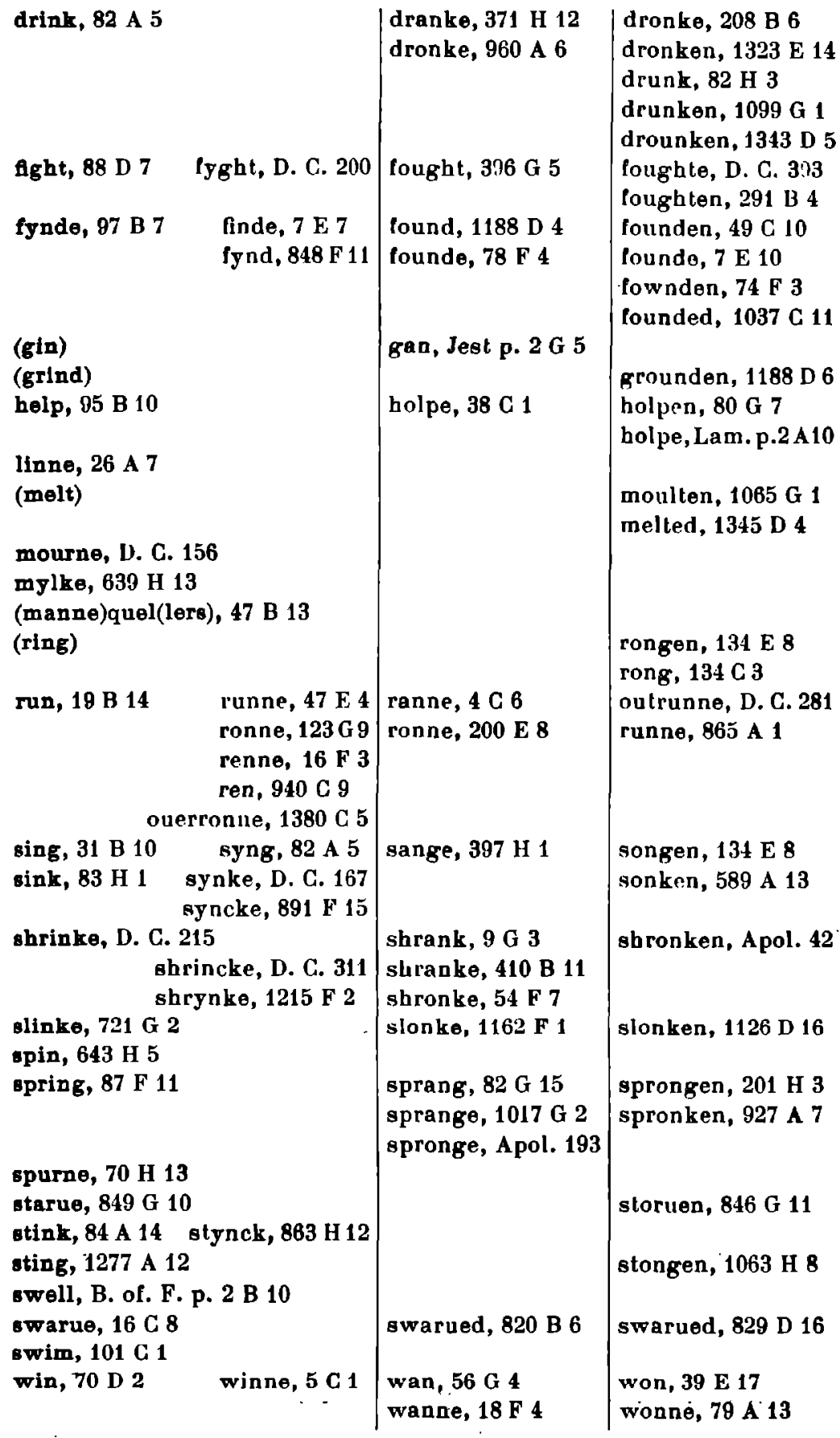




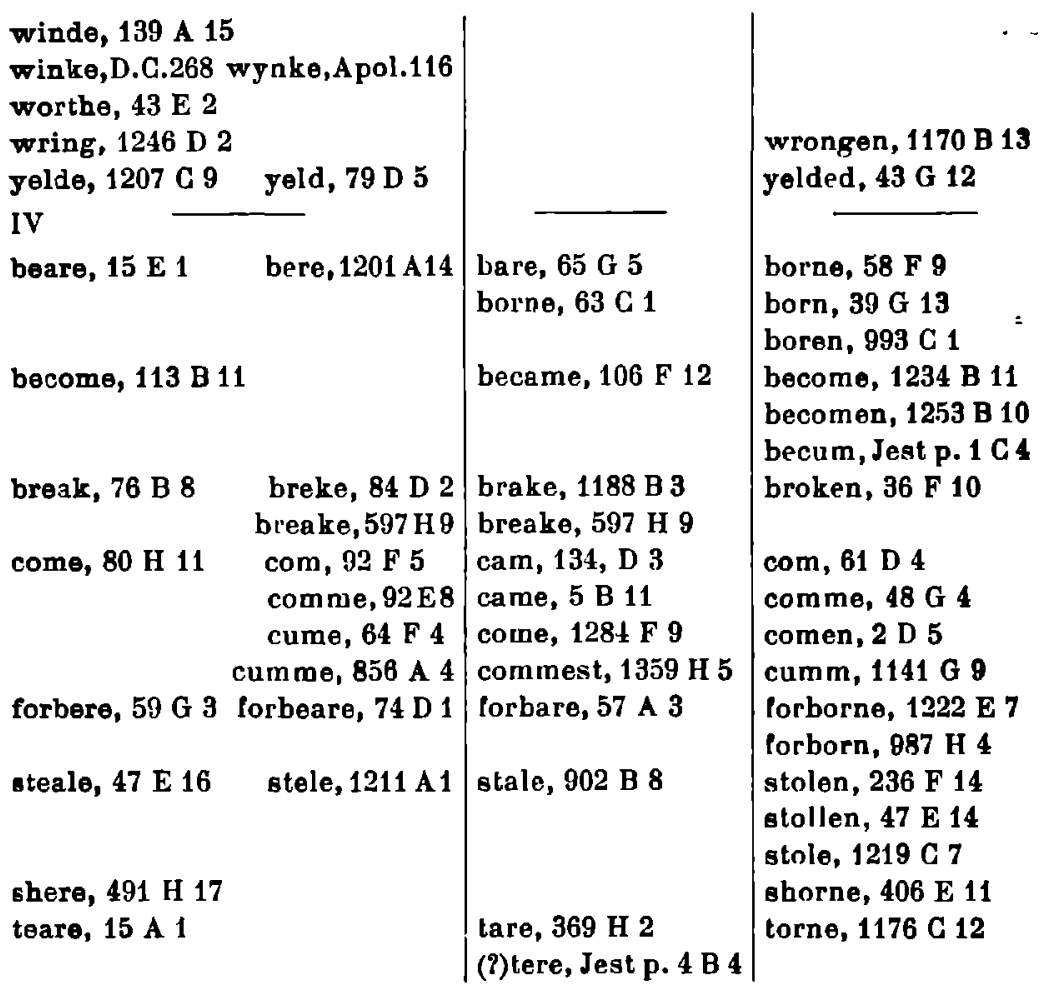

Were, 83 F 11 (weare 338 B 5), originally weak, (O. E. werian) has a "slrong" preterite ware : Cont. Tynd. $369 \mathrm{H} \mathrm{14,} \mathrm{the} \mathrm{self} \mathrm{same} \mathrm{cause} \mathrm{for}$ whiche he ware heere \& slept in a sacke. | Dial. Her. $116 \mathrm{C} \mathrm{7,} \mathrm{he} \mathrm{praied}$ and ware heare. - Also 314 F 8.

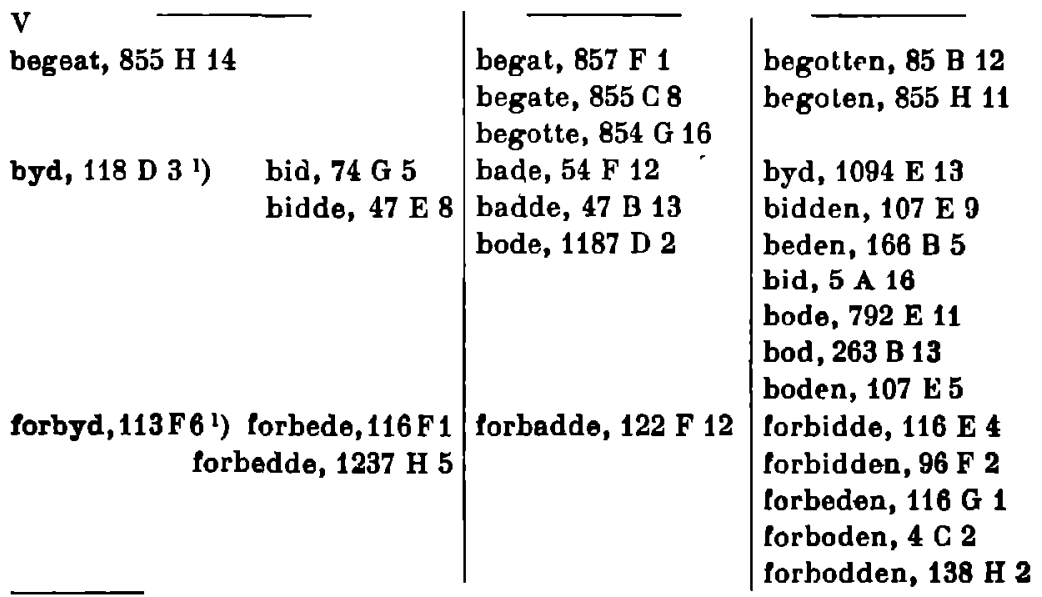

I) It is difflcult to find out which of the forms originally belonged to bede (Class II, OE. beodan) and which to bidde (Class V, OE. biddan). The forms and senses were already confused since about 1400. 


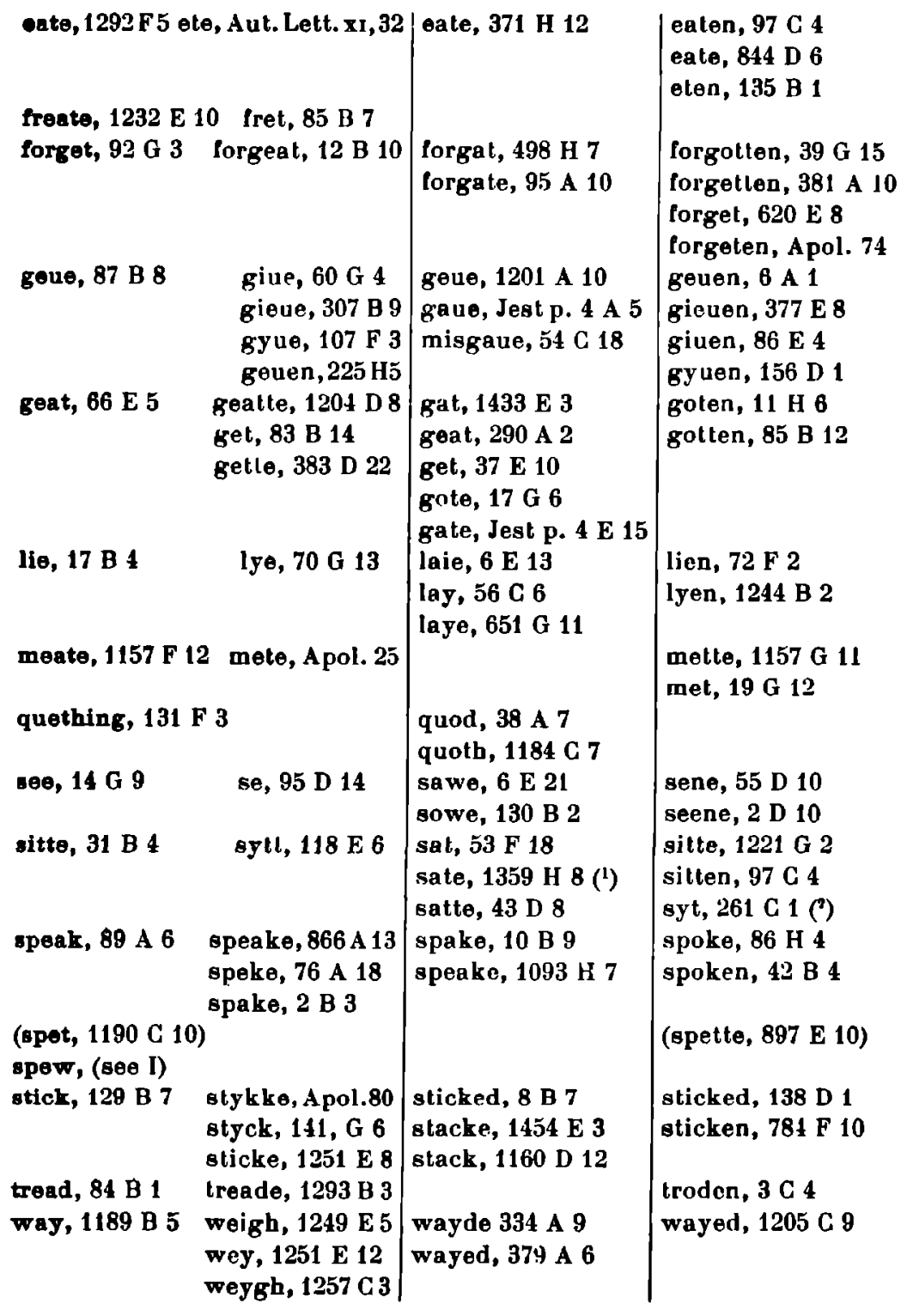

(1) Passion 1191 D 5, whan the howre was come, he sat hym downe at the table. | idem 1307 A 15, when the houre was com he sette downe at table. | idem 1321 D 17, he sat downe at the table.

(2) Passion $1313 \mathrm{H} \mathrm{11}$, whan he was sette downe agayne at the table. | idem 1317 B 12, when he was eet at the tahle agayne. 


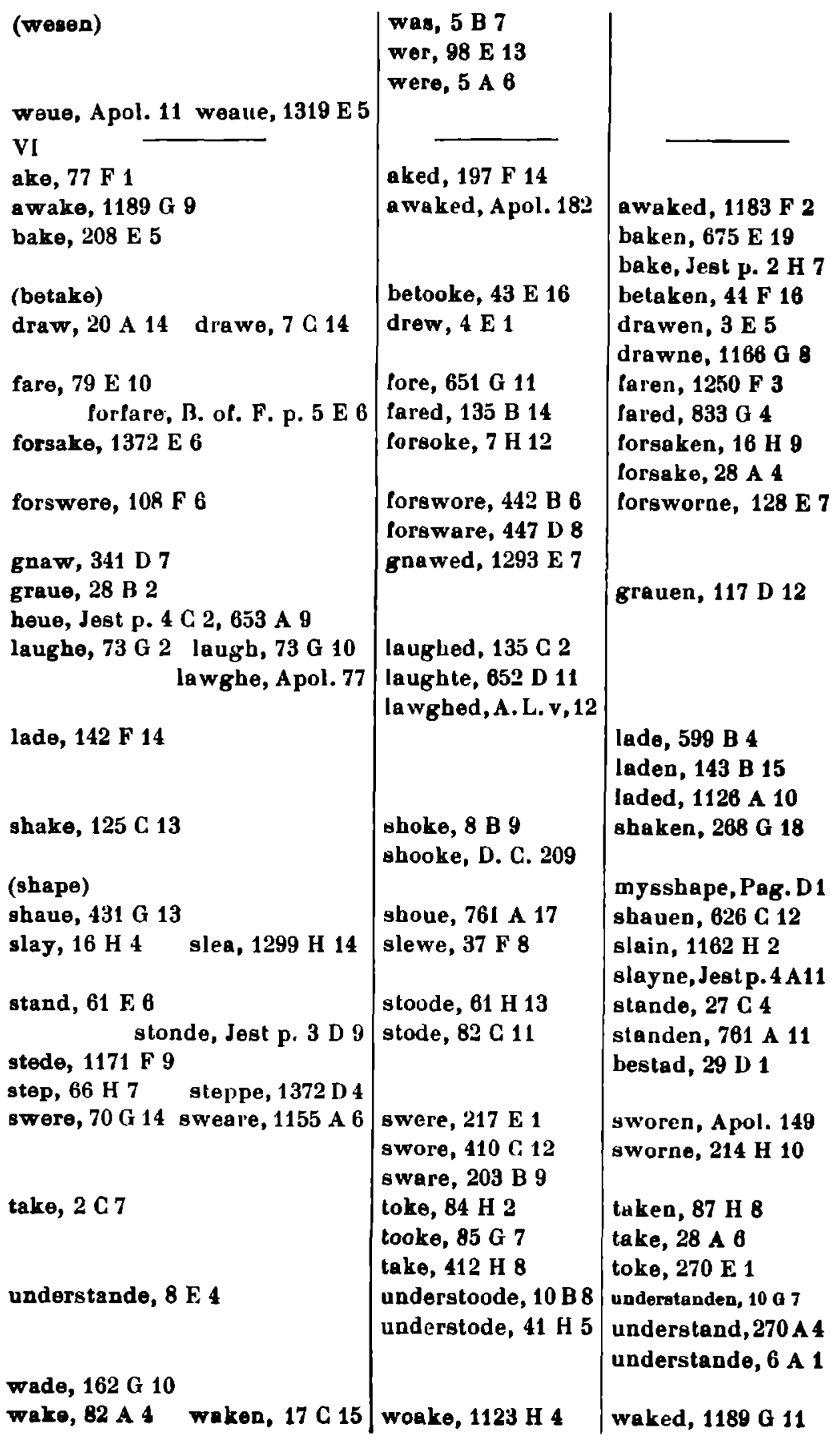




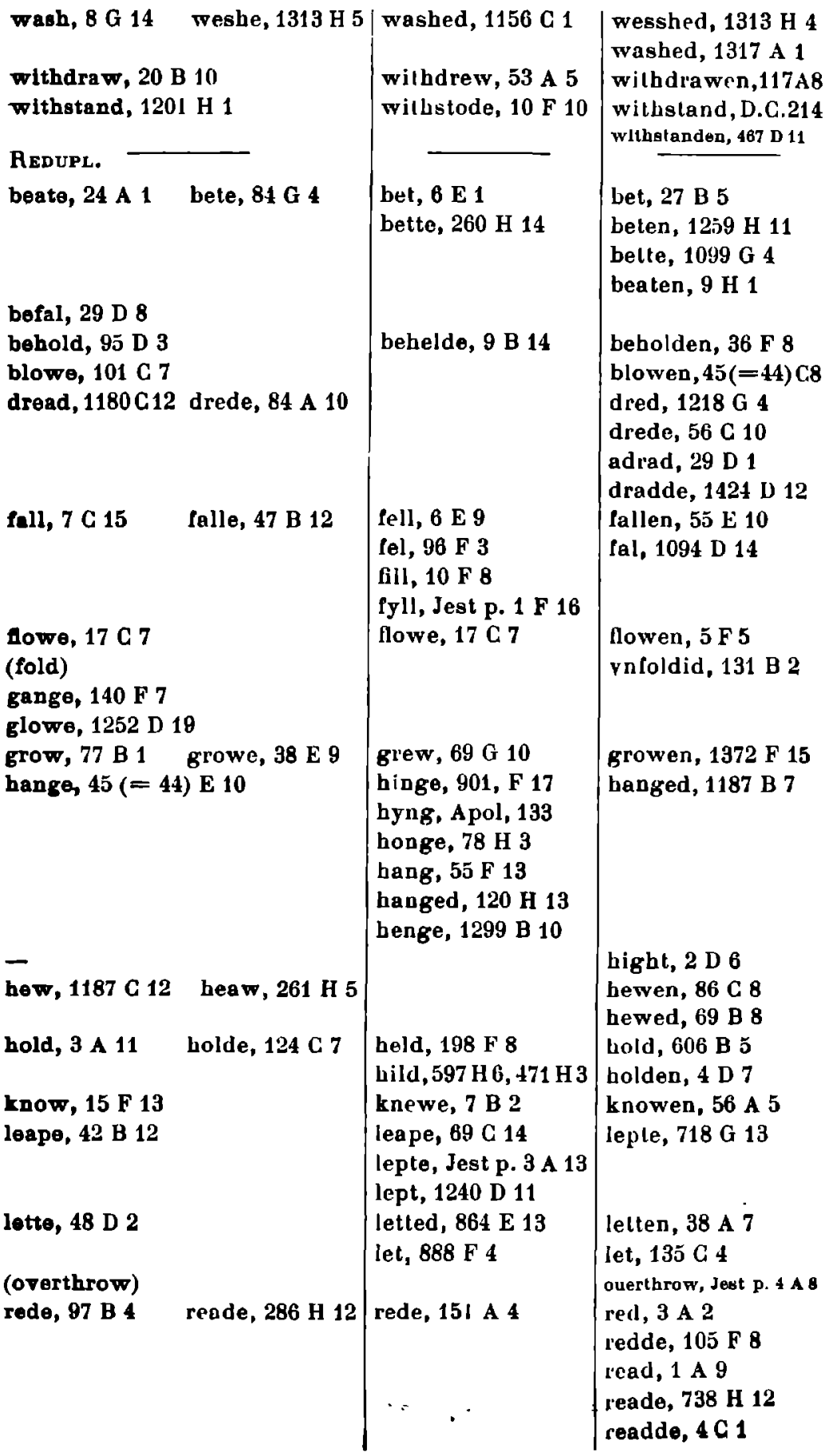


sheade, 385 F 13
show, 57 D 3 shew, 1205 C 13
sleepe, 1183 F 5
sow, 89 C 15
throw, 17 G 1
wield, 96 H 9 weild, 1237 F 10 walk, 126 A 9 wax, 83 D $5 \quad$ waxe, 83 C 12

wepe, 73 H 7 weep, 1154 G 6 Praeterito-praesentia

can, Jest p. 1 B1 canne, 864 F 10 con, 695 G 5 conne, $154 \mathrm{E} 2$

male, 11 G 7 may, 19 F 11 now, $885 \mathrm{C} 1$

mote, 139 A 2; 339 E 15 owe, 252 D 11 ; 78 D 13; 979 D 20 wete, 141 D 9 wette, $125 \mathrm{E} 1$ wit, 63 F 6 witte, $35 \mathrm{C} 3$ wylting, $40 \mathrm{~F} 10$ wote, 586 A 3 wotle, 866 B 15 wot, $12 \mathrm{G} 2$

shal, 86 D 3 shall, 12 B 18

daro, 48 A 12

$\begin{array}{ll}\text { Anomala } & \\ \text { be, 15 G } 7 & \text { bee, 45 D 10 } \\ & \text { bene, 20 F } 4\end{array}$

shedde, 393 D 16 shede, 8 H 2 shewed, 1205 B 3 slept, 69 C 12 sowed, 1154 H 3

threwe, Jest p. 4 F 4

walked, 849 E 1

waxed, 51 A 12

wepte, 42 F 5

coud, 262 G 13 coude, 164 E 10 could, 263 B 1 coulde, 43 F 6 might, 9 B 10 mought, 78 A 11 muste, 1222 E 4 ought, 40 D 3 wist, $37 \mathrm{C} 1$ wyst, $5 \overline{5}$ F 12 wiste, 1224 G 7 waste, $51 \mathrm{D} 12$

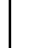

shold, 1247 \& 8 should ('), 87 C 1 shoulde, 245 F 3 sholde, Apol. 118 shuld, 987 A 6 shoold, 40 C 15 durst, $176 \mathrm{C} 1$ durste, 1182 B 12

was, 5 B 8 wer, 98 E 13 shedde, 834 B 14

shewed, 151 A 3 slept, 101 B 15 sowen, 1020 B 10 sowed, 1154 H 3 throwen, 7 D 2 ouerthrow, Jest p. 4A walked, 1202 H 8 waxen, 40 A 12 waxed, 1279 F 1 waxe, 368 E 15 bewept, B. of. F2 D8

coulde, $975 \mathrm{C} 11$ canned, $1210 \mathrm{~B} 8$ vncouth, 1237 F 10

mought, 107 H 1 ) $7 \mathrm{G5}$

(owne, 132 C 13) wist, $132 \mathrm{C} 13$

) $176 \mathrm{E10}$

) $252 \mathrm{D} 3$

wyste, $164 \mathrm{G} 2$

(') Sould in the following quotation represents the faulty pronunciation of " an Almaine of mine acquaintance " : Apol. (Wrs.) $895 \mathrm{H} \mathrm{7,}$ Fare to sould te laye men fasten, let the prester fasten. (= Whereto should the laymen fast, let the priests fast). 


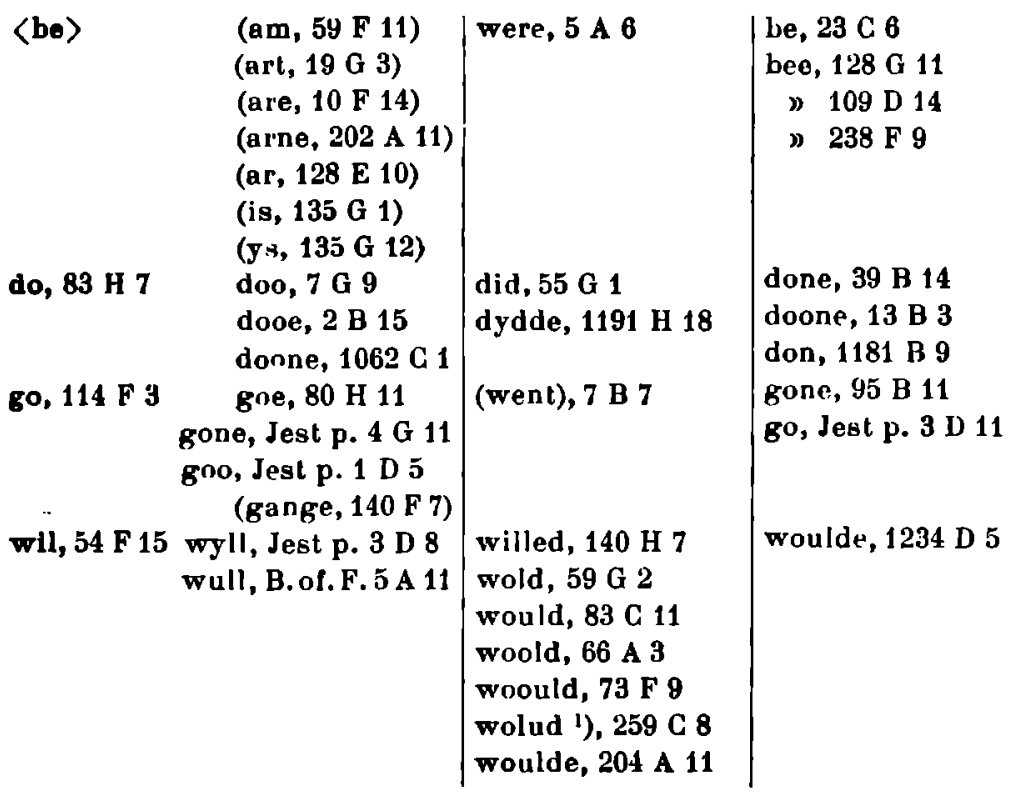

\section{TIME-SPHERE}

208. Past trme. - A great number of syntactical units in which a preterite occurs, denote an action that took place in the past, without any connection either in thought or result with the present ${ }^{2}$ ).

Rich. 69 B 4, Sir James Tirel dyed at Tower bill, beheaded for treason. | Rich. 35 D 11, This noble Prince deceased at his palice of Westminster. | Picus 2 D 8, the wonder that appeared before his byrthe. | Picus 7 F 14, His high stewarde came on a time to him. | Dial. C. (Wks.) $1170 \mathrm{~A} \mathrm{13,} \mathrm{betwen} \mathrm{you} \mathrm{and} \mathrm{me} \mathrm{it} \mathrm{fared,} \mathrm{as} \mathrm{il} \mathrm{did} \mathrm{once} \mathrm{belwene}$ a Nunne and her brother.

This usage is common to all periods of the English language $\left.{ }^{3}\right)$.

1) Occurs only once : probably a misprint.

2) For the use of $t o$ have + past $p$. in this case see $\S 592$.

3) A curious (esp. if compared with the Biblical texl II Cor. xı, 24 s.) coordination of the preterite with combinations consisting of have + past participle occurs in the following quotation :

Dial. G. (Wke.) $1259 \mathrm{H} \mathrm{9,} \mathrm{of} \mathrm{the} \mathrm{Jewes} \mathrm{hadde} \mathrm{I} \mathrm{.v.} \mathrm{times} \mathrm{.xL.} \mathrm{stripes}$ saue one, thrise haue I ben beten with roddes, once was I sloned, thryse have I ben in shipwrack, a day \& a night was I in the depth of the sea... 


\section{EARLIER}

Beowulf 2611, he usic garwigend gode tealde (OED).

a 1330 Otuel 738, Rouland was so ny, pat alle loure kinges he oy 3 (OED).

\section{LATER}

1592 Shaksp. Rom. \& J. III, iii, 138, But thou slew'st Tybalt.

1929 Priestley, Good Comp. V, II, 163, She spent Tuesday night at Market Harborough.

The following sequences of different forms referring to the same time-sphere are exceptional :

Passion 1313 F 6, And when souper was done, whan the deuyll hadde putte in to the hearte of Judas ... to betraye hym, Jesus knowynge that hys father hadde gyuen him allhynges in to bys handes, ... aryseth fro supper, and putteth of hys clothes, and toke a lynnen clothe and dydde grrde it aboute hym. Than he dydde putte water in to a basyn, and beganne to weshe the feete of hys dyscyples, and wype them with the lynnen cloth ... Than comineth hee to Symon Peler, and Peler sayeth vnto hym : Lorde washest thou my feete? Jesus aunswered...

Dial. C. (Wks.) 1156 B 11, At the poole that the gospell speaketh of besyde the temple wherin they washed the shepe \& they tary to so the water stired I).

As may be seen from the last quotation the preterite was also used (just as in older and in Pres. D. Eng.), when the reference is to an action that was habitually performed or repeatedly done in a period belonging to the past. A few more instances follow :

Picus 4 H 12, Great librairies, it is incredible to consider, with how merueilouse celeritee he readde them ouer $\&$ wrote out what him liked. | Picus 5 D 4, There was nothing passed him of those captious subtillies.

209. Neutral Time. - The preterite is often used when there is no reference to any special time-sphere ${ }^{2}$ ), especially in units stating a general truth or in proverbs, but also in other cases. (For reported speech see $\$ \S 172,173,214$ and 215 ).

a. Rich. $62 \mathrm{G} \mathrm{4,} \mathrm{thys} \mathrm{wote} \mathrm{you} \mathrm{wel} \mathrm{al,} \mathrm{that} \mathrm{whoso} \mathrm{was} \mathrm{beste,} \mathrm{bare}$ alway lest rule. | Dial. Her. 241 A 11, But yet as weomen saye, somewhat it was alway that the cat winked whan her eye was oute.

$\beta$. Last Th. $75 \mathrm{E} \mathrm{2,}$ it should therof folow, that the farther a manne proceded in the parfeccion of spiritual exercise, in the worsse case he were. | Last Th. 88 A 8, who could be angry for the losse of goodes, if he well remembred howe litle while he should kepe them, how sone deth might take them from him. | Apol. (Wks.) 849 G 7, how proueth

1) John V, 2, Ad probaticam piscinam expectantes aque molum.

") Jespersen's " generic preterit" (1922 p. 74) or " gnomic preterite" (1924 p. 250): 
he that poysoned bread wer better than no bread? | Last Th. 75 G 19 , whan folke baue lewe wordes \& use much musyng, ... if the minde be not occupyed well, it were lesse euil ... to blabber on trifles somewhat sottisblye.

The use of the preterite in the quotations of section $\beta$ is due to the modality of the syntactical units. (See $\$ \$ 219-243$.

The usage instanced above is common to the language of all periods, both earlier and later :

a 1307 Thrush \& Night., in Rel. Ant. I, 241, This world were nout $3^{\text {if }}$ wimen nere. | 1599 Shakesp., Much Ado 11, iii, 65, Men wer deceiuers euer. | Proverb : Faint heart never won fair lady.

210. Present Time. - The preterite is also used when the time of the action is contemporaneous with the time of speaking, especially if the action is imaginary, or is represented as an improbability or impossibility (See the sections on modality $\$ \S 219-243$ ).

Picus 31 B 5, He burneth euer as it were with a fre. | Apol. 35, I can not se what nede there were that I shold rayle vpon the clergy. | Picus $1 \mathrm{~F} 1$, which workes I wolde require you gladly to receiue : ne were it, that thei be such, that for the goodly mater maie delite \& please any person. I Hich. $68 \mathrm{D} \mathrm{3,} \mathrm{Alas} \mathrm{I} \mathrm{woulde} \mathrm{my} \mathrm{vacle} \mathrm{woulde} \mathrm{lette} \mathrm{me} \mathrm{haue} \mathrm{my}$ lyfe yet. | Rich. 54 A 9, what were they worthy to haue, that compasse \& ymagine the distruccion of me.

This usage is common to all periods.

211. Future Time. - The preterite occurs in eyntactical units referring to future time, either from the present moment or from a point in the past or in the future; the units mostly denote imaginary facts.

Picus 6 E 10, what so euer sholde happen, ... he could neuer as him tbought, be moued to wrath : but if his chestes perished, in which his bokes laie... | Jest p. 2, B 4, In his owne brest, He thought it beat, His money to enclose, Then wist he well, What euer fell, He coulde it neuer lose. | Last Th. $82 \mathrm{C} 10$, And this is true, although ye wer sure that the place of your execucion stode [= would stand] so farre beyond his. Dial. G. (Wks.) $1161 \mathrm{G} \mathrm{2,} \mathrm{And} \mathrm{than} \mathrm{begynneth} \mathrm{he} \mathrm{to} \mathrm{thynke} \mathrm{that} \mathrm{it} \mathrm{were}$ good to make sure and to be mery. | Last Th. $74 \mathrm{G} \mathrm{12,} \mathrm{Long} \mathrm{wer} \mathrm{it} \mathrm{to}$ reherse the places that proue this point. | Suppl. 292 D 2, nor do [we] purpose to cumber you with rehearsal ... of all his lies, for that wer to long a worke. | Rich. $55 \mathrm{D} \mathrm{13}$, Vpon the very tower wharfe so nere the place where his hed was of so sone after, there met he with one Hastinges. | Rich. 59 D 11, albeit he would gladly that she shold take it wel, yet was [he] at a pointe in his owne mynde, toke she it wel or other- 
wise. | Rich. 70 A 15, considered ... in what peril the duke stode if he fell once in suspicion of the tiraunt. | Aich. $67 \mathrm{H} \mathrm{11,} \mathrm{the} \mathrm{thyng} \mathrm{were} \mathrm{right}$ harde that he wold reluse.

This was a common idiom in older English. In Pres. D. Eng. constructions with attendant verbs are preferred, in many cases are even obligatory, e. $\mathrm{g}$. " so near the place where his head would be [instead of was] off so soone after; " in what peril the duke would stand [instead of stode]; "the thing would be hard [instead of were hard], that he would refuse; " that would be [instead of were] too long a work, etc. ')

\section{EA ALIER}

c 1400 Maundev. Tr. 91-30, zif pei dronken it openli pei sholde ben repreued (M).

c 1400 Maundev. Tr. 3-9, But wolde god pat the temporel lordes were at gode acord (M).

\section{LATER}

1897 A. Locke, Derelicts 223 Every caress I gave you would be sin (J).

1904 Andrew Lang, Tennyson 74

It were superlluous labour to point at special heauties (J).

212. The Time-sphene stretcheg from a Point in the Past up to the Present Moment. - Apol. (Wks.) 894 $\mathrm{B}$ 4, the thousande yeare was never the tyme that all so dyd. | Rich. $39 \mathrm{C} 1$, But this wote I well ye neuer had so great cause. | Last Th. $76 \mathrm{G} \mathrm{11,} \mathrm{Though} \mathrm{we} \mathrm{dayly}$ se mon dye, and therby knowe the death, yet our selfe neuer felte it.

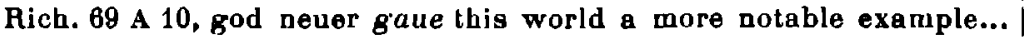
Boke of F. 6 D 1, The rollyng dyse ... ye wote your selle came neuer in myno hande. | Rich. 55 F 14, I was neuer so sory, nor neuer atode in so great dread in my life. | Last Th. $76 \mathrm{G} \mathrm{8}$, Though we haue heard of hel, yet came we neuer in it. | Lett. $1448 \mathrm{~F} 5$, Nor never longed I since I came bether to set my fote in myne owne house, for any desyre of or pleasure

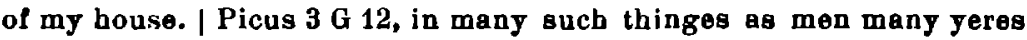
nouer attayned to.

Apol. 42, serche whether the fayth of all the holy sayntes \& of all the whole corps of crystendome thys .xv. hundred yere to gether were trewe or false.

With the adverb never the preterite seems to have been the rule; in other cases More prefers constructions consisting of to have + past participle (See $\$ \$ 588-592$ ) :

Rich, 55 C 2, yet hath it ben of an olde rite \& custome obserued as a token often times ... Poregoing some great misfortune.

1) Contrary to Pres. D. practice, however, would is used in the temporal clause occurring in the following passage.

Passion 1329 F 9, he sayde, that himself would dryncke no more therof, tyl be would dryncke it wyth theym newe in the kyngedome of God. 


\section{This accounts for the use of was and have been in :}

Supplic. 301 G 3, there was neuer yet seene that the spiritual lordes bended them selfe there as a partye against the temporall lordes. But it hathe been seene that the thing which the spiritual lordes moued \& thought resonable the lemporal lordes haue denied \& relused.

Constructions without to have did not occur frequently before More's time. In Pres. D. Eng. they are exceptional or only possible in special cases (Jespersen 1932 pp. 62-63). With the adverb never both constructions with and without the auxiliary are found to-day.

Earlier : c 1400 Mandev. Tr. 202, 11, Of paradys ne can I not speken propurly for I was not there. | c 1400 idem 83, 19, I wente neuer be pat weye (M). | 15.3 Berners, Froiss. III, 3:20, Sirs, quod she, I sawe no man entre into this house this nyght (KI).

Laler : 1605 Shakesp., Lear v, iii, 41, Sir, you haue shew'd me to day your valiant strain, And Fortune led you well. | 1922 Walpole, Dark Folest 33, I determined that I would be satisfled with myself. Well, of course I never was ... never have been (J).

213. The Action occuraed in the Pre-Past ') - Dial. Her. 123 H 2, many Jewes were there, that came lo Jerusalem. / Fich. 37 B 13, [he was] ... bastely drouned in a Butte of Malmesey, whose death Kyng Edwarde (albeit he commaunded it) ... pitiously bewailed. | Lett. 1429 C 1 , I heard also that maister Vicare of Croidon, and all the remenant of the priesles of London that were sent for, wer swurne. | Rich. $41 \mathrm{C} 12$, All the worlde woulde ... say that thei had vnwyselye ... broken the amitie and peace that the king ... so prudentelye made, betwene hys kinne and her's in his death bed. | Picus $4 \mathrm{E} 5$, dispiaing the blast of vaine glorie, which he before desired, now with all his mind he began to seke the glorie ... of Christes churche. | Rich. $69 \mathrm{G} \mathrm{11}$, Some haue 1 heard say, that the duke a litle before the coronacion among other thinges, required of the protector the duke of Herfordes Landes. | Rich. 55 F 9 , That ment he by the lordes of the quenes kindred that were taken belore and should that day be bohedded at Poumfreit. | Picus 9 F 5, he shuld haue excelled... al them that died this . viij. G. yere before him.

Hich. $51 \mathrm{D} 10$, Natheles the lorde Chamberlen (which tro the death of king Edward kept Shoris wife) ... answered and said ... | Dial. Her. 134 F 7 , he ... asked whyther be could neuer se nothing at al in al his life before. | Hich. $5+$ D 8, no man was there present, bul wel knew that his barme was euer such since his birth ${ }^{2}$ ).

I) I. e., the period before the past time of the principal sentence.

?) In the last three quotations (second paragraph) the time-sphere stretcles from a point in the pre-past to the past, as in c 1400 Mandeville, Tr. 58, 32, And pere oure lord heled a man of the palasye pat lay .xxxviij. zeer (M.). 
This usage is very common in More, though in many cases he expresses this particular time-sphere more emphatically by means of a construction with had, e.g. :

Rich. 67 F 8, King Richarde after his coronacion, tokyng hys way to Gloucester ... deuised as he roode, to fulfil the thing which he before had intended. | Last Th. 75 A 9 , they reioysed \& ioyed that god had accounted them wortby for Cluristes sake. | Dial. C. (Wks.) 1234 B 6 , a greate kynge, that hadde so Inder loue to a sermaunte of his, that he had ... forsaken and leafte of all hys worldelye wealthe. | Debell. 931 $H 2$, he the more meruaileth that I would in that boke write arainst any treatise of his, who neuer had anye thing writen againgl any worke of mine. (For further discussion see $\$ \S 59-1-599)$.

In older English the preterite was fairly frequent in these cases. In modern and in Pres. D. Engl. it seems regular after the conjunction after ${ }^{1}$ ), e. g. :

1891 Kipling, Light that F. 7, Dick was silent after le handed Torpenhow the filled pipe; 1901 B. Shaw Cash. B. Pr., he stood motionless after she disappeared.

It occasionally occurs after as soon as, before, until, \&c. :

1893 A. C. Doyle, Adv. S. H. 133, I determined to wait until I got back to town before telling my story to the police.

Here follow a few quotations from works witten before More's time :

13... Pearl 1172, My bede vpon pat hylle wat 3 layde per as my perle to grounde strayd (OFD). I c 1400 Mandev. Tr. 2, 13, See now how dere he boughte man pat be made after his owne ymage (M). | idem, 2, 18, the tree of the cros ... was of pat tree pat Adam ete the appull of (M).

In Shakespeare we find :

Gent. Ir, v, 13, after they cloas'd in earnest, they parted very fairely in iest.

Einenkel discusses this usage in $1916 \S 8$, where he adduces from O. E. :

c 1000 W. S. Gospels, John xr, 21, Gil pu ware her, nare min bropor dead ;

and further from Caxton :

Blanch. 43. 8, (we) shall shewe the manyere that she kept after the kysse that blauchardyn toke of her.

See Caro 1898 pp. 56 ff; Wandschneider 1887 pp. 41 ff; Kellner $1913 \$ 373$; Buffin 1925; V. d. Meer $1929 \S \S 15$ \& 16 ; Koziol 1935 p. 100 ; Johnson 1936 ; Sugden $1936 \S 300$.

1) By some grammarians, however, this is looked upon as not really " correct". 
INDIRECT SPEECH.

214. When the verbum dicendi is a present tense (he says)

a. the present tense of the original statement remains unshifted. See $\S 172$.

b. the preterite of the original statement remains unshifted :

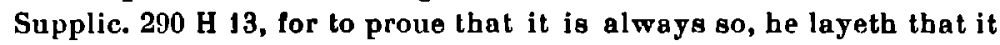
hath been so thryse : and as it shall after bee shewed, he lyeth in all three. The first he layeth that the bishoppe of London was in a greate rage for endyghtynge of certaine curates of extorcyon. | Last Th. $85 \mathrm{E} \theta$, Esop ... as I thynke ye have heard, fayneth that one of the paynym goddes came down into earth.

215. When the verbum dicendi is a preterite (he said)

a. the present tense of the original statement is shifted into the preterite, except in the case of general truths and natural phenomena. See $\$ 173$.

b. the preterite which the reported statement originally contained either remains unaltered or is shifted into a construction with had :

Dial. Her. 134 D 4, [a begger] ... was walking about the towne ... sayenge that he was borne blinde, and neuer sacse in hys lyfe. | Rich. $70 \mathrm{~B} 10$, I haue heard of som that said they $8 a w$ it, that... | Rich. $60 \mathrm{~B} 5$, she sayed his grace spake so louing wordes.

Rich. $71 \mathrm{~A} \mathrm{1}$, euen there he left, saying that he had alredy medled to muche with the world. | Rich. 42 D 7, they sayde that the Lorde Marques hadde entered into the Tower of London.

In the last cases it is, however, diffcult to say whether had medled, hadde entered represent original has medled, has entered or medled, entered.

216. A well-known feature of the language of More and his predecessors was the sudden lapse from indirect to direct speech with retention of the conjunction that ${ }^{1}$ ). The frequent

1) Cases in which only a pair of inverted commas need to be inserted to get regular direct speech are not considered here :

Dial. C. (Wks.) $1156 \mathrm{D} \mathrm{2,} \mathrm{And} \mathrm{in} \mathrm{such} \mathrm{wise} \mathrm{deale} \mathrm{they} \mathrm{wylh} \mathrm{him} \mathrm{as} \mathrm{the}$ mother dolh sometyme wyth her chyld : which when the litle boy wyl not ryse in tyme for her, but lye styl a bed and slugge, \& when he is vp weepeth because he hath lien so long, fearing to be beaten at scoole for hys late commyng thither : she telleth hym them that it is but earely dayes, \& he shal com time inough and biddeth bym [: "] go good sonne I warrant the(e), I haue sent to thy mayster my self, take thy breade \& butter with thee, thou shalt not be beaten at al ["]. 
occurrence of this now unusual practice shows that it was not due to a kind of carelessness on the part of the writer, but rather to a tendency to make the narration more lively. A few instances may sufflce.

Lett. 1454 E 6, Wherto I said, that I was very sure, that myne own conscience so enfourmed as it is ... may stand with my ne own saluacion. I medle not with the conscience of them that thinke other wise ... It was also sayde vnto me, that ... Wherto I answered ... that I haue nol been a man of such holy liuing ... : and therfore I put not my self forward but draw backe. Howbeit if god draw me to it himself, than truste I in hys great mercy, that he shall not fayle to geue me grace and strength. In conclusion maister Secretarye sayde ...

Lett. $1430 \mathrm{~B} \mathrm{8,}$, To that I aunswered, that if there were no mo but myselfe upon my side, ... I woulde be sore afraide to leane to mine owne minde only against so many. But on the other side, if it so be, that in some thinges for which I refuse the othe, I have as I thinke I haue, upon my part as great a counsail and a greater to, I am not than bounden to change my consciens.

Dial. C. (Wks.) 1259 H 3, saynte Paule ... sayth of bymself that he hath ben ... in manye labors, in prisons ofter then other, in strypes aboue measure, at point of death often times, of the Jewes hadde $I$ .v. times .xL. stripes saue ove, lhrise halle I ben beten with roddes, once was $I$ stoned ...

Lett. 1452 G 5, I aunswerde, that I geue ${ }^{1)}$ no manne occasion to bolde any poynt one or other.

Lett. 1452 B 11, Wherunto he sayde, that lykewyse as the kynges hyghnesse would be gracious to them that he found comformable, so his grace woulde folowe the course of hys lawes towarde suche as he shall fynde obstinate.

Similarly without that :

Hich. 40 D 6, whose blood (quod he) ... was ful vnmetely to be malched with his: whiche nowe to be as who say remoued from the kyng, \& the lesse noble to be left aboute him, is (quod he) neither honorable to his magestie nor to ...

Dial. C. (Wks.) $1253 \mathrm{H} \mathrm{18,} \mathrm{Whereunto} \mathrm{the} \mathrm{tother} \mathrm{hart} \mathrm{aduysed} \mathrm{hym} \mathrm{to}$ Aye no farther, leste the bitche might happen to finde him again,... : and so shold he be kild lying, where he could not styre him. Wheras if hè wold turn \& fight, he wer in no peril at all. For the man with whom she hunteth, is more then a myle behind Ler, and she is but a little body scant half so much as thou.

This idiom traces back to the oldest times and is often met with in Gothic (e. g. Mark III, 22, Iah bokarjos pai af Iairusau-

1) Geue may, however, stand for gaue, since the passage continues : nor neuer gaue anye manne aduise or counsaile. 
lymai qimandans qepun patei Baiailzaibul habaip jah patei in pamma reikistin unholpono uswairpip paim unhulpom); it was not infrequently used in Old English (Huchon 1923 p. 279, Gorrell 1895 p. 130) :

c 897 Alf'ed, tr. Orosius (in Sweet, A. S. Reader iv, 2), He cwæp pet he bude on pæm lande norpweardum wip pa Westsæ. He sæde peah pæt pæot land sie swipe lang norp ponan; ac hit is all weste ...

Neither was the idiom rare in Middle English :

c 1386 Chaucer, Prol. C. T. 500, And this figure he added eek ther-lo, That if gold ruste, What shal Iren doo?

c 1400 Mandev., Tr. 196, 29, And panne pei asked him whi he was so proud \& so fierce \& so besy for to putten all the world vnder his subiection, right as pou were a god \& hast no terme of thi lit, neiper day ne hour. And wylnest to haue all the world at thi commandement ... (M). 1470-85 Malory, Mort d'A. 98, 35, Merlyn late wryte balyns name on the tombe with letters of gold, that here lyeth balyn le Saueage.

\section{ASPECT}

217. Since the first kind of aspect (Aspect I \$\$ 174-179) is inherent in the meaning of the verb, it does not change with the time-sphere of the syntactical unit, so that for instance both he catches and he caught are terminative. It has therefore been thought unnecessary to add examples of inchoative, durative, or terminative aspect of sentences containing a preterite to those given of the same kinds of aspect in sentences containing a present tense ${ }^{1}$ ).

The second kind of aspect (Aspect proper), however, deserves further treatment here, as it touches the structure of the predicate in syntactical units the time-sphere of which lies in the past.

218. In continuous narration events happening one after another necessarily have a perfective aspect. In More's language, just as in earlier and later English, we always find the preterite (and not a construction consisting of to be $+\ldots$ -ing) in this case.

1) A clear example of ingressive stood occurs in : Rich. 61 E 3, The protector ... went thorow the people into the place where the doctor. comonly stand in the vpper story, where he stode to hearken lbe sermon. 
Bich. 43 F 7, Then was there greate commocion and murmure aswell in other places about ... And somme Lordes ... assembled in sundry coumpanies, and went flockmele in harneis. | Rich. $45(=44) \mathrm{E} \mathrm{11}$, When the kynge approched nere to the citie, Edmonde Sha ... and all the other aldermenne... receiued hy reuerenllye... and accoumpanyed hiut in to citye, whiche hee entered the forwth daye of Maye.

If, however, the speaker looks upon a past action from the inside, i. e. from a position within the time-sphere of that aclion, so that he sees the action proceed from past to present or future (or, as Curme 1933 p. 375 puts it, as an unfolding event), and not as a completed whole, imperfective aspect is the result. In Pres. D. Eng. it has become usual to express this aspect by using a to be + -ing construction, e. g. Vachel, Spragge 164, 'An hour later, they were calmly fishing as if nothing had happened.'

This usage was not unknown to More :

A pol. 134, whyle the man was in betynge, I spied a lytle purse of his hangynge at his doubletle. | Rich. 45 $(=44)$ B 1, disturbynge the Kynges Coronacion, towarde whiche the Dukes were commynge vppe. |Dial. G. (Wks.) $1155 \mathrm{G} \mathrm{2,} \mathrm{two} \mathrm{disciples} \mathrm{that} \mathrm{were} \mathrm{goyng} \mathrm{into} \mathrm{the} \mathrm{castell} \mathrm{of}$ Emaus 1).

Yet there are in his English writings many cases in which this aspect remains latent and is consequenlly not expressed by means of a special verb-group; they contain preterites and the imperfectivity of the nction can only be inferred from the context or the situation. In the majority of the following quotations, if not in all, Pres. D. Eng. would prefer the to be + ing construction.

Picus $8 \mathrm{D} 5, . . . \mathrm{god}$. In tho loue of whom he so feruently burned that on a time as he walked with John Frauncis ... in an orchard at Farrare ... he brake out in to these wordes... | Picus 6 E 17, he considered, that he laboured only for the loue of God. | Rich. 51 A 11, The lord Cardinall perceiuing that the quene waxed euer the lenger the farder of, ... he said vnto her... | Rich. 53 A 9, While some for their busines made sute to them that had the doing, some were by their frendes secretly warned... | Rich. 54 F 8, for as shortely as he shranke, yet ranne the blood aboute his eares. | Rich. 64 D 5, not one woorde was there aunswered of all the people that stode before. | Rich. 55 F 12, which he wel wyst, but nothing ware, that the axe hang ouer his own hed. I Picus 2 D 10, there appeared a flerye garland standing ouer the chaumber of

1) For further discussion see the sections on the to be + ing colloeations, \$8 $605 \mathrm{fr}$.

mateRIALE IIX 
hy $\rightarrow$ mother whyle she trauailed. | Rich. $57 \mathrm{G} 10$, then thought the protectour, that whyle men mused what the maller ment, ... it were best hastly to pursue his purpose. | Rich. $71 \mathrm{C} 1$, The fox that saw him run so faste, asked him whither be made al that hast. | Rich. $45(=44)$ D 2, such of the Dukes seruantes as rode wilb the carles of theyr stuffe that were taken... | Dial. C. (Wks.) $1170 \mathrm{E} 10$, So happed it on a time, lhat his wyfe and be together, dyned or oupped wylh that neighboure of theirs, and than she made a mery quarel to him.

EAHLIER

c 900 tr. Bede's Hist. II, xiv 216,

He swa swipe swatte swa in owole middes sumeres (OED).

c 1290 Beket 1544 in S. Eng. Leg. 150 , In pe churche of Caunterburi me pouzle i stod ... And striuede for holi cburche azen pe kinge and his (OEI)).

1200 Ormulum 15556, and he fand $\mathrm{i}$ pe temmple pær wel fele menn, patt saldenn perinne bape nowivt and shep (OED).

c 1386 Chaucer, C. T. A 26.54, And whan that Theseus harde seyn this sighte Unto the folk that foghten thus echon, $\mathrm{He}$ cryde...

c 1400 Mandeville 15, 18, pere he saugh a damysele pat kembed hire hede and lokede in a my rour (M.).

\section{LATER}

1548 Hall, Chron. Henry vill 6 b, Every man toke much hede to them that daunsed (OFD).

1859 Tennyson, Marr. Geraint 385 , While the Prince and Earl Yet spoke together (OED).

$1853 \mathrm{Ch}$. Bronte, Villette, $\mathrm{Cb}$. I, Mrs. Bretton and I sat alone in the drawing-room waiting her coming... My godmoller read the evening paper while she waited, I sewed. It was a wet night; the rain lashed the panes, and the wind sounded angry and restless.

\section{MODALITY}

219. Whenever a preterite is used in a antactical unit the time-sphere of which is not distinctly the past, it helps to express and occasionally emphasizes the modality of nonreality. This usage is met with both in independent and dependent syntactical units.

\section{Independent Units}

220. The prelerite of will is frequently used to express this modality in independent units denoting a wish, mostly with the implication that fulfilment is not expected.

Rich. 49 (= 46) D 8, Woulde God some of the men of bor kynne, were 
women too. | Pageants, Chyldh. 1. 4, would to god these hatefull bookes all, Were in a tyre brent to pouder small.

221. Preterites may also be used to represent an action as existing only in the imaginalion. This usage is found in a) in rhetorical questions and $b$ ) in the apodoses of bypothetical statements.

a) Last Th. $86 \mathrm{~A}$ 1, couldest thou enuy a perpetual sick man ? Rich. $50 \mathrm{~B} \mathrm{9,}$, in what place coulde I recken him sure? | Last Th. $88 \mathrm{~A} 8$, who conlde be angry for the losse?

b) Rich. 71 E 11, In good fayth sir said the bishop if it did, the thing that I was about to say ... could deserue but thank. | Last Th. 88 B 16, of thys wold a man be the more ashamed, yt hee considred in how much peril ... his own life ... is. I Picus 14 C. 5, I had cast awaie bothe cost and labour of my studie, if I were so minded. | Lett. $1431 \mathrm{C} \mathrm{11,} \mathrm{if} \mathrm{I}$ had not ben... at a firme and fast point,... your... letler had not a litle

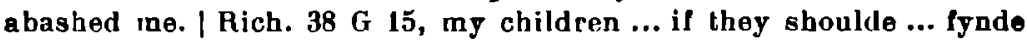
you at varyaunce, myght happe to fall themselfe at warre.

With must :

Hich. 66 B 15, If he woulde geue them a resolute aunswere to the contrarye, whyche they woulde bee lothe to heare, than muste they needes seke ... some other noble manne. | Dial. Her. $141 \mathrm{E} 9$, if I wer in this matter to dispute wilh a Painim ... must it nedes bee a long matter and much entriked or it shoulde come at the end.

\section{Dependent Units}

222. Modal preterites are frequently used in object-clauses after verbs that express a vain wish.

Aich. 63 D 3, Alas I woulde my vncle woulde lette me haue my life yet. | Rich. 53 H 9, woulde God I had some beller thing as redy lo your pleasure as that. | Rich. 39 D J, if the sacramentes of Christes Churche, beare that weighte with vs that woulde Godde thei $d t d$.

223 Attributive clauses with other modal preterites than were, might, could, had, etc., are comparatively rare.

Last Th. 75 D 10, yf they most pleased god, that in the bodily pain of their penance toke lesse spirytuall pleasure, it should therof follow... । Dial. Her. $152 \mathrm{E} 8$, This were in dede a good easy waye for a slouthfull mason that were an euill workeman, to make hym a squier and a ruler of lede, that he ... may bend the squier to the stone.

For further quotations with were see $\$ 231$.

224. Protases of hypothetical statements are freely constructed with modal preterites. All kinds of verbs are used here. 
Last Th. $75 \mathrm{D} 10$, yl thei most pleased god, that in the bodily pain of their penance toke lesse spirytuall pleasure, it should therof follow...' L ast Th. 85 H 5, whosoever enuye enother it is for some thyng, whereof him self wold be proude if be had it. | Last Th, 86 C I3, if we consydered euerye thyng a ryght... we should neuer see cause to enuy anye manne.| Picus 20 C 3, if a man had god alway before bis pies ... be shoulde shortly be perfect.

Occasionally the protasis instead of being introduced by if opens wilh the verb.

Dial. Her. $239 \mathrm{C} \mathrm{9,} \mathrm{wist} \mathrm{I} \mathrm{that} \mathrm{it} \mathrm{were} \mathrm{trewe,...} \mathrm{I} \mathrm{woulde} \mathrm{well} \mathrm{thynke,}$ that ... he hanged himselfe.

225. Equally frequent is the use of modal preterites in concessive clauses.

Aut. Lett. xiv 201, the kinges highnes thinketh that sith his army shall march in hard wether with many sore \& grevouse incommoditees if they shold also forbere the profite of the spoile the bare hope whereof though they gate litle was great encoraging to theym they shall have evill will to inarch far forward. | Lasl Th. $80 \mathrm{E} 11$, of that consumpcion shal we dye in conclusion, for al the medicines that we use, though never other sickenes came at vs. I Apol. 49, to match them therin, 1 neyther can lbough I wold, nor wyll neyther lbough I coulde.

The form lye, instead of liye, in the following passage is perhaps used because lay does not show the modality of the unit (rejected suppositiou) to the same degree as lie does.

Dial. Her. 151 B 8, Such a scabbed itche of vainglory calche they in thrir preaching, that though al the world wer the worse for it, \& their own life lye theron, yet would thei long to be pulpited.

With front-position of the verb and without though : Conf. Tynd. $476 \mathrm{~F} \mathrm{3}$, he shoulde elles fall headlong downe, beliened he neuer so well, and llued he neuer so wel also besyde.

226. In cliluses of rejected comparison the notion of nonreality is strongly pronounced.

Lament., Stanza 1 l. 3, o ye ... That so lyue as ye should neuer hence... | Last Th. 79 B 9, in which the folish sicke man is sometyme occupied, as though he thought that... | Boke of F. p. 2 D 7, Fast by her syde doth wery Labour stand,... His eyes drowsy and lokyng as he slept.

Occasionally the present tense is used here : Conf. Tynd. 627 A 13, he maketh as though he mocke but men of those latter daies.

227. WAS and WERE.

The preterite of to be appears in two forms : was and were (singular). As may be expected, the form was, though as adequate to indicate the modality of the sentence as the 
preterite of other verbs in the cases illustrated, is not nearly so often found as were. Indeed the latter may be called regular, the former exceptional.

228. was. In both the following quotations modal was occurs in the principal unit of a compound sentence; no examples of modal was in dependent units introduced by if have been found $\left.{ }^{1}\right)$.

Dial. C. (Wks.) 1188 H 14, But marye if he made hym first perceyue how he had bene deluded, and then templed hym to hys own dealb bi sharne \& by dispayre, then was it wythin oure maller lo, for then was his temptacion fallen down tro pryde to pusillanimiti, and was waxen that kinde of the nights fear that I spake of, wherin a good part of the counsail that wer to be geuen him, should baue nede to slande in good comforting, for then was he broughte into right sore tribulacion. | Aut. Lett. xIv 204, the kinges highnes thinketh that sith his army shall march in hard wether wilh many sore \& grevouse incommoditiees if they shold also forbere the profite of the spoile the bare hope wherof though they gate litle was great encoraging to theym they shall have evill will to march far forward.

Curme's statement (1933 p. 427) that the use of was " as a past subjunctive" arose in the seventeenth century appears erroneons. His first example is dated 1667 (Pepys Diary, July 12, She told him if he was not a foole he would not suffer his business to be carried on by fools).

229. WERE in object clauses.

Picus 14 E 9, This is farre out of the waie :... to thinke that it were shame to abide stil in the better, and not decline. | Lett. $1423 \mathrm{H} \mathrm{11,} \mathrm{And}$

1) There are a lew inslances of was in clauses opening wilh if, but here if introduces a conceded fact and not a supposition or condition :

Passion $1342 \mathrm{H} \mathrm{15}$, For if the worrde was verely fleshe, and yf we also verely receiue that woorde beyng fleshe in our Lordes meate, how shal he be taughte not to bee in va naturally (= si enim vere verbum caro factum est). | Last $\mathrm{Th} .78 \mathrm{~A} \mathrm{4}$, at that pointe he cryed loude once or twise to his father... Now if that death was so painful ... what intollerable torment wil death bee than to vs miserable wretches. (But compare : A. V., Luke xir, 28, If then God so clothe the grass ... how much more will be clotbe you.)

Was is similarly used in : Lett. 1429 $\mathrm{H} \mathrm{9,} \mathrm{Now} \mathrm{al} \mathrm{was} \mathrm{it} \mathrm{so,} \mathrm{that} \mathrm{in}$ rnine own mind me thought iny sell not concluded, yet... , - Fur al were it see $\$ 201$. 
if that in your so doing, your owne vertuous minde shal giue you ..., that ... I were a wrelche... | Last Th. 79 G 10, Comonly when we bo sick, ... than we think how meri a thing it wer to be prayiug in heallh, which we cannot now do for griep. | Supplic. 290 G 11, be laboureth to make the worlde wene that ther wer no purgatory at all. | Picus 19 Fi 10 , soun man wold paradienture think that it were foly for a man viterly to depriue himself from all pleasures. | Dial. C. (Wks.) 1182 G 10, Eye, what eyleth this gyrle? the eluish vrchin wenelh I wer a diuell I trow.

Dial. C. (Wks.) 1224 C 8, would God I were a manne.| Dial. C. 259, The manne is so much the lesse perfyte than I woulde he were... | Dial. C. 205 , Belgrad which wold God wer ours now as wel as it was then.

230. WERE in subject-clauses, announced by proleptic it in a formula expressing regret, etc.

Lelt. $1447 \mathrm{G} 11$, So was it an heauye hearynge to me, that the kynges grace ... wer likely to conceiue such high suspicion of me.

231. WERE in altributive clauses.

Debell. $330 \mathrm{E} \mathrm{12,} \mathrm{like} \mathrm{as} \mathrm{an} \mathrm{husband,} \mathrm{whose} \mathrm{wife} \mathrm{were} \mathrm{in} \mathrm{ber} \mathrm{trauaile,}$ lierkenelh euerye hand while, and faine would here good tydinges: so ... I longed of their long labour to se some good spede. | Last Th. $72 \mathrm{C} \mathrm{11}$, What would a man geue fur a sure medicin, that wer of such strength, that it should al his life kepe him fro sicknes? | Dial. C. 2200, yf we founde any such religious person, thal wer reputed for a man of singular vertue...

232. WERE in hypothetical statements, eilher in the apodosis or in the protasis.

Picus 16 C 4, conaider ... how much were thy madnes : if thou shouldest for the iudgement of madde men swarue from the good institucion of thy life. | Last TL. $93 \mathrm{E} \mathrm{13,} \mathrm{gret} \mathrm{madnes} \mathrm{wer} \mathrm{it,} \mathrm{if} \mathrm{we}$ would not rather take a short pain for the winning of euerlasting pleasure... | Dial. Her. 224 A 14, so were it ... litle labour... to translate the whole booke al new.

Apol. 6, yt this were vnlrew ... some of them could assign ... some one suche place tor a sample. | Picus 18 E 8 , if these more imperfecte creatures were not, the other that are more perfecte coulde not bee. I Last Th. 76 A 7, yl euer the wind wer emplye, il would bee emply whan the bodye slepeth. But yl it wer than al emply, we shoulde halle no dreames.

Picus 1 F 1, which workes I wolde require you gladly to receiue : ne were it, that thei be such, that for the goodly mater ... maie delite \& please any person. | Last Th. $74 \mathrm{E} \mathrm{9,} \mathrm{I} \mathrm{wold} \mathrm{not} \mathrm{so} \mathrm{long} \mathrm{tary} \mathrm{in} \mathrm{this}$ point, ... were it not that I wel parceyue... 
Exceptionally be is used instead of were : Dial. C. (Wks.) $1161 \mathrm{D} 9$, if it so be as these great learned men ... say ..., than wer ther in his dedes ... sundry degrees and differences of deseruyng ').

After conditional when modal were is not rare : Apol. (Wks.) $867 \mathrm{E} \mathrm{t}$, Some of theym saye, that ... I sette no so little by money, as to refuse il when it were offered.

233. WERE in concessive clauses, both syndetic and asyndetic.

Rich. 59 C 13, the only widowhed of Elisabeth Gray though she wer in al other thinges conuenient for you, shold yet sufflce ... to refrain you trom ber marriage. | Picus 29 A 10, the loner would ... thinke it eke to small, Though it wer death. | Last Th. 82 C 10, And this is true, although yewer sure that the place of your execucion stode so farre beyond his. | Last Th. 81 G 10, he should truelye answer, that he wer goyng out of the towne, al wer the towne so long that he had ten mile to go... | Dial. Her. $167 \mathrm{H} \mathrm{10,} \mathrm{if} \mathrm{any} \mathrm{woulde} \mathrm{after} \mathrm{take} \mathrm{the} \mathrm{contrary}$ waye, were it one or mo, were it fewe or many ... yet can I nothing doubte which parte to beleue.

234. WERE in clauses of rejected comparison.

Picus 31 B 4, eate he, drinke he, sille, lye down or walke, He burneth euer as it were with a fire. I Apol 103, he maketh as though the hole people ... were so inalycyouse. | Apol. 15, And therfore are they content to fynde no fawle at the leugng out of them, but make as though all were in.

235. WERE in temporal clauses opening with ere, etc.

Hich. $53 \mathrm{C} \mathrm{1}$, while one man is there which is neuer thence,... it should be in mine eares ere it were well oute of their mouthes.

236. A special kind of modality is found in those sentences in which the preterite is used instead of the present tense in order to render the statements less apodictic or blunt and more modest or reserved.

Conld. Last. Th. 88 H 9, if yo beleue not me, I coulde fynd ye recurd. Prayer 1418 B 5, beare me good lord thy loue \& fauor, which thyng my loue to theewarde ... could not but of thy great goodness deserue (cl. \$ 509).

Would. Picus 30 D 6, A very louer beleueth ... On whom ... he hath his heart Ibento ... surmounting farre ... All other ... and woulde that

1) Note the incongruity of were and see in : Dial. Her. $282 \mathrm{~B} 2$, if they wer once lond out \& examined, we see them alway first ready to lye and forsweare themselfe, if that will serue. 
euery manne should thinke the same. / Last Th. $79 \mathrm{E} \mathrm{15}$, likiwise as wiues would their husbandes shoulde wene by thexaumple of Sara, that there wer no woman so olde but she might haue a childe, so is there none olde man so olde, but... he trusteth to liue one yere yet. A pol. 56, And now wolde theyr dyscyples that I shold nol speke agaynste theyr execrable heresyes. | Hich. $68 \mathrm{D} 3$, Alas I woulde my vacle wonldo lette mo haue my lyfe yet, though I lese my kingdome. | Dial. C. 25y, The manne is so much the lesse parfyte than I would be were. / Last Th. 83 G 10, Thun arte neyther hote nor cold but luke warme, I wonld thou wele colde that thou mighteat waxe warme. I Dial. C. 185, I woulde I could as easily mende my faulte as I well knowe it.

Wene is also found in this case :

Last Th. $76 \mathrm{C} 11$, betler were it for the while to let one wanton woorde passe vncontrolled, than geue occasyon of twain. | Rich. $48(=45)$ D 12, mee thynketh it were not woorste to sende vnto the Quene..., some honourable, trustye manne. | Last Th. $74 \mathrm{G} 12$, Long wer it to reherse the places that proue this point. I Supplic. 292 D 2, [we] do not purpose to cumber you with rehearsal ... of all his lies, for that wer to long a worke. | Rich. 70 G 13, surely my lord foly wer it for me to lye. | A , ol. 44, it were not good that yonge men sholde wene so. | Dial. Her. 109 II 12, it were wisdom not to call them Lutherans. | Rich. $45(=44) \mathrm{E} 10$, it were alinoise to hang lbem. | Hich. 54 A 8, when be had silten slil a while, thus be began : what were they worthy to haue, that compasse \& ymagine the distruccion of me? | Dial. Her. 138 B 4, lothe wer I to hyt it wilh a ful shot...

In these quotations could, would, were are almost equivalent to can, will, is respectively, but for the element of hesitation or modesty ').

The collocations were good, were better, had liener, elc. are used in a similar way : Dial. G. 255, Some man that hath not two ducates in his house, were better forbeare them bolh and leue himself not a farthing. | Dial. C. 262, They were in manner as good be dead at once. | Dial. C. 286, a man were almost as good lack both. | Rich. 55 B 5, yet had I leuer that men should se...

No instances have been found in More's English of the type : I wanted (=should like) to ask you if... | I called to ask you if you would join us.

237. So far (\$\$ 219-236) all the quotations have served to exemplify the use of the preterite in syntactical units the timesphere of which is not the past. In units with a distinct past time-sphere the preterite has nothing in its form that belps

1) For diarst in this function see $\$ 544$. 
to denote the modality of (hose units ${ }^{1}$ ); the form were (sing.) is the only exception :

Hich. 56 F 17, albeit she were out of al array saue her kyrtle only : yet went she ... fair \& louely. | Picus 3 F' 10, [His enuiours] as it were with priuie trenches enforced to undermine him... | Rich. 4 E 8, and so began he to ordie his condicions, that from thenceforth he might havo ben approued : and thongt his enemye wel'e his iudge. | Dial. C. 169. And what game they came than to, god knoweth and not I. I pray god it wer good, but I feare it very sore. | Picus $7 \mathrm{~F} 3$, shewing him, that it was his dishonestie and rebuke, when it was reported (were it trew or false) that his negligence... rane his seruauntes occasion of disceil and robberie. | Rich. 37 is 8, heinous Treason was there layde to his charge, and flnallye wer hee fitutye were hee faultlesse, attainted was hee by

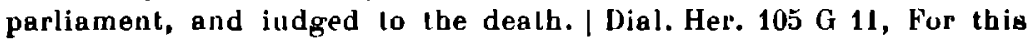
cause me thonght that for the more suerty, my parte were to send our communicacion to my said frende in wrytyng. | Dial. Her. $168 \mathrm{C} \mathrm{4}$, ye both confessed, that neither ... coulde any further thing finde therein, he sayenge still that his waye were? ${ }^{\text {? }}$ the truthe, ... and your self percey uynge in your owne mynde none olher. | Last Th. $92 \mathrm{E}$ 16, Which thing is the cause that our sauiour Christ said it were ${ }^{q}$ ) as harde for the riche manne to come into beauen, as a greal cable or a Camel to go through a nedles eye. | Dial. C. 225, I douled whilter I were a sleepe or a wake. | Rich. $45(=44)$ H 2, the protectoure so soore thyrsted for the Anyshynge of that hee hadde begonne, that thoughte euerye dage a yeare tyll it were alchyeued. | Rich. $55 \mathrm{C}, 10$, The same morning ere he were vp, came a knigltt vnlo him. | Rich. 56 a 15, they were coupled ore she wer wel ripe.

That this usage differ's from that dealt with in the preceding sections (preterite in units whose time-sphere is not the past) appeary among other things from the fact that here a possible substitute for were is not is, bul was. There are, moreover, a few quotations in which the verb, instead of referring to an imaginary action, denotes a fact (e. g. ere he were vp).

238. Notwithstanding the fact that concessive clauses opening with though require the form were, it somelimes

1) Occasionally a special word-order takes over this task : Dial. Her. 163 F 8, that ones knowen, that god telletb them, semed they neuer so far vulikely, nor neuer so lar impossible, I neither shold nor could haue any doute, but that thei were hothe twayne trewe.

2) This is a case of a modal form in reporled speech, a usage common in Old English (and still in Gerraan) : Allric, Homilies I, 16, Nu cwedon gedwolmen pæit deofol gesceope sume gesceafte. | See Curme 1933 p. 417. 
happens that More consciously rejects this modal form in order to stress his belief in the truth of the statement :

Dial. C. (Wks.) $1164 \mathrm{E} \mathrm{6,} \mathrm{thoughe} \mathrm{there} \mathrm{none} \mathrm{was,} \mathrm{nor} \mathrm{none} \mathrm{coulde}$ bee in his most blessed parsone but excellente, and incomparablye passinge the prayer of anye pure crealure : yet his owne not all alyke, but somme one fart'e aboue somme other.

239. It should be noted that the second person singular (thou knewest) never occurs without the ending -st in the cases enumerated above ').

Rich. 55 F 6, Thou wouldest fay so quod he, if thou knewest asmuch as I know, which few knowe else as yet \& moe shall shorlly. | Last Th. 86 B 5, If it so were that thou knewest a great Duke, kepyng so great estate..., that thou being a ryght meane manne, harldest in thyne heart great enuy thereat,... if thou sholdest sodeinly be surely aduertised, that ... he shold vndoutedly be taken the morow ... shonldeste thou not ... chaunge into pily ? / Last Th. 79 G 4, Thou wouldest somewhat remernber death the more effectually ..., yf thou knewest thy self sick, \& specially of anye perilous sicknes that wold make an end of thee, though thou feltest yel lille payne. / Last Th. 86 A 11, I suppose yf there wer one right farre aboue thee, yet thou wouldest nol greally en uy his estate, if thou thoughteste that thou myghteste bee his malche the next weke. | Dial. C. 355, what folly is it then ... to llee trom that deatb, whiche thou seest thou shalle shortelye after wish thou haddest dyed.

The form thou were, however, occurs frequently :

Picus 26 i 7, It thou shouldest god offende, thinke how therefore, Thou were foorthwith in very ieopardous case. Last Th. 81 F 2, Now tel me than if thou wer guing out of a howse whither arte thou goynge out onely whan thy fote is on the vtlermosl ynch of the threhold, or els... | Conf. Tynd. 728 E 13, Diddest not thou tell me... that thou wer ${ }^{2}$ ) at the graue thy self?

1) The ending -(e)st, originally unknown in the preterite (subjunctive) in O. E., is often found in later Old English texts (Siever's 1921 s 365 Anm. 3). In Chaucer the form in -st had already ousted that withoul $-8 t$ to a great extent, e. g. C. T. 554, And thurgh thy dronke nose scmelh the soun As though seydest ay Sampson. (Cr. Kittredge 1891 \$100: "The indicative preterite form in -est is often used in constructions properly subjunctive" and B. ten Brink $1920 \$ 192$ : “ Im schwachen Praet. hat die 2. Pers. Sing. bei Chaucer vielfach die Endung des Indicativs angenommen. ") The short form, however, had not yet enlirely died out by More's time; Dahlheimer 1899 p. 66 registers three instances of thou wolde in Burclay's Shyp of Folys.

2) Another example of a modal form in indirect discourse. See $\$ 237$ note. 
240. Historical Remarks to $§ \S 219-239$.

More's use of the preterite in units not referring to past time to denote or emphasize modality does not differ essentially from that in earlier periods, as may be gathered from the evidence presented below. As regards Pres. D. Eng. it may be said that, whereas literary English has preserved the usage in the majority of cases, the ordinary conversational language has discarded the preterite in almost every case (exc. after if ; for were and modest statements see $\$ \S 241-3$ ). Even in literary English some cases are rather exceptional, e. $g$. in the apodosis of a hypothelical statement with other verbs than would, could, etc. (\$211 b.) ; in attributive clauses $\left.{ }^{1}\right)(\$ 223)$; in temporal clauses opening with ere (\$235).

EARLIER. c 1170 Poeme M. 317, Swunche we for godes luue healf pet we dop for æhte ne beo we nabt swa of bicherd ne sa uuele bi kehte. $3^{i f}$ we serueden gode swa we dop erminges marr we hedden en beuene penne eorles her end kinges. | a 1240 On God Ureisun of Ure Lefdi 107, $z^{\text {if }}$ pu henedest wreche inumen of mine lupernesse, iwis ich heuede al uorloren paradises blisse. | a 1300 Dame Sirip (Zupitza) 249, I wis, Nelde, ne woldi pat pou hevedest vilani. | a 1300 idem 98, Ich were ounseli if ich lernede to ben on hore. | c 1386 Chaucer, A. R. 7326, Myn lemman Streyueth-A bstinence, Hath myster of my purveyaunce; She hadde ful longe ago be deede, Nere my councel and my rede.

LATER. 1595 Shakesp., Much Ado II, i, 202, it had not been amisa the rod had been made, and the garland too. I idem, Merry W. I, i, 201, I'faith Ile eate nothing : I llianke you as much as though I did. | 1817 Bgron, Lett. to Moore, 25 March, Heigh ho! I wish I was drunk. | 1885 F. Anstey, Tinted Venus II, 24, I wish to heaven I did. 1910 Hergesheimer, Cytherea p. 288, You ought to be beaten until you fell down. Pres. D. Eng. : It he came, I should lake to flight.

241. WERE in units the time-sphere of which is not the past (\$\$ 227-35) was used in older English in the same cases as have been illustrated in More. In present-day spoken English this were is almost exclusively found in subordinate clauses of condition, concession and rejected comparison introduced by the conjunctions if, though, as if, as though, etc. In literary

1) But compare : 1918 Times Educ. Supp. 20,8, The rustic who went to London believing that its streets were paved with gold would give a very different account of the wealth of the Metropolis from that of a man who... (Kr.)| Thackeray, Fancy your wife attached to a mother who dropped ber h's (J.). 
English it is still frequently used in other cases; in attributive clauses, however, (a mason that were an euill workman) it is rare.

earlier. c 1200 Ormulum, Preface 79, ribht alls iff it ware patt wa33n. pal gap o tow wre wheless (OED). I a 1300 Dame Sirip (Zupitza) 103, never more his lif-wile, pan he were on hondred mile Bi-zende Home. I c 1400 Mandev., Tr. 3, 9, wolde god pat the temporal lordes... were at gode acord (M.).

LATER. 1520 Everyman 159, Hye the, that thou were gone to Goddes magnylycence. | c 1615 Fletcher, Mad Lover $I_{\text {, }}$ i, If I were given to that vanity ... what a most precious sulsject had I purchased (OED). | 184 ? Macaulay, Hist. Eng. I, I, 3, I should very imperfectly exccute the task ... if I were merely to treat of battles and sieges. | Pres. D. spoken Eng. : If he were to comp, what shuuld we do? | If I were you, I should not do it.

242. Since Pres. D. spoken English knows the use of $[I$, thou, he, she, it] were to denote modality in units with a past time-sphere ( $\$ 237$ ) in the irrealis only (Curme 1933 p. 425), there is a marked difference between the present-day idiom and that of More's time. Thus it is no longer used when the

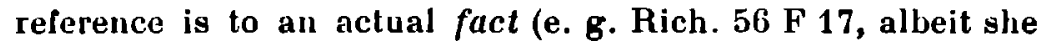
were out of al array ... yet went she... fair \& lovely | Rich. 56 G 15 , they were coupled ere she wer wel ripe) and in reported passages ( $\$ 237$ note ; $\$ 239$ note). Neither is were any longer used to introduce a clause (e. g. Rich. $37 \mathrm{~B} \mathrm{9}$, w'er bee fautye wer hee faulllesse, attainted was hee).

EArLIER. Old Eng., hie cwædon $p æ l$ he were god cyning (Sweet 1903 \$259). | c 1470 Malory, Morte D. 690, 7, Syre Eclor wold nol away til Gawayne were hole (OED). | c 1470 Malory, Morte D. 39, 27, Alle the barons asked ... Merlyn, what counceill were best (OED).

LATER. 1600 Rich. Apollonius and Silla 83, She knew not whether she were awake or in some dream (OED). | 1714 Addison, Spect. No 557, 2, He would not accept of one [witness], tho' it wer Cato himself (OED). । 1911 Allen, A Kenlucky Cardinal, Ch. 6 p. 56, I felt as though I were in a moonlit calhedral (Kr.).

243. The usage of the preterile in modest or reserved statements (\$236) is still living with the torms could \& would; were, however, has been ousted by constructions with auxiliaries in Pres. D. spoken English. Thus More's "that were to long a worke" > " that would be too long a work".

In. Shakespeare this " modest" were is still frequently. found (Franz $1924 \$ 638$ ). 
EARLIER. a 1300 Dame Sirip (Zupitza) 62, I shall setten spel on ende, And tellen pe al, Wat ich wolde, and wi ich com. | a 1300 idem 244, For al pe world ne wolde nout pat ich were to chapitre i-brout. I a 1300 Cursor M. 4555, Cond ') pu [v. r. cuth, cowde; Trin. condestou] tell me quat il ware?

c 1460 Townelcy Pl., Sec. Past. (Pollard) 280, Now were tyme for a man, that lakkys what he wold, To stalk prevely than unto a fold.

LATER. 1611 Bible, Josh. xv, 18, Caleb said vnlo her, What wouldest thou? (OED). | 1882 Tennyson, Charge Heavy Brig., Epil. 10, 11, I would that wars should cease.

1604 Shakesp., Othello 11 , iii, 156, It were not for your quiet nor your good... | 1703 Moxon, Mech. Ex. 278, You were beat to mark the lower closier in each course (OFD). | 1908 A thenrum, March 7, p. 280, Anylhing mole transparent than the incognito of the author ... were bard to discover.

\section{THE INFINITIVE}

244. In More's time the infinitive preceded by to had ceased to show in its form anything reminiscent of the old dativegoverning force of the preposition, and inflected and uninflected infinitives (writan, to writenne) had long since come to be levelled under one and the same form. Though in a number of constructions the particle to was still more or less vividly felt as a real preposition, wilh a strong final ${ }^{2}$ ), pointing or translocal function, as in hie comon pat land to sceawienne, in the majority of cases this to had bccome nothing but a next to meaningless preformative ${ }^{3}$ ). This loss of meaning was one of the reasons why the infinitive preceded by to came to be used in cases in which originally only plain infinitives had been possible, and by More's time to + infinitive had succeeded in crowding out the simple or bare stem to almost the same degree as in Pres. D. standard English.

1) The earliest quotation in OED (s. v. can B 7) of could (" in past subjunctive, expressing an inclination in a conditional form ") is dated 1658-9 [Col. White, in Burton Diary (1828) IV, 39, I could like well that they should be in that House]. Cf. OED can B 6.

2) Sweet (1903 p. 118) uses the term "supine of purpose".

3) According to H. Boch (1931 p. 130) not befole the 13th century : "Vollige Verblassing der sinnlichen Bedeutung der Preposition bis zum Functionslosigkeit und unterschiedlose Gleichsetzung des toInfinitivs mit dem reinen ist erst für das 13. Jahrbundert anzusetzen ". 
The few cases in which the infinitive without to more or less regularly occurs in More will be mentioned and illustrated.

For a discussion of the constructions in which an infunitive enters into a nexus with another verb (as in Jest $\mathrm{p} .2 \mathrm{G} 4$, he gan enquere | Dial. Her. 114 A 7, then nede we ... to sherve | Dial. Her. 130 H 11, I nede not beleue | Dial. C. 252, till he goe seke vp all his creditors | Apol. 106, the kynge that ... longe mote be | Hich. 71 C 1, The for that saw him run) see the sections on syntactical units with two verbs ( $\$ \$ 389 \mathrm{fr}$ ).

The dual character of the infinitive (as a verb and as a noun) is brought out by its capability of performing the same functions in the sentence as nouns ${ }^{1}$ ) and of taking the same attributes ${ }^{2}$ ) and complements ${ }^{3}$ ) as verbs. As, however, the infinitive cannot be preceded by prepositions (apart from to and for to) or by possessive pronouns, the nominal characler is less prominent than that which the form in -ing sometimes assumes (Cf. Pompen 1924).

\section{THE INFINIVE AS SLBJECT.}

Last Th. $98 \mathrm{G} 15$, to tell va worldly wretches the wordes of holy wrytte, is but a dul profe. | Dial. Her. $107 \mathrm{E} 1$, with whome to commune ... shall not mislike you. | Rich. $64 \mathrm{~F} \mathrm{10,} \mathrm{that} \mathrm{thing} \mathrm{in} \mathrm{which} \mathrm{to} \mathrm{bee}$ parteners is your weale \& honour. Picus $33 \Lambda 9$, To geue them also that vnworthy bee, more godly is. / Rich. $58 \mathrm{D} \mathrm{1,} \mathrm{To} \mathrm{lay} \mathrm{bastardy} \mathrm{in}$ kynge Edward, sowned openly to the rebuke of the proteclours owne mother. | Instr. 1405 D 12, to punishe an euill man lieth in his charge, by reason of his offce. | Dial. C. 186, as thoughe to heare of heauen were an heauy burdayne.

In Old English this construction was very rare (Callavay 1913), since the infinitive-subject usually had endposition and was either announced by proleptic $i t$ (c. g. Elfr., Hom. I 394, ac hit ne fremede him swa gedon), or depended on a form of the verb beon + adjective (e. g. Mk. 9,47 , betere pe is mid anum eagan gan on Godes rice) or on

1) E. g. as subject: Dial. C. 186, as thoughe to heare of heauen were an heauye burdayne; as direct object: Rich. $53 \mathrm{E} 10$, whither he could thinke it possible to winne the lord Hasting into their parte.

2) E. g. adoerbs : Con. Tynd. 481 H 2, tyll menne... fell to forgeatte them ... and then to not belieue them. | Lett. 1449 F 3, in his owne temptacion he was fain thrise to call vnto God.

${ }^{3}$ ) E. g. objects (see firat quotation in \$245). 
a construction of the type me gepuhte (e. g. L. I 3, me gepuhte, geornlice eallum [tram fruman gefulgdum] on endebyrdnesse writan pe). Plain inflnitives never occurred as subjects in Old English (Boch 19:31 p. 247). In Middle English the infinitivesubject in front-position (with and without $t o$ ) is frequently met with, for which French influence may perhaps be assumed (e. g. Rou. II 937, se vanter e menter, l'un e l'altre ert folie). Boch (1931 p. 247), however, states that the exegetic infinitive played the most important part in this development ("Bei dem Aufkommen des to-Infinitivs, als Subject und als Ergänzung von Verben hat der exegetische Infinitiv die gröszte Rolle gespielt"). A few Middle English instances follow :

a) Without to. a 1225 Ancren R. 4, Richten hire and s'nepen hire [scil. the heart] is of euch religioun... pe god $\&$ al pe strengpe. | Idem 10 , Gon iseon swuch \& elnen ham \& helpen ... pis is right religioun. | c 1374 Chaucer, Troil. III, 1631, As great a crafl is kepe wel as wynne. | c 1412 Occleve, De Reg. Pr. 58, use luste for luste ... contrarie To Goddes bestes is.

This idiom became obsolete not long after Chancer; it is not mentioned by Buchtenkirch 1889 (Occleve), nor by V. d. Meer 1929 (Mandeville). H. Juhl (1921 p. 24) says that it occurs much less frequently in Occleve and in Lydgate than in Chaucer ("Bei dem Inf. in Subjektstellung ist der reine Inf., der sich bei Chaucer noch verhältnismäszig häufig findet, bei Occleve und Lydgate in starkem Abnehmen hegriffen ").

b) With to. 1388 Wyclif I Sam. xv, 22, To herkenne Goddis word is more than to offre the ynnere fatnesse of rammes. / c $1450 \mathrm{tr}$. De Imit. II viii $48, T o$ be wipoute ihesu is a greuous helle.

The construction with to has remained the usual practice : 1539 Bible [Great] Sam. xv, 22, Behold, to obeye is belter then sacrifice. | 1709 Pope, Essay Grit., 525, To err is human, to forgive, divine.

In Pres. D. Eng. the infinitive as subject [e. g. To see is to believe] has a rival in the form in -ing, to which it is preferred if the speaker or writer wants " lo bring out the attributes of phenomenality - action and quickness". (Sweet 1903\$2326)').

1) Cf. Poutsma 1929, xıx, 10 ; Pompen 1324 and Kruisinga $1931 \$ 393 / 7$. Regarding, the two forms Curme (1933 p. 491) says : "It has been claimed that the gerund is preferred in stating a general fact, while the infinitive is used in referring to special circumstances of a particular individual act ... Actual usage knows nothing of this distinction ". His 
More's use of the form in -ing in this function is illustrated in $\S 335$.

Not infrequently the infinitive-subject is preceded by its own subject $\left.{ }^{1}\right)$ :

Dial. C. (Wks.) 1193 D 18, you maye toll him agayn that menne thus to talke together as you dooe ... is ... a dayly common thing. | Lett. 1453 F 1, Whose highnes to haue of me now such opinion, is my great heavines. | Debell. 990 D 4 , al these differences... proueth ..., that the order not to procele wilhout an open presentment wer belter. I Conf. Tyud. $477 \mathrm{~B} \mathrm{14,} \mathrm{a} \mathrm{chy-lde} \mathrm{to} \mathrm{be} \mathrm{confirmed} \mathrm{or} \mathrm{lo} \mathrm{be} \mathrm{chrystened}$ oyther, ... or a man to shryue himselfe ol his sinnes, or to doe penance, or to doe any good workes towaid heauenward, or to be aneled ... All these thinges be by Tindall as protilable for the soule, as smoke is for sore eyes. | Dial. C. (Wks.) 1215 \& 9, to haue that good purpose al their life, someth me no more harme ... than ... a poore begger that halh neuer a peny, to thinke that yt he had great substaunce, he wold geue great almose for gods sake. | Rich. $40 \mathrm{G} \mathrm{12,} \mathrm{it} \mathrm{neythrr} \mathrm{was} \mathrm{reason} \mathrm{...}$ that the yong king ... shoold bee in the ... cuslodye of his mothers kinred, ... whose blood ... was ful vnmetely to be matched with his [scil. the Duke of Gloucesler's] : whiche nowe to be ... remoued from the king, \& the lesse noble to be left aboute him, is (quod he) neither honorable to bys magestie, nor valo vs. I Lett. $1436 \mathrm{G} 12$, one man to be prowde that he bearelh rule ouer olher men, is much like as one mouce wold be proude to beare a rule oucr other mice in a barne. I A Table of many matters (s. v. S, $3^{\text {m }}$ column), Scripture to be in englyshe is not necessary to saluacion.

This usage was common in older English : 1470-85 Malory, Morte D., 453, 4, Thou to lye by our moder is to muche shame for vs to sutfre (D.) | c 1460 Towneley Myst. xvir, 31, A mayden to bere a cbyld,... that were ferly. (For further instances see Zeillin 1911 p. 649 ; Stoffel 1894; Kellner $1913 \$ 406$ ).

It is difficult to ascerlain the funclion of the infinitive to be in the following passage :

Dial. C. (Wks.) 1238 F 13, And yet haue I left vntouched, the bondage that almost euery man is in that bosleth himselfe for free, the bondage I meane of synne, which to be a very bondage, I shall haue oure Sauyour himselfe to beare me good record.

To be may depend on record, or on the whole unit, thus

view seems to be corroborated by the lact that in More both constructions occasionally occur side by side in the same sentence, e. g. Debell. $1004 \mathrm{C} 7$, to confesse hymself gyltie ... and putting hymself in worse case ... wer but a poore poynt.

b) Sometimes called the " nominative + inflnitive construction". 
our saviour bears me record this (= which) to be a bondage. In condensed form this would become : our saviour declares this to be a bondage. It is, however, also possible to recognize here a sudden change in the syntactical build of the sentence, in which at the outset which to be a very bondage was meant fur the subject. Similar shiflings were not infrequent in More's language, and though they give an anacoluthic impression now, seem to have been quile regular at the time. Compare :

Dial. G. 145, Some younge louely lady, lo, that is yet good enough, God secth a storme com loward her. | Dial. C. 355, Bul to feare whyle the payne is cumming, there is all our let. | Dial. G. 348 , he that ouercometh, I wil make a pillour in the temple of my God.

In (1594) Marlowe \& Nashe, Dido v, ii, we read :

Yet he, whose heart['s] of ademant or flint, My tears nor plaints could mollify a whit.

Shakespeare has :

Rich. III, III, ii, 57, They who brought me in my masler's hate I live to look upon their tragedy.

For + (Pro)noun-subject. In Pres. D. Finglish the pro(noun)subject is preceded by for. In Shakespeare we read :

Rich. It, ii, 123, For ys to lesy power Proportionable to th'enemy, is all unpossible. | Cor. II, ii, 28, for their tongues to be silent ... were a kind of ingratelul injury. | Hamlet $\left(Q^{2}\right) \mathrm{II}, \mathrm{ii}, 316$, for, for mee to put him to his purgation, would perhaps plunge him into more choller.

Though no instances of this usage have been found in More, it may be supposed that it was not unfamiliar to him, since he uses it in the parallel construction in which the subject, after being announced by proleptic $i t$, has end-position (e. $g$. Lament., stanza 9 l. 6, It booteth not for me to wepe or cry). Compare, moreover, the following quotation with as for :

Debell. 936 B 11, But as for me to peruse hys whole book of deuision thorow was no part of my purpose.

For To. Constructions in which the infinitive (used as gubject) is preceded by for to are rare in More. Only the following instance has been found, which, however, allows of a different interpretation ( $\$ 249$ ).

Lett. $1448 \mathrm{~B} 5$, for to be put to death wrongfullye for doing wel (as I am very sure $I$ doe, in relusing to swere against mine own conscience...) it ${ }^{1}$ ) is a case in which a man may leese his head and yet have none harme.

1) C. 40 (two subjects). 
Chaucer uses this construction in :

Troilus $\mathrm{I}, 690$, For for to tristen som wight is a preve of trouthe,... । C. T., F 690, For to pleye at dees ... is his usage.

246. THE INFINITIVE AS LOGIGAL SUBJECT AFTER CONSTRUCTIONS OF THE TYPE : me rueth.

Picts 34 B 9, Graunt me fro Sathanas seruice to astart, with whom me rueth so long to haue be thrall. | Dial. C. 280, the Almain tong wherin ... me listed to shew my cunning. / Pageants p. 7A 5, me nedeth not to bost I am Eternitee. | Dial. C. 169, of heauen and of hell that yrketh them to think of. | Mich. 63 A 8 , them were lener to leese all ... then to halie suche a villany done them. | Boke of F. p. 1 B 9, me list not frendly on them loke.

This usage is restricted to the few verbs that outlived the transition from the "impersonal" to the "personal " construction. In the majority of cases More uses the infinitive with to; the plain infinitive after me list '), however, proves that the usage was not yet completely seltled. Already in Layamon the plain infinitive had become less frequent than to + infinitive (Lichtsinn 1913); Chaucer uses more prepositional than plain infinitives (Kenyon 1909 pp. 118 ff.); this is also the case in Occleve (Buchtenkirch 1889 pp. 2/3). In Mandeville and in Malory the plain stem seems to have been rare; among the instances V. d. Meer $1929 \$ 6 \mathrm{lb}$ adduces from the former author there is not one with the infinitive without to; the only quotation with a plain infinitive cited by Dekker 1932 $\$ 314$ from the latter writer opens with thou wer better. Klausmann's quotations (1919 \$ 119) from Berner's Froissart all contain infinitives with $t o$.

A few illustrations of earlier usage follow.

Bede 74, 18, liwaper alefap hire in circan gongan oppe pam geryne onfoon pære halgan gemænsumnesse. | c 1000 pr. Life St. Guthl. xx 85, geryno pa nanegum men ne alyfap to secganne. I c 1205 Layamon, Brut 28810, pæt næuer seoppen bi his dajen ne lusten heum hider uaren. | idem 30253, pan kinge luste slepe. | 1385 Chaucer Troil. v 631, hym liked yn bise songes shewe. | idem C. T. A 2377, as thee lyst deoyse. | c 1412 Occleve De Heg. Pr. 22, whan that hym happethe To chirche gone. | idem 112 hym owethe knowe his errour, and quenche that firy loue. | 1470-85 Malory, Morte d'A. 187, 5, ther fore the behoueth now to chese one of vs four. | idem 228, 33, thou were better flee by tymes.

1) The quotation is a line from a poem ; it is therefore possible that the use of the plain infinitive is merely due to poetical licence. 
With the disappearance in Pres. D. Eng. of the constructions of the type me rueth, this usage died out. The only survival, me thought, is never followed by an infinitive now. The only Irace left occurs in $I$ had better go.

As the subject of the infinitive-subject is al ways the same as that denoled by the oblique form of the pronoun of the introductory construction (me lyst not), it is never separately expressed before the infinitive.

Fон то. No constructions with for to have been discovered in . More. They were common in earlier English, e. g. :

c 1400 Mandev. Tr. 2, 21, Right wel aughte us for to loue ... such a Lord. I c 1412 Occleve Reg. Pr. 117, Sithen that lever hym was for to forgo His dignitee.

247. THE INFINITIVE as LOGICAL SUBJEGT AFTER PROLEPTIC $I T+$ venв. Type : it nedeth not to assigne.

Dial. Her. $181 \mathrm{~B} 12$, it nedeth not to assigne any place, wher the very churche \& true christen congregracion is. | Dial. Her. $121 \mathrm{~A} \mathrm{6}$, it smelleth of ydolatry, to visil this place. | Hich. $53 \mathrm{~A} \mathrm{12,} \mathrm{it} \mathrm{might} \mathrm{happelye} \mathrm{tourne}$ them to no good, to be to much atlendaunt about the king. | Rich. 59 A 9 , it boted not greally to say nay ').

In the following passage the two collations: it is out of all question and he is sure are interwoven in a curious way.

Last Th. 82 B I1, [he] wold not take much more plesure, than his felow in the length of his waye, ... beinge sure and out of al question to dye at the ende.

lu the following quotations (type : it liked him to bring) there is a pronoun which does duty as (indirect) object ${ }^{2}$ ) to the first verb and at the same time as subject of the infinitive.

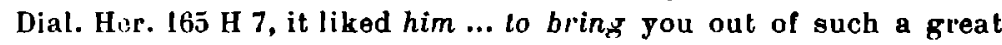
perplexite. | Dial. C. 133, it may please him to helpe and encrease it. | Dial. C. 217, it liked her wel to thinke theron. | Hich. 55 E 4, it had happened them before, to mete in like manner. | Dial. Her. $263 \mathrm{E}$ 3, it happed me to be lately present.

If, however, the pronoun you or a noun is used, any outward sign of the object-relation is absent :

Dial. Her. 130 G 8, It maye... fortune you, to liue so long. | Dial. Her. 152 A 7 , it shall please our lorde ... to renele it. | Dial. C. 134, it booteth

1) Also with to have [geuen] as subject : Rich. 71 F 11, it might ... haue pleased Godde... to haue geuen him some of suche other excellent vertues.

") Ge. Callaway 1913, “ The predic. inflnitive with dative subject". 


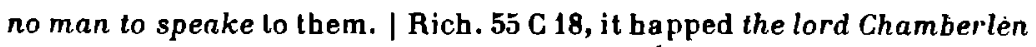
by the way to stay his horse. I Aut. Lett. $w$, 29 , if it shold happen $m y$ lord Dacre to he distressed with his cumpany.

It must have been a small step for the idea of objectrelation in similar cases (especially when the noun before the infinitive denoted a thing instead of a person) to be cntirely lost and for analogous constructions to come into use in which the intervening noun was merely the subject of the infinitive :

Lett. $1422 \mathrm{H} 1$, if it shold happen any boke to come abrode. | Dial. C.

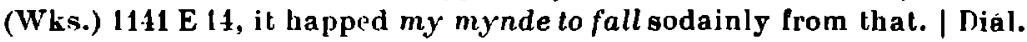
C. (Wks.) 1I5̃ D 18, it is not without peril a man to think otherwise.

This is particularly manifest with the verbs to seem and to appear :

Conf. Tynd. 485 G 4, sometyme the paragraphes ... haue so euyll dependence one toward another, that it semeth the maller to be galhered by dyuers folke. | Dial. Her. 255 H 1, the booke ... was so deuised ..., that it should seeme some other to haue made it, \& not hymselfe. | Dial. C. (Wks.) 1207 B 1, in such wise as it may well appeare the saying of the wise man to be verifyed in them ').

In the following sentence the subject is expressed twice :

Dial. Her. 131 F 5, It happed them ... the one to cast the mind to the other.

In all the above instances the infinitive is preceded by to. Plain infinitives are very rare :

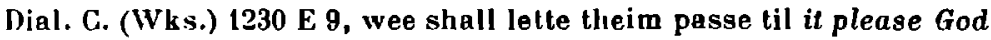
shewe him self vnto theim.

FOH $+($ PHO)NOUN-SUBJECT. It is not rare for the subject of the infinitive to be preceded by for :

Lament., Stanza 9 1. 6, It booteth not for me to wepe or cry. I Jest p. 3 G 4, It longeth for our order, To hurt no man. / Conf. Tynd. 754 B 8 , what woulde it auayle for me to defende the credence of the generall consayles.

From a syntactical standpoint the use or omission of for does not seem to have made a great difference; compare :

Rastell's edition (1557) : Rich. 47 G 12, Knoweth anye manne anye place wherein it is lawefull one manne to dooe another wrong. Hardyng 1543 : wherin it is lawfull for one manne to dooe another manne wrong.

1) St. John Fisher has : Wks. 170, 28, it seemeth almyghty god to be in maner in a deed slepe. R. E. L. Weyl (1937\$ 76) calls this " a blending of an impersonal construction with a nominative + infinitive". 
Fon To. Only one instance can be quoled :

Dial. C. (Wks.) 1195 B 8, I dooe not mene ... Lhat enery foole shold at aduenture fall in hand with him, for so loe might it happe for to dooe harme in cledte.

In the following quotation the person clesignaled by the pronoun him is, contrary to Mure's practice, not the subject of the following infinitive :

Lett. 1449 A 9, Your doughterly louyng lolter ... was and is ... much more inward comforte vnto me, then my pente can wel expresse you, for diuers thyngs ... : but of al things most cspcidilly, for llat god ... geueth you the grace to consider, the incomperable dilference, betwene lho wretched estate of this present lyfe, and the welthy state of the lyle to come..., and to praye god ..., that it maye please hym ... of his tender pitie so firmely to reste our loue in him, with litle regard of this world, and so to he sinne and embrace vertue, that we maye saye... Perhaps a few words (e. g. to help us; to grant us) have fallel out belween pitie and so frmely; as it stands the construclion is anacoluthic.

Historical note.

The usage illustrated above was known from the oldest times. In the beginning the plain and the prepositional infinitive occured side by side, but gradually the plain inflnitive lost ground, so that in Layamon (Lichtsinn 1913 p. 29) and in Orm (Weyel 1896 p. 91 ) it was already in the minority. In More and Fisher no plain infinilives were used, and afler their time the prepositional infinitive remained the rule. In Pres. D. Eng. the possibility of using the construction has become considerably restricted; lypes like if it shold happen any boke to come abrode; it is not without peril a man to think otherwise do no longer occur. After it seems and it appears a that-clause is used now.

\section{EARLIER}

c 1374 Chaucer, Bo. 11, 93 it ne suffyseth ... to loken.

With (pro)noun-subject. c 1000 Elfric, Hom. I 394, ac hil ne fremede him swa gedon.

\section{LATER}

1590 Speuser, F. Q. I1I, vii, 51, Ay for my name, it mistreth not to tell.

1828 Arnold, in Life \& Corr. I, ii, 88, It boots not to look backwards (OED).

1613 Shakesp. Henry VIII, II, iii, 103, It faints me To think what follows. 
c 1215 Layaman, Brut 3684, ah ich pe wulle lanen ut pat heom behouep to haban on fore (L.).

c 1386 Chaucer, (.. T., G 1093, it dilleth me to ryme.

c 1400 Mandev. Tr. 177, 31, And pogh it happene sum of hem to fortune to gon out (M.).

With for to.

c 1412 Occleve, Heg. Pr. II, 357, And eke it nedeth nought for to devyse At every cours the ordre and aervyce (MI.).
1852 Stowe, Uncle T. C. $x \times v 289$, It ... grieves me to have you be so naughty (OED).

1678 Gudworth, Intell. Sysl., I, iv, $\$ 34,5.44$, Whereby it may uppeur the world to be Governed by a Divine mind (OED).

248. The infinitive ag logical sChJect afteh pholeptic: IT + Adjective. 'Type : it wer good to be mery.

Dial. C. 167, it were good to make sure and to be mery. | Last Th. 7.2 C 4, Long would it be to take the beste of lheyl. woordes and compate it with these wordes of holy writ. | Mich. $59 \mathrm{~B} \mathrm{9,} \mathrm{it} \mathrm{was} \mathrm{not} \mathrm{princely} \mathrm{to}$ mary hys owne subiect. | A pol. (Wks.) $846 \mathrm{H} \mathrm{1,} \mathrm{then} \mathrm{is} \mathrm{it} \mathrm{ethe...,} 10$ geae the selye soule a falle. | Hich. $57 \mathrm{H} \mathrm{2,} \mathrm{it} \mathrm{wer} \mathrm{best} \mathrm{bastly} \mathrm{to} \mathrm{pursue} \mathrm{his}$ purpose.

Without to. Last Th. $95 \mathrm{D} 11$, Men commonly say, it wer belter fil his bely than his eye.

Sometimes there is no proleptic $i t$ :

Dial. C. 226, there are many kindes, wherol wer to long to talk now. i Picus $7 \mathrm{D}$ 6, a thing farre excelling all the conning that is possible for vs in this life to obtaine.

As a rule the subject of the infinilive is not expressed if it can be inferred from the context; there are, however, cases in which it cannot be omitted :

Passion $1290 \mathrm{C} 12$, it was notbynge meete, the seruaunt to stande in better condicion than his maister. | Dial. Her. $211 \mathrm{G} \mathrm{9,} \mathrm{beller} \mathrm{wer} \mathrm{it} \mathrm{the}$ faute to be quytte, than the fautes to be punished. | Rich. $47 \mathrm{G} 12$, Knoweth anye manne anye place wherein it is laweful one manne to done anotler wrong? | Lett. $1423 \mathrm{HI} 1$, But vnlo my self, it is not possible any part of my sayd demeanure to seme euil. | Hicb. $41 \mathrm{~B} 3$, [it] shold be ieopardous, the king to come vp strong.

Without to : Dial. Hel' $124 \mathrm{H} \mathrm{13}$, who can reken bim self sure of hys owne molher, for possible it wer that he wer changed in the cradel, \& a riche mannes norce bringe home her owne chylde for her maisters, and kepe her maisters for her owne, to make her owne a gentilman good chepe. 
Very exceptionally the subject is placed after the infinitive :

Dial. Her. $259 \mathrm{~F} \mathrm{13}$, It is not quod I al one to be some nought and all nought.

For + (Pro) voun-subject. The (pro)noun-subject is often preceded by for :

Picus 5 B 13, it were not possible for a inan to ottre neither more conning, nor more conningly ${ }^{1}$ ). | Jest p. 1 A 10 , best is for a man : ... in no wyse, To enterpryse, An other faculte. | Apol. 180, Thys good man... persuadeth to hymselfe that it were not possy-ble for hym to lese it by the law. | Picus 29 A 2, as honest in behauour, As it is possible for thee

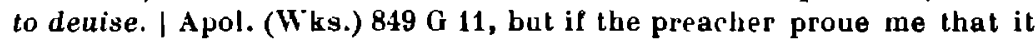
wer better for a man to kyll bymself then dye. | Dial. Her. $125 \mathrm{D} \mathrm{1,} \mathrm{it}$ wer hard for thein ... to beleue that euery man lieth... | Dial. Her. 243 F 10, I can in no wise agree with you that it were mete for men onlearned to be busy with the chamming of holy scripture. / Dial. C. 227 , it is not laweful for any other mayde to folowe their saumple. 1 Dial. C. (Wks.) $1166 \mathrm{E} 9$, it is not so readye for the wealthye manne to bee contente to be in the tribulacion. I idem $1166 \mathrm{E} 1$, it is easy for the parsone that is in trybulacion, to bee well wyllyng to doe the self same yf he coulde. | Aut. Lett. xrv 126, it wold be right hard for hym to ffynd the money.

For is not repeated when there are two infinitives each

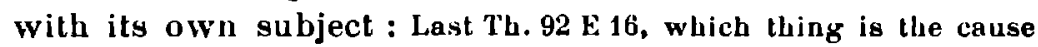
that our sauiour Christ said it were as harde for the riche manne to come in to heauen, as a great cable or a Camel to 80 through a nedles eye.

Fon To. Jest p. 1 A 10 , best is for a man : Diligently For to apply, The busines that he can.

Historical note.

A summary of the evidence presented above shows that there was the following astonishingly rich variety of constructions in More :

1. it is lawful (to) go there.

2. it is lawful a man go there.

3. it is lawful a man to go there.

1. it is lawful for a man to go there.

5. it is lavful for to go there.

6. it is lawful for a man for to go there.

7. it is lawful to go a man.

The types 1, 3 and 4 would seem to have been the normal ones, of which, however, type 4 far outnumbers type 3 . That

l) An interesting instance of the use of one and the same verb (to utter) in two different functions, lirst as an objective, then as a subjective verb. 
the type for + (pro)noun-subject + infinitive should be so abundantly used is only natural, since for hele has preserved its original force and is a natural complement to the adjeclive (possible for, best for, hard for, etc.). Type 3, however, is far from rare; it is also frequently met wilh in St. John Fisher, More's contemporary :

Wks. 73, 19, for the whiche it sholde be profitable and necessary the pyle of god to be purchased for vs.

The types 1, 3, 4 and 5 occurred before More's time; those with plain infinitives were the most prevalent, so that instances of the type it is necessarie avise him are not difficult to collect. Type 5 (it is lawful for to go there) was perhaps beginning to be felt as obsolete in More's time. Of lhe Iypes 2, 6 and 7 no instances have been found in other wrilers.

In Pres. D. Eng. only constructions of type 1 (with prepositional influitive) and 4 are possibly. Type 1 with a plain infinitive is only met with in special cases, as in Better not say too much of it.

A few instances of earlier usage follow :

1. c 1380 Chaucer, Boke of D. 844, Hil wer better serve her. I 1412 Occleve, Reg. Pr. 84, Or a king swere it is fulle necessarie Avise hin wele (B.).

3. 1388 Hible, Luko xvi, 17, Forsolhe it is $l_{3}$ ter heuene and erthe to passe (C.). I e 1112 Occleve, Reg. Pr. 80 Perilous is it a man his feilbe to breke. I c 1445 Pecock, Donet 6, It is honest ynough a man to speke and write aftir oon of po opyniouns. | 1454 Pecock, Follower (ed. Hitclicock) p. 3, 24, It is semeli him to knowe alle pe spicis of knowyngal verlues. 1470-85 Malory, Morte D'A. 859, 38, \& whan be waked it were harde one tonge to telle the doleful complayntes (D.).

4. 1470-85, Malory, Morle D'A. 131, 21, And yf il were possyble for me to dye (D.).

5. 1386 Chancer C. T. C 473, it is grisly for to hiere hem swere. I c 1412 Occleve, Rrg. Pr. 126, 0 Alesaundre it is unconvenable The for to have the peples regyment (B.).

249. The Infinitive as logical subject after pholeptic $I T+$ Noun. Type : it is not sinne to have riches.

Hich. 57 C 7, sinne it wer to belie the deuil. / Last Tb. 92 F 5, il is not sinne to haue riches. | Hich. $54 \mathrm{G} \mathrm{9.} \mathrm{A} \mathrm{merueilouse} \mathrm{case} \mathrm{is} \mathrm{it} \mathrm{to} \mathrm{here,}$ either the warninges of that he shoulde have voided, or... | Rich. 59 A 14, it was his honor, profite, and surety, also, to mary in a noble progeny out of his realm. | Conf. 'Tynd. $543 \mathrm{G} \mathrm{2,} \mathrm{many} \mathrm{open} \mathrm{places} \mathrm{of}$ holy scriptul'e,... which were... almost a lost labour to rehearse. | 
Mich. 55 A 7, it is plaine witch[c]raft to beleue in suche dremes. | Picus 7 A 5, it was no praise to gather richesse, but to refuse them. | Dial. Her. $133 \mathrm{H} \mathrm{16}$, it is a great ontowardnes ... to mystrust all them that say they haue sene it.

Vith to seem instead of to be :

Dial. C. 353, it semelb a proude high mind to desyre marlyrdom.

The subject of the inflitive is expressed in :

Conf. Tynd. $736 \mathrm{~B} 7$, it is no new thinge, a madde wilde bull to runne oute at rouers, ... nor a rude asse to make bis rude roring, nor a fonde ape to make mockes \& mowes, nor an abhominable whore to brawle, chide and scolde, nor no newelty the deuill no the deuilles limme to be lalse and lye. | Rich. 41 A 14, he secretly ... caused the Quene to be perswaded ... that it neither wer nede, \& also shold be ieopardous, the king to come vp strong. | Picus $1 \mathrm{~B} 9$, It is... a custome in the beginnyng of the new yere, frendes to sende betwene, presentes or gyltes.

FOR + (PHO)NOUN-SUBJECT.

Debell. 978 C 9, it was foly for him to speake therof. | Dial. C. (Wks.) 1:40 D 14, yel were it in ing mynde no lylle griefe... for a man to be pinned vp. | Picus 19 E 10, And forasmuch as som man wold paraduenture think, that it wer foly for a man vtterly to depriue himself from al pleasures therfore the prophet addeth :... Dial. C. 294, it is a shame for him to be so flckle. | Dial. C. (Wks.) $1255 \mathrm{C} \mathrm{3,} \mathrm{it} \mathrm{is} \mathrm{but} \mathrm{a} \mathrm{feined} \mathrm{faith}$ for a man to say to god secretly, that... | Last Th. $88 \mathrm{C} \mathrm{4}$, shame were it for men to bee wroth like women. | Rich. $70 \mathrm{G} 13$, surely my lord foly wer it for me to lye.

FOR To.

Lett. $1448 \mathrm{~B} 1$, I thanke oure lord, that in that conflict, the spirite had in conclusion the maslye, and reason with help of faythe finally concluded, that for to be pul to death wronglullye for doing wel (as I am very sure $I$ doe...) it is a case in which a man may leese his head and yet haue none harme ').

Historical Note.

There are four types in More :

1. it is a shame to go there.

2. it is a shame a man to go there.

3. it is a shame for a man to go there.

(1. it is a shame for to go there).

Just as in Pres. D. English type 1 is the normal one when the subject need not be expressed. Type 2 has died out in ordinary diction, but is still found in popular speech and in Irish English (Curme 1933 p. 192). Among the instances of

1) This passage has also been quoted in $\$ 245$; the interpretation is doubtful. 
type 3 there are a few in which for is not organic (as in : Dial. C. 340, it is a feined faith for a man to say...), a usage so common in Pres. D. English ${ }^{1}$ ). Type 4, obsolete now, was of frequent occurrence in earlier periods.

\section{EARLIEA}

1. 1412 Occleve, Reg. Pr. 86, Grete wisdom were it trete faire and solte, And holden truly her couenauntes (B.).

2. c 1350 Perceral of Gales (Campion) 60,14 , it es no synn, The man, pat may pe mete wynn, To byffe pe travellande.

1386 Chaucer, C. T. Prol. 501, if a preest be foul,... No wonder is a lewed man to ruste.

1470-85 Malory, Morte d'A. 67, 10 , it is gods wyll youre body to be punisslied for your fowle dedes (D.).

3. 1470-85 Malory, Morte d'A. 290, 31 , hit wer no corrshtp for me to slee the (D.).

4. 1397 Rolls of Pailt. III 379, 2, It was my meny"lg and my wenyng for to haue do the best for his persone (OED).

c 1412 Occleve, Reg. Pr. 179, it is my dotage For to have expresse or touche ony of tho (B.).

\section{LA TEA}

1896 A. E. Housman, Shropsh. Lad. v, Some lads there are, 'lis shance to say, That only court to thieve (OED).

15.39 Great Bible, Ps. 133, Beholde, how good \& ioglull a thing it is brethren to dwell together in vnite ${ }^{2}$ ).

Pros. D. popular speech : Oliphant, (Sec. Son), I lelt it as if it was a greal compliment him to come in friendly like (Curme).

Irish English : Lady Gregory, A great wonder he not to have come (Curme).

1912 Atheneum 9 Nov., It was doubtless a step in advance for the law to admit that insanity was a disease (Kr.).

Pres. D. popular speech : Mrs. Gaskell, Sylvia's Lovers, Ch. xxvi, It 's not manner's for thelp oursel's (Curne).

1) It also occurs in Shakespeare : Caesar $11, \mathrm{ii}, 96$, it were a mock Apt to be render'd, for some one to say "Bieak up the senate lill another time".

2) Quotation taken from Aug. Bjórling's Studies in the Grammar of the Early Printed Eng. Hible Versions (1926 p. 159). She calls this a Latin construction, comparing it with : Ecce quam bonum, et quam jucundum liabitare fratres in unum; if she means that the translators created this idiom and that it was alien to existing usage, the assertion is at variance with fact (See More's usage and the earlier quotations). But Latin influence may be admitted in the sense that the writers preferred an (existing) English construction that was conformable to the loreign language, to one that was built in an entirely different way. 
The following quotation contains a variant of type 2 (with for to) : c 1345 Rich. Rolle, Pros. Tr. (EETS) 27, 24, it es a velany $a$ man for to be curyouslye arrayede apon his beuede with perre and precyous stanes.

250. The infinitive AFter a COPUla ').

Type : his pleasure is to have 's pray snto him.

Dial. C. (Wks.) 1161 B 8, God sendetls vs also suche tribulacion sometyme, because his pleasure is, to haue vs pray vnto hyu. | Last Th. $79 \mathrm{~F} 10$, the wiser way wer to recken, that a youge man may die soone... | Picus $28 \mathrm{D} 2$, The third point of a perfit louer is, To make him freshe to see that al thing bene, Appointed wel.| Picus 28 A 3, The first point is to loue but one alone. | Lett. $1452 \mathrm{H} 13$, the whole purpose is ... to dryue me to say precisely the tone way. | Dial. C. 300, the greatest comforte that any man maye haue in this tribulacion is to hane hys harte in heauen. | Dial. Her. 105 (i 11, For llis cause me thought that for the inore suerty, my parte were to send our cornmunicacion to my said frende in writing. | Mich. 35 B 11, [Kyng Edwarde]... dyed ... leauinge much fayre yssue, that is to wilte, ... Elisabelh, whose fortune and grace was after to bee Quene.|Picus 12 D 3, the very deadly pestilence is this : to be conuersaunt ... among them, whose life is ... an allectiue to synne. | Dial. Her. 221) F 11, To tell you all that ... were ... to reherse you, al the whole boke.

With nothing but between the copula and the infinitive : Dial. Her. 222 D 10, that a priestes offyce is nothing but to preache.

Or the use in Old English of an infinitive after a copula no instances seem to be on record. In Chaucer the idiom is seldom found, yet - according to Mätzner 1885 p. 22 - more frequently than Einenkel 1887 p. 231 states. It is rare in Layamon (Lichtsinn 1913 p. 29), in Orm (Weyel 1896 p. 11), in the Ancren Riwle (Redepenning 1906 p. 83) and in Mandeville's Travels (V. d. Meer $1929 \$ 62$ ). In Occleve it seems to occur less infrequently : Buchtenkirch (1889 p. 24) is able to cite flve inslances with the plain stem and ten with to + infinitive (apart from two with for to). More does not use the plain infinitive in this construction.

In Pres. D. Eng. copula + prepositional infinitive is common; it has a rival in the group consisting of copula + form in -ing (e. g. That is hitling that nail on the head). For this usage in More see $\$ 336$ a.

1) For the types he is to go; that is to wit see $\$ \mathbf{4 1 2 - 4 1 7}$ (Syntuctical units with two verbs). 
A few earlier instances of the inflnitive after a copula follow :

a 12:5 Ancr. A. 10, Clene religiun is iseon and helpen widuwen (Huchon 1930 p. 162). I c 1412 Occleve, Reg. Pr. 168, The vertu is of liberalitie, Yeve and dispende in lyme or place due (B.). | idem 4, His moste desire is to be solitarie (B.). | c 1400 Mandev. Tr. 170, 24, the pridde weye is pat comelh to Comanye \& pan to go be the grete see (M.).

No conslructions with for + (pro)noun-subject have been observed in More. Constructions with for to are very rarely met with and may already have been obsolescent :

Passion 1403 E 8, the sureste remedy for a manne to master his sensualilye was for to flye awaye.

They are also exceptional in St. John Fisher :

Wks. 269, 14, lel no man thynke that myn entent ts for to pray-se him.

In older English they were of frequent occurrence :

c 1386 Chaucer C. T. F 301, to love God is for to love that he lovelh. I c 1412 Occleve, Reg. Pr. 50, hir usage is for to flitte tro place to place (B.). | c 1400 Mandev. Tr. 166, All bere lust ... is for to putten all londes vnder hir subieccion.

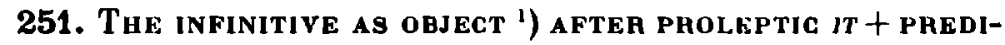
cative adjunct. Type : he thought it possible to go.

Rich, 5:3 E 10, whither he could thinke it possible to winne the lord Hasting into their parte. | Rich. $66 \mathrm{~B} \mathrm{9,} \mathrm{they} \mathrm{thought} \mathrm{it} \mathrm{for} \mathrm{the} \mathrm{weale}$ oniversal to take that way. | Dial. Her. 105 C 12, I thought it ... ynough to tell the messenger my minde by mouth. | Dial. Her. $110 \mathrm{H} 12$, be tbought it heresye, to thinke the oppinions of any man to bee good...

Without proleptic $\boldsymbol{\imath t}$ :

Conf. Tynd. 388 F 13, To do penaunce he taketh for idolatry. | Pich. $38 \mathrm{H} \mathrm{4}$, Ye se theit youthe, of whiche I reckon the only suretie to reste in your concord.

For + (1'RO)nOun-subject.

Lett. 1451 E 5, I thought it lytle nede for me to bestowe muche tyme vppon theym.

Fon to. Only one instance with a construction in which the infinitive is preceded by for to has been observed :

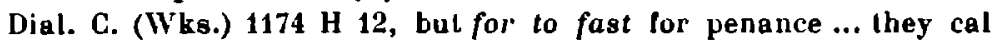
playne iniurye to the passion of Christ.

The use of the infinitive as object after it + predicative adjunct, bolb with and without for + (pro)noun-subject, has

1) For constructions of the types to intend to go; ought to go; to go move; llke to go; begin to see; I saw him go see 98389 \&. 
been preserved in Pres. D. Eng. The idiom was known before More's time. Buchtenkirch 1889, p. 6, quoting several instances from Occleve, says : "So natürlich nun auch diese Konslruktion klingt, so scheint sie doch wunderbarer IVeise vor O[ccleve] nicht vorzukommen, sie wird wenigstens weder von $\mathrm{Ch}$ [ild] noch von $M[$ [ätzner] erwähnt, und auch mir ist es nicht gelungen sie vor O[ccleve] nachzuweisen".

Earlier and later instances :

c 1400 Mandev. Tr. 145, 1, And all be it pat sum men wil not trow me, but holden it for fable to tellen them lhe nobless of his persone (M.). I 1653 Walton, Compl. Angier 177, to do no, they account a profa. nation (OFD). | 1913 Walser, Outl. Vict. Lit. 5, To discover hi in and then do him and his work justice, Carlyle regards as the first duty-

252. The INFinitive in the OBJECT GhOUP : What TO THINK, ETc.

Aich. $57 \mathrm{G} \mathrm{13,} \mathrm{no} \mathrm{man} \mathrm{wist} \mathrm{what} \mathrm{to} \mathrm{thinke} \mathrm{nor} \mathrm{whome} \mathrm{to} \mathrm{trust.} \mathrm{|} \mathrm{Dial.}$ G. (Wks.) 1263 B 4, be can not see where to fasten a stroke on vs.

The infinitive is here used in a kind of condensed indirect question. The phrase may have developed out of the Old English full construction of the type hwcet heom to donne wcere (Kenyon 1909 p. 141), as in :

Chron. 215, $1085 \mathrm{E}$, nyston hwal heom to donne socere. | O. E. Laws (Thorpe) 368 il Cnut, c 84, smeage swype georne, hwot him sig to donne \& hwæt to forganne.

More differs from the usage in Middle English, where both plain and prepositional infinitives were possible, in that he uses only infinitives preceded by to '). Chaucer and Mandeville seem to have preferred the latter construction too.

1225 Kalh. 315 pe king ... nusle hwet seggen. | 1297 Rob. of Gloc. 15, hii nuste wider drasue. $\mid \mathrm{c} 1350 \mathrm{~W}$ illiam of Pal. 618, where soiourne wot i neuer. I c 1374 Ghaucer, Troilus I 301, Unnetbes wiste he how to loke or winke. | c 1400 Mandev. Tr. 200, 14, pei wyle not what to done wilh hire godes. | 1697 Dryden, Fneis Iv, 423, Jove will inspire him when, and what to say.

For to. No instances with for to, as in Chaucer's He n'hath wheron now lenger for to honge (Troilus V, 1199), have been found in More's English.

1) Cf., however, the following passage: Dial. Her. $181 \mathrm{E} \mathrm{3}$, therefore be they drieuen to denye for the churche the people that bee knowen for the churche. And go seke another they neyther knowe what nor where. 
252. The infinitive as adungt to a noun ${ }^{1}$ ).

The relation between the infinitive and the preceding noun is not alvays of the same character. The following cases may be distinguished :

a. Type : a desire to get before his neybour. Here the infinitive is used as a kind of apposition to the noun, and thus equivalent to an attributive clause of contents ${ }^{8}$ ).

b. Type : rediness to wax angry. The infinilive, though used attributively, is closely akin to an adverb adjunct of purpose or a prepositional object; in this case the particle to has retained a good deal of its original prepositional character ${ }^{3}$ ).

c. 'Type : the world to come. The infinitive is a pure atlributive adjunct and equivalent to an adjective.

254. Type a. : a desire to get hefore his neybour.

Last Th. 83 B 13, [he] taketh his enuy for an boly desire, to get before his nrybour in veltue. | Rich. 59 G 2, I wold not be a kyng wilh that condicion, to forbere mine owne lyberty in choise of my own mariage. | Dial. C. (Wks.) $1215 \mathrm{C} 3$, the medecine that I haue heard taught one for the tolhe ache, to goe thryse about a church yaide, and never thyoke on a fox layle. | Dial. C. (Wks.) 1184 D 3, when I conie bome [[] $\mathrm{Am}$ fain to do the labour to plucke her my selfe. | Picus 28 B 11, whoso hath the grace to come thereby, He iudgeth him in perfit ioy. I Rich. 47 F 3, a licence ... to dooe more. | Last Th. 84 D 1, yet have they some hope ... to breke prison... | Dıal. C. 301, ieopardye ... to lyue

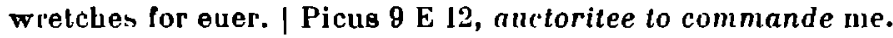

This usage is common in all periods; now often with of + form in -ing.

Fon + (PRo)nous-guBject. No instances of constructions in which the subject of the infinitive is expressed by for + (pro)noun have been found. Cf. Pres. D. Eng. : Your plan for me to go doesn't please me (Curme 1933 p. 203).

For To. No instances found.

EARLIER.

13... Minor Poems fr. Vernon MS. 593, Haue now hope to liuen

l) Not announced by proleptic it, that is. See $\$ 249$.

2) For the rival construction with a furm in -ing (torment of beating) see $\$ 351$.

3) For the rival construction with a form in -ing (dexterity in acheging) see \& 355 . 
longe (OED). I c 1386 Chaucer, C. T., A 3191, al his fantasye Was turned for to lerne astrologye, And koude a cerlain of conclusiouns, To demen by interrogaciouns... (OED).

LATER.

1665 Boyle, Occas. Ren. Introd. Pref. 13, I look Pleasure to imagine two or three of my Friends to be present (OED).

The inflnitive has an activo-passival characler (see $\$ 285$ ) in :

Dial. C. (Wks.) 1253 D 8, thys dooeth reason alone in manye casés, where it hathe muche lesse help to take hold of, then it hath in this matter of fayth.

More often this relation is expressed by means of a group consisting of to be + past participle, e. g. thinges to be believed; a proclamation to be made. See $\$ 563$.

255. Type b. : redines to wax angry.

The line of demarcation between this group and that illustrated in $\$ 254$ is not always easy to draw, the difference being sometimes very sublle.

In many cases it is difficult to decide whether the infinitive refers to the noun only (as in so should they have occusion to cal for grace) or to the contents of the preceding synlactical unit as a whole, especially if the infinitive + to denotes purpose ; consequently the classification is occasionally more or less arbitrary and some of the quotations might as well have been placed in the paragraph on adverbial adjuncts of purpose (\$ 259). In a few cases (e. g. redines to) there is a strong similarity to the prepositional objects ; here to has not so markedly weakened in meaning as in other constructions; in Pres. D. Eng. verbal forms in -ing are not rare after this pregnant $t o$.

Last. Th. $87 \mathrm{C} 7$, the redines that men haue to wax angry. | Last. Th. $83 \mathrm{D} 4$, so shold they hane occasion to cal for grace \& wax good. | Last Th. 82 F 17, occasion to flee vain plesures... | Picus 12 D 15, These be they, whom our lorde bath deliuered into the passions of rebuke, and to a reprouable sense, to dooe those thinges, that are not conuenient. I Ricl. $70 \mathrm{G} \mathrm{4,} \mathrm{he} \mathrm{craftelye} \mathrm{sought} \mathrm{the} \mathrm{waies} \mathrm{to} \mathrm{pricke} \mathrm{him} \mathrm{forwarde.} \mathrm{I}$ Dial. C. 346, he shal neuer haue list to slepe. | Last Th. $89 \mathrm{~A} \mathrm{4,} \mathrm{god} \mathrm{hath}$ not geuen bim leue to eat of it. | Last Th. 79 A 1, vnlawefull longyng to lyve. | Dial. C. 137, a meane to get man thys first comfort. | Last Th. 76 A 18, Ther is as scripture saith, time to speke \& time to kepe thy tong. I Supplic. 316 F 11, diuers doctours allege diuers causes of his heauines and lothnes at the time to depart \& die. 
A common idiom in all periods.

\begin{tabular}{|c|c|}
\hline EARLIEA & LATER \\
\hline $\begin{array}{l}\text { 13... Cursor I. } 11814 \text {, Nu neghes } \\
\text { tim to take his lai (OED), } \\
\text { c } 1385 \text { Chaucer, L. G. IV. 200) Rown } \\
\text { To welde an axe. }\end{array}$ & $\begin{array}{l}1635 \text { Quarles, Embl. I vir } 3 \text {, Is this } \\
\text { a time to pay thine idle vowes } \\
\text { (OED). } \\
\text { a } 1845 \text { Hood, Lay of Labourer } 1 \text {, } \\
\text { A hook to reap, or a scythe to } \\
\text { mos (OED). }\end{array}$ \\
\hline
\end{tabular}

For + (pro) nocn-gubject.

In those cases in which the subject of the inflnitive is expressed it is preceded by for, just as in Pres. D. Engl.

Picus $14 \mathrm{G} \mathrm{5,} \mathrm{Ye} \mathrm{writ} \mathrm{vnto} \mathrm{ine,} \mathrm{that} \mathrm{it} \mathrm{is} \mathrm{tyme} \mathrm{for} \mathrm{me} \mathrm{now} \mathrm{to} \mathrm{put} \mathrm{my}$ selfe in houshould with some of the great princes of Italie. | Passion 1271 B 8, it should not haue left any place in them, for any contrarious appetite or affeccion to enter I).

\section{EARLIEA}

c 1386 Chaucer, C. T. A 3268, She was a prymerole, a piggesnye, For any lord to leggen in his bedde.

\section{LATER}

1908 A. Bennelt, Old W. T., ch. I, The girls made way for him to pass them at the head of the twisting stairs.

Fon to. Infinitives preceded by for to do not seem to occur in More. Cf. :

c 1412 Occleve, Heg. Pr. 169, A gentille hert for to begge hath shame. | c 1400 Mandev., Tr. 7, 16, oyle of mercy for to anoynie with the membres.

256. Type c. : the world to come.

Dial. G. 195, we should amend and be beller in the time to come. I Last Th. 8t B 1, Wold not ... the depe consideracion of this sodein channge so surely to come, ... withdraw the wind that puffelh vs vp in pride... | Last. Th. $88 \mathrm{G} \mathrm{13,} \mathrm{these} \mathrm{couetous} \mathrm{nigardes} \mathrm{...} \mathrm{alway} \mathrm{spare} \mathrm{al}$ for their time to come, thus driue thei forth wrechedly, til al their time be past \& none to come. | Last Th. $98 \mathrm{E} \mathrm{8,} \mathrm{jet} \mathrm{speake} \mathrm{I} \mathrm{not} \mathrm{of} \mathrm{the} \mathrm{world}$ to come, but of the lifo present. | Rich. 55 A 9, tokens of thingis to come. | Last Th. 74 HI 11, hope of his glory to come.

There seems to have been in Middle English and still in More some hesitation about the most suitable form of the verb, with its implication of futurity, in this kind of collocation. Usage vacillated between the (world) to come, the

1) With of instead of for : Dial. C. 151, [there] hath appeared good lykelyhood of som good agrement to growe to gether in one accord of our faythe. 
(world) coming, the (world) for to come 1), the (world) to coming ${ }^{2}$ ), the to comyng (hr(r)est) ${ }^{3}$ ). There was probably confusion of the verbs to come and to to-come ${ }^{4}$ ). In More only the first two combinations ${ }^{5}$ ) occur; there are, however, but few instances of the second :

Last. Th. 89 I) 6, Whosoever he bo that herelh this, and yet puleth \& wimpereth for dout \& fere of lack in time comming, ... he beleueth not that Christ spake these wordes. / Prayer 1419 D 2, prouision to be marle ... Ior sede thys yere comming.

In Pres. D. Eng. only the first of the four variants (the world to come) has been preserved.

Earlier : $1382 \mathrm{Wyclif,} \mathrm{Matt,} \mathrm{m,} \mathrm{7,} \mathrm{Who} \mathrm{shewide} \mathrm{to} \mathrm{zou} \mathrm{for} \mathrm{to} \mathrm{Mee}$ from wrath to cumme [v. r. comynge; 1388 that is to come] 1400 Apol. Loll. 5 , in pis tyme, and in tyme to come.

By the side of the concise (the worlll) to come two fuller formulae were used, viz. (the world) that is to come $(\$ 414)$ and (the world) that is coming :

Dial. C. (Wks.) $1263 \mathrm{~F} \mathrm{14,} \mathrm{the} \mathrm{glorye} \mathrm{that} \mathrm{is} \mathrm{to} \mathrm{come.} \mathrm{|} \mathrm{Last} \mathrm{Th.} 74$ F 7, not oncly in the worlde that is comniyng, but also is this present life.

Nore does not make use of the construclion that is to coming ${ }^{8}$ ), so frecuently met with in Wyclif, e. $\mathrm{g}$.

Acts $x I x, 4$, in hyin that was to comynge. | idem xxIr, 29, thei that weren to turmentinge him. | 2 Peter I, 6, putle hem the ensaumple of hem that weren to doynge yuele. John, vI, 71, this was to bitraiynge him. | Luke xxu, 23, who it was of hem that was to doynge this thing.

A comparison of the combination noun + infinitive, as illustrated here ( $($ orld to come), with that discussed in $§ 255$ (time to go) shovs that there is an important difference : in

1) Used by St. John Fisher, by the side of to come (Weyl 1937, \$227).

2) 1387 Trevisa, Polychr. I 267, For misbyleued men in time to comynge shulde porw 3 hem be conuerled and i-torned to good byleue.

3) 1483 Caxton, Gold. Leg. 239, 1, The lirst fruyte of the to comyng haruest. | 1490 Gaxton, Eneydos (E. E. T. S.) 4, My tocomynge naturell and souerayn Lord. | 1485 Caxton, Ch. Gr. 134, 27, Guy, hir loue and to coming hushand.

4) See OFD s. v. To-come 2 (1393 Langl. P. Pl. C xxII, 343, These tocomen to conscience. | 1455 Gharter in Liber Eccl. de Scon. 185, To all paim to quhais kwalagis pir present lettres sal to-cum).

5) The last two seem to have become obsolete before More's time, the latest quotations in OED being dated respectively 1382 and 1490.

6) This is probably a case of phonological confusion, in looking upon the endings -enne, -ende, -inde, -eng(e) and -ing(e) as one morpheme.

MATERIALS XIX 
the world to come the noun is the subject of the infinitive, which is not the case in time to $g^{\circ}$; here the subject of the infinitive is not expressed.

The follorving Pres. D. Eng. sentences show combinations of noun-subject + infinilive the character of which is somewhat different from that in the world to come, with its distinct implication of simple futurily :

She was the woman to make the most of such fears. | He was hardly the man to overasse a crowd of hard characters.

Instances of this usage in More are not rare :

Debell. $1000 \mathrm{E}$ 1, he whiche confesseth himselfe ones forsworn, is by reason mistrusted, as one ... to he able to swere fals. | Dial. Her. 139 B 5, onely Christ is our Sautiour and mediator to bring our nature again to god. | Dial. C. (Wks.) $1260 \mathrm{C} 7$, He is our guyde to guyde vs thither. Conf. Tynd. 629 B 7, concerning the stone to go thorow the wharle, and the stone to fal thorow the eartb. | Last Th. 95 D 8, the eye is not only the coke \& the tapster, to hring the rauenous appetile of delicate meale \& drink into the bellye... but the eye is also the band, to bring the hert to the desyre of the ... beslly pleasure henethe the bely.

The most striking feature of this construction is the vagueness of the relation between the subject and the verb; the context seems to be the only guide to a right interpretation (one.. to be able = one who is able; mediator to bring = mediator who will bring; our guyde to guyde = our guyde whose task it is or who can guide us; the stone to go = the stone which is to or has to go through the whorl; the tapster to bring = the tapster who hrings or who will bring). This vagueness is perhaps the cause why this idiom survived in a few cases only.

No data have been discovered concerning the earlier history of this idiom.

\section{Type The first man to go.}

This is clearly an instance of the construction discussed in $\$ 256$. It is common in Pres. $D$. Eng., but seems to have been unknown to More; in his language first is always followed by a clause opening with a relative pronoun :

Picus 20 E 15 , Christ was the first, whiche entered paradise, \& opened the Iyfe vnto vs, and was the first that rose againe.| Letl. $1428 \mathrm{D} \mathrm{2}$, I was the first that was called in. I Rich. $41 \mathrm{G} \mathrm{13,} \mathrm{to} \mathrm{bee} \mathrm{the} \mathrm{fyrste} \mathrm{that}$ shoulde that daye attende vppon the Kynges highnesse.

The use of an infinitive after first seems to have sprung up 
in very recent times; in all the quotations in $O E D$, ranging from c. 1200 to 1857, Arst is followed by a clause ').

258. The INFINITIVE AS ADJUNCT TO AN ADJEGTIVE ${ }^{2}$ ).

Type They are content to fynde no fawte.

It is difficult to decide whether the infinitive was felt as an adjunct to the adjective [the fautes were hateful ... to here] or whether the adjective + infinitive formed a close group serving as a complement to the verb [the faltes were... hateful to here]. There is no outward sign which gives a clue one way or the other, but in some cases only one interpretation is possible, e. $\mathrm{g}$. they are content ... to finde no fawte; conetous are ... hard to hele ${ }^{3}$ ) (Jespersen 1928, p. 216). After some adjectives the influitive is equivalent to a prepositional object : fain to; ready to ; elc. ").

Rich. $55 \mathrm{G} \mathrm{10,} \mathrm{he} \mathrm{was} \mathrm{a} \mathrm{goodly} \mathrm{parsonage,} \mathrm{and} \mathrm{very} \mathrm{Princely} \mathrm{to}$

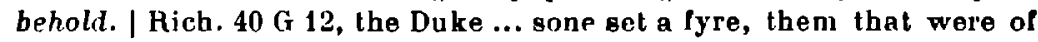
themself ethe to kindle. | Last Th. $77 \mathrm{~F} 2$, lhough it be ongly to behold. | Apol. 3, my writing is ouerlonge, and therefore to tedyouse to rede. I Dial. C. 180, the thing be liefull to require. | Debell. $935 \mathrm{~B} 2$, fautes that were hatefull and odiouse to here. | Last Th. $93 \mathrm{~B} \mathrm{3}$, couetous be hard to hele. | Rich. $59 \mathrm{G} \mathrm{13,} \mathrm{neither} \mathrm{of} \mathrm{vs} \mathrm{is} \mathrm{lyke} \mathrm{to} \mathrm{be} \mathrm{barain.} \mathrm{|} \mathrm{Hich.} 41 \mathrm{C} \mathrm{11,}$ the moste harme there [was] like to fal where he lest would. | Hich. 41 C 9, the hurte ... which was likely not to be litle. | Picus 11 A 10, glad to paie some money. | Last $\mathrm{Th} .78 \mathrm{H} \mathrm{4}$, he is sure to keepe bym for euer. | Picus $32 \mathrm{D} 5$, who able were to beare thy punishement? | Last Th. 6. $\mathrm{H} 5$, [they] be as loth to spend ought, as thei be glad to get al. I

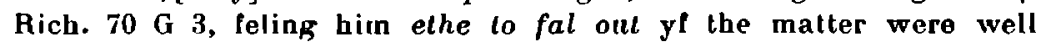
handled. | Apol. 15, therfore are they content to fynde no fawte. | Dial. C. 210, when I come home [I] am fain ${ }^{5}$ ) to do the labour to plucke her $\mathrm{my}$

1) The question seems, however, to require further investigation, since there is an example of the parallel construction with the last + infinitive daled 1535 in OED : Coverdale 2 Sam. xix, II, Why wyl ye be the last to fetch the Kynge agayne vnto his house? Cr. Jespersen 1928 , p. 393.

2) Not announced by proleptic it (see $\$ 248$ ).

3) For the activo-passival character of this infinitive see $\$ 285$.

4) For the rival construction with other prepositions and a form in -ing (swift in taking) soe $\$ 355 \mathrm{c}$.

$\left.{ }^{3}\right)$ The word fain often has tho meaning obliged in More's English :

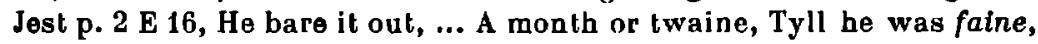
To laye his gowne to pledge. | Jest p. 2 A 15, So was be faine, From 
self. | Picus $19 \mathrm{C} \mathrm{14}$, ydolaters wer wont ') to gather the bloode of their sacrifice togelher. I Picus 9 F 8, He was wont to be conuersaunt wilh me.| Picus 26 A 4, holde to synne. | Dial. C. 316, ready to vomite. | Debcll. 933 В 13, desirouse to se.

Sometimes verbal forms (willing, ashomed) are used as adjectives in this construction :

Dial. C. 217, such as are wel willing to do any purpose that is so shameful. | Last Th. 88 B I2, ashamed to be wroth.

Litlle and much allow of the same construction :

Dial. Tynd. 118 I 18, if there were so lyttle to do. | Aut. Lett. xiv 209, theyre capitayns shall haue inuch $a$ doo ${ }^{2}$ ) to kepe theym from crying home.

All the above instances contain infinilives with to. The plain infinitive is very exceptional :

Dial. C. (Wks.) 1214 B 3, manye of these felowes thut are mete for the war, fyrst wer wont as it were in sport, and in a while after half betwene game and earnesle, and ... nowe not farre from layre flatle earneste in dede, talke as thoughe they looked for a dyye, whan with a turne vnto the Turks fayth, they shoulde be made mayster's bere.

For + (PRo) NOun-subJect.

Though there are numerous instances of constructions in which the infinitive is an adjunct to an adjective, the number of examples in which it is preceded by for + (pro)noun is comparatively small.

Picus 7 D 5, a thing farce excelling all the conning that is possible for us in this lite to obtaine. I Debell. $938 \mathrm{C} \mathrm{2}$, which is the thing that as I gaid semeth me neither bonorable nor profilable ... for ani english man to do. | Aut. Lett. xiv 110, if the french king approch they in with an army riall which is more easy for hym to do in his awne realme than for the kinges grace to rescue theym with a lyke arny.

thence agayne, To put it (scil. his money) in a cup. | Rich. 37 E 9, with large giftes hee get (= got) him vnsted faste frendeshippe, for whiche hee was fain to pil and spoyle in other places. | Dial. C. 327, yet after were his brethern fayne to seke vppon hire for breadde. | Dial. C. 281, The man ... swette with the laboure so that he was fain ... now and than to wipe his face. I - But cf. Dial. C. 217, she wold so fayne bring it to passe.

1) If wont stands without preceding to be, it may be looked upon as a verb instead of an adjective : Picus $3 \mathrm{~A}$ 1, the verses, which he heard once red : he woulde ... holde it in sure remembrance : which in other folkes coont commonly to happen contrary. I - See OED s. v. wont.

2) ado, northern dialect form for to do; originally Norse. 
Only the context prevents the reader from misunderstanding the following sentence : Picus $29 \mathrm{C} 8$, Thus shouldest thou, in thine heart wish, coueit and be glad For him to suffer. The meaning is to suffer for him.

No instances have been found in which the subject is not preceded by for '), as in the following quotation from Mandeville :

Travels 83,10 , For the lond and the contree is not wortht houndes to duell jnne (M.).

Fon тo. Instances with for to preceding the infinitive are very rare :

Dial. C. (Wks.) $1253 \mathrm{E} 11$, thys maketh him well content and glad also for to take it.

In St. John Fisher we find :

Wks. 192, 20, Whan our lord bath ... made vs able in vertues for to preche and shewe his blessed name.

EARLIER :

c 890 tr. Heda's Hist. II i 98, pæel he selfa zeara wære ... pæet weorc to fiemmenne (OED). I c 1412 Occleve, Reg. Pr. 145, Alle the world hade not be suffiaunt To haue receyued so large a geaunt (B.).

c 1400 Maundev. Tr. 133, 30, pei ben hidonse for to loke vpon (M.). I c 1412 Occleve, Heg. Pr. 71, Whas vertu I am insufficient For to discrive (B.).

Occasionally the adjective is separated from the infinitive by a noun :

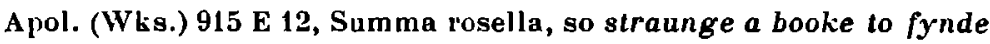
\& so harde to vnderstande. | Last TL. 93 A 5, For surely it is a hard nore to care. | Hich. $64 \mathrm{H} \mathrm{9,} \mathrm{il} \mathrm{was} \mathrm{a} \mathrm{goodly} \mathrm{cry} \mathrm{and} \mathrm{a} \mathrm{joyfull} \mathrm{to} \mathrm{here.}$

This usage is quite common in Pres. D. Eng., e. g. :

1900 Gissing, House of Cobwebs 267, an ensy man to deceive. | 1911 Chesterton, Inn. F. Br. 215, The little priest was not an interesting man to look at.

There are in More parallel constructions in which the passivity of the action is expressed by means of a group consisting of to be + past participlo :

Kich. 57 D 5, I doubt not some shal think this woman to sleight a thing to be writlen of.

Fon ro. In earlier English the infinitive was often preceded by for to :

147085 Malory M. D'A. 305, 12, good knyghles and hard men for to wynne in bataille.

l) Coinpare, however, $\$ 248$. 
No instances of this usage have been observed in More.

LATER :

1583 Peele, Atraign. Par. 1, ii, 26, A pretty fable, Paris, for to read.

259. The infinitive as an equivalent to an adverbial CI.AUSE OF PURPOSE.

Type He departed to Bononie to studie.

Dial. Her. 275 D 5, they had used al the waies thei could to allect the people by preacbing. I Apol. 176, they baue made that noyse ... to fere the ordynaryes therwilh. | Last Th. 81 F 6, whan thou beginnest to set the first foote forward to goe out. | Picus 3 B 3, he departed to Bonomie to studye in the lawes of the church. | Dial. C. 229 , a greal crosse that be had made to nayle a newe carued crucifixe vppon ').

In Middle Engligh at was often used instead of to in this function :

1280 Kemble's Cod. Dipl. 11 186, Na man sal have at do. | c 1344 Guy Warw. 88, That he cum with the at ete. 1470 Harding, Chron. Pref. 1 , Lordes sonnes bene sette... To scole at lerne.

There are no examples of this usage in More. The latest quotation in OED is dated 1470.

The subject of the infuilive is expressed in :

Picus 4 F 3, for wich many worthie philosophers ... resorted busely vnto him, as to a market of good doctrine. Some for to moue questions \& dispule : somme... to heare.

This is the nearest approach in More to constructions of the type pal bows... was opene at eiper ende, to gon yn al pat wolde. The much discussed Old English sentence (Vülfing 1901, \$487; Shearin 1903, p. 15; Zeillin 1911, p. 145 and Callaway 1913, p. 169) from Orosius : hie heura here on tu todældon, oper at ham beon Leora lond to Lealdanne, oper ut faran to winnanne is by some grammarians looked upon as the prototy pe of the construction in question. There are numerous instances in Middle and later English : 1362 Piers Pl., pe chiel balle pal was made fol meles, men to eten inne (E.). I 1440 Pall., The semynair is even dolven londe ..., plantes in to stonde (E.). | 1523 Berners Froissart 1368 , thenglysshmen made great dykes and bedges about, their archers to be more stronger (KI.).

In view of the fact that this construction occurs rather frequently in Berncrs, More's contemporary (Klausmann 1919, p. 106), it is not easy to account for its rare occurrence in

1) For the rival construction wilh a lorm in -ing (e. g. Picus 2 F 10 , they be borne to the atchieulng of some great thing) see $\$ 334$ and 365 . 
More. There is, horvever, something similar in the following sentence :

Hich. 66 D 15, here we take vppon vs the royall estate, preeminence and kyngdome of the twoo noble realmes, England and Fraunce, the tone fro this day forward by ve and our heires to rule, gouerne and defend, the tother ... to geat again and subdewe, and established for euer in due obedyence vnto this realme of Englande.

The passive character of the infinitives (to rule, gouerne, etc.) is brought out by the adjunct by vs and our heires. It is possible to assume confusion of two constructions : a) the tone (for us) to rule, etc.; b) the tone by us to be ruled. The strange form established, if not a misprint, points to the truth of this conjecture.

FOH + (PHO)NOUN-SUBJECT.

No instances have been found in which the subject of the infinitive is preceded by for, the idion so common in Press. D. Engl. : 1910 Bennet, Old W. Tale, ch. II, 81 Constance rang the boll for Maggie to clear the table.

Fon to.

To strengthen the idea of purpose for to is often used instead of the weaker to.

Aut. Lett. vi 2, for to put ') the mater in the more surtie the said Iwoo sh[ipp]is shall in any wise goo lorth. / Supplic. $290 \mathrm{H} \mathrm{13,} \mathrm{For} \mathrm{to}$ proue that it is alway so, he layeth that it has been so thrice. | Jest p. 2 A 3, For to put out, All maner dout, He made a good puruay. | Last

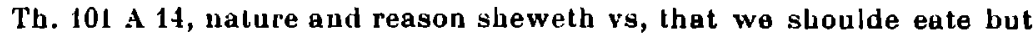
for to liue. | Jest p. 1 G 8, His sonne be wolde, Should baue this golde, For to beginne wilh all.

Occasionally for to is expanded inlo for as much as to :

Picus $20 \mathrm{~A} 1$, but for as mach as to haue this lygbt of vnderstandyng ... therelore the prophete suyngly saith...

No instances of for with a plain infinitive have been found ill More, as in : c 1205 Layamon, Brut. A 13305, ict wm icumen po pus næl. ... for suggen po tipende.

EA HLIEH

971 Blickl. Hom. 165, To whom

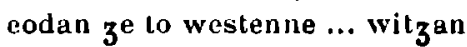
to secenne (OED).

\section{I.ATEH}

1577 B. Googe, Heresbach's Husb. I 3, I get into my closet to serue God (OED).

1) Cf. the construction with for + form in -ing illuslrated in $\$ 354$

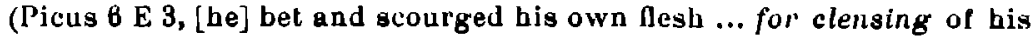
olde offences). 
1388 Wyclif, Matt. Iv, i, Thanne Jhosus was led of a spirit in to desert, to be templid of the feend (OED).

c 1386 Chancer C. T. A 4156 , The cradel at hir beddes leet is set, To rokken, and to yeve the child to sowke.

c 1412 Occleve, Reg. Pr. 12, The sacromente he lete lette this wrecche to converte (B.).

IVith for to only earlicr quolations have been found :

c 1205 Brul $817 \%$, pe wes pudere icumen for to iseon pare cnichte gomen (OED). I i 1412 Uevleve, lleg. Pr. 40, Barres and lokkes strunge for to haue, His goode from theves for to kepe and save (B.).

260. Type Beare the swerde to the cullers to grinde.

Supplic. $299 \mathrm{E} 2$, and tell hym his swerde is to dull: as though ho would bid him beare it to the cullers to grinde. | Rich. $45(=44)$ F 16 , the lamb was betaken to the wolfe to kepe.

In these quotations, as in those of $\$ 259$, the infinitives denole purpose; their relation to the rest of the sentence is, however, of a different character. More than one interprelation is possible : grind may have the cutlers and kepe may have the wolf as subject [beare it to the cutler's (for them) to grind (il); was betaken to the wolfe (for him) to kepe (it)]. If this is the rase, the influilive has an aclive meaning. Swerde and lamb may, however, be regarded as the objects of the infinitives, which would then have a passive characler [beare it to the cutlers to be ground].

The construction was in use before More's time :

13... Cur's. M., Prol. 232, pis ilke bok it es translate. Into Inglis tong to rede For pe love of Inglis ledle, Inglis lede of Ingeland. | c 1386 Chancer, C. T., A 4156, The cradel at hir heddes fect is set, To rokken, and to yeue the child to sowke. | illem, BI. 48 , we hit me took to rede. I c 1400 Three Mi. Eng. Sermons (Grisdale 1939) 59, 28.3, pat tresur pal God luk vs for to kepe.

In Pres. D. Eng. These terse constructions are no longer used ; the passive character is generally expressed by a group of verbal forms, as, in conversalional language, in : I took the battery to the wireless man's to be charged. Lsually, however, to have it charged would be preferred. 
In the following passage the construction is of a slightly dilferent nature :

Last Th. 95 B 14, Which thyng if we dyd as well remomber, as wo wal know, we ... wold put into pore mens purses our money to kepe, that deth ... shold not finde it aboul vs.

Poor men is evidently meant as the logical subject of to kepe.

Jn similar cases Ben Jonson and Shakespeare use a form in -ing.

Ben Jonson, Poetaster $\mathrm{II}, \mathrm{i}, 407$, you sbould have seen me unrip their noses now, and haue sent them to the next barber's to stitching. I Shaksp. Wives Iv, ii, 105, Behold what honest cluthes you send furth to bleaching!| idem Ado Ir, iii, 4l, happy are they that hear their detractions, and can put them to mending.

261. Type I shal gene him to eate.

Dial. C. (Wks.) 1.59 I) 9, To him that ouercomelh, I sbal geue him to eate of the tree of life. | Debell. $1093 \mathrm{G} \mathrm{10}$. Christ sheweth what ho would gyue them to eate.

In Old and Middle English this construction was frequently used. The main part of the formula mostly contains a verb of giving or bringing, and the infinitive almost exclusively denotes eating or drinking (Shearin 1903, p. 13; Kenyon 1909, p. 111). In Old Eng. and in the Ancren Riwle (Redepenning 1906, p. 20) plain infinitives are employed. Later writers (e. g. Chancer, Occleve and Layamon) use the plain and the prepositional infinitive proniscuously. Sometimes at is found instead of to :

Gregory 329, 36, Me pyrste \& ge me scaldon drincan. | c 1205 Layamon, Brut. 13580 me heom brohte drinken.

c 1205 Layamon, Brut 30795 , per mid heo bar to drinken.

c 1340 Pseudo-Holle Pr. Consc. 619, And yhe wald nolt gyfe ne at ete.

In Pres. D. Eng. the usage is archaic.

262. Type To say the truth.

Closely akin to the adjuncts of purpose are the clauseequivalents of the above type, though an idea of condition is not excluded ${ }^{1}$ ). The subject, which is not expressed, must be inferred from the context and is in many cases not the same as that in the main part of the sentence (absolute use).

1) As a proot the following four variants in Shakespeare may be adduced : to say the sooth, H. V, III, vi, 151 ; to say 800 th, H. VIII, II, iii, 30 ; yooth to say, Etr. $1 \mathrm{v}, \mathrm{iii}, 72$; if I say sooth, IIcb. I, ii, 36. 
The collocations that most frequently occur are : to be briefe. to come to the point.

to be short. to passe oser other. to sily the truth. to make an end. to begynne with. to be plaine. short tale to make. so to say. to retonrne (to my purpose). to tell you forth.

a) Related.

Lett. 1452 H 10, And verelye to bee short. I parceue litlle difference. | Dial. Her. $138 \mathrm{D} 10$, to saye the trouth I neuer herde any thyng sayde so sore therin. | Picus $13 \mathrm{G} 5$, Now to make an ende with this one thing, I warne the(e). | Dial. C. (Wkg.) 1236 E 2, And therefore... to begynne with, let vs be of good comforte.

b) Absolute.

Pagsion 1402 F 12, And to be briefe, by thexaumple of thys yong man are we laught... | Dial. C. 220 , How be it, to be short, it is sone sene, that therin the sum and effect of the counsayle must ... rest. | Rich. $57 \mathrm{C} 6$, her he loued, whose fauour to sai the trouth ... she neuer abused to any mans hurt. | Last Th. $76 \mathrm{E} 6$, But now to retourne to my purpose ... it must ... ensue, that we shal consequently do good... | Kich. 38 B 3 But nowe to returne to the course of this hystorye, ... certayn is it... I Hich. 69 A 16, For first to beginne with the minister's, Miles Forest at sainct Martens pecemele rotted away. | Picus 2 F 12, Hut to passe ouer other '): The great Saint Ambrose, a swarme of bees flew about bis mouth... | Dial. C. (Wks.) 1242 B 7, yet to be playne with you ... my minde findeth not it self satisfyed in this poynt. | Dial. Her. $131 \mathrm{~F} 15$, But now shorte tale to make, this jonge woman... | Dial. Her. $134 \mathrm{E} 4$, But to tell you forth whan the kyng was comen, \& the towne full, sodainlye thys blind man... | Dial. Her. $141 \mathrm{C} \mathrm{4}$, But now to come to the pointe. | Dial. Her. 207 B 13, wherin so to say thei can haue no more bulde than if they would say the crowe were white.

Common usage in all periods of the English language. The well-known Middle Eng. collocation sooth to seyn has not been found in More, though it survived lill Shakespeare's time. Some of More's phrases are no longer used in Pres. D. Eug. (e. g. short tale to make, to pass ouer other, etc.).

EA RLIEH

c 1305 St. Kenelin 266, to telle hit wipoute rym pus wordes rizt hit were (OED).
LATEH

1600 Sluk. A. Y. L. I, i, 8, He keepes me rustically at home, or (to speak more properly) staies me Leere at home vikept.

1) Tiansl. of "ut omittam rellquos". 
c 1386 Chaucer, C. T. A 1895, And shortly to concluden, swich a place Was noon in erthe.

1483 Caxton, G. de la Tour g. v. b, And shortly to a ay he lost alle that he had (OED).
1888 Bryce, Amer. Comwiw. IIJ vi xcIc, 387, All their ins and outs (to use an American phrase) (OED).

For to. In older English this construclion was oflen preceded by for to (Buchtenkirch 1889, p. 42 ; Dekker 1932, \$249) :

c 1386 Chaucer C. T. A. 1341, shortly for to seyn this Palamoun Perpetually is dampned to prisoun. | c 1412 Occleve, Heg. Pr. 141, But for to speke of corage of a kjng. He... | 1470-8j Malory, Morte D'A. 487, 3, And for to make a short tale he smote doune the bretheren of syre Gawayns.

No instances found in More ; occasionally, however, in later English :

1583 Peele, Arraign. Paris I, $i, 182$, It rests in fine, fur to confirm my tulk, ye deign to pass along to Dian's walk.

Type As to loke on death.

There is some resemblance between this type and that illustrated above, though here the idea of purpose or condition is absent, it being merely an introductory formula to a following statement.

Lett. $1430 \mathrm{E} \mathrm{12,} \mathrm{Surely} \mathrm{as} \mathrm{to} \mathrm{swere} \mathrm{to} \mathrm{the} \mathrm{succession,} \mathrm{I} \mathrm{see} \mathrm{no} \mathrm{perill.}$ Last Th. $94 \mathrm{E} \mathrm{9,} \mathrm{as} \mathrm{to} \mathrm{loke} \mathrm{on} \mathrm{deth} \mathrm{we} \mathrm{be} \mathrm{for} \mathrm{the} \mathrm{most} \mathrm{part} \mathrm{pore} \mathrm{blinde}$ all the mayny.

This manner of introducing a statement seems to have died out soon after More '). It was not unknown before his time :

c 1374 Chaucer, Troylus v 974, But as lo speke of love ... I Ladde a lord to whom I wedded was.

The following Pres. D. Eng. sentence may be compared :

Speaking of volcanus, I have seen Etna in full eruption (OED).

In the following instance as for is used instead of as to :

Debell. $991 \mathrm{G} 13$, as for accuse folke openly for heresy, euery man hatb experi[e]nce inough.

Compare the earlier usage in :

1470-85 Malory, Morte D'A. 785, 22, As for to kysse yow said sir launcelot I maye doo that and lese no worstip (D.). I idem 610, 29, As for to doo this batail sayd Palomydeg I dar ry 3 t wel ende it (D.).

1) OED has only one quotation, dated 1374. The usage is not mentioned in Schmidt 1902. 
As Fon + (PRo)noun-subject. If in the introductory phrases the subject is expressed, it is preceded by for :

Dial. Her. $127 \mathrm{C} \mathrm{13,} \mathrm{as} \mathrm{for} \mathrm{yron} \mathrm{...} \mathrm{to} \mathrm{be} \mathrm{so} \mathrm{drawen} \mathrm{in} \mathrm{length} \mathrm{ye} \mathrm{shall}$ se it done in .xx. shoppis in one street. | Dial. C. (Wks.) 1152 G 14, as for any payne dewe for our sinne to be minished in purgatory ... there are ... many that viterly deny thet.

\section{The infinitive as an Equivalent to an aDVERBial} CLAUSE OF CONCESSION.

Type He wolde neuer goo back .. to dye therefore.

Dial. Her. 214 F 3 , yet woulde he not to dye therfore confesse himself faultie. | Lett. 1452 A 1, Whereunto I shortlye answerd for a very trouth, that I woulde newer medle in the worlde agayn, to haue the worlde genen me. | Picus $18 \mathrm{D} 7$, he woulde not once offende god to haue them all. | Dial. Her. 183 F 11, some that ... woulde neuer goo back with goddes woorde to dye therefore. | Rich. 67 G 16, who plainely answered that he would neuer putte them to death to dye therfore. I Other examples : Conf. 'Tynd. 761 E 8 ; idem 815 E 1 ; Passion 1390 D 17.

The earliest instances of this usage seem to date from the fourteenlh century (Einenkel 1916, p. 21) The origin is unknown. In Chaucer and Caxton occur examples wilh for : c. T. D 961, she swoor him nay, for al this world to wynne, She nolde do that vileynye or synne. | C. T. B 1327, Ne shal I never, for to go to helle, bywieye a word. | Sonnes of Aymon xu, 296, I shall nevel doo that for to deye for it.

More does not know this use of for.

The idiom (without for) was common in later Middle English, and remained so for at least a century after More's time, Shakespeare using it several times. In Pres. D. Eng. it is only occasionally met with, e. G. You could nol do that to save your life (Curme 1933, p. 340).

Examples of the usage before and after More :

c 1374 Chaucer Troilus iv 1237, I nolde a forlong wey on-lyve han be After your dealh, to han be crowned queene. | c 1412 Occleve, Heg. Pr. 168, But tho that welthy nen ban be biforne And vertuous ben, and han her goode lost, And kan not begge to be dede therfore, On hem fulle wele bystowede is the cost. | 1470 Malory, Morte D'A 127, but for by cause this Damas is so fals and so ful of treason we wold neuer fyghte for him to dye for it. | 1523 Berners, Fr. 111 276, in no wyse they wolde do so, nor forsake to be Frenche, to dye in prison. | 1592 Shakesp. Hou. J. Iv, i, 30, I would not buy Their mercy at the price of one fail' word, ... To have ' $t$ with saying 'Good morrow' | 1600 Shaksp. As Y. L. I, ii, 146, I would not clrange that calling, To be adopted hcil to Frederick. 
264. The infinitive as an equivalent to a clause of hesULt, appointMent or degtination.

Type Some man is borne, To have a lucky howe.

Jest p. 2 C 10, In mirlh and play, Full many a day, He liued merely, And men had sworne, Some inan is botne, To haue a lucky howre. I Rich. $48(=45) \mathrm{C} 2$, those that bee neyther farre vnder, nor farre aboue his age. And uathelesse of eslate conuenient to accoumpanye his noble

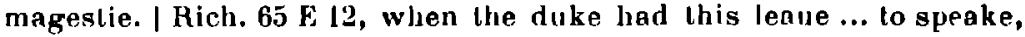
then waxed he bolde to shewe hym theyr intent and purpose. | Dial. C. (Wks.) 1258 G 3, the desyre, expectacion, and hoauenly hope therof, shall ... make vs stronge, to su/fer und sustaine...

The infinitive could be so used in older English. The usage has been preserved in Pres. D. Eng.

\section{EARLIER}

a 1380 St. Augustin 108 in Horatm. Alteng. Leg. 63-2, pei forsok pat alle men sluulde rise in flesh, to liue $a_{z} e n$.

c 1386 Chaucer, C. T. B 1171, What eyleth the man so sinfully to swere.

\section{LATER}

1638 G. Sandys, Palaphr. Job xxvil 34, Borne to begge their bread.

1781 Cowper, Charity 74, We come with joy from our elernal rest, To see the oppressor in his turn oppressed.

Pras. D. Eng. : He woke up to find the lamp still burning.

265. Very often the clause-equivalent is announced by adverbs of degree (too, so, etc.) in the main part of the sentence; in this case the infinitive implies result as vell as degree.

Too.

Rich. $58 \mathrm{H} \mathrm{9,} \mathrm{as} \mathrm{she} \mathrm{wist} \mathrm{hersolf} \mathrm{to} \mathrm{simple} \mathrm{to} \mathrm{be} \mathrm{his} \mathrm{wife,} \mathrm{so} \mathrm{thought}$ she her self to goud to be his concubine. | Dial. Her. 131 A 7, One or two or three ... semeth me to few to trust their credence. I Rich. 54 D 1, For wel thei wist, that the quene was to wise go to aboule any such folye.

With for $+($ pro)noun-subject :

Dial. Her. $137 \mathrm{G} 4$, the fashion [was] it self to straunge for any nuan to faine. I Answer 1037 A 2, his handes are to lumpish \& this messe also to greate for hym to conueye clene.

With for to.

Dial. C. (Wks.) 1189 C 1, his hart was to feable for to beare the beholding of another mans glory ').

More's usage is identical with that of older English ; the difference between his idiom and that of Pres. D. Eng. lies in the use of for to, which is now no longer possible.

l) With very instead of too : Dial. Her. 132 E 12, ye seme to ... reken this cause very sleight for god to show such an high miracle. 
EA HLIER

a 1300 A Sarmun xxxv in F. E.P. 5, Hit is to late whan pou ert pal'o To crie ihsu bin ore (OED).

c 1375 Ghaucer, Tr. It 725, To wys is he to do so gret a vice.

With for + (pro)noun.

To earlier examples found.

\section{LATER}

1560 Daus, ir. Sleidane's Comm. $113 \mathrm{~b}$, It is nowe to late to examyne the licence.

Pres. D. Eng. : The tea is too hot to drink (OED).

1908 R. Bagot, A. Culhbert xix, Too large an apartment for two people not to feel somewhat lost in it.

268. so. If the principal part of the sentence contains the adverb of degree so, the clatse equivalent may have three different forms :

Type 1. I am not so proud to look.

Type 2. I am not so proud as look.

Type 3. I am not so proud as to look.

More does not use lype 2 very frequently, most of the construclions being of the lypes 1 and 3 ; he does not show any preference for either of these, so that the only reason for his using or omitling as may have been a question of rhythm.

Type 1. I am not so proud to look.

Rich. 63 G 11, 1 am not so pronde to looke therfore. | Rich. 59 F I1, my cosein ... neither louelb me so litle, to grudge al that I loue, nor is so vnresonable to loke that... | Dial. Her. $209 \mathrm{H} \mathrm{4}$, ere we should iudge any man for so euil to commyt it... | Last Th. 85 If 15, For tbou woldest not for shame, that men should think thee so mad, to enuy a poore soule. | Last Th. 88 A 11, Who could set so much by himself, to take to heart a leude rebukeful word.| Rich. $40 \mathrm{G} \mathrm{2}$, none of vs ... is so vnwyse, ouersone to truste a newe frende made of an olde foe.

Type 2.1 am not so proud as look.

Apol. (Wks.) $845(=847)$ E 9, Whome it irketh to dooe so much as loke it ouer. | Lett. 1423 A 4, be so good maister to me as helpe to bringe vs both together ').

Type 3 . I am not so proud as to look.

Leit. 1431 D 4, But surely they all touched me nener so nere, nor were so greuous vnto me, as to se you ... labonr to parewade vinto

1) The following quotation seems to belong here, though the character of wil is doubtful : Apol. 869 D 3, I am not so ambycious of such folkes prayse, as[,] to be called indifferent, wil in writing againste their heresyes helpe them forth in theyr rayling. 
me... | Suppl. 299 G 8, he sheweth hymself to haue so much presumpcion and so littel witt, as to aske the king a question and appoint hym his answor. | Dial. C. 185, I dare not be so sole as vtterly to forbid it. I Apol. 75, who so prye vpon euery mannys dede so narowly, as to spy that taute. I $\Lambda$ pol. 46 , For I can neylher so much poetry nor so much rhelory'jue noyther, as to finde good nam's for euyll thynges.

The quolations of lype 2 (so good as helpe) appear to be a couple of straggling survivors of a well established idiom in Midrlle English. No instances seem to have come down to our limes, except the crystallized formula (not) ... so much as + infinitive, used to emphasize a negation : 1782 Miss Burney, Cecilia vir, I should not expect any lady would so much as look at him. In Occleve's Do Regimine Principum the plain infinitive is used after as : 95 , Is none so good as lete us mollifie Our hertes, and stande to his gentrie. Shakespeare has : Meas. I, iv, 17, Can you so stead me As bring me to the sight of Isabella... | Henry V, v, i, 27, Will you be so good, scauld knave, as ent it ?

The first type : I am not so proud to look represents an idiom that is now regarded as irregular and must have become so between Shakespeare's time and the present day. Cr. Shakesp., Rich. III, Ir, iii, 26, I wonder he is so fond To trust the mockery of unjust slumbers ').

\section{EARLIER}

c 1380 Troil. $v$ 1685, so cruwel wende I not youre herte $y$ wys To sle me thus.

c 1412 Occleve, Reg. Pr. 43, I was never so aventrous renoune to winne.

The quotations of type 3 are constructed in accordance with present-day usage (I am not so proud as to look).

267. When did this correlative as come into use? It is very interesting to notice whal some investigators of the language before More have discovered in this respect. Buchtenkirch (1889) has not found this as in Occleve and says : "In allen Belegen steht der Inf. mit to und zwar ohne das im Neueng. als Korrelat von so hinzutretende as, wie denn as als Korrelat von so vor dem Inf, im Alteng. über-

1) Also : Mid. Iv, i, 142 ; Tw. N. 11, ii, 8 ; Mid. I, i, 75. 
haupt nicht gebräuchlich var". V. d. Meer states that in Mandeville "so is not followed by the correlative as" (1929 $\$$ 52). In Malory's Morte D'A. as is also absent; according to Dekker (19.32 \$2.57) : "Infinitive clauses of degree, referring to the adverb of clegree so, do not open with as". This seems rather peculiar, since Malory's work is within half a century from More. That More did, however, nol invent lhis idiom, though he is perhaps the first to use it so regularly, appears from the following dala. In Chaucer, one example (though slightly different, since the correlative as is followed by for to) proves the possibility of ils use in the $14^{\text {th }}$ century : Troil. II 633, To don my lerte as now so gret an ese As for to dwelle here.

Kenyou (1909 p. 65) remarks that this is the only example found by him in Chaucer of the influitive of result wilh as in the apodosis. Then there is a cuotation dated 1445 in OED, which also brings the usage back to before Malory; the name of the author is, however, not mentioned; OED refers to Auglia xxviu 271. It runs as follows :

Nevir the(e) she 80 diseasyd as oonys ... To folowe her wile.

In Paston Lelt. (Gairdner) $n^{\circ} \mathbf{7 6 2}$, dated 1470, we read :

a man cowyd not have hyred me for v. mark with so gode wil to have rydon in to NorfT. as to have at thys season ther to have awaytyd in bys Lordsbyp ').

These instances may not be sufficient to prove that this construclion was already before the $16^{\text {th }}$ century a wellestablished idiom in the written language, they show at any rate that it existed. And from More's free usage we may gather that it was of common occurrence in the spoken language. It is notable in this connection that More's more 'literary' contemporary, Lord Berners, hardly ever dares to use it (Klausmann 1919, p. 96). Further investigation will be needed to trace the origin and earlier development of the idiom.

If so is placerl at the end of the principal part of the sentence instead of in the middle, the combination so as to is the

1) Kellner 1913, p. 75 has an instance dated 1429 of as to without preceding correlative. 
result. No instances of this usage have been found in More. The earliest quotation with so as to in OED (s. v. as adv. 20 ; cf. OED s. v. so adv. $28 \mathrm{c}$ ) is dated 1662 : H. More, Antid. Ath. I $x_{1}$ 3.j To bear themselves so as to cause an A chitrarious Ablegation of the Spirits.

The construction (with as, but without preceding so) in the following passage deserves notice :

Instr. $1407 \mathrm{~B} \mathrm{12,}$ what foly is it for the(e) than, to auoid this temporall death, as thereby to fall in perill to purchase thy selfe eternall death ?

No inslances have been fond in More in which the subject is expressed by a (pro)noun before the infinilive, as in :

1709 Swift, Merlin's Prediction, Wks. 1755 I, i, 177, The river Thames frozen twice in one year, so as men to walk on it.

268. The infinitive as an equivalent to a clause of cause.

Type He laugheth to see the foolysh apes.

Boke of F. p. 5 A 2, That other laugheth to see the foolysh apes, Howe earnestly they walke about theyr iapes. | Boke of F. P. 4 D 7, the fyrot can neupr cease but wepe, To see how thick the blynded people go. I Jest p. 3 A 12, His harle for pryde, Lepte in his syde, To see how well he freered. | Dial. C. 170, me tbynke I dooe you verye much wronge to gene you occasion to laboure yourselle so much.

The causal force is less distinct in :

Answ. 112l F 5, Frith was but a loole so to straite and to limite the power of almighlye god.

This use of the infinitive in a causal function was not unknown before More's time; cf. Chaucer : Booke of D. 99, I ferde the worse ... to thenken of her sorwe. Even in Old English the infinitive occasionally denoted cause, but then it always was coordinated with another verb (e. g. ic gefeo pioswan; ic earma nu aforhtige to secgenne, see Callaway 1913, p. 160) For similar constructions in More see the sections on syntactical units with two verbs.

The usage did not die out after More; Shakesp. frequently makes use of it (cf. 1 Henry IV, I, iii, 44, He call'd them untaught knaves ..., To hring a slovenly, unhandsome corse ').

In Pres. D. Eng. the construction is somewhat artificial ${ }^{2}$ );

1) For further examples, see E. Scholz 1908, pp. 17-21.

2) Of course not so after verbs (to rejoice) and adjectives (glad, etc.). 
it has mostly been replaced by constructions consisting of at, in, on, for, of, by, etc. + form in -ing; or by clauses opening with because or synonyms.

\section{EARLIER}

1423 James I, Kingis Quair 163, Ane vgly pit, depe as ony helle. That to behald thereon I quoke for lere.

Fon + (pRo) noun-suBJEct ; For to.

No such constructions have been found in More. Cf. c 1400 Manndev. Tr. 23, 15, And alter pat pei weren at gret discord for to make a so:Idain (M.) | 1470-85 Malory, Morte $\mathrm{V}^{\prime} \mathrm{A} . \mathrm{hk} . \mathrm{xv}, \mathrm{ch} .1$, he who brake his order for to wear a shirt where he ought to wear none (D.).

269. The infinitive as an equivalent to a clavge of CONDITION OR SUPPOSITION.

Type What wonder wonld he make to see the sonne.

Lelt. $1128 \mathrm{H} \mathrm{l,} \mathrm{What} \mathrm{should} \mathrm{they} \mathrm{be} \mathrm{the} \mathrm{better} \mathrm{to} \mathrm{gine} \mathrm{me} \mathrm{any}$ othe? | Dial. Her. 132 B 3, If a man borne blind had sodenly his sight, what wonder would he make to see the sonne. | Dial, Her. $152 \mathrm{E} 8$, This were in dede a good easy way for a slouthfull mason that were an euill wolkeman, to make ') hym a squier and ruler of lede, that ... he may bend the squisr to the stone. Jest p. 1 B 15, A blacke draper, with whyte paper, To goe to writing scole, ... I wene shall proue a fole. I Dial. Her. $281 \mathrm{E} 10$, For either is his way naught, \& than doth he naught to teache it.

These inflnitives express facts or suppositions which form the foundation of the statements in the main part of the sentence; the construction is equivalent to a clause opening with if.

The usage in earlier English and in Pres. D. Eng. (in which it is still possible) ${ }^{2}$ ) is illustrated in the following quotations :

EARLIER.

c 1385 Chaucer, Troilus $v, 493$, to take of hym our leue He wolde wondren on it trewely (K.) | c 1400 Mandev., Tr. 182, 14, wylde men pat ben hidouse to loke on (M.) | c 1412 Occleve. Reg. Pr. 75, clethe was to hestife To renne on the and reve thy life (B.).

1) May also be explained as the subject, announced by this.

2) Curme 1931, p. 331 ("Abridginent of Clauses of Condition"). 
LATER.

1592 Shakesp., Rom. J. Iv, i, 23, To answere that, I should confesse to you. | 1610 Shakesp. Tempest II, $\mathrm{i}, 22 \mathrm{l}$, which to do, Trebles thee o'er. | $188 \pm$ R. W. Church, Bacon Ju, 59, He was no more idealist or recluse to undervalue ... the real grandeur of the world (OFD). $\mid 1887$ L. Carroll $\$ 1,15$, You will do well to work out a lot more for yourself (OED).

For + (Pro) voun-subJect; fon to. No instances found. Compare :

c 1400 Mandev., Tr. 196, 8, he thoughte pat he sholde do gret synne for to trouble hem (M.).

\section{The infinitive PReceded by A PREPosition ').}

Type Without to make any noise.

Instances of this usage abound in earlier writers :

c 1200 Orm. 6359, His Drihhtin wel to cwemen W'pp dazzsang \& wipp uhhtennsang, \& wipp to letenn swingenn himm pe bodiz. | 1490 Caxton, Eneydos, xviii, 68, wythoul to make mo a knowen thereof. I idem, Paris \& V. 32, Vyenne salewed parys wythoute to make [Fr. sans faire] ony semblaunce of Love.

No instance of this usage has been discovered in More ${ }^{2}$ ). It lived on for a time after him, and is found in Pres. D. Eng. with the preposition from.

$1556 \mathrm{~J}$. de Flores' Aurelio F 6, without to see it whiche is written. I 1590 Spenser, F. Q. 111, 12, 35, Nought may save thee from to dy. | 1879 Mallock, Life Worth Liv. 17, Not to affirm is a very different thing from to deny.

Generally a form in -ing is preferred now.

By the side of the type without to make any noise there occurred in Middle English the type without any noise to make, in which the preposition and the infinitive were separated by a noun :

1127 Chronicle $256 \mathrm{~b}$, se king hit dide for to hauene sibbe of se eorl Angeow, for helpe to hanene togænes his neue. | 1340 Dan Michel, Aycnbite, Blisse and lost ine god to servi and to louie. | idem, ssel come to uore pe kinge in his chombre uor zome grace to bidde. | 1489 Caxton, Blanch., wythoute aduenture to fynde ${ }^{3}$ ).

1) Other than to and for to.

$\left.{ }^{2}\right)$ In St. John Fisher we find : Wks. 86, 30, it may not be done without some man more myghty than they withstande \& defende hym. - But here without $=$ unless.

3) Einenkel 1916, p. 16, compares Old French usage : pour eus a detranchier; sans nous a parjurer; je te defends sur les membres coper. (The above illustrations are his). 
No instances of this usage have been found in More. It does, however, not seem to have been obsolete in his time, for in Spenser occurs a similar construction : F. Q. II, xii, xxvı, 4, ... to worke dreed us, And diaw from on this journey to proceed.

\section{The infinitive iN NON-DEPENDENT UNITS.}

In exclamalions :

Picus $15 \mathrm{D} 10,0$, madde marchaunt, $O$ foolish marchandise, To bye a tryfle, $O$ childishe reckening, And paye thereforo so dere a precious thing.

This usage of the infinitive to express indignation, astonishment, longing, etc., does not seem to have been very old. The earliest quotalion in OED is dated 1450 ; it is slightly different, since the infinitive is preceded by its orv subject :

a 1450 Cov. Myst. vin, 77, I to bere a child that xal bene alle mannys blysa ... lio mythe have joys more! ')

The construction is a common stylistic feature in Pres. D. Eng. : 1871 R. Fillis, Calullus Lxv 9, Alı! no more to address thee, or hear thy kindly replying, Mother!... ne'er to behold thee again !

Also with why: Conf. Tynd. 765 I) 5, For why to use dylygence and forbeare haste, and be ware and believe...

The infinitive wilhout to is similarly used to repeat an infinitive in a preceding sentence :

Dial. Her. 197 H 10, ... he answered bim, Credere en le diable, wy sir no, io graund falige a credere in dio. Beleue in ye deuil $q(u o d)$ he, nai nai syr...

Earlier example : c 1412 Occleve, Heg. Pr. 6, "I bope I shall the curc." "Cure, good man? ... thow art a faire leche".

Slill found in Pres. D. Eng.

272. The infinitive is occasionally used as an equivalent to a preterite in the middle of a narration of past events.

Rich. $69 \mathrm{C} 9$, he toke ill rest a nighthes, lay long wakgng and musing, ... rather slumbrod then slept, tronbled wylh fearcful dreames, sodainly sommetyme sterle op, leape oul of his bed \& runne about the cham ler, so was his restles herte continually tossed \& tumbled with ... the stormy remembrance of his abominable dede.

At first sight this sentence gives the impression of being irregular; a comparison with the language in earlier stages, however, reveals the fact that in the Middle Ages this use of

1) Curme 1931, p. 331, adduces an instance with for + noun-subject in Pres. D. Eng. : Wilkie Collins, Woman in White, p. 222, Oh, for a friend to help us and advise us ! 
the iufinitive in a narration of past events was not alien from genuine Euglish. Among the authors who use it are Langland (Wandschneider 1887, p. 73); Layamon (Lichtsinn 1913, p. 64); Chaucer (Kenyon 1909, p. 80) and Caxton (Kellner 1890, §29).

E. g. 1362-93 Langland, P. Pl., al pat he wist wikked by any wizte, tellen it, and blame men behynde her bakke. | c 1275 Layamon, Brut, 30945, pe king Penda ... sumnede terde and forth him fusen and senden (L.).

The construction occurred not only with a plain infinitive, but also with an infinitive with to; More has no examples. Cr. : a 1375 Barbour Bruce vin 351, He turnit his bridill, and to ga. I c $1380 \mathrm{Chaucer} \mathrm{Tr}$. I 788 , So cesselt love, and forth to loce. | idem, Log. G. Wom. 635, Up gooth the trumpe and for to shoute and shete, And paynen hem to selte on with the sonne. | 1480 Henryson, Fables 215, With that the woll gird up sone and to ga.

273. If the subject of the action denoted by the infinitive dilfers from that in the rest of the sentence, it is expressed and placed immedialely before the infinitive. There is a very clear instance in More :

Dial. C. (Wks.) $1254 \mathrm{k} 1$, on she came gerning loward the place : whom as soone as the hartes herd: they to go bull twayn apace.

This idiom was more frequently used in Middle English than that without subject expressed.

c 1200 Layamon, Brut 21655 , Arthur come sone mid selere strengpe, And Scotles to fleonne. | 1225 Liflade of St. Juliene (ed. D'Ardenne 1936) 451 , and he to rarin reowliche. $\mid 1385$ Chaucer, Tr. In 1108, And she to laughe ') it thought here herte brest. | idem L. G. W. 653, Antonye ... put hym to the flight And al his folk to goo ') that best go myght. I 1470-85. Malory, Morte D'A. 270, 25, and there he dyd homage and feauet to syr gareth and these knyghtes to hold of hym for euermore. | a $141 \overline{0}$ Lyfe St. Birgette [EE'TS] liii, \& then he to speke vnto her shameful ... wordes. | 1534 Berners, Iluon [EFTs] 754, 3, than thei to murdle him in his bed.

According to Einenkel (1916, p. 22) the early history of this construction is still obscure. He surgesty an ellipsis of a verb like begin and compares Old French : Quant chil Englès les perchurent, ils ferirent des esperons apriès eulx, et li F'rançois à euls sauver (Froissart) ').

1) Kenyon 1903, pp. 82-3, explains these instances in Chaucer in a dilferent way, rejecting the appellation " historic inlinitive".

8) Still a very vivid idiom in tnodern French : El les Français de se sauver! There is something similar in Dutch : Bilderdijk, Elius vi, Hij snikt! - "Welaau, ik ben voldaan, Zie daal mijn lot volkomen!" Hij splak, zigt om, en grijpt zijn staal, É - beken bloeds aan't stroomen. 
The construction is often compared with the Latin historic infinitive. It strongly resembles the use of the present tense in narrations of past events ("historic present") as illustrated in $\S 163$.

Pres. D. Eng. has lost this efficient expedient to represent a past event in a very vivid way. It seems to have died out in the course of the sixteenth cenlury; indeed, in More, to judge from the scarcity of its occurrence, it may already have been obsolescent. No instances of the usage in Shakespeare seem to be on record; the following quolations, however, show that the idiom was not unknown to Gaseoigne and Spenser, though in the latter it perhaps represents a conscious revival of obsolete usage.

1566 Gascoigne, Supposes, Wks. 34, I to fuge and away hilber as fast as 1 could. | 1590 spenser, F. Q. vı, xlvii, 6, 'Lo! then, for Itine ayd, Here take iny lover's token on thy pate?' So they to fight.

The quotalion in OED from Pepys is not very convincing, as his elliptic style did not reflect the language as it was used at the lime : 1668 Pepys, Diary, 18 Sept., 1 ... away home,... and theie to read again and sup will Gibson ${ }^{1}$ ).

Foh + NuUn-subject; Fon to. No instances found in More.

274. The infinitive is also used as an equivalent to a coordinated sentence expressive of a regulation or a testamentary disposition.

Type (Pres. D. Eng.) Accounts to be strictly kept.

Debell, 1011 A 17, whiche witues be sufflcient and which nol, must bo wayed by the spirituall Judges, and vppon theyr waying of the matter for lyght or heauy, to folowe the arrest of the partie, or the leauing of the arrest. | Passion 130 J D 1, it was ordeined ... that ther shuld be but one prince of the priestes, ... and he to contynie hys oflice during bis life.

The prototype of this construction has not yet been found

1) The usage discussed in this paragraph ought to be kept apart from that illustrated in the following Pr. D. Eng. quotations : Arlen, May Fair p. 132, He could throw it from the top of a bus and no one notice (Kr.). | idem Green Hat p. 247, There isn't... any thing in the world mor'e irritating than to be angry wilh a woman and she not notice (Kr.). These collocations introduced by and are equivalent to atverb clauses of attendant circumstances (= without any one noticing it; without her noticing it). 
in Old English ; nor are there parallels in foreign languages (Einenkel 1916, p. 20). In Middle English the construction crops up profusely, as witness the numerous examples in e. g. Einenkel 1916, p. 20 and Kellner 1913, $\$ 399-400$. It is frequenlly used by Malory (Dekker 1932, $\$ 253$ ), by Berners (Klausmann 1919, p. 108) and in the Paston Letters '). From Shakespeare the following quotalion may be given : As Y. L. v, iv, 22, Keep you your word, Phebe, that you'll marry me; Or else, refusing me, to wed this shepherd.

The usage is well established in Pres. D. Eng., though restricted to formal (technical or legal) language. See below for an instance.

\section{EARLIER}

a 1300 Debate Body and S., wji schope thou me to wrother-bele, To be thus togged and totoren, and othere to haven al mi wele (OED).

1387-1439 Early Eng. Wills, If all thre sonnes die withoute heires ... theire moder than lyvyng, then she for to haue al the same maners (OED).

1503 Paston Lelt. (Gairdner) $n^{\circ}$ 1074, all this to be perfurmyd ... after our avise.

\section{LATER}

1849 Dickens, David Copp. I, 2, The caul was put up in a rafle down in our part of the country, to fifty members at Lalf-a-crown a head, the winner to spend five shillings.

1912 Everyman, 24 Iec., In regard to the Albanian problem Austria and Ilaly agreed on the principle of nationality, the country to be neutralised under the guarantee of the Great Powers.

For + noun-ohject ; for to. No examples found. For an instance with for to in earlier English see the quotation in the left column above dated 1387.

275. The infinitive + object as an atthibutive adjunct. Type A breakneck pace.

No examples of these combinalions, which in recent times have become very frequent - lack-lustre eye ${ }^{2}$ ); want-wit agitation $^{3}$ ); a lock-jaw business ${ }^{4}$ ); a take-leave call ${ }^{5}$ ); etc. -

1) E. g. 1503 Letler Prom John Yaxlee (Gairdner n' 1074): And if the seid Sir John relise to have the maner, then the seid Hoger to have the same maner ...; and the seid Syr John to geve answer which he will chose ... And all this to be perfurmyd and put in surle after our avise.

9) Shak. As Y. L. I. I1, vii, 21.

3) Eigerton Castle, Keynotes, 44 (J.).

4) Caine, Cbristien, 44 (J.).

s) Austen, Sense and S., 296 (J.). 
have been found in More. The earliest examples found by Jespersen 1928, 14, 71, are dated 1556 and 1562.

276. The infinitive after a.d, (N)OH, (RATHEh) than, but.

And + infinitive.

Usage does not seem to have been settled in More, the inflnitive after and appearing now with and now without to. The plain forms are, however, in the majority.

Plain infinilive. Rich. $65 \mathrm{H} 1$, to depose the prince \& take himselt the crown. | Rich. 42 B 12, readye to leape on horsebucke, and departe forwarde. | Last Th. 76 B 3, it is better to holde thy tong \& thinke on some beller thing. | Picus 14 E 13, it were shame to abide stil in the better, and not decline. | Dial. C. 128, we shall stand in peril ... to be more bardelye handelled, and dye more cruel death. | Lelt. 1449 F 3, in his owne temptacion he was fain thrise to call and crye ont vnto god.

Infinitive with to. Rich. $65 \mathrm{E}$ 14, then waxed he bolde to shewe hy in theyr intent ..., and ... to beseche hys grace, that... | Answer 1121 F 5, Frith was but a foole so to straite and to limite the power of almightye god. | Dial. C. 167, it were good to make sur'e and to be mery. | Picue 9 F 8, He was wont to be conuersaunt wilh me, and to breake to me the secreles of his beart.

For + NOUN-SUbJect ; For to. No instances found ').

277. (N)Or + infinilive.

The prepositional infinitive seems to be the rule.

Last TI. $84 \mathrm{D} 1$, yet haue they some hope ey ther to breke prison the while, or to escape there by fauor. | Dial. C. 253, he promised not, neither to geue awaye all, nor to become a begger. | Apol. 85, [they were] fayne to fynde a place to hyde theyr heddes, or to kepe them from pryson. | Last Th. 89 A 4, god bath not geven bim leue to eat of it or to enioy it.

For + NOUn-SUbJect ; FOR to. No instances discovered.

278. Than + infinilive.

Usage seems unsettled, though plain infinitives only rarely occur.

Rich. 58 if 6, hym whose harte she perceined more firmly set, then to fall of tor a worde. | Ricl. $60 \mathrm{C} 2$, god loued her better, then to graunt her her bone.| Last Th. $88 \mathrm{C} \mathrm{14}$, How much is it now the more foly, if we consider that we be but going in pilgrimage, ... than to chide \& fight for such folyes by the way. | Last Th. $75 \mathrm{H} \mathrm{4}$, il were lesse

1) C. 1375 Barbour, Bruce v 4, pe nychtingale begouth rycht meraly to syng and for to mak... syndiy notis and soundis sere. 
euil ..., to blabber on trifles ..., than ... to fantasye. | Hich. 63 A 8, them war leuer to leese all that thoi haue...., then to haue suche a villany done them. | Last Th. 76 B 3, il is better to holde thy tong ..., than to geue eare therto.

Last Th. $76 \mathrm{C} 11$, beller were it for the while to let one wanton woorde passe vncontrolled, than geue occasion of twain.

The subject of the inflnitive is expressed in :

Dial. C. (Wks.) 1215 A 9, to haue that good purpose al their life, semeth me no more harme ..., than a poore begger that hath neuer a peny, to thinke that $y$ ' he had great substaunce, he would geue almose. | Aut. Lett. xiv, 31, his highnes estemeth no thing in counsuile more perilouse than one to persever in the mayntenaunce of his advise.

FOR + (PRO)NOUN-SUBJECT.

Dial. C. (WVks.) 1204 B 11, It is more easy for a Camell ... to goe thorowe a nedles eye, then for a mehe manne to enter into the kingdome of God. | Aut. Lett. xiv, 110, which is more easy for hym to do ... than for the king to rescue theym.

Zeitlin (1908 Ch. Iv) disputed Jespersen's assertion (1894 $\$ 211$ ) that " Such sentences as 'I dou't know what is worse lhan for such wicked strumpets to lay their sins al honest men's doors' would be sought in vain before the eighteenth century". As Zeitlin, however, did not adduce any examples of earlier usage, Jespersen challenged the objection in an article in the Viëtor Festschrift (1910, pp. 8589$)$ and emphatically reasserted his first statement. Its fallacy was, however, indisputably demonstrated in the Journal of E. \& G. Phil. (vol. $x$ 1911, p. 649) by Zeillin's adducing two examples of the conslruction in question antedating Jespersen's earliest quotation by one and a half and two centuries; the first of them was from IVilson's Art of Rhetoric (1553) : Prol. p. 1, what greater pride can there be then for any man to thinke himselfe wise... or what greater tolly can there be imagined then for one to think... With the above quotations from More evidence of the occurrence of the conslruction in the $16^{\text {th }}$ century has bcen brought still further back.

The use of that precerling the subject of the infinitive (instead of for ?) in the following sentence is very exceptional :

Dial. (.. (Wks.) 1291 A 1, There canne not in tbys worlde be a wursse mynde then that a man to delite and take comfort in auie commodylye, that bee taketh by synnefull meane.

This curious construction can perhaps be accounted for by assuming contamination between then a man to delyte and then that a man delyte(th). 
Fon to. No instances with for to before the infnitive have been observed in More, which is rather surprising as this usage is not infrequently met with in st. John Fisher (Veyl 1937, \$ 228). F. g. :

Wks. $408,8^{*}$, No man can shewe greater charitie, then for to put hys own life in ieopardie for his friendes.

279. Halher (Leuer) than + infinilive.

Here all sorts of construclions seem to have been possible; there are either two plain infinitives (e. g. rather suffer than become...), one preposilional and one plain infinitive (e.g. to way rather then take), or two infinitives preceded by to (e. g. rather to endure than to cast).

Vial. C. 327, he thinketh it is not lawefull for any other mayde to folowe their saumple, but rather suffer other to dooe her any maner violence hy force ... than willingly ... Lerself become an homicide of berself.

Dial. Her. 212 F 2, To way them rather then take lliem by tale. Picus 7 E. 6, yet bad we leuer alwaie by knowlage, nener finde that thing that we seke : then by loue to possede that thing, whiche...

Diat. C. 343 , well contente to endure al the payn ... rather then ... to cast our self into the payne of hell.

Foh + (PHO)NOUN-sUBJEct ; FOR to. No instances discovered.

Suffereth (and not suffer) is used in :

Debell. 932 $\mathrm{F} 3$, he rather taketh the matler all whole vpon him, then suffereth any part to be layd from hym.

280. But + infinitive.

Both prepositional and plain infinitives occur :

Last Th. $92 \mathrm{~F} \mathrm{~J}$, it is not sinne to haue riches, but to loue riches. | Picus 7 A 5, it was no praise to gather richesse, but to refuse them.

Dial. C. 305, yet sulfiell them not to dye therin, but lyue many years after. | Picus 5 A 2, all his life [he] hath doone notbing els, but reade tben.

In St. John Fisher only plain infinilives are used (VVeyl $1937, \S 229$ ).

There is in More another word but with a different meaning from that illustrated above; it is construed both with and without to before the infinitive :

Dial. Her. 243 E 13 , it wer more than madnes for them to medle withal, but leaue al these thinges to them whose hole study is beset therupon. | Apol. (Wks.) $893 \mathrm{C} 1 \mathrm{l}$, forbidding them to reason or dispute there against but obey it. | Conf. Tynd. 719 B 7; 344 B 5.

Dial. Her. $243 \mathrm{~F} \mathrm{10,} \mathrm{I} \mathrm{can} \mathrm{in} \mathrm{no} \mathrm{wise} \mathrm{agreo} \mathrm{with} \mathrm{you} \mathrm{that} \mathrm{it} \mathrm{wer} \mathrm{mete}$ 
for men vnlearned to be busy with the chamming of holy scripture, but to haue it chammed vnto them. | Picus 29 A 4, I meane not hereby, that thou shouldest arise. And in the glasse vppon tby body prowle, But with faire vertue to adourne thy soule.

This meaning of bul is not recorded in OED; it seems to be equivalent to instead of -ing. It also occurs in Shakespeare ') :

Wint. T. II, i, 160, Why, what need we Commune with you of this, but rather follow our forceful instigation.

Histopical note on $\$ \$ 276-280$.

In older English the use of either the plain or the prepositional infinitive after such connecting words as and, or and than appears to have been as unseltled as it was in More. According to Shearin (1903 p. 30) repetition of to was regular in O. E. prose. Weyel, who illustrates (1896 pp. 50-51) the arbitrariness of the use and absence of to after than in Orm, criticizes the "rules" laid down for the usage in Langland (Wandschmeider 1887), IVilliam of Pal. (Pilschel 1890) and Occleve (Buchtenkirch 1889). Layamon frequenlly, but not regularly, suppressed the second to after and, but, etc. (Lichtsinn 1913, p. 9). In Chaucer the cases in which to was not repeated outnumbered the other (Kenyon 1909, p. 159 mentions a ratio of $249: 129)$. In Mandeville's Travels it was usual for the plain inflitive to be used after and, or, pan (V. d. Meer $1929, \$ 85$ ). Infinitives with to are more frequent than plaiı infinitives in Malory, who shows his preference for the prepositional infinitive by the frequent use of to before the second inflnitive even when the tirst is plain (Dekker 1932, \$230).

In Pres. D. Eng. suppression of the second to is fairly regular (Mätzner 1885, 55 ; Curme 1933, p. 181, 5). If the infinitives are connected by than eilher bolh have to or are both without it ${ }^{2}$ ); until c 1800, esp. after had rather and had better, the second infinitive often had to when the first was without it.

281. Better than + infinitive.

The type We know better than to do that is represented in More by :

1) Not mentioned in Schmidt 1902, s. v. but.

I) So in OED, but see Kruisinga 1931, \$\$ 344-350. 
Debell. 1032 D 17, I much better loue hym then in that point to beliene him. | Rich. 58 H 6, bym whose barte she perceiued more furmely set, then to fall of for a worde.

Here than is anmounced by a comparative (or its equivalent with more). It deserves notice that the earliest example in OED of this usage is clated 1611 : Beaumont \& Fl., Philaster I, i, Your nalure is more constant than to inquire after state-news.

Pres. D. Eng. would often substitute too with the positive for the comparalive with than: more constant than inquile $>$ too constant to inquire.

\section{EARLIEA}

And. c 1205 Layamon, Brul 27333, alle we beop $3^{\text {arewe to libhen }}$ and to liggen (L.).

a 1360 Chancer, H. H. 2321, to you it longith ay To harpe and glitterne, daunce and play.
Or. c 1386 Chaucer, C. T., I, 818, the unmesurable appetit and desordeynce coveitise to elen or to divinke.

c. 1386 Chaucer, C. T., C 16, Apelles, Zanzis, sholde werche in veyu, Ouller to grave, or pernte, or forge, or bete.

Than. c 1386 Chancer C. T., B 114, Bet is to dyen than have indigence.

c 1386 Chaucer C. T., F 692, he hath levere talken with a page than to comune witb any gentil wight.

\section{LA TEH}

1523 Ber'ners, Froiss., vi, 365, We wyl be felawes to gyders and neuer to fayle (Kla.).

1858 Trollope, Dr. Thorne xxvi, 277, She was anxious to make her friend smile, and to smile with her (Kr.).

19:20 Times, Lit. S. 11.3, Another simplitication is to follow the stream and ignore the eddies (Kr.).

1535 Steward, Cron. Scot. II 172, The Scoltis than weill wist nocht in that caice. Quhidder to byde or follow on the chace (OED).

1889 Stevenson, Ballantrae iJ, But which is it to be? Fight or make friends (OED).

1913 Walpole, Fortitude u Ch. 5 p. 196. They can't do more than refuse it $(\mathrm{Kr}$.$) .$

1912 Times W. 1, 11, We know better than to make any such concession (Kr.).

\section{The 'Split Infinitive'}

282. Answer 1125 A 1 , would ge not be as hasly to not beliene it? | Dial. Tynd. 481 if 2, tyll menne... Iell to forgeatle thenı... and then to not belieue them.

These are the only instances found in More of this syntactical tmesis and both have the negative adverb not between 
to and the verb. This order of words in constructions with not was known in Middle English. Y. d. Gaaf (1933) illustrates this usage in a series of quotations from writers before 150), and shows that it held its ground till far into the sevenleenth century. The placing of not between to and the verb was, however, not imperative in More's English. In the following examples it has the same place as in Pres. D. Eng. Picus 12 G 6, For it is verelye a great madnesse not to belene the gospel. | Supplic. $292 \mathrm{~F} 10$, ye wer at libertie not to beletue vs.

Other adverbs or adverb adjuncls than not are never found between to and verb in More; yct from the $13^{\text {th }}$ century on it had been possible to place them and even objecls there, and in the course of the $15^{\text {th }}$ century it had become quite common for some writers to avail themselves of this stylistic expedient; especially Pecock (c 1395-c 1460) uses it copiously. V. d. Gaaf counted upwards of 120 inslances in his works, among which there are a number of a most bold character (from a Pres. D. standpoint, that is) : e. g. Donet, 6,23 , torto enye suche bi her owne laboure fynde, make and multiplie. This profuseness in Pecock exhibits a striking contrast with the scarcity (or absence, but for the cases with not) of the usage in More. It can hardly be accounted for by referring to the distance in time between the two writers. V. d. Gaal conjectures that Pecock's language must have been of the type spoken in intellectual circles in Oxford, where heled the life of a student and scholar for about twenty years. Now More had been an Oxford student too and must consequently have been familiar wilh this usage as well as Pecock. So that the only conjecture that seems safe is to assume that More consciously avoided the breaking up of the formula to + verb in all other cases than those with not.

For about three centuries after Nore the split form remained exceptional, though constantly cropping up even in the best authors. In Pres. D. Eng. it is frequently used (except wilh not), notwithstanding the fact that some grammarians persist in calling it ungrammatical ').

1) For a comprehensive discussion of origin, form and development of the "split infinitive" and for an eloquent plea in favour of it see Curme 1931, pp. 455-456 and Stuart Robinson 1936, pp. 505 If. On the term "split-infinitive" see Jespersen 1935, p. 191. 


\section{EARLIER}

1380 Wyclif, Matt. v 34, Forsothe $Y$ say to you to not swere on al manere (G.).

13... Cursor M. C. 3318, To temple make he sal be liest (G.).

irlem C 12965, He sal pe send Angols for to pe defend (G.).

c 1400 Three Mi. Eng. Sermons (Grisdale 1999), 6, 36, To stoutlich with-slonden hem makith stirwle pride, to meklich taken hem inakith lownes drede, \& to gladlich rede \& reseye hem makith hi loue or mode.

\section{LA'CER}

1633 Butler, Hudibras, Chandos $\mathrm{Gl}$. p. 328, And if we had not weighty cause To not appear in making laws, we could ... force you... (G.).

1890 Kipling, Phanlom Rickshaw, which prompls a man to sacagely stamp on the spider he has but half killed (C.).

\section{TO I.Y END-POSITION WITHOUT FOLLOWING INFINITIVE.}

Type Yoll may go, if youl want to.

An instance of this usage in More is :

Conf. Tynd.135 H 13, Nowe for as much as man can doe no good but if god begyn,... therfore the grace "ith whiche God begynneth to sette vs a woorke, is called 'Gralia preueniens'. And for as muche as we shold sone rease to, but if grace continued with vs, as our eye shold cease to kep, if that wee lacked lyghle: God continued his grace with vs to worke with vs, whiche is called ' gracia conperans'.

The construction was occasionally resorted to at leasl since the $14^{\text {th }}$ century.

13... Minor Poems from Vernon MS. xxxir, 74, pe soules of synners, ... per to lake and resseyue so as pei on eorpe deserueden to. | 1448 J. Schillingford, Letl. 114, He wol amende hit as sone as God well yeve hym grace and tyme to (OFD). I 1470 Paston Lelt. (Gair(ner) $n^{\circ} 761, \mathrm{Be}$ ware how that ye spend it, but in acquilyng yoll ageyn such as ye be in dalinger to, or about the good speed of your materis.

Einenkel 1916, p. 195 adduces the following instance :

1303 Berune, Handl. Synne, Executer pat wyl nat do As pe dede ordeynede to, He shal haue ful eugl endyng.

He adds : "scheint mir zwar in seiner Vereinzelung<my ilalics $>$ etwas zweifelhaft, immerhin glaube ich ihn mehrseitiger Belrachtung nicht vorenthalten zu dürfen ".

Shakespeare does not know this usage (Franz 1924, § 651, Nachlrag p. 596).

In Pres. D. Eng. it has become a well-known colloquialism, e. . : :

1883 Howells, Register I, I kept on, ... I had to (OED). 


\section{VOICE OF THE INFINITIVE}

284. As the infinitive is neutral as to voice, i. e. incapable of expressing its voice by any change in form '), it is only through andysis of the context that the real character of the infinitive can be found.

In the majority of the quotations given in the preceding paragraphs the context shows that the stem is active in meaning, e. g. in ' me nedeth not to bost' (=that $I$ bost); ' it smelleth of idolatry to visit this place' (= if people visit this place); I am fain to do the labour; the world to come; who were able to beare thy punishment'; etc.

There are, however, in More's English four types of constructions in which the character of the infinitive is different.

Type 1 A fire that were ethe to kindle (\$258).

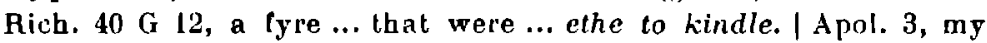
writing is ... tedyouse to rede. | Dial. C. (WVks.) $1213 \mathrm{E} 8$, the thing be liefull to require. | Debell. $935 \mathrm{~B} 2$, lautes that were hatefull and odionse to here. | Last Th. 93 B 3 , coliplous be hard to hele.

Type 2 There is lillle to do ( $\$ 258)$.

Dial. Tynd. 118 H 18, if there were so lyttle to do. | Picus 7 G 7, Ther is no more to do. $\mid$ Boke of F. P. 1 D 8, there is no more to say.

Type 3 Beare the swerde to the cullers to grinde (\$260).

Supplic. $299 \mathrm{~F} \mathrm{2,} \mathrm{and} \mathrm{tell} \mathrm{hym} \mathrm{his} \mathrm{swerde} \mathrm{is} \mathrm{to} \mathrm{dull} \mathrm{:} \mathrm{as} \mathrm{lhough} \mathrm{be}$ would bid him beare it to the cutlers to grinde. | Fich. 45 (=44) F 16, the lamb was hetaken to the wolfe to kepe. I Answer $1042 \mathrm{G} 9$, He geue them breade from heauen to eate.

Type 4 Help to take holite of.

Dial. C. (IVks.) 1253 D 8, hys dnoeth reason alone in manye cases, where it hathe muche lesse help to take hold of, then it hatl in this matter of fayth.

285. In those four types the character of the infinilive is activo-passival, that is to say, the constructions allow of being analysed in two different ways, one pointing to the passive character of the infinitive (the fire is ethe to he kindled; there is little to be done; hear the swerde to the cutlers to be ground), the other to the active sense of the

1) To be + past participle (to be seen) cannot grammatically be called a form of the infinitive; it is a group of words with the same function as a form in other languages. See $\$ \$ 518-65$. 
infinitive '): the fire is ethe for us to kindle it; there is little for us to do; hear the swerde to the cutlers for them to grind $i \ell$. That the infinitive had this dual characler already in Older English is proved by the fact that the concise formula actually developed into both the corresponding expanded constructions; to be (seen) ${ }^{2}$ ), however, made its appearance earlier than for us (to see) ").

286. In More the constructions of the types easy to see and easy to be seen occur side by side; the shorter form, however, seems to be in the minority. This is also the case in his contemporary, St. John Fisher (Weyl 1937, § 237). A ferv illustralions of the expauded construction follow :

Ersy. Aut. Lelt. xiv, 93, some be not so facile \& easy to be taken. I Ait. Lett. xiv, 109, after his army witdrawen \& discharged they wilbe ... ensy to be lost. | Aut. Lett. xiv, 107, if the townys be so eusy to he wonne. | Passion 1275 D 8, more eth to be begiled.

Able. Dial. Her. 14I B 14, if it might hold \& be bidden by, \& wer as well able to bee proned lrew.

Ready. Dial. C. (Wks.) 1173 G 3 , a work ol Galiën...is ready to be solde.

Sure. Ricl. 6!) E 14, they were sure to be compelled to no larger proofo then themselfe list to make.

Wont. Dial. Her. 121 G 4, saint Stephens chyrche in Myllayne where many iniracles were wont to be shewed.

Less. Dial. IIcr. $133 \mathrm{E} 4$, therwilh be they but women, which be more light \& lesse to be regarded,...

Digne. Picus 1 A 7, whose life and woorkes bene worthy and digne to be read, and often to be had in memoly.

1) It seems futile to try to prove that the character of the infinitive in these constructions is either merely passive or merely active. [Ct. Callaway (1913 p. 150), who " (lespite the presence of the Latin passive infinilives in these sentences", sees " no necessily for considering the corresponding infinitives in Anglo-Saxon as passive", and V. d. Gaal (1928), who breaks a lance with him and considers the infinitives to have a passive meaning in a number of cases similar to those quoted above from Hore]. It should be borne in mind that the procedure usually followed is after all only the analysis of syntaclical synonyms and not of the actual constructions. The term activo-passival would seem to obviate unprofitable controversy, as it clearly points out that a twofold interpretation is possible.

$\left.{ }^{2}\right)$ End $14^{\text {th }}$ century (V. d. Gaaf 1928); with worth $(y)$ already much earlier.

3) In the latter half of the 15th century. 
Worthy. Picus 4 A 2, A worke of great erudiclon and elegant, and stuffed with the cognicion of many thinges worthy to be lerned. Apol. 48, Were not a man ... very farre ouersone and wurthy to be compted vncourtayse, that wolde ... presume... | Aut. Lett. $\mathrm{x} t \mathrm{r}, 11$, Such thinges of waight \& substannce as to yor high wisedome semed wurthy to be notede. / Rich. 57 I 10, me semeth the chaunce ... worthy to be remembred.

The wold worthy ${ }^{1}$ ) is of frequent occurrence and is never followed by the activo-passival infinitive, but always by a group with to be. Only one example with its synonym digne has been discovered.

287. Besides these instances of groups with to be to denote passivity in post-adjectival position, there are numerous other (ases in which the group with to be is found ${ }^{2}$ ).

Apol. 68, he wenelh yt lesse to be lamented, that debate and stryfe sholde be belwene prestes and relygyouse persons ... then belwene those that are both the partyes prestes. I Hich. $59 \mathrm{C} 7$, In whose parson ... ther was nothing to be misliked. / Hich. $59 \mathrm{D} \mathrm{3}$, il is an vnsitting thing, \& a veri blemish ... to the sacre magesty of a prince ..., to be defouled with bigamy... | Lett. 1448 B 3,... for to be put to death wrongfullye for doing wel ... it is a case in which a man may leese his head and yet haıe none harne. | Dial. Her. $127 \mathrm{C} 13$, as for yron ... to be so drasuen in lenglh ye shall se it done in .xx. shoppis almost in one strete | Debell. 934 D 12, he supposeth to make it appere ... that myne ohieccions are lyttle to be pondered. | Dial. C. 227, now this good man neilher hath any of goddes enemies to be by his own deth reuenged on, nor any woman that violently pursue him by force. / Rich. $57 \mathrm{D} \mathrm{5,} \mathrm{I}$ doubt not some shal think this woman to sleight a lhing, to be written of $\ldots{ }^{3}$ )

\section{Historical Note.}

In none of the cases illustrated above (activo-passival infinitive and groups with to be) did More make innovations. Nor is there a great difference from the usage in Pres. D. Eng. The type : beare the swerde to the cullers to grinde does not

1) Worth occurs in : Dial. Her. $286 \mathrm{G} \mathrm{14}$, he is not worth the reding.

2) For the typos : she delited to be suid onto; it beginneth to be patd; $I$ hoped to be liked the betler see the sections on syntaclical units with two or more verbs.

3) It is worth noticing that in all these instances the character of the group to be + past participle is kinetic and not static. See $\$ 555$. 
seem be usual now. The to be + past farticiple constructions after ensy and similar adjectives are less frequent to-day than the shortel formulae : easy to see, difficult to understand. The phrase easy to be entreated has come to be cristallized.

\section{EA RLIER}

Without to be :

c 888 Aifred, Boeth. xxxiv $\$ 11, \mathrm{Hi}$ biop swipe epe to todrelenne (OFI)).

c 950 Lindisf. Gosp. Mark 119 , Hwet is eapir to cuoepanne (OED).

c 1200 Trin. Goll. Hom. 31, Gode lipinge and murie to heren (CFD).

1300 K. Alis. 6312, Heo buth the lothJokest men on to seon (OED). 1340 Pseuda Rolle, Pr. Consc. 705, A flour, pat es fayre to se (OHD).

TVith to be :

137781 Chaucer, Boeth. II pr. vi, $90 \mathrm{~F}$, For contracious thinges ne ben nat wont to ben $y$-felawshiped to-gidere (G.).

1388 Purvey, Acts XxI, 13, Y am redi, not oonly to be bounden, but also lo die (G.).

c 1400 Tryamour 364, The quene was aferde to be shente (G.).
I,ATER

1805 Scott, Last Minstr. 1, j, Deadly to hear, and deadly to tell (OED). 1899 WV. T. Grecne, Cage Birds 71, Macaws ... very gorgeous creatures to look at (OED).

Uxf. Eng. Dict. s. v. Difflcult $1 \mathrm{c}$, Hard to understand ... 2 of persons, a. Hard to please or satisfy.

289. TrPe Easily to be knocked off his feet.

This lype, which occasionally occurs in Pres. D. Eng. (Jespersen 1932, p. 219 ; V. d. Gaaf 1928), and owes its form to the contamination of easy to knock off and easily knocked off, does not seem to have been known in More's time. There is, however, a use of the words metely and unmetely which shows a strong resemblance to that of easily in the above type.

Dial. Her. 135 E 3 , men might well think that a yong she saint, was not metely to be shrynid quicke. | Rich. 40 D 6, whose blood ... was Pul onmetely to be matched with his.

The answer to the question if these quotations contain instances of the construction under discussion depends upon 
the character of (un)metely, i. e. whether ( $u n)$ metely is an adverb or an adjective. There is one fact that may be used as an argument in favour of the appellation adjective, namely the following quotation from More : Passion 1316 B 6, Peler thought it in hys mynde onmetely that hys lorde and mayster shoulde weshe his fcele. As an argument in favour of the appellation $a d v e r b$ it may be adduced that Hardy in his edition of More's vorks prinls inmete instead of onmetely. The only example of unmetely as an auljective in OED, apart from the quotation from More's Passion, is : a 1400-50 Alexander 321, A mouthe as a mastis hunde, snmetely to shaw.

The earliest instance of adverb in $-l y+$ to be in OED is : 1577 Gnoge in Heresbach' Husb. III, 139, The olde Ewes .. be easilyer to be entreated.

290. TYPE Not-to-he-conceived sighs.

This type seems to have sprung up after More's time; Jespersen's earliest example (1928 II p. 340) is from Lyly. A ferv of his quotalions follow : Lyly, Campaspe 293, whose deepe and not-lo-be-conceitzed sighs. | Shakesp., Lear I, iv, 223, breaking forth In ranke and (not to bo endur'd) riots.

\section{Modality of The INFINITIVE}

291. The infinitive having no forms to indicate modality, the modality of the unit in which it occurs must he inferred from the context. A few instances will suffice, as this usage has remained unaltered.

Modalily of fact : Rich. 71 G 1, The fox that saw him run.

" " emotion (regret, etc.) Picus 34 B 10, me rueth so long to haue be thrall.

" " imagination : Last Th. $95 \mathrm{D} 12$, it wer better fil his bely than his eye.

") supposition : Rich. $57 \mathrm{C} \mathrm{7}$, sinne it wer to belie the deuil.

" " possibility : Picus 7 D 6, all the conning that is possible for us .. to obtaine.

" " hesitation (modesty) : Dial. Her 105 G 12, me thought that .. my parte were to send our communicacion to my ... friend.

" "wish : Last Th. 79 A 1, vnlawefull longyng to lyne. 


\section{TIME-SPHERE AND ASPECT OF THE INFINITIVE}

292. The infinitive having no forms ') to express time-sphere or aspect, it can only be gathered from the context or situation whether the action denoted by it occurs in the past, the present or the future ${ }^{2}$ ); whether the time-sphere is ueutral, and whether the aspect is perfective or imperfective.

Nentral time. Picus 33 A 9, To gene them also that vnworthy bee, More grodly is.

Present time. Lett. $14.53 \mathrm{~F} \mathrm{l}$, Whose highnes to haue of me now such opinion, is my great heauiness.

Past time. Ricl.58 D 1, To lay bastardy in kynge Edward, sowned openly to the rebuke of the protectours owne mother. | Dial. Her. 262 E 3, It liapperl me to bee lately present.

Future time. Hirlh. 11 B 3, [it] shold be ieopardous, the King to come sp strong. | Rich. 55 A 9, tokens of thinges to come.

Perfective aspect. Last Th. 84 D 1, some hope ... to hreke prison.

Imperfective aspect. Lament. Stanza 9 I. 6, It bootetl not for ne to wrpe or ciry.

The possibility of expressing the imperfective aspect of the action by means of a group consisting of the infinitive of to be + a form in -ing, as in Pres. D. Eng. I cannot bear io he always suspecting people; We'd helter be going back; You are much too young yet to he meeting young men, does not seem to have existed in More's time.

233. There is one case in which the infinitive, on account of its incapacity to express time-sphere and aspect, is ralher frequently replaced by a group consisting of to have + past participle.

'Type He was loth to have lost him.

Rich. 53 E 5, vndoutitedly the protectour loued him wel, \& loth was to haue loste him. I I'icus 31 I3 9, Graunt me fro Sathanas seruice to

1) To have + past participe (to have seen) cannot grammatically he called form of the infinilive. C. $\$ 284$, nole.

2) In Pres. D. Eng. futurity can be expressed by pulting ahout before the infinitive: a meeting about to take place. For instances of this usage in More see $\$ 660$. Since auxiliaries of future time (shall, will) cannot lie placed between such attendant verbs as need to and want to and the infinitive, they are often put before these attendant verbs : Conl. Tynd. $628 \mathrm{H} \mathrm{I}$, we shal not neede to ymagin an hole bored thorow, for it halh an hole bored through in deede. 
astart, with whom me rueth so long to haue be thrall. | Hich. $67 \mathrm{H} \mathrm{12,}$ James Tyrell ... way a man ... woortby to haile serued a muche better prince. | Hich. 62 D 17, it suflised in a riche man for a pretext ol treson, to haue ben o: kindred or alliaunce... with any of those that were at any lime the kinges enemies '). | Diul. Her. $115 \mathrm{G} 5$, it is lyttell doubte but Solomon myght laue founde poore folke ynoughe to haue gyuen his golde vito. | Dial. C. 209, he hadde leuer haue sylten al that whyle at breakfast wyth a good fat goose. | Aut. Lett. xxi, 112, I was aboute to haue shewed his highnes sumwhat of my pore mynde in the mater. | Aut. Letl. xxI, 31 , the kinges grace answered that no creature ... was more lolbe to hane cummen to the warre. | IDial. Her. $175 \mathrm{~F} 3$, what wold it Laue profiled to haue put you in remembraunce of Christes wordes. I Passion 1.299 II 12, they thereuppon denysed ... to haue slayne Lazare. Dial. C. 126, hym of whom you recognyse to haue hadde ... helpe and coumforte. I Dial. (.. 143, if he had neuer come in tribulacion, [he] had bene in peryl neuer baply to haue hadde iust remorse. I Instr. $1407 \mathrm{E} \mathrm{1,}$ cause hast thou none... so sole to feare that thing h., fall, which as lhuu knowest thyselfe righte well, thou wouldest wythyn a wliyle after, haue wished to haue fallen vato them before. I Conf. Tynd. 494 E 12, which... he would haue taken to haue standen in no stede. A pol. (Wky.) 902 A 3, I would not baue suttered him go if it would haue pleased hy In to haue taryed styl in the stockes. | Hich. 71 F 11, I was about to wish, that ... it might haue pleased Godde... to haue geuen him... $\left.{ }^{g}\right)$

This usage is frequently met with in Layamon's Brut (Lichtsinn 1913, p. 4), in Mandeville (V. d. Meer 1924, § 45), in Malory (Dekker 1932, $\$ 231$ ) and in other Middle English writers (Trnka 1930, pp. 81/2 ; Kellner 1913, $\$ 234$ ), e. g. :

c 1412 Occleve, Reg. P'r. 145, Alle the world hade not been sufflsaunt To haue receyved so large a geaunt. | c 1470 Malory, Morte D'A. xv, 2, then they ... drew out swords to have slain him. | 1450 Paston lett. (Gairdner) $n^{\circ} 126, j$. ax and j. Llok was brought forth to hace smetyn of myn hede.

The same usage is found in Shakespeare (Franz 1924, p. 544), in Spensel and in later English (Jespersen 1924, p. 285 and 1932, p. 88), e. g. :

1590-6 Spenser, F. Q. I, iii, 5, Wilh gaping mouth at her ran greedily,

1) Comprare wilh this quotalion the following of a similar characler, but witlout to hase : Hich. $59 \mathrm{D} 3$, it is an vnsitling thing, \& a veri blemish ... to the sacre magesty of a prince,... to be defouled with bigamy in Lis tirst mariage [Instead of : to have been defouled]. Debell. $1003 \mathrm{~B} \mathrm{9,} \mathrm{there} \mathrm{was} \mathrm{not} \mathrm{only} \mathrm{torbuden} \mathrm{to} \mathrm{beare} \mathrm{witnes,} \mathrm{he} \mathrm{that} \mathrm{appeared}$ to be once forsworn, bul also... [Instead of to have been forsworne].

2) For the types thought to have seen, would have seen see \$8 671-75. 
To have attonce devourd her tender corse. | 1753 George Washington, Diary, 16 Dec., Several times we were like to hase been staved against Rocks (G.). | Walpole, Forlitude I, Ch. 12, p. 146, A God tbrie must be somewhere to have given him all this splendour (Kr.).

Instead of the type : it was your happe to hase been there More occasionally uses: it hath been your happe to be there:

Dial. Her. 203 F 1, it hath been your happe to be there. | A pol. 72, yet hath it delyted ... hym ... to lay these fawles to the clergyes face.

294. Summahy of the USE of the PRepositional and The Plain infinitive ${ }^{1}$ ).

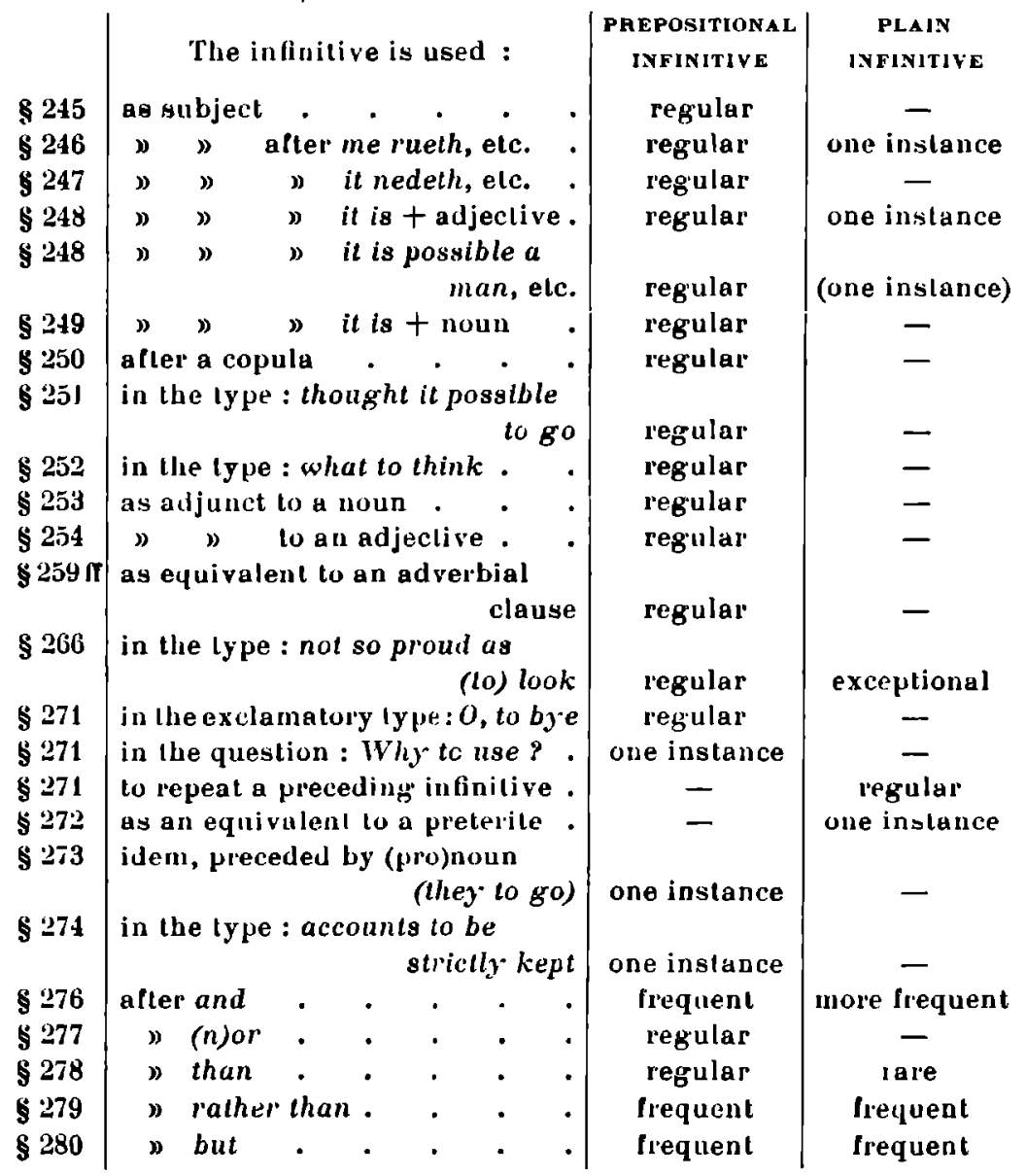

1) For the use and absence of to in such combinations as will go, want to go, saw him go, made him to go see the paragraphs on synlactical units with two or more verbs. 
295. SUMmaAy of the USE OF (PHO)NOUN-SUBJECT + INFINITIVE (I), FOH + (PHO)NOUN-SUBJECT + INFINITIVE (II) AND FOR TO + INEINITIVE (III).

\begin{tabular}{|c|c|c|c|c|}
\hline & The inflnitive is used : & a man to go & $\begin{array}{l}\text { II } \\
\text { for a man } \\
\text { to go }\end{array}$ & III \\
\hline$\$ 245$ & as subject & Irequent & - & (rare) \\
\hline$\$ 246$ & D D after me rueth, etc. & - & 一 & - \\
\hline$\$ 247$ & 》 it nedeth, etc. & frequent & not infrequent & one inslance \\
\hline 248 & 》it is + adjective & frequent & frequent & one instance \\
\hline$\S 249$ & $m \quad$ $\gg$ it is + noun. & frequent & frequent & (rare) \\
\hline$\$ 250$ & after a copula. . . . & - & - & - \\
\hline 251 & $\begin{array}{l}\text { in the type: } \\
\text { he thought it possible to go }\end{array}$ & - & one instance & one instance \\
\hline $\begin{array}{l}\$ 254 \\
\$ 255\end{array}$ & $\begin{array}{l}\text { in the type : a desire to go } \\
\text { in the type : } \\
\text { readiness to wax angry }\end{array}$ & - & frequent & - \\
\hline $\begin{array}{l}\text { \& } 258 \\
\text { § } 259\end{array}$ & $\begin{array}{l}\text { in the type : ethe to kindle. } \\
\text { as an adverb adjunct of }\end{array}$ & - & frequent & rare \\
\hline & purpose & ral'e & 一 & frequent \\
\hline $\begin{array}{l}\$ 262 \\
\$ 262\end{array}$ & $\begin{array}{l}\text { in the lype: to say the trulh. } \\
\text { in the type: }\end{array}$ & - & - & - \\
\hline 263 & $\begin{array}{l}\text { as ... to loke on death } \\
\text { as an adverb adjunct of } \\
\text { concession }\end{array}$ & - & nol infrequent & - \\
\hline § 264 & as an adverb adjunct of result & - & - & - \\
\hline 8265 & idem after too. . . . & 一 & frequent & rare \\
\hline$\$ 266$ & 》 $) 80$. & 一 & - & - \\
\hline 8268 & as an adjunct of cause. & - & - & - \\
\hline $\begin{array}{l}\$ 269 \\
\$ 271\end{array}$ & $\begin{array}{c}\text { " } " \text { of condition } \\
\text { in the exclamatory lype : } \\
0, \text { to bye }\end{array}$ & - & - & - \\
\hline $\begin{array}{l}\$ 273 \\
\$ 274\end{array}$ & $\begin{array}{l}\text { as an equivalent to a preterite } \\
\text { in the type : accounts to be }\end{array}$ & one instance & - & - \\
\hline 276 & $\begin{array}{l}\text { strictly kept } \\
\text { after and or (n)or. }\end{array}$ & one instance & - & - \\
\hline$\S 278$ & "than . & frequent & not infrequent & - \\
\hline 279 & 》 rather than & - & - & - \\
\hline 280 & but. . & - & - & - \\
\hline
\end{tabular}

296. From column $I$ in $\$ 295$ it appears that the expressing of the subject by means of a (pro)noun before the infinitive was restricted to a small number of cases. After More the usage became obsolete even in these cases, so that in Pres. 
D. Eng. constructions like if it should happen any book to come; men thus to talk is a daily common thing are very uncommon. The only case in which the idiom has been preserved is that in which the infnitive is used in a construction expressive of a regulation or testamentary disposition.

297. From column II it can be seen that the lypes it is a shame for him to be so fickle; it is not lawful for any mayde to folowe their sample; it was foly for him to speak; time for me to go; easy for him to do and the fashion was too strange for any man to faine occurred most frequently. This is not to be wondered at, since the word for is used here in a natural way and not " inorganically", as oftell in Pres. D. Eng., e. g. Everett Green, Miss Malory p. 111, I would like for you to tell the story (C.). In the olher cases represented in column II the usage does not yet seem to have become well established; as a matler of fact the idiom was comparatively young and not yet known in earlier Micldle English. Kelluer $(1913, \$ 71)$ mentions the year 1474 as the earliest date of its appearance. In the course of the $16^{\text {th }}$ century it began to supplant the construction in columu $I$ in various cases, and about 1600 it is found as subject at the beginning of a senlence (usage nnknown in More). Nowadays it can be used in nearly all the cases listed in $\$ 295$.

298. The for to construclion (column III) was oftener used in earlier English than in More. About its origin there is no consensus. Einenkel (1916, pp. 17 If.) believes in French, Mätzner (1885, p. 57) in Norse influence (analogy of for at). Boch $(1931$, p. 187) and Lichtsinn $(1913$, p. 6) point at the possibility of its development out of the older language. Indeed Shearin (1903, p. 18) adduces two quotalions from late Old Euglish, one from the Codex Diplom. Aevi Sax., one frotn the A. S. Chronicle ( 256,1127 E) '). Originally used to strengthen the notion of purpose, it soon began to alternate with to in functions in which the latter particle had been the only legitimate word (Sander 1914, Boch 1931, pp. 189 fr.).

) According to OED (s. v. for 11) for to is met with since the 12th century. 
Already in Layamon (Lichtsinn 1913, p. 6), Wyclif (Smith 1907, p. 465), Orm (IVeyel 1896, p. 12), the Ancren Riwle (Redepeuning 1906, pp. 95 and 101) and Occleve (Buchtenkirch 1889 , p. 25) there seems to have been hardly any difference between the use of to and for to. In subsequent writers to and for to kept on baing used interchangeably, so much so that for to lost its pregnant meaning of in order to and reached the point at which it had nothing to recommend itself by the side of the simpler to with exactly the same meaning. Naturally decay set in. The dala in the third column show that in More's time for to was well on its way lowards obsolescence; only in equivalents of clanses of purpose it was still frequently employed, just as in St. John Fisher (IVeyl 1937, $\$ \$ 205 / 7 ; 222 / 6 / 7$ ). Its use became still more restricted by the time Shakespeare lived, and in the course of the $17^{\text {th }}$ century it was generally avoided in literary language. In Pres. D. Eng. it lives on in popular and dialectal speech only, e. g. Stevenson, Treas. Isl. p. 14, Black dog .. come for to see his old shipmate Billy. | Mrs. Gaskell, Sylvia's L. xxv, It's not manner's for t'help oursel's.

\section{THE PAST PARTICIHLE}

299. The past participle of originally " weak" verbs ends in -ed(e), -id, $-y d,-d e$, and occasionally in $-t$ and $\left.-t e^{1}\right)$ : \begin{tabular}{l|l|l} 
confuted Conf. Tynd. 982 E 2 & tenderid Hich. 49 A 5
\end{tabular} proned Conf. Tynd. $982 \mathrm{G} 13$ robde Dehell. $961 \mathrm{H} 2$ handeled Conf. Tynd. 982 H 2 playde Debell. 1010 F 7 laied Conf. Tynd. $983 \mathrm{C} 4$ tempt Picus $22 \mathrm{~A} 3$ constrewyd Dial. Her. 159 C 3 husht Rich. 64 B 15 framyd Lett. $1430 \mathrm{E} 2$ mockte Conf. Tynd. 811 A 15 forelaborid Rich. 49 C 8 pulle Last Th. 85 G5

Besides infect Debell. 1008 H 5, suspect Rich. 67 E 6 and excommunicate Debell. 981 E 13 we find infected Conf. Tynd. 811 C 7, (un)suspected Lett. Fryth 833 C 9 and excommunicated Debell. 981 H 5.

A few originally weak verbs have past participles in -en: casten out Conf. Tynd. 528 F 13; descenden Answer 1042 H 6 ; rewarden Conf. Tyud. 722 H 14 ; moulden Apol. (WVks.) 930 D 2 ; ondershoren Conf. Tynd. 473 D 9.

1) For details see Grünzinger 1909, g 223. 
Old Eng. $3 e-$ is preserved in the form of $y$ - or $i$ - in : Ibente Picus 30 D 7 ; yclensed Picus 34 A 7 ; yset Picus 29 B 2 and Iwrought Picus 31 A 6.

For the past participles of the originally "strong" verbs see 207 .

300. The past participle can be used in the following vays ') :

a. as an attributive adjunct preceding a noun, e. g. a cursed branche $\$ \$ 301-308$.

b. as an altribulive adjunct following a noun, e. g. counsayle geuen $\$ 309-314$.

c. after a copula, e. g. I be foule vgly lene and mysshape $\$ 315$.

d. as a predicative adjunct, e. g. I took it for finyshed $\$ 316$.

e. as an equivalent lo an adverb clause, e. g. all grieues forgotten, eche of you loue other $\$ \$ 317-322$.

f. in a few more exceptional cases $\$ \S 323-329$.

301. 'The PAST PARTICIPLE AS a PHE-NOMINAL ADJUNCT.

a. Wilhout adverbial modifiers.

The pre-nominal use of the past-participle unaccompanied by adverbial modifiers is very common in More :

Dial. Her. 114 C. 9, these carued \& painted ymages. | Last Th. 77 B 10, the chosen people of god. | Boke of F. p. 6 B 10, borowed ware. | Kich.

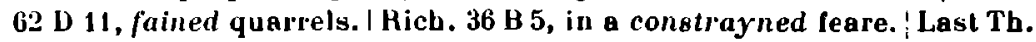
96 H 8, a stufled body. | Dial. Her. 240 A 2, the goodnes of God broughte suche hidde mischiefe lo lyght. | Last Th. $96 \mathrm{~F} 2$, forbidden fruit. | Rich. $50 \mathrm{Ci} 10$, his painted processe. | Hich. $47 \mathrm{E} \mathrm{14}$, theyr stollen goodes. | Dial. C. 182, a rosted crabbe. | Dial. C. 347, euery saued soule. | Dial. C. 162, gods written law. I A pol. 22., my sayed dyalogue. I Rich. 63 E 14, the said ... doctor. | Picus 1 G 9, the sayde Emperour.

Borne. Answer $1035 \mathrm{~F} 11$, all thoughe tho thing touched hys owne borne brother. | Rich. $37 \mathrm{G} 1$, to some other then his owne borne brother. | Dial. C. 128, there is no borne Turke so cruell to christen folke, as is the false christen that...

Borne blind. Dial. C. 347, but those that are very verteous, are yet in a maner as farre therefro, as the borne-blind man, tro the right y maginacion of colours.

1) For constructions like: he is punished; he has punished, I saw it done see the sections on syntactical units with two (three) verbs. 
Here the past participles denote a quality or a state as the result of the action or occurrence expressed by the verb; time-sphere and agent are only vaguely thought of .The usage was known before and after More's time and is still common in Pres. D. Eng.

The collocation borne blynd ( + noun) is obsolete now.

\section{EARLIEA}

a 1400 Morte Arth. 3375, I salle redily ... reche the pe riche wyne in rynsede coupes (OED).

1461 Rolls of Parlt. v 491, 1, The pretended and recoked Parlement last bolden at youre Toune of Coventie (OED).

\section{LATEH}

1546 J. Heywood, Prov. 22, All is not folde that glisters by tolde tales (OFI).

1643 Miltun, Divorce I, viii, Wks. Iv, 40, reiterated scandals and seducements (OED).

302. The parliciples in the following quotations are of a slightly different character.

Picus 2 F 3, such onknowne and straunge lokens. | Apol. 181, the knowen trouth of theyr mater makelh them oner bolde. I Last Th. 82 G 15, As for wigthe and enuy, be the knowen children of pride. / Rich. 61 A 15, [they] more resembled otber knowen men then him. | Hich. 62 A 10, fiftenes sumsed not, nor ani vsual names of knowen taxes. | Picus 3 C 4, he left these ... troden palhes. I Picus $18 \mathrm{H} \mathrm{11,} \mathrm{those} \mathrm{blessed}$ citeseyns. | Boke of F. p. ' $\mathrm{D} 1$, on whiche the mased people gase and staro. | Picus 11 H 13, Lhe damned wretches. | Last Th. 87 F 10, a cursed braunche.

In a less degrce than in the preceding paragraph the qualities or states expressed by these past participles are felt as the result of an action; this seems due to the nonconclusive ${ }^{1}$ ) or non-terminative characler of the verbs (to know, to tread). No idea of time-sphere or of an agent being evoked, the verbal character of the participle has almost disappeared.

Occasionally the past parliciple forms a kind of quasicompound with the following noun :

Apol. (Wks.) 866 F 15, wilh ... raylynge is all their roste meate basted.

Earlier usage : c 1400 Mandev. Tr. 1, 8, to envyrone pat holy lond with his blessede feet (M.). | c 1400 idem 36, 8, many wedded men (M.).

1) Jespersen $1932,7,6,1$. 
303. The following quotations illustrate the usage wilh subjective verbs :

Apol. (WVks.) 89. ci 4, Bayfielde the monke... lhat was an abiured, and afler periured and relapsed heretyke. | Hich. $54 \mathrm{C} 15$, a withered aim. | Aul. Lelt. xıv, 21, wete welher and roten ways. | Debell. 930 D 1, he spake but of moulden breade. I Cont. Tynd. $626 \mathrm{E} 12$, yet halle the man as much shame in his face, as a shotten hering hath slurimpes in ber taile.

Picus 1 B 11 , wore mete for secrete communicacion of lerned men. I Jest p. 3 E 9 , This officere, This fayned frere.

Instances are not numerous and some doubtul (lerned, fayned). There are a few more in $\$ 306$ (thy's new com ouer booke; long lien drugges; this late sprongen dyuysyon). In accounting for the origin of this idion it should be borne in mind that past participles like come and relapsed often formed groups with to be to denote a slate, e. g. Rich. 64 E 2, Fitz IVyllyam ... whiche was ... new come into that office; Apol. 889 (11'ks) E 1, he was eylher relapsed, or elles dyd of obstinacy staud stil in them.

The earliest quotation in OED of relapsed, used as illusirnted here, is dated 1570, of shotten hering (= that has spawned) 1451. In Pres. D. Eng. this idiom has become very usual with a number of verbs denoting motion or change, e. g. The returned mistress; a travelled person; a departed guest; a retired basiness-man. In such constructions the verb has a terminative aspect ${ }^{1}$ ).

304. Before More's time it seems to have been rare for past participles of subjective verbs to be so used, as may appear from the following list of the earliest dates in OED of the use of a number of such verbs in this construction. The instances between brackets are open to a double interpretation.

\begin{tabular}{ll|ll} 
a very advanced period & 1628 & the deceased ghost & 1586 \\
the great ascended Bishop & 1861 & his departed dog & 1599 \\
a new comen up matler & 1562 & a vell descended gentleman & 1665 \\
such decayed men & 1563 & their emigrated countryman & 1794
\end{tabular}

1) Deutschbein (1931, p. 145) remarks that " von intransitiven Yerben ein Parlizip-perfect als Adjeklivum (natürlich im aktiven Sinne) nur dann gebildel werden $\langle k a n n\rangle$, wenn dieses perfectiv is. (Vgl. dtsch. eine gesprungene Saite, aber nicht ein gesprungener Hase)". 


\begin{tabular}{|c|c|c|c|}
\hline the entered cloud & 1796 & our returned fortine & $\begin{array}{l}1600 \\
1821\end{array}$ \\
\hline the escaped con vict & & the risen sun & 1821 \\
\hline the expired commonwealth & 1648 & run wines & 1669 \\
\hline (the exploded fluid) & 1858 & your shricelld arlizans & $160 \mathrm{a}$ \\
\hline faded llowers & 1595 & shrunke death & 1592 \\
\hline the fallen branches & 1776 & the lirst sprong rose & $1575^{2}$ \\
\hline pne ald fail feit priest & 1496 & strayed shepe & \\
\hline fled soules & 1621 & tho ucwly snceceded Lord & \\
\hline (the floated cord) & 1799 & sunke & \\
\hline their far-flown wings & 1608 & lled lonast) & 161 \\
\hline a gone man & 1598 & spired n & \\
\hline immigrated Corsicans & 1882 & the trunsuded matters & \\
\hline (jumped potatoes) & 1871 & auncyen tranayled men & \\
\hline migrated Europeans & 1790 & sonte turned wine & \\
\hline monldered pe & 1615 & his canished delight & \\
\hline a relnpsed hereticke & 1570 & my wrined state" & \\
\hline retired leasure & 1632 & his wandered senme & \\
\hline (your retreated troops) & 1663 & roilted peaches & \\
\hline
\end{tabular}

It is interesting to nolice that a number of "strong" forms appear to have been used in this way much earlier :

\begin{tabular}{l|lr} 
to grow & cueri grene grosie tre & 1340 \\
to shrink & shrunken lyppis & c 1400 \\
to sink & a sonkyn bote & 1375 \\
to sterve & storye bestes & 1390 \\
to swell & swollen swyn & 1325 \\
to thrive & he had pre pry'en sunez & $13 \ldots$ \\
to wax & waxen bujes & c 1250
\end{tabular}

The usage is not recorded in OED of disappeared, roved, walked, leapt, arrived, appeared and started.

305. Dronken. This seems the usual form of the verb to drink when used as a pre-nominal attributive adjunct.

Last Th. $82 \mathrm{H} \mathrm{1,} \mathrm{what} \mathrm{shold} \mathrm{seme} \mathrm{farther} \mathrm{fro} \mathrm{pryde} \mathrm{than} \mathrm{dronken}$ glotonye. | Picus 16 D 4, the company of them which like dronken men without a guide wandre ... in obscure darkenes.

In other positions drunk seems to be preferred :

Last Th. 82 H 1, drink themself sow drunk. | Dial. C. (Wks.) 1251 B 2, be perceyuelh hymself drunke ${ }^{3}$ ).

1) Not registered in OED; but s. v. escapee it says = an escaped convict.

2) But see the earlier quotation from More in $\$ 306$ (late sprongen dyuysyun).

3) But : Picus 11 B 3, Let vs then beware that we be not dronken. 
In both cases the forms are evidently in an advanced stage of dissociation from the verbal system '); cf. bounden in $m y$ bounden duty (see below).

Accustumed. Aut. Lett. $x$ 38, ye shew yer acrustunede goodnes \& bynde me that that in my service lakketh in my pore prayor to supplie. Aut. Lell. xvir 33, myn accustumed maner.

This is a form of the now obsolete verb to accustom $=$ to prartise habitually; cf. 1477 Earl Rivers, Dictes 74, Angre the not sodeynly, for if thon acustume it, it wolle tourne ones to thy harmes.

Bonnden dity. The earliest quotation in OFD is dated 1530 ; it is possible that the collocation sprang up in More's time :

Aut. Lell. $x$ 37, hit lyketh yor good grace so thankfully to acceple my pore devoire in doing right small part of my bounden dutie.

306. The PAst participle as a PRE-Nominal adjunct.

b. With adverbial modifiers.

Type An old said saw.

There are numerous instances of this usage :

A bove. Picis $9 \mathrm{~B}$ 1, He shewed also to the aboutenamed Albertus...

(A)Fore. Itich. F 21, thafore remembred mariage. | Rich. 57 E 20, the fore remembred lordes. | Last Th. $76 \mathrm{H} \mathrm{3}$, the foresaid words.

Long. Rich. $40 \mathrm{G} \mathrm{2,} \mathrm{a} \mathrm{long} \mathrm{accustomed} \mathrm{malice.} \mathrm{/} \mathrm{Hich.} 65 \mathrm{~F} 1$, the long continued distres. | Last Th. 72 F 1, long lien drugges. | Debell. $932 \mathrm{C} 13$, the very good old and long approued lawes.

Sone. Letters 1424 D 11, sone spoken woordes of light and sone changeable people.

IVell. Dial. C. 239, There is set the deuils wel acquainted ${ }^{2}$ ) pricke, and his very iust marke. | Allt. Lett. xill 9, yor graces wel approsed wisedome. | Rich. 42 B 4, a very well spoken manne. | Lament. Stanza 1I I. 2, my welheloned sisters. | Hich. $56 \mathrm{D} 2$, his wel deserued deth. | Rich. 67 E 6, many well counterfaited iewels. | Mich. $40 \mathrm{D} 15$, our welproned euil willers. | Last Th. $76 \mathrm{~B} \mathrm{12,} \mathrm{thy}$ well minded sylence. I Supplic. 292 $\mathrm{E} 5$, the wel disposed people.

The adverbial qualifiers in this section are adverbs that do not occur in another form (e. g. lengthened by -ly).

Clere. Picus 2 B 9, in a clere polished inyrroure.

Deep. Jast Th. 77 F 6 , the depe conceined fantasy of deathe.

Enil. Rich. 40 B 3, euil disposed parsons. | Dial. Her. 241 B 3, an euill

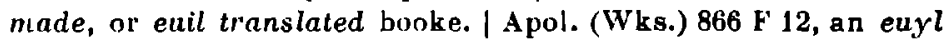
dressed dinner.

1) Kruisinga, Participles dissociated from their verbal system (1031, $\$ \$ 66-69)$.

2) Wel acquainted (= well-known) is obsolete or archaic now. 
False. Passion $1318 \mathrm{G}$ t0, this false framed deuocyon holpe hym not.

Fond. Dial. C. (Wks.) $1243 \mathrm{~F} \mathrm{4}$, a fond ymagined fantasy.

First. Last Th. 85 B 11 , l be first hegotten doughter of pryde.

Late. A pol. (Wks.) 914 E 2, thys late sprongen diui sion. | Rich. $40 \mathrm{~F} 16$, the iate made attonemente.

Madde. Apol. (Wks.) 48t F 10, Is not this a madde concluded argument?

New. Supplic. $302 \mathrm{C} 10$, as lyerce \& as angerly as a new hunted sow. I Answer $1038 \mathrm{~B} 7$, as touching thys new rom ouer booke. I Conf. Tynd. 394 G 4, ne.s recelued. | Conf. Tynd. 670 A 14, new told. I Debell. $913 \mathrm{H} \mathrm{3,} \mathrm{some} \mathrm{cerleine} \mathrm{nerve} \mathrm{fashioned} \mathrm{foundarion} \mathrm{').}$

Open. Apol. (Wks.) $868 \mathrm{~F}$ 15, I dare be bolde... to speake agaynale open knowen theetres, open knowen murderers, open knowen periured persons, open knowen apostataes, open knowen professed or conuicled heretikes.

Proper. Apol. (Wks.) 869 E 11, he hathe founden some certayne proper inuented fygures.

Hertely. Picus 1 D 6, myne herlely beloned sister.

Suttle. Apol. (Wks.) 925 F 9, any such suttle inuented ways that lay the fautes of the badde to the whole body.

The adverbial adjuncts in this section are adverbs used without the ending $-l y$, which in other posilions and cases they often lake (exc. hertely).

Falsli. Rich. 56 C 13, his falsli conceiued treson.

Lawfully. Rich. $63 \mathrm{~F} 16$, the very lacofully begotten sonns.

Willingly. Passion $1288 \mathrm{H} 11$, the bydeous tormente and wyllyngly taken payn.

The adverbial modifiers in these three quotalions a re adverbs ending in $-l y$.

Old. Dial. Her. 105 B 3, it is an olde said saw, that one busynes begetteth \& bringeth forth a nother. | Dial. C. 145, in slede of her old acquainted knight ... a new acquainled knaue. | Dial. C. 35̃, not only old writen stories ... but expetience genchl vs proofe inough.

Here old is used as an adverb with the meaning of of old, long, anciently.

Not. Cont. Tynd. 483 F 9 , the doyinge of those not understanden ceremonyes.

Dough. Dial. Her. $208 \mathrm{~F} 7$, he hath much dongh baken brede among.

The rvord dough, though equivalent to imperfectly, is a noun.

1) Fangle (= Pres. D. Eng. fangled) in : Dial Her. $150 \mathrm{G} \mathrm{1,} \mathrm{some} \mathrm{new}$ fangle heresies is not a verbal form. (Cf. OED s. v. fangle). 
307. Historical note (on $\$ 306$ ).

In the main, usage has remained the same, and in Pres. D. Engl. most of the combinations listed ahove are still possible. The idiom illustrated in the second section, however, (with e. g. clere) would seem to have become somervhat less usual '). Fond is archaic now ; clere has been superseded by clean; harlely (adverb) is obsolele; open and proper are not instanced in OED; in ordinary language deeply is more usual than deep, though in poetical language combinations of deep with past participle are formed at will (deep-affected; deepaffrighted; deep-buried elc. ; crystallized quasi-compounds : deep-read, deep-set ; decp-seated). First still frequently occurs in first-born (son). Evit, though rivalled by evilly, has remained in many collocations : evil-disposed; evil-gotten; evil-won, etc. ; late, loo, enters in innumerable quasi-compounds of the lype under discussion : late-begun; late-born; late-protracled, elc. The combinalions with old may have been innovations of More's lime; the earliest instances in OED) are later (old-accustomed 1592; old-acquainted 1535). An old said saw is now obsolete.

The use of new in the construction under discussion does not secm to have occurred oflen before More's time, as appears from the following list of earliest dates in OED.

\begin{tabular}{lr|lr} 
new-blown & 1667 & new-found & 1492 \\
new-born & 1300 & new-invented & 1573 \\
new-broached & $\left.1547^{2}\right)$ & new-laid & 1528 \\
new-broken & 1660 & new-made & c 1400 \\
new-built & 1596 & new-married & c 1540 \\
new-cast & 1650 & new-minted & 1593 \\
new-coined & 1598 & new-modelled & 1654 \\
new-come & 950 & new-mown & 1470 \\
new-created & 1656 & new-raised & 1667 \\
new-devised & 1588 & new-risen & 1591 \\
new-discovered & 1654 & new-vamped & 1675 \\
new-fallen & 1592 & new-waked & 1674 \\
new-fashioned & 1611 & new-yeaned & 1567 \\
new-formed & 1647 & &
\end{tabular}

1) Not considered are parasynthetical derivations like open-mouthed, clear-sighted, deep-monthed.

2) But : Apol. (Wks.) 850 F 5, a secrete brother of this new broched brotherhodde. 
In Pres. D. Eng. new is the regular form in new-born and new-laid; it is usual in new-found, new-made and new-mown. For the rest newly is, apparently, the ordinary form. Fresh as a synonym of new (fresh-oiled) is a later innovation.

308. Ty PE Her self-imposed mission.

No instances of this usage have been observed in More. It may have been unknown in his time : the earliest examples on record in OED date from the last part of the $16^{\text {th }}$ century (self-conceived 1599; self-disliked 1596 ; selfe-forsaken 1590 ; self-furnish't 1591; self-arched 1598 ; self-conceited 1595 ; self-contained 1591 ; self-hred 1587).

\section{The past participle as a post-nominal adjunct.}

a. IVithout adverbial modiflers.

Dial. C. 356, your good counsayle geuen. | Rich. 64 E 15, [they] stode as they had hen men amased. | Jest p. $4 \mathrm{E} \mathrm{14}$, The fryre frappe, Gate many a swappe. Tyll he wass full nygh slayne. | Picus $4 \mathrm{G} \mathrm{13}$, in detestacioun of his vice passed. | Dial. C. (Wks.) 1259 E 5, I wil geue hym a whyte suffrage, and in bis suffrage a new name critten. | Dial. C. (Wks.) $1220 \mathrm{C} \mathrm{5}$, thinges sette by and beloued. | Rich. 39 F 3, thynges passed connot be gaine called. | Rich. 63 D 8, at Poules crosse

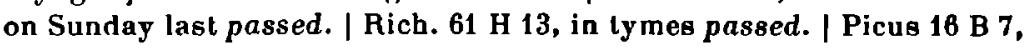
we preche Christ crucified. | Rich. $53 \mathrm{G} \mathrm{3}$, the time appointed.| Dial. Her. 117 D 7, all these names spoken, and all these wordes written. 1 Dial. Her. $280 \mathrm{E} 4$, many a man onlearned...

The freedom of placing the past participle in the postnominal position appears to have been greater than it is in Pres. D. Eng.; a good counsayle geuen, a new name written would be unusual now. If the past participle is found in post-position in Pres. D. Eng. in non-crystallized combinations it is due (apart from rhythmical motives) to an - often unconscious - tendency to mark the verbal character.

\section{EARLIER}

c 1475 Caxton, Receyell 146, Alle Lawe posilyp and alle lawe wreton condempne the vnto the deth (OED).

1470-75 Malory, Morte D'A. 234, 27, there they dranke the wyne, and ete the veneson and the foules baken (D.).

\section{LA T E R}

1564 Grindal, Fun. Sermon. 10, [He] highly commended the parties discessed (OED).

1820 Scott, Abbot $x i x, 198$, The party injured growled fortb an oath or two of indignation (P.).

Pres. D. Eng. : the guests inolted, the information required, the direction indicated, etc. 
310. The past participle as a post-nominal adunct.

b. Vith adverbial modifiers.

With adverhs. Last Th. $73 \mathrm{E} 2$, a byrall or Christall wel counter. fayted. | Last Th. 79 A 12, a thing well wonne. | Last Th. $72 \mathrm{~F} \mathrm{13,} \mathrm{foure}$ herbes, comen and well knowen. | Rich. $39 \mathrm{~B} 12$, a thing right wel intented. | Rich. $67 \mathrm{C} 10$, the thinge enill gotten. | Rich. 63 F 5, these

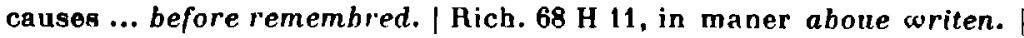
Iich. $45(=44) \mathrm{F} 11$, at the counsayle next assembled. | Picus 4 B 9, many thinges straunge, and not fully declared. | Apol. 14, a sermon ... openly preched. | Dial. Her. 177 D 1, certayne things before proned.

With other verb-modifiers (objects, adverb adjuncts, etc.).

Last Th. $86 \mathrm{E} \mathrm{4,} \mathrm{a} \mathrm{wrong} \mathrm{done} \mathrm{us.} \mathrm{|} \mathrm{Aut.} \mathrm{Lett.} \mathrm{vil,} \mathrm{77,} \mathrm{lettres} \mathrm{sent} \mathrm{onto}$ his Grace. | Passion $1281 \mathrm{H} \mathrm{9,} \mathrm{sacrifies} \mathrm{duelye} \mathrm{referred} \mathrm{to} \mathrm{God.} \mathrm{I} \mathrm{Aut.}$ Lett. Iv, 1, this daje I receiued yor graces lettres dated yesterday. I Lett. 1447 A 14, somo causeles suspicion, growen ... vpon some secret ... informacion. | Dial. Her. 114 B 12, the coste done opon the arche. I Picus 27 B 5, his precious heart carued in twayne. | Last Th. 72 E 11 , herbes and rootes, fet out of far countreis. | Rich. $45(=44) \mathrm{F} 12$, the onely manne chose and thoughte moste mete, to bee protectoure. | Last Th. 93 C 8, a thefe once cast at Newgate. | Last Th. 77 E 7, the liuely imaginacyon grauen in thyne owne heart. | Last. Th. $86 \mathrm{C} 1$, secret treason lately detected to the king. | Rich. $62 \mathrm{~B} 12$, a word spoken in hast. | Last Th. 74 F 2, it is not a fantasye fownden of myne owne herd. | Rich. $40 \mathrm{G} \mathrm{4}$, a newe fiende made of an olde foe. | Apol. (Wks.) $873 \mathrm{H} \mathrm{1,}$ lawes not made by them self but ... the comon lavs of al christendome.

IVith subjective verbs.

Picus 2 D 4, a woman comen of a noble stocke. | Dial. C. 240, a good man, comen into great autorile. | Answer 1138 bis B 1, these faultes of the prinler escaped in this boke. I Boke of F. p. 2 C 8, Lyke swarmyng bees come fickeryng her aboute. | Dial. Her. 191 D 10, I durst be boulde to say that aaint Austin did neuer write such wordes, but it is a worde ronne ${ }^{1}$ ) in many mens mouthes, begonne bi mistaking, \& beleued without examinacion.

In these ingtances the verbal character of the past participle is clearly brought to the fore by the adverbial qualifiers. Since in Pres. D. English the post-nominal position is the usual one, the constructions are more in harmony with the practice of today than those in which the past participle stands by itself.

1) This meaning of to run not registered in OED. Or perhaps an irregular form of the verb to round (rown, roune, rownen $=$ to whisper, to murmur)? 


\section{EARLIER}

a 1400 Gbaucer, Rom. R. 1214, White as snowe falle newe (OED).

1470-85 Malory, Morte D'A. 167, 9 , Syltynge by a graue newe made (OED).

1512 Act 4 Henry VIII, xI, Everything ... byfore rehersed (OED). 1470-8j Malory, Morte D'A. 49, 32, in a place conered with clothe of gold (M.).

\section{LATER}

c 1586 C'tesse Pembroke, Ps. Lxxir, ii, As showres thrown On meades new moron (OED).

1746 Fielding, T. Jones xur, xii, There is a somelbing in persons wel-born, which others can never acquire (OED).

1921 Lytton Strachey, Vict. p. 282, Her three years with Pitt, passed in the very centre of oplendid power, were brilliant and exciting.

As a rule the adverbial modifiers follow the past participle (letters sent unto his Grace and not letters unto his Grace sent). There are, however, exceptions :

D al. C. (Wky.) $1176 \mathrm{C} 11$, a heart broken, torne, and with tribulacion of heuinesse for hys sinnes laide a lowe. I Picus 31 A 6, all the creatures in this world Iwronght. (For the form Iwrought see $\$ 299$ ).

This order of words is avoided in Pres. D. English.

311. From the great number of instances in $\$ 310$ it should not be concluded that post-position of the past particle when accompanied by a prepositional adjunct is imperative. As still in modern Dutch and German the pre-nominal position was also possible in More :

Passion 1346 G 6, vnderstanding without any diffcultie the woordes of scripture therin, by their foretaught and fro tyme to tyme kept and continued faith. | Passion 1347 A 5, the fore taught and receyued, and by the whole catholike church beleued and professed faith.

312. Not infrequently the past participle is used as a pregnant construction, in which there is a connotation of reason, condition, restriction, etc. :

Rich. 48 (=45) D 7, suche euyll oppinyon once ') fastened in mennes heartes, harde it is to wraste out. | Dial. Her. $150 \mathrm{~A} \mathrm{14}$, thus once prowdly perswaded a wrong way, thei take the bridle in the teth \& renne foorth. | Rich. $71 \mathrm{E} \mathrm{12,} \mathrm{the} \mathrm{thing} \mathrm{that} \mathrm{I} \mathrm{was} \mathrm{about} \mathrm{to} \mathrm{say,} \mathrm{taken}$ as wel as afore god I ment it, could deserue but thank. | Dial. C. 130, The thinges ... eumming to 08 , are matter of worldly wealth : and

1) The earliest quotation in OED of once as a conjunctive adverb (- When once, if once) is dated 1761. In Shakespeare : Venus 408, the lesson is but plain, and once made perfect, never lost again. 
taken from os be matter of aduersitie. / Rich. $59 \mathrm{E} \mathrm{4,} \mathrm{him} \mathrm{semed} \mathrm{that}$ this mariage euen wordly considred, was not vnprofitable.

These participial construclions share their subject with the principal part of the sentence, and are thus distinguished from those discussed in $\$ \S 317-22$, which have a subject of their own.

The same usage is met with in older and later English :

c 1410 Pall. on H., Thi bene $y$-weeded twyes wal availle (E.). $\mid 1599$ Shakesp. Henry V, Iv, vii, 189, For I do know Fluellen valiant, And, touched with choler, hot as grunpowder. 1911 Athenæum, 7/10, Arriced at the spot, the party lost no time in getting to work (Kr.).

Occasionally the subject is expressed twice over, by repeating it by means of the relative pronoun which at the head of the participle construction :

Last Th. 72 D 8, the soul whiche here preserued from the sicknes of sin, shal after this eternally liue in iny.

From a Pres. D. Eng. standpoint which is redundant. In More its use appears to have been quite normal; he even uses wherof and wherupon in the same way:

Supplic. 291 F 9, about thexaminacion ... of such a mad malicious boke, we haue neither lust nor leysure to bestowe the time, whereof mispent in our life we [scil. the souls in purgatory] geue now a hard and a heuy rekenyng. | Passion 1272 B 10, what abhominable sinne it is ... when any creature falleth into the delyte... of it self : as the thing whertuon continued, ineuitably fayleth not to folowe,... the neglecting of God.

It was not yet very usual in the beginning of the $16^{\text {th }}$ century to express the relation between the construction illustrated above and the rest of the sentence by means of conjunctions ${ }^{1}$ ). Only one ${ }^{2}$ ) instance has been found in More; it contains the conjunction as, in the meaning as if.

1) Einenkel (1916, p. 4) states that these conjunclions made their appearence "el'st sehr spät" and gives as earliest inslance a line from Marlowe's Edward It. On p. 192 (Anhaing) he tries to correct this slatement by adducing the following quotation : For that maketh me eche, where so highly favored, Roister $D$. When we look up Udall's comedy we find that this sentence is of Finenkel's own making, the passage in question running [206-8 (Scheurweghs 1939, Materials xvi)] :

I am sorie God made me so comely doubtlesse.

For that maketh me eche where [= everywhere!] so highly fauoured, And all women on me so enamoured.

2) See, however, the quotations with once in $\$ 312$, in which this adverb is well on its way towards assuming the charaater of a conjunction. For conjunction + form in -ing see 361 . 
Hich. 66 ; 2, yel must he bee twise asked whyther he wil be bishop or no, and he musle twyse say naye, and at the third tyme take it as compelled ther vuto by his owne wyll.

After More this usage gained considerable ground '). In Pres. D. Eng. it is common with such words as though, as if, if, when, unless, etc.

1593 Marlowe, Edw. II (Taucbn. Ed. p. 173), Thus lives old Edward not reliev'd by any, And so must die, though pitied by many. 1606 Shakesp. Troil. I, i, 34, when my heart, As wedged with a sigh, would rive in twain. | 1590-96 Spenser, F. Q. v11, 36, 9, where yet it may be seene, if sought. | idem A View Pres. St. of I., 626 a, reliques of the true antiquity, though disguised. | 1669 Worlidge, Syst. Agric. 222, The Trees ... are now naked, unless cloathed in white. $1763 \mathrm{~J}$. Brown, Pocty \& Ilus. $\$ 6,97$, One of them (as wounded) fell down (OED).

313. Type Things unheard of.

Picus 3 E 8, many other thinges strange : \& to all, folke ... before that day, not vuknowen only : but also unherd. Of (= unberd of.) al which questions in open places ... be fastened and set vp. | Last Th. 86 E 10, the sodaine brunte of the iniurye not forethought opon.

These participles are used in post-position. Of front-position, a usage so common in Pres. D. Eng. (the much-talked-of perils, his doted-on Anne, the agreed-upon price) no instances have been observed. The usage does not seem to have been very old, judging from the following dates of earliest quotation in OED : unheard-of 1599 ; undreamed-of 1636 ; untouched-ıpon 1746 ; unloked-for 1538 ; spoken-of 1595 ; long-lalked-of 1841.

314. Type A butler, become a culler, shall prove a fool. Jest p. 1 C 2, An olde butler, Becum a cutler, I wene shall proue a fole.

In Pres. D. Eng. this use of the past participle of the copula become still seems possible :

Gissing, Born in Exile, B 141, Earwaker, remarkably developed and become a very interesting man (J.).

315. The past participle after a copula.

Type That peril is past.

If the past participles of subjective verbs are found after to be, they have almost lost their verbal meaning and have

1) Rbyne 1910, pp. 1 fi. 
assumed the character of an adjective in which as a rule all time-association is absent. Consequently they are often met with in juxta-position with original adjectives, as in lerned and ignorant. (See $\$ 559$ a). With other than subjective verbs the character of to be is not always that of a copula; in actional ") passive constructions (e. B. he was constantly reproved) it is clearly an auxiliary of voice. In static ") passive constructions (e. g. he was amazed; the play is done) the character of to be does not seem to differ greatly from that of the same verb in the types he is rich, that peril is past.

A few instances of the past participle after to be are given below without comments, since the point is discussed more in detail in the sections on syntactical units with two verbs (\$§ $554 \mathrm{ff}$ ).

Rich. 40 F 6, thanke be to his grace that peril is paste. | Ricls. $61 \mathrm{G} \mathrm{3,}$ he was neither vnlearned, and of nature ... well spoken. | Picus 11 B 3, Let vs then bewale ... that we be not dronken. | Picus 5 D 10, otber folke as wer in very science much better lerned, and in those trifles ignorant. | Rich. 57 B 1, Now is sbe old, lene, withered, \& dried vp.

Last Th. 84 B 10, the play is done. | Last Th. 93 B 5, bis bely is wel flled. | Pageants, Deth, 1. 1. I be foule vgly lene and mysshape. | Jest p. 4 F 6, Tho frere arose, But I suppose, Amased was his hed. | Rich. $35 \mathrm{G} 10$, He was a goodly parsonge,... in aduersitie nothynge abashed, in prosperitie, rather ioyfull then prowde.

Earlier usage :

a 1400-50 Alexander 4008, Quen pe gouernoure is gane pan is the gomes wasted (OED). | 1485 Caxion, Paris \& V. 31, Coude not be contente ne fylled to beholde hyr layre loue.

Sometimes the verb to be appears to be used in the dual function of a copula and an auxiliary :

Dial. G. 80, This is very trewe... in dede, and wel obiected too. | Rich. $40 \mathrm{E} 1$, the prince ... which is lighte of beltefe and sone perswaded.

Similar slightly sylleptic constructions are still occasionally found in Pres. D. Eng.

816. The past pahticiple as a predicative adjunct.

Rich. 40 A 9, which countrey ... was ... waxen wild, robbers and riuers walking at libertie oncorrected. | Last Th. $84 \mathrm{E} 9$, in 1 bis prison of yerth we drive forth a while, some bounde to a poste.|Rich. 43 D 7, The Quene ... satte alone ... all desolate and dismayde. | Aut. Lett. xix,

1) See $\$ 560 . \quad$ 3) See $\$ 555$. 
44, fyndyng his enemyes strong and the fortressis wel manned \& furnished... | Rich. 37 D 2, shee coulde not bee deliuered of hym onculte. | Rich.56 B 13, to pil \& spoil whom thei list encontroled. | Last Th. $86 \mathrm{E} \mathrm{11,} \mathrm{commyng} \mathrm{vpon} \mathrm{vs} \mathrm{onproulded.} \mathrm{|} \mathrm{Rich.} 51 \mathrm{D} \mathrm{9,} \mathrm{he} \mathrm{coulde} \mathrm{not}$ be conuaied out untaken. | Rich. 43 F 6, none coulde passe onserched. | Apol. 176, heretykes may go onarrested. | Last Th. $76 \mathrm{C} \mathrm{12}$, to let one wanton woorde passe oncontrolled. | Rich. $53 \mathrm{H} \mathrm{18}$, he returned into the chamber... al changed. | Rich. 69 B 4, sil James Firel dyed at Tower hill, beheaded for treason. | Dial. C. 203, by m that suffreth dark and onknowen. I Apol. 21, they whyche wyll not byleue goddes worde but $y$ l he putte it in wrytynge be as playne infydeles as they that will not byleue it wryten. | Picus 22 D 10, lest he thee onpuruetd, and vaready catche. | Apol. (Wrs.) $846 \mathrm{G} \mathrm{9,} \mathrm{he} \mathrm{bringeth} \mathrm{hyın} \mathrm{foorthe} \mathrm{Heble,} \mathrm{faynt,}$ and famished, and almost honger storuen '). | Picus $25 \mathrm{C} \mathrm{7,} \mathrm{Thou} \mathrm{shalt}$ it finde ... little, simple, short, and sodainly past. | Dial.Her. 105 D 7, my busyness that I toke for finyshed. | Dial. C. 345, [they] shall hereafter sit, full gloriously crowned in heauen. | Jest p. 2 D 11 [he] would not go, Companied so. I Dial. Her. 215 B 10, I couldẹ myștrust their talę well ynough ... as they stode onsworne.

Drunk.

Last Th. $82 \mathrm{H} \mathrm{2,} \mathrm{And} \mathrm{yet} \mathrm{sbal} \mathrm{ye} \mathrm{find} \mathrm{mo} \mathrm{that} \mathrm{drink} \mathrm{themself} \mathrm{sow}$ drunk of pride to be called good felowes. | Dial. C. 332, he perceyueth hymself drunke and geatteth hym to bedde.

The great number of instances, which could easily be added to, shows how frequently the past participle was used in the function of a predicative adjunct. In this respect More's usage does not seem to differ from that in earlier and later periods of the language.

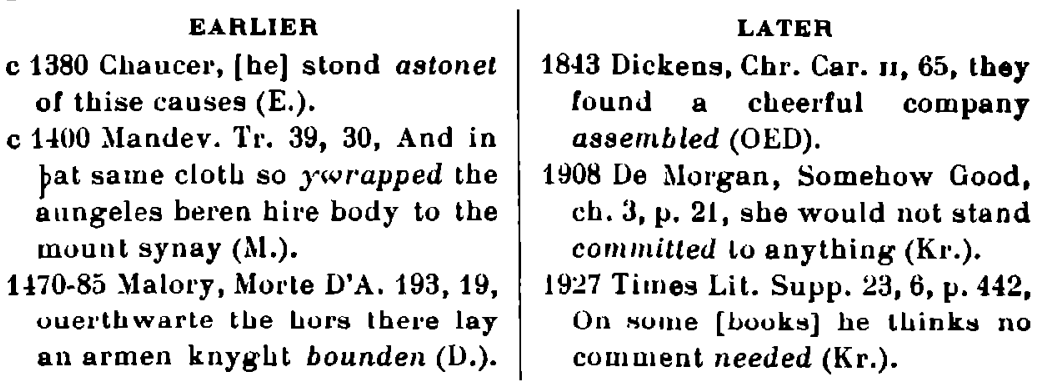

1) The type honger storuen was not unknown before More's time : 1470-85 Malory, Morte D'A. 674, 21, whiche was worme ete and feeble. I In Pres. D. Eng. there aro a number of si milar combinations: Tennyson, Ger. \& En. II, 351, But Enid fear'd his eyes, Moist as they were, wineheated from the least. | Tennyson, En. Ard. 51, breaker-beaten coast. | Mary Bowen, a moss-covered bridge. | - More has also : fleeblowen edrours and mothe eaten beresies (Conf. Tynd. 582 A 8). 
The past participle was also used as a predicative adjunct after as :

Dial. C. (Wks.) 1249 D 1, [God] instructeth our reson ... to receiue theim [the spiritual affections] as engendred and planted in our soule.

917. The past participle equivalent to an advehbial CLAUSE.

The type This done, he retired.

In the majority of the instances quoted below the action or state denoted by the past participle and that denoted by the verb in the principal part of the sentence have different subjects, which subjects are both expressed. This usage, conventionally called the " absolute participle construction", seems to be an imitation of the Latin ablativus absolutus, to which the dativus absolutus of Old English corresponds (forlcetenre dare ceastre, he com). For a long time during the Old Euglish period the construction appears to have been felt as a foreign importation, alien to the genius of the language; in many translations from Latin it has ostentatiously been avoided (e. g. in Boethius, cf. Callaway 1889, pp. 22-31); in those works that are free from Latin influence it is hardly ever used. In some Middle English writers, the influence of Latin and later of French is clearly visible; others, again, steer clear of it. Dekker $(1932, \S 307)$ adduces a long list of quotations illustrating the usage under discussion from Malory's Morte D'Arthur, whereas V. d. Meer $(1924, \$ 109)$ states that in Mandeville's Travels "perfect participles are rare in free adjuncts". In the course of the Middle English period, with its disappearance of case distinctions, the noun preceding the past participle was more and more felt as the subject, so that the pronouns changed from him, her etc. into he, she, except in the case of intentional imitation of the Latin construclion, as in the following quotations from Milton : Paradise L. vil, 142, by whose aid This inaccessible bigh strength, the seat of Deity suprene, oy dispossessed He trusted to have seized. | Par. L. Ix, 130, For only in destroying I find ease To my relentless thoughts; and him destroyed ... all this will soon Follow.

318. The construction : noun-subject + past participle used as an equivalent of an adverb clause is a great favourite of 
More's '), and in this respect his language markedly differs from Pres. D. Eng. ; indeed the construction never seems to have belonged to the language of the people ${ }^{2}$ ); it now all but exclusively obtains in the higher strata of the language. An investigation.into the use of this construction in More's contemporaries is essential before it can be stated in how far, if at all, More deviates from the usage prevalent in his time.

The use of prepositions (with, without, after, by, at, upon, etc.) before the construction is of later origin than the use of the construction without prepositional introduction; the idiom was influenced by Latin (ante Christum natum), by French (apres la paix conclue) and perhaps in the earlier stages also by Old Norse (eptir Ingjald lipinn, at Gamla fallin; cf. Einenkel 1916, p. 4). In More's English the prepositional constructions are profusely used. Pres. D. Eng. generally prefers a group consisting of preposition + noun + being + past participle. Such groups do not occur in More.

\section{The pagt Pahticiple equivalent to an adverb clauge} OF TIME.

Type This done, he retired.

Rich. 42 B 5, they ... pulte bim in warde, and that done, fohrthwyth wente to horsebacke. Picus $22 \mathrm{D} 5$, One sinne vainquished loke thou not tary. | Apol. 143, the kynges bygines commaunded certain of the gretest lordes ... to know how the matter stode. Whyche knowen and reported to the kynges grace his hyghnes gaue ... suche answere... I Rıch. 60 B 11, This examinacion sole[m]pnly taken,... the king with gret feast ... maried dame Elisabeth Grai. | Lell. 1423 G 3, I am bold eftsones vpon your goodnes to desire you to shew me the fauour, that I might the rather by your good meanes, haue a copy of the bil. Which sene, if I finde any valrue surmise therin as of liklihode there is, I may make mine humble sule vnto the kinges good grace. / Rich. 63 G 2, Which thing well considred, \& the greale knightly prowes pondred ..., the nobles \& commons ... haue condiscended... | Dial. C. (Wks.) 1163 C 12, one doubte yet temaineth..., and that doubt soyled, I wyll ... oncoumber you no farther. | Dial. Her. $112 \mathrm{~B} \mathrm{1,} \mathrm{On} \mathrm{the} \mathrm{morow} \mathrm{he} \mathrm{was}$ comen again somwhat before .vij. of the clocke ... taking bim with me into my study, \& my seruauntes warned,... I set him down with me, at a litell table.

1) They are also (requent in St. John Fisher (see Weyl 1937, 88 289-80).

?) Ross 1892, pp. 23 ff and Franz 1924, pp. 548-9. 
This usage was well-known before More's time and is still often met with in Pres. D. Eng., especially in stock phrases and formal speech. It also occurs frequently in St. John Fisher (Weyl 1937, § 115).

\section{EARLIER}

1380 Wyclif, Mik. v, 36, the word

herd that was seide, Jhesus seith

to the prince of the synagoge (OED).

1390 Gower, Cont. A. I, 888, The

consell in this wise take, The

Prestes fro this lady gon.

\section{LATER}

1918 Times W., 22, 2, The reading ended, the Prince took the oath of allegiance (Kr.).

Pres. D. Eng. : Tea over and the tray removed, she again summoned us to the fire (C.).

The construction also occurs with a personal pronoun in the common case [he] :

Dial. C. (Wks.) $1242 \mathrm{G} 5$, Tell me then (cosin) ... if ther wer a man attainted of treason or of felong, \& after iudgement geuen of bys deth, \& that it wer determined that he sholde dye, only the time of his execucion delayed tyll the kinges fertber pleasure knowen, and he therupon deliuered to certayne kepers, and put $v p$ in a sure placo out of which he coulde not scape, wer this man a prisoner or no ?

INTRODUCED BY after.

Lett. $1447 \mathrm{E} \mathrm{2,} \mathrm{if} \mathrm{I} \mathrm{sholde} \mathrm{after} \mathrm{the} \mathrm{causes} \mathrm{disclosed} \mathrm{and} \mathrm{declared,}$ finde them so auswered as my conscience shuulde thynke it selfo satislyed, I would thereupon sweare the otb. | Dial. Her. $165 \mathrm{C} \mathrm{4}$, If after your speciall prayours made, ye wrote the one parte in one paper... | Rich. 61 E 9, thei stode as thei had bene turued into stones, tor wonder of this shamefull sermon. After whiche once ended, the preacher gate him home. | Lett. $1428 \mathrm{D} \mathrm{11,} \mathrm{Than} \mathrm{desired} \mathrm{I} \mathrm{the} \mathrm{sight} \mathrm{of}$ the act of the succession, which was deliuered me in a printed rol. After which redde secretly by my self, and the othe considred with the acte, I shewed unto them... | Hich. 69 F 12, [the protector] ... after secrete metling \& communicacion had, eftsoone, departed. | Last Th. 93 B 8, The lecherous, after his foule plesure past, may suffer to here of contynence. | Hich. $43 \mathrm{G} \mathrm{2,} \mathrm{And} \mathrm{thereuppon} \mathrm{by} \mathrm{and} \mathrm{by} \mathrm{after} \mathrm{the}$ messenger departed, hee caused in all the baste al his seruauntes to bee called vppe. | Dial. Her. $105 \mathrm{C} \mathrm{14}$, accomptyng that after our commanicacion ended, I sholde neuer uede ferther busynes therin. I Answer $1039 \mathrm{H} \mathrm{2}$, I wyll guod reader peruse the remanant of this booke after this Rr'st par't answered. I Rich. 58 F 19, After which done ..., this pore Lady made humble sute vnto the King. | Last Th. $95 \mathrm{~B} 1$, If thou knewest very cerlainlye that after all thy good gathered together, thou shouldest be sodainly robbed... | Picus 8 D 11, the substaunce that I have loft "), after certalne bokes of myne finished, I intende to geue out to poore

ग) $=$ left. 
Polke. | Dial. Her. $108 \mathrm{E} 1$, Your Prende first after your leller redde ... shewed me that ye had sent him to me. | Aut. Lett. xiv 109, after his army withdrawen \& discharged, they wilbe ... easy lo be loste. | A pol. 177, after great tyme taken, and myche dilygence ssed, we... | Rich. $70 \mathrm{D} 7$; idem 61 F 11 ; idem 68 C 8; idem $69 \mathrm{C} 1$; idem $69 \mathrm{E} 9$; Dial. Her. $165 \mathrm{C} 4$; etc.

This idiom is often met with in older periods and is also frequently used by More's contemporary, St. John Fisher. Aftel More's time it seems to have become less common. There are not many instances of it in Shakespeare. Spenser, however, uses it a number of times (Sugden 1936, $\$ 345$ ), e. $g$. F. Q., Intr. III, 9, and with you bring triumphant Mart,... After his murdrous spoyles and bloudie rage allayd. I F. Q. I, vi, 27, 1, His loving mother ... chaunst ... to meet him ... After his sportes ... donne. In Pres. D. Eng. it is only rarely found (OED does not mention it), collocations with after (hav)ing being the rule now. The construction with which (e. g. after which done; after which redde) is no longer possible.

\section{EARLIER}

1470-85 Malory, Morte D'A. 162, 29, after the reuenrence made they made relacyon of their ansuer (D.).

1470-85 Malory, Morte D'A. 182, 31, after lycence gyuen he relorned (D.).

\section{LATER}

1667 Milton, P. L. 248, Nor delay'd the winged Saint, After his charge received (Kl.).

1925 Galsworthy, Caravan 15y, After all said ${ }^{1}$ ), it was in his dealings with children that the best... side of his personality was manifested ( $\mathrm{Kr}$.).

\section{INThODUCED BY upon.}

Aut. Lett. xxI 51, Where as mon sieur deselstayne oppon the hoope hadde of eny good wais of peace ... olf red hyuselfe to cum over. | Iticb. 41 A 1, Upon this concluded, the Duke... secretly caused the Quene to be perswaded. | Rich. 66 A 13, Vpon this answer geaen, the Duke... rouned ... with olber noble men about Lim. | Rich. 19 G 11, he nothing doubted, but that those lordes ... should spon the matter examined, do wel ynough. | Hich. 66 B 3, opon ... pardone desyred and oblayned, he shewed aloude vnto the protectour, that... | Apol. (Wks.) 901 E 6, spon that poynte perceiued and knowen, I caused a seruaunt of myne to stryppe hym. | Passion 1308 A 9, oppon the scrypture in this poynto mysse taken, the churche of Grece fell fro the churche of the Latyns. I Lett. 1423 D 1, I cannot mistrust bis graces lauoure towardes me, opon the trouth knowen.

1) This does not seem to be stundard English; for most English people it has an ungrammatical " feel " about it. 
This idiom was not unknown belore More's time; it seems to have Pallen into disuse afterwards. In Pres. D. Eng, it does not occur ').

EARLier : 142 -1509 Pastun L., upon due examinacion had upon the mater ... ye take such direction as... (E.).

LATER : 1646 Winllirop, Journ., July 5, Upon the peace concluded between the Dutch and the same Indians, she was restored to the Dutch governor.

INTRODUCED BY before.

Con. Tynd. $490 \mathrm{C} 7$, the Apostles themselfe ... sayed masse many a time and oft before any ghospell written. | Passion 1327 A 7, wyne, whych he dranke next before those wourdes spoken. | Supplic. 297 H 2, Nowe is it of trowth well knowen, that he was detected of heresye before the premunile sued or thought opon. | Dial. C. (Wks.) 1139 B 3, Who wold haue went, ... afore a fewe yeres passed, that such ... sholde come...

Of this construction, which not infrequently occurs in More, no earlier inslances have been found. It is obsolete now ${ }^{1}$ ).

Cf. $15: 38$ Slarkey, England 118, Before the materys examynyd and tryed... (T.).

\section{INTRODUCED BY at.}

Rich. $54 \mathrm{E} 10$, And therwith as in a great anger, he clapped his fist vpon the borde a great rappe. At which token giuen, one cried treason. I Dial. Her. 146 F 11, holy scripture ... at those words spoken, was not yel all written.

No earlier iustances have been found. The usage is now obsolete ${ }^{1}$ ), though it seems to have been possible in poetical language for some time after More, wilness the following quotalion from Milton : P. L. $x, 687$, At that tasted fruit the sun turn'd bis course intended.

INTRODUCED BY from.

Apol. (Wks.) $849 \mathrm{H} \mathrm{16}$, For els had it ben wrong with english people from the fayth fyrst broughte into thys realme, vnto oure owne dayes...

This is the only instance found in More. No earlier examples have been discovered. The construction is not possible in Pres. D. Eng. ').

INTRODUCED BY till.

Dial. C. (Wks.) $1242 \mathrm{G} \mathrm{9,} \mathrm{the} \mathrm{tyme} \mathrm{of} \mathrm{his} \mathrm{execucion} \mathrm{delayed} \mathrm{tyll} \mathrm{the}$ kinges ferther pleasure knowen... | Dial. Her. $185 \mathrm{C} \mathrm{14}$, Which he neuer was after the deede done, till the excommunycacion denounced.

1) Nol mentioned in OED. 
No instances of earlier usage have been met with. The construction is obsolete now ${ }^{1}$ ). Cf. :

1533 Th. Gromwell, Lett. to Henty VIII, July 23, I commgited them rnto ward where they now do remaine till your gracions pleasure knowen. | 15 月0 96 Spenser, F. Q. I, i, 12, your stroke, Sir Knight, wilhbold, till further tryal marde.

320. The past PaRTiciple equivalent to an adverb clause OF REASON, CAUSE OR MEANS.

Type The time and place known, it will be easy to withstand him.

Aut. Lett. xvI, 17, his grace thinkslh the tyme \& place so cerlayuly knowen, it shalbe a good occasion to the scottes ... to withstand his enterprise. | Dial. C. (Wks.) 1141 D 11, partlye dissencions fallen among our self, partly that no manne careth what harme other folke feele : ... The Turke is in fewe yeres woonderfully encreased. | Dial. Her. $280 \mathrm{C} 1$, it is now all one to call him a Lutherane or to call him an heretike, those two wordes being in maner equivalent, Luther teaching almost nothing but heresies, nor none heresies founden any where alinost that the Lutherans baue not among them.

INTHODUCED BY by.

Dial. C. (Wks.) 1194 E 14, then were it a token, that the deuil had either ... brought him in despayre, or reraduenture by his reuelacions founden false and reproued, or by some secrete sinne of his deprehended and dinulged, cast him ... in despayre of heauen. | Rich. 60 G 12, though ... some by the ignoraunce of the world \& the trouth hid fro knowlege enherited ... other mennes landes. | Apol. (Wks.) 849 C 2, the entent that by those woordes changed, the people shold be noseled. | Dial. C. (Wks.) 1163 D Ia, I perceyue well by youre aunsweres gathered and consydered together, that you wyll wel agree that a manne...

The following quotations illustrate earlier and contemporary usage :

c 1380 Chaucer, Boece v, 1725, And yif men ne wene nat that hope ne preieres ne han no strengthis by the necessite of thingis to comen I-resceyved, what thing is ther thanne by whiche... | 1470-85 Malory, Morte D'A. 249, 24, by this done he was so faynt that vnnethes he myght stande. I a 1535 St. John Fisher, Wks. 80, 4, \& anone by that dylygent inquysycyon made reason shall shewe at the laste yf ony peryll be hydde vnder by fraude or gyle.

No instances of later usage have been found.

INTRODUCED BY for.

Dial. C. (Wks.) $1234 \mathrm{G} \mathrm{9,} \mathrm{wretched} \mathrm{worldly} \mathrm{goodes,} \mathrm{for} \mathrm{whose} \mathrm{shorte...}$

1) Not mentioned in OED. 
pleasure in this lyfe forborne, we shall be... euerlastyngly recompenced of God.

No instances of earlier or later usage have been observed.

INTRODUCED BY thorow.

Dial. Her. 281 A 4 , accursed is he ... that thorow his trust put in any man, belieueth the contrary.

INTRODUCED BY by the meane of.

Lett. $1424 \mathrm{C} \mathrm{16}$, it may like your highues... somwhat to tender my pore bonesty, \& neuer suffer (by the meane of such a byll put forth against me) anye man take occasion hereafter againgt the troth to slaunder me.

321. The past participle equivalent to an adverb-clause OF CONDITION ') OR RESTRICTION.

Type The words once read, the truth shall show itself.

Debell. 931 A 14, the woordes ones red: the trouth should shewe it solfe. | Rich. $48(=45)$ D 7, suche elyyil oppinyon once fastened in mennes heartes, barde it is to wraste oute... | Dial. Her. 187 F 6, And it so taken, \& their opinton so reputed, they reken it a ground to thinke the miracles done at the ymages ... to be illusions of the deuil. | Last Th. $87 \mathrm{G} \mathrm{3}$, the fountayne once stopped, the sore shal sone beale of it self. | Rich. 69 A 9, Which thinges ... wel pondered : god neuer gaue his world a more notable exauple. / Last Th. 75 F 9, the vain pleasures of the worlde, whiche once excluded, there is place made and cleane purged, to receive the very swete and pure pleasure of the spirite. I Letters $1424 \mathrm{C} \mathrm{2}$, Which if your hignes did not, as I trust in god and your grel goodnes (the matter by your own high prudence examined and considered) ye wil not... / Last Th. 74 A 9, [he] hath lost the natural light of leason, and the spirituall light of laith : which.II. lightes of knowledge and snderstanding quenched, what remayneth in bim more, than... | Hich. 70 A 12, many rightwise men, think it vnlikely, (the depe dissimuling nature of those bothe men considered...) tbat ... the proteclor wold geue the duke occasion of displeasure. | Fich. 49 B 6, it were... greal commoditie to them both as for yet a while, to ben in the custody of their mother, the tender age consydered of the older of them botb. | Apol. (Wks.) 855 B 11, this thynge hadde in mynde and considered, all hys reason after ... waxeth euen deadde for cold. | Picus $18 \mathrm{C} 3$, that thing taketh be for his chief good, which only hadde,... ho thinketh himsolfe happye. | Dial. Her. $279 \mathrm{E} \mathrm{3,} \mathrm{Which} \mathrm{few} \mathrm{wel} \mathrm{repressed}$ ... ther shall farre the fewer haue lust to folow.

2) The conditional force is very plain in the following non-absolute constructions : Apol. 19, the word of god is as atrong uncuryten as wryten. | Dial. C. 302, how muche more profitable they [scil. our worldly gooda] bee well geven then euyll kept. 
Dial. C. (Wks.) $1253 \mathrm{G} \mathrm{12,} \mathrm{By} \mathrm{my} \mathrm{trouth} \mathrm{vncle,} \mathrm{woordes} \mathrm{can} \mathrm{I} \mathrm{none}$ find, that shoulde haus anye reason with them (fayth alwaie presupposed, as you protesled in the beginning for a grounde). I Dial. C. (Wks.) 1242 H 16, Yea adde yet... that he wer suffered to goe and ryde also ..., onelye this one poynte alwaye prouyded and foreseene, that bo should euer be surely seene to...

This usage was known before More's time :

1390 Gower, Conf. A. Jv, 226, Bot verlu set in the cornge, Ther mai no world be salvage, Which migte it take, and don awaie. | 1470-85 Malory, Morte D'A. 246, 26,... this lady my sister is yours at al lymes her worship saned, for wete ye wel she loueth you as wel as ye doo her and better (D.).

Later instance :

1865 Kingsley, Herew. $x, 200$, All this is ... probable enough, the dates considered.

In all the above quotations from More the past parliciple is preceded by its (passive) subject : the fountain once stopped, the matter examined. Occasionally the reversed order is met with (cf. \$322) :

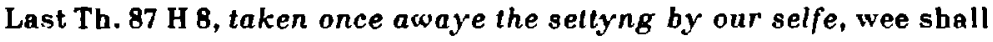
not grelly dote vppon that we set lyttle by. I Supplic. 315 C 12, presupposed the immortalitie of mans soule..., \& therto agreed the righteonsness of god \& his goudnes ..., purgatory must nedes appere.

This latter usage seems to have developed more fully after More's time; indeed, in Pres. D. Eng. there are a number of past participles (such as granted, given) which almost exclusively occur in front position and are consequently well on their way towards assuming the character of a mere conjunctive word :

1926 Jones, Journ. of Eng. \& G. Phil. p. 288 July, Granted then these correspondences ... we may pass to an inquily into... | 1925 Ashdown, in Atl. Monthly, June, Given the choice of a fino homo without a car and a modest with a car, the latter will win (C.).

322. The past partioiple equivalent to a ciause of ATTENDANT CIRCUMSTANCES.

Type All the commons gathered before him, he spoke.

Only if introduced by with or without is the character of the construction clearly that of a clause denoting attendant or concomitant circumstances. In other cases the relation may be rather vague and there is often a connotation of reason, cause, instrumentality, condition, time or restriction.

Rich. 61 F 11, there in the east onde of the hall where the maire kepeth the hustinges ... all the commons of the citie, Bathered before 
them, after silence commaunded ... : the Duke stode vp and ... hee saide... | Rich. 39 G 10, I exhort you and require you al ..., from this time forwarde, all grieues forgotten, eche of you loue other. I Picus 6 A 9, to thende that all the charge and busines of rule or lordship set a side, he might leade his life in rest. | Boke of F. p. 2 A 9, [Thow] that bepest vp this wretched worldes treasure, Thy fingers shrined with gold, thy tawny skynne ... garnished out of measnre... | Picus 16 H 7, if thei now backbite the(e) liuing vertuously, thei shal doe the same neuerthelesse if (vertue forsaken) thou were ouerwhelmed wilh vice. Rich. 36 G 12, hys cause was ... so farrefoorth auaunced, that kinge Henrye his bloode... itterlye reiected, the Growne was by authoritye of parliament enlaylled vnlo the Duke of York. | Rich. 55 E 13, that iubardy so wel passed : it gaue bim great pleasure to talke with him. Last Th. $72 \mathrm{E} 9$, The physicion sendeth his hill to the poticary, \& therin writeth sommelime a costly receite of many straunge herbes and rootes, fet out of far countries, long lien drugges, al the strength worn out, \& some none such to be goten.

The same usage before and after More, though in Pres. D. Eng. it is less frequently found.

\section{EARLIER}

1390 Gower, Cinf. A. III, 2093,

Egisle was take and was forlh brogbt Hise hondes bonnde.

1390 Gower, Gonf. A. v, 3964, Hir

her tospred sche gan to fare.

\section{LATER}

1861 Eliot, Sil. Marner $v$, The light of faith quite put out and his affections made desolate, he had clung with all the lorce of his nature to his work and his money.

Front-position of the past participle occurs in :

Last Th. 77 D 11, those pictures expresse only the lothely figure of our dead bony bodies biten away the Resh. (C. \$ 321).

INTRODUCED BY without.

Dial. C. (Wks.) $1145 \mathrm{G} \mathrm{11,} \mathrm{without} \mathrm{this} \mathrm{comfort} \mathrm{fyrst} \mathrm{hadde,} \mathrm{there} \mathrm{can}$ in tribulacion none other good comfort come forth. | Dial. G. (Wks.) $1142 \mathrm{~F} \mathrm{8,} \mathrm{wilhout} \mathrm{thys} \mathrm{way} \mathrm{taken} \mathrm{with} \mathrm{them,} \mathrm{they} \mathrm{shall} \mathrm{not} \mathrm{fayle} \mathrm{to} \mathrm{doe,}$ as many bold blynde poticaries done. I Rich. $65 \mathrm{D} \mathrm{13}$, withoute whiche pardon obtayned they durst not be bold to move him of that matter. I Apol. (Wks.) $870 \mathrm{~F} \mathrm{2,} \mathrm{Thys} \mathrm{bathe} \mathrm{ben} \mathrm{bytherto} \mathrm{the} \mathrm{whole} \mathrm{summe} \mathrm{of} \mathrm{my}$ wrytynge, wythoule anye dyspleasaunt woord osed either toward temporaltye or spiritualtye. | Dial. C. (Wks.) 1158 F 1, that preyer wythoute other condlcion added or imployed were inordinale. | Dial. C. (Wks.) 1143 B 5, the grounde \& loundacion of fayth, without which had ready before, all the spirituall coum[ort ... can neuer auaile a fye.

St. John Fisher also often avails himself of this construction :

Wks. 211, 8, for truly confessyon without contrycyon had before profyteth very lytell or no thynge.

Cf. : Shakespeare 1 Henry VI, II, iii, 72, They set him Iree without his ransom paid. 


\section{INTRODUCED BY with.}

Rich. 43 G 6, with his owne householde aboute bym, and euerie manne weaponed, hee tooke the greate Seale with him. | Apol. (Wks.) 909 H 3, than should sone after with heretikes increaced \& multiplyed, the fayth be vndone.

\section{EARLIER}

c 1386 Chaucer, C. T. A 4277, And in the foor, with nose and mouth to-broke, They walwe as doon two pigges in a poke.

147i-85 Malory, Morte D'A. 408, 14, Thenne the shelde was brought forth and the feld was guldysh with a kynge and a quene therin paynted.

\section{LATER}

1805 Scott, Lay L. M. Iv, $\operatorname{xxxv,13,}$ With my minstrel brethern fled, My jealousy of song is dead.

1915 Times W. 2. 8, Even now, with the conversion accomplished, we should be immensely strengthened (P.).

\section{The Past Pafticiple USED as a Rounding-off FORMUla.}

It is worthy of nolice how often the participial construction (cp. $\S 322$ ) is used to round off a period or passage :

Dial. Her. $132 \mathrm{~A} 11$, he that had neuer sene it,... would at the fyrst sight wonder sore therat, to se that great water come wallowing vp agaynst the wynde, kepyng a commen course to \& fro, no cause per-

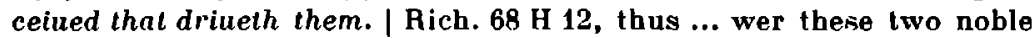
princes ... depriued of their estate, shorty shitle vp in prison, and priuily slaine and murthered, theyr bodies cast god wote where. | Rich. $57 \mathrm{~B} 1$, now is she old, lene, withered, \& dried vp, nothing left but ryullde skin \& hard bone. | Dial. C. (Wks.) $1162 \mathrm{H} 1$, an euil aunswer bad he, and an euil spede therafter, his army discomfited and himself slain.

There are numerous instances in which this construction in this function is preceded by and :

Dial. C. (Wks.) 1239 G 13 , a man may be let walke at large where he wyll, and yet a payie of fetters fast riueted on his legges. | Dial. C. (Wks.) 1186 E 4, many a good man and woman ... haue ... well \& vertuously withstand it, and bene in conclusion clearely delyuered of it, and their trybulacion nothing knowen abrode, and therfore nothing talked of. I Dial. Her. 151 A 14, Some of them let not with lyes \& periury to defend them self, and some to stande in defence of their errours or false denying of theyr own dede... And al thls done because ... thei think if thei abiure, thei shall after be suffred to preache again. | Rich. 70 B 15, But men say that he was of trouth not wel at ease, \& that both to king Richard wel knowen, \& not yl taken, nor ani demaund of the dukes oncourteisly reiected. | Dial. Her. $282 \mathrm{~F} 11$, Whose false opinions haue been ... openly condemned by many holy synodes ... \& now ... not onely theyr opinions quenched, but also al theyr bokes cleane gone, and 
vanished quyte away. | Debell. 993 H 1, many great ryottes go by vnfound, and the concelours neuer spoken of. I Conf. Tynd. 474 A 2, For fyrst I might agreo all that ho sayeth, and hys purpose neuer the more prooued.

324. The subjoined evidence testifies to the occurrence of this idiom in all periods of the English language from the Middle Ages on :

c 1400 Mandev. Tr. 173, 17, the cristene men wenten where hem lykede best ... withouten leltynge of one creature \& hire enemyes enclosed \& confounded in derkness. | 1470-85 Malory, Morle D'A. 708, 35, there was grete Ioye bitwene them for there is no tonge can telle the Ioye that they made eyther of other and many a frendely word spoken betwene as kynde wold. | idem 430, 26, They ete and drank ... and their horses walkyng and somme teyed. | a 153.j St. John Fisher, Wks. 211, 2, But this cry must be sofle without noise of wordes, it must be in the secrete places of the herte, no voyce, no sounde, in one wyse sherved outwardly. | idem 3, 24, Notwithstandynge the goodnesse of almighty god onely dyde electe and chose hym, all his brethren regecte and set aparte(W.). | 1646 E. F(isher), Mod. Divinily 7, Let all the fruits of Paradise be in thy power one tree except. | 18830 . Wilde, Duchess of Padua, 11, While we sit in gorgeous pomp and slate, gaunt poverty Creeps through their sunless lanrs, and with sharp knives Cuts the warm throats of children slealthily And no word said.

325. Here is, perhaps, the best place to draw the atlention to the fact that besides the past participle construction two other constructions with verbal forms were also used by More to round off a period or passage, viz. the construction with the infinitive and that with the form in -ing.

Dial. C. (Wks.) $1254 \mathrm{C} 1$, on she came gerning toward the place : whom as soone as the bartes herd : they to go both twayn apace.

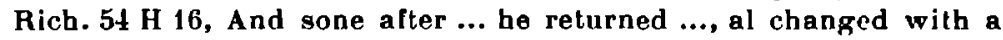
wonderful soure angrye countenance, knitting the browes... and knawing on his lyppes, \& so sat him downe, in hys place: al the lordes much dismaied \& sore merueiling of this maner of sodain channge.

To the examples given in $\$ \$ 272,273$ of the earlier and later use of the infinitive in this function the following evidence may be added :

1600 Shakesp., As Y. L. II, ii, 161, Heaven would that she these gifts should have, And $I$ to live and die her slace. | 1605 Ben Jonson, The Fox v, ii, 134, Wom. My lady's come most melancholy home, And says, sir, she will straight to sea for phisic. Sir P. And $I$ to shun this place and cllme for ever. | 1821 Scott, Ken. Iv, 41, Men talk of your being under soine special protection; nay, stare not like a pig that is stuck. 
mon, thou canst not dance in a net and they not see thee. | 1926 Arlen, Green Hat 247, There isn't, I suppose, anything in the world more irritating than lo bo angry with a woman, and she not notice.

Oftener than the infinitive the form in -ing was and is used in this way; it is especially frequent in Pres. D. Irish English :

1412 Lydgate, Troy Book 6126, And Troyens, as pei stood a lofte, Pulte bem of, pat entre pei ne my 3 t, With cast of stoon ... \& schot of arblasteria. And her gonnels stondynge at corners. I c 1400 Mandev. Tr. 159, 1l, And all this chambre is conered with jnne of plate of fyn gold dubbed with precyous stones \& grete perles, And iiij. Olifaunts and iitj. grete desteres all white \& couered with riche couertoures ledynge the chariot. | c 1386 Chaucer, Clerkes Tale, Iv, 91, What couthe a stourdy housebondo more devyse, To prove hir wylhode and her stedfastnesse. And he contynuyng ever in stourdynesse. | 1470-85 Malory, Morte D'A. 430, 26, They ete and drank ... and their horses walkyng and somme teyed.|17/0-13, Swift, Journ. to St. 285, I envy people maunching peaches and grapes, and $I$ not daring to eat $a$ bit. $1847 \mathrm{E}$. Brontë, Wuth. H. vi, And many a time I've cried to myself to walch them growing more reckless daily, and I not daring to speak a syllable. | 1911 A. Bennett, Accident (Tauchn. ed.) Ch. x, p. 89, it was so difncult to see properly, and the train moving all the time too. $\mid 1912$ G. B. Shaw, Androcles \& The L., 113, Why didn't you say so before? and us losing our time listening to your silliness (J.). | 1923 Lady Gregory, Goal Gate, It wes not a little thing for him to die, and he protecting his neighbour (C.).

326. The Pagt PARTICIPLE in the closing Formula of a LETTER.

Picus 15 C 4, Writen at Paris the .xv. daje of October, the yere of

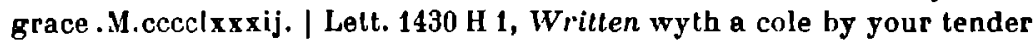
louing lalher.

This use of the past participle in the closing formulae of letters and official documents has been common throughout all the periods of English.

EARLIER. 1443 in Willis \& Clark, Cambridge (1886) I, 386, Yoven the day and the yere abouesaid. | 1584 Past. Lett. No 887, 111, 325, Goven at Long Stratton the .xx. day of October (OED). | idem 1477 John Paston, in Lett. 915, Wretyn at Mawtby, on Seynt Petrys Day.

LATER. 1833 Fraser's Mag. vil, 49, 'Done at Batlle, in the County of Sussex'; signed as our ambassador at Paris would sign a treaty of peace (OED).

Compare the usage in Norman-French :

1403 in Royal \& Hist. Lett. Reign of Henry IV, I, 159, Eacript a Hereford, en tresgraunle haste, a trois de la clocke apres noone, le tierce jour de Septembre. 
327. The PAst PARticiple as a kind of headivg on title.

Occasionally the past participle is used as a kind of heading or title announcing in a terse way the discussion of a particular subject :

Rich. 68, The yong kyng and hys brother murthered. | Rich. 60, The king fledde. | Rich. 60, The prince borne. | Rich. 60, King Henry the .vr. set op. | Rich. 57, The I,orde Riuers and other behedded.| Rich. 54, The lord Standley wounded. | Rich. $45(=44)$, The protectoure made. | Rich. 42, The Lorde Rivers putte in warde.

These syntactical units, found in the margin of the pages indicated, show a usage which is still preserved in the headings of the news-items in our modern newspapers.

328. The past participle in a parenthetigal unit.

Type The prayse geuen to god.

The construction with the past participle used parenthetically in the following passage could not be given a place in any of the above classifications :

Rich. $66 \mathrm{~A} \mathrm{3}$, he woold doe his vtlermost deuor to set the realm in good state. Whiche was alreadye in this little while of his protectorship (the prayse geuen to god) wel begon, in that...

The construction is clearly equivalent to an independent, coordinated syntactical unit and appears to mean praise be given to god. No parallels have been observed in writers either before or after More.

329. The PASt PARTICIPLE IN SHORTENED UNits AFter Why.

Another usage which could not be classified is illustrated in the following quotation :

Conf.Tynd. 496 E 1, ... how Tindal can proue me that the children of Israell, or as I say Moises either, vnderstode al the ceremonies commaunded by God aboute theire departing out of Fgipt? why lambe, why a kidde, why of one yere, why without spotte, why taken the .x. daye, why offred the .rII. why the vengeaunce of godde put from the house at the token of the blood put vpon the postes, why eaten by night, why none left til the morow, but rather the remenaunt burnt, why vnleuened bread, why wilde letuse.

Earlier and later use does not seem to be on record. The infinitive is similarly used in :

Apol. (Wks.) 486 D 4, When our sauiour himselfe sente oute hys disciples, and bade them in the confirmacion of their doctrine, laye theyr handes vpon sicke folke, and thei should be whole, and that they should anoynte some with oyle: woulde it not ... haue done verye well, 
that they shoulde haue sayd nay, but if he would tell them why lay their handes more then speake their bare word, \& why anoynt them with oyle rather then smere them with butter.

330. Pahticipial consthuctions not found in mohe's whitings.

a. Type Struck dead at first, what needs a second striking.

In this quotation trom Shakespeare (Ven. \& Ad. 250) the subject of the past participle (struck dead) is not contained in, nor can be inferred from the principal part of the sentence. More seems to have looked vpon this way of joining two syntactical units as irregular, for he never avails himself of this grammatical short-cut. In Pres. D. Eng. this construction (with the "dangling participle", as it is called) ${ }^{\prime}$ ) is considered a solecism ").

b. Type Her soules goon a blakeberied.

Constructions of the above type were not infrequently used in Middle English :

Chaucer, C. T. C 406, her soules goon a blakeberied. | idem F 1579, I lare To goon a-begged in my kirlle bare. | idem D 354, she wolde ... gon a cuterwawed. | Gower, C. Am. 1, 2030, he wolde ryde amayed.

This usage, which seems to have found its origin in mistaking the noun huntap in gangen (riden) on huntap ${ }^{3}$ ) for a verbal form, appears to have become obsolete before More's time.

c. Type His threatned speare (= his threatening spear).

In this construction a past participle is used where in Pres. D. Eng. a present participle would be employed. Of this usage, so often met with in Shakespeare 4), Marlowe 5) and Spenser ${ }^{6}$ ), no examples have been found in More.

Spenser, F. Q. II, i, 26, Suddenly that warrior gan abace His threatned speare. | idem I, viii, 34, Whose sencelesse speach, and doted ignorance. | idem I, ix, 28, so creeping close, as Snake in hidden weedes. ! Shakesp., Eirr. v, i, 298, Careful hours with time's deformed hand bave

1) Hussell 1935 ; Sugden 1936, $\$ 344$.

2) Not so with the form in -ing in a few cases and with the infinitive in the type to say the truth.

3) As in 1298 Hob. Glouc. (Skeat Spec.) p. 14, 387, As he rod an hontep.

4) Franz 1911, \$661; Schmidt 1902, p. 1417.

5) Vogt 1908, 16 .

6) Sugden 1936, §347; Hoffmann 1909, p. 14. 
written strange defeatures in my face. | Sonn. 122, 7, Till each to razed oblivion yield bis part of thee.

\section{Convehsion of the past pahticiple.}

In many cases the character of the past participle is that of an adjective, though the conversion is not always of the same degree. In comparing a rosted crabbe (Dial. C. 182) with borowed ware (B. of F. p. 6 B 10), it is found that the adjectival nalure is the least prominent if - as in the first example - the idea of action or occurrence is not absent. Farthest removed from the adjectival character are 1) those participles that are accompanied by an adjunct necessarily associated with the idea of time or action [e. g. adverbs, as in long lien drugges (Last Th. $72 \mathrm{~F} \mathrm{1)],2)} \mathrm{those} \mathrm{that} \mathrm{are}$ used as equivalents to adverb-clauses or 3 ) those that occur in post-position.

Words like dead (used pre-nominally), drunken, bounden (in my bounden $d u t y$ ), etc. may be said to have undergone complete conversion.

Just as in Pres. D. Eng. past participles take $-l y$ when used as adverbs :

Cont. Tynd. $786 \mathrm{G} \mathrm{12,} \mathrm{he} \mathrm{shall} \mathrm{speake} \mathrm{onlernedly.}$

In St. John Fisher we read :

Wks. 67, 25, I fought occasyon to synne, not faynedly but from the very herte of me. | Wks. 273,1 , for the whiche it may be thought ondoutedly that he had grete bope and confydence in prayer.

EA RLIER. a 1400 Chester PI. II, 50, One of them thou arte assuredlye.

The use of more and most to express degrees of comparison may be taken as a proof that the conversion from verb to adjective is complete :

Aut. Lett. xnI, 21, yor humble Orator \& moost bounden Beednan Thomas Moore. | Hich 56 C 9, an vuhappy ending : which be was now put vato, by the most drede commaundement of the kinges highnes.

332. There are a few instances of the conversion of the past participle into a noun.

Conf. Tynd. 518 H 9, I haue rebersed in the new law the .xy. of the actes, that menne shoulde abslayne fron strangled, and fron bloode. | Conf. Tynd. 442 E 12, to make it open to learned and onlearned both. । Conf. Tynd. $430 \mathrm{~A} 12$, if onelye shauen and annoynted maye preache... | Cont. Tynd. 467 F 9, But when be shal come ... to peruert ... the very chosen to... 
Strangled in the flrst of these two examples refers to things and represents a usage unknown in Pres. D. Eng. Coverdale's tranglation of the same Bible-text (Acts $x v, 20$, a suffocatts et sanguine) runs : from things strangled...

The idiom illustrated in the second and third quotation (learned, shtven, annointed) was known in earlier English : c 14:0 Lydg., Commend. Our Lady, 60, Of al Christen protectrice and tutele ... To wery wandred tent and pavilion. The usage has not been preserved in Pres. D. Eng. in the same form : when the reference is to a whole class, the definite article is used (the shaven, the annointed, the learned); in other cases people or a synonymous noun is put behind the participle (shaven people). There are also examples of this latter usage in More :

Apol. (Wks.) 868 E 15, I dare be bolde... to speake agaynste open knowen theeues, open knowon murderers, open knowen periured persones.

The collocations the lerned and a lerned in the following quotations are semi-independent and do consequently not instance complete conversion :

Dial. Her. 117 B 10, me thinketh that they be good bokes, bothe for

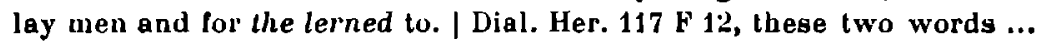
do not so lyuely represent vs the remembrance of his bitter passion, as dolhe a blessed ymage of the crucifix, neither to lay man nor vnto a lerned.

The conversion is also incomplete in the following instances :

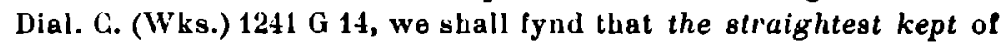
them both ... is ... al hys free libertie to bee where he will. | Passion 1326 B 3. The bloude of the Paschal lambe was shedde onely for the first begoten among the children of Israel.

Words like abject, elect must be looked upon as pure nouns; they can take $-s$ when used in the plural :

Dial. C. (Wks.) 1145 A 4, he is not an abiect, cast out of gods gracious fauour. | Conf. Tynd. 394 B 8, an vnkuowen churche of electes. | idem C 1, we be electes.

Departed in the following passage is not used as a noun, but rather as an attributive adjunct to one :

Hich. 57 A 10, Whose iugement semeth me somwhat like, as though men sbould gesse the bewly of one longe before departed, by her scalpe taken out of the charnel house.

Similarly with knowen and unknowne in :

Lett. 1451 D 1, [I] went out with master Leuetenante into the galery to hym, where I mette manye, some knowen and some onknowne in the way. 
In Shakespeare we read :

Meas. III, ii, 286, His old betrothed bul despis'd. | Tit. v, iii, 109, I am the turned fortb. | Troil. IIr, iii, 76, the declined. | Troil. 1, iii, 24, the unread. | Sonn. 78, 7, the learned's wing.

The plural meaning of the converted past participle is quite exceptionally axpressed by the addition of $-s$ :

Passion 1295 F 5, these first begottens that shoulde that night be slayne. | idem $1296 \mathrm{C} 2$, the slaughter of al theyr first begottens.

This form of begotten is not mentioned in OED. The following quotation witnesses to the occurrence of this idiom in earlier English :

1429 Wills \& Inv. N. C. (1835) 78, Euery hows of almouse ordeynt for bedrydens [ = bedridden people] (OED).

In Pres. D. Eng. the usage is rare and restricted to the past participles of only a few verbs, such as wanteds $[=$ in colloq. speech : persons wanted by the police] and unknowns $[=$ unknown persons, but especially in malhematics : unknown quantities].

333. The use of the participle as a conjunction is not clearly demonslrable, though there is often a tendency for that verbal form to develop a conjunctive character when it is placed at the beginning of a clause-equivalent, as in :

Supplic. $315 \mathrm{C} 12$, presupposed the immortalitie of mans soule ,.., \& therto agreed the righteousness of god \& his goodness ..., purgatorie must nedes appere.

Provided and except are perhaps the only past participles that show complete conversion :

Dial. G. (Wks.) $1171 \mathrm{H} \mathrm{11}$, he that cannot long endure to hold vp bis head \& hear talking of heuen except he be nowe \& than betwene ... refreshed with a meri folish tale. | Lett. Frith 834 H 18, Prouided ... Le misconstrue not the seripture.

Graunted introduces a that-clause in :

Gonf. Tynd. $410 \mathrm{~F} \mathrm{4,} \mathrm{But} \mathrm{graunted} \mathrm{now} \mathrm{that} \mathrm{those} \mathrm{fautes} \mathrm{wer} \mathrm{his} \mathrm{...,}$ yel is this none of them.

The earliest quotation in OED of graunted so used is dated 1884. More uses graunte in a similar way :

Apol. (Wks.) 484 F 13, For graunte that priesthod was an ofllee : yet night... 


\section{8. - THE FORM IN $-I N G{ }^{1}$ )}

334. In the following enumeration and classification of the meanings and functions of the verbal form in -ing no account Las been taken of its twofold parentage, i. e. it has been disregarded whether in a particular case the furm has descended from an Old English verbal noun in -ung (-ing), or from an Old English " present participle". By the time More wrote, any formal ${ }^{2}$ ) distinction had long disappeared and in most cases nominal and verbal characteristics ivere conjointly present - either in esse or in posse - in one and the same form. A division into two groups corresponding to the usage in Old English is therefore not quite justifled. For a more satisfactory classification see $\$ 368$.

In $\$ \$ 335-369$ the different functions of the form in -ing in the syntactical unit are discussed.

\section{THE FORM IN -ING AS SUBJECT ${ }^{9}$ ).}

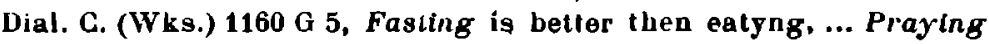
is batter then drinkyng ... Waking in good busines is much more acceptable to God then slepyng. | Dial. C. (Wks.) $1188 \mathrm{E} \mathrm{11,} \mathrm{\&} \mathrm{therfore}$ comforting of her, could baue no place. | Last Th. 81 E 12, What thing is dying?

1). In the following passages -ind and ydge may be misprints for -ing and -ynge respectively : Apol. (Wks.) $888 \mathrm{E} \mathrm{14}$, what good and charitable handeltnd wyll he deuise to saue bis body. | Dial. C. (Wks.) 1184 E 8, the true performydge of their penaunce. 1 - For this lorm performydge, however, see : A pol. (Wks.) $860 \mathrm{~B} 1$, Tyndalles confutacion in mockage of mannes endeuoure towarde the beliele, and in scorninge that manne shoulde captiue hys vnderstandinge... | - The form gestinst, occurring in the following quotation, is not recorded in OED : Supplic. 304 B 1, [Martha] ... was busy aboute almes and Lospitalitie and the gestinst of the best poore man and most gracious gest that euer was gested in thys world.

-enge occurs in Apol. (Wks.) 865 B 13, prayenge; Dial. Her. 166 C 7, sayenge.

8) It is, however, possible that there was a difference in pronunciation, as still at the present day in Northumberland and the Southern Counties of Scotlend (see OED s. v. - ing ${ }^{8}$ ).

3) For the rival usage with the infinitive (e. g. To geue ... more godly is) see 99245 and 367 . 
With the :

Hich. 56 F 20, the wondering of the people caste a comly rud in her chekes. | Dial. C. (Wks.) $1164 \mathrm{G} 7$, the lyftinge vp of theyr heart alone... is more accepteble to him...

With (pro)nouns :

Picus $9 \mathrm{C} \mathrm{10}$, What sorrow and heuines his departing out of this world was, ... | Dial. Her. $136 \mathrm{C} 11$, And any beyng trow al wer thei right few, suffised for our purpose. | Dial. Her. $148 \mathrm{E} 4$, ye saide, that Christes being with hys church, was onely the leuyng of his holy scripture to vs.

The same usage in Pres. D. Eng. No examples with proleptic $i t$ have been found ${ }^{1}$ ); $c f$. :

c 1400 Mandev., Tr. 110, 37, And also to such folke it is an euyll meetynge of Havenes (M.). I Thackeray, Virg., Ch. xcr, p. 984, It was not pleasant coming near bim (P.).

Occasionally the form in -ing as logical subject is announced by proleptic this :

Picus $14 \mathrm{C} \mathrm{10,} \mathrm{This} \mathrm{is} \mathrm{a} \mathrm{very} \mathrm{deadly} \mathrm{\&} \mathrm{monstrous} \mathrm{perswucion,} \mathrm{which}$ hath entred the mindes of men, beleuing that the studies of philosophie ar'e of estates and princes.

Pres. D. Eng. would use to belleve in similar cases.

$$
\text { EARLIER }
$$

1470-85 Malory, Morte D'A. 800, 9 , Your goynge oute thys nyghte shalle wrathe vs alle (D.).

\section{LATER}

1922 Times, Lit. S. 14, 9, p. 571, Reading $h(m$ is like looking at a series of pictures by Rubens (Kr.).

: No inslances of the type Myn is the drenching have been found in More. Cf. :

Chaucer, C. T. A 2456, Myn is the drenchyng in the see so wan,... Myn is the stranglyng and hangyng by the throle.

Constructions with introductory there are very rare :

Conf. Tynd. 469 A 13, that there was wrytynge in the world long ere Abrahatn... | Conf. Tynd. $469 \mathrm{~B} \mathrm{9,} \mathrm{though} \mathrm{it} \mathrm{wer} \mathrm{proued} \mathrm{as} \mathrm{it} \mathrm{is} \mathrm{not,}$ that there wer wrytyng from the begynning.

Chaucer has something similar :

C. T. A 1649, Ther nas no 'Good day', ne no saluyng.

Here, however, to be is approximately synonymous with to happen, whereas in the quotations from More it has the meaning of to exist. Construclions like there is no accounting for tastes do not occur ; they are common in Shakespeare :

Henry VIII, I, iii, 43, There's no converting of 'em. | Caes. v, v, 30, there is no tarrying here.

1) CR. $\$ 9247 \mathrm{fH}$. 
396. The form in -ing afteh a copula.

a. Identifying.

Dial. Her. $140 \mathrm{~F} 11$, these viages ben but wandring about vanitie or supersticious deuocion.

Last Th. 83 D 9, our lord, which al way standeth at the dore of mans hert and knocketh, ... And one of bis good and gracious knocking is, the putting $v$ in remembrance of death. | Dial. Her. $148 \mathrm{E} 3$, ye saide, that Christes being with hys church, was onely the leuyng of his holy scripture to vs. | Picus 5 H 3, The fyfth (scil. cause) was the...dispising of al erthly thinges.

Dial. C. (Wks.) 1214 A 14, which is an heauy hearyng in myne eare. idem $1167 \mathrm{C} 14$, the resystynge of suche mocions, is ... a miny-shyng of Deshlye weallbe. | Conl. Tynd. 604 B 8, all this he sayelh, was no fayling of Peters layth, but an oppressyng for the while.

This evidence shows that the form in -ing after a copula was mostly preceded by an adnominal word (article, possessive pronoun, etc.). Only one example (the tirst) in which the form in -ing stands by itself has been found; it would seem that More prefers the influitive in this case. See $\$ 250$.

Compare :

c 1366 Chaucer, Rom. R. 2601, Hit ts but foly and wrong wenyng. I 1548 Hugh Latimer, Serm. on the Ploughers 84, ye that be prelates loke well to your offlce, for right prelatynge is busye labourynge \& not lordyng. | 1865 Mr's. Gaskel, Wives II, 245, Telling Roger's father is not making it public (Kr.). | Pres. D. Eng. : That is hitting the nail on the head.

b. Qualifying.

Picus 7 G 14, howe slipper, \& howe falling it is, that we liue in nowe. | Picus 12 F 11, It wer farre more seeming that they ghoulde... begin to be men. | Picus 13 C 2, And verelye it is accordyng, that god should despyse theo being a man, whan thou being a man despysest a man. | Dial. Her. $105 \mathrm{G} \mathrm{2,} \mathrm{[1]} \mathrm{am} \mathrm{my} \mathrm{selfe} \mathrm{so} \mathrm{lyttell} \mathrm{mistrustyng.} \mathrm{!}$ Dial. Her. 146 B 12, whoso be willing to mend \& be belter, may alway haue lyght to see how.

Even the form being is used in this way :

Dial. Her. 146 F 5, a name which from all creatures ... clerelye discerneth his Godhead, which is euer being \& present without difference of time past or to come.

There is hardly any verbal idea left in these forms in -ing and they do consequently not essentially differ from ordinary adjectives, with which they are indeed frequently found in juxtapositiou (slipper and falling; being and present). 
EARLIER

c 1400 Mandev., Tr. 33, 15, the naturell bawme is full cleer $\&$ of citryne colour \& strongly smellynge (M.).

1412-20 Lydgale, Troy Book $x, 3937$, And pe see is calme and blaundisching.

\section{LATER}

1913 Walpole, Fortitude 1, Iv, 38, They were too young ..., too unenterprising (Kr.).

Pres. D. Eng. : the winter was very trying for our patients.

There are numerous combinations of to be + form in -ing (e. $\mathrm{g}$. it is perteyning to him; those conclusions were good and standyng with the faith), in which the character of to be as a copula is doubtful. They are discussed in the sections dealing with syntaclical units containing two verbs, together with collocalions of the types he was in betynge; the book was in making ; etc. ( $\$ 805 \mathrm{ff}$.)

337. Occasionally the nominal predicate is preceded by of + possessive pronoun ( + own) :

Dial. C. (Wks.) $1176 \mathrm{G} 3$, And be knoweth the frayltye of his earthen vessell that is of his owne making.

With a noun in the genitive :

Lett. 1422 F 6, the matter \& the booke both, concel'ned the porest man in a towne, \& w.re of the simplest mans making.

Earlier example :

1470-85 Malory, Morte D'A. 460, 27, Anone as Elias wyst that he said bit was of Sir Tristams doyng (D.).

In to be of the true making the form -ing is almost equivalent to the noun make or brand in Pres. D. Eng. :

Passion 1301 D 2, The oyntment was of Nardus of the true making, as the gospell declareth in thys worde, nardi pistici. And that oyntment truly made, was veri costly : which was the cause that the true making was lesse vsed, and lolke for the great cost thereol, vsed a nother making therof, that was called counterfeit ointment of Nardus. But this was of the true makynge.

338. There are no examples in More of the type they are of good flying as in :

c 1330 Holle, Nature of the Bees (Horstmann $1,196,6$ ), Some are of kude flyghynge lor thay fly f'a erthe to bevene. | 1491 Paston Lett. (Gairdner) no 1051 , ye thynke he woll be of gode guydyng and demenyng in lyme comyng. 
339. THE FoRM IN -ING AS DIRECT OBJECT ${ }^{1}$ ).

Dial. C. (Wks.) 1175 A 10, with these reasons in Saxony, many cast fastyng of. | Picus 15 G 11, we be wel serued, if we have the grace to suffre chiding. | Apol. (Wks.) $882 \mathrm{H} 6$, betore I heard little talking of such maner of deuices. | Dial. Her. $238 \mathrm{~B} 4$, misse vnderstanding maketh misse reporting. | Dial. G. (Wks.) 1259 F 7, those that were whyte, signifyed approouyng, as the blacke signifyed reproouing. | Dial. Her. 151 E 6, then would I counseile him, speciallye to studie for the vertuous framing of bis own affeccions, \& using ${ }^{3}$ ) gieat moderacion \& t)mperance in the preching to other men. | Picus $8 \mathrm{~B} 1$, wedding. \& worldly busines, he fled almost alike. | Dial. C. (Wks.) $1176 \mathrm{~B} \mathrm{4,} \mathrm{The}$ scripture is full of places that proueth fastyng not to be the inuencion of man.

Though here the form in -ing is not preceded by adnominal modifiers, its nominal character is clearly evinced by its being used as a direct object.

\begin{tabular}{|c|c|}
\hline $\begin{array}{l}\text { EARLIER } \\
\text { 1478-85 Malory, Morte D'A. 265, } 21 \text {, } \\
\text { there he heard moche mornynge } \\
\text { (D.). }\end{array}$ & $\begin{array}{l}\text { LATER } \\
\text { 1913 Hicbens, Ambition, vi, } 78, \\
\text { She loved giving people the } \\
\text { jmpression that she was adven } \\
\text { turous (Kr.). }\end{array}$ \\
\hline
\end{tabular}

340. In ils function as direct object the form in -ing is frequently preceded by $a$, the, a possessive pronoun or another adnominal-word :

Passion 1274 D 2, he made it haue a beyng. | Last Th. 101 B 15, than shal they fele a swimming \& aking in theyr dronken hed. | Prayer 1418 A 13, Geue me, good lord, a longing to be with the(e). | Dial. Her. 175 G 3, il manifest reason ... cannot yet print in your heart a perceiuing that the assistence of god ... must nedes preserue his churche.

Last Th. $87 \mathrm{G} \mathrm{13,} \mathrm{while} \mathrm{we} \mathrm{cut} \mathrm{of} \mathrm{the} \mathrm{braunches,} \mathrm{we} \mathrm{lette} \mathrm{wol} \mathrm{the}$

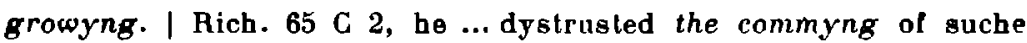
noumber. | Rich. $43 \mathrm{~A} 1$, she diswaded the gatheryng of power aboute the kinge.

Rich. 56 G 5, many good folke ... hated her liuing ${ }^{3}$ ). | Rich. 42 E 9, thei haue kepte theire deallng in these matters farre fro the knowledge of your good grace.

341. An unusual construction is met with in the following sentence :

Rich. $61 \mathrm{C} \mathrm{13}$, the protector found by the way tarying lest he should preuent those woordes.

1) For collocations such as he left off talking see the section on gyntactical units with two verbs (\$ 396).

2) For this juxtaposition of a form in -ing (using) with an infinitive (studie), both in the same function see 367.

3) The context shows that this means : her way of living. 
The form found is the past tense of a now obsolete verb to found = to contrive, not mentioned in OED in exactly this sense. [Nearest : found $\mathrm{v}^{\prime} 3$ (with inf.); $3 \mathrm{~b}$ (with clause) and 4 b.]. The past participle of this verb is used by More in Last Th. $74 \mathrm{~F} \mathrm{2}$, a fantasye fownden of myne owne head. The meaning of the above sentence is therefore the protector contrived to be late and tarying is approximately synonymous wilh delays. That this is the right interpretation is clearly brought ont by the Latin moras nectente. Cf. Reed, Phil. Notes to The Eng. IVks. I, 191.

342. The Form in -ING as an attributive adjunct.

Picus 4 D 2, a shining light. | Picus 13 A 2, into euerlasting fyer. Picus 20 b 3, to lining god. | Boke of F. p. 5 C 5, her wandering eyes. Boke of F. p. 2 D 5, wanteryng rychesse. | Boke of F. p. 2 C 8, swarmyng bees. | Boke of F. p. 6 D 1, The rollyng dyse. | Lasl Th. 85 B 5, the hurnyng hyl of Fthna. | Last Th. 84 A 14, stinking carien. | Rich. 70 A 13, the depe dissimaling nature. | Rich. 59 D 3, an onsitting thing. | Aich. 55 G 16, A louing man. | Rich. 51 A 14, biting wordes. | Last Th. $75 \mathrm{~B} 8$, the prompt and willyng mynde.

The same usage in earlier English :

1470-85 Malory, Morte D'A. 96, 22, trauellynge men are often wery (D.).

In Pres. D. Eng. very common, e. B. moving pictures, talking films, etc.

344. A form in -ing, not accompanied by verbal modiflers, is mostly placed before the noun it qualifies. There are, however, a few cases of post-position :

Dial. C. 341 , he came forth at the whitsuntide ensuing. | Instr. 1405 B 6, Beare no malice ... to no man liuing. | Bless. Body $1265 \mathrm{G} \mathrm{9,} \mathrm{no}$ manne lining knoweth, whether... | Picus $20 \mathrm{~F} 1$, And also the prophele more expressely declareth in the verse folowing. | Picus $10 \mathrm{~B} \mathrm{9,} \mathrm{She}$ spake of the seconde death and enerlasting. | Answer 1043 B 7, life enerlastyng.

In Middle English, too, words like ensuing, following and everlasting were often found in the post-nominal position : 1390 Gower, Cont. A. vir, 3736, The night suiende.|1470-85 Malory, Morte D'A. 61, 32, as it telletls in the book of auentures folowyng. I - Later example : 1937 Davies, Super Tramp Ch. 1I, p. 93, There was not much chance to ship again for two or three weeks, owing to the number of men wailing (Kr.).

Cf. Pres. D. Eng. for the time being; no one living. 
345. If the form in -ing is accompanied by verbal modifiers (objects or adjuncts) the post-nominal position is regular, just as in earlier ') and still in Pres. D. Eng.

Rich. 48 (=15) F I, thereby shall bee ceased the slaunderous rumoure and obloquye now goynge. | Picus $4 \mathrm{E} 1$, he drew backe his mynd flowing in riot. Picus $2 \mathrm{D} 10$, fiery garland standing out the chaumber. | Last TL. 83 G 1, other kindes of pride, risyng of bewty, strength, wit, or cunning. | Last Th. $90 \mathrm{~F} 8$, the thynges comming of the earth. | Rich. $55 \mathrm{C} \mathrm{7}$, a token ... often times ... foregoing some greal misfortune. 1 Rich. $36 \mathrm{C} \mathrm{4}$, The yere foregoynge hys deathe. | Rich. 56 B 17, many thinges highlye redonnding to the minishing of his honor. | Bless. Body $1265 \mathrm{C} 5$, a swyne, wrootynge in the dirle.

Ill and well do not seem to prevent front position :

Dial. C. (Wks.) 1179 A 9, such a faythful wel hopyng man. | Rich. 55 H 11, old il faryng briginders.

Compounds like way faring and way walking are placed belore the noun :

Dial. C. (Wk8.) 1241 A 12, whether enerye way walking begger, be by thys reason oute of prieson or no, we shall consider ferther. | Passion 1340 B 3, Our sauiour ... walking with his two disciples toward the castel of Emaux in fourme of a way faring man.

\section{Earlier}

1390 Gower, Conf. A III 857, Hate

is a wrath the noght shewende, Bot of long time gaderende (E.).

\section{LATER}

1927 Davies, Super Tramp Ch. 13, p. 102, The bodies were not those of men coming from the city in search of employment (Kr.).

346. The form in -ing in post-nominal position can often be expanded into a relative clause of a restrictive character (the thynges comming of the earth = that come of the earth). There are, however, also cases in which the form in -ing is equivalent to a continuative clause, as in the following quotations.

Rich. 54 A 9, what [punishment] were they worthy to have, that compasse \& ymagine the destruccion of me, being so nere of blood vnto the king (= me, who am). | Rich. $37 \mathrm{~F} \mathrm{8,} \mathrm{He} \mathrm{slewe} \mathrm{with} \mathrm{his} \mathrm{owne} \mathrm{handes}$ king Henry the sixt, being prisoner in the Tower (= Henry, who was). ! Rich. 67 i 12, This John Grene did his errande vnto Brakenbery, kneling belore our Lady in the Tower, who plainely answered that ... (=Brakenbery, who was kneeling). | Rich. 63 F 1, ouery man lorbereth

1) In Pecock, however, we find : Folower p. 3, 28 (Hitchcock), pei ben not ... in her propre to hem receyuyng placis (= in the places proper to receiue them). 
to say that he knoweth in auoidinge dyspleasure of my noble lord protector, bearinge as nature requireth a filial reverence to the duches his mother (= the protector, who bears).

In Pres. D. Eng. similar constructions would be considered solecisms, since the subject of the form in -ing is now regularly understood to be identical with the subject of the principal part of the sentence. The above construction misses clearness, so that the correct interpretation depends on the context only; this may be the reason why in later periods the usage was avoided. Occasionally, hovever, instances are met with in Pres. D. Eng., cf. B. Shaw, Candida, Act I, I passed him in the paik, arguing with somebody. Earlier instances are not difficult to find:

1380 Wyclif, Mt. 9, 32, thei brougten to hym a doumbe man, hauynge a deuel. | 1590.96 Spenser, F. Q. v, 28, 3, The Gods, that ... marked well her grace, beeing of stature tall ... and beautifull ... as any of the Goddesses, ... stood all astonied. | 1592 Shakesp., Ven. 376, having no defects, why dost abhor me?

347. Type In time coming.

There are not many instances of this construction, More generally preferring the type time to come $(\$ 256)$.

Last Th. 89 D 6, Whosoeuer he lje that hereth this, and yet puleth \& wimpercth for dout \& fere of lack in time comming. ... be beloueth not that Christ spake these wordea. / Prayer 1419 D 2, prouision to be made... for sede thys yere comming.

This usage, which is now obsolete, was well known in earlier English :

c 1374 Chaucer, Tr. 1, 378, unavised of his wo cominge.

To coming in pre-nominal position (her to coming husband), so frequent in Caxton ( $\$ 256$ note 3), does not occur in More.

For the construction which is to come [coming] see $\$ 414$.

348. Type Medecines of their own devising ').

This construction is frequently met will :

Dial. C. 131, [they] geue sicke folke medlcines of their owne deuising. | Dial. Her. 242 G 7, thynges of mennes making. | Dial. C. 283, [he] had on a time of his own drawyng, a certaine treatice. | Debell. 943 F 2, [I will] stande by myne other words \& verify them wyth a good excluding of this mans including.

The same usage in older English :

a $1366^{2}$ ) Chaucer, Rom. R. 5863, With all the folk of her ledyng. I

') For the type this is of my own making (after copula) see $\$ 337$.

2) Earliest quotation in OED is dated 1526 (s. v. of 41). 
idem Rom. R. 5068, she ... Ne may a jewel or other thyng Take of her loves fre yeuyng. I 1374 idem Anelida 44, all the floure of fortunes yesyngs. | 1410 York $\backslash$ em. Bk. (Surtees) I, 78, That noon ... make no capez nother of meld woll nor meld garn, nother of their asse spynnyng nor bought spon.

In Shakespeare we read :

Tempest II, i, 133, Millaine and Naples have Mo widdowes in them of this businesse making, Then we bring men.

In Pres. D. Eng. the idiom is well known (the quarrel is none of my seeking; trees of my own planting; etc.).

Instead of the genitive More uses a noun preceded by of in :

Dial. Her. $129 \mathrm{G} 2$, it can not otherwise be but that anything of the making of hys goodnes must nedes be good.

No data as to the earlier or later use of this construction have been discovered.

\section{Type Frying pan.}

Dial. Her. $179 \mathrm{~F} \mathrm{4}$, than lepe they lyke a flounder out of a frying panne into the fyre. | Debell. $948 \mathrm{G} 6$, as for the rayling fashion, gf I durst be bold to tel so sad a man a merye tale, I would tel him... | Conf. Tynd. $494 \mathrm{G} \mathrm{2,} \mathrm{he} \mathrm{maketh} \mathrm{saint} \mathrm{Paules} \mathrm{wordes} \mathrm{to} \mathrm{serue} \mathrm{hym} \mathrm{for}$ hys iuglinge sticke. | Last Th. 102 F 5, we take it as for a laughynge matter. | Jest p. 1 C 1, To goe to writyng scole. | Rich. 60 E 3, vntil his dieng day. I Passion $1270 \mathrm{C} 1$, We haue not here a dwellyng citie. I Last Th. 88 D 2, [we] baue here no dwellyng place. / Last Th. 81 A 17, b urne with the falling sicknes. | Dial. C. (Wks.) $1183 \mathrm{E} 10$, those prayers, that the priest in his clensing dayes, pray for them that are then confessed alredy. | Pageant, Childh. 1. 7, to myne endyng day. | Dial. C. (Wks.) $1172 \mathrm{G} 8$, my mending daies come very seld, \& are very shortly gone. | Dial. C. (Wks.) $1154 \mathrm{G} \mathrm{7,} \mathrm{he} \mathrm{setteth} \mathrm{the} \mathrm{weping} \mathrm{tine}$ before, for that is the time of this wretched world \& the laughynge tyme shall come after in heauen. | Dial. C. (Wks.) $1233 \mathrm{~B} 6$, with their hookes and theyr stocking yrons, grubbe vppe these wycked woedes. I Dial. C. 1154 G 14, thys short sowyng tyme. | Passion 1297 H 13, our walking staffe in our hand. |Supplic. 328 A 17, a paire of hedging gloues.

All these collocations have this in common that (in contradistinction to the type a moving spot) the noun is not the subject of the action denoted by the form in -ing, and that the nature of the various relations between the two components is determined by the sense. In this peculiarity the form in -ing betrays its descent from the 0 . E. verbal substantive; whether the combination was characterized by uneven stress in More's time as it is to-day, cannot be ascertained, 
but seems plausible. Examples in Middle and in Pres. D. Eing. abound. A number of similar collocations have now become expressions with established designations, and are regularly hyphenated as an indication of their character as compounds (dancing-master ; reapiug-look).

Many of the collocations used by More are no longer current now e. g. laughing time, my mending days, the weping time, writing scole, dwelling city, stocking tron, railing fashion.

The earliest quotation in OED with juggling stick is dated 1589.

Earlier examples are :

13... Curs. M. 26775, And sipen pai sal you cast in bine As men do wit salting swine. | 1380 Wyclif, J. 21, 5, whethir 3 e han ony souping thing. | 1470-85 Malory, Morte D'A. 310, 16, hit was called the castel pluere that is to saye the wepynge castel (D.). I c 1403 Lydgate, weping teares ; sobbing teres.

St. John Fisher has :

Wks. 158, 8, wepynge teres; idem 151 , 21, restynge place; idem 295,1 , etynge day ... fastynge day; idem 325, 22, a brennyng glasse(W.).

In Berners we read :

Froiss. I1, 302, scalynge ladders; II, 403, restyng place; $\nabla, 13$, huntyng tyme; v, 239, a hewynge axe; $v, 281$, the kynges dressyng borde; $v, 381$, a resortynge place.

More's use, in the following passage, of the synlactically ambiguous combinations weeping time and langhing harvest is a fine instance of word-play :

Dial. C. (Wks.) (F 14, in thys short sowyng tyme of thys weepyng worlde, inust wo water our seede with the showres of our leares, and then shal we haue in heauen a merye laughing haruest for euer.

350. The collocation weeping time alternates in More's English with tyme of weepynge : Dial. C. (IVks.) $1154 \mathrm{G} \mathrm{6}$, without any perceptible difference in meaning. Bolh are translations of tempus flendi, just as tempus ridendi is rendered by laughing time (idem 1155 A 1 ; 1154 G 9) and time of laughing (idem $1154 \mathrm{G} \mathrm{7).} \mathrm{By} \mathrm{the} \mathrm{side} \mathrm{of} \mathrm{sowyng}$ tyme (idem $1154 \mathrm{G} \mathrm{14)}$ we find tyme of sowyng :

Dial. C. (Wk8.) $1154 \mathrm{G} \mathrm{11,} \mathrm{Ther} \mathrm{is} \mathrm{also} \mathrm{a} \mathrm{tyme} \mathrm{of} \mathrm{sowyng,} \mathrm{\&} \mathrm{a} \mathrm{tyme}$ of reapyng to.

Other constructions with of occur in :

Dial. Her. 245 D 4, the stone of stumbling and the stone of falling. I Dial. C. (Wks.) $1153 \mathrm{D} \mathrm{13}$, in purgatory punishment serueth for onelie purging, because the place of deseruing, is passed. 
The fact that in the following characteristic paraphrase of the biblical domus luctus (Eccl. vil, 3) wepynge and waylynge are accompanied by a prepositional object (for some mannes death) made of course the shorter construction (weeping house, wailing house) impossible :

Dial. C. (Wks.) $1165 \mathrm{~F} 1$, Belter is it to gooe to the house of wepynge and waylynge for some mannes death, than to the house of a feast.

\section{Type The torment of beating.}

In this combination the former of the two nouns denotes the (lass of which the latter is a particular example, so that the former is a counotative and the latter a denotative term ").

Apol. (Wks.) 878 B 2, this fante ... of serning god for laude, is ... som what umended of late. | Dial. C. (Wks.) 1184 F 7, the tormente ... of beating, nailinge, and stretching out al his limmes... / Rich. $38 \mathrm{C} 11$, vnder the pretext of reluengynge of olde displeasure. | Dial. C. 143, a good purpose ... of sure standinge by his holye lailhe. | Apol. (Wks.) $859 \mathrm{C} \mathrm{10}$, the necessittie of the putling of all thyng in scripture. | Dial. C. (WVks.) $1146 \mathrm{D} \mathrm{9,} \mathrm{the} \mathrm{fear} \mathrm{of} \mathrm{losing} \mathrm{...} \mathrm{the} \mathrm{lyfe} \mathrm{of} \mathrm{his} \mathrm{sely} \mathrm{soule.}$

This use of the form in -ing as a kind of appositional adjunct is common in earlier and later English :

1470-85 Malory, Morte D'A. 40, 9, that they shold to london come by Christmas vpon payne of cursyng. | 15 H5 Roper, Life of M. XxxIv, 19, All corruption of wronge doinge or bribes taking. | 1647 Chas. I Let. in Antiquary I, 97, The fear of your being hronght within the power of the army. I Pres. D. Eng. : New methods of falsifying historical truth; the action of running; the fact of your meeting him; the circumstance of there being no one near (OED).

\section{Fohm in -ing as a predicative adjunct.}

Picus 11 f 9, these erthly thinges,... sweting and panting we shall vnneth ohtayn. | Picus 2 D 10, there appeared a fierye garland standing ouer the chaumber of hys mother whyle she trauailed. | Picus 16 D 3, God, whiche hath illumined the(e) sytting in the shadow of death. I Picus $16 \mathrm{H} \mathrm{7,} \mathrm{thei} \mathrm{now} \mathrm{back} \mathrm{bite} \mathrm{the(e)} \mathrm{lining} \mathrm{vertuously.} \mathrm{|} \mathrm{Picus} 20 \mathrm{D} 9$, it shal aryse in the day of iudgement immortall and shynyng. | Dial. C. 227 , tell him by what mene you know that you be talking with him well waking and dreme it sleping. | Dial. C. 225, things that are done waking. | Dial. C. (Wks.) $1254 \mathrm{C} 1$, on she came gerning toward the

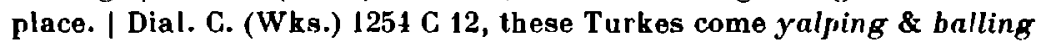
vpon vs. | Last Th. $72 \mathrm{G} \mathrm{14,} \mathrm{he} \mathrm{...} \mathrm{that} \mathrm{goeth} \mathrm{forth} \mathrm{fasting} \mathrm{among} \mathrm{sick}$

1) For the rival construction with an infinitive (a desire to get before his neybour) see 8254 . 
lolk. | Dial. C. (Wks.) $1180 \mathrm{G} 9$, the Lyons whelpes walke about roryng in the nyght. | Last Th. $85 \mathrm{~F} \mathrm{2,} \mathrm{[he]} \mathrm{...} \mathrm{shewed} \mathrm{bymselle} \mathrm{wyllynge} \mathrm{to}$ geve eche of them a gyfl. | Rich. $58 \mathrm{~F} \mathrm{1,} \mathrm{the} \mathrm{File} \mathrm{...} \mathrm{founde} \mathrm{the} \mathrm{parties}$ toward \& willing. | Dial. C. (Wks.) $1254 \mathrm{~A}$ 5, so sbolde he be kild lying, where he could not slyrre him.

Dial. Her. $111 \mathrm{C} 5$, Logicke he reckened but bablynge.

In the following quotation the form in -ing is preceded by $a$. Answer $1076(=1078) \mathrm{H} 5$, like as if a ryght great man woulde wantonly walke a mumming and disguise hymself ${ }^{1}$ ).

Occasionally these predicative adjuncts are not easily to be distinguished from adverb adjuncts of manner, and a strict line of demarcation cannot be drawn.

Some instances of the usage in earlier and later English follow.

\begin{tabular}{|c|c|}
\hline $\begin{array}{l}\text { in this wise I lete hem fightyng } \\
\text { dwelle. }\end{array}$ & $\begin{array}{c}1592 \text { Greene, Mess } \\
\text { side she had har } \\
\text { lous rich purse }\end{array}$ \\
\hline $\begin{array}{l}\text { 39) Gower, A. I 3346, she the king } \\
\text { with wordes wise knelende } \\
\text { thonketh. } \\
1400 \text { Mandev. Tr. } 7-9 \text {, Oure lord } \\
\text { was ynaylled on the cros lyg- }\end{array}$ & $\begin{array}{l}1918 \text { Valpole, Fort } \\
\text { p. 28, Mr. West } \\
\text { day doing busines } \\
\text { Proverb : I call this } \\
\text { to pay Paul. }\end{array}$ \\
\hline
\end{tabular}
gynge (M.).

1470-85 Morte D'A. 678, 7, thus he rode sekyng a grete whyle (D.).

\section{Type Al wakende.}

No instances of this usage have been found in More.

Ct. 1390 Gower, Conf. A. III 51, al wakende I dreme and meete. I idem vi 1746, al bledende he kest him ofte. | a 1300 Floriz and Bl. (in Emerson Mi. Eng. R. p. 39 l. 3l), Quap Blauncheflur. 'Ich am couninge', Ac beo hit sede al slepende.

\section{THE FORM IN -ING AFTER PREPOSITIONS.}

Jest p. 4 B 7, Tyll with luggyng And with tugging, They fell downe at last. | Last Th. $90 \mathrm{H} \mathrm{4,} \mathrm{yet} \mathrm{oughtest} \mathrm{not} \mathrm{to} \mathrm{...} \mathrm{dispayre} \mathrm{of} \mathrm{gods} \mathrm{pro-}$ myse for thy lyuing. | Last Th. $88 \mathrm{C} 7$, now shal ye ge men lal at varyance for kissyng of the pax. | Last Th. $93 \mathrm{C} 2$, who so geueth him aduise to be liberall, semeth to preach to a gloton for fasting. / Rich.

1) Cl. : 1523 Berners, Froiss. 1, 116, He was thre dayes a landyng of all his provision. | 1534 Tindale, Matt. Ix, 9, He saw a man eyt a receauynge of custome. 
$47 \mathrm{E} 11$, thei dare not abyde with their housbandes for beallnge. | Rich. $61 \mathrm{H} \mathrm{14}$, who... woulde recken hym selfe Lorde of his own good, among

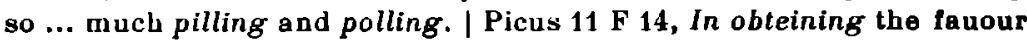
of the princes ... what an heape of heuines ther is. | Dial. Her. 191 D 12, it is a worde ronne in many mens mouthes, begonne bi mistaking, \& beleued without examination. | Apol. (Wks.) 865 B 11, they wryte ... agaynste watchynge and prayenge, fastynge, and wylfull pouerlye.

After as for (prepositional character not clear).

Last TL. 84, As for escaping no man can looke for.

After concerning.

Lett. 1423 B 12, there is a byl put in against me into the higher house ... concerning my communicacion with the nonne of Canterbury, \& mt writing vnto her. | Lelt. 1451 B 10, [this] may happe to put you in trouble and feare of mind, concerning me being here prisoner.

After final for.

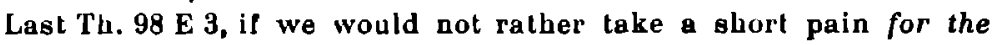
winning of euerlasting pleasure, than... | Aut. Lelt. vil, 70, instruclions geuen vato they $m$ for the semblable avauncyng of themperors army. I

Picus 3 C 7, For the purchasing wherof ... he scrupulously sought out the famous doclours. | Last. Th. $74 \mathrm{D} \mathrm{9,} \mathrm{for} \mathrm{the} \mathrm{pulling} \mathrm{owle} \mathrm{of} \mathrm{whych}$ weedes ... there is not a more mete instrument.

Picus 6 E 3, [he] bet and scourged his own flesh ... for clensing of his olde offences. | Hich. $5 \pm F$ 13, this were done for sauing of bis othe. | Dial. C. (Wks.) $1158 \mathrm{~F} \mathrm{10,} \mathrm{the} \mathrm{church} \mathrm{...} \mathrm{aduyseth} \mathrm{euerye} \mathrm{man} \mathrm{to} \mathrm{fast} \mathrm{to}$ watche, \& pray, bothe for taming of his fleshly lustes, \& alsu to mourne \& lament bys synne before commilted...

The use of the form in -ing without preceding arlicle or other adnominal word, as illustrated in the last three of these quotations is no longer possible. Cf. :

c 1366 Chaucer, Hom. R. 2206, Keye, That was sometyme, for mysseiyng Hated bothe of olde and ying.

For the rival construction with an infinitive (For to put out al maner dout) see $\$ 259$.

\section{After to.}

Picus 2 F 10, they be borne to the alchieuing of some great thing. I Last Th. 72 B 12, this onely text ... conleinelb more fruitfull aduise ... to the formyrg and framing of mannes maners in vertue, ... then... I Picus $12 \mathrm{E} \mathrm{1}$, are woorthy death : not onely they that do such thinges : but also they, which consent to the doing. | Picus 5 G 7, To the bryngyng foorth of so wondreful effects in so small time, I considre fiue causes to have come together. | Last Th. 75 F 6, To thattaining of which mynde ... there is not anylhing ... more accomolodate nor more effectuall, than... 
Quite exceptionally the form in -ing stands withont article in :

Boke of F. p. I C 2, And thus from man to man continually, She uselh to geue and lake, and slily tosse, One man to wynnyng of an others iosse. | Supplic. 335 E 8, we might be ... borne out to burying.

Compare :

1380 Wyclif, John 1,7 , This man cam in to witnessyng that he shulde bere witn 3 ssing of the lizt. | 1601 Ben Jonson, Poetast. II, iv, 103, you ahould have seen me unrip their noses now, and have sent them to the next barber's to stitching.

The usage of the form in -ing after to may be opposed to that illustrated in $\$ 259$, where to is followed by an infiuitive (e. g. Dial. Her. 275 D 5, they had used al the waies thei could to allect the people by preaching). The construclion with -ing is not possible, if there is no direct object following (e. g. Picus 3 B 3, he departed to Bononie to studie). Where the two constructions appear side by side there is no perceptible difference in meaning; the word to, however, when introlucing a form in -ing, would seem to have preserved more of its original prepositional force than the particle to before an infinitive. The difference between the lwo constructions may be one of aspect.

In Pres. D. Eng. too, there are two possibilitics :

1788 Rcid, Active Powers 1, vii, 530, Ve ate accustomed to call the first the callse, and the last the effect. | Athenæum, 28/3, 14, 4, Another reasun is that Europeans are accustomed to seeing women and Turks are not (Kr.).

In the following quolations the word to does not express aim or purpose :

Last Th. 88 B 12, who wold not disdain to be wroth will a wrelched prisoner, with him that is in the carl $\&$ in the way to hanging. I Hich. 55 G 3 , his hor's twise or thrise stumbled with bim almost to the falling.

In both cases Pres. D. Eng. would prefer a different construction.

355. Among the cases in which forms in -ing are preceded by a preposition there are a fow in which they have the character of a prepositional object. They may be dependent on a verb, on a noun or on an adjeclive :

a) Dependent on a verb.

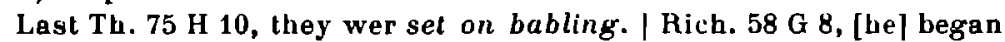
to entre in talking. | Last Th. $73 \mathrm{H} \mathrm{3,} \mathrm{Thys} \mathrm{olher} \mathrm{sage} \mathrm{foole} \mathrm{laugheth} \mathrm{at}$ the castyng of hys own soule into the fire of hel. | Debell. 890 A 14, 
[rathor then] trouble the countrey with callyng vp of the iuries. | Dial. Her. 131 B 5, ye speke of seking to saintys. | Dial. C. (Wks.) 1141 E 13, I deulsed with my selfe opon the Turkes cumming.

Usage known before and after More :

c 13066 Chancer, Hom. H. 2042, It cared me of langwisshing. 1535 Roper, Life of M. LIV, 26, Mr. Pope... could not refrayne from weepinge. | 1920 Chapin, New Morality, Brit. Plays p. う52, save him from promising anything that be can't perform (Kr.).

b) Dependent on a noun ${ }^{2}$ ).

Prayer 1417 H 7, Almighty god, lake from me all ... appetite of reuengynge ..., all pleasure in prouoking any parson to wrath. 1 Aut. Lelt. xil 9, yor ... dexterite in thacheving \& bringing to good passe his vertuouse \& honorable appetites. | Last Th. $95 \mathrm{D} 2$, [she] toke ... such delyte... in the beholding of the apple. | Last Th. 72 B 15, fruitfull aduise ... to the formyng and framing of mannes naners.

Usage known before and after More :

\section{EARLIER}

1483 Caxton, G. de la Tour D vj, The delite that men take in the ... etyng of them (OED).

\section{LATER}

1908 Bennett, Old W. T. Iv, Ch. 3, $\$ 3$, an astonishment which she had real difficulty in concealing (Kr.).

c) Dependent on an adjective ${ }^{2}$ ).

Apol. 91, they waxed wery of the sekynge. | Dial. C. 240, to kepe a serpent in thy bosome and yet be safe from stinging. | Picus 3 A 7, they lhat are swifte in taking, be often times slowe in remembring. I A ut. Lett. II 23, though lie be not glad of the Cardinalles delyng yit is Le glad that... | Last Th. 84 B 6, proud of the wering of a gay golden gown... | Dial. Her. 154 D 9, we be not sure how long it would be in learnyng. | Dial. C. 183, you that haue bene at lerning so long. | Dial. C. (Wks.) 1221 F 7, Never was he saciate of hearinge his owne prayse. Conf. Tynd. $414 \mathrm{G} \mathrm{11,} \mathrm{[hey]} \mathrm{were} \mathrm{conuenient} \mathrm{for} \mathrm{mouing} \mathrm{men} \mathrm{to} \mathrm{deuocion.}$

Usage known before and after More :

\section{EA RLIER}

1362 Langl., P. Pl. A. Prol. 7, I was weori of wandringe (OED).

c 1366 Chaucer, Hom. R. 3812, His tunge was ... wonder bilter in spekyng.

\section{LATER}

a 1586 Sidney, Arcadia 109, Phalantus angry of this defacing his shield.

1918 Walpole, Fortitude I Ch. 2, p. 15, Peter was not afrald of belng alone.

') For the rival construction with an infinitive, e. g. redines to wax angry see $\$ 255$.

8) For the rival construction with to + infinitive (glad to get al) see 8258. 
After worth the complement follows without preposition : Dial. C. 160, Some of them ... be not worth the meating.

The same usage in Pres. D. Eng., but mostly withoul the definite article (e. g. Everything he wrote is worth reading).

356. Ty pe $\mathrm{He}$ gave it in lentng.

This construction does not occur in More. Cf. :

Chancer, Rom. R. 2373, if thou yevest it in lenyng.

357. The ForM IN -ING AFTER thaN AND BUT.

Last Th. 87 B 10, The cause is none other but thappeasyng of his minde... | Last Th. 76 B 6, yet betler wer it then holdynge of thy tong.

Many instances of this usage have not been found. From $\$ \$ 278-80$ it appears that infinitives were preferred here. Compare :

1607 Shakesp. Cor. Iv, v, 234, This peace is nothing but to rust lion... 1756 Toldervy, Hist. 2 Orphans 1,123 , Have you nothing else to do but cleaning the books (OED). | Collinson, Spoken Eng. p. 26, My watch gains, which is belter than losing.

- In Pres. D. Eng. there is occasionally hesitation as to the right form of the verb, as Fowler 1926, p. 274 (-ing 5) points out. He discusses the following sentences : America is doing more than furnishing us with loans. I We are bound to suspect that Italy is doing sometbing more than raise a diplomatic question. He adds that raising is easily defensible but unidiomatic; and that raise is less easily defensible, but idiomatic.

358. The fohm in -ing equivalent to a clause.

Just as the corresponding constructions with a past participle these constructions fall into two groups: they are either relaled or absolute. In the former case they share their subject with that of the principal part of the sentence; in the latler they have a subject of their own.

The majority of these constructions denote attendant circumstances or simultaneity and are consequently equivalent to clauses opening with while. Occasionally, however, ideas of time, reason, condition etc. are so clearly implied that classification into separate groups is justifiable.

In the non-ibsolute constructions the relations are sometimes of a nature to make it doubtful whether they had not better be called predicalive ') or attributive adjuncts.

1) See the Arst quotation of $\$ 359$. 
359. The Form IN -ING EqUivaleNt TO A CLAUSE OF ATTENDANT CIRCUMSTANCES.

Related $\left.{ }^{2}\right)$.

Picus 8 D 14, fensyng my selfe with the crucifixe, bare fote walkyng about the worlde,... I purpose to preche Christ.| Dial. Her. 173 G 2, These thynges ... haue I-spoken to you abiding here with you | Picus $17 \mathrm{~F} 9$, therefore Dauid, speaking in the parson of a ryghtuous manne of his estate, beginneth wilh these wordes... | Debell. 933 D 20, as thoughe Salem talking with Bizance, had not the wylte to perceiue when Bizance speaketh himself. | Rich. 68 B 5, this communicacion had he sitting at the draught. | Rich. $60 \mathrm{C} \mathrm{12}$, Wher he remayned for the space of .ii. yeres, leuing hys new wife in westminster in sanctuary. I Apol. (Wks.) 882 D 8, this pacifier accompteth them for discrete, that leaning the clergy sulficient, woulde that al the remanaunt were taken away from them ${ }^{2}$ ).

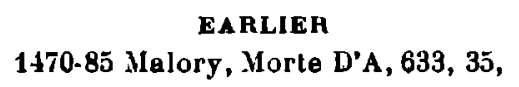
they belde alle the knyghtes... vader theyre obeyssance ... robbynge and pyllynge the poure peple of alle that they had (D.).

With prepositions (with, without, $t n$ ).

Last Th. 81 H 15, Whiche measuryng of time and minishing of life, with approchyng loward delh, is nothing els but... one contynual dying. | Debell. 931 A 9, Now had I supposed to remedy those thinges, \& make him an aunswer in three or four leaues, with only pointing the reader to the places, wilh writing in what leafe he should find the mater. | Picus 32 B 6, of reason bee we seruisable withoute the gapyng after any more, To suche as baue done muche for vs before. | Rich. $41 \mathrm{~A} 6$, it shoulde bee harde for him to brynge his purpose to passe, withoute the gathering and great assemble of people... | Last Th. 77 C 16, as one hearelh a worde, and let it passe by hys eare, without any receluing of the sentence into his heart. | Last Th. $81 \mathrm{G} \mathrm{3,} \mathrm{in} \mathrm{goyng}$ hence fro this town, $a$ inan is not onely goyng fro this towne... | Hich. 55 B 14, Certain it is also, that in the riding loward the tower..., his hors twise or thrise stumbled. | Picus 8 D 6, on a time gs be walked with John Frauncis ... in an orchard at Farrare, in the talkyng of the loue of Christ, he brake out in to these wordes... | Dial. C. (Wks.) 1171 G B, a certain holy father in makyng of a sermon, spake of heaven and heauenly thinges so celestially that...

In the riding ( $=$ while riding $)$, and in the talking $(=$ while talking) are no longer possible.

1) Deutsch bein 1931, p. 147 (" Parlicipium conjunclum ”).

2) For the collocations al slepende, al bledende, al wakende, see $\$ 353$. 


\section{EARLIER}

a 1320 Sir Tristr. 2620, Tristrem is went oway, wip outen coming again (OED).

1477 Earl Rivers (Caxton) Dictes 67, Gladnesse, which encresses daily in me in learnynge wysdom (OED).

\section{LATEA}

1597 Deloney, Gentle Craft, 128, 0 my faith (quoth Ioane) you say not true in so saying (T.).

Pres. D. Eng. He was drowned in crossing the river (OED).

\section{Absolute.}

Dial. Her. $166 \mathrm{C} 4$, ye both confessed, that neither of ye bothe coulde any further thing finde therein, he ') sayenge still that his waye were the truthe, ... and your self ... perceyuynge in your owne mynde Done otber. | Picus 16 E 15, their wickednes blinding them on this side: and the deuil pricking them forlbwarde on that side : thei renne forth hedling in to all mischiefe. / Hich. $54 \mathrm{~A} \mathrm{4}$, [he] sat him downe, in bys place: al the lordes much dismayed \& sore meruelling of this maner of sudain chaunge. | Kich. $43 \mathrm{~F} 7$, Then was there greate commocion and inurmule ... the people diuerselye diuintnge vppon this deatinge. I Hich. 38 $C 2$, a long continued grudge ... between the Quenes kinred and the kinges blood eyther partye enuying others authoritye. I Apol. 78 , the olde feruour of chery te so begynnynge to cole: it is to be fered at length, (bat... | Rich. $68 \mathrm{E} 12$, Then all the other beeing ${ }^{2}$ ) remoued from them, thys Niles Forest and John Dighton, about midnight (the sely children lying ${ }^{2}$ ) in their beddes) came into the chamber. | Rich. $68 \mathrm{~F} \mathrm{6}$, within a while smored and stilled, their breath failing ${ }^{3}$ ), they gaue up to god theit innocent soules. | Supplic. 289 E 8 , And the case so standynge 4), there woulde ... no manne doubte, but... | Dial. C. 227, Therelore in his case both playn against Goddes open precept, and the dispensacion straunge and withoute saumple, no cause appearting nor wel imaginable, but if be wold thinke, that... | Picus $18 \mathrm{~F} 1$, of whiche vniuersitie God is no part, but he is the begynnyng, nothing therupon dependyng. | Last Th. 93 D 10, But loke if yo see not some wretches that scant can crepe for age, his hed hanging in his bosom, and his body cruked, walk pit pat vpon a paire of patens. | Last Th. $84 \mathrm{E} 9$, in lhis prison of yerth we driue forth a while, some bounde to a poste, some wandring abrode, ... some bylding them bower's $\&$ making palaces in the prison, some weping, some ... laboring, some playing, ... no man

1) The oblique case of the pronouns was no longer used in this function : 1432 Paston Lett. (Gairdner) $n^{\circ} 24, \mathrm{p}$. 35, without th'advis of wy Lord of Bedford, him being in England, and him being out, of my Lord of Gloucestre.

2) Also tomporal force.

3) Also causal force.

4) Also conditional force. 
almost remembringe in what case he standeth. | Rich. $43 \mathrm{C} 10$, Aboulo whome he lound tnuche heauinesse, rumble, haste and businesse ... no manne vnoccupied, some lading, some goynge, somme descharging, somme commynge for more, some breakinge downe the walles to bring in the nexte way, and somme yet drewe to them that bolpe to cariy a wronge way.

\section{EARLIER}

1390 Gower, Conl. A. 1 2181, Thei wepte and made mochel mone, Here her hangende aboute bere eres.

1470-85 Malory, Morte D'A. 186, 35, And on the morne erly came these foure quenes passyngly wel bysene, Alle they byddyng hym good morne and he them ageyne (D.).

With prepositlons (without, with).

Rich. 40 F 9, oure enemyes ..., whiche without his wyttyng, might abuse the name of his commaundement lo ani of onr vadoing. | Last Th. 97 A 12, What good can the great gloton do with his bely standing a strote, like a taber ... but balk vp his brewes.

\section{EARLIER}

1412-20 Lydgate, Troy Book III 5052, Hia wif of newe crie gan $\&$ shoute, And with hir pappis also hanging oute ... A ... forn hir lord gan to wepe \& pleue (H.).

\section{LATEH}

1843 Dickens, Ghr. Car. II, They walked along the road, Scrooge recognising every gale, and post, and tree.

(18+3) Dickens (ciled by Wendt 1914, p. 179), Alarm-bells ringing, drams beating, the sea raging and thundering on its new beach, the attack begun.

\section{LATER}

1930 Eng. Hist. Hev. 45 p. 135, Mr.

Bickley might very well have cut down his volumes considerably without our losing very much (OED).

1848 Thackeray, Virg., With the enemy invading our country, it was my duty to go on the campaign (KI.).

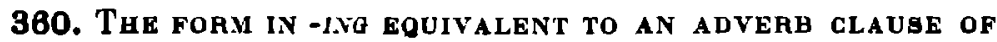
TIME.

Related.

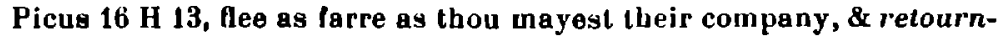
yng to thy selfe, often times secretly praye. | Hich. $38 \mathrm{G} \mathrm{4}$, the Kynge ltfinge vppe himselfe and vnderselte with pillowes ... on this wise sayd vato them. | Apol. (Wks.) $907 \mathrm{H} \mathrm{16}$, such as were taken for woorshippelull, beyng called in for witnesses, haue first made manye delayes. I Picus 9 D 6, [Charles Kyng of Fraunce] hearing of the sicknesse of Picus. ... sent him two of his owne phisicions.

These constructions are slill possible, though they are often introduced by on. 


\section{GAFLIER}

1412-20 Lydgate, Troy Book I, 222, And Anthenor, departyng from Troyens, Gan Rrst pe cite of Venycyens (H.).

With prepositions (after '), at, in, opon).

Picus 11 F 5 The marchaunt thinketh him selfe welle serued, if after .x. yeres failing, ... be maie at last baue a little the more gatbered together. | Hich. $53 \mathrm{H} \mathrm{4,} \mathrm{after} \mathrm{a} \mathrm{little} \mathrm{talking} \mathrm{with} \mathrm{them,} \mathrm{he} \mathrm{sayd} \mathrm{vnto}$ the Bishop... | Hich. $45(=44)$ D 4 , amonge whiche stuffe ... somme were harneys, whiche at the breakinge op of that housebolde, muste needes eyther bee broughte awaye or caste awaye. I A pol. (Wks.) 923 C 14, it was well perceiued what greale nede it was ... to represse ... suche sedicious heresies forlbwyth at the firste springing. | Dial. C. 338, no man can ... in such wyse chaunge the nature of payne, that in the hauing of payn, he fele it not. / Rich. 61 B 11, Nowe was it before deuised, that in the speaking of these wordes, the protector should Laue comen in among the people. | Rich. $56 \mathrm{E} \mathrm{1,} \mathrm{spon} \mathrm{the} \mathrm{proclaining}$ therol, one that was scole master of Poules... said vnto them that stode about bim...

EARLIER

c 1400 Sir Perc. 1531, Thay mone At thaire meting (OED).

Absolute.

Picus 2 C 13, In the yere of our Lorde God. 1463., Pius the seconde being then the generall vicare of Christ in hys churche : and Frederike the third of that name ruling the empire. | Rich. $00 \mathrm{H} \mathrm{1,} \mathrm{god} \mathrm{alway} \mathrm{so}$ prouidelh, that it continueth not in their blood long, but the trouth coinming to light, the rightful inberitors be restored...

EAHLIEH. 1470-85, Malory, Morte D'A. 169, 4, the Kynge beynge set at his dyner, ther cam in two messagers (D.).

LATEh. 1584 Lyly, Campaspe 1, iii, 5, I nrging him to giue some answer, hee tooke vp a bouke. | 1643 Prynne, Sov. Power. App. 28, Charles dying, hi,y sonue Charles the eight, was rel uted ... King (OED).

Occasionally the form in -ing precedes its subject, as in the following instances :

1) In the following passage we find somet instead of yometing : Supplic. 322 B 2, And diuers that a while had went thei slıould haue died for pain, yet after once somet or twayn [shall we see] so cleane ridde of their griefe, that they neuer fele displeasure of it alter. - This use of once before a noun of action is also found in other writers, e. $g$. 1548 Gest, Pr. Masse in H. G. Dugdale (1840) App. 40, Then is the once sacrlfice of Christ utterly to be abandoned and disauthorized. 
Rich. $63 \mathrm{D}$ !4, the children of King Edward the lourth wer neuer lawfully begotten, forasmuch as the king (liuing his very wise dame Elizaheth Lucy) ') was neuer lawlully married vnto the Quene. | Answer $1138 \mathrm{D} 3$, For this we may be sure, that whoso dishonor god : standing that false belief and infidelitie, all honoure that he doveth hym ... is odious. ( Conf. Tynd. 720 C 9 ; idem F 3.

This use of living and standing ${ }^{2}$ ) is now obsolete, but was current before More.

\section{EARLIER}

c 1380 Wyclif, Sel. Wks m $115, \mathrm{He}$ (Christ) becom man, stondynge his godhed, pat he my $\mathbf{z}^{\mathrm{t}}$ not lese (OED).

1390 Gower, Conf. A. 1723, He tok upon him alle thing of malice and of tirannie ... Livende his fader.

1529 Rastell, Pastyme (1811) 33, He was crownyd lyuing hys fader - by pope Johnn (OEU).

With prepositions (after, at) ${ }^{3}$ ).

Supplic. 298 A 9, After which thinge well apperyng, the matter went forth afore the bishop. I Rich. $58 \mathrm{~F} \mathrm{19}$, After which done, \& the Erle of Warcoik being in his embassiate aboute thafore remembred mariage, this pore Lady made humble sute vnto the king. I Rich. $40 \mathrm{~B} 5$, to the gouernaunce ... of this yong prince at his sending lbyther, was there appointed sir Antony Woduile. / Rich. $11 \mathrm{~F} \mathrm{3,} \mathrm{at} \mathrm{their} \mathrm{risinge} \mathrm{in} \mathrm{the}$ dawnyng of the day, thei sent about priuily to their seruantes. I Answer $1042 \mathrm{D} 14$, yet had it not bene euil to hegin somewhat before at Christes disciples going into the ship in the euening...

Instances of this usage are not numerous.

\begin{tabular}{c|c}
\multicolumn{1}{c|}{ EARLIER } & LATER \\
a 1400 Stanzaic Life of Christ 10153, & 1607 Stat, in Hist. Wakefield Gram. \\
And pat shwed wel be one thyng & Sch. 58, Leaues word thereof att \\
pat pe Apostels vseden her After & their howses in theire beinge \\
pe Holy Gost coming. & abrode (OED).
\end{tabular}

1) Expressing not only time, but also reason. CP. Rich. 67 G 1, his nephewes liuing, wen woulde not recken that bec could haue right to the realm.

2) Notwithstanding is always preceded by its subject, if this is expressed : which nothwithstanding, that notwithstanding, all this notwithstanding. See $\$ 366$.

3) Cf. the usage in Old Eng. : c 90 n tr. Bæda's Hist. I, vil, (Schipper). 29, Constantius ... be Diocletiane lyf zendum Gallia rice ... heold. 
1470-85 Malory, Morte D'A. 260, 1, At his againe comyng be semed blewe (D.).

Occasionally the absolute construction occurs without subject.

Aut. Lett. v, 2, 5, after that his grace was cummen home hither and had dyned being VI of the clokke in the nyht, I offred myselfe agayne to his grace in his awne chambre.

This usage, which was not yet old in More's days (\$ 25), seems to have lived on for a certain time after him. The following quotation from the Auth. Version shows a similar construclion, though the form in -ing can also be interpreted as dependent on day : John 20, 19 Then the same day at euening being the first day of the weeke. I In Pres. D. Eng. it is placed before being (it being six o'clock), if a different turn is not preferred.

361. The Form IN -ING EQUivalent to an ADVERB ClaUge of REASON, CAUSE, MEANS OR INSTRUMENTALITY.

\section{Related.}

Rich. 40 A 9, Which counlrey being far of from the law ... was begon to be farre oute of good wyll ... A Apol. 87, Hauyng mete and drynke and where wyth to be covered, lette vs be content. | Instr. $1405 \mathrm{D}$ 5, the roote halh moe branches to be wel waied \& considered then I can now conueniently, (hauing none other pen then a colc). | Picus 12 B 12, shall we wilfully make oul' self their hondemen $?$ and with them wretchedly liuing, more wretchedlie die? | Picus $22 \mathrm{~B} 9$, oft thou shalt, resisting valiauntly, The fendes might and sotle fiery darte : Our saulour Christ resemble in some part. | Rich. $49 \mathrm{C} 7$, with which desease nature being forelaborid ... waxeth the lesse able to beare out a new surfet. | Dial. Her. 181 G 2, than shall it lolowe, that he shall bee a nember of the very churche and so sigll continew, and neuer can be cast out being ') a stark heretique. | Dial. Her. $155 \mathrm{G} \mathrm{12,...} \mathrm{yel} \mathrm{were} \mathrm{he} \mathrm{not} \mathrm{valykely} \mathrm{...}$ to fall in to the secte and heresy of the Arrians. And ... to deuise such false gloses as thei dyd, were as ${ }^{2}$ ) beyng before taught and confirmed by the faithe of the church, ... [he] shall well perceyue ... that...

The same usage in earlier and later English. Cf. :

1300 Gower, Conf. A. 2479, He contrefeteth ... The vois ... in such a

1) Pres. D. Eng. would have for being a heretic.

2) The moaning of were as is whereas. W. E. Campbell, in his modern version (The Eng. Wks. II p. 90, $3^{\text {rd }}$ line from bottom) lonves were as unchanged; this, however, does not make sense. 
wise, That made hire of hire hedd arise, Wenende that it were he. 1 1412 Lydgate, Troy B mk I, 657, To Colchos ward pei helde pe weye ry $3^{t}$, Guying her cors by the lode sterre.

So far the usage illustrated conforms to Pres. D. idiom. Not so in the following instances, where the subject of the form in -ing is not identical with that of the principal part of the sentence, but is the same as that denoted by a pronoun occurring in the principal part of the sentence.

Lett. $1453 \mathrm{~B} \mathrm{8,}$ my ductie was being hys subiect ... to make a playne and a terminate aunswore. / Rich. $54 \mathrm{G} 17$, there upon euery mannes mind sore misgaue them, well perceiuing that this matter was but a quarel.

In Pres. D. Eng. a dependent clause opening with a conjunction would be preferred : as (since) I was his subject; as (since) they well perceived.

Similarly in : 1581 Lyly, Campaspe II, ii, 103, it is a king that loueth, and Alexander, whose affections are not to bee measured by reason, being immortall...

With prepositions (for, in, by, with).

Dial. Hor. 177 B 12, if I were ... lyke my wyle, I shoulde muse more theron now and eate no meat for longing to know. I Last $\mathrm{Th} .75 \mathrm{H} \mathrm{4}$, it were lesse euil ... to blabber on Irifles, ... than whyle they seeme sage, in kepyng silence '), secretly ... to fantasye wyth them self, fylthy sinful douises. I Picus 7 E 4, In loning him also we more profit our self. | Rich. 64 A 14, you shall doe gret profite to all this realme ... in

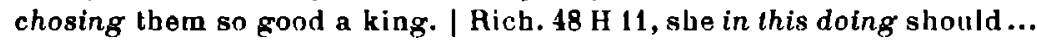
dooe great gond to the realme. I Apol. (Wks.) A 1, by twyse wedrynge [I] am come in the case that I canno newer be prieste. | Last Tl. $92 \mathrm{H}$ 8, [they] liue wrechedly by sparing from themself. | Dial. C. (WVks.) $1149 \mathrm{G} \mathrm{7,} \mathrm{[God]} \mathrm{sendeth} \mathrm{him} \mathrm{tribulacion} \mathrm{...} \mathrm{to} \mathrm{gar} \mathrm{him} \mathrm{ken} \mathrm{hys} \mathrm{maker,}$ and $b$, lesse likinge the false flattering world, set a crosse vppon the shyp of his hart. | Apol. (Wks.) 861 E 2, [he wyll] walke and woorke wyth God by captiuyng of hys owne rnderstandinge, and subdewinge of hys owne reason, ... and by callyng vpon the continuaunce of Goddes gracious helpe thaceunto. | Dial. Her. $150 \mathrm{~B} \mathrm{4,} \mathrm{with} \mathrm{sowyng} \mathrm{sedicion,}$ setting forth of errors ..., and spising their preching with rebuking of priesthode ..., they tourne many a man to ruyne. | Dial. C. (Wks.) 1230

1) An almost identical use of the lorm in -ing (sage in kepyng silence), but without preposition (deaf not herynge) is found in St. John Fisher :

Wks. 80,35 , suche as be ouercomen by temptacyons are very blynde not perceyuynge the vgsomnes of synne, also thry be defe not herynge the traude of the deujll, \& last they be dombe not spekynge \& wysely reprouynge thabomjnacyon of it.

No instances of this idiom have been lound in More. 
C 4, Maye he not leese this countrei egaine vnto Christen men, and you with the taking of this waye, fall in the same peryll then, that ye woulde nowe eschewe?

The same usage before and after More, except that in Pres. D. Eng. by would be substituted for with in the last two quotations.

\section{EA RLIER}

c 1200 St. Lucy 33, in S. Eng. Leg. I, 102, poruz touchingue of seinte Agace toumbe pouz schalt beo hol a-non (OFD).

c 1386 Chaucer, C. T. A 2466, I slow Sampsoun, in shakynge the piler.

c 1400 Mandev. Tr. III 19, Wee synne dedly, in shauynge oure berdes.

c 1460 Wistom 1105 in Macro Plays 72, By towchynge, I felte peyne smerte (OED).

\section{LATER}

c 1500 Medwall, Fulgens 11, p. 223, But I se well he is a made man In this message doyinge ( $\mathrm{T}$.).

1597 Deloney, Gentle Craft 193, proue not a foole by being too fearefull (T.).

1667 Dryden, tr. Life St. Fr. Xav. vi, 667 , many sick persone ... were cured with only seeing it (OED).

What about in the following quotation has the same meaning as what with (=) in consequence of) in Pres. D. Eng. :

Aich. 6: E 16, what about the getting of the garland, keping it, lesing \& winning againe, it hath coste more englishe blood then hath twise the winning of Fraunce.

Earlier example with what of :

a 1400-50, Wars Alex. 781, Quat of stamping of stedis \& sterfing of cernes, $A l l$ dymed pe dale.

In the following quotations the subject of the form in -ing is not the subject of the principal part of the sentence :

Lett. 1417 D 11, bis highnes shoulde for not disclosing the causes, accounte me for stubburne and obstinate. | Last Th. $85 \mathrm{H} \mathrm{15}$, For thou woldest not for shame, that men should think thee so mad, to enuy a poore soule, for playing the lord one night in an interlude. | Rich, 68 F 11, Whiche after that the wretches parceiued, first by the strugling with the paines of death, and after long lying styll to be thoroughly dead. | Dial. C. (Wks.) 1162 B 1, ... the self same sinnefull thinges with whiche thei displease God most, and at lengthe with manye times veynge thys maner, God vtterly casteth them of.

Pres. D. Eng. usually interpolates possessive pronouns : for my not disclosing, for his playing, by their struggling, their (using this manner) or uses clauses introduced by because, as, since, etc. 
There are a number of instances in which for means for fear of :

Dial. Hor. $157 \mathrm{H} \mathrm{12,} \mathrm{he} \mathrm{gaue} \mathrm{theim} \mathrm{a} \mathrm{great} \mathrm{hepe} \mathrm{of} \mathrm{lawes} \mathrm{...} \mathrm{to} \mathrm{kepe}$ them in straylely for strayenge abrode in ryot. | Apol. (Wks.) $881 \mathrm{~F} 13$, [they] ... wouldo than very faine saue for hanging robbe spirituall and temporall to. | A pol. (Wks.) $925 \mathrm{E}$ 10, those whose corrupte canker no cure can heale, cut of in season for corrupting farther. | Apol. (Wks.) $850 \mathrm{E}$ 2, lette bim kepe one copye therof with bymselfe for leesinge, and send anolher to rne. | Rich. $47 \mathrm{E} 10$, Mens wyues runne thither with theyr housebandes plate, and saye, thcy dare not abyde with theyr housbandes for beatynge. | Dial. Her. 247 A 2, the father doelh by his discrecion appoynte which of his children may ... kepe a knife to cut his meate, and which shal... baue his knife taken from him for cutting of hys fyugers. | Dial. Her. 168 A 13, I haue shewed you the contrary, and remoued that blocke oul of the way for stomblyng.

The following quotation illustrates earlier usage ${ }^{1}$ ) :

c 1460 Contin. Brut if 460 , The stretes wer strawed thurghout for slidyng of theire horses.

Shakespeare has :

Sonn. 52, 4, The which (treasure) he will not every hour survey, For hlunting the fite point of seldom pleasure. | Gentl. I, ii, 136, here they shall not lie, for catching cold. I 2 Henry VI, Iv, i, 74, now will I dam up this thy yawning mouth for swallowing the treasure of the realm ${ }^{2}$ ).

Later examples :

a 1592 Greene, Alphonsus (1861) 231, That you dare Nol use jour sword for staining of your hands. | 1785 Burns, Halloween xxiii, It chanc'd the stack ... Was timmer-propt for thrawin'. 1810 Scott, Lady of the L., v, 858, Spare not for spoiling of thy steed.

With conjunctions.

There are a few instances in which the causal construction is introduced by a conjunction (as ; for as much as) ${ }^{3}$ ) :

Last Th. $82 \mathrm{G} \mathrm{15}$, As for wrathe and enuy, be tho knowen children of pride as rising of an bie estimacion of our self. | Lelt. $1432 \mathrm{~F} 8$, For as much as being in prison, I cannot tel what nede I may haue... I hartely besech you all...

1) OED (s. v. for $23 \mathrm{c}$ ) has no quotations with a form in -ing anterior to More. There is one without a form in -ing : a 1430 Octouian 682, That wyf therst not say nay, For wordes $y$ lle. This usage was known to More too : Dial. Her. $186 \mathrm{G} \mathrm{7}$, Some that fainted and fled for martirdom, were not so ouyl as they that pursued them.

2) Schmidt (1902 I p. 437) calls this use in Shakespeare peculiar. The evidence from More shows that this epithet is not deserved.

3) For conjunction + past participle see \$\$ 319-22. 
Causal as and for as much as are not the only conjunctions used by More to introduce the clause equivalent with the form in -ing; in $\$ 363$ there is a quotation with as (=as if), in $\$ 366$ another with how be it (= though).

We seem to have here very early examples of a usage that was to develop more fully later on. None of the earliest instances found in other writers date further back than the last part of the $16^{\text {th }}$ century ') :

As (causal) 1657 Lud. Carlell, The Fool Would Be a Favouril, Acl iv, But if you shall make me a tender Of that love which at your Castle I rofused, As being then a prisoner to anothers beauly, Assure your selfe I shall redeem that errour (C.). | 1677 Mrorlon, Mech. Exerc. (1703) 203, The whole Work will be spolled, as being smaller than the proposed Diameter (OED s. v. os iv, 18, b).

As (= as if) 1590-6 Spenser, F. Q. 1, i, I, His angry steede did chide Lis foming bitt, As much disdayning to the curbe to yield. | c 1600 Shaksp. Sonn. 132, 1, as pitying me.

As if. 1584 Lyig, Alex. \& Campaspe, Diogenes moves about with a lantern, as if seeking someone (E.) [Earliest quot. in OFD 1821 s. v. if, 8, c].

Though. 1590-6 Spenser, F. Q. I, iii, 2, how she ... Though nor in word nor deede ill meriting, is from her knight divorced in despayre. I 1592 Shakesp., Ven. 842, lovers bours are long though seeming short.

Whensoever. 1551 tr. Life Father Paul Sarpi, 10, Either rising from the board, or from his bed at midnight, or whensoever applying himself wholly ... to the subject (OED).

While. 1819 Macaulay, Hist. Eng. v, i, 662, Cornish was arrested while transacting business on the Exchange (OFD).

But (= unless). 1606 Shakesp. Ant. iv, ii, 1, Hut being charged, we will be still by land.

When. 1606 Shakesp. Ant. II, ij, 75, I wrote to you when rioting in Alexandria.

Absolute.

Rich. 40 A 9, which countrey ... was ... waxen wild, robbers and riuers walking at libertie oncorrected. | Dial. Her. $280 \mathrm{C} 1$, it is now all one to cal him a Lutherane or to call him an heretike, those two wordes being in maner equiualent, Luther teaching almost nothing but heresies... | Dial. C. (Wks.) $1229 \mathrm{H}$ 5, Wene ye now ..., that Soudane and thls Turke, beinge bothe of one false secte, you may not finde them bothe like false of their promise.| Rich. $67 \mathrm{G} \mathrm{1}$, his nephewes liuing,

1) As touching occurs already in Chaucer : Melibeus, 189, And as touching thy frendes, thou schalt considere which of hem beth most faithful. | It is, however, doublful if this construction belongs here. 
men woulde not recken that heo could haue right to the realm. | Debell. $929 \mathrm{~F} \mathrm{13,} \mathrm{he} \mathrm{so} \mathrm{not} \mathrm{muche} \mathrm{minded} \mathrm{as} \mathrm{yet,} \mathrm{age} \mathrm{now} \mathrm{so} \mathrm{comming} \mathrm{on} \mathrm{and}$ waxing i) all vnwieldye, to goe thyther \& giue thassaute. | Last Th. $87 \mathrm{G} \mathrm{3}$, for the fountayne once stopped, the sore shal sone heale of it self, the matter faylyng that fed il. | Rich. 41 A 12, the kyng being on their side, his part should have the face and name of a rebellion. I

Dial. C. (Wks.) 1259 B 10, [we may wel knowe] ... that the very best man liuing bere vpon earth (the best manne... being no more but a man) cannot ... alteyn the right imaginacion therof.

Instances abound.

\section{EARIIER}

1403 Iydgale, Troy Book v, 725, Ceptre and crowne this yonge prince hal he lorne, Caranseus osurpyng moost falsly To be crowned kynge (H.).

\section{LATER}

1913 Punch 19, 2, We having occasion to shut up our flat for a month or so, my wife was all for taking our silver round to a sale deposit (Kr.).

362. The form in -iNG EqUivalent to a claUse of condition. Related.

Dial. C. (Wks.) 1191 E 10, But takyng the scrypture of God for a grounde for thys matter, you know veri wel your self you shal go som what a shorter wai to worke. | Dial. C. (Wks.) 1142 B 3, These thinges ... cumming to s8, are matter of wordly wealth : and taken frum ve..., be matler of aduersitie. | Diul. C. (Wks.) $1218 \mathrm{~F} 11$, [if we now consider ... these caluses] ... we shall well perceiue waying them well with reason, that ... thei shall well appeare ... thinges nothing so muche to be dred and fled fro.

This usage is in agreement with older practice. Shakespeare has :

Sonnets LII, 13, whose worthiness gives scope, lleing had, to triumph; being lack'd, to hope.

In Pres. D. Eng. the construction is often preceded by if.

\section{EARLIER}

1402 Lydgate, Troy Book I, 4357, Havyng rewarde to hir hiz ${ }^{\theta}$

degre. He shulde rather ... haue weddid hir perfore (H.).

In the following passage the subject of the form in -ing is not the subject of the principal part of the sentence :

1) The subject of waxing is he, the subject of the main part of the sentence ; the quatation, therefore, affords an instance of a mixture of an absolule and a related construction, a usage not poseible in Pres. D. Eng.
Pres. D. Eng. : This same thing, happening in wartime, would emount to disaster (C.). 
Rich. 48 B 6, neither king nor Pope can geue any place such a priueledge, that it shall discharge a man of his delles being able to paye.

In Pres. D. Eng. : if he is able to pay or who is able to pay. With preposition (in) :

Picus 12 A 11, What thing is ther to be desired among the delites of this world, which in the seking wery vs, in the halling blindelh vs, in the lasing peineth vs?

The conditional character of the prepositional coustruction in this passage is not very clear; the construction may be developed into: if we have them, if we lose them as well as into : when (while) we have them, etc.

\section{EAHLIFA}

c 1400 Manrlev. Tr. 3, 19, VVee synne dedly, in etynge of bestes (11.).

Constructions with in, clearly denoting condition, do not often occur in Pres D. Eng.

Huxley, Darw. Ch. II, 24, We do not spcak jestingly in saying that it is Mr. Darwin's misfortune to know more about the question ... than any man living (P.).

Absolute.

Ant. Lett. xiv, 57, such final delerminacion as may god willing be best \& moost conducible to the desired ende. | Dial. C. (IVks.) $1211 \mathrm{~A} \mathrm{4,}$ whan I wake, I wyl againe come to you, and than is (god willing) all this daye ours. | Dial. C. (Wks.) $1147 \mathrm{E} 12$, he dwelling with vs, what trouble can do vs harme? Picus $18 \mathrm{C} 3$, And that thing taketh he for his chicl good, which only hadde,... he thinketh himselfe happye, and whyche onely lacking,... he thinketh himself vnbappi. | Rich. $49(=46)$ H 6, she myghte happen to brynge that lo passe, (as it were no great maistrye, wee lettinge her alone)...

Similar conditional constructions are not often met with in Pres. D. Eng., except in stereotyped phrases such as God willing and weather permitting. Shakespeare has :

Meas. II, $i, 68$, But in what nature? - In such a one as, you consenting to 't, would bark your honour from that trunk you bear.

363. The Form in -ing equivalent to a GlaUse of Rejected COMPARISON.

Dial. Her. 140 B 14, they will make comparisons betwene our Lady of Ippiswitch and our Ladie of Walsingham. As wening that one image more of power then the other.

Though as if is now the usual introduction, as is still occasionally found (Curme 1931, p. 283) : 
1880 L. Wallace, Ben Hur., Cl. xI, Then the herald raised his eyes as seeking approval of someone far olf (C.).

For instances from Spenser and Shakespeare see $\$ 361$.

364. The FORM IN -ING EQUivalent to a CLAUSE OF RESUlt.

Last Th. $78 \mathrm{~F} \mathrm{3}$, [he] founde the meanes ... to depriue vs of paradise, \& bereue va our immortalitie, making vs into subieccion... | Last. Th. 85 A 13, [Envy] ... so dysfigureth the visage leuing it al bony, leane, pale \& wan.

\section{EARLIEA}

1402 Lydgate, Troy Book III, 1407, And amonge him, lik Mars by silf he rood, Full many Greke makyng for to sterue (H.).

\section{LATER}

Pres. D. Eng. : He mistook me for a friend, thus causing me some embarrassment (C.).

The relation is clearer if the preposition to precedes :

Mich. $62 \mathrm{~F} \mathrm{3,} \mathrm{In} \mathrm{which} \mathrm{inward} \mathrm{warre} \mathrm{among} \mathrm{our} \mathrm{sclf,} \mathrm{hath} \mathrm{ben} \mathrm{so}$ gret effucion of the auncient noble blood of this realme, that scarcely the half remaineth, to the gret infebling of this noble land. | Hich. $55 \mathrm{C} 2$, his hor:s twise or thrise slumbled wilh him almost to the falling.

Now often with a noun of action not ending in -ing, e. $g$. to the destruction of, to the total exclusion of.

\section{THE fORM IN -ING EQUIVALENT TO AN ADVERB CLAUSE OF} PURPOSE.

Picus 8 G 12, [very God and very man]... whiche at the last for washing of oure spottie synne, ... in the aulter of the crosse, shede out his most preciouse bloude.| Ditl. C. (Wks.) 1149 D 17, God somtyme sendeth tribulacion for keeping and preseruing a man from such syn.

Last Th. 99 A 11, For thabridgynge wherol, let vs consider it but in the selfe same sinne that we haue in band. I Hich. $58 \mathrm{~B} 2$, for the further appesing of the peoples mind, be sent inmediatli after diner...., one herode of armes.

Last Th. 77 A 12, thercby shall we make a profe, what marueilous effect may grow by the diligent remembraunce of all fower, towarde thauoiding of al the traines, dartes, entisinge ... of the three mortall enemies. I Apol. (Wkg.) 860 A 12, be a woorker with God towarde the attaining of faith.

A pol. (Wks.) $860 \mathrm{H} \mathrm{2,} \mathrm{God} \mathrm{vseth} \mathrm{the} \mathrm{tone} \mathrm{token} \mathrm{of} \mathrm{the} \mathrm{word} \mathrm{to} \mathrm{the}$ wasshinge \& clennesinge of the soule. | Picus 6 B 3, All that euer he receyued ... he bestowed in the bying of a litle land', to the finding of him and his howsolde. | Hicb. $40 \mathrm{~B} 5$, to the gouelnaunce and ordering of this yong prince ... was there appointed sir Antony Woduile.

The constructions introduced by to may be compared with those in which to (denoting purpose) is followed by an infini- 
tive, e. g. they used all the wayes they could to allect the people. See $\$ 259$.

The usage illustrated above differs from that in Pres. D. Eng. only in that forms in -ing not preceded by the or another adnominal word are rarer now than they were then. Introductory groups like with a view to, for the purpose of, with the object of are now often preferred.

Eahlien : 1340 Pseud. Hampole, Pr. Consc. 2889, For warnyng of fiendes pat lyefes. | 1451 Capgrave, Life St. Aug. 4, pei herd sai pat her child had a grete corage to lernyng.

LATER : 1601 Ben Jonson, Poelasler 111 , iv, 103, [1] have sent them lo the next barber's to stilching. | 1630.48 Bradford, Hislory of PI. Plantation 165. They all went to seeking of shelflsh (G.). | 1806 A. Hunter, Gulina ( $t d .3) 133$, You sit down to writing at your bureau (OED). | 1865 Swinburno 877, [I] stand, girt as they to hunting. | Pres. D. Eng. : Wo planted a hedge for preventing the cattle from straying (C.).

366. The Form in -ing equivalent to aN adverb clause of CONCESSION.

Prayer 1418 B 9, pardon me good lord, that I am so bold to ask so high pelicions, being so vile a sinfull wretch. | Apol. (Wks.) 863 D 7, god vppon suche folke as hauynge wytle and learntinge fall wylfullye frum faithe, to false heresye, shewelh hys wrathe. | Dial. Her. 144 E 11, the world ... \& the frailte of our flesh ... make vs ... well knowyng \& belening the good, yet to walke in the worse as doth somtime the sicke man, that belening his phisiclon, \& haulng had also right often good proofe ... before, that sone certain meate or driuke shall dooe hym harme, doth yet of an importune appetite fal for his litle pleasure to his great pain \& hurt.

The same usage in older and later English.

EAHLIER
1402 Ludgate, Troy Book v, 1349 .
Til by counseil of bis Eneas, To
support heu in pis gret nede pei
sent in haste for pis Diomede,
knowynge ful wel his desola-
cloun (H.).

LATER

1590-6 Spenser, F. Q. x, ii, 41, 5, yet, swimming in that sea of blisful joy, he nought lorgott how he whilome bad sworne.

With how be it.

Picus 6 B 10, He was conlent with meane fare al bis table : how be it somewhat yet reteyning of the olde plentie in deintie viande and siluer vessell.

For other conjunctions see $\$ 361$.

In the following quotation the subject of the form in -ing 
is not identical with the subject of the main part of the sentence :

Dial. G. (Wks.) 1221 H 14, I lyked my selfe the better, because mee thoughte my woordes beeynge but a straungyer, wente yet with some grace in the Almain tong.

The form Notwitustanding.

Notwithstanding does not seem to have already assumed the character of a preposition, since it is preceded by a pronoun or noun in the function of a subject; the combination this (that, etc.) notwithstanding is therefore clearly an absolute construction.

Lett. $1429 \mathrm{~A} 1$, they shewed me the roll, and let me se the names of the lordes ... which had sworne ... : Which notwithstanding when they saw that I refused to swere the same myself, ... I was commaunded to goe downe into the gardein. | Debell. 997 D 10, the law presuneth that his oth notwythstandyng he were lykely inough to lye. | Dial. Her. $150 \mathrm{D} \mathrm{4}$, some haue I sene, whiche when thei haue ... ben by their prelates prohibited to preache, baue (that nutwithstanding) proceded on stil. | Rich. 51 G 2, All this notwithstanding, here I deliver him and bys brother. | Dial. Her. $150 \mathrm{G} 4$, be would ... preache (ani prohibicion notwithstanding).

It is possible that this usage (subject preceding, not following) was not yet old when More wrote; the earliest quotation in OED of this idiom is :

1490 Caxton, Eneydos vi, 23, Thys nolwystandyng, alwaye they be in awayte.

In older English nought (withstunding) is often met with; this form does not occur in More :

1300 Gower, Conf. Am. v, 1611, Noght withstondende; idem vi, 683, nothing withstondende.

In Pres. D. Eng. the front-position of the subject is less usual than the back-position ; in literary English it is not rare :

1936 Times Lit. Supp., June 27 p. 530, Its indomitable energy notwithstcinding, the vast work is colourless and wanting in inner cohesion.

\section{JUXTAPOSITION OF FOHM IN -ING AND INFINITIVE.}

Juxtaposition of two different verbal forms in the same function, though in Pres. D. Eng. regarded as a solecism, does not seem to have been irregular in More's time, since it occurs rather frequently.

Dial. C. (Wks.) 1142 C 6, wythoute whiche ... all oller coumfortes are nothyng, that is to witte, the referring the fiual ende of theyr coumforte vnto God, and to repute and take for the speciall cause of 
coumfort, that by the patient sufferance of their tribulacion, they shall atteyne his fauoure. | Dial. Her. 151 F 6, then would I counseile him, speciallye to studie for the verluous framing of his own alfeccions, \& csing great moderacion \& temporance in the preching lo other men. I Debell. 1004 C 7, to confesse lyymself gyltie ... and puttyng hymself in worse case ... wer but a poore poynt. | Dial. C. (Wks.) $1206 \mathrm{G} \mathrm{6}$, he shold first haue spoken of making restitucion ... and then speke of geven his alines after.

In Chaucer we read :

C. T. I 90, Wepynge, and not for to stynte to do synne, may not avaylle.

Instances of this usage are not rare in More's contemporary, St. John Fisher :

Wks. 257, 33, not spekynge one thynge and thynke an olher. | idem 203, 26, A man doynge a trespasse ayenst almighty god \& lye longe in it offendeth more greuously... | idem 162, 8,... nedes be must be mercyfull \& mekely lorgyue vs wrelched \& of no strength, fallynge downe at bis fete knowledgynge our owne mysery \& aske of bym forgyueues. idem. 156,$13 ; 128,5 ; 218,20$ (W.).

That the idiom held its ground for some time after More, appeary from the following quotation :

1584 Lyly, Campaspe II, ii, 67, Fall not from the armour of Hars to the armes of Venus, ... from desplaying the eagle in thine ensigne to set downe the sparrow.

968. The DIFFEHENT CHAHACTERS OF THE FORM IN -ING.

Though the form in -ing is often of a complex nature, since it can simultancously have an adjectival or nominal and verbal character, there are cases in which one of these characters is more prominent than the other. Accordingly we get the following classification :

The characler of the form in -ing may be :

1. Adjectival.

2. Nominal.

3. Verbal.

4. Mixed.

5. Adverbial.

6. Conjunctional.

369. The adjectival character of THE FOHM iN $-I N$.

The form in -ing has an adjectival character :

a) When it is used as an attributive prenominal adjunct not accompanied by verbal complements and adjuncts. 
Picus 4 D 2, a shining light. | Hich. 51 A 14, biling wordes. | Last. Th. 75 B 8, the prompt and willyng mynde (\$ 342).

An exception form the indirectly defining atlributes in collocations of the type : frying panne, laughing matter. See $\$ 349-50$.

b) After a copula.

Diäl. Her. 105 G 2, I am ... mistrustyng (8 336).

c) Occasionally if the form in -ing is equivalent to a predicative adjunct, especially when occurring in juxtaposition with an ordinary adjective.

Picus $20 \mathrm{D} 9$, it shal aryse ... immortall and shynyng (\$ 352).

d) If more and most are used to denote degrees of comparison.

Lett. 1448 A 9, I founde my selfe ... very sensuall, and my fleshe muche more shrinking from payn and from dealh, tban... | Rich. 70 $\mathrm{C} 5$, in most louing \& trusly maner. | Picus $12 \mathrm{~F} 11$, It wer farre more seeming... ').

Degrees of comparison in -er and -est of the form in -ing do not occur. Shakespeare has :

2 Henry VI, II, i, 24, Then, Saunders, sit there, the lyingest knave in christendom.

Just as ordinary adjectives the forms in -ing sometimes take the ending $-l y$ when they are used as adverbs :

Passion 1321 D 1, linked and cheined ensewinglye together. | Dial. C. 190, [ho] did spred his arines ablode vpon the crosse, louyngly t', embrace al them that wil come. | Lett. $1449 \mathrm{D} \mathrm{3,} \mathrm{so} \mathrm{we} \mathrm{may} \mathrm{...} \mathrm{enjoye}$ each others company ... euerlastynglye in the blisse of heauen. | Picus 20 B 16, Then suyngly the prophete sheweth... | Dial. Her. 144 E 12, the frailte of our flesh wilh the enticement of our ghostlye enemies, make vs willingly \& wittingly well knowgng \& beleuing the good, yet to walke in the worse. | Passion 1313 D 2, felyngly.

This idiom was known in Middle English :

c 1386 Chaucer, C. T. A 1564, Love hath his firy dart so brennyngly y-stiked thurgh my trewe, careful herte. | idem A 2203, who moost felyngly speketh of love. | 1402 Lydgate, Troy Book I, 425, toward Jason he torne gan his face ful looyngly (H.). | 1454 Pecock, Folower (Hitchcock p. 198, 35), for to lyue leernyngly and remembitingll.

St. John Fisher uses W'ks. 307, 19, folowingly ; 127, 26, euerlastynglye ; 264, 11, louyngly (W.).

1) Earlier instance : 1412 Lydgate, Troy Book II, 2769, Because sche was fairest of echon, And most excellyng (H.). 
Adverbs in -ingly are not rare in Pres. D. Eng. Everlastingly, lovingly, willingly and wittingly are still used. Ensewingly and suyngly (= subsequently, afterwards), however, have fallen into disuse; More seems to have been (one of) the last to use them : OED has no later quotalions. For the adverbs exceding, passing and notwithstanding see s 374 .

370. The nominal chapacter of the form in -iNG.

The form in -ing has the characteristics of a noun :

a) When used as a subject :

Dial. C. (Wks.) $1160 \mathrm{G} \mathrm{5,} \mathrm{Fasting} \mathrm{is} \mathrm{belter} \mathrm{then} \mathrm{ealyng} \mathrm{...} \mathrm{Prayting} \mathrm{is}$ better then drinkyng (\$335).

b) After the identifying copula to be :

Dial. Her. $140 \mathrm{~F} 11$, these viages ben but wandring about vanitie or supersticious deuocion (\$336).

c) When used as an object :

Dial. H. 238 B 4, nisse vnderstanding maketh misse reporting (8 339).

d) When it is accompanied by adnominal words (articles, possessive pronouns, adjectives, etc.) :

Passion 1274 D 2, he noade it have a beyng. | Hich. $56 \mathrm{G} \mathrm{1,} \mathrm{the}$ wondering of the people. | Dial. C. 346, a glimnering. | Prayer 1418 A 13, a longing. | Picus 9 C 10, his departyng. | Picus 49 B 11, [be] nedeth good loking to. | Boke of F. p. 6 D 7, your owne fishyng and not mine. | Dial. C. (Wks.) 1175 C 8, [be] was of his owne liuyng somewhat auster. | Debell. 984 F 13, I se no great difference betwene those two men ..., saue that the tone lieth at his owne finding '), the tother at the bishoppes coast.

The deflnite article before the form in -ing is much more frequently used in More's Euglish than in Pres. D. Eng. More has :

Apol. (Wks.) $859 \mathrm{C} \mathrm{10}$, the necessitie of the putting of all thyng in acripture. | Picus 2 F 10, they be borne to the atchieuing of some great thing. | Picus 32 B 6, of resson bee we seruisable withoute the gapyng after any more. | Hich. $55 \mathrm{~B} \mathrm{14}$, in the riding toward the lower,... his hors ... stumbled.

The same preference for the definite article is met with in Malory (Dekker 1932, § 274), e. g. :

Morte D'A. 372, 18, And wel am I rewarded for the fyghtynge with sire márbaus. | idem 298, 10, in the fallyng be brake his thy $\mathbf{b}^{\mathrm{h}}$.

1) The phrase at a person's finding(s) (=at his own cost or expense) is obsolete now. Latest quot. in OED is dated 1612. 
e) After preposilions :

Apol. 47, they wryte ... agaynst watchynge and prayeng (8354).

f) When preceded by a noun in the genitive :

Dial. C. (Wks.) $1143 \mathrm{E} 5$, lette vs consider by Chrystes saying unto thern, ... | Dial. Her. 139 B 1, What should we geue credence to the ensample of mens doynges against the plaine commaundement of gods writinges? | Dial. Her. $212 \mathrm{G} \mathrm{7,} \mathrm{thynges} \mathrm{of} \mathrm{mennes} \mathrm{makyng.} \mathrm{|} \mathrm{Lett.} 1422$ F 8, of the simplest mans making. | Aut. Lett. III 23, though be be not glad of the Cardinalles delyng. | Answer 1012 D 14, yet had it not bene euil to begyn somewhat before at Christes disciples going into the ship in the euening, and Christes own walkyng after ypon the sea, and after that on the morowe the people coming after to seeke him in other shyps. | Dial. Her. 131 D 5, fiue or six days belore the kinges commynge thither. | Dial. C. (Wks.) 1210 B 2, this mannes hauyng of riches I myght ... match with another mannes forsakyng of all. | Dial. Her. $148 \mathrm{E} \mathrm{4,}$ je saide, that Christes being with hys church, was onely the leuyng of his holy scripture to vs. I Conf. Tynd. 727 D 11, [he] ... sente me woorde ... of Webbes being with him.| Dial. C. (Wks.) 1227 G 7, vnto them that by the Turkes ') ouer runnyng of the countrey, were happed to be spoyled and robbed. | Passion $1275(=1277)$ F 12, the womans preachynge and babelyng ... did so much harme.

Instead of the genitive, however, the equivalent constructions with of are sometimes used :

Dial. Her. $129 \mathrm{G} 2$, anything of the making of hys goodnes ${ }^{2}$ ) must nedys be good. | Hich. $56 \mathrm{~F} 20$, the wondering of the people caste a comly rud in her chekes.

The use of the neutral case of kynge in the following quotation lends a more verbal character to the form in -ing :

Lett. $1451 \mathrm{E} \mathrm{10,Then} \mathrm{he} \mathrm{asked} \mathrm{me} \mathrm{whyther} I$ badde not redde the fyrste statute of them, of the Kynge beyng hedde of the churche.

This construction made its appearance at least $t$ wo centuries before More, perhaps in imitation of French usage (V. d. Gaat 1928 a) :

1338 Rob. of Brunne, Chron. 68:, For the quene comynge he was ful glad. I a 1349 Pseudo Hampole, Pr. of Cunsc. 3994, sere takens sal com, of whilk men may here fynd wreten some, Als of ancrist commyng.

1) The context shows that Turkes is genitive singular: $1227 \mathrm{~B} \mathrm{5, \text {this }}$ tribulacion of the Turke; 1261 F 7 , if the Turke stode euen here with all his whole army ; $1262 \mathrm{E} \mathrm{8,} \mathrm{the} \mathrm{Turke} \mathrm{is} \mathrm{but} \mathrm{a} \mathrm{shadowe.}$

2) The genitive coastruction is perhaps avoided on account of the fact that goodnes ends in a sibilant. Compare the following parallel construction with gift instead of giving : Apol. (Wks.) $867 \mathrm{~A} 5$, fees as 1 Laue of the gyfte of the kynges most nuble grace. 
and his pouste. | 1461 Paston Lett. (Gairdner) n 451, p. 269, sone uppon the chef baron comyng I schall send you a lettre.

The usage, which seems exceptional in More '), held its ground in later English, by the side of the construction wilh the noun in the genitive :

1686, Orig. Lett. II, iv, cecxxxi (p. 91), It will end in his Grace becoming commander of Scotland. | 1605 Shaksp., Macb. I, iii, 44, By each at once her choppie finger laying Vpon her skinnie lips. | 1848 Thackeray, Van. F. x1, 48, ... I insist upon Miss Sharp appearing.

To-day the construction with the noun in the genitive is regarded as the regular form in literary English, excepl with names of things, and phraseological or involved denominations $\left.{ }^{2}\right)$.

g) If found in juxtaposition with ordinary nouns.

Aut. Lett. vir, 81 , trevaille ... taken in the device and pennyng of so many ... thinges. | Picus $25 \mathrm{C} \mathrm{3}$, Stande it in touching or in wanton

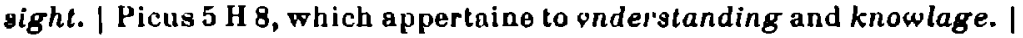
Picus 8 B 1, wedding, \& worldly busines. | Rich. $63 \mathrm{H} \mathrm{2,} \mathrm{the} \mathrm{guiding} \mathrm{\&}$ gouernance of his realm. | Last Th. 73 F 2, loule delite and filthyo lykinge. I Last Th. 73 C 6, thoperacion and workyng of this medicine.

In the following sentence a form in -ing is found in juxtaposition both with an ordinary noun and with an inflnitive :

Conf. Tynd. 42\& C 12, and therfore lettyng all suche bygh processe passe, of rype synnes, and ascendyng to heauen \& wakyng God out of slepe, and sette hyw on husbandry, and driae bym to beruest ... : I can no more $I^{3}$ ), but praye god amende by m \& make him a good man.

h) If an intlectional $-s$ is used to denote the plural.

Conf. Tynd. 350 B 11, [he] repeted those wordes with ... knockinges vppon bis brest. | Dial. C. (Wks.) 1260 A 1, [oft haue I been] ... in perylles by lalse brethern, in labour \& misery, in many nights watch in hunger \& thirst, in many fastinges, in cold and nakednes... | Aut. Lett. $x v, 44$, he hath commaunde 1 me to remitt all the said wrytinges. Last Th. 77 A 15, towarde thauoiding of the traines, dartes, sleightes,

1) When the noun denotes a person, that is. Non-personal nouns do

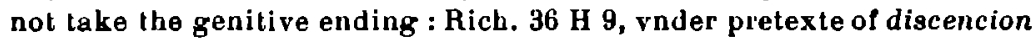
and debate arisynge in the realme. / Cont. Tynd. $580 \mathrm{C} \mathrm{4}$, without Goddes help and Goddes grace preuenting and foregoyng : no manue can belieue.

2) See OED s. v, -ing; Fowler 1926, pp 205 If ("Fused Participle"); Sweet 1903, $\$ 5$ 2328-32 ("Full Gerund" and "Hall-Gerund "); Curme 1931, p. 368 ; Poutsma 1929, xıx, 5 ; Onions 1905, 183 b ; Krüger 1907, $1917,4,82685$; Kruisinga $1931, \$ 115$.

3) For this repetition of the pronoun see $\$ 42$. 
entisinges, and assaultes of the three mortall enemies. | Last Th. 71 H 5, Howe coulde these .ii. sayinges stand together. | Dial. Her. 139 $B 1$, What should wo goue credence to the ensample of mens doynges... Rich. 57 E 6, Her doinges were not much lesse. I Picus 15 G 9 , the olde saintes suffred beatinges, bynding '), prison, swerdes, and death. I Dial. Her. $120 \mathrm{C} 1$, lhe lucre and lemporall aduauntage that them selfo receyue of the offinges. | Answer $1045 \mathrm{E} 6$, the maleryall meate that men eate here, hath two maner of perishinges. | Dial. Her. $165 \mathrm{~B} 11$, thre be lwo secondes after two maner countynges. | Dial. Her. 157 D 4 , pryde longed ... to gete ... many folkes lyuynges in his owne bandes. I Dial. C. (Wks.) $1199 \mathrm{~F} 5$, in the shooting of this arowe of plyde, ther be diuers purposinges \& apoyntinges.

The number of forms in -ing(e)s is much greater in More than in Pres. D. Eug. Combinations like two manner (of) countings, perishings are no longer possible. The following quotations illustrate the usage in periods anterior and posterior to More.

c 1386 Chaucer, C. T. A 281, Who knude telle you the forme of daunces so unkouthe, and so fresshe countenaunces, swich subtil lookyng and dissymulinges For drede of jalouse mennes aperceyoynges? | 1470-85 Malory, Morte D'A. 228, 23, he dredde his buffets soo that he graunled al his askinges. I idem 572,16 , Soo whanne they came there and gaf thankynges. | 1535 St. John Fisher, Wks. 396, 25, whereby wee may the more clearely perceiue the curitings of this booke. | idem 75, 22, Oflentimes at grete leestes, Ionkeryes, \& drynkynges we be made moré intemperate... |idem 201, 3, the dyuers fallynges downe of the synner. 1 1561 T. Norton, Calvin's Inst. Iv, xix (1634) 723, Some he healed with touchings, other some with his word.

A very peculiar use of the form in -ing occurs in the following quotation, where it is preceded by one of and does not take the sign of the plural :

Last Th. 83 D 9, our lord, which alway standeth at the dore of mans hert and knocketh, ... And one of his good \& gracious knocking ${ }^{2}$ ) is, the putting vs in remembrance of deth.

i) When the verbal character is practically absent on account of the meaning :

Picus 20 A 7, I shall blesse our lorde, which hath geuen me understandyng. I Picus 6 F 13, he purposed oftentymes to obey this inspi-

1) In Wynkyn de Worde's edition byndynges.

2) The sign of the plural is also missing in : 1503 Paston Lett. (Gairdner) $n^{\circ} 1071,[\mathrm{I}]$ send yow ... a booke of the seying of dyvers folks. | 1535 St. John Fisher, Wks. 275, 33, so many holdynge vp of his handes, so many lyftynge vp of his eyen, so many betynges and knockynges of his brest. 
racion, and folow his calling. | Rich. 58 A 1 , such as ... were in a authoritie among the peple for oppinion of ther lerning. | Dial. Her.

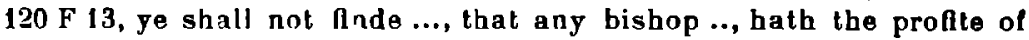
one grote of any suche offringe. | Dial. Her. 135 A 10, [many] ... wer fain to throw their offring ouer their felowes heddes. | Dial. Her. 126 G 10, they had jol at this daye lacked all that conning. | Last Th. 91 B 3, if ... the pore manne that nought hathe, shewe himselfe to lacke fayth ..., yf he lere lack of findyng... ').

\section{Notes.}

a) The strong resemblance between nouns of action like device, and forms in -ing is brought out by the following instances :

Dial. C. 218, then was she so glad in pleasant deuice thereol. | Rich. $48 \mathrm{H} 8$, the counsel ... had sent him vato her, to require her the deliuerye of him. I Supplic. 302 B 9, He is angry \& freteth at the spirituall iurisdiccion for the punishement of heretique and burning of their erroniouse bookes. | Dial. C. (Wks.) $1146 \mathrm{~F} 1$, to the preserued from the fal in temptacion.

It does not appear why More used these forms here instead of forms in -ing; in some cases it may have been a question of rhythm or euphony (delivering him, falling in).

b) In all periods of English we find the form in -ing (as in the earlier stages the form in -ande, -ende) used to denote persons colleclively :

c 825 Vesp. Psalter (Zupitza) 21, gefrea mec of pæm figendum mec. | c 950 Lindisl. Gosp. xxıv, 19, Wa uutedlice pem berundum \& foedendum. I a 1175 Cott. Hom. 223, Hi is mlra libbinde moder. | 1300 Curs. M. 27581 (Cott.), pe standand fall, pe falland rise. | 13... West Midl. Pros. Ps., Ps. xxIv, 6, pis is pe bi $z^{\text {etyng }}$ of pe sechand hym, sechand pe face of God of Jacob. | idem Ps. cill, 6, Our Lord is doand mercies and jugrement to alle pe suffrand wronge. I c 1350 Sir Perceval of Gales (Campion) 60, 14, it es no synn, The man, pat may pe mete wynn, To gyffe pe travellande. I a 1400 Minor Poems fr. Vernon MS. xxiii, 1129, pe geaunt ... pat wel a-wakep pe slepynge Of sleep of dep so long. I c 1470 Golagros \& Gaw. 954, Lord ... thow life lent to levand in leid. 1605 Shakesp. 2) Macb. I1, ii, 53, The sleeping, and the dead, Are but as Pictures. | 1611 Bible, Ruth ii, 20, He ... hath not left off his kindnesse to the liuing and to the dead. 1708 Chamberlayne, St. Gt. Brit. I, ii, vII, 69 , their offce is to confirm the wavering, convince the obstinate. I

') = provision, maintenance. Now obsolele.

2) Perhaps also in Slaksp. L. L. L. v, ii, 366, my lady in courtesy gives underserving praise, - though this verse is often interpreted in a different way. 
1859 Tennyson, Elaine 1359, If one may judge the living by the dead. I 1860 Flo. Nightingale, Nursing 71, Oh! how much might be spared to the dying.

No instances of this usage in More have been found ${ }^{1}$ ). It is, however, met with in the writings of some of his contemporaries :

1526 Tindale, Rev. $x x 1,8$, The singular fearful and unbeleoynge, and the abhominable, and murdres. 1535 Coverdale, Eccl. vi, 8, What helpeth it the poore, that be knowelh to walke before the lyaynge.

The lyuynge in the last quotation seems to refer to one person, a usage unknown in Pres. D. Eng.

By More's time it had already become cuslomary to denote nomina actoris by adding -er to the stem-form of the verb :

Rich. 47 B 12, And muche more mannequellers whome Godde badde to take from the aulter. I Picus 18 A 12, the saluacion of the asker. I Last Th. $100 \mathrm{H} \mathrm{1,} \mathrm{the} \mathrm{queste} \mathrm{is} \mathrm{charged,} \mathrm{the} \mathrm{verdit} \mathrm{geuen,} \mathrm{the} \mathrm{felony}$ founden, the doer endited. | Conf. Tynd. $730 \mathrm{H} \mathrm{18}$, after the perfayte fayth had, the hauer therof may do such horrible deedes... | Apol. (Wks.) $926 \mathrm{H} \mathrm{13}$, let hym not be lyghte of credence in the beleuing either the tone dysputer or the tother.

372. THE VERBAL ChARACTER OF THE FORM IN -ING.

The verbal character of the form in -ing is prominent :

1. When the form in -ing is used as a post-nominal adjunct :

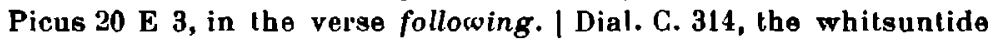
ensuing (\$34).

2. When it is accompanied by verbal modiflers (objects, adverb adjuncts, adverbs, etc.) :

Bless. Body $1265 \mathrm{C} \mathrm{5}$, [a] swyne, wrootynge in the dirte. | Hich. 56 B 17, many thinges highlye redounding to the minlshing of his honor. I Picus $8 \mathrm{D} 14$, fensyng my selfe with the crucifixe. | Rich. 5t $\mathrm{C} \mathrm{17}$, well perceiuing that this matter was but a quarel. | Last Th. $88 \mathrm{D} 7$, two men fighting together (\$ 345).

3. When the construction with the form in -ing is equivalent to an adverb clause :

1) The believing folk and not the beliesing in : Conf. Tynd. $470 \mathrm{~B} \mathrm{3,}$ they made the better belleuing folk the lewer, and the false part the greater.

In the following quotation llving is an attributive adjunct to many : Rich. 57 E 12, at this daye shee beggeth of many at this daye liuing. I Similarly in : Dial. Her. 188 B 12, he [ie] not the god of dead men but of liuing. 
Rich. 40 A 9, which countrey ... was ... waxen wild, robbers and riuers walking at libertie oncorrected. (For more examples see $\$ \$ 358-366)$.

373. The MIXED gharacten of the FORM IN -ING.

a. Adjectival + verbal.

A mixture of adjectival and verbal value is to be observed when the form in -ing is used as a predicalive adjunct :

Picus 11 G 9, these erthly thingas,... sweting and panting we shall vnneth obtain. | Picus 20 D 9, it shal aryse in the day of iudgement immortall and shynyng.

b. Nominal + verbal.

This mixed character is manifest when the form in -ing has an adjectival qualification with a verbal regimen :

Dial. C. (Wks.) $1206 \mathrm{D} 1$, for the not doing of the thing which god hatb geuen them no commaundemente of. | Lett. 1449 F 12, (God)... would not at his thrise praying, by and by take it from him. I Apol. (Wks.) 899 F 16, though their so sayeng be grounded but vpon imaginacion. | Dial. C. (WVs.) 1151 B 11, The bare pacient takyng of hys death, should haue serued Por... | Dial. C. (WVks.) $115+\mathrm{E} 10$, thys word is ... not oure cternal dwelling, but oure lyttle whyle wandryng. I Dial. C. (Wks.) 1169 D 2, since my last beynge here. | Dial. C. (Wks.) $1169 \mathrm{D} \mathrm{10}$, beefore my laste comminge to you. | Debell. $935 \mathrm{H} \mathrm{17,} \mathrm{the}$ myssehandelyng the people to theire distruccyon. | Dial. C. (Wks.) 1201 E 11 , the geuing op hys reckonving onto god. | Passion 1361 E 13, by this his so oft \& earnest calling hym father.

374. The adverbial character of THE FORM in -ING.

Only a for instances illustrating this usage have been found.

Rich. 55 G 10, Thus ended this honorable man, a good knight and a gentle ... A louing man \& passing wel beloued.

Boke of F. P. 7 D 1, But notwithatanding, ... I durst wel swere...

Dial. Her. 231 A 12, He saith that chastile is an exceding seldom gift and vnchastitie exceding perilous for the estate.

Passing and notwithstanding were so used before More's time :

1387 Trevisa, Higden (Rolls.) II, 411, pan Menelaus... gadrede passyng strong men. | 1471 Paston Lett. (Gairdner) no 791, Jamys Gressham hath ben passyng sekke and ys zet. | c1440 Alph. Tales, 8, Not-wilh-stondyng, afor his bruther was abbot, he was a wurthie merchand.

The earliest quotation in OED of exceeding (= exceedingly) is dated 1535 .

For everlastingly, wittingly, etc. see $\$ 369$. 
375. The conjunctional a.jo PRepositional characteh of TBE FORM IN -ING.

According to. Rich. $63 \mathrm{~F} 11$, the right and title ... is ... according to the comon law of this lande, deuolute \& comen vnto the ... lord protector. | Rich. 58 F 2, ho spedely according to his instruccions ... brought the matter to verye good conclusion.

As tonching. Dial. IJer. $114 \mathrm{~B} 12$, as touchinge the coste done vpon the arche ... there is a proper boke... | Aut. Lett. Ix, 11, As towching the veneson ... he was very gladde...

Concerning. Passion 1344 B 1, Concernyng our feare, we haue the A postle that sayth...

Considering that. Last Th. 82 A 8, So that we neuer ougltt to loke loward deth, as a thing farre of, considering that allhough he made no hast toward vs, yet we ... make hast toward him.

During ${ }^{1}$ ). Passion 1301 D 4,... to contynue his offce during his life. Not forbarring. Conf. Tynd. 438 D 1, this ... oure lorde dooeth, ... not forbarring his absolute merciful power.

Providing that. Conf. Tynd. 366 D 7, prouiding alwai that... | idem $779 \mathrm{G} 2$, prouiding that for feare of a rayne the whole plain haue a fayre rouf.

Saving (that). Rich. 62 G 14, that point which ... I am sorye to speke of, sauing that it is in vain to kepe in counsel that thing that al men know. | Rich. 53 E 6, loth was [he] to baue loste him, sauing for fere lest his life shoulde haue quailed their purpose. | Dial. Her. $134 \mathrm{E} 1$, he lieth here al saint Albonis, sauing some reliques of him, which thei there shew shrined.

Seeing ${ }^{2}$ ). Dial. Her. 138 H 14, And afler be sheweth the malediccions that shall fall therwpon. Seing lyke mote thei be to them al. |

Passion 1365 E 15, Could not he, seyng he was god, as well make then as bidde them do it?

Standing. Cont. Tynd. 720 C 6, I can not ... perceyne what counsayle Tyndall can geue any manne towarde saluacion, standyng his

1) It is possible that by More's time the conversing of during into a preposition was not yet complete : 1480 Caxton, Chron. Eng. Ixxxxriii, 72, She neuer was seyn among tolke hir lyf durynge. | 1523 Bernerg, Froiss. I, xxxvii, 52. This aege durynge, ther wer many skirmysshes. More uses enduring in the same way :

Answer 1050 G 7 , the Jewes were full of ... incredulitie, whiche vabeliefe enduring, they could not entre into the waye of saluacion.

2) More does not seem to use seen in this function, though it could be so employed in his time. The usage was apparently rather short-lived, the quotations in OED ranging from a 1470 to 1577 , e. B. Malory, M. A. v, viii, 175, For his [Arthur's] myght ... is most to be doubted seen the noble kynges and grete multitude of Knyghtes of the round table. 
Prantike heresies agaynst free will. | Rich. 59 B 3, he could not well otherwise do, standing that the Earle of warwik had so far moued already. | Answer $1138 \mathrm{~F} 5$, stanting that false belief and infdelitie, all honoure that he dooeth hyin ... is odious. | Dial. Her. 217 F 13, standing the matter in such case ... thei might bee ... deceyued ... Now the matter I say standing in suche case ... I wyll not say that.

Touching. Pasion 1320 \& 1, without fayth there can be no good worke that can be meritorious touchynge the blygse of heauen.

U itnessing. Conl. Tynd. $731 \mathrm{D} 4$, For fayth have they must, or elles they can neuer stund in goddes fauour and be saued, woltnessing ') saynt Paule, that without fayth it is impossible to please God.

According to, as touching, considering that, providing, saving, standing, standing that, witnessing were already used before More. The earliest quotations in OED of concerning (not referring to a preceding noun), saving that, seeing that and seeing are dated $1535,1535,1503$ and 1537 respectively. Standing (that) and witnessing are obsolete now. Not forbarring (= notwithstanding) is not mentioned in OED. Pending, supposing, regarding and providing are not used by More.

376. THE DIFFERENT IVAYS IN WHICB THE OBJECT OF THE FORM IN -ING IS EXPRESSED.

For the types their putting to death; nothing mistrusting; in the dede doing; in slede of our grief taking away; conforting of her; the doing of good; declaring the truth and the doing many good dedes see $\$ \$ 118-126$.

For the type to be aferde of the losing (without object following) see $\S 127$.

377. The DIFFERENT Ways IN Which The gubJegt OF The FORM IN -ING IS EXPRESBED.

That subject may be expressed in the form of :

1. A possessive pronoun.

2. A noun in the genitive.

3. A group consisting of of + noun after the form in -ing.

1) Witnessing alternates with as witnesseth: Conf. Tynd. 488 E 8, For our sauiour, loe, as witnesseth $\mathrm{S}$. John in the .xv. Chapter, sayd...

St. John Fisher uses wytnessyng and witnes : Wks. 275, 18, wytnessyng the prophete Ezechiel. | idem 254, 35, witnes his owne wordes. 
4. A personal pronoun in the oblique case.

5. A personal pronoun in the neulral or common case.

6. A noun in the neutral case.

\section{1. The subject is a possessive pronoln.}

Picus $9 \mathrm{G} 10$, What sorrow and heuines his departing out of this world was. | Boke of F. p. 16 D 7 , it is your owne fishyng and not myne. | Rich. 50 G 5, many good folko... hated her lining. | Hich. 55 H 9, at their comming, himself with the Duke of Buckingham, slode harnesed in old il faling briginders. | Lett. $1423 \mathrm{H} \mathrm{11,} \mathrm{in} \mathrm{your} \mathrm{so} \mathrm{doing.}$ your owne vortuous minde shal giue you ... that... | Rich. 40 F 9, oure enemyes ... whiche without his wyltyng, might abuse the name of his cominaundeinent. | Lett. $1453 \mathrm{H} \mathrm{7,} \mathrm{gaue} \mathrm{me} \mathrm{a} \mathrm{great} \mathrm{praise} \mathrm{aboue} \mathrm{my}$ deseruing. | Lett. 1453 A 6, And afler my coming, maisler Secretarye made rehearsall in what wyse be had reported... what had hcen aunswered by me to them, at myne other being ') before them here last. | Dial. C. (Wks.) 1169 D 1, I hearle of youre folk, that you baue hadde since my last beynge ${ }^{1}$ ) here ... moetely good reste. | Lett. 1449 F 12, [god] would at his thrise praying ..., take it from him.

This is in conformity with both earlier and later usage :

c 1400 Mandev., Tr. 148, 35, his folk pat weren full glad of hys comynge. | 1930 Eng. Hist. Rev. 45, p. 135, Mr. Bickley might very well have cut down his volumes considerably without our losing very much.

The form its, as in Pres. D. Eng. in honour of its being Christmas, does not occur in More; he uses the or whereof ${ }^{2}$ ) :

Dial. C. (Wks.) 1148 F 9, [God] bad them go seke the fault and trye it out by lottes, when the lot fel vpon the very inan that dyd it, being tryed by the $[=$ of the lot] fallyng lyrste vpon his trybe, and then vppon his famylye, and then uppon bis house... | Rich. 55 C 2, his horse twise or thrise stumbled with bim almost to the falling.

Dial. C. (Wks.) 1142 A 10, the going and the coming wherof.

If the agent of the action denoted by the form in -ing is identical with the subject of the verb in the main part of the sentence, there is mostly no possessive pronoun before the form in -ing :

1) At myne other being here, and at my last beynge here (= when I was here last time) are constructiong no longer possible in Pres. D. king.; being seems to be equivalent to presence, a meaning not recorded in OED.

2) Also when in Pres. D. Eng. its would be used as the logical object of the form in -ing : Last Th. 99 A 11, For thabridgynge wherof; Dial. C. 241 , the wel vsing therof; Last Th. $92 \mathrm{D} \mathrm{3,...} \mathrm{a} \mathrm{sure} \mathrm{medicine} \mathrm{(} \mathrm{y} /$ wo forglouth not the receiuyng). 
Apol. 42, they wil not myssespende their tyme in redyng of myne answer. | Dial. C. (Wka.) $1144 \mathrm{~F} 9$, lyke a man that in peril of drosining catcheth whatsoeuer comelh nere to hande.

Occasionally, however, the subject is expressed twice over :

Rich. 41 F 3, at their risinge in the dawnyng of the day, thei sent about prituly to their seruantes.

379. 2. The subject is a noun in the genitive.

See $\$ 370 \mathrm{f}$.

380. 3. The subject is a group consisting of of + noun.

Conf. Tynd. 10' C 5 , somr folk ... thinke this dealing of the clergye to be thus. I Picus $15 \mathrm{~A} 55$, the rombeling of your wordly businesse. Hich. 65 B 10, thereupon the duke sent worde vnto the Iord proteclour, of the heing there of a great and honourable coumpanye. | Picus t0 B I, the wordes, which Picus had saide in his sickenes, of the appering of our lady, caused him to doute and to feare. I Picus $16 \mathrm{E} 0$, like the rauing of bethlem people. Dial. Her. $132 \mathrm{~A} 9$, the ebbing and flowing of the sea.

This construction is only possible with subjective verbs. In the following quotation one word seems to be bolh subject and object :

Dial. Her. 132 B 10, cause can I se none, whye we shoulde ... inore meruaile of the rellyuyng of a dede man, than of the bredyng, bringyng forth and growing of a childe vnlo the slate of a man.

Ilere child is the logical object of bredyng and of bringyng forth and at the same time the logical subject of growing ').

381. 4. The subject is a personal pronoun in the oblique case.

Lett. 1451 B 10, [this] may happe to put you in trouble and feare of mind, concerning me being here prisoner.

The oblique form me seems due to the prepositional character of concerning. The usage is not frequently met with in More. There is one other instance, which, however, only occurs in J. Ristell's and IVinkin de Worde's editions, and not in that by W. Rastell :

Picus 15 E 28 (10), our lorde ... affimeth, thal our rewardes shathe

1) The causative use of to grow was not yet known in More's lime. Earliest quotations in OED are dated $1774,1847,1819$ and 1811. 
plentnous in beauen, when men speke euill to vs, and speake all ouill against os lyuing [lyuyge] for his name ').

This idiom was not uncommon in the periods before More and is nol infrequently used lo-day in unconstrained spoken English :

c 1477 Gaxton, Prol. to Life of Jason (Blades, p. 140), besettyng ... the Quenc to pardon me so presuming. I 1549 Latimer, Seven Sermons (Arbar), p. 160, I woulde haue no mans honeslye empayred by me tellynge. | 1918 Bennelt, These Twain I Ch. T, I don't like the idea of ss living in Maggie's house.

More does not make use of the lype him unwitting, the absolute construction so frequently found in the latinized language of some of his predecessors and contemporaries and a few aulhors who came after him ') :

c 1000 Ays. Gosp., Mark v, 35, Him pa $3^{y t}$ sprecundum hi comon. 1 13.. Gusp. Nicod. 17, hys cnibtas comon on ny ght, and eow slapendum,

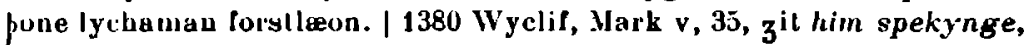
incssageris camen to the prince of a synagoge. | idem Jobn Iv, 51,

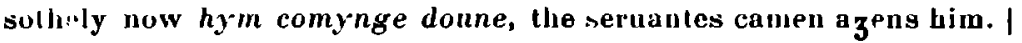
c 1400 Love, Bonavent. Mirr. (1908) 7t, After thal bis parents were gone Lomw arde, he dwelled stille there in Jerusalem, hem onwetynge. | 1449 Pecock, Hepr. 375, 17, Also this deede, a preest forto frecli lake and chese of all maidens to hem a wiif, so that he wedde not of the newe eftsoone, if his first will die him lyung ... was allowid of Poul. | 154y Coverdale, Erusm. Par. Acts $24 \mathrm{~b}$, Vntill he ascended vp (all us beholdying hym) to lieauen.

38.2. 5. The subject is a personalpronoun in the nentral case.

Dial. C. (Wks.) 1228 B 10. And yet they being ewen such, thys woulde I fayne aske one of them. | Rich. $49(=46) \mathrm{H} \mathrm{B}$, she myghte happen to biynge that lo passe, (as it were no greale maistrye, wee lettinge ber alone)... | Dial. C. (Wks.) $1147 \mathrm{E} \mathrm{12,} \mathrm{he} \mathrm{dwelling} \mathrm{wilb} \mathrm{vs,} \mathrm{what} \mathrm{trouble}$ can do vs harme? | Dial. Her. $166 \mathrm{C} 4$, ye buth confrssed, that neither of ye bothe coulde any further thing finde thesein, he sayenge still that his waye were the trutbe,... and your self ... perceyrynge in your owne mynde none other. | Dial. Her. 215 G 5 , If Simken ... layd his warer the contrarye, and than they bolh should chese vs for iudges, \&

1) This is a mistranslation of Matt. v, 11. et dixerint omne malum adversam oos mentientes, propter me. WV. Rastell correctly prints lying (iustead of living).

") Trnka 1930, p. 89 therefore wrongly includes More's nane in bis stalement luat "dative + participle ... occurs mainly in the writings of those authors, such as Pecock, Sir Thomas More, Milton, Tillolson and Bentley, who consciously imilated Latin". 
we coming all fowre into the waye: Wilken would shew vs... | Dial. C. (Wks.) 1260 R 7, Thys same shorte... I ribulacion of ours ... woorkelt willin vathe weight of glory aboue measure, in sublimale on high : we beholding not these lhynges that we see, but those thinges that we see not.

This is the construclion (" the nominative absolute") which, in the centuries immediately preceding Nore, had succeeded in supplanting the Old English dative absolute (eow sliependum, see $\$ 381)^{\prime}$ ). The construction is still found in Pres. D. Eng.

Earlier : 1470-85 Malory, M. A. 186, 35, And on the morne erly came these four quenes passyngly wel bysene, Alle they byddyng him good morne and he thrm ageyne.

Laler : 1777 Sheridan, Trip to Sc. I, 1, She failing in her promise, I have been diverling' my cliagrin.

In Pres. D. Eng. the pronouns it, $I$, they and he (or the latter) respectively, would not be omitted before the forms in -ing in the following sentences :

Aut. Lett. $v, 25$, after that his grace was cummen home hither and had dyned, being vi of the clokke in the night, I offred myselfe agayne to his grace. | Dial. C. (WVk.) 1221 H 14, I lyked my selfe the better, beecause mee thoughte my woordes beeynge but a straungyer, wenle yel with some grace in the Almain tong. | Dial. (. (Wks.) $1182 \mathrm{H} \mathrm{4,} \mathrm{of}$ that that is in dede no sinne, [he] maketh a venial: and that that is venial, imagineth lo be deadly, \& yel for al that falleth in them, being namolye of theyr nature such, as no man long liteth without. | Hich. 37 F 8 , He slewe with his owne handes King Henty the sixl, being prisoner in the Tower.

Shakespeare has: Merch, $v, i, 302$ she had rather stay, Or go to bed now, being two hours to day.

333. 6. The subject is a noun in the nentral case.

Picus 16 E I5, their wickednes blinding them on this side : and the

1) Occasionally, however, a possessive pronoun was substiluted for the dative pronoun, as in : a 1300 Cursor M. 3874, Bisid lya al nigbt he lai, His onwitand, til it was dai. | 1470 Pa:ton Lett. (Gairdner) n० 759, Le sente to my Lady of Torff. by Jobn Bernard ... my omwetyng. or withoul any preyer of me.

Even a noun in the genitive could be used : 1451 Paston Letl. (Gairdner) $n^{\circ} 179$, He thonglil that ye and James Gresham had do it in malyce,... your moders unknowyng.

More has : Rich. 40 F 9, oure enemyes, ... whiche without his wyttyng, might abuse the name. 
deuil pricking them forthwarde on that side : tbei renne forth hedling in to all mischiefe. | Hich. 54 A 4, [he] ... sat him downe, in hys place al the lordes much dismaied \& sore merueiling of this maner of sodain chaunge. | Rich. 43 F 7 , Tben was tuere greale commocion ... the people diuerselye diuininge vppon this dealinge. | Rich. 41 A 12, the Kyng being on their side, his part should hawe the face and name of a rebellion.

More instances are given in the sections on the form in -ing equivalent to an adverb clause (\$\$ 358-366), together with illustration of earlier and later usage.

If the form in -ing has a nominal character, the subjectnoun moslly appears in the genitive, unless it is plural or does not denote a person, as in :

Passion 1298 F 7, he gaue them warnynge of hys death coming so neare at hand.

See $\$ 370 \mathrm{f}$.

384. VOICE OF THE FORM IN -ING.

Whether the form in -ing has a passive or an active meaning can only be inferred from the context. Active meaning, however, is the rule, passivity the exceplion.

Active meaning.

Hich. $42 \mathrm{~F} 9$, thei haue kpplo their dealling in thise matters farto fro the knowledge of your grood grace. | Picus 9 C 10, what sol row ... his departing out of this world was. | Last Th. 85 A 13, [Envy] dysfiguretb the visage leuing it al bony, leane, pale, \& wan.

Instances abound.

Passive meaning.

Dial. C. (Wks.) $1200 \mathrm{~B} \mathrm{4,} \mathrm{to} \mathrm{kepe} \mathrm{a} \mathrm{serpent} \mathrm{in} \mathrm{lby} \mathrm{bosome,} \mathrm{\&} \mathrm{yet} \mathrm{be}$ safe from stinging. | Dial. Her. 127 D 12, the pore man von paine of cursynge, was commaunded... | Dial. Her. $286 \mathrm{G} 14$, he is not worth the reding. | Conf. Tynd. $110 \mathrm{~A} 13$, a sore thing ... that [thei] should in steede of teaching bee beaten cruelly. / Hich. $47 \mathrm{E} 11$, thei dare not abyde with theyr housbandes for beatinge. / Rich. $40 \mathrm{~F} \mathrm{12}$, to any of our undoing... | Dial. Her. 130 C 8 , no man was by al yuur christeninge. I Rich. 54 C 2, their putting to death. | Last Th. 88 B 15, hym that is in the cart \& in the way to hanging.

It should be noted that all those forms in -ing have a clearly pronounced nominal character ("gerunds"). To-day the complex formulae of the type being chidden, your being christened are frequently preferred in this case. More, 
however, does not use the analytic form "), though it was known before his time ${ }^{2}$ ) :

1417 Ellis, Orig. Lelle. I, 59, [Ley] may suffer their goods and caltels to remayne in the feilds day \& night without being stolen. 1 e 1446 Pecock, Folower Donet 126, pe instrument is not wircher of pe same actyue deede principali and poru 3 his owen strengp in beyng restid, but in strengp of an opir, and in beyng movid.

Till aboul 1600 the complex formula remains rare; Ascham, for one, almost exclusively employs the simple form. In Jonson, Spenser and Shakespeare both constructions occur, though the group consisting of being + past parliciple is in the minority.

It is only after Shakespeare that the analytic form becomes a regular feature.

\section{IVithout BEING :}

1584 Lyly, Campaspe $\mathrm{r}, \mathrm{ii}, 76$, there is among you, yea, and of your bringing vp, that sought to destroy Alexander. | 1591 Sbakesp., Gent, II, 1, 20, like one that peal's rohbing. | $1592 \mathrm{idem}$ Ven. 321, The unbacked breeder, lull of fear, jealous of catching... | 1598 idem M. Wiv. JI, iii, 206. Excuse his throwing into the water. | 1601 idem All's Well iv, iij, 1.27, This very instant disaster of his setting in the slocks.

With BeING :

1590-6 Spenser, F. O. nu, iv, 50, Yet former feare of being fowly shent Carried her forward wilh her fir'st intent. | 1604 Shakesp., Othello, I, iii, 137, Of being taken by the insolent foe. 1606 idem Ant. 1, iv, 44, by being lacked. | 1611 idem Cymb. II, iii, 132, hated for being preferred so well. 1647 Chas. I, Let. in Antiquary 1,97 , The teare of your being brought within the power of the army. | 1771 Goldsmitb, Hist. Eng. II, 203, From being altacked, the French now in turn became the aggressur's.

Both conslructions occur in juxtaposition in : $1605 \mathrm{~B}$. Jonson, Volpone III, vii, whal, is my Gold The worse for touching? Cloths for belng look'd on?

385. In those cases in which the characler of the form in -ing is not nominal ("gerund"), lout decidedly verbal

1) Compare the absence of being in constructions of the type : Picus 8 D 12, after certaine botes of myne finished; Hich. $69 \mathrm{~F} \mathrm{12,} \mathrm{after} \mathrm{secrete}$ meting ... had.

8) Franz 1924, \$ 665 erroneously stales : " das zusammengeselzle geruudium tritt er'st im zeitalter der Elisabeth auf... " Jespersen (1935 p. 181) says that aboul 1600 a [this] new form cawe into existence. 
(" present participle"), the use of the complex form with being is well established in More, as it was in the periods before him :

Apol. (Wks.) $908 \Lambda 1$, heyng called in for witnesses, [1bey] haue first mado manye delayes. | Rich. $68 \mathrm{E} 12$. Then al the other heeing remoned from them, thys Miles Forest and John Dighton, about midnight ... came into the cbamber. | Dial. Hor. 15,5 H 4, berng brfore tanght and confirmed by the faitha of the church, ... [he] shall well perceyue, ... that... I Rich. $49 \mathrm{C} \mathrm{6}$, nalure heing furelaborid, forweried and weaked, waxeth the lesse able to beare out a new surfet. | Dial. C. (Wks.) 1193 A 14, certain holy vertuous virgines, ... being by gods enemies infideles pu'sued sppon... | Rich. 68 \& 6, [The man], ... nor rising yot so fast as ho had hoped, being hindered and kept under hy the mearles of Sir Richarde Hatelife. | Last Th. $86 \mathrm{E} 8$, the sinne is som what lesse grieuous, the rule of reson being letted for the while by the sodaine brunte of the iniurye not forethought vpon. | Hich. 56 D) 1, his deliueraunce, whose hope now being by his wel deserued deth politikely repressed, al the realm shold bi gods grace rest in good quiele and peace.

Earlier examples :

1422 Ellis, Orig. Lett ${ }^{2} .1,96$, hy meane whereof he being sore febeled and dehrused, now falle to great age and poverty. | 1450 raston Lelt. (Gairdner) n' 101, p. 121, the seid Duke of Suffolk being releyned with you in your wages of werr ... hath often...

Later example :

Shakesp., Gent, I, iii, 20, how he cannot be a perlect man, Not being tried and butored in the world.

\section{TIME-SPHERE OF THE FORM IN -INf.}

The form in -ing being neutral as to time, the lime-sphere of the action denoted by it must be inferred from the conlext :

A-chronic : Dial. C. (Wks.) $1160 \mathrm{G} \mathrm{7,} \mathrm{Praying} \mathrm{is} \mathrm{betler} \mathrm{then}$ drinking.

Future time-sphere : Rich. $60 \mathrm{H} \mathrm{2,} \mathrm{the} \mathrm{trouth} \mathrm{coming} \mathrm{to} \mathrm{light,}$ the rightful inheritors be restared.

Present time-sphere : Dial. C. (Wks.) 1254 C 11, these Turkes come yalping \& balling vpon vs.

Past time-sphere : Dial. C. (Wks.) 1176 G 4, this enthen vessel that is of his owne making. | Picus $5 \mathrm{G} 7$, To the bryngyng foorth of so wondreful effects in so small time, I considre fiue carses to baue come together. | Rich. $53 \mathrm{H} \mathrm{4,} \mathrm{after} \mathrm{a} \mathrm{little} \mathrm{talking} \mathrm{with} \mathrm{them,} \mathrm{he} \mathrm{sayd} \mathrm{vnto}$ the Bishop... | Picus 11 F 6, aller .x. yer'es sailing. | Apol. (Wks.) 867 A 1, by twyse weddynge [I] am como in the case that I canne never be prieste.

The forms in -ing in the last paragraph have a nominal 
character ("gerunds") ; by the side of them no groups consisting of having + past participle (e. g. by having twice wedrled) have been discovered $\left.{ }^{1}\right)$. As late as 1600 the constructions with have are still rare; in Shakespeare the simple forms are the rule :

Gent. iv, i, 47, Myself was from Verona banished For practising to steal away a lady.

Having + p'tst part. occurs in :

Temp. III, i, 19, when this hurns, 'Twill wee $i^{\prime}$ for hacing searied you. I Gent. 1, iii, 15, which would be great impeachment of his age, in having known no travel in his youth.

387. Groups with having, however, are not infrequently used by More, when their cliaracter is verbal (" present parliciples") :

Dial. Her. $144 \mathrm{~F}$, as dolh somtime the sicke man, that beleuing his phisicion, \& hauing had also rizht often good proofe ... before, ... doth yet ... fal for his litlo pleasure to his greal pain \& hurt. | Dial. Her. 183 G 1, How ... if some infidels as Turkes, or Sarasins hauing heard of Ghristes name, did long to knowe his scripture.

Yel the simple forms are still in the majority :

Rich. 35 F 5, there was neuer anye Prince of this lande attaynynge the Clowne by battayle, so heartily belotied witl the substaunce of the people. I Picuts 12 B 12, shall we wilfully make oul self their bondemen? and with them wrelchedly liuing, more wretchedly die? | Rich. 38 G 4, the kynge liftinge appe himselfe and vndersette with pillowes ... on this wise said vnto them. i Dial. C. (Wks.) 1188 A 6, a rych wydowe ... hauing al hre life an high proud mynde... was at debate with a nother neighboure of hers.

Similarly with the groups with being jlluslrated in $\$ 385$ (being called in for witnesses and not : having been called in for witnesses etc.).

In Elizabethan English the use of the groups with having was well established ${ }^{2}$ ):

Shakesp., Much Ado I, iii, 59, that the prince should woo Hero for

1) Thus after that he had put and not after having put in : Cont. Tynd. $588(=598)$ B 5, after that he had put vnto bym the parable of the rich man,... he sayed forther vnto Dauyd ... in Ihis maner wise as foloweth.

2) The evidence shows the erroneousness of A. Baugh's statement (1935 p. 304): " the compound participle, having spoken thus, having decided to make an atlempt, etc., is conspicuous by its infrequency [in Flizabothan Englisb]. There are only three instances in Shakespeare and less than threescore in the Bible". 
himself, and having obtaingd her, give her to Cuunt Claudio. | idem Pericles II, i, 10, And having thrown him from your watery grave, Here to have death in peace is all he'll crave. I idem Cymb. v, v, 207, he could not But think hor bond of chastity quite crack'd, I having ta'en the torfeit. | idem Cymb. v, iii, 45, having found... | idlem Sonnets Ix, 5, having cllmid...| idem Temp. I, ii, 47.5, Having seen...| idem Ven. 828, Having lost... | idem Meas, I, ii, 23. Having bound up... / idem Merry Wives $111, \mathrm{i}$, 50, having received... | idem All's W. v, iii, 123, Having vainly fear'd ... | idem 2 Hen'y VI, Iv, iv, 53, having spoiled. I idem Haml. I, i, $43\left(Q^{2}\right)$ Haning ouer seene... | B. Jonson, Ev. M. Out of His H., Iv, iv, I, having bound up my wound... | idem Sejanus I, ii, Tiberius (having read the letters)... I idem Sejanus Ir, ii, Havinf commanded an imperial army seven years togelher...

Having been + past participle occurs in :

1590 Sidney, Arc. 49, shee said it might very well be, having bene many times taken one for an other.

\section{END \\ OF THE \\ FIRST PART}




